\title{
Onverschuldigde betaling door de overheid : een onderzoek naar terugvordering door de overheid en het gebruik van privaatrecht daarbij
}

Citation for published version (APA):

Bollen, C. J. M. (2002). Onverschuldigde betaling door de overheid : een onderzoek naar terugvordering door de overheid en het gebruik van privaatrecht daarbij. [Doctoral Thesis, Maastricht University]. Boom Juridisch. https://doi.org/10.26481/dis.20020626cb

Document status and date:

Published: 01/01/2002

DOI:

$10.26481 /$ dis.20020626cb

Document Version:

Publisher's PDF, also known as Version of record

Please check the document version of this publication:

- A submitted manuscript is the version of the article upon submission and before peer-review. There can be important differences between the submitted version and the official published version of record.

People interested in the research are advised to contact the author for the final version of the publication, or visit the DOI to the publisher's website.

- The final author version and the galley proof are versions of the publication after peer review.

- The final published version features the final layout of the paper including the volume, issue and page numbers.

Link to publication

\footnotetext{
General rights rights.

- You may freely distribute the URL identifying the publication in the public portal. please follow below link for the End User Agreement:

www.umlib.nl/taverne-license

Take down policy

If you believe that this document breaches copyright please contact us at:

repository@maastrichtuniversity.nl

providing details and we will investigate your claim.
}

Copyright and moral rights for the publications made accessible in the public portal are retained by the authors and/or other copyright owners and it is a condition of accessing publications that users recognise and abide by the legal requirements associated with these

- Users may download and print one copy of any publication from the public portal for the purpose of private study or research.

- You may not further distribute the material or use it for any profit-making activity or commercial gain

If the publication is distributed under the terms of Article 25fa of the Dutch Copyright Act, indicated by the "Taverne" license above, 
Onverschuldigde betaling door de overheid

Een onderzoek naar terugyordering door de overheid en het gebruik van privaatrecht daarbij 



\section{Onverschuldigde betaling door de overheid}

Een onderzoek naar terugvordering door de overheid en het gebruik van privaatrecht daarbij

\section{PROEFSCHRIFT}

ter verkrijging van de graad van doctor aan de Universiteit Maastricht, op gezag van de Rector Magnificus, Prof. dr. A.C. Nieuwenhuijzen Kruseman, volgens het besluit van het College van Decanen, in het openbaar te verdedigen op woensdag 26 juni 2002 om 14.00 uur

door

Carolus Jacobus Maria Bollen 


\section{Promotor:}

Prof. mr. G.E. van Maanen

\section{Co-promotor:}

Dr. W.J.J. Beurskens (Rechter Arr. Rechtbank Maastricht)

Beoordelingscommissie:

Prof. mr. A.Q.C. Tak (voorzitter)

Prof. mr. L.J.A. Damen (Rijksuniversiteit Groningen)

Prof. mr. T. Hartlief

Het onderzoek is afgesloten op 1 oktober 2001 . Hiema verschenen literatuur, rechtspraak en wetgeving zijn slechts incidenteel verwerkt.

\section{2, C.J.M. Bollen}

Alle rechten voorbehouden. Niets uit deze uitgave mag worden verveelvoudigd, opgeslagen in een geautomatiseerd gegevensbestand, of openbaar gemaakt, in enige vorm of op enige wijze, hetzij elektronisch, mechanisch, door fotokopiečn, opnamen of op enige andere manier, zonder voorafgaande schriftelijke toestemming van de uitgever.

Voorzover het maken van kopieën uit deze uitgave is toegestaan op grond van art. 16B Auteurswet 1912 jo. het Besluit van 20 juni 1974, Stb. 351, zoals gevvijzigd bij Besluit van 23 augustus 1985, Stb. 471, en art 17 Auteurswet 1912, dient men de daarvoor wettelijk verschuldigde vergoedingen te voldoen aan de Stichting Reprorecht (Postbus 882, $1180 \mathrm{AW}$ Amstelveen). Voor het overnemen van gedeelte(n) uit deze uitgave in bloemlezingen, readers en andere compilatiewerken (art. 16 Auteurswet 1912) dient men zich tot de uitgever te wenden.

No part of this book may be reproduced in any form, by print, photoprint, microfilm or any other means without written permission from the publisher: 


\section{INHOUDSOPGAVE}

Lijst van afkortingen

XIII

\section{Hoofdstuk 1}

Inleiding

1.1 Terugvordering door de overheid van onverschuldigde betalingen $\quad 1$ 1.1.1 Terugvordering 1

1.1.2 Overheid en privaatrecht 3

1.2 Probleemstelling 4

1.3 Afbakening 7

1.4 Plan van aanpak 9

1.5 Terugvordering en onverschuldigde betaling 11

1.5.1 Terugvordering: de bestuursrechtelijke weg 11

1.5.2 Terugvordering en onverschuldigde betaling: het BW 14

1.5.3 Korte vergelijking 15

$\begin{array}{ll}1.6 \text { Burgerlijke rechter en bestuursrechter } & 17\end{array}$

$\begin{array}{ll}1.7 \text { Begripsbepalingen } & 19\end{array}$

\section{Deel I}

\section{Hoofdstuk 2}

Administratie, burgerlijke rechter en burgerlijk recht: historische ontwikkelingen

2.1 Inleiding

2.2 De bevoegdheid van de burgerlijke rechter: de artikelen $165 \mathrm{Gw}$ 1815 en 2 R.O.

2.3 Van rechtsbescherming tegen de overheid naar rechtsbescherming voor de overheid

2.4 De competentie van de burgerlijke rechter 29

2.4.1 Verschillende leren

2.4.2 De bevoegdheid van de burgerlijke rechter inzake schuldvorderingen

2.4.3 Bevoegdheid en ontvankelijkheid

2.5 Toepassing van privaatrechtelijke regels in geschillen met de overheid: de verjaringstermijnen uit het $\mathrm{BW}$

2.6 De bevoegdheidsafbakening door de burgerlijke rechter in de twintigste eeuw 


\section{Hoofdstuk 3}

Opkomst van het publiekrecht en de administratieve rechtspraak

3.1 Inleiding

3.2 De ontwikkeling van de administratieve rechtspraak in de negentiende eeuw

3.3 De pogingen om tot een algemene regeling van administratieve rechtspraak te komen in de eerste helft van de twintigste eeuw

3.4 De periode na de Tweede Wereldoorlog

3.4.1 Inleiding

3.4.2 De Wet beroep administratieve beschikkingen (Wet bab)

3.4.3 De Wet administratieve rechtspraak overheidsbeschikkingen (Wet arob)

3.4.4 De Algernene wet bestuursrecht (Awb)

3.5 Bijzondere administratieve rechtspraak

\section{Hoofdstuk 4}

Competentie'perikelen'

4.1 Inleiding

4.2 Rechtshandeling naar burgerlijk recht/publiekrechtelijke rechtshandeling

4.2.1 Inleiding

4.2.2 De Wet arob: rechtshandeling naar burgerlijk recht

4.2.3 De Awb: publiekrechtelijke rechtshandeling

4.3 Administratie, administratieve rechtsgang en de burgerlijke rechter

4.3.1 Inleiding

4.3.2 De invloed van het ontstaan van administratieve rechtspraak op de bevoegdheid van de burgerlijke rechter

4.3.3 De ontvankelijkheid van eiser

4.3.4 Ontvankelijkheid en formele rechtskracht

4.3.5 De rechtsgang naar de burgerlijke rechter door de overheid bij het bestaan van een bestuursrechtelijke regeling

\section{Hoofdstuk 5}

Overheid en privaatrecht; verschillende theorieën

5.2 Uitgangspunt: de overheid mag gebruik maken van het privaatrecht

5.2.1 Gemene rechtsleer, eenheid van het recht en de opvatting van 
5.2.2 De tweewegenleer

5.2.3 Verdere beperkingen op het gebruik: van privaatrecht door de overheid

5.2.4 De gemengde rechtsleer $\quad 89$

5.2.5 De doorkruisingsleer $\quad 92$

5.3 Uitgangspunt: de overheid mag geen gebruik maken van het privaatrecht

5.3.1 De negentiende eeuw: Thorbecke en Loeff 96

5.3.2 De invullende rechtsleer $\quad 98$

5.3.3 De invullende rechtsleer in de jurisprudentie $\quad 100$

5.3.4 De invullende rechtsleer in de wetgeving 105

5.4 Conclusie 108

\section{Deel II}

\section{Hoofdstuk 6}

Sociale zekerheid

6.1 Inleiding

6.2 De Armenwetten en de Algemene Bijstandswet tot 1997

6.2.1 De Armenwet 1854 114

6.2.2 De Armenwet $1912 \quad 115$

6.2.3 De Algemene Bijstandswet $1963 \quad 117$

6.2.4 De Wet terugvordering en verhaal 119

6.3 De ontwikkeling in de sociale zekerheid tot de Tweede Wereldoorlog 122

6.3.1 Inleiding 122

6.3.2 Terugvordering in de socialezekerheidswetten voor de Tweede Wereldoorlog 123

6.3.3 De bevoegdheid van de burgerlijke rechter en toepassing. van het burgerlijk recht 126

6.4 Terugvordering in de sociale zekerheid na de Tweede Wereldoorlog 129

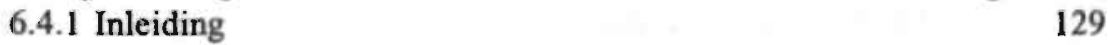

6.4.2 De ontwikkeling tot $1978 \quad 130$

6.4.3 Wet tegengaan van oneigenlijk gebruik van te ruime bepalingen 133

6.4.4 De situatie in de socialeverzekeringswetten vanaf $1978 \quad 135$

6.4.4.1 Inleiding. 135

6.4.4.2 De toekenningsbeslissing 136

6.4.4.3 De intrekkingsbeslissing 137

6.4.4.4 De terugvorderingsbeslissing 138

6.4.4.5 De invorderingsbeslissing en de executie 141

6.4.4.6 Samenvatting 142 
6.4.5 Wet boeten, maatregelen en terug- en invordering sociale zekerheid

$\begin{array}{ll}6.4 .5 .1 \text { Inleiding } & 12\end{array}$

6.4.5.2 Intrekking 14

6.4.5.3 Terugvordering en terugvorderingstermijnen $\quad 14$

6.4.5.4 Invordering en executie 14

6.5 Sociale zekerheid, burgerlijk recht en de burgerlijke rechter

6.5.1 Inleiding 15)

6.5.2 De toepasselijkheid van de verjaringstermijnen uit het $\mathrm{BW} \quad 12$

6.5.3 Het omzeilen van de terugvorderingsbepalingen via de regeling van onverschuldigde betaling in het $\mathrm{BW}$

6.5.4 Invullen van een leemte in de terugvorderingsbepalingen met behulp van de regeling van onverschuldigde betaling in het BW 10

6.5.5 De titel van betaling en de hoedanigheid van de ontvanger 16 6.5.5.1 De titel van betaling 16

6.5.5.2 De hoedanigheid van de ontvanger 16

6.5.6 Artikel 1395 BW (oud) en het verkrijgen van een executoriale titel

6.5.7 Het omzeilen van de publiekrechtelijke terugvorderingsregeling anders dan via onverschuldigde hetaling

\section{Hoofdstuk 7}

Ambtenarensalarissen en overheidspensioenen

7.1 Inleiding

7.2 Ambtenaren

7.2.1 Inleiding

7.2.2 De ontwikkeling van het ambtenarenrecht tot de Ambtenarenwet 1929

7.2.2.1 De negentiende ceuw

7.2.2.2 De twintigsie eeuvv

7.2.3 De Ambtenarenwet 1929

7.2.3.2 Competentieverdeling in de Ambtenarenwet 1929

7.2.3.3 De jurisprudentie van de ambtenarenrechter met betrekking tot terugvordering.

7.2.4 Terugvordering van betalingen aan ambtenaren 
$\begin{array}{ll}7.3 \text { Overheidspensioenen } & 202\end{array}$

7.3.1 Inleiding

7.3.2 Pensioenen tot de Pensioenwet 1922

7.3.3 De Pensioenwet 1922

7.3.4 De Algemene burgerlijke pensioenwet uit $1966 \quad 207$

7.3.4.1 Inleiding 207

7.3.4.2 Wettelijke terugvorderingsbepalingen 208

7.3.4.3 Gebruik van artikel $1395 \mathrm{BW}$ (oud) en de bevoegdheid van de burgerlijke rechter 211

$\begin{array}{ll}\text { 7.3.4.4 Samenvatting } & 215\end{array}$

7.4 Conclusie

216

\section{Hoofdstuk 8}

Subsidies en sociaal-economisch recht

8.1 Inleiding

8.2 Subsidies en de Afdeling (bestuurs)rechtspraak van de Raad van State 221

8.2.1 Grondslag voor subsidiëring voor de inwerkingtreding van de Awb

8.2.2 De subsidietitel in de Awb 224

8.2.2.1 Inleiding 224

8.2.2.2 Het vereiste van wettelijke grondslag 225

8.2.2.3 Subsidieverlening en subsidievaststelling 227

8.2.2.4 Intrekking en terugvordering 229

8.2.2.5 Commentaar op de regeling 231

8.2.3 Huursubsidie 234

8.2.4 Het karakter van subsidiëring en de rechtsbescherming 237

8.2.5 Terugvordering 240

8.2.6 Afdeling bestuursrechtspraak Raad van State 2.1 oktober $1996 \quad 241$

8.2.7 De rol van de burgerlijke rechter 246

8.3 Studiefinanciering: het College van beroep studiefinanciering 248

8.3.1 Algemeen 248

8.3.2 Terugvordering 251

8.4 Het College van Beroep voor het bedrijfsleven:

de sociaal-economische ordening 253

8.4.1 Inleiding 253

8.4.2 De ontwikkeling van het sociaal-economisch recht 254

8.4.3 Rechtsbescherming 256

8.4.4 Terugvordering 260

8.4.5 De burgerlijke rechter 265

8.5 Conclusie 269 


\section{Deel III}

\section{Hoofdstuk 9}

De 'algemene-rechtsbeginselenjurisprudentie': terugvordering en legaliteit

\subsection{Inleiding}

9.2 Het terugvorderingsbesluit

9.3 Het legaliteitsbeginsel

9.3.1 Inleiding

9.3.2 Legaliteit: beginsel of vereiste?

9.3.3 Terugvorderingsbesluiten en legaliteit 284

9.4 Constitutionele aspecten

9.4.1 Inleiding

9.4.2 Het huidige grondwettelijk systeem inzake de rechtsmachtverdeling

9.4.3 De kritiek van Kortmann 294

9.4.4 Besluit of publiekrechtelijke rechtsbetrekking? 295

9.5 Het (processuele) connexiteitsvereiste 295

9.6 Verdere reacties 298

9.6.1 Verdere reacties op de jurisprudentie betreffende

het zuiver schadebesluit

9.6.2 De gevolgen voor de terugvordering 302

9.7 Conclusie en vooruitblik

\section{Hoofdstuk 10}

De bevoegdheid tot terugvordering

10.1 Inleiding

10.2 Een wettelijke grondslag voor terugvordering

10.3 De wettelijke regeling met betrekking tot terugvordering:

een bijzondere of een algemene regeling?

10.4 Uitgangspunten van de wettelijke regeling

10.4.1 Inleiding

10.4.2 Uitgangspunten

10.4.3 Tengvordering van betalingen die niet overeenkomstig het toekenningsbesluit zijn gedaan

10.4.4 De algemene regeling in de Awb

10.5 Bepaling van de aanvang van de termijnen en het rechtskarakter ervan

10.7 Conclusie 


\section{Hoofdstuk 11}

Overheid, terugvordering en privaatrecht

11.1 Inleiding

11.2 Het gebruik van privaatrecht bij terugvordering door de overheid

11.3 De publiekrechtelijke rechtsbetrekking in het kader van de terugvordering

11.4 De publiekrechtelijke rechtsbetrekking en het gebruik van privaatrecht door de overheid

11.5 Verdere kritiek op de doorkruisingsleer

11.6 Conclusie

\section{Hoofdstuk 12}

Rechtsbescherming: bestuursrechter of burgerlijke rechter?

12.1 Inleiding

12.2 Rechtsbescherming door de bestuursrechter

12.3 Het besluit als publiekrechtelijke rechtshandeling en het besluit als rechtsingang bij de bestuursrechter

12.4 De publiekrechtelijke rechtsbetrekking als bevoegdheidscriterium

12.5 Overheid, burgerlijke rechter en burgerlijk recht

12.6 Bestuursrechtspraak en de rechterlijke macht

12.7 Bevoegdheid van de burgerlijke rechter en artikel $112 \mathrm{Gw}$

12.8 Conclusie

Samenvatting

Summary

Lijst van aangehaalde literatuur

Lijst van aangehaalde rechtspraak 


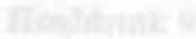

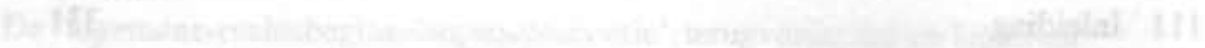

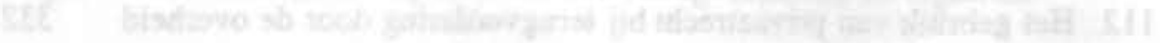

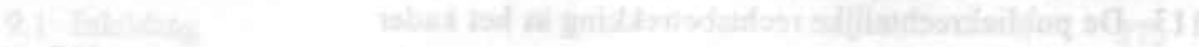

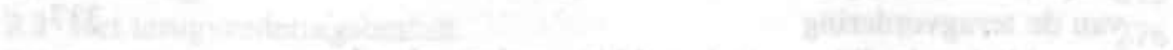

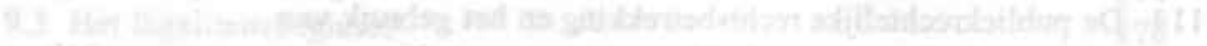

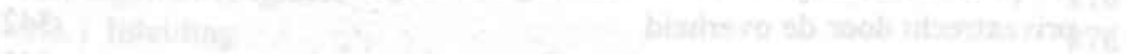

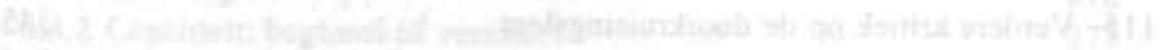

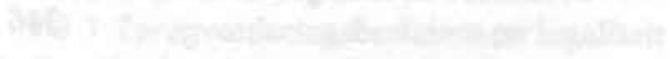

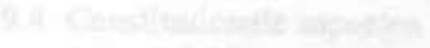

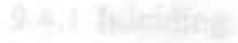

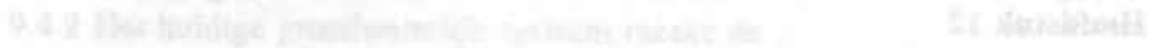

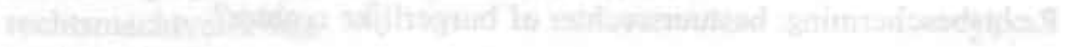

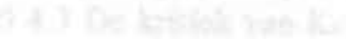

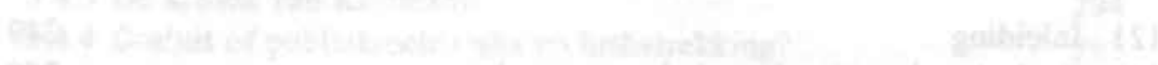

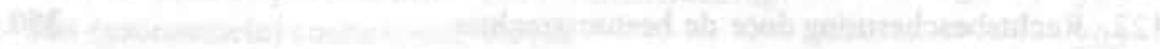

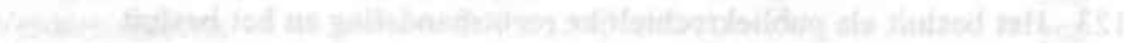

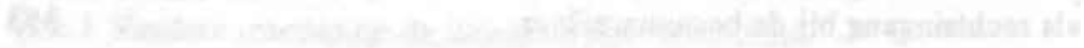

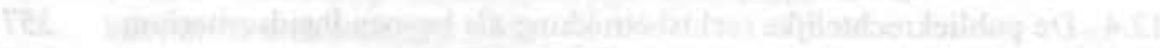

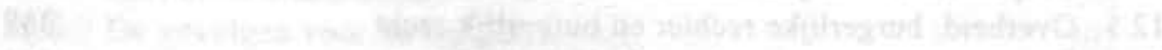
1600

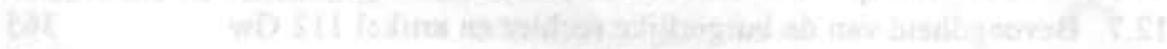
Sint

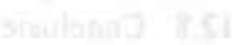

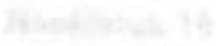

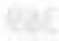

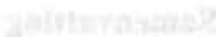

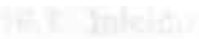

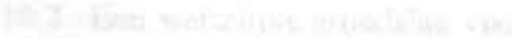

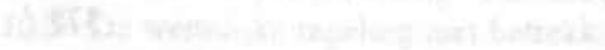

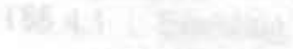

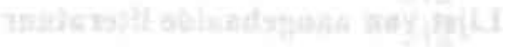

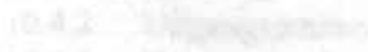

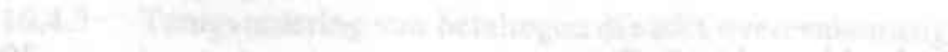

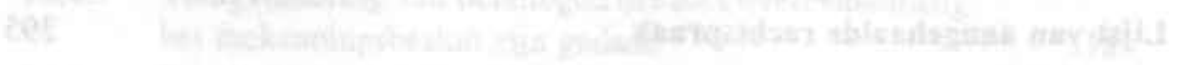

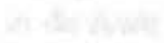




$\begin{array}{ll}\text { AAe } & \text { Ars Aequi } \\ \text { Aant. } & \text { Aantekening } \\ \text { AAW } & \text { Algemene Arbeidsongeschiktheidswet } \\ \text { AB } & \text { Administratiefrechtelijke Beslissingen } \\ \text { ABP } & \text { Algemeen burgerlijk pensioenfonds } \\ \text { ABPW } & \text { Algemene burgerlijke pensioenwet } \\ \text { ABRvS } & \text { Afdeling bestuursrechtspraak Raad van State } \\ \text { Abs. } & \text { Absatz } \\ \text { ABW } & \text { Algemene Bijstandswet (tot 1996) } \\ \text { Abw } & \text { Algemene bijstandswet (vanaf ig96) } \\ \text { Afl. } & \text { Aflevering } \\ \text { Ag. } & \text { Ambtenarengerecht } \\ \text { AMPW } & \text { Algemene militaire pensioenwet } \\ \text { AMvB } & \text { Algemene maatregel van bestuur } \\ \text { AOW } & \text { Algemene Ouderdomswet } \\ \text { ARRvS } & \text { Afdeling rechtspraak Raad van State } \\ \text { Art. } & \text { Artikel } \\ \text { Aw } & \text { Ambtenarenwet } \\ \text { Awb } & \text { Algemene wet bestursrecht } \\ \text { AWW } & \text { Algemene Wezen- en Weduwenwet } \\ \text { B en W } & \text { (College van) burgemeester en wethouders } \\ \text { Blz. } & \text { Bladzijde } \\ \text { BW } & \text { Burgerlijk Wetboek } \\ \text { CBB } & \text { College van Beroep voor het bedrijfsleven } \\ \text { CBS } & \text { Centraal Bureau voor de statistiek } \\ \text { Cbsf } & \text { College van beroep studiefinanciering } \\ \text { CRvB } & \text { Centrale Raad van Beroep } \\ \text { Diss. } & \text { Dissertatie } \\ \text { Dl. } & \text { Deel } \\ \text { EG-verdrag } & \text { Verdrag tot oprichting van de Europese Gemeenschap } \\ \text { EHRM } & \text { Europees Hof voor de rechten van de mens } \\ \text { EU } & \text { Europese Unie } \\ \text { EVRM } & \text { Europese Verdrag voor de rechten van de mens } \\ \text { EZ } & \text { (Ministerie van) Economische Zaken } \\ \text { FBV } & \text { Federatie van Bedrijfsverenigingen } \\ \text { GS } & \text { Gedeputeerde staten } \\ \text { Gst. } & \text { Gemeentestem } \\ \text { Gw } & \text { Grondwet } \\ \text { HR } & \text { Hoge Raad } \\ & \end{array}$




\begin{tabular}{|c|c|}
\hline HSW & Huursubsidiewet \\
\hline HvJ EG & Hof van Justitie van de Europese Gemeenschappen \\
\hline IBG & Informatie Beheer Groep \\
\hline I.f. & In fine \\
\hline IHS & Wet individuele huursubsidie \\
\hline IOAW & $\begin{array}{l}\text { Wet inkomensvoorziening oudere en gedeeltelijk arbeidson- } \\
\text { geschikte werkloze werknemers }\end{array}$ \\
\hline IOAZ & $\begin{array}{l}\text { Wet inkomensvoorziening oudere en gedeeltelijk arbeidson- } \\
\text { geschikte gewezen zelfstandigen }\end{array}$ \\
\hline IW & Invaliditeitswet \\
\hline JAWB & Jurisprudentie Algemene Bijstandswet \\
\hline JB & Jurisprudentie Bestuursrecht \\
\hline$j^{\circ}$ & juncto \\
\hline Jrg. & Jaargang \\
\hline JSV & Jurisprudentie Sociale Voorzieningen \\
\hline Jurispr. & $\begin{array}{l}\text { Jurisprudentie Hof van Justitie van de Europese Gemeen- } \\
\text { schappen }\end{array}$ \\
\hline $\mathrm{KB}$ & Koninklijk besluit \\
\hline Ktr. & Kantongerecht \\
\hline Lisv & Landelijk instituut sociale verzekeringen \\
\hline LNV & (Ministerie van) Landbouw, Natuurbeheer en Visserij \\
\hline m. aant. & met aantekening \\
\hline $\begin{array}{l}\text { M.m. } \\
\text { m.nt. }\end{array}$ & $\begin{array}{l}\text { Mutatis mutandis } \\
\text { met noot }\end{array}$ \\
\hline $\begin{array}{l}\text { m.nt. } \\
\text { Ned. Regtspraak }\end{array}$ & $\begin{array}{l}\text { met noot } \\
\text { Nederlandsche Regtspraak }\end{array}$ \\
\hline NJ & Nederlandse Jurisprudentie \\
\hline NJB & Nederlands Juristenblad \\
\hline NJV & Nederlands(ch)e Juristen-Vere(e)niging \\
\hline nr. & nummer \\
\hline NTB & Nederlands Tijdschrift voor Bestuursrecht \\
\hline NTBR & Nederlands tijdschrift voor Burgerlijk Recht \\
\hline NTER & Nederlands Tijdschrift voor Europees Recht \\
\hline 0. & Overwegende \\
\hline OW & Ongevallenwet \\
\hline PG & Parlementaire geschiedenis \\
\hline Pres. & President \\
\hline PS & $\begin{array}{l}\text { Periodiek voor sociale verzekering, sociale voorzieningen } \\
\text { en arbeidsrecht }\end{array}$ \\
\hline Pub ECHR & Publications of the European Court of Human Rights \\
\hline PW & Pensioenwet \\
\hline PWL & Pensioenwet voor de landmacht \\
\hline PWZ & Pensioenwet voor de zeemacht \\
\hline Rb. & Rechtbank \\
\hline Red. & Redactie \\
\hline RM Themis & Rechtsgeleerd Magazijn Themis \\
\hline
\end{tabular}


R.O.

RSV

Rv

RvB

RvdW

RWW

S\&J

SER

SEW

SMA

SR

$\mathrm{Sr}$

Stb.

Stcrt.

SVB

SVR

SZW

TAR

$\mathrm{tB} / \mathrm{S}$

TvO

UCB

UCV

USZ

VAR

Vgl.

VROM

VwVfG

$\mathrm{V} z$.

W.

WAO

WAR

WBA

Whbo

WBM

WBO

WBP

WBPZ

Wet arbo

Wet arob

Wet bab

Wet odol
Wet op de rechterlijke organisatie

Rechtspraak sociale verzekeringen

Wetboek van Burgerlijke Rechtsvordering

Raad van Beroep

Rechtspraak van de Week

Rijksgroepregeling werkloze werknemers

Schuurman \& Jordens

Sociaa!-Economische Raad

Sociaal-economische wetgeving, Tijdschrift voor Europees en economisch recht

Sociaal Maandblad Arbeid

Nederlands tijdschrift voor sociaal recht

Wetboek van Strafrecht

Staatsblad

Staatscotirant

Sociale Verzekeringsbank

Sociale Verzekeringsraad

(Ministerie van) Sociale Zaken en Werkgelegenheid

Tijdschrift voor ambtenarenrecht

Ten Berge/Stroink e.a. (red.), Administratieve Rechtspraak Overheidsbeschikkingen

Tijdschrift voor openbaar bestuur

Uitspraken College van Beroep voor het bedrijfsleven

Verslag uitgebreide commissievergadering

Uitspraken Sociale Zekerheid

Vereniging voor administratief recht

Vergelijk

(Ministerie van) Volkshuisvesting, Ruimtelijke Ordening en Milieubeheer

Verwaltungsverfahrensgesetz

Voorzitter

Weekblad van het recht

Wet op de arbeidsongeschiktheidsverzekering

Wetboek van Administratieve Rechtsvordering

Weekblad voor de Burgerlijke Administratie

Wet bestuursrechtspraak bedrijfsorganisatie

Wet boeten, maatregelen en terug- en invordering sociale zekerheid

Wet op de Bedrijfsorganisatie

Wet buitengewoon pensioen 1940-1945

Wet buitengewoon pensioen zeelieden-oorlogsslachtoffers

Wet administratieve rechtspraak bedrijfsorganisatie

Wet administratieve rechtspraak overheidsbeschikkingen

Wet beroep administratieve beschikkingen

Wet onrechtmatige daden overheidslichamen 
Wet RvS

Wmb

Wnd.

WPNR

WRSV

WSF

WSW

WW

WWV

Z.j.

Z.p.

ZW
Wet op de Raad van State

Wet milieubeheer

Waarnemend

Weekblad voor Privaatrecht, Notariaat en Registratie

Weekblad voor de Rechtspraak der Sociale Verzekerg

Wet studiefinanciering

Wet Sociale Werkvoorziening

Werkloosheidswet

Wet Werkloosheidsvoorziening

Zonder jaar van uitgave

Zonder plaats van uitgave

Ziektewet 


\title{
INLEIDING
}

\subsection{Terugvordering door de overheid van onverschuldigde betalingen}

\begin{abstract}
'Van de zijde van de overheid worden dagelijks vele betalingen in geld aan de burger gedaan. Voor een zeer belangrijk deel vloeien deze voort uit bijzondere administratieve verhoudingen en worden zij vooraf gegaan door een administratieve beschikking. Over deze betalingen gaat het in dit opstel: ambtenaarssalarissen, ambtenaarspensioenen, sociale uitkeringen, subsidies, beurzen, schadeloosstellingen, premies, toeslagen, enz. De vraag zal behandeld worden of dergelijke betalingen als zij om wat voor reden dan ook ten onrechte zijn geschied, kunnen worden teruggevorderd en zo ja, op welke wijze. Het gaat hier om zeer veel geld: alleen al ingevolge de sociale verzekeringswetten werden in 1980 meer dan 70 miljard gulden uitgekeerd. Het deel hiervan dat ten onrechte zal zijn uitbetaald, zal ongetwijfeld betrekkelijk klein, maar in absolute cijfers toch wel indrukwekkend zijn.'
\end{abstract}

Met deze woorden begon J. de Boer in 1981 zijn artikel Terugvordering door de overheid van onverschuldigde betalingen in RM Themis.' In mijn onderzoek komen dezelfde twee vragen aan de orde: kunnen door de overheid ten onrechte gedane betalingen worden teruggevorderd en zo ja, op welke wijze? Anders dan bij De Boer, die dit punt slechts zijdelings aanstipt, zal hierbij de vraag worden betrokken of de overheid bij terugvordering gebruik mag maken van het privaatrecht, met name van de regeling van onverschuldigde betaling, zoals neergelegd in het Burgerlijk Wetboek (hiema: BW). Hiermee wordt het onderzoek tevens in een breder kader geplaatst: het betreft niet alleen de vraag naar de mogelijk- en onmogelijkheden van terugvordering, maar ook de vraag naar de mogelijk- en onmogelijkheden van het gebruik van privaatrecht door de overheid.

\subsubsection{Terugvordering}

Zoals De Boer in zijn hiervoor geciteerde inleiding al aangeeft, gaat het bij terugvordering van onverschuldigde betalingen door de overheid om grote bedragen. Het door hem genoemde bedrag van 70 miljard gulden, dat in 1980 ingevolge de socialeverzekeringswetten werd uitgekeerd, was in 1992 gestegen tot 115 miljard gulden, terwijl in dat jaar ook nog eens, ruim 26 miljard gulden aan sociale voorzieningen werd uitgekeerd, zodat de totale uitgaven in de sociale zekerheid meer dan 140 miljard gulden bedroegen. ${ }^{2}$ Inmiddels zijn deze uitgaven aan sociale zekerheid onder invloed van het gunstige economische klimaat weer

1. De Boer (1981).

2. CBS, Nationale rekeningen 1992, 's-Gravenhage 1993, tabel S 63.4 (Sociale verzekeringsuitkeringen naar aard en regeling), blz. 169; tabel S 61.8 (Uitkeringen sociale voorziening), blz. 154. 
afgenomen tot iets meer dan 105 miljard gulden in $2000,{ }^{3}$ maar het blijven enorme bedragen. En dan zijn dit alleen de uitgaven in de sfeer van de sociale zekerheid. Uiteraard zijn de uitgaven van de overheid niet hiertoe beperkt. Het is onvermijdelijk, dat bij zulk.e bedragen ook ten onrechte wordt betaald; het bedrag van die ten onrechte gedane betalingen zal in absolute cijfers inderdaad 'indrukwekkend' zijn, zoals De Boer stelt."

Het ligt voor de hand, dat de overheid deze ten onrechte gedane betalingen zoveel mogelijk zal willen terugvorderen, vooral - maar uiteraard niet alleen - in die gevallen waarin sprake is van fraude. Het is zelfs de vraag of de overheid het te veel betaalde niet zoveel mogelijk moet terugvorderen. Bij alle uitgaven die de overheid doet, betreft het immers geld dat toebehoort aan de gemeenschap, en dat direct of indirect is bijeengebracht door die gemeenschap. Deze uitgaven moeten dan ook het belang van de gemeenschap - dit is het algemeen belang - dienen. De vraag, welke bestedingen in het algemeen belang zijn, zal moeten worden beantwoord via democratische besluitvorming. Betalingen gedaan in overeenstemming met deze democratische besluitvorming, dus bijvoorbeeld op grond van een wettelijke regeling, zijn daarom in het algemeen belang, althans moeten worden geacht in het algemeen belang te zijn. Uiteraard is dit anders, indien die betalingen worden gedaan aan personen die daar geen recht op hebben. In dat geval kan zelfs worden gesteld, dat het algemeen belang eist dat wordt teruggevorderd. Een ander (aan het algemeen belang ontleend) argument om ten onrechte gedane betalingen zoveel mogelijk terug te vorderen is, dat het niet corrigeren van fouten misbruik in de hand zal werken. Dit zal zeker het geval zijn als blijkt dat fraude loont, omdat het door de fraude behaalde financiële voordeel mag worden behouden, maar niet alleen in dat geval.

Daar staat tegenover, dat in een groot aantal gevallen bij de burger een bepaalde mate van afhankelijkheid bestaat van de financiële bijdragen, die hij van de overheid krijgt. Deze afhankelijkheid kan zelfs bijzonder groot zijn, namelijk daar waar mensen door middel van deze bijdragen moeten voorzien in hun levensonderhoud. Hierbij kan worden gedacht aan socialezekerheidsuitkeringen of ambtenarensalarissen. In andere gevallen is deze afhankelijkheid weliswaar geringer, maar kan zij toch nog aanzienlijk zijn. Hierbij kan bijvoorbeeld worden gedacht aan bepaalde subsidies, zoals huursubsidie, of studiefinanciering. Hetzelfde kan zich voordoen bij rechtspersonen; er zijn genoeg stichtingen die financieel vrijwel geheel afhankelijk zijn van overheidssubsidies, denk bijvoorbeeld aan stichtingen in de culturele sector. Dit kan ook gelden voor commerciële rechtspersonen, bijvoorbeeld bij startsubsidies voor beginnende bedrijven en 'overlevings-

3. CBS, Nationale rekeningen 2000, Voorburg/Heerlen 2001, tabel D 0.8 (Sociale uitkeringen in geld), blz. 158. In euro's is dit meer dan 47 miljard euro.

4. Zo hadden in 1994 ongeveer 500.000 personen een periodieke uitkering op grond van de $A B W$ of RWW. Krachtens die wetten werd in dat jaar 11,2 miljard gulden uitgekeerd. In datzelfde jaar betrof de geconstateerde uitkeringsfraude bị de gemeentelijke sociale diensten, die hoofdzakelijk verantwoordelijk zijn voor đeze uitkeringen, 240 miljoen gulden. Zie het artikel. 'Meer fraude door effectieve opsporing', CBS index' 1995, nr. 3, blz. 26-27. 
subsidies' voor noodlijdende bedrijven. Terugvordering kan dus bijzonder ingrijpend zijn, te meer als wordt bedacht dat het feit dat te veel is betaald, niet automatisch een gevolg is van fraude. Het komt regelmatig voor dat een fout van een bestuursorgaan de oorzaak is van het te veel betalen. Gelet op de mogelijke afhankelijkheid en de vaak grote gevolgen van terugvordering - mensen kunnen erdoor onder de armoedegrens belanden, bedrijven kunnen erdoor failliet gaan -, is er veel voor te zeggen om terugvordering niet mogelijk te achten, omdat zij een te vergaande aantasting vormt van de persoonlijke belangen van burgers of rechtspersonen. De overheid zal met deze belangen rekening moeten houden. Men kan zelfs betogen, dat het algemeen belang zich in genoemde gevallen verzet tegen terugvordering!

Het zal duidelijk zijn, dat een belangenafweging zal moeten plaatsvinden: zowel het altijd mogelijk achten als het altijd uitsluiten van terugvordering is in strijd met het algemeen belang. Een van de doelen van dit onderzoek is dan ook te bezien, hoe die afweging moet worden gemaakt en welke uitgangspunten bij terugvordering moeten worden gehanteerd. Hierbij zal de vraag aan de orde moeten komen, of het mogelijk is om algemene uitgangspunten te vinden, of dat de verschillende rechtsgebieden verschillende uitgangspunten rechtvaardigen.

\subsubsection{Overheid en privaatrecht}

Momenteel bevat een aantal publiekrechtelijke regelingen bepalingen betreffende terugvordering; er zijn ook regelingen waarin zulke bepalingen ontbreken. Het is de vraag of de overheid in beide gevallen gebruik mag maken van andere wegen dan de publiekrechtelijke, en dan meer in het bijzonder van de regeling betreffende onverschuldigde betaling in het $\mathrm{BW}$, om het ten onrechte betaalde terug te krijgen. ${ }^{5}$ Ook deze vraag zal in het onderzoek aan de orde komen. Hiermee wordt het onderzoek in een breder kader geplaatst, namelijk dat van de vraag, of de overheid gebruik mag maken van het privaatrecht. In de praktijk komt dit gebruik van privaatrecht door de overheid veelvuldig voor. Dit is vooral historisch te verklaren. Sinds het ontstaan van de Nederlandse staat in 1814 is de ontwikkeling van zowel het materiẻle als het formele bestuursrecht in een langzaam tempo verlopen. Lange tijd hebben hier aanzienlijke hiaten bestaan. Vooral het ontbreken van een bestuursrechter, die de burger rechtsbescherming kon bieden tegen de overheid, is een doorslaggevende factor geweest. Dit leidde er nameiijk toe, dat de burgerlijke rechter deze taak op zich is gaan nemen. Deze rechter was geneigd het hem bekende recht toe te passen: het privaatrecht. Bovendien was dit recht veel verder ontwikkeld dan het bestuursrecht, dat nog in de kinderschoenen stond. Het privaatrecht bood dus oplossingen voor problemen, waarvoor nog geen oplossingen bestonden in het bestuursrecht. Zodoende werd het privaatrecht na verloop van tijd gezien als het algemene recht, dat niet alleen gold tussen burgers onder-

5. Andere mogelijkheden zouden bijvoorbeeld kunnen zijn het instellen van een vordering uit onrechtmatige daad of mogelijk het gebruik maken van het strafrecht. 
ling, maar ook tussen burger en overheid en zelfs tussen overheden onderling. De ontwikkeling van het materiêle bestuursrecht had wel consequenties, maar dir leidde slechts tot uitzonderingen op de hoofdregel, dat het privaattrecht ook van toepassing was op verhoudingen waarbij de overheid partij was; het uitgangspunt dat de overheid gebruik mocht maken van het privaatrecht bleef weinig omstreden. Ook de ontwikkeling en verdere uitbouw van de bestuursrechtspraak kon deze situatie niet veranderen. Uiteraard hadden beide ontwikkelingen wel invloed, maar deze betrof niet zozeer de vraag of de overheid gebruik mocht maken van het privaatrecht, maar de vraag hoever die bevoegdheid reikte.

Inmiddels heeft de emancipatie van het bestuursrecht geleid tot het stellen van de principiële vraag of de overheid überhaupt wel gebruik mag maken van het privaatrecht. Worden op die manier niet fundamentele bestuursrechtelijke beginselen en noties omzeild, althans kunnen deze niet op die manier worden omzeild? Deze vraag is vooral van belang omdat Nederland een rechtsstaat is, waarin ook de staat is onderworpen aan het recht. Dit brengt onder andere met zich mee, dat hetgeen de overheid doet democratisch moet zijn gelegitimeerd. ${ }^{6}$ Het is de vraag of deze legitimatie (deels) kan worden gevonden in het privaatrecht.

Aan de andere kant is het zo, dat ondanks de sterke groei van het bestuursrecht die de laatste tijd heeft plaatsgevonden en die nog steeds voortgaat, nog niet gezegd kan worden dat dit bestuursrecht aanspraak kan maken op volledigheid. Het is, zeker in die gevallen waarin het bestuursrecht hiaten bevat, de vraag, of de overheid dan niet 'gewoon' het privaatrecht moet kunnen gebruiken, zoals zij dat reeds meer dan een eeuw doet. Deze vraag zal des te klemmender zijn wanneer het optreden van de overheid in het algemeen belang plaatsvindt. Of is het wellicht zo, dat het algemeen belang juist meebrengt dat géén gebruik mag worden gemaakt van het privaatrecht?

\subsection{Probleemstelling}

Naar aanleiding van hetgeen hiervoor aan de orde is gekomen, kan een aantal vragen worden geformuleerd, die het uitgangspunt vormen voor het onderzoek. Deze vragen zal ik in deze paragraaf expliciteren.

Zoals gezegd bevat een aantal publiekrechtelijke regelingen bepalingen met betrekking tot terugvordering indien te veel is betaald door de overheid. Vooral sinds de jaren tachtig van de twintigste eeuw is de regelgeving op het gebied van terugvordering sterk toegenomen. Dit wil niet zeggen, dat de in die regelingen gegeven mogelijkheden onbegrensd zijn. Begrenzingen zijn niet enkel te vinden in die regelingen zelf, zij zijn ook ontwikkeld in de jurisprudentie. Het is de vraag of in die regelingen en de jurisprudentic een duidelijke lijn zit en, voor zover dit het geval is, of die lijn ook de juiste is.

6. Uiteraard betekent dit niet, dat door die democratische legitimatie ook sprake is van recht, dat dit optreden ook legitiem is. Hierbij spelen bijvoorbeeld ook volkenrechtelijke aspecten een rol. 
Voor de beantwoording van de vraag of ten onrechte gedane betalingen mogen worden teruggevorderd, zal in de eerste plaats moeten worden gekeken of de (publiekrechtelijke) regeling, op grond waarvan is betaald, hierop antwoord geeft. Als die regeling bepalingen bevat met betrekking tot terugvordering, kan men zich afvragen of die bepalingen voldoen. Een andere vraag, die ik reeds heb aangestipt in 1.1.2, is of de overheid ook, naast of in plaats van die bepalingen, gebruik mag maken van de regeling betreffende onverschuldigde betaling in het BW. Deze vraag zal zich ook - en waarschijnlijk zelfs in sterkere mate - voordoen, als de betrokken regeling geen terugvorderingsbepalingen bevat.

De vraag of de overheid gebruik mag maken van het privaatrecht en zo ja, of daaraan grenzen moeten worden gesteld, staat sterk in de belangstelling. De bedoeling van dit onderzoek is om op een beperkt terrein, namelijk de terugvordering, het gebruik van privaatrecht door de overheid te beschrijven en beoordelen. Vervolgens zal ook worden bekeken of vanuit dit beperkte terrein meer algemene conclusies kunnen worden getrokken ten aanzien van het gebruik van privaatrecht door de overheid. Centrale vraag op dit punt is: mag de overheid uberhaupt gebruik maken van het privaatrecht? $\mathrm{Zo} \mathrm{ja}$, is deze bevoegdheid dan onbegrensd?

Met het beantwoorden van deze vragen is nog geen antwoord gegeven op de vraag, welke rechter het optreden van de overheid dient te beoordelen. Moet dit exclusief worden overgelaten aan de bestuursrechter, of kan de burgerlijke rechter ook een deel van die rechtspraak op zich nemen? Deze vraag hangt uiteraard met het voorgaande samen. Zoals gezegd was het feit, dat er lange tijd geen aparte, onafhankelijke bestuursrechter bestond, een van de redenen dat de overheid gebruik is (kunnen) gaan maken van het privaatrecht. De burgerlijke rechter was hierdoor immers min of meer gedwongen de burger rechtsbescherming te bieden tegen de overheid, waarbij hij gebruik maakte van het hem bekende en vertrouwde recht, het privaatrecht. Zodoende is het gebruik van het privaatrecht langzaam in bestuursrechtelijke verhoudingen tussen de overheid en burgers geslopen. Het overlaten van een deel van wat feitelijk bestuursrechtspraak is (of zou moeten zijn) aan de burgerlijke rechter bergt het gevaar in zich, dat deze situatie blijft bestaan. Indien de conclusie moet zijn dat het gebruik van privaatrecht door de overheid niet is toegestaan, ligt het voor de hand dat de burgerlijke rechter niet meer bevoegd zou moeten zijn geschillen tussen de overheid en burgers of tussen overheden onderling te beoordelen. Een andere vraag, die zich in die situatie gaat voordoen, is of de bestuursrechter bij de huidige stand van zaken altijd bevoegd is die geschillen te beoordelen. Als blijkt dat dit niet zo is, zou zich namelijk wederom een hiaat in de rechtsbescherming tegen de overheid gaan voordoen, hetgeen uiteraard niet wenselijk is. In veel gevallen zal dit zelfs in strijd zijn met het internationale recht. ${ }^{7}$ De vragen, die in dit kader aan de orde moeten komen, zijn dan de volgende. Welke rechter(s) moet(en) oordelen over geschillen tussen burger en overheid? Is (zijn) deze rechter(s) hiertoe voldoende geëquipeerd? Zo nee, kunnen dan voorstellen worden gedaan waardoor dit wel het geval wordt?

7. Bijvoorbeeld in strijd met artikel 6 EVRM. 
Een en ander leidt tot een probleemstelling, die de volgende vragen omvat. Wanneer rnag de overheid onverschuldigd gedane betalingen terugvorderen? Kan zij hierbij naar huidig recht gebruik maken van de regeling van onverschuldigde betaling in het $\mathrm{BW}$ ? Zo ja, is dit gebruik maken van het privaatrecht door de overheid bij terugvordering en meer in het algemeen gewenst? Welke rechter dient het overheidsoptreden te beoordelen, zowel bij terugvordering als daarbuiten? Kan dat ook de burgerlijke rechter zijn en, zo ja, hoe wenselijk is dat?

Uitgangspunt bij de beantwoording van deze vragen zal het positieve recht zijn. Ik zal in het tweede deel van het onderzoek - de hoofdstukken 6,7 en 8 - een beschrijving geven van de stand van zaken op de belangrijkste terreinen waarop de overheid financieel presterend optreedt. Bekeken zal worden of op deze terreinen specifieke terugvorderingsbepalingen bestaan in de relevante publiekrechtelijke regelingen en zo ja, hoe deze bepalingen eruit zien. Hierbij zal tevens aan de orde komen of de (eventuele) bepalingen voldoen. Ook zal aan de orde komen of op die specifieke terreinen naar huidig recht nog een rol is weggelegd voor het privaatrecht en de burgerlijke rechter bij terugvordering.

In deze hoofdstukken zal tevens aandacht worden besteed aan de historische ontwikkeling op het desbetreffende terrein. De huidige situatie is immers mede een gevolg van die historische ontwikkeling en dus slechts goed te begrijpen tegen de achtergrond van die ontwikkeling. Dit geldt zowel voor de ontwikkeling van specifieke regelingen, voor het gebruik van privaatrecht bij de terugvordering op het betreffende terrein als voor de rol die de burgerlijke rechter daarbij speelt. Om deze historische ontwikkeling op de verschillende te behandelen terreinen in de juiste context te plaatsen, is het noodzakelijk ook in meer algemene zin de geschiedenis te beschrijven van het gebruik van privaatrecht door de overheid en de rol die de burgerlijke rechter in deze heeft gespeeld, alsmede de ontwikkeling van het bestuursrecht en met name de bestuursrechtspraak. Dit zal gebeuren in het eerste deel van het onderzoek. Daar zullen ook de theoretische onderbouwingen aan de orde komen, die in de loop van de tijd zijn gegeven aan het gebruik van privaatrecht door de overheid. De opvattingen over de (on)mogelijkheden van het gebruik van privaatrecht door de overheid zijn immers ook van invloed geweest op de in de loop van de tijd gemaakte keuzes en daarmee op het huidige stelsel. In dit deel zal tevens blijken in hoeverre keuzes met betrekking tot het gebruik van privaatrecht door de overheid en met betrekking tot de competentie van de burgerlijke rechter, welke in het verleden zijn gemaakt tegen de in die tijd bestaande specifieke achtergrond, zijn blijven bestaan ondanks het feit, dat die achtergrond sindsdien is gewijzigd.

In het derde deel zal ik bekijken of het positieve recht met betrekking tot terugvordering, zoals dat mede historisch is gevormd, voldoet aan de in 1.1.1 weergegeven uitgangspunten, of dus een juiste balans is gevonden tussen de belangen van de samenleving als geheel en van de (rechts)persoon van wie wordt teruggevorderd. Hiertoe zal ik beschrijven hoe deze uitgangspunten in concreto dienen te worden uitgewerkt. Daarbij zal ik ook bekijken of het mogelijk is tot een algemene, publiekrechtelijke terugvorderingsregeling te komen of dat, gelet op 
de verschillen tussen de afzonderlijke rechtsgebieden, per rechtsgebied of mogelijk zelfs per regeling afwegingen moeten worden gemaakt, welke tot verschillende uitkomsten kunnen leiden. Verder zal in dit deel ook de vraag aan de orde komen naar het gebruik van privaatrecht door de overheid in het kader van de terugvordering: mogelijk kan het, maar is het ook wenselijk? Een zelfde vraag kan worden gesteld met betrekking tot de competentie van de burgerlijke rechter. Als nog ruimte blijkt te bestaan voor het adiëren van deze rechter in het kader van de terugvordering, is dit dan een gewenste toestand? Ten slotte zal in dit deel ook de ruimere vraag aan de orde komen of de overheid in het algemeen de mogelijkheid zou moeten hebben om gebruik te maken van het privaatrecht en welke rechter in het algemeen het overheidsoptreden dient te beoordelen. Ik zal hiertoe een aantal lijnen, die ik met betrekking tot terugvordering heb uiteengezet, doortrekken naar deze algemenere vragen. Hierin zit tevens een beperking: conclusies op het meer algemene terrein zijn niet het gevolg van een alomvattend onderzoek op alle terreinen van het bestuursrecht. Desalniettemin ben ik van mening, dat het onderzoek naar de terugvordering door de overheid, mede door de inbedding in de algemene geschiedenis en theorie van het gebruik van privaatrecht door de overheid en de competentie van de burgerlijke rechter, voldoende aanknopingspunten biedt om een aantal lijnen vanuit dit beperkte terrein door te trekken.

\subsection{Afbakening}

Bij de beantwoording van de zojuist geschetste probleemstelling zal ik een aantal grenzen in acht nemen. Een van die grenzen vloeit voort uit de probleemstelling. zelf. Ik zal alleen de terugvordering bekijken van betalingen gedaan door de overheid, waarbij het de overheid is die terugvordert. Het spiegelbeeld, onverschuldigd gedane betalingen aan de overheid, laat ik dus buiten beschouwing."

Een tweede begrenzing is dat het onderzoek alleen betalingen betreft, waalsbij de overheid in eerste instantie presterend optreedt. Hierbij kan bijvoorbeeld worden gedacht aan door de overheid gedane uitkeringen, subsidies, ambtenarensalarissen enzovoort. Deze begrenzing betekent dat een groot deel van de onverschuldigde betalingen in de sfeer van de belastingen buiten het onderzoek valt. Indien op dit terrein sprake is van een onverschuldigde betaling door de overheid, zal dit vaak zijn in de situatie waarin de belastingplichtige in eerste instantie te veel heeft betaald en dit te veel betaalde vervolgens terugkrijgt. Wanneer blijkt dat deze teruggave (deels) ten onrechte is geschied, kan zich de vraag naar terugvordering door de overheid voordoen. In dit geval treedt de overheid niet in eerste instantie presterend op. Ook overigens blijft het belastingrecht buiten beschouwing. Het kent zulke specifieke uitgangspunten, dat het moeilijk is vanuit dit terrein algemenere conclusies te trekken.

8. In zijn dissertatie en een artikel in het NJB gaat M.W. Scheltema op diverse plaatsen wel in op de onverschuldigde betaling aan de overheid, zie Scheltema (1997) en Scheltema (1998). 
Verder zal ik in dit onderzoek alleen de terugvordering van betalingen bekijken, die zijn verricht op grond van een eenzijdige rechtshandeling, waarbij deze rechtshandeling vaak een besluit is. Deze beperking betekent dat terugvordering van betalingen verricht in het kader van een overeenkomst als zodanig niet in dit onderzoek worden betrokken. Verder beperk ik mij tot betalingen, die als definitief bedoeld zijn. Het is zo, dat vele publiekrechtelijke regelingen, op grond waarvan een betrokkene een financiële aanspraak kan krijgen jegens de overheid, de mogelijkheid kennen om in afwachting van de definitieve vaststelling van de aanspraak een voorschot toe te kennen en te betalen. De reden hiervoor is dat de betrokkene vaak in een bepaalde mate financieel afhankelijk is van de bijdrage van de overheid, terwijl het vaststellen van de anspraak veelal enige tijd vergt aan de kant van het bestuursorgaan. In de tussentijd kan dan een voorschot worden toegekend en betaald. Indien de vervolgens toegekende aanspraak lager is dan het betaalde voorschot, of indien blijkt dat de betrokkene in het geheel geen aanspraak geldend kan maken, zal de overheid dit voorschot willen terugvorderen. De terugvordering van deze voorschotten zal niet aan de orde komen. Het gaat dan immers niet om als definitief bedoelde betalingen. Bepaalde aspecten die bij terugvordering van als definitief bedoelde betalingen spelen, zullen bij terugvordering van voorschotten minder van belang zijn. Terugvordering van voorschotten zal in het algemeen op korte termijn plaatsvinden, terwijl de betrokkene weet dat er nog geen sprake is van een definitieve toekenning. Overigens wil dit niet zeggen dat bij terugvordering van voorschotten niet mogelijk dezelfde regels kunnen worden toegepast als bij terugvordering van wel als definitief bedoelde betalingen; dit heb ik - zoals gezegd - niet in het onderzoek betrokken.

Ten slotte zal ik alleen betalingen in geld bekijken. In het normale spraakgebruik wordt met de woorden betalen en betaling vrijwel altijd gedoeld op betalingen in geld. Juridisch gezien zijn deze begrippen niet hiertoe beperkt. Zo omvatten zij bijvoorbeeld ook het geven van zaken of het verrichten van diensten. ${ }^{9}$ Het door de overheid ter beschikking stellen van een gebouw of een terrein als vorm van subsidie kan ook een betaling zijn. Als achteraf blijkt dat dit ter beschikking stellen, deze betaling dus, ten onrechte is geschied omdat er geen rechtsgrond bestond voor deze betaling, kan zich de vraag voordoen of de overheid deze betaling kan 'terugvorderen', bijvoorbeeld door een waardevergoeding te vragen. ${ }^{10}$ Deze vraag zal ik dus buiten beschouwing laten.

Momenteel wordt bij het rechtswetenschappelijk onderzoek vaak gebruik gemaakt van rechtsvergelijking. Het kan voor een beter begrip van het eigen stelsel nuttig blijken een blik over de grenzen te werpen. Daarbij speelt mee dat, zeker in Europa, de meeste landen een soortgelijke economische, politieke en sociale ontwikkeling hebben doorgemaakt, zodat kan worden geleerd van elkaars juridische oplossingen voor gesignaleerde problemen. Toch heb ik ervoor gekozen mij

9. Rank (1996), blz. 142-143 en Scheltema (1997), blz. 30.

10. $\mathrm{Vgl}$. artikel $6: 210$ lid $2 \mathrm{BW}$. 
te beperken tot het Nederlands recht. De reden hiervoor is een praktische. Juist op het terrein van het bestuursrecht bestaan in Europa (en daarbuiten) grote verschillen. Dit komt mede doordat het bestuursrecht in de verschillende landen nooit een gemeenschappelijke 'voorouder' heeft gehad, zoals dat well het geval was bij het privaatrecht. Daarnaast is het zo, dat het bestuursrecht zich in de verschillende landen op uiteenlopende wijzen heeft ontwikkeld. Zo heb ik in 1.1.2 aangegeven, dat een belangrijke factor bij het toepassen van privaatrecht, ook in verhoudingen waarbij de overheid betrokken is, is geweest het ontbreken van een bestutrsrechter, die de burger rechtsbescherming kon bieden. Dit leidde ertoe, dat de burgerlijke rechter deze taak op zich is gaan nemen en conflicten is gaan oplossen met behulp van het hem bekende recht, het privaatrecht dus. In Frankrijk daarentegen is de administratieve rechtspraak wel in een vroeg stadium van de grond gekomen." Daar heeft de situatie met betrekking tot het gebruik van privaatrecht door de overheid een geheel andere ontwikkeling doorgemaakt. Het vergelijken van de situatie met betrekking tot terugvordering in Nederland en Frankrijk vergt dus een vergelijking van het hele publiekrechtelijk stelsel en de geschiedenis ervan, evenals vergelijking van de verhouding tussen privaatrecht en publiekrecht. Hetzelfde geldt voor de vergelijking met Duitsland of Groot-Brittanniē. Bovendien is het de vraag of regels afkomstig uit een ander stelsel bruikbaar zijn in de Nederlandse situatie, mede gelet op de grote verschillen. Het onderzoek zou te omvangrijk worden als de vragen, die ik wil beantwoorden, tevens rechtsvergelijkend aan de orde zouden komen. Om deze reden heb ik hier van afgezien.

Bij terugvordering kan voorts het communautaire recht een rol spelen. Dit zal vooral het geval zijn bij subsidies. Door lidstaten aan ondernemingen verstrekte subsidies kunnen namelijk onder de regeling van staatssteun als bedoeld in artikel 87 EG-verdrag vallen. In dat geval bepaalt het Europese recht (mede) de regels die gelden bij de vraag of en hoe moet worden teruggevorderd. Daarnaast is het zo, dat ook de EU subsidies verstrekt. In dat geval wordt gesproken van communautaire steunverlening. De lidstaten fungeren in dat geval als intermediair. Uiteraard kunnen ook deze subsidies ten onrechte worden verstrekt of betaald. Ook can wordt de terugvordering grotendeels beheerst deor regels van Europees recht, zij het dat hier duidelijke invloeden zijn van het nationale recht. Ik laat ook deze 'Europese terugvorderingsregels' buiten beschouwing; ik heb hier eerder een artikel aan gewijd en volsta met hiernaar te verwijzen. ${ }^{12}$

\subsection{Plan van aanpak}

Een belangrijk deel van de wijze van behandeling die in het onderzoek wordt gevolgd, heb ik reeds uiteengezet in 1.2 . Het onderzoek is opgesplitst in drie delen. Het eerste deel, bestaande uit de hoofdstukken 2 tot en met 5, bevat meer

11. Zie hierover Verheij (1994), blz. 8-11.

12. Bollen (1999). Zie ook Luja (2000). 
algemene historische en theoretische uiteenzettingen met betrekking tot de rechtsbescherming tegen de overheid, de ontwikkeling van het bestuursrecht en het gebruik van privaatrecht door de overheid. Hoofdstuk 2 is gewijd aan de geschiedenis van de rechtsbescherming tegen de overheid door de burgerlijke rechter en de invloed hiervan op het gebruik van privaatrecht door de overheid. In hoofdstuk. 3 wordt de ontwikkeling van het bestuursrecht en de administratieve rechtspraak behandeld. Hoofdstuk 4 is gewijd aan een aantal problemen, dat zich heeft voorgedaan bij de afbakening van de bevoegdheid van de ene rechter ten opzichte van de andere. Door de in de hoofdstukken 2 en 3 geschetste ontwikkelingen is het namelijk mogelijk, dat in bepaalde gevallen zowel de bestuursrechter als de burgerlijke rechter bevoegd is te oordelen over een geschil tussen de overheid en een burger of (privaatrechtelijk) rechtspersoon. Het gebruik van privaatrecht door de overheid en de vraag, of dit gebruik is toegestaan of niet, heeft geleid tot de nodige wetenschappelijke beschouwingen. In verband hiermee is een aantal the0rieěn ontwikkeld, welke in hoofdstuk 5 worden behandeld.

In het tweede deel, de hoofdstukken 6 tot en met 8 , worden de belangrijkste rechtsgebieden behandeld waarop de overheid financieel presterend optreedt $\mathrm{en}_{\mathrm{n}}$ waarbij de terugvordering dus van belang is. Het betreft de sociale zekerheid (hoofdstuk 6), het ambtenarenrecht (hoofdstuk 7) en het subsidie- en sociaaleconomisch recht (hoofdstuk 8). In deze hoofdstukken worden de historische ontwikkelingen op de betreffende terreinen geschetst en wordt bekeken in hoeverre op die terreinen wettelijke regelingen bestaan, in hoeverre die regelingen bepalingen bevatten met betrekking tot terugvordering, en hoe die bepalingen eruit zien. In deze hoofdstukken wordt dus het positieve recht beschreven en geanalyseerd. Hierbij zal op specifieke punten ook kritiek worden geleverd op de bestaande regelingen en jurisprudentie. Verder wordt bekeken hoe de op die terreinen bevoegde bestuursrechters omgaan met terugvordering en of er bij (geschillen over) terugvordering eventueel ruimte is voor de burgerlijke rechter of toepassing van het burgerlijk recht.

Het derde deel bestaat uit de hoofdstukken 9 tot en met 12. Hierin zal ik een antwoord geven op de in 1.2 gestelde vragen. In hoofdstuk 10 wordt bekeken of de bevoegdheid tot terugvordering wettelijk moet worden geregeld en zo ja, aan welke vereisten deze regeling moet voldoen. In dit hoofdstuk komt dus de publiekrechtelijke weg bij terugvordering aan de orde. In hoofdstuk 11 wordt vervolgens de vraag behandeld of bij terugvordering mogelijk ook de privaatrechtelijke weg openstaat voor de overheid. Verder zal ik in dit hoofdstuk bekijken of de conclusies die zijn getrokken met betrekking tot het gebruik van privaatrecht bij terugvordering, mogelijk ook een ruimere gelding hebben. Hoofdstuk 12 bevat het antwoord op de vraag, welke rechter rechtsbescherming tegen de overheid moet bieden, zowel bij terugvordering als daarbuiten. In de hoofdstukken 10 tot en met $12 \mathrm{zal}$ het positieve recht kritisch worden bekeken. Als opmaat naar deze hoofdstukken wordt in hoofdstuk 9 een belangrijke recente wijziging in de jurisprudentie van de bestuursrechters behandeld, waarbij deze rechters publiekrechtelijke bevoegdheden aannemen, waarvoor geen uitdrukkelijke wettelijke grondslag bestaat in het publiekrecht. Een antal rechters leidt deze bevoegdheid af uit alge- 
mene rechtsbeginselen. ${ }^{13}$ Deze jurisprudentie betreft onder meer de terugvordering. Aan de hand van deze jurisprudentie zal ik in dat hoofdstuk ook mijn eigen standpunt behandelen met betrekking tot een aantal publiekrechtelijke beginselen die van belang zijn bij de terugvordering, zoals het legaliteitsbeginsel.

Het onderzoek wordt afgesloten met een samenvatting van de bevindingen.

\subsection{Terugvordering en onverschuldigde betaling}

\subsubsection{Terugvordering: de bestuursrechtelijke weg}

Het onderzoek heeft betrekking op de terugyordering door de overheid, waarbij onder meer de vraag aan de orde komt of daarbij gebruik mag worden gemaakt van de regeling betreffende onverschuldigde betaling in het BW. In deze paragraaf zal ik kort aangeven wat moet worden verstaan onder de begrippen terugvordering en onverschuldigde betaling. De regeling van onverschuldigde betaling in het privaatrecht is neergelegd in het BW; ik zal de hoofdlijnen van deze regeling kort bekijken in 1.5.2. Het bestuursrecht kent geen algemene regeling met betrekking tot terugvordering of onverschuldigde betaling; in zoverre wijkt het dus af van het privaatrecht. Wel kan in het bestuursrecht een aantal stappen worden onderscheiden, die (afhankelijk van de concrete situatie) bij terugvordering aan de orde kunnen en veelal ook zullen komen. Deze stappen worden in deze paragraaf kort. besproken. Hierbij wordt slechts een algemene 'mal' gegeven; sommige wetten, regelingen en rechtsgebieden bevatten afwijkingen en nuanceringen, welke hier buiten beschouwing blijven. Waar nodig zullen zij later in het onderzoek aan de orde komen.

Het onderzoek richt zich, wat de bestuursrechtelijke weg betreft, op terugvordering van betalingen, verricht op basis van een eenzijdige, publiekrechtelijke rechtshandeling, of althans waarbij ervan werd uitgegaan (door een of beide partijen) dat deze betaling werd verricht op basis van een dergelijke rechtshandeling. Normaliter is deze rechtshandeling een besluit, en wel naar de aard een beschikking. In het (publiekrechtelijke) traject dat uiteindelijk tot de terugvordering leidt, kunnen de volgende stappen worden onderscheiden: de aanvraag, het toekenningsbesluit, de betaling, de intrekking van het toekenningsbesluit door het intrekkingsbesluit, het terugvorderingsbesluit, het invorderingsbesluit en ten slotte de executie.

Een beschikking wordt veelal genomen, nadat de belanghebbende daartoe een aanvraag heeft ingediend. Bij deze aanvraag $\mathrm{zal} \mathrm{hij} \mathrm{meestal} \mathrm{bepaalde} \mathrm{inlichtingen}$ moeten geven. Het besluit waarbij positief op het gevraagde wordt beschikt, is het toekenningsbesluit. Dit besluit vormt de rechtsgrond voor de betaling. Wordt

13. Ik spreek van een recente wijziging, hoewel dit niet voor alle bestuursrechters juist is. Zo zal in hoofdstuk 7 blijken, dat bijvoorbeeld de CRvB als ambtenarenrechter deze constructie reeds in de jaren. vijftig van de twintigste eeuw toepaste. 
vervolgens conform dit besluit uitbetaald, dan kan deze betaling niet zonder meer ongedaan worden gemaakt als blijkt dat ten onrechte is betaald. Voor deze ongedaanmaking, de tenugvordering, is namelijk vereist dat de rechtsgrond voor de betaling ontbreekt. ${ }^{14}$ Dit betekent dat als achteraf blijkt dat ten onrechte is betaald omdat ten onrechte is toegekend, de rechtsgrond met terugwerkende kracht aan de betaling moet ontvallen, wil kunnen worden teruggevorderd. Hiertoe moet de toekenningsbeschikking met terugwerkende kracht worden ingetrokken. Dit gebeurt door het intrekkingsbesluit. Als een intrekkingsbesluit is genomen, dan is daarmee slechts de rechtsgrond aan de betaling ontvallen. De betaling heeft dan zonder rechtsgrond, onverschuldigd, plaatsgevonden. Hetzelfde is ook het geval bij een betaling die niet conform een toekenningsbesluit is gedaan. Hierbij kan bijvoorbeeld worden gedacht aan de situatie dat meer is uitbetaald dan werd toegekend. Een intrekkingsbesluit is in dat geval niet nodig.

Het feit dat geen rechtsgrond (meer) bestaat voor de betaling en dat deze dus onverschuldigd is gedaan, betekent nog niet dat ook daadwerkelijk kan worden teruggevorderd. Hiertoe moet het bestuursorgaan allereerst een terugvorderingsbesluit nemen: een besluit waarin het bestuursorgaan aangeeft dat het tot terugvordering zal overgaan. Aangenomen wordt dat door dit terugvorderingsbesluit de (terug)betalingsverplichting, de rechtsvordering, ontstaat. Vervolgens moet het bestuursorgaan nog aangeven op welke wijze de terugvordering ten uitvoer zal worden gelegd, hoe het het onverschuldigd betaalde zal gaan invorderen. Hiertoe moet een invorderingsbesluit worden genomen. ${ }^{15}$ Weigert de betrokkene vervolgens te betalen, dan kan het bestuursorgaan niet zonder meer tot executie overgaan; hiervoor dient het over een executoriale titel te beschikken. De hoofdregel is dat het hiervoor naar de burgerlijke rechter zal moeten gaan, maar de uitzonderingen hierop worden steeds talrijker. Ten slotte zal met de (terug)betaling het terugvorderingstraject worden afgesloten.

Zoals is gebleken, is het niet zo dat altijd alle beschreven stappen moeten worden gevolgd. Als bijvoorbeeld het toekenningsbesluit correct is, maar een fout is gemaakt bij de daarop volgende betaling - er is meer betaald dan was toegekend -, dan hoeft geen intrekkingsbesluit te worden genomen. Executie is bijvoorbeeld niet nodig indien de betrokkene direct en vrijwillig terugbetaalt.

Het bestuursorgaan mag niet zonder meer overgaan tot intrekking van het toekenningsbesluit. Dit geldt ook wanneer in eerste instantie ten onrechte is toegekend, wanneer het toekenningsbesluit dus onjuist is. Verder is het zo dat wanneer wel kan worden ingetrokken en teruggevorderd, de bevoegdheid daartoe zal moeten worden begrensd. In beide gevallen zullen de algemene beginselen van behoorlijk

14. Uiteraard kunnen partijen anders afspreken; de ontvanger van een betaling kan vrijwillig terugbetalen, ondanks het feit dat de rechtsgrond voor die betaling formeel nog steeds bestaat.

15. In een voorkomend geval moeten dus, een intrekkingsbesluit, een terugvorderingsbesluit en een invorderingsbesluit worden genomen. Dit wil niet zeggen dat deze besluiten afzonderlijk moeten worden genomen; zij kunnen ook in één besluit worden vervat. 
bestuur een rol spelen, met name het rechtszekerheids- en het vertrouwensbeginsel. Deze beginselen zullen dan ook ten grondslag moeten liggen aan een eventuele wettelijke regeling. Hoe de precieze uitwerking van deze beginselen dient te luiden, zal in het vervolg van dit onderzoek uitgebreid aan de orde komen. Hier volsta ik met kort aan te geven wat ik onder deze beginselen versta en waar en in welke omstandigheden zij aan de orde komen. Het rechtszekerheidsbeginsel is overigens niet alleen een algemeen beginsel van behoorlijk bestuur, maar het is een algemeen rechtsbeginsel, dat in het bestuursrecht een specifieke uitwerking krijgt.

Bij de vraag of het toekenningsbesluit kan worden ingetrokken en of het onverschuldigd betaalde kan worden teruggevorderd, speelt het vertrouwensbeginsel een belangrijke rol. Het gaat dan om de vraag of de betrokkene er gerechtvaardigd op mocht vertrouwen dat het toekenningsbesluit of de betaling correct was. In de jurisprudentie wordt in dit verband nogal eens gesproken over 'de rechtszekerheid waarop de betrokkene aanspraak heeft, ${ }^{16}$ terwijl in de literatuur in dit verband ook wel wordt gesproken van het materiële rechtszekerheidsbeginsel. ${ }^{17}$ Wat de gevolgen zijn van het (al dan niet ontbreken van dat) vertrouwen komt later uitgebreid aan de orde. Als vervolgens, blijkt dat het vertrouwensbeginsel niet aan intrekking of terugvordering in de weg staat, betekent dit niet dat het onverschuldigd betaalde onbeperkt kan worden teruggevorderd. Mede gelet op de belangen van de betrokkene zal er een begrenzing in de tijd moeten plaatsvinden. Hierbij speelt het rechtszekerheidsbeginsel een rol; op een bepaald moment dient duidelijkheid te worden verkregen over de positie van partijen, zeker waar één der partijen in een afhankelijke positie verkeert. ${ }^{18}$ Dit beginsel ligt onder andere ook ten grondslag aan de verjaringstermijnen uit het $\mathrm{BW} .{ }^{19}$ Ook de gevolgen van het rechtszekerheidsbeginsel bij terugvordering zal ik hierna in dit onderzoek uitgebreid uitwerken.

Ik heb reeds aangegeven dat het geschetste beeld slechts een algemene indruk beoogt te geven van het terugvorderingstraject. Het is gebaseerd op de huidige opvattingen van hoe dit traject eruit dient te zien. Op tal van terreinen hebben de wetgever en de rechter de beschreven stappen inmiddels 'voorgeschreven': de

16. Zie de jurisprudentie aangehaald bij Van Wijk/Konijnenbelt \& Van Male (1999), blz. 367, die deze jurisprudentic, naar mijn mening dus terecht, bespreken bij de behandeling van het vertrouwensbeginsel. Overigens liggen het vertrouwensbeginsel en het (materiele) rechtszekerheidsbeginsel erg dicht bij elkaar, het zijn dan ook keerzijden van dezelfde medaille. 'Waar de ene kant in de andere overgaat, is niet altijd scherp aan te geven', aldus Van Wijk/Konijnenbelt \& Van Male (1999), blz. 355.

17. Zie bijvoorbeeld De Haan/Drupsteen/Femhout 1 (2001), blz. 137, 138 en 142-144. Zie over het gebruik van de termen 'vertrouwensbeginsel' en 'rechtszekerheidsbeginsel' uitgebreider 7.2.4.2.

18. Vgl. de memorie van toelichting op de subsidietitel in de Awb, PG Awb III, blz. 247 en 254 255. Zie ook CRvB 26 april 1990, AB 1991, 157, m.nt. HH, TAR 1990, 138. Deze uitspraak komt in 7.2 .4 .2 verder aan de orde.

19. Zie. onder meer Asser-Hartkamp I' (2000), blz. 585 en Koopmann (1993), blz. 5. 
wetgever in meer recente wetten, ${ }^{20}$ de rechter op die terreinen waar recence wetgeving ontbreekt. ${ }^{21}$ Dit zal blijken in de hoofdstukken 6 tot en met 8 .

\subsubsection{Terugvordering en onverschuldigde betaling: het $B W$}

De (privaatrechtelijke) regeling met betrekking tot onverschuldigde betaling is neergelegd in de artikelen 6:203 tot en met 6:211 BW. In deze paragraaf zal ik de hoofdlijnen van deze regeling beschrijven. Deze regeling betreft de terugvordering van alle onverschuldigd verrichte prestaties. Gelet op de hiervoor gegeven beperking van dit onderzoek tot betalingen van geld, zal ik mij hiema beperken tot de regels die op die betalingen van toepassing zijn.

Artikel 6:203 lid 1 geeft de algemene regel: 'Degene die een ander zonder rechtsgrond een goed heeft gegeven, is gerechtigd dit van de ontvanger als onverschuldigd betaald terug te vorderen'. Het tweede lid voegt daaraan toe: 'Betreft d: onverschuldigde betaling een geldsom, dan strekt de vordering tot teruggave van een gelijk bedrag'. Wanneer ontbreekt een rechtsgrond? Onder rechtsgrond moet worden verstaan een rechtsfeit, dat aanleiding heeft gegeven tot het verrichten van de prestatie. Grofweg kunnen dan twee categorieën worden onderscheiden waarbij de rechtsgrond ontoreekt: er is nooit een rechtsgrond geweest voor deze betaling en er is op het moment van betaling wel een rechtsgrond, maar deze wordt later met terugwerkende kracht vernietigd. ${ }^{22}$ In het eerste geval kan het zo zijn dat er nooit een schuld is geweest: men betaalt per vergissing aan iemand aan wie niet hoeft te worden betaald. Het kan ook zo zijn dat er wel een schuld is geweest, maar dat deze al is betaald. Wordt dan een tweede keer betaald, dan is er voor die betaling nooit een rechtsgrond geweest. Hetzelfde doet zich voor als na de ontbinding van een wederkerige overeenkomst alsnog wordt betaald of als de rechtshandeling op grond waarvan is betaald, nietig is, bijvoorbeeld wegens strijd met de goede zeden. ${ }^{23}$

Bij de tweede categorie - er is op het moment van betaling wel een rechtsgrond, maar deze wordt later vernietigd - is er een geldige verbintenis, en dus rechtsgrond, geweest, maar deze is later met terugwerkende kracht aan de betaling ontvallen. Zo kan de verbintenis bijvoorbeeld tot stand zijn gekomen onder invloed van een wilsgebrek. ${ }^{24}$ Deze verbintenis is dan geldig tot het moment dat zij wordt vernietigd. Deze vernietiging heeft terugwerkende kracht, zodat achteraf alsnog de rechtsgiond aan de betaling komt te ontvallen. ${ }^{25}$ Dit is overigens bij ontbinding van een wederkerige overeenkomst wegens tekortschieten anders.

20. Onder meer in de socialezekerheidswetten zoals in 1996 gewijzigd door de Wet boeten, maatregelen en terug. en invordering sociale zekerheid, en in de subsidietitel in de Awb.

21. Bijvoorbeeld het ambtenarenrecht.

22. Asser-Hartkamp III (1998), blz. 310-314 zeeft een verdere onderverdeling.

23. Zie artikel $3: 40$ lid $\mathrm{I} B W$.

24. Zie de artikelen 3:44 en 6:228 BW.

25. Zie artikel 3:53 lid $1 \mathrm{BW}$ : 'De vernietiging werkt terug tot het tijdstip waarop de rechtshandeling is verricht'. 
Onder het huidige recht is het namelijk zo, dat de ontbinding geen terugwerkende kracht heeft. ${ }^{26}$ Artikel 6:271 bepaalt dan ook uitdrukkelijk dat de rechtsgrond voor reeds nagekomen verbintenissen in stand blijft. Wel ontstaan wat deze reeds nagekomen prestaties betreft zogenaamde ongedaanmakingsverbintenissen, die verplichten tot het 'terugdraaien' van die reeds verrichte prestaties. Prestaties verricht na de ontbinding ontberen, zoals gezegd, wel een rechtsgrond; zij kunnen dan ook worden teruggevorderd als zijnde onverschuldigd betaald.

Is aan de vereisten voor een vordering uit onverschuldigde betaling voldaan, dan is het rechtsgevolg dat een verbintenis tot ongedaanmaking ontstaat, en wel op het moment dat de onverschuldigde betaling plaatsvindt. Wordt deze verbintenis niet nagekomen, dan zijn de algemene regels met betrekking tot het niet nakomen van een verbintenis van toepassing, zij het dat de afdeling over onverschuldigde betaling specifieke bepalingen bevat, die als leges speciales boven de algemene bepalingen gaan. Daar deze bepalingen vrijwel uitsluitend zien op situaties waarin geen sprake is van betaling van een geldsom, maar van een andere prestatie, laat ik deze hier verder onbesproken.

Artikell 3:309 BW geeft de verjaringstermijn van de rechtsvordering uit onverschuldigde betaling: deze rechtsvordering 'verjaart door verloop van vijf jaren na de aanvang van de dag, volgende op die waarop de schuldeiser met zowel het bestaan van zijn vordering als met de persoon van de ontvanger is bekend geworden en in ieder geval twintig jaren nadat de vordering is ontstaan'. Zoals gezegd ontstaat de vordering op het moment van betaling. Op dat moment gaat ook de twintigjarentermijn lopen. De vijfjarentermijn begint wanneer de betaler ook daadwerkelijk weet dat onverschuldigd is betaald, en aan wie. Dit kan op een later tijdstip zijn. Als bijvoorbeeld onder invloed van dwaling een overeenkomst wordt aangegaan die later wordt vernietigd, dan zal de vordering uit onverschuldigde betaling ontstaan op het moment dat de overeenkomst wordt aangegaan. Op dat moment begint dus de termijn van twintig jaren te lopen. Uiteraard zal hier vaak sprake zijn van een juridische fictie, vandaar de tweede termijn van vijf jaren. De schuldeiser zal immers pas met het bestaan van de vordering bekend worden op het moment van de vernietiging; deze vernietiging leidt - weliswaar met terugwerkende kracht tot een eerder moment, namelijk het tijdstip van het sluiten van de overeenkomst - tot het ontstaan van de vordering uit onverschuldigde betaling en op dat moment zal de termijn van vijf jaren aanvangen. ${ }^{27}$

\subsubsection{Korte vergelijking}

Deze beschrijving van het tenugvorderingstraject in het bestuursrecht en het privaatrecht laat zowel overeenkomsten als verschillen zien. Ik zal er een aanta! uitlichten en kort bespreken. De belangrijkste overeenkomst is, dat in beide

26. Artikel 6:269 BW.

27. Zo ook Scheltema (1997), blz. 136, noot 25. Vgl. PG Boek 3 BW, blz. 922-923, Asser-Hartkamp I (2000), blz. 601 en Koopmann (1993), blz. 58. 
gevallen onverschuldigd moet zijn betaald, alvorens kan worden teruggevorderd; de rechtsgrond voor de betaling moet ontbreken. Daarbij kan het zo zijn dat er nooit een rechtsgrond is geweest voor de betaling - het bestuursorgaan heet meer betaald dan waarop de betrokkene recht had op grond van het toekenningsesluit, de rechtshandeling waarop de betaling is gegrond, is nietig of er is betaalcterwijl er geen schuld bestond - of dat de rechtsgrond achteraf met terugwerkend kracht aan de betaling is ontvallen - het toekenningsbesluit is met terugwerkendt kracht ingetrokken, de rechtshandeling is met terugwerkende kracht vernietigl. Een andere overeenkomst is dat zowel in het bestuursrecht als in het privaatecht de mogelijkheid tot het terugvorderen van onverschuldigde betalingen in de tijd is begrensd. De uitwerking hiervan is echter verschillend. In het BW is een secifieke regeling met betrekking tot verjaringstermijnen bij onverschuldigde letaling opgenomen, welke toepasselijk is op alle vorderingen, gegrond op de regelng van onverschuldigde betaling in het BW. Een dergelijke uniforme ternijn betaat in het bestuursrecht niet; verschillende regelingen kennen verschillende terưvorderingstermijnen, terwijl de rechters de mogelijkheid tot terugvordering in de tijd hebben begrensd op die terreinen, waarop geen wettelijke termijnen bestoiden of bestaan.

Er bestaan ook verschillen tussen de (regeling betreffende) terugvordering in het privaatrecht en het bestuursrecht. Een belangrijk verschil is dat wanneer eenmaal onverschuldigd is betaald, wanneer de rechtsgrond ontbreekt, de betaler in het privaatrecht gerechtigd is het onverschuldigde terug te vorderen zonder dat aan verdere formele vereisten moet worden voldaan. In het publiekrecht is het enkele ontbreken van een rechtsgrond niet voldoende om tot terugvordering over te gaan. Er moet eerst nog een terugvorderings- en een invorderingsbesluit worden genomen. Voorts is het zo, dat in het privaatrecht de omstandigheden waaronder onverschuldigd is betaald er in beginsel niet toe doen. In het bestuursrecht is dit vaak anders. Als bijvoorbeeld een werkgever te veel loon betaald aan een werknemer, dan kan hij dit terugvorderen als zijnde onverschuldigd betaald. De vraag of de werknemer wist of behoorde te weten dat te veel werd betaald, doet in het algemeen niet ter zake. Als de overheid een werknemer - een ambtenaar - te veel betaald, wordt de vraag of de ambtenaar wist of behoorde te weten dat te veel werd betaald, wel relevant. Het vertrouwensbeginsel kan aan de terugvordering in de weg staan. Meer in het algemeen kan worden gesteld dat de algemene beginselen van behoorlijk bestuur een prominente rol spelen in het bestuursrecht. In het privaatrecht kan weliswaar de redelijkheid en billijkheid een vergelijkbare rol spelen, dit correctiemechanisme dient echter terughoudend te worden toegepast. ${ }^{28}$ 
gevallen onverschuldigd moet zijn betaald, alvorens kan worden teruggevorderd; de rechtsgrond voor de betaling moet ontbreken. Daarbij kan het zo zijn, dat er nooit een rechtsgrond is geweest voor de betaling - het bestuursorgaan heeft meer betaald dan waarop de betrokkene recht had op grond van het toekenningsbesluit, de rechtshandeling waarop de betaling is gegrond, is nietig of er is betaald terwijl er geen schuld bestond - of dat de rechtsgrond achteraf met terugwerkende kracht aan de betaling is ontvallen - het toekenningsbesluit is met terugwerkende kracht ingetrokken, de rechtshandeling is met terugwerkende kracht vemietigd. Een andere overeenkomst is dat zowel in het bestuursrecht als in het privaatrecht de mogelijkheid tot het terugvorderen van onverschuldigde betalingen in de tijd is begrensd. De uitwerking hiervan is echter verschillend. In het BW is een specifieke regeling met betrekking tot verjaringstermijnen bij onverschuldigde betaling opgenomen, welke toepasselijk is op alle vorderingen, gegrond op de regeling van onverschuldigde betaling in het BW. Een dergelijke uniforme termijn bestaat in het bestuursrecht niet; verschillende regelingen kennen verschillende terugvorderingstermijnen, terwijl de rechters de mogelijkheid tot terugvordering in de tijd hebben begrensd op die terreinen, waarop geen wettelijke termijnen bestonden of bestaan.

Er bestaan ook verschillen tussen de (regeling betreffende) terugvordering in het privaatrecht en het bestuursrecht. Een belangrijk verschil is dat wanneer eenmaal onverschuldigd is betaald, wanneer de rechtsgrond ontbreekt, de betaler in het privaatrecht gerechtigd is het onverschuldigde terug te vorderen zonder dat aan verdere formele vereisten moet worden voldaan. In het publiekrecht is het enkele ontbreken van een rechtsgrond niet voldoende om tot terugvordering over te gaan. Er moet eerst nog een terugvorderings- en een invorderingsbesluit worden genomen. Voorts is het $z o$, dat in het privaatrecht de omstandigheden waaronder onverschuldigd is betaald er in beginsel niet toe doen. In het bestuursrecht is dit vaak anders. Als bijvoorbeeld een werkgever te veel loon betaald aan een werknemer, dan kan hij dit terugvorderen als zijnde onverschuldigd betaald. De vraag of de werknemer wist of behoorde te weten dat te veel werd betaald, doet in het algemeen niet ter zake. Als de overheid een werknemer - een ambtenaar - te veel betaald, wordt de vraag of de ambtenaar wist of behoorde te weten dat te veel werd betaald, wel relevant. Het vertrouwensbeginsel kan aan de terugvordering in de weg staan. Meer in het algemeen kan worden gesteld dat de algemene beginselen van behoorlijk bestuur een prominente rol spelen in het bestuursrecht. In het privaatrecht kan weliswaar de redelijkheid en billijkheid een vergelijkbare rol spelen, dit correctiemechanisme dient echter terughoudend te worden toegepast. ${ }^{28}$ 


\subsection{Burgerlijke rechter en bestuursrechter}

Een van de vragen, die in dit onderzoek aan de orde komt, is welke rechter rechtsbescherming moet bieden tegen de overheid. In verband daarmee zal ik hier kort beschrijven wat in theorie de belangrijkste karakteristieken zijn van zowel de bestuursrechtelijke als de civielrechtelijke rechtsgang. Twee uitgangspunten vallen op. De civielrechtelijke rechtsgang is vooral gericht op het beslechten van geschillen. Uiteraard is dit bij de bestuursrechtelijke rechtsgang ook de bedoeling, maar daar spelen nog andere aspecten een rol. Zo was controle van het bestuur in het verleden een belangrijke factor om voor de burger de weg naar de bestuursrechter open te stellen, terwijl tegenwoordig vooral rechtsbescherming tegen de overheid aan de bestuursrechtspraak ten grondslag ligt. ${ }^{29}$ Uit deze punten kan ook een tweede uitgangspunt worden afgeleid: in het burgerlijk proces wordt uitgegaan van de gelijkheid van partijen; in het bestuursprocesrecht daarentegen van de ongelijkheid. Hoewel op deze twee uitgangspunten nogal wat af te dingen valt, zeker tegenwoordig, zijn zij mijns inziens bepalend voor de verschillen tussen beide rechtsgangen en de beginselen die eraan ten grondslag liggen. Ik zal nu kort deze beginselen bespreken.

Over de beginselen van bestuursprocesrecht is in 1978 door Van Galen en Van Maarseveen gepreadviseerd voor de VAR. ${ }^{30}$ Een groot deel van de door hen beschreven beginselen is terug te voeren op de ongelijkheid van partijen. Binnen het bestuursprocesrecht is altijd een van de partijen de overheid. Er is dan ook vaak sprake van ongelijkheid tussen partijen in zowel financiële, sociale als juridische zin. Naar mijn mening is de ongelijkheidscompensatie dan ook het leidende beginsel. Het trachten deze ongelijkheid op te heffen heeft onder meer geleid tot een laagdrempelige toegang tot de procedure en tot een actieve rol van de rechter. De laagdrempeligheid komt onder meer tot uiting in het beginsel van procesmondigheid, dat meebrengt dat verplichte rechtsbijstand niet bestaat, partijen mogen dus zelf procederen, en het beginsel van kosteloosheid, dat inhoudt dat de staat buiten griffierechten geen andere heffingen vraagt en dat de extra kosten, waarbij kan worden gedacht aan kosten van getuigen of deskundigen, ten laste van de staat

29. In de Awb heeft de wetgever gekozen voor de rechtsbeschermingsfunctie als primaire doelstelling van het bestuursprocesrecht; handhaving van het objectieve bestuursrecht, de controlefunctie dus, is dan ook niet. langer een zelfstandig doel, zodat 'die kenmerken van de bestaande regelingen van bestuursprocesrecht die uitsluitend, dienstbaar kunnen zijn aan het verwezenlijken van de doelstelling van het handhaven van het objectieve publiekrecht' in de Awb niet terugkeren. Hiermee is overigens niet gezegd, aldus de memorie van toelichting, dat het handhaven van het objectieve bestuursrecht in het geheel geen rol meer speelt, zie PG Awb II, blz. 174. Zie ook Van Wijk/Konijnenbelt \& Van Male (1999), blz. 569.

30. Van Galen/Van Maarseveen (1978). 


\subsection{Burgerlijke rechter en bestuursrechter}

Een van de vragen, die in dit onderzoek aan de orde komt, is welke rechter rechtsbescherming moet bieden tegen de overheid. In verband daarmee zal ik hier kort beschrijven wat in theorie de belangrijkste karakteristieken zijn van zowel de bestuursrechtelijke als de civielrechtelijke rechtsgang. Twee uitgangspunten vallen op. De civielrechtelijke rechtsgang is vooral gericht op het beslechten van geschillen. Uiteraard is dit bij de bestuursrechtelijke rechtsgang ook de bedoeling, maar daar spelen nog andere aspecten een rol. Zo was controle van het bestuur in het verleden een belangrijke factor om voor de burger de weg naar de bestuursrechter open te stellen, terwijl tegenwoordig vooral rechtsbescherming tegen de overheid aan de bestuursrechtspraak ten grondslag ligt. ${ }^{29}$ Uit deze punten kan ook een tweede uitgangspunt worden afgeleid: in het burgerlijk proces wordt uitgegaan van de gelijkheid van partijen; in het bestuursprocesrecht daarentegen van de ongelijkheid. Hoewel op deze twee uitgangspunten nogal wat af te dingen valt, zeker tegenwoordig, zijn zij mijns inziens bepalend voor de verschillen tussen beide rechtsgangen en de beginselen die eraan ten grondslag liggen. Ik zal nu kort deze beginselen bespreken.

Over de beginselen van bestuursprocesrecht is in 1978 door Van Galen en Van Maarseveen gepreadviseerd voor de VAR. ${ }^{30}$ Een groot deel van de door hen beschreven beginselen is terug te voeren op de ongelijkheid van partijen. Binnen het bestuursprocesrecht is altijd een van de partijen de overheid. Er is dan ook vaak sprake van ongelijkheid tussen partijen in zowel financiële, sociale als juridische zin. Naar mijn mening is de ongelijkheidscompensatie dan ook het leidende beginsel. Het trachten deze ongelijkheid op te heffen heeft onder meer geleid tot een laagdrempelige toegang tot de procedure en tot een actieve rol van de rechter. De laagdrempeligheid komt onder meer tot uiting in het beginsel van procesmondigheid, dat meebrengt dat verplichte rechtsbijstand niet bestaat, partijen mogen dus zelf procederen, en het beginsel van kosteloosheid, dat inhoudt dat de staat buiten griffierechten geen andere heffingen vraagt en dat de extra kosten, waarbij kan worden gedacht aan kosten van getuigen of deskundigen, ten laste van de staat

29. In de Awb heeft de wetgever gekozen voor de rechtsbeschermingsfunctie als primaire doelstelling van het bestuursprocesrecht; handhaving van het objectieve bestuursrecht, de controlefunctie dus, is dan ook niet langer een zelfstandig doel, zodat 'die kenmerken van de bestaande regelingen van bestuursprocesrecht die uitsluitend dienstbaar kunnen zijn aan het verwezenlijken van de doelstelling van het handhaven van het objectieve publiekrecht' in de Awb niet terugkeren. Hiermee is overigens niet gezegd, aldus de memorie van toelichting, dat het handhaven van het objectieve bestuursrecht in het geheel geen rol meer speelt, zie PG Awb II, blz. 174. Zie ook Van Wijk/Konijnenbelt \& Van Male (1999), blz. 569.

30. Van Galen/Van Maarseveen (1978). 
komen. ${ }^{31}$ De actieve rol van de rechter is terug te vinden in het inquisitoire beginsel. Als eenmaal een procedure is aangebracht dan heeft de rechter de touwtjes in handen: hij is dominus litis. Dit blijkt ook uit het vrij-bewijsbeginsel: hij bepaalt wie wat moet bewijzen en hij waardeert zelfstandig het geleverde bewijs, hij kan getuigen of deskundigen oproepen enzovoort. Het beginsel van de procesmondigheid kan ook slechts bestaan wanneer een rechter actief is: de rechter zal dan de balans in aanwezige kennis, zowel juridisch als anderszins, moeten waarborgen en zo nodig herstellen.

Een fundamenteel onderscheid tussen het bestuursprocesrecht en het burgerlijk procesrecht zit naar mijn mening in de partij-autonomie: in het burgerlijk proces zijn partijen domini litis. Een kenmerk van dit proces is dan ook de lijdelijkheid van de rechter. Dit vloeit mijns inziens mede voort uit het feit dat partijen gelijk worden geacht en vrij zijn zelf te bepalen hetgeen zij aan de rechter willen voorleggen. Daarnaast is het zo dat in het burgerlijk procesrecht de drempel om te gaan procederen hoger is dan in het bestuursprocesrecht; zo is er veelal sprake van verplichte procesvertegenwoordiging, terwijl Van Boneval Faure aan het eind van de negentiende eeuw de niet-kosteloosheid als een hoofdbeginsel van het burgerlijk procesrecht vermeldde. ${ }^{32} \mathrm{Bij}$ het voorgaande moet wel worden bedacht dat de genoemde beginselen in belangrijke mate zijn ontleend aan de 'klassieke' civiele procedure: de dagvaardingsprocedure. Op het moment lijkt in het civiele recht de verzoekschriftprocedure steeds belangrijker te worden. De verschillen met het bestuursprocesrecht blijken bij die procedure kleiner te zijn. ${ }^{33}$ Verder is het zo dat door de herziening van het burgerlijk procesrecht, die in werking trad op 1 januari 2002, de dagvaardingsprocedure wijzigingen heeft ondergaan, waardoor de verschillen tussen deze procedure en de verzoekschriftprocedure zijn afgenomen. ${ }^{34}$ Zo is de lijdelijkheid van de burgerlijke rechter ook in de dagvaardingsprocedure teruggedrongen, ${ }^{35}$ zodat deze rechter in de praktijk een veel actievere rol kan spelen. Hiermee lijken ook de verschillen tussen de dagvaardingsprocedure en het bestuursprocesrecht op dit punt te zijn verminderd.

Een aantal van de genoemde karakteristieken van het bestuursprocesrecht kan evenwel worden genuanceerd, bijvoorbeeld door de zogenaamde argumentatieve fuik, die een aantal bestuursrechters in bepaalde gevallen hanteert. Deze argumen-

31. Overigens is het zo, dat de griffierechten bij de inwerkingtreding, varn de Awb zijn gestegen, terwijl tegenwoordig ook de mogelijkheid bestaat dat de rechter de burger in de kosten veroordeelt die de andere partij, het bestuursorgaan dus, voor de behandeling van het beroep voor de rechter redelijkerwijs heeft moeten maken, zie artikel 8:75 Awb. Wel beperkt lid 1 van dat artikel deze mogelijkheid: 'een natuurlijke persoon kan slechts in de kosten worden veroordeeld in geval van kennelijk onredelijk gebruik van procesrecht'.

32. Van Boneval Faure (1893), blz. 118-119. Zie over de hoofdbeginselen van het burgerlijk procesrecht Hugenholtz/Heemskerk (1998), blz. 7-13.

33. Van Wijk/Konijnenbelt \& Van Male (1999), blz. 571.

34. Zie bijvoorbeeld Wiersma (2002), blz. 8 .

35. Wiersma (2002), blz. 12-13. 
tatieve fuik houdt kort gezegd in, dat bedenkingen in een zo vroeg mogelijk stadium van de procedure naar voren moeten worden gebracht. Gebeurt dit niet dan kan de rechter deze bedenkingen in een later stadium buiten de beoordeling houden; zij mogen dan niet meer naar voren worden gebracht. Concreet betekent dit, dat bijvoorbeeld bedenkingen, feiten of omstandigheden die in de bezwaarfase naar voren hadden kunnen worden gebracht, niet pas bij de rechter mogen worden aangevoerd. ${ }^{36}$ Dit betekent echter dat van de betrokkene een gedegen (juridische) kennis wordt verwacht. Deze zal vaak niet aanwezig zijn. Ongelijkheidscompensatie kan niet meer plaatsvinden; het is immers 'einde oefening' voor de betrokkene. Het feit, dat procesvertegenwoordiging niet verplicht is, kan dan ook in het nadeel van betrokkene werken. ${ }^{37}$ Ook overigens wordt kritiek geuit op het bestuursprocesrecht, zoals dat in de praktijk werkt. ${ }^{38}$ Het is hier echter niet de plaats om uitgebreid in te gaan op de vraag of de bestuursrechtelijke rechtsgang voldoet; dit komt later aan de orde. ${ }^{39}$

\subsection{Begripsbepalingen}

Ter afsluiting van de inleiding zal ik een aantal begrippen, die in het onderzoeksverslag worden gebruikt, kort toelichten. Zo zal een aantal termen als synoniem worden gebruikt. Dit geldt bijvoorbeeld voor de termen burgerlijk recht en privaatrecht; zij zijn inwisselbaar, ik heb althans niet beoogd met deze termen verschillende zaken aan te duiden. ${ }^{40}$ Hetzelfde is het geval met de begrippen rechtsverhouding en rechtsbetrekking.

Enkele regelmatig terugkerende begrippen zijn administratief recht, bestuursrecht en publiekrecht. De eerste twee begrippen zijn wederom synoniemen. Werd oorspronkelijk gesproken van administratief recht, tegenwoordig wordt vrij algemeen de voorkeur gegeven aan de term bestuursrecht. ${ }^{41}$ De term publiekrecht is ruimer; het omvat niet alleen het bestuursrecht, maar ook het staatsrecht. In een nog ruimere betekenis vallen ook strafrecht, internationaal recht en procesrecht eronder. Desalniettemin zal ik veelal geen onderscheid maken tussen de begrippen publiekrecht en bestuursrecht. Dit is ook niet problematisch, nu uit de context blijkt als de term 'publiekrecht' ruimer wordt bedoeld dan het bestuursrecht. Iets soortgelijks kan worden gezegd van de begrippen 'overheid', 'bestuur' en 'bestuursorgaan'. Ook tussen deze begrippen kan een onderscheid worden gemaakt; ik heb dit hier niet beoogd. De 'wederpartij' van de overheid heb ik ook

36. Zie hierover onder meer Damen (1999-1), blz. 27-33 en Schlossels (1999), blz. 181-185.

37. Zie Bollen (2000), blz. 311.

38. Bijvoorbeeld door Tak (1999-I).

39. Zie onder meer hoofdstuk 12.

40. Tak (1999-II), blz. 3-4 maakt wel onderscheid tussen beide termen.

41. Zo veranderde de Vereniging voor administratief recht in 1998 haar naam in 'Vereniging voor bestuursrecht' en heet het vertrouwde handboek Van Wijk/Konijnenbelt sinds de lle druk uit 1999 niet meer Hoofdstukken van administratief recht, maar Hoofdstukken van bestuursrecht. 
met verschillende termen aangeduid: burger, betrokkene en soms belanghebbende. Hierbij moet worden bedacht dat deze wederpartij niet altijd een natuurlijk persoon hoeft te zijn; het kan immers ook een (privaatrechtelijke) rechtspersoon zijn. Uit de context zal veelal blijken of met de genoemde begrippen burger, betrokkene of belanghebbende mede die rechtspersonen worden bedoeld. In bepaalde gevallen zal uit de aard van de materie reeds blijken dat alleen wordt gedoeld op natuurlijke personen, bijvoorbeeld bij socialezekerheidsuitkeringen of ambtenarensalarissen; anders ligt dit bij bijvoorbeeld subsidies. ${ }^{42}$

Ten slotte zal de term intrekking (van het toekenningsbesluit) regelmatig worden gebruikt. In 1.5.1 is reeds ingegaan op de positie die de intrekking inneemt in het terugvorderingstraject. Naast intrekking kan ook herziening van het besluit plaatsvinden, terwijl voorts bij intrekking kan worden onderscheiden tussen intrekking alleen voor de toekomst en intrekking die ook of alleen voor het verleden werkt. Wat de periode betreft waarop de intrekking betrekking heeft: verleden, toekomst of beide, het volgende. In dit onderzoek zal de term 'intrekking' worden gehanteerd wanneer het gaat om een intrekking met terugwerkende kracht, de intrekking ex tunc. Voor het intrekken van een besluit voor de toekomst - het betreft dan dus intrekking ex nunc - prefereer ik de term 'opzeggen' van het besluit. ${ }^{43} \mathrm{Bij}$ het intrekken van een besluit in de hiervoor aangegeven betekenis kan voorts een onderscheid worden gemaakt tussen het geheel intrekken en het gedeeltelijk intrekken. Dit laatste wordt veelal aangeduid als 'herzien'; de oorspronkelijke beslissing krijgt een gewijzigde inhoud. In het kader van dit onderzoek geldt dat hetgeen gezegd wordt over intrekking ook geldt voor herziening. Feitelijk zou dan ook vrijwel overal waar ik de term intrekking hanteer, tevens de herziening moeten worden genoemd. Om redenen van leesbaarheid heb ik daarvan afgezien. In plaats van te spreken van intrekkings- en herzieningsbesluit (of intrekkings-/herzieningsbesluit) of intrekkings- en herzieningsbevoegdheid zal ik kortheidshalve de terrn intrekkingsbesluit of intrekkingsbevoegdheid gebruiken. Ik zal hier slechts sporadisch van afwijken, bijvoorbeeld indien de betrokken wet uitdrukkelijk de term 'herzien' gebruikt in plaats van 'intrekken'. Dan is een afwijking gerechtvaardigd, omdat anders citaten uit de wetstekst of uit uitspraken verwarring kunnen wekken. Dit is bijvoorbeeld het geval bij de Wet studiefinanciering 2000 en de voorloper van deze wet, de Wet op de studiefinanciering, en bij overheidspensioenen. ${ }^{44}$

42. Maar ook hier kan de aard van de subsidie uiteraard meebrengen, dat slechts natuurlijke personen worden bedoeld, denk bijvoorbeeld aan huursubsidie.

43. Anders Van, Wijk/Konijnenbelt \& Van Male (1999), blz. 428, die het begrip "intrekken" hanteren als algemeen begrip, waaronder zowel het intrekken voor het verleden als voor de toekomst valt. Intrekken met terugwerkende kracht noemen zij terugnemen, intrekking voor de toekomst opzegging.

44. Zie respectievelijk 8.3 en 7.3 . 
DEEL I 



\section{ADMINISTRATIE, BURGERLIJKE RECHTER EN BURGERLIJK RECHT: HISTORISCHE ONTWIKKELINGEN}

\subsection{Inleiding}

Historisch gezien bestaat er een nauw verband tussen de omstandigheid dat er lange tijd geen specifieke rechter is geweest, die het handelen van de overheid, van de administratie, ten opzichte van de burger kon controleren en de omstandigheid dat de overheid gebruik is gaan maken van het privaatrecht. De burgerlijke rechter is namelijk de leemte gaan invullen, die bestond in de rechtsbescherming tegen de overheid. De criteria die hij daarbij hanteerde om zijn bevoegdheid vast te stellen en af te bakenen, waren echter zo ruim dat deze ook voor de overheid een rechtsingang boden. Mede door het grotendeels ontbreken van administratief recht, was de rechter geneigd privaatrecht toe te passen, ook in verhoudingen waarbij de overheid was betrokken. Wel zag hij in dat de administratie een bepaalde mate van vrijheid moest worden gelaten; zoals zal blijken deed hij dit uiteindelijk niet via de bevoegdheidsvraag, maar via de ontvankelijkheidsvraag.

Vanaf het begin van de twintigste eeuw heeft een geleidelijke uitbouw plaatsgevonden van de administratieve rechtsbescherming door (specifieke) bestuursrechters, een ontwikkeling waarvan het (concrete) begin kan worden gesitueerd in 1901. Deze ontwikkeling heeft op twee manieren invloed gehad op het gebruik van het privaatrecht door de overheid. In de eerste plaats hield de burgerlijke rechter rekening met het feit dat in bepaalde gevallen een administratiefrechtelijke rechtsgang openstond, hetgeen ertoe leidde dat hij in bepaalde gevallen geen inhoudelijk oordeel gaf over het geschil dat bij hem voorlag. In de tweede plaats gaven (bepaalde) administratieve rechters het privaatrecht vee! minder ruimte dan de burgerlijke rechter in een verhouding tussen de overheid en de burger.

In de komende drie hoofdstukken zal deze ontwikkeling kort worden beschreven. Aan de orde zal dus zijn de wisselwerking tussen de rechtsgang en het gebruik van privaatrecht door de overheid. Deze hoofdstukken zullen dus niet specifiek gericht zijn op terugvordering, maar op de wat bredere context van het gebruik van privaatrecht door de overheid.

In dit hoofdstuk zal ik vooral de rol van de burgerlijke rechter bekijken. Deze rechter heeft (zoals gezegd) met betrekking tot het gebruik van het privaatrecht. door de overheid in de negentiende eeuw een belangrijke rol gespeeld. Een afronding van de ontwikkeling van die fase kan worden gesitueerd in 1915, toen de Hoge Raad in het arrest Noordwijkerhout-Guldemond ${ }^{\prime}$ definitief het criterium heeft gegeven aan de hand waarvan de burgerlijke rechter zijn bevoegdheid diende 
te bepalen.

In hoofdstuk 3 zal ik de opkomst en de ontwikkeling van de administratieve rechtspraak beschrijven. De vraag hoe de burgerlijke rechter reageerde op het bestaan van een administratiefrechtelijke rechtsgang en de vraag hoe de bestuursrechter zijn bevoegdheid bepaalde, zullen aan de orde komen in hoofdstuk 4 .

Hiervoor heb ik al enige malen de term 'burgerlijke rechter' gebruikt. Deze term is echter minder juist waar het het begin van de negentiende eeuw betreft; in die tijd kende men het begrip 'burgerlijke rechter' namelijk nog niet. Men sprak over de gewone rechter of de rechterlijke macht. Hieronder vielen wat wij heden ten dage noemen de burgerlijke rechter en de strafrechter. Hieronder vielen niet de administratiefrechtelijke colleges, voor zover die al bestonden. De tegenstelling administratieve rechter-burgerlijke rechter was dus onbekend.

Een van de redenen waarom de term burgerlijke rechter in genoemde tijd niet geheel juist is, is dat de term 'burgerlijk' toen een andere betekenis had dan deze term nu heeft. Onder burgerlijk werd namelijk verstaan 'vermogensrechtelijk', op geld waardeerbaar. Het kwam overeen met de toen gebruikelijke betekenis van 'civiel'. ${ }^{2}$ De term had dan ook tevens betrekking op verhoudingen tussen overheid en burgers, op de vermogensrechtelijke positie van het bestuur. Als zodanig stond 'burgerlijk' dus niet tegenover - in de huidige terminologie - het publiekrecht. ${ }^{3}$ Pas in de jaren veertig van de negentiende eeuw werd aan het begrip burgerlijk voor het eerst de huidige betekenis toegekend. lk heb er desondanks voor gekozen de term 'burgerlijke rechter' ook in deze periode te gebruiken als synoniem voor de gewone rechter of de rechterlijke macht.

\subsection{De bevoegdheid van de burgerlijke rechter: de artikelen $165 \mathrm{Gw} 1815$ en 2 R.O.}

Vrij snel na het ontstaan van het Koninkrijk der Nederlanden in 1814 werd in de Grondwet een artikel opgenomen, dat de competentie van de gewone rechter regelde. Artikel 165 van de Grondwet van 1815 bepaalde:

'Aile wwistgedingen over eigendom of dasruit voortspruitende regten, over schuldvordering of burgerlijke regten, behooren bij uitsluiting tot de kennis van de regterlijke magt'.

Dit artikel werd ingegeven door de wens om een (van de administratie) onafhankelijke rechter bescherming te laten bieden tegen aantastingen van het particulier vermogen, ook en voornamelijk door de overheid. ${ }^{4}$ Aangezien een administratieve

2. Ik zie op het eerste gezicht parallellen met het begrip 'civil rights', 'burgerlijke rechten', in artikel 6 EVRM. Zie over (de uitleg van) dit begrip Viering (1994), blz. 102-142.

3. Zie hierover Teunissen (1996), blz. 60-63.

4. Het was dan ook een reactie op het Franse conflictenstelsel, dat ook in het Koninkrijk Holland heeft gegolden tussen. 1810 en 1814. Zie hierover Drion (1950), blz. 57-60. 
rechter niet bestond, was men aangewezen op de gewone rechter. ${ }^{5}$ Doel van de grondwetsbepaling was dat niet de administratie, maar de rechter zelf over zijn competentie diende te beslissen; hij kreeg de zogenaamde Kompetenz-Kompetenz toegewezen. Dit doel werd bereikt door de woorden 'bij uitsluiting' in artikel $165 .^{6}$ Met deze woorden werd dan ook bedoeld dat de rechterlijke macht bij uitsluiting van de administratieve macht haar competentie diende te bepalen. ${ }^{7}$ Het feit dat de rechterlijke macht 'bij uitsluiting' bevoegd was, betekende dus niet, dat zij exclusief bevoegd was, zoals later wel werd aangenomen." Voorts bracht deze bepaling met zich mee, dat de burgerlijke rechter competent was indien een van de genoemde rechten werd geschonden, ook als dit gebeurde door een overheidslichaam, zelfs als de overheidsgedraging was gebaseerd op een publiekrechtelijke bevoegdheid.' Artikel 165 Gw 1815 werd in 1827 overgenomen in artikel 2 Wet op de Regterlijke Organisatie. ${ }^{10}$ Vanaf dat moment ging de rechter zijn bevoegdheid (vooral) baseren op dit laatste artikel.

Op grond van eerst artikel $165 \mathrm{Gw}$, later artikel 2 R.O., achtte de burgerlijke rechter zich dus competent kennis te nemen van vorderingen tegen de overheid, mits werd voldaan aan het vereiste dat sprake was van een twistgeding over eigendom of een daaruit voortspruitend recht, een schuldvordering of een burgerlijk recht. Hierbij speelde een rol dat de burger vaak geen andere mogelijkheid had om bij een onafhankelijke instantie op te komen tegen administratieve handelingen: administratieve rechtspraak bestond niet, afgezien van het terrein van de belastingen. De burgerlijke rechter was zodoende de enige die de burger rechtsbescherming kon bieden tegen de overheid. Hierbij speelde in deze tijd de aantasting van de eigendom en de onrechtmatige daad een belangrijke rol. Vooral de eigendom was heilig; inbreuken op een eigendomsrecht, gepleegd door de overheid in het algemeen belang waren niet onmogelijk, maar dienden wel vrijwel altijd te berusten op een wettelijke grondslag.

Het feit dat de burgerlijke rechter de burger rechtsbescherning ging bieden, was zeer tegen de zin van de administratie. $\mathrm{Zij}$ vreesde dat de rechter op deze wijze kon ingrijpen in haar (beleids)vrijheid. De mogelijkheid bestond immers dat

5. Teunissen (1996), blz, 163-164.

6. Zie Drion (1950), blz. 77-78.

7. Zie ook Alen (1984), blz. 694-697 en Poortinga (1987), blz. 261. De Vries (1917), blz. 339 (noot 2) kwam tot een andere slotsom.

8. Bijvoorbeeld door Zonderland (1954): blz. 60-63. De opvatting van Zonderland komt aan de orde in 2.4.1.

9. Zie voor een overzicht, van de rechtspraak over de bevoegdheid van de burgerlijke rechter in de periode 1815-1821 De Vries (1917).

10. Wet van 16 april 1827, op de zamenstelling der Regterlijke magt en het beleid der Justitie "Stb. 20. Artikel 2. luidde: 'De kennisneming en beslissing van alle geschillen over eigendom of daaruit voortspruitende regten, over schuldvorderingen of burgerlijke regten, en de toepassing van alle soort van wettig bepaalde straffen, zijn bij uitsluiting opgedragen aan de regterlijke magt, volgens de verdeelingen van regtsgebied, de regterlijke bevoegdheid en de werkzaamheden bij deze wet geregeld'. 
de rechter op vordering van een burger de administratie zou veroordelen ie ts te doen of te laten, dus een gebod of verbod zou uitspreken tegen de overheid. ${ }^{1}$ De administratie kende dan ook aan artikel $165 \mathrm{Gw}$ een beperkte betekenis toe: de burgerlijke rechter kon slechts competent zijn indien geen sprake was van een uitoefening van een administratieve bevoegdheid; was hiervan wel sprake, dan diende het oordeel hierover te worden gegeven door de administratie zelf, eventueel door een hogere administratieve instantie. Daarnaast vond de administratie, anders dan in vele gevallen de rechter, dat zij zelf moest oordelen ove $e_{r}$ de omvang van haar bevoegdheid. ${ }^{12}$

Deze strijd tussen de administratie en de rechterlijke macht leidde uiteindelijk tot het in 1822 door Koning Willem I uitgevaardigde Conflictenbesluit, ${ }^{13}$ dat de kant van de administratie koos. ${ }^{14}$ De consequentie van dit besluit was dat uiteindelijk niet meer de rechter oordeelde over zijn eigen competentie, maar dat dit verd gedaan door de Kroon, de administratie dus. De Kroon kon namelijk op grond van dit besluit de geschillen, door artikel $165 \mathrm{Gw}$ ter uitsluitende kennisneming opgedragen aan de burgerlijke rechter, onttrekken aan deze rechter.

Het Conflictenbesluit betekende een afname van de rechtsbescherming die de burger genoot tegen handelingen van de overheid. Het stuitte dan ook op veel bezwaar. Het was duidelijk in strijd met (de geest van) artikel $165 \mathrm{Gw} .{ }^{15} \mathrm{Om}$ dit laatste verwijt te omzeilen werd zowel artikel $165 \mathrm{Gw}$ als artikel 2 R.O. meerdere malen restrictief geïnterpreteerd: de burgerlijke rechter zou volgens deze uitleg slechts bij uitsluiting bevoegd zijn indien het recht, bijvoorbeeld het eigendomsrecht of het bezit, werd ontkend door de wederpartij. Alleen in dat geval was volgens deze interpretatie sprake van een twistgeding. ${ }^{16}$

Het verzet tegen het Conflictenbesluit werd ten slotte zo sterk dat de minister van Justitie in april 1842 het opwerpen van nieuwe conflicten verbood. In 1844

11. Dat deze mogelijkheid niet denkbeeldig was, blijkt bijvoorbeeld uit de zaak betreffende de Rosolymolen, Hoog Geregtshof der Vereenigde Nederlanden 28 oktober 1818, A.gemeen Rijksarchief 's-Gravenhage, Archief Hooggerechtshof 1811-1838, Eerste civiele kamer, inv. nr. 497, ongefolieerd, audientieblad 1143. De uitspraak wordt vermeld door onder meer De Vries (1917), blz. 345-347 en Drion (1950), blz. 118-120.

12. Zie over deze strijd tussen de rechter en de administratie het derde hoofdstuk van Drion (1950). Zie ook Vegting (1957), blz. 355-357.

13. Besluit van 5 oktober 1822 , houdende voorziening, aangaande de conflicten van attributen tusschen de administrative en regterlijke authoriteiten, Stb. 44 .

14. Zie over het Conflictenbesluit onder meer Drion (1950).

15. Drion (1950), blz. 170-171. Zo ook Vegting (1957), blz. 360. Dit was in de periode vóór de inwerkingtreding van het Conflictenbeșluit ook uitdrukkelijk het oordeel van de Raad van State en de Koning, zie hierover Drion (1950), blz. 78-92, in het bijzonder blz. 90 en Van Poelje (1984), blz. 121. Overigens vond niet iedereen een conflictenstelsel in strijd met (de bedoeling van) artikel $165 \mathrm{Gw} 1815$. Zo vond bijvoorbeeld Thorbecke een dergelijk stelsel grondwettig. mits neergelegd in een wet in formele zin. Zie hierover Poortinga (1987), hoofdstuk 7.

16. Zie Drion (1950), blz. 177-178 en Meijers (1916), blz. 468. 
werd het Conflictenbesluit ingetrokken. ${ }^{17}$ Dit betekende dat de burgerlijke rechter weer zelf zijn competentie kon bepalen op grond van artikel 2 R.O. Was echter geen sprake van een geschil 'over eigendom of daaruit voortspruitende regten, over schuldvorderingen of burgerlijke regten', dan bleef de burger grotendeels verstoken van rechterlijke bescherming. Een administratieve rechter bestond immers niet. ${ }^{18}$

\subsection{Van rechtsbescherming tegen de overheid naar rechtsbescherming voor de overheid}

Sedert de jaren veertig van de negentiende eeuw was het dus voor de burger weer mogelijk om naar de burgerlijke rechter te stappen indien de overheid een inbreuk maakte op zijn eigendomsrecht of onrechtmatig jegens hem handelde. Opvallend genoeg zien we sinds deze tijd ook gevallen waarin de overheid een actie instelde tegen een burger, eveneens een beroep doende op (inmiddels) artikel $163 \mathrm{Gw}$ $1840^{19}$ en artikel 2 R.O., teneinde een publiekrechtelijk doel te bereiken.

Zo diende in september 1842 een zaak voor de Rechtbank Deventer, waarbij het Rijk amotie vorderde van een gebouw dat door de weduwe Zuithoff op een aan de weduwe toebehorend stuk grond was gebouwd binnen een bepaalde afstand van de vesting Deventer. Op grond van artikel 11 Wet militaire 's lands gronden en gebouwen ${ }^{20}$ was het de eigenaren of bewoners van onder meer 'buitenplaatsen, stallingen, huizingen, boerenwoningen, schuren of getimmerten van welken aard ook', welke zich binnen een afstand van 300 roeden van de vesting bevonden, verboden hieraan verdere vertimmeringen te doen dan nodig waren voor het behouden van de eigendommen in de staat waarin zij zich bevonden. De controle hierop was opgedragen aan de officieren van de genie in de vestingen, die bij overtreding 'zich daarover moeten adresseren aan het plaatselijk bestuur, hetwelk alsdan de noodige maatregelen daar tegen zal in het werk stellen, en zich, ingeval van verschil, daarover aan den Secretaris van Staat voor de Binnenlandsche Zaken adresseren'. Een regeling ingeval van geschillen kende de wet niet.

Het Rijk wendde zich tot de burgerlijke rechter. De rechtbank verklaarde zich onbevoegd, maar het Provinciaal Geregtshof in Overijssel vernietigde deze

17. Besluit van 20 mei 1844 , omtrent het intrekken en buiten werking stellen van dat van de 5 October 1822. (Staatsblad $\mathrm{n}^{\circ} .44$ ), aangaande de conflicten van attributien tusschen de administrative en regterlijke authoriteiten, Stb. 25.

18. Slechts op een enkel terrein, bijvoorbeeld belastingen (zie Vegting (1957), blz. 364), en in enkele wetten werden regelingen opgenomen voor de beslechting van geschillen. Maar deze 'rechts'gangen waren onbevredigend; er waren geen procedurele regels, terwijl de betrokken burger veelal niet bij de rechtsgang werd betrokken. Dit gold speciaal in procedures: bij de Kroon, Donner (1987), blz. 308, Vegting (1957), blz. 364-365.

19. Dat gelijk was aan artikel $165 \mathrm{Gw} 1815$.

20. Wet van 16 november 1814 , houdende bepalingen omtrent de militaire 's lands gronden en gebouwen; en het bouwen en aanleggen van woningen, tuinen, boomgaarden of andere gestichten in den omtrek van vestingen, sterkten, posten en linien van defensie, Stb. 106. 
uitspraak. De weduwe ging in cassatie, stellende dat de burgerlijke rechter niet competent was over de vordering te oordelen. Het Rijk ageerde immers niet als eigenaar, noch was ex sprake van een twistgeding als bedoeld in artikel 2 R.O.; het Rijk handelde slechts als uitvoerende macht.

Het verweer van het Rijk was dat de burgerlijke rechter wel bevoegd was, onder meer omdat de ingestelde vordering strekte tot handhaving van een recht, bij wet aan de Staat toegekend, terwijl de regeling daarover geen verdere bepalingen bevatte, zodat de burgerlijke rechter bevoegd was. Bovendien stelde het Rijk dat de vordering betrekking had op rechten van Zuithoff, welke voortsproten uit haar eigendom. ${ }^{21}$

De Hoge Raad oordeelde als volgt:

'Overwegende, dat, ingevolge art. 163 der Grondwet, alle twistgedingen over eigendom, of daaruit voortspruitende regten, over schuldvordering of burgerlijke regten bij uitsluiting behooren tot de kennisneming der regterlijke magt, zonder uitzondering tusschen welke personen, of door of jegens welke ligchamen die twistgedingen worden gevoerd;

O., dat. de Staat of het Rijk der Nederlanden dienvolgens het onderhavig regtsgeding, strekkende tot amotie van een gebouw, door de eischeresse in cassatie op haren grond (zoo de Staat beweert ten onregte) gesticht, te regt heeft gebragt voor der eischeresses dagelijkschen en gewonen regter, en wel verre van daardoor de voornoemde Grondwetsbepaling te hebben geschonden, dezelve integendeel met juistheid heeft gebragt in toepassing, en dat dan ook met even veel juistheid bij het beklaagde arrest de daartegen door de eischeresse opgeworpen exceptie van incompetentie is verworpen, vermits hier ontwijfelbaar geschil is over eigendom en daaruit voortspruitende regten'. ${ }^{22}$

Er was dus volgens de Hoge Raad sprake van een geschil over eigendom en daaruit voortspruitende rechten en dus was de burgerlijke rechter bevoegd.

Voor zover ik heb kunnen nagaan was dit de eerste keer dat de overheid naar de burgerlijke rechter stapte met als doel de naleving af te dwingen van een publiekrechtelijke regeling. Naar de reden van deze stap valt slechts te gissen. Men zou verwachten dat de overheid, zeker nu een publiekrechtelijke regeling het bouwen van de woning verbood, de eigenaresse zou sommeren het gebouwde af te breken, of, indien zij hieraan geen gehoor gaf, het gebouwde zelf zou afbreken: een soort toepassing van bestuursdwang dus. Maar dit deed zij niet; de overheid vond het kennelijk nodig hiervoor van tevoren toestemming te krijgen van de burgerlijke rechter - een in die tijd onbekende en hoogst ongebruikelijke stap.

De verklaring hiervoor lijkt te moeten worden gezocht in de tijd waarin deze zaak zich voordeed. Begin 1842 had de minister van Justitie het opwerpen van conflicten immers verboden, terwijl het in de jaren daaraan voorafgaand al duidelijk was dat het Conflictenbesluit zijn langste tijd had gehad. Opruiming nu van het gebouw van Zuithoff betekende een inbreuk op haar eigendomsrecht, zelfs

21. Dit is opvallend, daar deze stelling, van het Rijk neerkomt op het volgende: door mijn vordering poog ik een inbreuk te maken op het eigendomsrecht van eiseres en dus is de burgerlijke rechter bevoegd.

22. HR. 12 januari 1844, W. 469, Van den Honerh, Gemengde zaken deel 2, no. 89. Mijn cursivering. 
als dit gebeurde op grond van een publiekrechtelijke regeling. Kennelijk was de Staat beducht dat zijn handelen door de burgerlijke rechter op vordering van de weduwe achteraf als onrechtmatig zou worden beoordeeld. Dit nu was typisch een zaak waarin een paar jaar eerder een conflict zou zijn opgeworpen, maar dat was niet meer mogelijk. De overheid, die niet achteraf wilde worden geconfronteerd met een veroordeling tot betaling van schadevergoeding, vroeg dus maar vooraf van de rechter een verklaring dat zij niet onrechtmatig handelde.

De Hoge Raad gaf vervolgens in het arrest alle ruimte aan de hier geschetste ontwikkeling, door in zeer ruime bewoordingen te oordelen dat alle twistgedingen die onder artikel $163 \mathrm{Gw} 1840$ vielen, tot de competentie van de burgerlijke rechter behoorden, 'zonder uitzondering tusschen welke personen, of door of jegens welke ligchamen die twistgedingen worden gevoerd'.

Bijna drie jaar later - in november 1846 - wees de Hoge Raad een arrest dat kan worden gezien als een onderbouwing van deze verklaring. In deze zaak ging het om de vraag of de burgerlijke dan wel de strafrechter bevoegd was kennis te nemen van een vordering tot amotie van hetgeen was gebouwd in strijd met een plaatselijke verordening. De Hoge Raad overwoog dat de vordering 'eene zuiver burgerlijke handeling' betrof, namelijk de wegruiming van een gebouw. Verder overwoog hij

\begin{abstract}
'dat, indien het al mogt kunnen opgaan, dat de eischers bevoegd waren, om, uit krachte der reserve, voorkomende in art. 12 van het meerbedoelde reglement, bij nalatigheid des verweerders, de facto, de amotie in verschil te bewerkstelligen (tegen welke daad alsdan, niettemin, ongetwijfeld aan den verweerder, indien hij dezelve onregtmatig oordeelde, de recursus tot den gewonen Regter zou zijn verbleven), het, in allen gevalle, aan de eischers vrijstond, zich aan dergelijke handeling niet te wagen, maar hun beweerd regt door den competenten Regter, contradictoir met den verweerder, indien hij niet mogt verkiezen aan de vordering te voldoen, te doen uitmaken, en, gewapend met 's Regters gewijsde, casu quo, veilig, de bevolene amotie ten uitvoer te leggen, en dat alweder niemand anders dan de gewone burgerlijke Regter tot de beregting dier vordering, hetzij dezelve gegrond of ongegrond, noodig of onnoodig mogt geacht worden, kan bevoegd zijn'. ${ }^{23}$
\end{abstract}

\title{
2.4 De competentie van de burgerlijke rechter
}

\subsubsection{Verschillende leren}

De burgerlijke rechter verklaarde zich dus bevoegd van de vordering kennis te nemen als sprake was van een twistgeding over eigendom of een daaruit voortspruitend recht, een schuldvordering of een burgerlijk recht, ook als deze vordering werd ingesteld door of tegen de overheid. Het is echter de vraag, wanneer sprake was van een dergelijk twistgeding. Deze vraag ging vanaf de tweede helft van de negentiende eeuw een steeds belangrijker rol spelen.

23. HR 13 november 1846 , W. 772 , Ned. regtspraak deel $25, \$ 59$. Cursiveringen in oorspronkelijke tekst. 
Was pas sprake van een twistgeding als de eigendom of het recht volledig werd ontkend door de gedaagde, zoals wel door de administratie werd gesteld ten tijde van het Conflictenbesluit? Deze visie is (vrijwel) nooit gevolgd door de rechter. ${ }^{24}$ Algemeen werd aangenomen dat twee stelsels bestonden, waarop de rechter zijn bevoegdheid baseerde, namelijk het stelsel waarin het voorwerp van het geschil, het petitum, bepalend was en het stelsel waarin de aard van het recht, waaruit het geschil voortsproot, de competentie besliste. Het eerste stelsel staat bekend als de leer van het petitum of de leer van het objectum litis, het tweede als de leer van het fundamentum petendi. ${ }^{25}$ Beide zijn in de literatuur verdedigd.

Thorbecke stond bijvoorbeeld een strikte scheiding tussen privaat- en publiekrecht voor. Artikel $163 \mathrm{Gw} 1840$ doelde volgens hem dan ook op geschillen met betrekking tot rechten van bijzondere personen: 'schuldvorderingen' in artikel 163 Gw 1840 diende te worden gelezen als 'privaatrechtelijke schuldvorderingen', terwijl de 'eigendom en daaruit voortspruitende regten' slechts zag op de privaatrechtelijke eigendom en de 'burgerlijk voortspruitende' rechten. ${ }^{26}$ Schuldvorderingen ontstaan uit het publiekrecht behoorden volgens hem dus niet meer 'bij uitsluiting" tot de kennisneming van de burgerlijke rechter. ${ }^{27}$ Thorbecke kan dus een aanhanger worden genoemd van de fundamentum petendi-leer. ${ }^{28}$

Buijs daarentegen betoogde ruim veertig jaar later dat het de bedoeling van de (grond)wetgever was geweest het object van de strijd beslissend te doen zijn, de leer van het objectum litis dus. ${ }^{29}$

Beide stelsels zijn in de negentiende eeuw toegepast door de rechter. ${ }^{30} \mathrm{Zo}$ oordeelde de Hoge Raad in $1857^{31}$ dat de burgerlijke rechter onbevoegd was kennis te nemen van een vordering tot schadevergoeding tegen de Staat in verband met het langer in dienst houden van een milicien dan volgens eiser was toegestaan op grond van de Wet op de nationale militie:

'O., ten aanzien van het regt, dat deze beweerde inlijving door en van wege den Staat is ecne daad, strekkende ter uitvoering van de wetten en wettelijke verordeningen, betreffende de nationale militie; o., dat de beoordeeling van die daden daarbij geheel is opgedragen aan en uit haren aard behoort tot

24. Meijers (1916), blz. 468.

25. Volgens Meijers (1916), blz. 468 werkte 'een zoodanige kenschetsing' echter verwarrend. Hij zag als beslissend voor de uitlegging van artikel 2 R.O. de vraag, wanneer sprake is van een geschil.

26. Thorbecke (1843), blz. 155.

27. Vegting (1957), blz. 474-475. Zie ook, De Vries (1917), blz. 337.

28. Hierbij moet overigens worden bedacht dat deze leer "eerst enkele decennia later in het Nederlandse rechtsdenken gestalte kreeg', aldus Burkens (1978), blz. 8. Zie ook Poortinga (1987), blz. 259.

29. Buijs (1887), blz. 295. Zo ook De Jonge (1865), blz. 81 .

30. Zie het overzicht in Van Schaik (1905), blz. 205-216. Zo ook Vos (1902), blz. 161, volgens wie echter de jurisprudentic van de Hoge Raad zich als regel in de richting van de petitum-leer heeft bewogen.

31. HR 18 december 1857, W. 1917. 
de administratieve magt, en met het oog op art. 148 der Grondwet" niet kan geacht worden begrepen te zijn onder de zaken, waarvan de kennisneming aan de regterlijke magt is opgedragen;

0 ., dat hierin geene verandering wordt te weeg gebragt door de omstandigheid, dat de eischer bij de actie, die hij te dier zake tegen den Staat heeft ingesteld, als eene daaruit voortvloeijende verpligting, eene geldelijke schadevergoeding vordert, omdat die vordering in casu onafscheidelijk is van den étenigen grondslag, waarop die schadeloosstelling wordt geêischt, en die in deze ingestelde actie niet kan worden onderzocht en beoordeeld, zonder in een onderzoek te treden van en te beslissen omtrent het regtmatige en onregtmatige van de daad, welke aan den Staat wordt ten laste gelegd of voor welker gevolgen deze wordt beweerd aansprakelijk te zijn;

O., dat de Hooge Raad mitsdien is onbevoegd om van de ingestelde vordering kennis te nemen:"33

De Hoge Raad volgde in dit arrest dus de fundamentum petendi-leer: de aard van het recht, waaruit het geschil voortsproot, was publiekrechtelijk van aard en dus, was de burgerlijke rechter onbevoegd kennis ervan te nemen. ${ }^{34}$

In 1873 overwoog hij daarentegen

'dat de beslissing der vraag, of de in deze door den verweerder ingeroepen bepaling der door hem bedoelde keur is eene wettige verordening, daarvan afhangt, of de administratieve magt is bevoegd den eigendom van den eischer op de door hem gelegde buizen in dier voege te beperken, als dit is geschied bij de bedoelde keur; (...)

Overwegende, dat hieruit volgt, dat het onderwerpelijk geding inderdaad betreft een geschil over eigendom of daaruit voortspruitende regten; dat de kennisneming daarvan bij art. 2 der wet op de regterlijke organisatie bij uitsluiting is opgedragen aan de regterlijke magt; dat de regter in deze is gekomen tot eene tegenovergestelde beslissing, door vooruit te loopen op de eerst bij de behandeling der zaak ten principale en niet nu reeds bij die der exceptie te pas komende vraag over de ontvankelijkheid of gegrondheid der vordering en de kennelijke verwarring dier vraag met die over zijne bevoegdheid? 35

In dit arrest lijkt dus de Hoge Raad de objectum litis-leer te volgen. Verrassend was dit niet; in deze zaak werd namelijk een inbreuk op de eigendomsrechten van eiser gesteld. De rechtspraak van de Hoge Raad was echter niet duidelijk, hetgeen advocaat-generaal Smits deed verzuchten:

'Wanneer ik zeg dat de vraag naar de grens van de bevoegdheid van de regterlijke magt eene moeijelijke is, zal ik, naar ik geloof, wel geene tegenspraak ontmoeten. (...) Daarvoor getuigt de jurisprudentie van de Hoogen Raad, dikwijls in strijd met de conclusien van het Openbaar Ministerie, en die mij, hetzij met eerbied gezegd, ten aanzien van deze materie, niet altijd consequent en buiten tegenspraak met zich zelf toeschijnt te zijn gebleven'. ${ }^{36}$

32. Artikel $148 \mathrm{Gw} 1848$, de 'opvolger' van artikel $163 \mathrm{Gw} 1840$.

33. Cursivering in oorspronkelijke tekst.

34. De Jonge (1865), blz. 81-82, is echter van mening dat de Hoge Raad in dit geval de objecrum litis-leer toepast, maar dat de vraag naar de geldigheid van de administratieve handeling een voorvraag is, die de burgerlijke rechter niet mag beslissen. Hij kan dus geen oordeel geven over de hoofdvraag en moet zich dus onbevoegd verklaren.

35. HR 17 oktober 1873, Ned. regtspraak, deel 105, $\$ 9$.

36. Conclusie voor HR 29 mei 1874, Ned. regtspraak, deel 107, $\$ 11$. 
Thorbecke zag schuldvorderingen in artikel $163 \mathrm{Gw} 1840$ dus als privaatrecitelijke schuldvorderingen. Deze visie lijkt te zijn overgenomen door de grondwetgever van 1848. Was in artikel 163 Gw 1840 de rechterlijke macht nog bij uitsluting bevoegd kennis te nemen van geschillen over eigendom, schuldvorderingen of burgerlijke rechten, in artikel $148 \mathrm{Gw} 1848$ werd hij bevoegd kennis te nmen van geschillen over eigendom, schuldvorderingen en andere burgerlijke rechten. Schuldvordering moest kennelijk worden gelezen als burgerlijke schuldvordering. Deze opvatting is echter door een aantal schrijvers verworpen; volgens hen was slechts sprake van een redactionele wijziging, waarmee geen inhoudelijke vijziging werd beoogd. ${ }^{37} \mathrm{Nu}$ moet worden gezegd dat de toelichting van Thorbecke, die deze wijziging had voorgesteld in zijn Aanteekening op de Grondwet, 1ogal kort en cryptisch was, ${ }^{38}$ zodat men daarmee alle kanten op kon. ${ }^{39}$ De farlementaire stukken gaan niet in op de wijziging, ${ }^{40}$ zodat inderdaad kan werden verdedigd dat de grondwetgever geen inhoudelijke wijziging voor ogen stond

In de praktijk was de wijziging overigens niet van belang. De rechter bleef zijn bevoegdheid baseren op het ongewijzigde artikel 2 R.O. en behoefde zici dus niet te bekommeren om de betekenis van de grondwetswijziging. Overigens veeft. de Hoge Raad de bevoegdheid van de burgerlijke rechter in de negentiende eeuw ook een aantal maal uitdrukkelijk op artikel 1 R.O. gebaseerd. ${ }^{41}$ Ik heb twee arresten gevonden waarin dit geschiedde; ${ }^{42}$ beide betroffen geschillen met betrekking tot belastingen. ${ }^{43}$ De Hoge Raad gaf in deze arresten aan, dat hij in artikel 1 R.O. las dat algemene rechtsmacht was toegekend aan genoemde rechters, tenzij de Grondwet of een andere wet een andere rechter had aangewezen. Zonderland stelde dan ook, mede naar aanleiding van deze arresten, dat artikel 1 R.O. het bevoegdheidsartikel was. Artikel 2 R.O. noemt hij het monopolieartikel: op grond van artikel 1 R.O. kon de wetgever een andere rechter aanwijzen, ten aanzien van de geschillen genoemd in artikel 2 R.O. kon dit echter niet; op die terreinen was

37. Zie bijvoorbeeld Vos (1902), blz. 164-167.

38. Thorbecke (1843), blz. 155.

39. Burkens (1978), blz. 7-8.

40. Zie Burkens (1978), blz. 7.

41. Artikel 1 R.O. zoals gewijzigd bij wet van 28 april 1835. Stb. 10, bepaalde zeer ruim: 'De regterlijke magt wordı (onverminderd het regtsgebied over bepaalde onderwerpen bij de grondwet of bij andere wettelijke bepalingen aan bijzondere kollegien toegekend) uitgeoefend, door:

$1^{\circ}$. De kantongeregten;

$2^{\circ}$. De arrondissements-regtbanken;

$3^{\circ}$. De provinciale geregtshoven, en de criminele regtbank in de provincie Holland;

$4^{\circ}$. Den hoogen raad'.

42. HR 24 maart 1865, W. 2681 en HR 28 januari 1886, W. 5266.

43. Dit is mijns inziens van belang, aangezien artikel 146 lid $3 \mathrm{Gw} 1848$ bepaalde dat de wet 'de regtspraak over geschillen en overtredingen in zake aller belastingen' regelt. Er was dus sprake van een 'regtsgebied' over een bepaald onderwerp bij de Grondwet aan een bijzonder 'kollegie' toegekend als bedoeld in artikel $1 \mathrm{RO}$., en dus zou de rechterlijke macht op dat gebied niet worden uitgeoefend door de in artikel 1 R.O. genoemde gerechten. De Hoge Raad oordeelde echter dat, nu de in de Grondwet genoemde wet niet tot stand was gekomen, de uitzondering genoemd in artikel 1. R.O. niet aan de orde was, zodat de rechterlijke macht bevoegd was. 
de burgerlijke rechter exclusief bevoegd. ${ }^{44}$ Deze opvatting steunt echter op een verkeerde lezing van de woorden 'bij uitsluiting'. Met deze woorden werd immers niet bedoeld bij uitsluiting van andere rechters, maar dat de burgerlijke rechter op genoemde terreinen bij uitsluiting van de administratie over zijn eigen bevoegdheid diende te oordelen. ${ }^{45}$

\subsubsection{De bevoegdheid van de burgerlijke rechter inzake schuldvorderingen}

De burgerlijke rechter was bevoegd te oordelen over schuldvorderingen, aldus artikel 2 R.O. Maar koos de burgerlijke rechter met betrekking tot zijn bevoegdheid inzake schuldvorderingen voor de fundamentum petendi- of de objectum litisleer? Deze vraag is van belang voor de bevoegdheid van de burgerlijke rechter met betrekking tot terugvordering. Terugvordering van hetgeen onverschuldigd is betaald, veronderstelt namelijk een schuldvordering. Zoals we hebben gezien, diende volgens Thorbecke 'schuldvordering" in artikel $148 \mathrm{Gw} 1848$ te worden gelezen als 'privaatrechtelijke schuldvordering'.

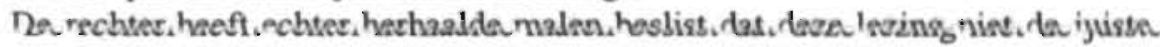
is. In zaken, waarin het veelal een burger was die terugvordering vroeg van ten onrechte aan een bestuursorgaan betaalde bedragen, werd door de administratie vaak het verweer opgeworpen dat de burgerlijke rechter onbevoegd was kennis te nemen van de vordering, nu sprake was van een administratieve daad. Veelal werd dit verweer verworpen, vooral sinds de jaren zestig van de negentiende eeuw. Zo oordeelde het Geregtshof te 's-Hertogenbosch in 1877 'dat de kennisneming van twistgedingen over schuldvorderingen aan de regterlijke magt is opgedragen, onverschillig of die schuldvorderingen uit publiekregtelijke, dan wel uit privaatregtelijke handelingen zijn voortgesproten' ${ }^{46}$

Uit een arrest uit 1866 blijkt impliciet dat de Hoge Raad ook deze redenering volgde. Het betrof een vordering tot verhaal van verleende onderstand door het burgerlijk armbestuur van de gemeente Numansdorp op de gemeente Strijen. Deze laatste beriep zich op verjaring. De Hoge Raad oordeelde dat sprake was van een schuldvordering, en dat alle geschillen over schuldvorderingen "burgerlijke geschillen' zijn 'en dus van privaatregtelijken aard'. ${ }^{47}$ Het lijkt er dan ook op dat. de burgerlijke rechter in deze gevallen de objectum litis-leer toepaste. ${ }^{48}$

\footnotetext{
44. Zonderland (1954), blz. 60-63. Zie ook Tak (1987-I), blz. 289-290.

45. Zie 2.2 .

46. Geregtshof 's-Hertogenbosch 13 februari 1877', WBA 1877, 1453. Zo ook bijvoorbeeld HR 19 juni 1908, W. 8722 (Meester-Staat).

47. HR 23 november 1866 , W. 2854.

48. Zie ook HR. 28 januari 1886, W. 5266.
} 


\subsubsection{Bevoegdheid en ontvankelijkheid}

De burgerlijke rechter verklaarde zich dus herhaalde malen onbevoegd om kennis te nemen van een vordering op grond van de overweging dat het oordeel van de rechter omtrent deze vordering een. oordeel vereiste omtrent een achterliggende bestuurshandeling. De aard van het geschil was volgens de rechter in dat geval niet privaatrechtelijk, maar publiekrechtelijk: de leer van het fundamentum petendi. Als de rechter zich echter wel bevoegd achtte op grond van de ingestelde vordering - als dus de leer van het objectum litis werd gevolgd - wilde dit niet aitijd zeggen dat de rechter ook een uiteindelijk oordeel kon geven met betrekking tot het geschil. Zoals blijkt uit het in 2.4.1 geciteerde arrest van de Hoge Raad van 17 oktober 1873, hoefde de bevoegdheid van de rechter niet tevens te leiden tot ontvankelijkheid van de eiser. ${ }^{49}$ Vergde het oordeel over de vordering een oordeel over een administratieve daad, welk laatste oordeell was voorbehouden aan de administratie, dan verklaarde de rechter eiser niet-ontvankelijk.

De burger kon in deze gevallen dus niet bij de gewone rechter terecht; deze verklaarde ofwel zich onbevoegd ofwel de burger niet-ontvankelijk in zijn vordering. In deze situatie deed het ontbreken van onafhankelijke administratieve rechtspraak zich gevoelen. Weliswaar vonden in de negentiende eeuw verschiliende pogingen plaats om tot een regeling van de administratieve rechtspraak te komen, maar geen daarvan was uiteindelijk succesvol.

De vraag, welke leer de heersende was, namelijk die van de objectum litis dan wel die van het fundamentum petendi, werd uiteindelijk in 1915 beantwoord door de Hoge Raad in het bekende arrest Noordwijkerhout-Guldemond. ${ }^{50}$ In dat arrest koos de Hoge Raad definitief voor de objectum litis-leer. Dit arrest zal uitgebreider aan de orde komen in 2.6.

\subsection{Toepassing van privaatrechtelijke regels in geschillen met de overheid: de verjaringstermijnen uit het $\mathrm{BW}$}

De burgerlijke rechter achtte zich sedert 1843 bevoegd recht te spreken als de overheid een vordering instelde tegen een burger. Hij was in ieder geval competent als er sprake was van een inbreuk op een eigendomsrecht, eerst nog op de grond dat sprake was van een inbreuk op dit recht van de burger - zie het arrest inzake de weduwe Zuithoff -, vervolgens ook omdat er sprake was van een inbreuk op de eigendom van de overheid. ${ }^{51}$ Vervolgens achtte de rechter zich

49. HR 17 oktober 1873, Ned. regtspraak, deel 105, $\$ 9$. Zie bijvoorbeeld ook de conclusie van. procureur-generaal Van Maanen voor HR. 18 december 1857, W. 1917.

50. HR 31 december 1915, NJ 1916, 407.

51. Een voorbeeld hiervan geeft. HR 10 oktober 1851 , Van den Honert, Gemengde zaken deel 11, no. 532 . 
competent om kennis te nemen van schuldvorderingen, ongeacht of deze vorderingen ontsproten uit het publiek- dan wel privaatrecht.

Daarnaast ging de overheid zich al snel beroepen op aan het privaatrecht ontleende verweren, wanneer zij werd geconfronteerd met tegen haar ingestelde vorderingen, die werden behandeld door de burgerlijke rechter. Zo beriep een college dat namens de provincie Noord-Brabant een schadeloosstellingsfonds beheerde, zich in 1854 voor het Provinciaal Geregtshof in Noord-Brabant op de vijfjarige verjaringstermijn van artikel 2012 BW (oud), toen van dit college in rechte de uitbetaling werd gevorderd van een bedrag van $f 1200$ voor schadevergoeding over de tijdvakken van 1829 tot en met 1848. Het bestuurscollege erkende de gegrondheid van het gevorderde, maar concludeerde tot niet-ontvankelijkheid van de eis over de periode tot het jaar 1846. De eerste rechter ging voorbij aan het verweer van het college en veroordeelde het tot betaling van de gevorderde som. In hoger beroep werd het appel afgewezen, aangezien de verjaringstermijn van artikel 2012 niet kon worden ingeroepen 'in handelingen gepleegd op het terrein van het staatsregt, (...) alwaar de gevorderde betaling niet het gevolg is van eenige burgerlijke overeenkomst, maar alleen van publiek regtelijke bepalingen en administrative maatregelen, welke door eigene regelen worden beheerscht'. ${ }^{52}$

Ruim tien jaar later, in 1866, oordeelde de Hoge Raad anders. ${ }^{53}$ In een geschil tussen het burgerlijk armbestuur van de gemeente Numansdorp ${ }^{54}$ en de gemeente Strijen omtrent het verhaal van door het armbestuur verleende onderstand, voerde de gemeente de exceptie van verjaring, zoals neergelegd in de Armenwet 1854, aan. Dit verweer werd verworpen; de verjaring zou zijn gestuit door een erkentenis als bedoeld in artikel 2019 BW (oud). De gemeente ging in beroep en uiteindelijk in cassatie, stellende dat op de actie tot verhaal van onderstand, 'als zijnde van zuiver publiekregtelijken aard', de bepalingen van het BW niet van toepassing waren, tenzij daarnaar uitdrukkelijk werd verwezen. In ieder geval zouden de bepalingen omtrent stuiting en verjaring niet van toepassing zijn omdat de Armenwet daaromtrent bijzondere voorschriften gaf. De Hoge Raad volgde de gemeente niet. Hij oordeelde dat het verhaal van verleende onderstand betrof, dus een schuldvordering. Hij vervolgde dat 'alle geschillen over schuldvorderingen zijn burgerlijke geschillen en dus van privaatregtelijken aard, en dat derhalve daarop zijn toepasselijk de bepalingen van het Burgerlijk Wetboek, voor

52. Provinciaal Geregtshof Noord-Brabant 20 juni 1854 , Ned. regtspraak, deel $50, \$ 81$.

53. Dit arrest is reeds kort aan de orde gekomen in 2.4.2.

54. Dit burgerlijk armbestuur was een (semi)overheidsinstantie, namelijk het armbestuur vanwege de burgerlijke overheid, zie de memorie van toelichting op de Armenwet 1854: 'De beoordeeling omtrent de noodzakelijkheid tot ondersteuning (...) moet plaatselijk blijven en in elke gemeente worden uitgeoefend of door haar bestuur regtstreeks, of middellijk door van wege dat bestuur tot stand gebragte of daaraan ondergeschikte burgerlijke of algemeene instellingen van weldadigheid', Tweede Kamer 1853-1854, bijlagen, 5le vel, blz. 196. De Armenwet kende dan ook onder meer gemeente-instellingen, door de burgerlijke overheid geregeld en van harentwege bestuurd (art. 2 onder a Armenwet 1854). 
zooverre daaromtrent bij meergenoemde wet niet zijn gegeven bijzondere voorschriften'. 55

Overigens bepaalde artikel 72 Armenwet 1854:

'Geschillen over (....) het verhaal en het verhaalbaar bedrag van onderstand krachtens deze wet verstrekt (...) behooren, indien zij niet door de administratieve magt in de minne worden afgedaan, tot de kennisneming van de regterlijke magt'.

In de toelichting op dit artikel stelde de regering dat zij op grond van de tekst van artikel $148 \mathrm{Gw} 1848$ ook niet anders kon dan de burgerlijke rechter bevoegd te maken met betrekking tot deze geschillen. ${ }^{36}$ De toelichting zei echter nergens dat in dat geval de bepalingen uit het BW van toepassing waren.

Met deze uitspraak gaf de Hoge Raad de overheid de ruimte om bij terugvordering van onverschuldigde betalingen gebruik te maken van het privaatrecht. Terugvordering is immers altijd een schuldvordering, waarop dus de bepalingen van het BW van toepassing zijn, tenzij een publiekrechtelijke regeling bijzondere voorschriften geeft.

Een ander voorbeeld van de toepassing van de privaatrechtelijke verjaringstermijnen biedt het arrest van de Hoge Raad van 19 juni 1908. Meester was benoemd tot ridder in de Militaire Willemsorde, aan welke benoeming een riddersoldij verbonden was. De orde was hem echter ontnomen wegens drankmisbruik. Nadat hij een aantal jaren later zijn drankprobleem kennelijk had overwonnen, werd hem de orde en het riddersoldij weer toegekend. Meester maakte echter ook aanspraak op de riddersoldij, die hij had gederfd in de periode dat de orde hem was ontnomen. Hij stelde dat niet voldaan was aan de wettelijke vereisten voor deze ontneming. De Staat voerde hier tegen aan dat de beoordeling van de vraag of de ontneming terecht was geweest binnen de grenzen van de administratie viel en dat dus sprake was van een publiekrechtelijk geschil. Voorts beriep hij zich op de verjaringstermijn van artikel $2012 \mathrm{BW}$ (oud). De rechtbank achtte zich bevoegd van de vordering kennis te nemen, maar oordeelde met betrekking tot de toepasselijkheid van de verjaringstermijnen uit het BW dat de vordering een uitkering, verbonden aan een koninklijke benoeming, betrof. Deze uitkering vond haar oorsprong in het publiekrecht; daarop waren volgens de rechtbank de bepalingen van het BW niet van toepassing. ${ }^{57}$ Zoals te verwachten op grond van de boven aangehaalde jurispnudentie, vernietigde het hof dit vonnis. De rechtbank had terecht geoordeeld dat de burgerlijke rechter bevoegd was, maar op de rechtsvordering waren tevens de verjaringsbepalingen uit het BW van toepassing. De wetgever had volgens het hof blijkens de bepalingen van artikel 2 R.O. en van de Grondwet 'schuldvorderingen, afgescheiden van den rechtsband, hetzij deze was van publiekrechtelijken of van burgerrechtelijken aard, waaruit zij oorsprong

55. HR 23 november 1866 , W. 2854.

56. Tweede Kamer 1853-1854, bijlagen, 53e vel, blz. 203.

57. Rb. 's-Gravenhage 9 januari 1906, W. 8327. 
namen, (...) beschouwd als burgerrechtelijke rechtsvorderingen, omdat zij uiting gaven aan den wil om te innen eenige geldschuld, die deel van het vermogen van den eischer vormde'. Op deze rechtsvorderingen waren de bepalingen van het BW wel toepasselijk. ${ }^{58}$

De Hoge Raad verwierp vervolgens zowel het door Meester ingestelde principale beroep in cassatie, als het incidentele beroep, ingesteld door de Staat. Wat betreft de toepasselijkheid van de verjaringstermijnen uit het BW overwoog hij:

'dat, immers, wanneer (...) de rechtsvordering door den eischer tegen den Staat ingesteld tot betaling van zekere geldsom is eene schuldvordering, zoodat de kennisneming van het geschil daarover behoort tot de bevoegdheid van den burgerlijken rechter, als daarmede samenhangende moet worden aangenomen, dat het vervallen door verjaring van het recht tot vorderen naar de bepalingen van het B.W. moet worden beoordeeld, nu daaromtrent ten aanzien van de ingestelde vordering bij geene andere wet bijzondere bepalingen zijn gemaakt. 59

Volgens de Hoge Raad waren dus alle geschillen over schuldvorderingen 'burgerlijke geschillen en 'dus van privaatregtelijken aard', waarop in beginsel de bepalingen van het BW van toepassing waren. Dat de burgerlijke rechter geneigd was privaatrecht toe te passen, als eenmaal de hindernis van de bevoegdheids- en de ontvankelijkheidsvraag was genomen, lag voor de hand. Veelal was er geen publiekrecht, terwijl de burgerlijke rechter ook gewend was om te gaan met privaatrecht en dit recht toe te passen. Dit kan worden afgeleid uit het feit dat slechts een enkele keer werd stilgestaan bij het toepassen van de bepalingen uit het BW in geschillen, waarbij de burgerlijke rechter bevoegd was en de overheid een der partijen was. Thorbecke sprak dan ook van het 'burgerlijk regtsoog' van de burgerlijke rechter. ${ }^{60}$ Ook Vos was het opgevallen dat het 'burgerlijk rechtsoog' van de civiele rechter 'zooveel sterker ontwikkeld was dan zijn 'publiekrechtelijk'. Volgens hem was dit een 'quaestie van usance, van routine', 61 Voor hem was het reden om ervoor te pleiten om de rechtspraak in publiekrechtelijke geschillen in ieder geval niet onder te brengen bij de burgerlijke rechter. ${ }^{62}$ Dit

58. Hof 's-Gravenhage 16 december 1907, W. 8636.

59. HR 19 juni 1908, W. 8722 . (Meester-Staat).

60. Thorbecke (1848), blz. 85-86. Volgens Thorbecke eiste rechtspraak op het terrein van het 'politische regt' een afzonderlijke rechter: 'De wetgeving, naar welke de politische regter regt moet spreken, een van het burgerlijk regt geheel onderscheiden tak, door verschillende beginselen geregeerd, eischt, om in haar verband te worden gekend, afzonderlijke studien, voorbereiding en oefening. Het is bijkans onvermijdelijk, en de voorbeelden zijn niet verre, dat de burgerlijke regter, aan wien een politisch geschil wordt onderworpen, er den aard van miskent, dewijl hij het met een burgerlijk regtsoog beschouwd'. Onder 'politisch regt' verstond Thorbecke het bestuursrecht, zie Van der Hoeven (1989), blz. 64, vgl. Poortinga (1987), blz. 107.

61. Interventie van H. Vos bij de bespreking van de preadviezen voor de Nederlandsche JuristenVereeniging van Van Houten en Buijs, Verslag NJV (1891), blz. 127. Zie over dit "burgerlijk rechtsoog' voorts De Hooge Raad en het publiekrecht, WBA 1902, no. 2771. H. Vos is vermoedelijk de (anonieme) auteur van dit stuk.

62. Verslag NJV (1891), blz. 127 en Vos (1902), blz. 190. 
laatste was overigens geen nieuw geluid. ${ }^{63}$ Zo zag de Staatscommissie Kappeyne van de Coppello in het feit dat het voor de burgerlijke rechter een te grote belasting was zich 'die grondige kennis van het zoo uitgebreide administratieve recht eigen te maken, welke voor een goede berechting der administratieve rechtsgeschillen gevorderd moet worden', een reden om te adviseren de administratieve rechtspraak niet op te dragen aan die burgerlijke rechter. ${ }^{64}$ Ook dit is een aanwijzing dat de burgerlijke rechter niet gewend was om te gaan met het publiekrecht.

\subsection{De bevoegdheidsafbakening door de burgerlijke rechter in de twintigste eeuw}

De lijn die de burgerlijke rechter volgde met betrekking tot zijn bevoegdheid in het begin van de twintigste eeuw, bewoog zich steeds meer in de richting van de leer van het objectum litis. Zo overwoog de Hoge Raad in 1907 dat uit het feit dat een betrekking tussen een onderwijzer en een gemeentebestuur in de eerste plaats publiekrechtelijk van aard is, niet volgt dat de vordering van de onderwijzer tot betaling van zijn bezoldiging zou ophouden een schuldvordering te zijn. Op die grond was de rechter dan ook bevoegd van het geschil kennis te nemen. ${ }^{65}$ En in 1911 besliste de Hoge Raad dat onder twistgeding over schuldvorderingen, welke bij uitsluiting tot de kennisneming van de rechterlijke macht behoren, ook behoorde de vordering uit onverschuldigde betaling, "ook al heeft deze betaling moeten dienen tot voldoening eener vermeende schuld van publiekrechtelijken aard, omdat hieruit niet volgt, dat de vordering tot teruggave zou ophouden eene schuldvordering te zijn' ${ }^{66}$

In 1915 heeft de Hoge Raad, zoals hiervoor reeds kort werd vermeld, in het arrest. Noordwijkerhout-Guldemond definitief gekozen voor de leer van het objectum. litis. ${ }^{67}$ De Hoge Raad baseerde deze keuze op historische gronden. Hij lijkt hiermee de opvatting van Buijs te volgen, die reeds in 1887 dezelfde historische gronden aanvoerde om te betogen dat de grondwetgever in 1815 de bedoeling had om het objectum litis bepalend te laten zijn voor de competentie van de burgerlijke rechter. ${ }^{68}$ De Hoge Raad overwoog onder meer dat niet kon worden aangenomen dat artikel $165 \mathrm{Gw} 1815$

63. Zie reeds het in noot 60 aangehaalde citaat van Thorbecke.

64. Verslag Staatscommissie Kappeyne van de Coppello (1894), blz. 5. Evenzo Buijs (1891), blz. 73.

65. HR 20 december 1907 , W. 8641 .

66. HR 30 juni 1911, W. 9197 , m.nt. J.W.M. Zie ook bijvoorbeeld HR 12 juni 1908, W. 8722.

67. HR 31 december 1915, NJ 1916, 407.

68. Buijs (1887), blz. 294-296. Zie ook de conclusie van advocaat-generaal Tak. 
'eene zuivere onderscheiding wilde maken tusschen privaatrechtelijke en publiekrechtelijke geschillen, welke onderscheiding in 1815 nagenoeg onbekend was, doch dat blijkens de woorden 'bij uitsluiting', daarbij de gedachte heeft voorgezeten, om de macht der Administratie te beperken, en de in dat artikel genoemde rechten onvoorwaardelijk te stellen onder de hoede der rechterlijke macht;

O., dat derhalve niet het publick- of privaatrechtelijk karakter van het geschil, maar het te beschermen recht de uitsluitende bevoegdheid der rechterlijke macht zou bepalen, gelijk nader blijkt uit den Franschen tekst van dit Grondwetsartikel: "Les contestations qui ont pour objet la propriété ou des droits qui en dérivent etc.":

O., dat aan art. 2 RO. dezelfde beteekenis moet worden toegekend, gelijk nader blijkt uit hetgeen bij de totstandkoming dezer wet in April 1827 in de Tweede Kamer der Staten-Generaal is voorgevallen' 69

De conclusie van de Hoge Raad was dan ook dat de bevoegdheid van de rechterlijke macht 'is afhankelijk gesteld van het voorwerp van het geschil, dat is van het recht waarin de aanlegger vraagt te worden beschermd, en niet van den aard van het recht waarop de verweerder zijn verweer grondt'. ${ }^{70}$ Het gevolg van dit arrest was dat, mits de eisende partij als voorwerp van het geschil een eigendomsrecht, een schuldvordering of een burgerlijk recht aanvoerde, er altijd een bevoegde rechter was.

Het feit dat de burgerlijke rechter koos voor de objectum litis-leer om zijn bevoegdheid te bepalen, was begrijpelijk en zeer wel te verdedigen vanuit rechtsbeschermingsoogpunt. Zoals zal blijken in het volgende hoofdstuk kwam een algemene regeling met betrekking tot administratieve rechtspraak niet van de grond, zodat een burger die een conflict had met een overheidsorgaan veelal slechts terecht zou kunnen bij de administratie zelf, wanneer geen rechtsgang had opengestaan naar de burgerlijke rechter. Door zijn bevoegdheid te laten afhangen van de vordering was de rechter sneiler bevoegd dan wanneer hij zijn bevoegdheid liet afhangen van de aard van het recht waaruit het geschil voortkwam. Het probleem was immers dat juist in publiekrechtelijke geschillen grote behoefte bestond aan rechtsbescherming door een onafhankelijke rechter.

In latere arresten maakte de Hoge Raad duidelijk dat dit criterium niet alleen gold indien de burger een vordering instelde voor de burgerlijke rechter, maar ook wanneer dit gebeurde door de overheid. Een voorbeeld biedt een arrest uit 1944 . De gemeente Alkmaar vorderde van de provincie Noord-Holland levering van elektriciteit. De Hoge Raad overwoog dat het recht om deze levering te vorderen een schuldvordering in de zin van artikel 2 R.O. is en

\footnotetext{
"dat voor de vraag, of er een recht van schuldvordering naar dat artikel aanwezig is, niet afdoet, of de verbintenis wordt beheerscht door publiek- dan wel door privaatrecht, doch bovendien de beweerde verbintenis tusschen concessionaris en derde - ten deze toevallig beiden publiekrechtelijke lichamen tot levering van elektriciteit onderworpen is aan het burgerlijk recht, ook al zou de concessie zelf worden beheerscht door publiek recht' ${ }^{71}$
}

69. Cursivering in oorspronkelijke tekst.

70. Zie over de historische gronden, waarop de Hoge Raad zich beriep, uitgebreid De Vries (1917).

71. HR 18 augustus 1944, NJ 1944-1945, 598 (Alkmaar-Noord-Holland). Een ander, ouder voorbeeld geeft HR 20 april 1923, NJ 1923, 689. 
Dat sprake is van vaste rechtspraak blijkt ook uit onder meer de arresten LimmenHoutkoop en Kabayel. In het eerste arrest, gewezen in 1973, probeerde de gemeente Limmen via een onrechtmatigedaadsactie naleving van publiekrechtelijke voorschriften door Houtkoop af te dwingen. Volgens de Hoge Raad was de burgerlijke rechter bevoegd, maar diende de vordering te worden afgewezen; het algemeen belang dat voor elk overheidslichaam is betrokken bij de naleving van die wettelijke voorschriften behoorde niet tot de door artike! $1401 \mathrm{BW}$ (oud) beschermde belangen. ${ }^{72}$ In 1994 is de Hoge Raad in het arrest Kabayel op dit laatste teruggekomen. Wederom was de bevoegdheid geen probleem, er was sprake van een schuldvordering. Verder oordeelde de Hoge Raad dat niet vereist was dat de Staat aan de vordering een 'civielrechtelijk belang' ten grondslag legde, een 'voldoende belang' was genoeg. ${ }^{73}$ Dit kan ook het algemeen belang zijn, dat voor ieder bestuursorgaan bij de naleving van wettelijke voorschriften is betrokken.

Een uitzondering, naast de in 4.3.2 te behandelen meer algemene uitzonderingen op het terrein van onder meer het ambtenarenrecht, vormde het arrest Verkiezingsafspraak Elsloo. ${ }^{74}$ Een aantal kandidaten voor de gemeenteraad had afgesproken dat de kandidatenlijst in willekeurige volgorde zou worden opgesteld, maar dat de kandidaten met de meeste stemmen plaats zouden nemen in de gemeenteraad. Hoger op de lijst geplaatste kandidaten zouden daartoe moeten bedanken als lid van de gemeenteraad. Een van de kandidaten hield zich niet aan deze afspraak, waarop de kandidaat die op grond van de gemaakte afspraak in aanmerking kwam voor een zetel in de raad hem dagvaardde in kort geding. De president achtte zich bevoegd (en wees de vordering toe). In cassatie, ingesteld in het belang der wet, oordeelde de Hoge Raad dat de burgerlijke rechter onbevoegd was van de vordering kennis te nemen. De bevoegdheid van de rechterlijke macht moet weliswaar worden beoordeeld 'naar de aard van de door de aanlegger gestelde rechtsverhouding en het recht waarin deze vraagt te worden beschermd', maar de gemaakte afspraak strekte uitsluitend daartoe een van de Kieswet afwijkende regeling te treffen. Uit zodanige afspraak vloeide echter niet voort 'eigendom of enig daaruit voortspruitend recht, een schuldvordering of een burgerlijk recht'.

Uit het arrest Tegelen-Provincie Limburg uit 1999 zou mogelijk kunnen worden afgeleid dat de Hoge Raad wat de bevoegdheid van de burgerlijke rechter betreft de lijn van het arrest Verkiezingsafspraak Elsloo heeft verlaten. In casu ging het om een gemeentelijke herindeling, waarbij de gemeente de provincie verweet de voorgeschreven overlegprocedure niet correct te hebben gevoerd. Hierdoor zou de provincie onrechtmatig hebben gehandeld. In kort geding werd gevorderd dat kort gezegd - niets met het voorstel van gedeputeerde staten tot wijziging van de gemeentelijke herindeling zou worden gedaan. De Hoge Raad stelde voorop dat de

72. HR 9 november 1973, NJ 1974, 91, m.nt. W.F.P. Het betrof hier overigens een kort geding.

73. HR 18 februari 1994, NJ 1995, 718, m.nt. MS. Ook hier betrof het cen kort geding.

74. HR 26 maart 1971, NJ 1971, 434, AB 1971, 135, m.nt. DJ. Veegens. 
gemeente aan haar vordering ten grondslag heeft gelegd dat de provincie jegens haar onrechtmatig heeft gehandeld, zodat de burgerlijke rechter bevoegd is. De vordering stuitte vervolgens af op het grondwettelijk toetsingsverbod van formele wetten. ${ }^{75}$ In zijn noot onder het arrest in de $\mathrm{AB}$ spreekt Drupsteen treffend van jurisprudentie met 'een hoog Sesam-open-U-gehalte'.

\subsection{Conclusie}

Een gevolg van het ontbreken van administratieve rechtspraak was dat de burgerlijke rechter in bepaalde gevallen rechtsbescherming is gaan bieden tegen de overheid. Artikel $165 \mathrm{Gw} 1815 \mathrm{gaf}$ hem daartoe de ruimte. Door de ruime bewoordingen van dat artikel werd het ook mogelijk voor de overheid rechtsvorderingen in te stellen tegen burgers bij de burgerlijke rechter, ook ter bescherming van publiekrechtelijke belangen. Deze rechter was van nature geneigd het hem bekende recht, het privaatrecht, toe te passen, ook wanneer de overheid bij het geschil was betrokken. Wel zag de rechter in dat de overheid een bepaalde vrijheid diende te hebben, zodat er geschillen waren die de rechter niet beoordeelde. Hierbij hanteerde hij verschillende criteria. Enerzijds deed hij dit via de bevoegdheidsvraag: in een aantal gevallen paste hij de fundamentum petendi-leer toe en achtte zich op die grond niet bevoegd kennis te nemen van het geschil. Anderzijds leidde toepassing van de objectum litis-leer, waarbij de rechter zich snel bevoegd achtte kennis te nemen van het geschil, niet altijd tot een inhoudelijke beoordeling van dat geschil. Bevoegdheid van de rechter leidde niet automatisch tot ontvankelijkheid van de eiser. Erg duidelijk was deze situatie niet. In 1915 heeft de Hoge Raad de knoop doorgehakt waar het de bevoegdheidsvraag betrof: deze moet worden bepaald aan de hand van het voorwerp van geschil, het objectum litis. De bevoegdheid van de burgerlijke rechter werd daarna steeds minder en minder een probleem. Vanaf dat moment heeft de afbakening van de vraag of de rechter een inhoudelijk oordeel kon geven over een geschil, waarbij de overheid was betrokken, vooral plaatsgevonden via de ontvankelijkheidsvraag. Hierop zal ik verder ingaan in hoofdstuk 4 .

75. HR 19 november 1999, NJ 2000, 160, m.nt. TK, AB 2000, 387, m.nt. ThGD, JB 2000, 1, m.nt. R.J.N. S. 



\section{OPKOMST VAN HET PUBLIEKRECHT EN DE ADMINISTRATIEVE RECHTSPRAAK}

\subsection{Inleiding}

In het vorige hoofdstuk is gebleken dat de burgerlijke rechter kon oordelen over geschillen waarbij de overheid betrokken was (hetzij als eiser, hetzij als gedaagde). Dat heeft ertoe geleid, althans er sterk toe bijgedragen, dat die overheid gebruik is gaan maken van het privaatrecht. In dit hoofdstuk zal ik de ontwikkeling van het administratieve recht en de administratieve rechtspraak met de daarbij behorende administratieve rechters behandelen. De nadruk zal liggen op de pogingen om te komen tot een algemene regeling van administratieve rechtspraak. Weliswaar gaat het bij administratieve rechtspraak om rechtsbescherming tegen de overheid, toch is deze ontwikkeling van belang voor de vraag of de overheid gebruik mag maken van privaatrecht. De bestuursrechter lijkt namelijk minder snel geneigd het gebruik van privaatrecht door de overheid toe te staan. Dit speelt het sterkst daar, waar een bestuursrechter een ruime competentie heeft met betrekking tot een bepaald rechtsterrein, zoals bijvoorbeeld het geval is in het ambtenarenrecht en in (een deel van) het sociaal-economische recht.

Voor een goed begrip van de ontwikkelingen in de twintigste eeuw is het noodzakelijk kennis te nemen van pogingen om tot een algemene regeling van administratieve rechtspraak te komen, die in de negentiende eeuw plaatsvonden. Deze zal ik in 3.2 beschrijven, in $3.3 \mathrm{zal}$ ik de ontwikkeling in de twintigste eeuw tot de Tweede Wereldoorlog bespreken en in 3.4 de periode na de Tweede Wereldoorlog. Zoals zal blijken waren deze pogingen tot 1963 weinig succesvol, waardoor op een aantal specifieke terreinen regelingen met betrekking tot (onder meer) administratieve rechtspraak werden gemaakt. In 3.5 zal ik deze ontwikkelingen behandelen. De beschrijving van de ontwikkeling van de administratieve rechtspraak zal bondig zijn. Dit kan ook, nu deze ontwikkeling reeds vaker uitstekend is beschreven, onder meer door Van der Hoeven.'

\subsection{De ontwikkeling van de administratieve rechtspraak in de negentiende eeuw}

In de negentiende eeuw was het dus vooral de burgerlijke rechter, die de burger rechtsbescherming moest bieden tegen de overheid. Administratieve rechtspraak of een administratief-rechtelijke rechtsgang ter beslechting van geschillen bestond er slechts in zeer bescheiden mate op een beperkt aantal terreinen. Binnen de admini- 
stratie heerste de nodige weerstand tegen een dergelijke vorm van rechtspraak. Dit blijkt bijvoorbeeld uit de strijd tussen administratie en burgerlijke rechter in de periode tussen 1815 en 1848, welke periode grotendeels werd beheerst door het in 2.2 behandelde Conflictenbesluit.

Waar de burgerlijke rechter niet competent was, bleef de burger grotendeels verstoken van rechtsbescherming, evenals in het geval dat deze rechter weliswaar bevoegd was, maar de eiser niet-ontvankelijk werd verklaard. Het besef groeide echter dat ook in die gevallen rechtsbescherming nodig was. Het belangrijkste bezwaar tegen een onafhankelijke administratieve rechter bleef dat beslissingen in administratieve geschillen werden beschouwd als een daad van uitvoering en dus door de uitvoerende macht dienden te worden genomen. Hierop stuitte bijvoorbeeld in de jaren zestig van de negentiende eeuw het plan af om de Raad van State om te vormen tot onafhankelijke rechter in administratieve geschillen. ${ }^{2} \mathrm{Wel}$ werd in de Wet op de Raad van State uit 1861 de Kroon aangewezen als instantie die in hoogste aanleg besliste over administratieve geschillen. Een uit de Raad van State gevormde afdeling kreeg hierbij een adviserende taak. De wet gaf tevens procedureregels. De Kroon werd niet algemeen bevoegd; de competentie diende in de afzonderlijke wetten te worden geven. Er bleven de nodige geschillen bestaan, waarmee de burger bij het bestuur noch bij een rechter terecht kon.

De behoefte aan een algemene regeling betreffende de administratieve rechtspraak bleef dan ook bestaan. Hierbij speelde vooral de rechtsstaatgedachte een rol: ook de overheid is aan het recht gebonden en dus is er behoefte aan onafhankelijke rechtspraak. De administratie kon dan ook niet tegelijk partij en rechter zijn in een geschil. $^{3}$ Tijdens de grondwetswijziging van 1887 kwam het vraagstuk van administratieve rechtspraak aan de orde. Tot een verplichting tot invoering van administratieve rechtspraak kwam het uiteindelijk niet. Wel werd artikel 153, dat gelijk was aan artikel $148 \mathrm{Gw} 1848$, 'aangevuld' door artikel 154, dat luidde:

'De wet kan de beslissing van twistgedingen, niet behoorende tot die, vermeld in art. 153, hetzij aan den gewonen regter, hetzij aan een collegie met administrative regtspraak belast, opdragen; zị regelt de wijze van behandeling en de gevolgen der beslissingen:

Artikel 76 stelde buiten kijf dat (een afdeling van) de Raad van State een dergelijk 'collegie' was aan wie de rechtspraak kon worden opgedragen. ${ }^{4}$ De discussie spitste zich vervolgens toe op de vraag hoe aan artikel 154 invulling diende te worden gegeven. Naast de vraag, welke instantie als rechter diende te worden angewezen, speelde ook de vraag wat de rechtsmacht van deze instantie diende te

2. In 1848 werd daartoe een regeringsvoorstel gedaan, nadat reeds eerder een voorstel was gedaan door de zogenaamde negen-mannen, waaronder Thorbecke, zie Donner (1987), blz. 308-309.

3. Zie bijvoorbeeld Buijs (1887), blz. 324-325 en 346-347.

4. Artikel $76 \mathrm{Gw} 1887$ luidde: "De wet kan aan den Raad van State of aan eene afdeeling van dien Raad de uitspraak over geschillen opdragen'. 
zijn. $^{5}$

In 1891 werd de Staatscommissie Kappeyne van de Coppello ingesteld, die de opdracht kreeg een wetsontwerp te maken met betrekking tot de regeling van de administratieve rechtspraak. Zij bracht in 1894 verslag uit, ${ }^{6}$ waarin zij onder meer voorstelde een nieuw administratief hooggerechtshof op te richten dat administratieve handelingen (in de ruimste zin van het woord) diende te toetsen op wetmatigheid. De doelmatigheidstoets diende te geschieden door de administratie zelf. Het gerechtshof moest de beleidsvrijheid van de administratie dan ook respecteren. Het wetsvoorstel vond geen bijval ${ }^{7}$ en verdween dan ook in de ijskast.

\subsection{De pogingen om tot een algemene regeling van administratieve recht-} spraak te komen in de eerste helft van de twintigste eeuw

Het mislukken van dit voorstel betekende niet dat de pogingen om te komen tot een algemene regeling van administratieve rechtspraak werden opgegeven. Maar tevens zien we de ontwikkeling van het 'moderne' bestuursrecht beginnen.

Zo kwam in deze periode de eerste Nederlandse socialezekerheidswet tot stand, de Ongevallenwet $1901 .^{8}$ Een uitgebreide regeling omtrent de rechtspraak werd hierin niet neergelegd. Nu de regering nog steeds bezig was met het werken aan een algemene regeling van de administratieve rechtspraak wilde zij zichzelf niet voor de voeten lopen door een regeling van het formele recht in de Ongevallenwet neer te leggen. Er werd voor gekozen om de beroepsgang in een afzonderlijke wet neer te leggen, ${ }^{9}$ de Beroepswet $1902 .{ }^{10}$ In artikel 1 van deze wet werd onder meer bepaald dat hoger beroep tegen de beslissingen van de Raden van Beroep kon worden ingesteld bij de Centrale Raad van Beroep. De regeling werd door de regering als een voorlopige gezien, die te zijner tijd zou opgaan in de algemene regeling van de administratieve rechtspraak. ${ }^{\text {II }}$

In. 1905 vond een volgende poging plaats om te komen tot een dergelijke algemene regeling. In dat jaar diende de minister van Justitie J.A. Loeff drie wetsontwerpen in, gezamenlijk getiteld de ontwerpen van wet houdende maatregelen tot

5. Het belangrijkste geschilpunt was of deze rechter alleen een wetmatigheidstoets dan wel tevens een doelmatigheidstoets mocht hanteren. Zie hierover onder meer de preadviezen voor de NJV uit 1891 van Van Houten (1891) en Buijs (1891).

6. Verslag Staatscommissie Kappeyne van de Coppello (1894),

7. Zie Vegting (1957), blz. 385-386.

8. Wet van 2 januari 1901 , houdende wettelijke verzekering van werklieden tegen geldelijke gevolgen van ongevallen in bepaalde bedrijven, Stb. 1.

9. Faber (1992), blz. 4-5.

10. Wet van 8 december 1902 , tot uitvoering van artikel 75 der Ongevallenwet 1901, Stb. 208. De Beroepswet trad op 14 december 1902 in werking, besluit van 8 december 1902, Sth. 209.

11. Vegting (1957), blz. 387 . Ik zal in 6.3 .2 verder ingaan op deze twee wetten. 
regeling der Administratieve Rechtspraak, de Ontwerpen-Loeff. ${ }^{12}$ Belangrijkste was het ontwerp-Wetboek van Administratieve Rechtswordering, het ontwerp WAR.

Het doel van deze ontwerpen was bescherming bieden tegen 'schennis van het publiek recht door de Overheid'. ${ }^{13}$ De administratieve rechtspraak diende te worden opgedragen aan de gewone rechters. Hiertoe zouden bij de rechtbanken, gerechtshoven en de Hoge Raad afzonderlijke administratieve kamers dienen te komen. Uitgangspunt was een behandeling in drie instanties. Beroep kon worden ingesteld tegen besluiten, handelingen of weigeringen van administratieve organen (artikel 74 lid 1 ontwerp WAR) door hem, die persoonlijke belangen heeft, welke rechtstreeks door het aangevallen besluit of de aangevallen handeling of weigering worden getroffen (artikel 15 lid 1 aanhef en onder $1^{\circ}$ ontwerp WAR). Beroepsgrond was 'schennis van publiekrechtelijke wetten of wettelijke voorschriften' (artikel 84 ontwerp WAR). De rechter kon dus niet treden in de beoordeling van de wijze van uitoefening van de discretionaire bevoegdheden door de administratieve organen. ${ }^{14}$ Werd het beroep gegrond geacht, dan werd het aangevallen besluit, de aangevallen handeling of weigering geheel of gedeeltelijk onwettig verklaard (artikel 183 lid 1 ontwerp WAR).

Het ontwerp WAR bevatte voorts een artikel met betrekking tot terugvordering, artikel 14, dat bepaalde dat 'naar publiek recht onverschuldigd betaalde gelden moeten worden teruggegeven'. Uit de memorie van toelichting bleek dat dit artikel zag op terugvordering door de burger, die te veel had betaald aan de overheid. ${ }^{15}$ In een latere versie werd dan ook voorgesteld de tekst van artikel 14 te wijzigen, waardoor deze bedoeling werd verduidelijkt: 'Krachtens publiek recht geïnde, onverschuldigd betaalde gelden moeten worden teruggegeven'. ${ }^{16}$

De ontwerpen (b)leken hun tijd ver vooruit. ${ }^{17} \mathrm{Zij}$ vonden dan ook de nodige

12. Tweede Kamer 1904-1905, 159, nrs. 2, 4 en 6, zie ook. Ontwerp-Loeff (1905). Het was de bedoeling dat op een later tijdstip nog drie ontwerpen zouden worden aangeboden, waaronder een ontwerp van een nieuwe Beroepswet, Tweede Kamer 1904-1905, 159, nr. 3, blz. 23-24.

13. Memorie van toelichting ontwerp-WAR, Tweede Kamer 1904-1905, 159, nr. 3, blz. 24, Ontwerp-Loeff (1905), blz. 64-65. Het door Loeff beoogde doel was dus handhaving van het objectieve publiekrecht, en niet zozeer rechtsbescherming voor de burgei. Administratieve rechtspraak moest immers bescherming bieden tegen 'schennis van het publiekrecht door de overheid'. Dit was in overeenstemming met de ideeên die Loeff reeds in 1887 in zijn proefschrift had neergelegd, zie hierover 5.3.1.

14. Ten Berge/Tak (1983), biz. 16.

15. Tweede Kamer 1904-1905, 159, nr. 3, blz. 26, Ontwerp-Loeff (1905), blz. 70.

16. Tweede Kamer 1914-1915, 47, nr. 1, blz. 60, Ontwerp-Loeff (1915), blz. 127.

17. Er wordt wel gesteld dat vele denkbeelden uit de ontwerpen zijn terug te vinden in Algemene wet bestuursrecht. Het is de vraag of dat correct is. Bij Loeff stond namelijk controle van het bestuur en dus, handhaving van het objectieve publiekrecht, voorop, zie ook de uitwerking van zijn denkbeelden in zijn dissertatie (Loeff (1887), zie hierover 5.3.1), aan de, Awb-bepalingen met betrekking tot bestuursrechtspraak en het bestuursprocesrecht ligt vooral de rechtsbeschermingsgedachte ten grondslag, zie PG Awb II, blz. 174. Wel kan worden gezegd dat de ontwerpen en de Awb grote overeenkomsten vertonen in de uitwerking van de bepalingen. 
bestrijding, onder meer door Struycken. ${ }^{18}$ Diens voornaamste bezwaar was dat de rechter de administratie niet mocht controleren; dit diende de administratie zelf te doen. De kritiek van Struycken had zoveel invloed dat de ontwerpen na 1915 niet verder werden behandeld en in 1937 ook formeel werden ingetrokken.

$\mathrm{Na} 1915$ werd de idee van een algemene regeling van administratieve rechtspraak voorlopig verlaten. Wel werd de rechtsbescherming tegen de overheid ook na die tijd uitgebreid; dit gebeurde via specifieke regelingen. Zo werd het Kroonberoep uitgebreid, evenals het administratieve beroep op bijvoorbeeld gedeputeerde staten. ${ }^{19}$ Voorts verschenen nieuwe administratieve rechters ${ }^{20}$ en werd door sommige wetten de rechtspraak opgedragen aan de burgerlijke rechter. ${ }^{21}$ Ten slotte werd aan bestaande colleges voor administratieve rechtspraak, waarvan de belangrijkste de Centrale Raad van Beroep was, steeds meer rechtspraak opgedragen. ${ }^{22}$

In 1931 werd het vraagstuk van de algemene administratieve rechtspraak weer actueel door de instelling van de Commissie van Advies inzake verhoogde rechtsbescherming tegen de overheid, de Commissie-Koolen. Zij bracht in 1932 verslag uit. ${ }^{23}$ De (verhoogde) bescherming diende te worden geboden door een onafhankelijke rechter, in hoogste instantie de Centrale Raad van Beroep, welke zou worden hernoemd tot Hoog Administratief Gerechtshof. De rechtsmacht van deze administratieve rechter zou zijn, te oordelen over besluiten, handelingen en weigeringen van administratieve organen. Wel zou de rechtsbescherming aanvullend zijn; waar een specifieke administratieve rechtsgang bestond, was de algemene administratieve rechter niet bevoegd. Beroepsgronden waren strijd met de wet en détournement de pouvoir.

Ook deze voorstellen leidden tot niets, onder meer als gevolg van de crisis die in deze tijd uitbrak. ${ }^{24}$ Een andere oorzaak was dat het leerstuk van de onrechtmatige overheidsdaad in een stroomversnelling kwam en hierin (een deel van) de oplossing werd gevonden. ${ }^{25}$ Aan het einde van de negentiende eeuw had de Hoge Raad de mogelijkheid om de overheid aan te spreken op grond van een onrechtmatige daad sterk beperkt in arresten als Vrouwe Elske en Rhedense koe. ${ }^{26}$ Deze lijn werd in het begin van de twintigste eeuw langzaam verlaten. De

18. Zie Struycken (1910).

19. Zie yoor voorbeelden Van Wijk/Konijnenbelt \& Van Male (1999), blz. 542.

20. Bijvoorbeeld de Raden van Beroep voor de directe belastingen. Zie over deze raden Widdershoven (1989), blz. 77 en 94-95.

21. Zie Van Wijk/Konijnenbelt \& Van Male (1999), blz. 543 en. Ten Berge/Tak (1983), blz. 18 voor enige voorbeelden.

22. De Centrale Raad van Beroep werd bijvoorbeeld bevoegd op het terrein van het ambtenarenrecht. Zie uitgebreid hierover 7.2.3.

23. Verslag Commissie-Koolen (1932).

24. Zie Widdershoven (1989), blz. 66 en Van Wijk/Konijnenbelt \& Van Male (1999), blz. 543.

25. Zie Vegting (1957), blz. 402 en Van Wijk/Konijnenbelt \& Van Male (1999), blz. 543.

26. Respectievelijk HR 29 mei 1896, W. 6817 en HR 21 april 1898, W. 7116 . Zie hierover onder meer Van Maanen (1996), blz. 46-52. 
mogelijkheden om een onrechtmatigedaadsactie in te stellen tegen de overheid werden geleidelijk (weer) verruimd. ${ }^{27}$

\subsection{De periode na de Tweede Wereldoorlog}

\subsubsection{Inleiding}

Spoedig na de Tweede Wereldoorlog werden de pogingen om de rechtsbescherming uit te breiden via aanvullende regelingen hervat; in $1946 \mathrm{kreeg}$ de Commissie-De Monchy opdracht om de stand van zaken met betrekking tot de rechtsbescherming tegen de overheid op te nemen en om daarbij aan te geven in hoeverre behoefte bestond aan verhoogde rechtsbescherming. ${ }^{28}$ Een van de door deze commissie voorgestelde ontwerpen leidde uiteindelijk, zij het in gewijzigde vorm, tot de Wet bab, de eerste wet die aanvullende rechtsbescherming beoogde te bieden. Hiermee werd de weg in de richting van het huidige stelsel ingeslagen. Een tussenstation blijkt achteraf de Wet arob te zijn geweest. Deze wet werd ingetrokken toen in 1994 de Algemene wet bestuursrecht in werking trad.

\subsubsection{De Wet beroep administratieve beschikkingen (Wet bab)}

Nadat de Commissie-De Monchy haar opdracht had gekregen, bracht zij in 1950 verslag uit. ${ }^{29}$ In dit verslag waren eif voorontwerpen van wet opgenomen. De twee belangrijkste waren het voorontwerp voor de Wet beroep administratieve beschikkingen, de Wet bab, en het voorontwerp Wet onrechtmatige daden overheidslichamen, afgekort tot Wet odol. Het eerste betrof een regeling met betrekking tot beschikkingen, het tweede met betrekking tot andere handelingen.

Ten aanzien van beschikkingen stelde de commissie een aanvullende regeling voor; tegen beschikkingen, waartegen geen beroep bij een onafhankelijke rechter of bij de Kroon openstond (of had opengestaan), kon beroep worden ingesteld bij de Kroon, die deze beschikkingen op rechtmatigheid kon toetsen. Voorgesteld werd een aantal toetsingsgronden op te nemen, namelijk strijd met algemeen verbindende voorschriften en strijd met algemene beginselen van behoorlijk bestuur.

Het uitgangspunt van het ontwerp odol was dat de gewone rechter competent bleef. Aan de artikelen omtrent de onrechtmatige daad uit het BW diende in een afzonderlijke wet een aantal bepalingen te worden toegevoegd met betrekking tot de onrechtmatige overheidsdaad. Dit ontwerp ontmoette veel kritiek: het werd onder meer onwenselijk geacht de Hoge Raad door starre wetsbepalingen te

27. Zie hierover onder meer Vegting (1957), blz. 480-484 en Van Maanen (1996), blz. 59-62. Zie over de gehele ontwikkeling vanaf het eind van de negentiende eeuw tot de Tweede Wereldoorlog Van Maanen/De Lange (2000), blz. 29-35.

28. Van Wijk/Konijnenbelt \& Van Male (1999), blz. 543.

29. Verslag Commissie-De Monchy (1950). 
belemmeren in de ontwikkeling van dit rechtsgebied. ${ }^{30}$

De Wet odol bracht het niet verder dan ontwerp. Het ontwerp bab kende een gunstiger levensloop; in 1963 trad de Wet bab in werking. ${ }^{31}$ Deze wet week op een aantal belangrijke punten af van de voorstellen van de commissie. Zo kon de natuurlijke persoon of rechtspersoon, die door een beschikking rechtstreeks in zijn belang was getroffen daartegen bij de Kroon voorziening vragen, ${ }^{32}$ aldus artikel 4 lid 1 aanhef, maar anders dan in het voorontwerp was het begrip beschikking beperkt tot schriftelijke wilsverklaringen van de centrale overheid (artikel 2 lid 1). Voorts zonderde artikel 5 een groot aantal beschikkingen uit van Kroonberoep. Het aanvullende karakter van de wet werd neergelegd in artikel 5 aanhef en onder d. De toetsingsgronden waren te vinden in artikel 4 lid 1: strijd met een algemeen verbindend voorschrift, détournement de pouvoir, willekeur en het anderszins in strijd met enig in het algemeen rechtsbewustzijn levend beginsel van behoorlijk bestuur beschikken, ${ }^{33}$ kortom; een rechtmatigheidstoets. Toch was geen sprake van echte rechtspraak; de toetsing vond immers plaats binnen de administratie. ${ }^{34}$

\subsubsection{De Wet administratieve rechtspraak overheidsbeschikkingen (Wet arob)}

De Wet bab was de eerste wet waarin een aanvullende rechtsbescherming werd neergelegd. Toch was er kritiek op deze regeling. Het uitgangspunt, ook van de Commissie-De Monchy, dat de algemene administratieve rechter competent zou zijn indien geen andere (specifieke) administratieve rechter bevoegd was, werd niet onverkort toegepast in de Wet bab. Vooral het feit dat alleen tegen beschikkingen van de centrale overheid (aanvullend) beroep bij de Kroon openstond, werd bekritiseerd. Reeds in 1965 werd de Commissie-Wiarda ingesteld, die tot opdracht kreeg na te gaan in hoeverre het mogelijk en wenselijk was een verhoogde rechtsbescherming te bieden met betrekking tot beschikkingen van organen van lagere overheidslichamen. ${ }^{35} \mathrm{Zij}$ bracht in december 1967 haar rapport uit. ${ }^{36} \mathrm{Zij}$ stelde voor de Wet bab te wijzigen door ook beroep tegen beschikkingen van lagere overheden open te stellen. Daarbij zag zij geen reden een beroep in twee instanties voor te schrijven. Meestal was al een dergelijke procedure aanwezig. Waar dit niet zo was, stelde zij voor om voorafgaande aan het 'bab-beroep' een bezwaarschriftprocedure te creëren bij het orgaan dat de beschikking had gege-

30. Van Wijk/Konijnenbelt \& Van Male (1999), blz. 544.

31. Wet van 20 juni 1963, Stb. 268.

32. De Kroon besliste vervolgens, nadat de Afdeling, voor de geschillen van bestuur van de Raad van State advies had uitgebracht, artikel 13 Wet bab.

33. Deze toetsingsgronden waren inmiddels ook al opgenomen in de Wet administratieve rechtspraak bedrijfsorganisatie, die in 1955 in werking trad. Zie hierover 8.4.3.

34. Rapport Commissie-Wiarda (1968), blz 14.

35. Zie de installatierede van minister van Justitie Scholten, Rapport Commissie-Wiarda (1968), blz. 2. Voorzitter G.J. Wiarda was ook reeds lid van de Commissie-De Monchy.

36. Rapport Commissie-Wiarda (1968). 
ven. ${ }^{37}$ Een tweede belangrijk voorstel was om het beroep weg te halen bij de administratie. De Afdeling voor de geschillen van bestuur van de Raad van State, in de Wet bab adviseur van de Kroon, diende belast te worden met de beslissing op het beroep. ${ }^{38}$

De voorstellen van de Commissie-Wiarda waren voor de regering aanleiding om in 1971 een wetsontwerp in te dienen tot vervanging van de Wet bab door de Wet administratieve rechtspraak overheidsbeschikkingen, de Wet arob, ${ }^{39}$ tezamen met een ontwerp-wijziging van de Wet op de Raad van State. ${ }^{40}$ Beide wetten verschenen in 1975 in het Staatsblad ${ }^{41}$ en traden op 1 juli 1976 in werking. ${ }^{42}$

Door de wijziging van de Wet op de Raad van State werd de Afdeling rechtspraak van de Raad van State in het leven geroepen (artikel 63 Wet RvS), welke werd belast met de beslechting van geschillen, haar bij de wet opgedragen, namelijk het beroep tegen beschikkingen op grond van de Wet arob. Evenals de Wet bab gaf de Wet arob een algemene, aanvullende rechtsgang: stond tegen een beschikking een andere administratiefrechtelijke voorziening open, dan kon geen voorziening worden gevraagd bij de Afdeling rechtspraak. Ook de voorgestelde bezwaarschriftprocedure werd opgenomen in de wet. Beroepsgronden waren de reeds uit de Wet bab (en de Wet arbo $^{43}$ ) bekende vier rechtmatigheidsgronden, namelijk strijd met een algemeen verbindend voorschrift, détournement de pouvoir, willekeur of strijd met enig in het algemeen rechtsbewustzijn levend beginsel van behoorlijk bestuur (artikel 8 ). Uitgesloten van toetsing, want volgens de Wet arob geen beschikking, was onder meer de rechtshandeling naar burgerlijk recht (artikel 2 lid 2). De uitsluiting van deze rechtshandelingen was ook reeds opgenomen in de Wet arbo ${ }^{44}$ en, zij het in andere bewoordingen, in de Wet bab. In $4.2 \mathrm{zal}$ ik nader ingaan op de consequenties van deze uitsluiting.

\subsubsection{De Algemene wet bestuursrecht (Awb)}

In 1983 vond een wijziging van de Grondwet plaats, waarbij artikel 107 lid 2 werd opgenomen, dat bepaalde dat 'de wet $(\ldots)$ algemene regels van bestuursrecht vast(stelt)'. Hiermee kreeg de wens tot codificatie van het algemene bestuursrecht een grondwettelijke basis. Het ontstaan en de ontwikkeling van die algemene

37. Rapport Commissie-Wiarda (1968), blz. 18-21.

38. Rapport Commissie-Wiarda (1968), blz. 14-16. Een belangrijke overweging hierbij was; dat op die manier de autonome sfeer van de lagere overheidslichamen beter gewaarborgd zou blijven.

39. Tweede Kamer 1970-1971, 11 279, nrs. 1-3.

40. Tweede Kamer 1970-1971, 11 280, nrs. 1-3.

41. Respectievelijk als Wet van 1 mei 1975 tot wijziging van de Wet op de Raad van State en een aantal andere wetten, Stb. 283 en Wet van 1 mei 1975, houdende regels betreffende beroep op de Raad van State tegen overheidsbeschikkingen (Wet administratieve rechtspraak overheidsbeschikkingen), Stb. 284.

42. Respectievelijk besluit van 22 april 1976, Stb. 233 (Wet tot wijziging van de Wet op de Raad van State) en besluit van 20 april 1976, Stb 234 (Wet arob).

43. Zie 8.4 .3 .

44. Zie hierover 8.4 .3 en verder. 
regels van bestuursrecht kan niet los worden gezien van de herziening van de rechterlijke organisatie, zodat ook daarop moet worden ingegaan.

In de jaren zestig kwam van verschillende kanten kritiek op de bestaande rechterlijke organisatie. ${ }^{45}$ In 1971 besloot de minister van Justitie tot het instellen van een staatscommissie, die een herziening van de rechterlijke organisatie diende voor te bereiden. Deze staatscommissie werd voorafgegaan door de werkgroepWiersma, volgens welke de in te stellen staatscommissie onder meer de mogelijkheid moest onderzoeken van samenvoeging van de administratiefrechterlijke macht en de gewone rechterlijke macht. ${ }^{46}$

In 1976 werd de Staatscommissie Herziening Rechterlijke Organisatie ingesteld. ${ }^{47}$ In het eerste deel van haar eindrapport uit 1984 deed zij een aantal voorstellen, waarvan het belangrijkste met betrekking tot de administratieve rechtspraak was dat de administratieve rechtspraak diende te worden opgedragen aan administratieve kamers bij de gewone rechtbanken, gerechtshoven en de Hoge Raad. Deze kamers dienden tot de rechterlijke macht te gaan behoren. ${ }^{48}$

Een en ander was voor de regering aanleiding over te gaan tot het doen van een voorstel met betrekking tot een herziening van de rechterlijke macht. Deze herziening zou zich in drie fasen moeten voltrekken. Voor het bestuursrecht waren de eerste en derde fase van belang. De eerste fase zou bestaan uit het instellen van administratieve kamers bij de rechtbanken, welke in eerste aanleg dienden te oordelen in geschillen betreffende onder meer socialezekerheidszaken, ambtenarenzaken en arob-zaken. De rechtsmacht in hoger beroep in onder meer arobgeschillen diende in deze fase te worden opgedragen aan de nieuw te vormen Afdeling bestuursrechtspraak van de Raad van State. ${ }^{49}$ Deze Afdeling bestuursrechtspraak zou ontstaan door fusie van de Afdeling voor de geschillen van bestuur en de Afdeling rechtspraak. De tweede fase diende de integratie van de kantongerechten en de rechtbanken te regelen en een definitieve regeling van het hoger beroep in straf- en civiele zaken. De derde fase zou de voltooiing van de herstructurering van het stelsel van bestuursrechtelijke rechtsbescherming omvatten. Belangrijkste punt hierbij was de definitieve regeling van hoger beroep en cassatie in de administratieve rechtspraak. ${ }^{50}$

De Wet voorintegratie bewerkstelligde dat in 1992 de Raden van Bleroep en de Ambtenarengerechten op hielden te bestaan als zelfstandige instanties. Hun taken werden overgenomen door de administratieve kamers bij de rechtbanken. ${ }^{51}$

45. Zie hierover Hirșch Ballin (1993), blz. 272 en Van den Haak (1997), blz. 68.

46. Rapport werkgroep-Wiersma (1972), blz. 9.

47. Bij KB van 1 april 1976, nr. 71. Zie ook Rapport Staatscommissie-Van Zeben (1984), biz. 1. Tot 1979 was Ras voorzitter van de commissie, sedertdien Van Zeben.

48. Rapport Staatscommissie-Van Zeben (1984), blz. 26. Dit kwam overeen met hetgeen Loeff had voorgesteld, zie 3.3 .

49. Tweede Kamer 1991-1992, 22 495, nr. 3, blz. 11, PG Awb II, blz. 71.

50. Tweede Kamer 1991-1992, 22 495, nr. 3, blz. 11, PG Awb II, blz. 71.

51. Wet van 3 juni 1992, Stb. 278. 
Naast de herziening van de rechterlijke organisatie bestond de wens naar codificatie van het algemene bestuursrecht, welke in 1983 dus een grondwettelijke basis had gekregen. Hiertoe werd in 1983 de Commissie wetgeving algemene regels van bestuursrecht ingesteld, de Commissie-Scheltema. ${ }^{52} \mathrm{Zij}$ koos voor een systeem van aanbouwwetgeving; de wet zou in verschillende stappen, tranches genaamd, tot stand worden gebracht. Het in een keer codificeren van het bestuursrecht was een te grote opgave. Begin 1987 bood de commissie een voorontwerp Algemene wet bestuursrecht Eerste Deel aan. In 1989 diende de regering vervolgens het voorstel Algemene regels van bestuursrecht (Algemene wet bestuursrecht) in. ${ }^{53}$ In deze eerste tranche van de Awb werd voornamelijk het algemene deel van het materiële bestuursrecht geregeld. Deze tranche werd wet op 4 juni $1992 .^{54} \mathrm{De}$ inwerkingtreding werd echter uitgesteld; gekozen werd voor de datum waarop ook de tweede tranche in werking zou treden.

De tweede tranche werd niet voorbereid door de Commissie-Scheltema, maar maakte deel uit van het wetsvoorstel dat de eerste fase van de herziening van de rechterlijke macht zou voltooien. Deze tranche zou namelijk de regels betreffende het uniforme bestuursprocesrecht bevatten, die de administratieve kamers van de rechtbanken en de andere bestuursrechters zouden moeten gaan toepassen. De invoering van deze regeís kon volgens de regering niet los worden gezien van de voltooiing van de eerste fase van de herziening van de rechterlijke organisatie. ${ }^{55}$ Het wetsvoorstel werd op 16 december 1993 wet $^{56}$ en trad op 1 januari 1994 in werking, tezamen met de eerste tranche van de Awb. Op dat moment begon ook de nieuwe Afdeling bestuursrechtspraak met haar werkzaamheden.

Met de inwerkingtreding van de Awb is de situatie in grote lijnen de volgende. Voor alle bestuursorganen geldt een uniform algemeen deel van het bestuursrecht, waarin het 'besluit'begrip centraal staat. Volgens artikel 1:3 lid 1 is een besluit een schriftelijke beslissing van een bestuursorgaan, inhoudende een publiekrechtelijke rechtshandeling. Nu het moet gaan om een publiekrechtelijke rechtshandeling, vallen rechtshandelingen naar burgerlijk recht niet onder het besluitbegrip. Een belanghebbende, die door een besluit van een bestuursorgaan rechtstreeks in zijn belang is getroffen, kan tegen dit besluit beroep instellen bij de bestuurskamer van de arrondissementsrechtbank (artikel 8:1 Awb), tenzij de wet een andere rechtsgang voorschrijft (artikel 8:6) of beroep door de Awb wordt uitgesloten (artikelen 8:2-8:5). Uitgesloten wordt onder meer beroep tegen een

52. KB van 23 augustus 1983, Stb. 417. Voorzitter was M. Scheltema.

53. Tweede Kamer 1988-1989, 21 221, nrs. 1-3.

54. Wet van 4 juni 1992, houdende algemene regels van bestuursrecht (Algernene wet bestuursrecht), Stb. 315.

55. Tweede Kamer 1991-1992, 22, 495, nr. 3, blz. 12, PG Awb II, blz. 72.

56. Wet van 16 december 1993 tot wijziging van de Wet op de rechterlijke organisatic, de Algemene wet bestuursrecht, de Wet op de Raad van State, de Beroepswet, de Ambtenarenwet 1929 en andere wetten, alsmede intrekking van de Wet administratieve rechtspraak overheidsbeschikkin. gen (voltowiing eerste fase herziening rechterlijke organisatie), Stb. 650 . 
besluit ter voorbereiding van een privaatrechtelijke rechtshandeling (artikel 8:3). Wel dient de belanghebbende alvorens beroep in te stellen tegen het besluit bezwaar te maken (artikel 7:1). Vervolgens kan tegen de uitspraak van de rechtbank hoger beroep worden ingesteld bij de Afdeling bestuursrechtspraak, de Centrale Raad van Beroep of het College van Beroep voor het bedrijfsleven, afhankelijk van het soort geschil. ${ }^{57}$ Deze instanties oordelen dan als hoogste rechter. Zoals gezegd kan de wet een andere rechtsgang voorschrijven. Zo oordeelt de Afdeling bestuursrechtspraak op grond van een aantal wetten, waarvan de belangrijkste is de Wet milieubeheer (artikel $20.1 \mathrm{Wmb}$ ), in eerste en enige aanleg. Ook de Centrale Raad van Beroep wordt in bepaalde wetten aangewezen als enige beroepsrechter. Daarnaast blijt het College van Beroep voor het bedrijfsleven voor zover oordelende op grond van zijn algemene rechtsmacht op grond van de Wet bestuursrechtspraak bedrijfsorganisatie in eerste en enige aanleg competent." Wel geldt voor deze instanties het uniforme bestuursprocesrecht zoals neergelegd in hoofdstuk $8 \mathrm{Awb}^{59}$ en dienen zij het bestreden besluit te toetsen aan de regels van het algemene bestuursrecht, zoals neergelegd in de Awb. ${ }^{60}$

Inmiddels is duidelijk dat de derde fase van de herziening van de rechterlijke macht niet conform de oorspronkelijke planning zal worden uitgevoerd; er zal enige jaren een pas op de plaats worden gemaakt. ${ }^{61}$ Slechts enkele kleine aanpassingen zullen plaatsvinden in het stelsel van bestuursrechtelijke rechtsbescherming en bestuursrechtspraak. ${ }^{62}$ Deze pas op de plaats betekent niet dat de met de derde fase beoogde ontwikkeling van eenheid in het administratieve recht van de baan is $\mathrm{nu}$, in ieder geval gedurende de komende tijd, verschillende hoogste administratieve rechters actief blijven. Vanuit de verschillende colleges is namelijk een coördinerend overleg opgezet, waarin de rechtsontwikkelingen van die colleges zoveel mogelijk op elkaar worden afgestemd. ${ }^{63}$

Op het gebied van de Algemene wet bestuursrecht wordt wél de nodige vooruitgang geboekt. De derde tranche is op 1 januari 1998 in werking getreden. ${ }^{64}$ Het voor dit onderzoek belangrijkste onderwerp uit deze tranche is de subsidietitel (titel 4.2). Inmiddels is ook een voorontwerp voor de vierde tranche gepubliceerd. In dit voorontwerp zijn bepalingen met betrekking tot vier onderwerpen opgeno-

57. Artikel 37 lid 1 Wet RvS, artikel 18 lid 1 Beroepswet en artikel 20 lid 1 Wbbo.

58. Zie hierover 8.4.3.

59. Zie bijvoorbeeld artikel 36 en 39 Wet RvS en artikel 17 en 21 Beroepswet.

60 . En uiteraard aan de specifieke regels in de afzonderlijke wetten.

61. Zie hierover 12.6 .

62. Brief van de minister van Justitie aan de Tweede Kamer, Tweede Kamer 1996-1997, 25 425, nr. 1, blz. 11-12. Een van die aanpassingen is inmiddels gerealiseerd: het in 1986 ingestelde College van beroep studiefinanciering, dat bevoegd was te oordelen over besluiten genomen op grond van de Wet op de studiefinanciering, is opgeheven. Zie hierover 8.3.1.

63. Zie hierover Van der Ham (1997).

64. Wet van 20 juni 1996 tot aanvulling van de Algemene wet bestuursrecht (Derde tranche Algemene wet bestuursrecht), Stb. 333. 
men, waaronder bestuursrechtelijke geldschulden (beoogde titel 4.4). ${ }^{65}$ Ook hebben de ministers van Justitie en van Binnenlandse Zaken en Koninkrijksrelaties in een brief aan de Tweede Kamer 'mogelijke onderwerpen voor een vijfde tranche' aangegeven. De eerste prioriteit ligt bij de volgende onderwerpen: nadeelcompensatie (en schadevergoeding), intrekking en wijziging van beschikkingen en (bestuursrechtelijke) overeenkomsten. ${ }^{66}$ Wel wordt in dezelfde brief aangegeven dat 'voor het ter hand nemen van nieuwe onderwerpen, en dus voor een vijfde tranche van de Awb, (...) de komende tijd maar in zeer beperkte mate ruimte' bestaat. ${ }^{67}$

\subsection{Bijzondere administratieve rechtspraak}

Naast de pogingen om te komen tot een algemene regeling van administratieve rechtspraak werd op een aantal specifieke terreinen een wettelijke regeling gemaakt met betrekking tot de rechtsbescherming. Hierbij werden ook bijzondere administratieve rechters ${ }^{6 \mathrm{I}}$ in het leven werden geroepen. Ik heb reeds gewezen op de introductie van de Centrale Raad van Beroep in de Beroepswet. Vanaf het begin van de twintigste eeuw, en zeker na het mislukken van de Ontwerpen-Loeff, vond de uitbouw van de administratieve rechtspraak vooral langs deze weg plaats: specifieke regelingen met een specifieke administratieve rechter. Ik zal hier kort de hoofdlijnen van deze ontwikkeling beschrijven; zij zal uitgebreider aan de orde komen in de hoofdstukken 6 tot en met 8.

Door de Beroepswet 1902 werd dus de Centrale Raad van Beroep in het leven geroepen. De rechtsmacht van deze Raad werd neergelegd in artikel 1: hij oordeelde bij uitsluiting in hoogste instantie 'over de beslissingen van het bestuur der Rijksverzekeringsbank, waartegen, ingevolge de bepalingen der Ongevallenwet 1901 , beroep openstaat'. Met de uitbouw van het socialezekerheidsrecht werd ook de rechtsmacht van de Centrale Raad van Beroep ${ }^{69}$ uitgebreid. Tegen de meeste besluiten van de op grond van de verschillende socialezekerheidswetten ingestelde uitvoeringsorganen stond voor de betrokkenen beroep open bij een administratieve rechter. Hoofdregel was dat in deze gevallen de Raden van Beroep in eerste aanleg oordeelden, met de mogelijkheid van hoger beroep bij de Centrale Raad van Beroep. Het in dat geval toepasselijke formele recht was (in de regel) neergelegd in de Beroepswet. Op deze hoofdregel bestond een aantal uitzonderingen, waarvan (tot 1935) die in de Ziektewet de belangrijkste was.

65. Voorontwerp Commissie-Scheltema Awb IV (1999), blz. 2.

66. Brief van de ministers van Justitie en van Binnenlandse Zaken en Koninkrijksrelaties, Vaststelling van de begroting van de uitgaven en de ontvangsten van het Ministerie van Justitie (VI) voor het jaar 2000, Tweede Kamer 1999-2000, 26800 VI, nr. 7, blz. 8-10.

67. Tweede Kamer 1999-2000, 26800 VI, nr. 7, blz. 8.

68. Ik. gebruik deze term als tegenstelling tot een algemene administratieve rechter.

69. En van de Raden van Beroep. 
Een tweede te behandelen terrein waarvoor een specifieke administratiefrechtelijke rechtsgang in het leven werd geroepen, was het ambtenarenrecht. Sinds het midden van de negentiende eeuw leefde de algemene opvatting dat de ambtenaar met betrekking tot zijn rechtspositie bescherming diende te krijgen tegen de willekeur van de administratie. Aangezien in ambtenarenzaken steeds mede openbare belangen een rol spelen, diende de beslechting van geschillen tussen ambtenaren en de administratie niet te worden overgelaten aan de gewone rechter. Dit was (een van) de belangrijkste reden(en) dat een wettelijke regeling lange tijd niet van de grond kwam. Uiteindelijk werd na een aantal pogingen in 1929 de Ambtenarenwet 1929 (hierna: Aw 1929) in het Staatsblad gepubliceerd. ${ }^{70}$

De Ambtenarenwet richtte zich voornamelijk op het formele recht. Beroep kon worden ingesteld tegen besluiten, handelingen en weigeringen om te besluiten of te handelen, ten aanzien van ambtenaren als zodanig door een administratief orgaan genomen, verricht of uitgesproken. Er werden nieuwe Ambtenarengerechten ingesteld, die in eerste instantie oordeelden. Hoger beroep kon worden ingesteld bij de Centrale Raad van Beroep (artikel 3 lid 1 Aw 1929). In een aantal gevallen was de Centrale Raad in eerste en enige aanleg competent (artikel 3 lid 2 Aw 1929). De procedure leek sterk op die van de Beroepswet. Besloten werd dan ook de standplaatsen van de Ambtenarengerechten bij de Raden van Beroep in te richten, zodat de expertise van deze Raden ten goede kon komen aan de Ambtenarengerechten. Dit werd versterkt door het feit dat het ondersteunende personeel bij de Raden ook werd ingezet bij de Ambtenarengerechten.

Een laatste belangrijk terrein waarop administratieve rechtspraak tot ontwikkeling kwam, was het gebied van de sociaal-economische wetgeving. Op dit terrein speelden bedrijfsorganisaties een belangrijke rol. De ontwikkeling van deze bedrijfsorganisaties was een gevolg van de crisistijd in de jaren dertig van de twintigste eeuw. Het voor en tijdens de Tweede Wereldoorlog vooral op het terrein van de voedselvoorziening opgebouwde stelsel werd na het einde van die oorlog verder uitgewerkt, ook buiten dat terrein.

Zo kwam in 1950 de Wet op de Bedrijfsorganisatie (hierna: WBO) tot stand. $^{\text {" }}$ Deze wet introduceerde de Sociaal-Economische Raad (artikel 1 WBO) en opende onder meer de mogelijkheid product-, hoofdbedrijf- en bedrijfschappen in het leven te roepen (artikel 66 WBO). Op grond van artikel 32 lid 1 WBO had de SER verordenende bevoegdheid. Ook de schappen hadden die bevoegdheid ten aanzien van de hen bij wet of algemene maatregel van bestuur toegekende onderwerpen (artikel 93 WBO). Alle genoemde openbare lichamen konden publiekrechtelijke besluiten nemen en handelingen verrichten, indien de bevoegd-

70. Wet van 12 december 1929 , houdende regelen betreffende den rechtstoestand van ambtenaren, Stb. 530. Het duurde vervolgens tot 1 maart 1933 voor de wet in werking trad, besluit van 26 januari 1933, Stb. 32.

71. Wet van 27 januari 1950 tot toepassing ten aanzien van het bedrijfsleven van de artikelen $80 \mathrm{en}$ 152 tot en met 154 van de Grondwet (Wet op de Bedrijfsorganisatie), Stb. K 22. 
heid daartoe in de verordening was neergelegd. De rechtsbescherming werd geregeld in de in 1955 in werking getreden Wet administratieve rechtspraak bedrijfsorganisatie (hiema: Wet arbo). ${ }^{72}$ Artikel 4 van deze wet riep een nieuw administratief-rechterlijk college in het leven, het College van Beroep voor het bedrijfsleven. Dit college oordeelde 'bij uitsluiting' over het beroep tegen besluiten en handelingen van onder meer de genoemde lichamen, met uitzondering van besluiten, strekkende tot het verrichten van een rechtshandeling naar burgerlijk recht (artikel 4 lid 2). Beroepsgronden waren strijd met een algemeen verbindend voorschrift, détournement de pouvoir, willekeur en strijd met enig in het algemeen rechtsbewustzijn levend beginsel van behoorlijk bestuur (artikel 5), dezelfde gronden die negen jaar later werden opgenomen in de Wet bab. ${ }^{73}$

Met de uitbouw van de sociaal-economische wetgeving werd ook de competentie van het College van Beroep voor het bedrijfsleven uitgebreid: het werd belast met de rechtspraak tegen besluiten of handelingen van bestuursorganen op grond van vele van deze wetten. ${ }^{74}$ In deze gevallen kreeg het College een specifieke rechtsmacht, dit in tegenstelling tot zijn algemene rechtsmacht op grond van de Wet arbo. De consequenties hiervan zullen worden behandeld in hoofdstuk 8 .

\subsection{Conclusie}

Gedurende de negentiende en het begin van de twintigste eeuw werd een aantal pogingen gedaan om te komen tot een algemene regeling van administratieve rechtspraak. Deze pogingen stuitten echter voornamelijk af op het bezwaar dat ook rechtspraak in administratieve geschillen werd gezien als besturen, hetgeen aan het bestuur moest worden overgelaten en niet aan een rechter. Een gevolg hiervan was dat de wetgever sinds het begin van de twintigste eeuw op een aantal terreinen bijzondere rechtsgangen heeft ontwikkeld, waarbij specifieke bestuursrechters in het leven werden geroepen. Later, sinds 1963, werd de uitbouw van de rechtsbescherming tegen de overheid deels bereikt via aanvullende regelingen: was geen specifieke administratieve rechter bevoegd, dan was de algemene, aanvullende bestuursrechter bevoegd. Dit systeem kende echter belangrijke hiaten. De belangrijkste beperking was wel dat zowel in de Wet bab, de Wet arob en de Awb feitelijke overheidshandelingen van de competentie van de 'aanvullende' rechter waren uitgesloten, evenals rechtshandelingen naar burgerlijk recht. Bij een aantal specifieke bestuursrechters was dit anders. Zo waren (en zijn) de Centrale Raad van Beroep als ambtenarenrechter en het College van Beroep voor het bedrijfsle-

72. Wet van 16 september 1954, houdende administratieve rechtspraak bedrijfsorganisatie, Stb. 416 . De wet trad in werking op 1 juli 1955, Elesluit van 3 juni 1955, houdende inwerkingtreding van de Wet administratieve rechtspraak, bedrijfsorganisatie, Stb. 226.

73. Zie 3.4.2. Deze beroepsgronden waren ook al opgenomen in het verslag van de Commissie-De Monchy, zij het dat de daar voorgestelde grond 'strijd met algemene beginselen van behoorlijk. bestuur' verder werd uitgewerkt.

74. Zie voor een opsomming Mulder (1980), blz. 395-396. 
ven oordelend op grond van zijn algemene rechtsmacht ook bevoegd te oordelen over (feitelijke) handelingen van de overheid.

De belangrijkste consequentie van het feit dat sprake was van een rechtshandeling naar burgerlijk recht, was dat de burgerlijke rechter competent was en dat op die rechtshandeling (in beginsel) burgerlijk recht van toepassing was. De administratieve rechter leek minder ruimte te laten voor rechtstreekse toepassing van het privaatrecht, vooral de bijzondere bestuursrechters die een ruime competentie hadden. Zo zal in hoofdstuk 7 aan de orde komen dat bijvoorbeeld de ambtenarenrechter geneigd was privaatrechtelijke regels te vertalen naar meer algemene regels, welke het privaatrecht overstegen wanneer hij werd geconfronteerd met een probleem waarvoor het privaatrecht een regeling bevatte, welke in het publiekrecht ontbrak. Deze algemene regels werden vervolgens toegepast, waarbij zij werden 'ingebed' in het publiekrechtelijk normenstelsel. De vraag hoeveel ruimte de bestuursrechters lieten voor toepassing van het privaatrecht zal aan de orde komen bij de bespreking van de verschillende rechtsgebieden.

Een belangrijke vraag is dus, wanneer sprake is van een rechtshandelingen naar burgerlijk recht. Is immers sprake van een dergelijke fechtshandeling, dan is de burgerlijke rechter veelal bevoegd. Het privaatrecht kan in dat geval een belangrijke(re) rol spelen. Ik zal deze vraag in het komende hoofdstuk behandelen. In hoofdstuk 2 is aan de orde gekomen dat de burgerlijke rechter zijn bevoegdheid afbakent aan de hand van objectum litis. Voor de competentie van de bestuursrechter is veelal beslissend of sprake is van een beschikking of onder de Awb een besluit. Deze criteria stemmen niet overeen, waardoor een competentiegeschil kan ontstaan. Dit kan een negatief geschil zijn: zowel de burgerlijke als de bestuursrechter acht zich niet competent kennis te nemen van het geschil. Vaker zal zich voordoen dat sprake is van een positief competentiegeschil, waarbij beide rechters zich bevoegd achten. Hoe dit 'geschil' wordt opgelost zal ook aan de orde komen in het volgende hoofdstuk. 



\section{COMPETENTIE'PERIKELEN'}

\subsection{Inleiding}

Gebleken is dat bij de afbakening van de bevoegdheid van zowel de burgerlijke als de bestuursrechter het uitgangspunt is dat ieder van deze rechters bij uitsluiting bevoegd is te oordelen over zijn eigen competentie. Nu de door beide rechters gehanteerde criteria niet op elkaar aansluiten, kan dit tot problemen leiden. Enerzijds kan het voorkomen dat beide rechters zich niet bevoegd achten, anderzijds (en deze situatie doet zich in de praktijk vaker voor) kan het zo zijn dat beide zich wel bevoegd achten. Er kan dus zowel een positief als een negatief competentieconflict ontstaan. In dit hoofdstuk wordt bekeken of en zo ja, hoe de burgerlijke en de bestuursrechter zulke conflicten hebben opgelost en welke wisselwerking er eventueel bestaat tussen deze rechters en de rechisgangen. Het belang hiervan voor het onderzoek is dat bij de burgerlijke rechter de ruimte voor het gebruik van privaatrecht groter (b)lijkt te zijn dan bij de bestuursrechter.

De burgerlijke rechter bepaalt zijn competentie aan de hand van het objectum litis, het voorwerp van het geschil zoals dat wordt verwoord door eiser, zie 2.6. Als de eisende partij haar vordering maar op de juiste manier inkleedt, is de burgerlijke rechter snel en tegenwoordig zelfs vrijwel altijd bevoegd. De afbakening van de bevoegdheid van de bestuursrechter is veelal afhankelijk van de betrokken wettelijke regeling. Het belangrijkste gehanteerde criterium is de vraag of een beschikking/besluit voorligt. Zoals gezegd sluiten deze criteria niet op elkaar aan. Hoe gaat de burgerlijke rechter om met een positief competentiegeschil? In de conclusie van hoofdstuk 2 heb ik al aangegeven dat de burgerlijke rechter de vraag of hij een geschil, waarbij de overheid is betrokken, inhoudelijk zal beoordelen, tegenwoordig vooral zal beantwoorden aan de hand van de ontvankelijkheidsviaag. Voorts speelt de door de Hoge Raad ontwikkelde leer van de formele rechtskracht een rol. Deze punten zullen aan de orde komen in 4.3.

Een andere vraag betreft de wijze waarop de bestuursrechter zijn bevoegdheid afbakent. Het belangrijkste criterium hiertoe is dus de vraag of een beschikking/besluit voorligt. Dat is niet het geval als sprake is van een rechtshandeling naar burgerlijk recht. Uiteraard is het dan van belang te bekijken wanneer sprake is van een dergelijke rechtshandeling. Deze vraag zal ik eerst behandelen. 


\subsection{Rechtshandeling naar burgerlijk recht/publiekrechtelijke rechtshandeling}

\subsubsection{Inleiding}

Op grond van de Wet arob kon een rechtstreeks belanghebbende in beroep tegen een beschikking bij de Afdeling rechtspraak van de Raad van State, tenzij een andere rechtsgang openstond of had opengestaan. Bepaalde beschikkingen werden uitgezonderd. Géén beschikking in de zin van de Wet arob waren (naast besluiten van algemene strekking) de rechtshandelingen naar burgerlijk recht. Ook in de Awb is deze uitzondering opgenomen, zij het in een andere formulering. Volgens artikel 1:3 lid $1 \mathrm{Awb}$ is een besluit namelijk een schriftelijke beslissing van een bestuursorgaan, inhoudende een publiekrechtelijke rechtshandeling.

Reeds de Wet bab kende een soortgelijke uitzondering: volgens artikel 2 lid 1 moest het gaan om een beschikking, gegeven krachtens een in enig staats- of administratiefrechtelijk voorschrift vervatte bevoegdheid of verplichting. Hiermee werd het publiekrechtelijke karakter van de beschikking tot uitdrukking gebracht.' Volgens de tweede druk van het Rapport ABAR uit 1959 werd met deze woorden beoogd 'de besluiten van zuiver privaatrechtelijk karakter buiten te sluiten'.'

Het onderscheid tussen een rechtshandeling naar burgerlijk recht en een publiekrechtelijke rechtshandeling is van belang op het moment dat de aanvullende administratieve rechter - eerst de Afdeling rechtspraak van de Raad van State, nu de administratieve kamers van de rechtbanken en de Afdeling bestuursrechtspraak van de Raad van State - in beeld komt. Deze rechters bepalen namelijk hun rechtsmacht aan de hand van de vraag of de ene dan wel de andere rechtshandeling voorligt. Is sprake van een publiekrechtelijke rechtshandeling, dan is in beginsel de administratieve rechter competent, bij rechtshandelingen naar burgerlijk recht de burgerlijke rechter. Dit heeft ook consequenties voor het toepasselijke recht; het besluit wordt beheerst door bestuursrecht, zoals onder meer neergelegd in de Awb, bij een rechtshandeling naar burgerlijk recht zal de burgerlijke rechter burgerlijk recht toepassen.

In de volgende paragrafen zal ik ingaan op de betekenis van het Arob-begrip 'rechtshandeling naar burgerlijk recht' (4.2.2) en het begrip 'publiekrechtelijke rechtshandeling' uit de Awb (4.2,3).

\subsubsection{De Wet arob: rechtshandeling naar burgerlijk recht}

Het ontwerp van de Wet arob hanteerde in artikel 2 de in de Wet bab gebruikte formulering. ${ }^{3}$ Later is het criterium, dat de beschikking moest zijn 'gegeven krachtens een in enig staats- of administratiefrechtelijk voorschrift vervatte

1. Memorie van toelichting, Tweede Kamer 1958-1959, 5363, nr. 3, blz. 12.

2. Rapport ABAR (1959), blz. 2. In de praktijk paste de Kroon het criterium echter ruimer toe, zie hierover de vierde druk van het rapport, Rapport ABAR (1973), blz. 57.

3. Tweede Kamer 1970-1971, 11 279, nr. 2, PG arob, blz. 138. 
bevoegdheid of verplichting' vervallen. ${ }^{4}$ De conclusie kan worden getrokken dat het de bedoeling van de wetgever was dat indien het bestuursorgaan handelde in de uitoefening van een administratiefrechtelijke bevoegdheid of verplichting - als er sprake was van een publiekrechtelijke titel ${ }^{5}$-, er sprake was van een beschikking. ${ }^{6}$ Wel diende deze titel in het algemeen geschreven te zijn. Niet vereist was dat er een 'speciaal' voorschrift aan de bevoegdheid of verplichting ten grondslag lag, ${ }^{7}$ voldoende was dat sprake was van 'een in enig, hoe algemeen ook geformuleerd, voorschrift neergelegde staats- of administratiefrechtelijke bevoegdheid of verplichting'. 'Dit vereiste zou voortvloeien uit het legaliteitsbeginsel.'

Ook de arob-rechter stelde veelal deze eis, wilde hij een beschikking aannemen. ${ }^{10}$ Hij greep hierbij meestal terug op het criterium uit de Wet bab, dus een geschreven wettelijk voorschrift. Slechts in een aantal gevallen wilde hij dit vereiste wel eens laten vallen. " Het voor dit onderzoek belangrijkste geval betrof subsidies. ${ }^{12}$ Toekenning van subsidie werd als een begunstigende beschikking gezien, waarbij vaak een enkele begrotingspost als voldoende bevoegdheidsgrondslag werd aangenomen. De Afdeling rechtspraak baseerde zich hierbij veelal op wetshistorische argumenten. ${ }^{13}$ Ging het om terugvordering van ten onrechte verstrekte subsidies, een voor de betrokkene belastende ingreep, dan was weer wel een uitdrukkelijke, geschreven publiekrechtelijke titel vereist. Was die niet aanwezig, dan was sprake van een rechtshandeling naar burgerlijk recht. ${ }^{14}$

In het kader van de terugvordering speelde de Wet arob slechts een doorslaggevende rol bij subsidies en aanverwante terreinen. Voor terugvordering van socialezekerheidsuitkeringen was namelijk meestal een uitdrukkelijke, geschreven publiekrechtelijke grondslag. De bevoegdheid van de ambtenarenrechter was niet beperkt tot beschikkingen, hij mocht ook oordelen over handelingen, terwijl ook

4. Vierde nota van wijziging, Tweede Kamer 1973-1974, 11 279, nr. 26, PG arob, blz. 151. Zie hierover Rapport ABAR (1976), blz. 11-12.

5. Zie Borman (1981), blz. 27.

6. Zie onder meer de memorie van antwoord, Tweede Kamer 1973-1974, 11 279, nr. 8, blz. 6, PG arob, blz. 142 en Handelingen Tweede Kamer 1973-1974, blz. 4543, PG arob, blz. 149.

7. Zie bijvoorbeeld Simon (1989), blz. 470-471.

8. Aldus Berman (1981), blz. 38-39.

9. Ik zal hierop verder ingaan in. hoofdstuk 11.

10. Stroink (1979), blz. 392.

11. Zo werd in een aantal gevallen een grondslag gevonden in het publieketaakcriterium. Zie Borman (1981), blz. 41-50 en Michiels (1987), blz. 168-183. Borman (1981), blz. 50-51 komt tot de conclusie dat de Afdeling haar bevoegdheid ruim zag door te zoeken naar een bestuursrechtelijke titel, neergelegd in enig voorschrift, daarbij het begrip bestuursrechtelijke titel in voorkomend geval - zie bijvoorbeeld het publieketaakcriterium - ook nog ruim uitleggend.

12. Michiels (1987), blz. 158. Het ging dan om eenzijdige subsidiebesluiten.

13. Damen (1987), blz. 758. Het argument was dat de in de Wet bab neergelegde bepaling dat in het algemeen geen voorziening openstond tegen beschikkingen tot het toekennen of weigeren van subsidie, in de Wet arob was geschrapt. A contrario werd daaruit afgeleid dat de wetgever die beslissingen als beschikking beschouwde. Zie hierover uitgebreider 8.2.4

14. Bijvoorbeeld Wnd. Vz. ARRvS 31 december 1982, tB/S V, nr. 290, m. aant. $\mathrm{B} / \mathrm{S}$. Zie hierover uitgebreider hoofdstuk 8. 
het College van Beroep voor het bedrijfsleven zijn bevoegdheid veelal ruim zag. Dit alles komt aan de orde in deel II van het onderzoek. De jurisprudentie van de Afdeling rechtspraak en de burgerlijke rechter op het terrein van subsidies en de rol van de Wet arob daarbij wordt uitgebreider behandeld in hoofdstuk 8.

\subsubsection{De Awb: publiekrechtelijke rechtshandeling}

In de Awb staat bij de afbakening van de rechtsmacht van de aanvullende administratieve rechter niet meer centraal het negatieve vereiste dat geen sprake mag zijn van een rechtshandeling naar burgerlijk recht, maar het positieve vereiste dat sprake dient te zijn van een publiekrechtelijke rechtshandeling. Insteek bij de Awb is het besluit. ${ }^{15}$ Dit is volgens artikell 1:3 lid 1 Awb 'een schriftelijke beslissing van een bestuursorgaan, inhoudende een publiekrechtelijke rechtshandeling'. Deze definitie is mede geïnspireerd door artikel 2 Wet arob. ${ }^{16} \mathrm{Zij}$ heeft dan ook gemeen met het beschikkingsbegrip uit artikel 2 Wet arob dat rechtshandelingen naar burgerlijk recht er niet onder vallen, zij het dat de Awb een kortere formulering hanteert: er moet sprake zijn van een publiekrechtelijke rechtshandeling.

Er bestaan echter verschillen tussen het beschikkingsbegrip uit de Wet arob en het besluitbegrip uit de Awb, zo blijkt uit de wetsgeschiedenis. ${ }^{77}$ Belangrijk is dat de Awb-wetgever de werking erkent van algemene rechtsbeginselen in het bestuursrecht, beginselen die niet slechts privaatrechtelijk of publiekrechtelijk zijn, maar algemene gelding hebben. ${ }^{18}$ Verder lijkt het of hij de rechtsbetrekking op de voorgrond plaatst. Is deze publiekrechtelijk, dan kan het handelen in het kader van die rechtsbetrekking ook snel als publiekrechtelijk worden gekwalificeerd. ${ }^{19}$ Daarnaast merkt de wetgever een aantal rechtshandelingen, die onder het oude recht veelal als rechtshandelingen naar burgerlijk recht werden gezien, expliciet als publiekrechtelijk aan, bijvoorbeeld het terugvorderingsbesluit. ${ }^{20}$

Van belang is te kijken hoe het begrip 'publiekrechtelijke rechtshandeling' is ingevuld in de rechtspraak. Volgden de administratieve rechters de door de wetgever gedane handreiking? ${ }^{21}$ In eerste instantie bleven de administratieve kamers

15. Memorie van toelichting, $\mathrm{PG}$ Awb I, blz. 153.

16. Menorie van toelichting, PG Awb I, blz. 154.

17. Zie hierover Simon (1997), blz. 57.

18. PG Awb II, blz. 500 en 501 . Als voorbeeld geeft de wetgever het beginsel dat hetgeen ten onrechte als betaling is ontvangen, moet worden terugbetaald.

19. Zie Simon (1997), blz. 57. Verder vindt Simon de vooropstelling van het begrip 'publiekrechtelijke rechtshandeling' opvallend: als een schriftelijke rechtshandeling van de overheid als publiekrechtelijk kan worden gekwalificeerd, dan is er sprake van een besluit, waarbij de wetgever uitgaat van een ruim begrip 'publiekrechtelijk'.

20. Tweede Kamer 1991-1992, 22 495, nr. 3, blz. 246 (nict opgenomen in PG Awb II). Ik kom hierop terug aan het einde van deze paragraaf.

21. Voor zover zij de door de wetgever aangegeven weg niet reeds volgden. De CRvB als ambtenarenrechter en het $\mathrm{CBB}$, oordelend op grond van zijn algemene bevoegdheid keken bijivoorbeeld al geruime tijdi achter de vorm waarin de beslissing was gegoten naar de rechtsverhouding tussen partijen, terwijl de CRvB ook de algemene rechtsbeginselen, reeds genuime tijd uitdrukkelijk 
van de rechtbanken en de Afdeling bestuursrechtspraak op de lijn zitten van de jurisprudentie van de Afdeling rechtspraak met betrekking tot de afbakening van de rechtshandeling naar burgerlijk recht. Vereist was dus een publiekrechtelijke titel, waarbij ofwel een geschreven publiekrechtelijke bevoegdheid werd vereist, ofwel deze bevoegdheid werd gevonden in het publieketaakcriterium.

In 1996 kwam een ommezwaai; in dat jaar verruimde de Afdeling bestuursrechtspraak het begrip publiekrechtelijke titel en dus het begrip publiekrechtelijke rechtshandeling. Voor een publiekrechtelijke titel was niet langer vereist dat sprake was van een geschreven publiekrechtelijke bevoegdheid of van cen bevoegdheid in het kader van een publieke taak. Een publiekrechtelijke bevoegdheid kan onder omstandigheden ook worden ontleend aan het ongeschreven recht, met name aan ongeschreven rechtsbeginselen. Het meeste stof opwaaien deed de omslag in de rechtspraak van de Afdeling bestuursrechtspraak met betrekking tot het zuiver of zelfstandig schadebesluit. ${ }^{22}$ Werd voorheen altijd geoordeeld door de Afdeling (bestuurs)rechtspraak dat een verzoek om schadevergoeding dat niet was gebaseerd op een uitdrukkelijke publiekrechtelijke regeling (eventueel kon een gepubliceerde beleidsregeling volstaan), een rechtshandeling naar burgerlijk recht was en dus geen publiekrechtelijke rechtshandeling, in haar uitspraak van 29 november 1996 oordeelde de Afdeling bestuursrechtspraak dat de beslissing op een dergelijk verzoek een besluit was. Het publiekrechtelijk rechtsgevolg van een dergelijk besluit vloeide voort 'uit het in het besluit in ieder geval vervatte oordeel over de aanspraken die al of niet zouden bestaan op schadevergoeding in verband met het in geding zijnde bestuurshandelen'. ${ }^{23}$ De Afdeling sloot met deze uitspraak aan bij de jurisprudentie van de Centrale Raad van Beroep als ambtenarenrechter en het College van Beroep voor het bedrijfsleven, oordelend op grond van zijn algemene bevoegdheid, die reeds langere tijd het zuiver schadebesluit als publiekrechtelijk besluit zagen. ${ }^{24}$ Ook waren na de inwerkingtreding van de Awb de Centrale Raad van Beroep als socialezekerheidsrechter, het College van Beroep voor het bedrijfsleven op grond van zijn bijzondere rechtsmacht en het College van beroep studiefinanciering in deze de Afdeling bestuursrechtspraak voorgegaan. ${ }^{25}$

De Afdeling gaf in deze uitspraak niet aan wat de grondslag was voor de schadevergoeding. Ook de vraag, waarom sprake was van een publiekrechtelijke rechtshandeling kwam niet aan de orde. Dit was wel het geval in latere uitspraken, het duidelijkst in een uitspraak van 6 mei 1997. Daarin overwoog de Afdeling:

erkende, zie 7.2.3.3. Het CBB deed dit laatste naar mijn mening implicier, zie 8.4.4.

22. Een eerste overzicht van de commentaren op deze jurisprudentie geeft Simon (1998), blz, 64-65.

23. ABRvS 29 november 1996, AB 1997, 66, m.nt. PvB, JB 1996, 253, m.nt. red. (Alpha Kledingreinigingsbedrijf).

24. Bijvoorbeeld CRvB 3 mei 1972, AB 1973, 232, mnt. v.d. H., CBB 17 mei 1963, SEW 1963 , 196 (blz. 531-533), m.nt. J.P. en CBB 22 april 1975, AB 1975, 149, m.nt. J.P., SEW 1975, blz. 449-452, m.nt. J.P. Zie over de uitspraken van het CBB 8.4.3.

25. Zie de verwijzingen in de noot van de redactie onder ABRvS 29 november 1996, JB 1996, 253. 
'De schriftelijke beslissing van een bestuursorgaan op een verzoek on vergoeding van schade, die veroorzaakt zou zijn binnen het kader van de uitoefening door dat orgaan van een aan het publiekrecht. ontleende bevoegdheid, is - ook indien dat verzoek niet op een specifieke wettelijke grondslag is gebaseerd - een publiekrechtelijke rechtshandeling en dus een besluit in de zin van artikel 1:3 van de Awb.

De Afdeling overweegt hiertoe het volgende. Een publiekrechtelijke rechtshandeling is een op rechtsgevolg gerichte beslissing van een bestuursorgaan, dat de bevoegdheid tolt het nemen van die beslissing ontleent aan het publiekrecht. Zoals volgt uit de uitspraak van de Afdeling van 29 november 1996 berust de bevoegdheid van een bestuursorgaan tot het nemen van een beslissing op een verzoek om vergoeding van schade, voorzover het schade betreft ten gevolge van de onrechtmatige uitoefening van een aan het publiekrecht ontleende bevoegdheid, op het - in artikel 6:162 van het Burgerlijk Wetboek en in artikel $8: 73$ van de Awb tot uitdrukking komende - algemeen geldende rechtsbeginsel, volgens hetwelk degene die door aan hem toerekenbaar onrechtmatig handelen of nalaten schade heeft veroorzaakt, is gehouden die aan de benadeelde te vergoeden. Dit rechtsbeginsel is publiekrechtelijik van aard indien het zijn werking doet voelen in een door de vitoefening van een aan het publiekrecht ontleende bevoegdheid ontstane rechtsverhouding ${ }^{\prime 26}$

Het algemeen rechtsbeginsel dat hij die toerekenbaar onrechtmatig schade veroorzaakt, gehouden is deze schade te vergoeden, vormt dus de bevoegdheidsgrondslag voor het bestuursorgaan om een beslissing met betrekking tot de schade te nemen. Dit alleen is niet voldoende om deze beslissing tot besluit te bestempelen. Daarvoor is tevens vereist dat het rechtsbeginsel in het concrete geval publiekrechtelijk van aard is. Dit is zo als het zijn werking doet gevoelen in een rechtsverhouding, die is ontstaan door de uitoefening door het bestuursorgaan van een aan het publiekrecht ontleende bevoegdheid. De achterliggende verhouding dient dus in het concrete geval publiekrechtelijk van aard te zijn.

Het schadebesluit is in dat geval dus een besluit in de zin van de Awb. ${ }^{27}$ Hiermee is niet gezegd dat de bestuursrechter ook bevoegd is dit besluit te beoordelen. De Afdeling eist namelijk voor een positief antwoord op de vraag of beroep openstaat bij de bestuursrechter een processuele connexiteit tussen het schadeveroorzakende bestuurshandelen en de beslissing op het verzoek tot schadevergoeding. $Z \mathrm{Zj}$ verwijst hiertoe naar het stelsel van de $A w b$. De bedoeling van de wetgever, zoals die onder meer blijkt uit de pariementaire geschiedenis van artikel $8: 3$, was volgens de Afdeling zo veel mogelijk te voorkomen dat verschillende rechters zouden moeten oordelen over nauw met elkaar samenhangende beslissingen. Volgens de Afdeling 'past het in dit stelsel de algemene dan wel bijzondere bestuursrechter slechts bevoegd te achten tot kennisneming van beroepen tegen een zuiver schadebesluit, indien die rechter ook bevoegd is te oordelen over

26. ABRvS 6 mei 1997, AB 1997, 229, m.at. PvB, JB 1997, 118, mnt HUS (Van Vlodrop).

27. Overigens stelde de CRvB 28 juli 1994, AB 1995, 133, m.nt. RMvM, JB 1994, 221, m.nt. ELB/ABJH als socialezekerheidsrechter in eerste instantie cen strenger vereiste; er diende sprake te zijn van samenhang tussen de schade en een eerder (appellabel) besluit, wil de beslissing op een verzoek tot vergoeding van de schade als besluit in de zin van artikel 1:3 Awt worden aangemerkt. Matericel heeft dit echter (vrijwel) geen gevolgen. De CRvB is later hierop teruggekomen en volgt nu de lijn van de Afdeling bestuursrechtspraak, zie onder meer CRvB 24 september 1997, AB 1997, 431, m.nt. FP en CRvB 23 april 1998, AB 1998, 251, m.nt. HBr. 
beroepen tegen de schadeveroorzakende uitoefening van de publiekrechtelijke bevoegdheid zelf ${ }^{28}$ De rechter die bevoegd is over het achterliggend, schadeveroorzakend feit te oordelen, is tevens bevoegd te oordelen over het zuiver schadebesluit. Is het schadeveroorzakend feit dus bijvoorbeeld een feitelijke handeling of een algemeen verbindend voorschrift - waarover de administratieve rechter niet bevoegd is te oordelen, zie de artikelen $8: 1$ en $8: 2$, en waarbij dus de burgerlijke rechter bevoegd is -, dan betekent dit dat die rechter ook niet bevoegd is te oordelen over het schadebesluit, ondanks het feit dat sprake is van een besluit in de zin van artikel 8:1 en dit besluit in de overige artikelen van afdeling 8.1.1 niet wordt uitgesloten. De betrokkene zal dus naar de burgerlijke rechter moeten om het schadebesluit (of de weigering een dergelijk besluit te nemen) aan te vechten. $^{29}$

De omslag van de Afdeling bestuursrechispraak kwam niet geheel onverwacht. Zoals gezegd opende de parlementaire geschiedenis de mogelijkheid dat bevoegdheden werden gebaseerd op ongeschreven (publiek)recht. Daarnaast werd in de memorie van toelichting op artikel 8:1 uitdrukkelijk ingegaan op het feit dat de jurisprudentie van de Centrale Raad van Beroep als ambtenarenrechter en het College van Beroep voor het bedrijfsleven, oordelend op grond van zijn algemene bevoegdheid, enerzijds en de overige rechters, de Afdeling rechtspraak voorop, anderzijds met betrekking tot het zuiver schadebesluit uiteen liep. De regering stelde zich op het standpunt dat de rechters zelf zouden moeten oordelen welke koers zij gingen volgen. Wel overwoog zij uitdrukkelijk dat zij geen reden zag voor wijziging van de rechtspraak van de Centrale Raad en het College van Beroep voor het bedrijfsleven. ${ }^{30}$ Twee mogelijkheden bleven dus over: of de rechters bleven ieder hun eigen weg volgen, of de Afdeling bestuursrechtspraak en de andere rechters die de rechtspraak van de Afdeling volgden, stelden hun jurisprudentie bij. ${ }^{31}$ De eerste mogelijkheid was niet gewenst, de bedoeling van de Awb was immers mede om de jurisprudentie van de verschillende rechters zoveel mogelijk op een lijn te krijgen.

De schokgolf die de rechtspraak van de Afdeling bestuursrechtspraak teweeg bracht, was vooraf gegaan door een kleinere golf: in haar uitspraak van 21 oktober 1996 bestempelde de Afdeling een terugvorderingsbeslissing, waarvoor

28. ABRvS 6 mei 1997, AB 1997, 229, m.nt. PvB, JB 1997, i18, m.nt. HJS (Van Vlodrop).

29. Zoals gezegd eiste ook de CRvB als socialezekerheidsrechter deze processuele connexiteit; het ontbreken ervan leidde in eerste instantie echter tot andere gevolgen dan bij de Afdeling bestuursrechtspraak. Bij de Afdeling was het gevolg van het ontbreken van processuele connexiteit dus dat er sprake was van een besluit, maar dat dit geen appellabel besluit was; bij de CRvB was het gevolg dat er geen sprake was van een besluit. De CRvB stelde dus een dubbel connexiteitscriterium, zo blijkt uit CRvB 28 juli 1994, AB 1995, 133, m.nt. RMvM, JB 1994, 221, m.nt. ELB/ABJH. Zoals gezegd in noot 27 is de CRvB hier inmiddels op teruggekomen.

30. PG Awb II, blz. 380.

31. De theoretisch bestaande derde mogelijkheid dat de CRvB en het CBB hun koers zouden bijstellen in de richting van de Afdeling, was na de uitlatingen van de regering niet meer aan de orde; dit zou bovendien een achteruitgang betekenen in de rechtsbescherming voor de betrokkenen. 
geen geschreven grondslag was te vinden in de wet, als besluit. ${ }^{32}$ Ook hier werd de bevoegdheid tot terugvordering gevonden in een algemeen rechtsbeginsel, namelijk het beginsel dat hetgeen onverschuldigd is betaald, kan worden teruggevorderd. Op deze uitspraak, die terugvordering van geldelijke steun bij aankoop van een nieuwe woning betrof, zal ik uitgebreid ingaan in de hoofdstukken 8 en 9 . Deze uitspraak kon niet als een verrassing komen; de regering had namelijk in de memorie van toelichting bij het wetsontwerp voltooiing eerste fase herziening rechterlijke organisatie al aandacht besteed aan de vraag of een terugvorderingsbeslissing een besluit was. Naar aanleiding van een artikel van Dorhout, ${ }^{33}$ waarin deze wees op het feit dat de jurisprudentie van de Centrale Raad van Beroep en de Afdeling rechtspraak met betrekking tot het rechtskarakter van een terugvorderingsbeslissing uiteenliep, had zij gesteld:

'(D)e oorsprong van de onderhavige terugvorderingsbeslissingen ligt in het publiekrecht. (...) Gelet op het feit dat ook de onderliggende rechtsverhouding door de administratieve rechter beoordeeld wordt, ligt het in de rede dat ook de terugvorderingsbeslissingen worden beoordeeld door de administratieve kamer van de rechtbank en derhalve worden gekwalificeerd als besluiten in de zin van artikel 1:3 van de Awb: ${ }^{34}$

Inmidåls heeft de Afdeling bestuursrechtspraak ook geoordeeld dat het algemene rechtsbeginsel dat hij die ongerechtvaardigd is verrijkt ten koste van een ander, verplicht is, voor zover dit redelijk is, diens schade te vergoeden tot het bedrag van zijn verrijking bestuursrechtelijk van aard kan zijn, namelijk als het zijn werking doet gevoelen in een door het bestuursrecht beheerste verhouding. ${ }^{35}$

Deze jurisprudentie-omslag, zowel wat betreft het zuiver schadebesluit als wat betreft het terugvorderingsbesluit, is niet onomstreden. Het belangrijkste bezwaar tegen deze uitspraken was dat het legaliteitsvereiste zou zijn verlaten nu bevoegdheden kennelijk kunnen worden gebaseerd op algemene rechtsbeginselen. Daarnaast zou de administratieve rechter in strijd met de Grondwet zijn competentie verruimen en daarmee die van de burgerlijke rechter verengen. Op deze, kritiek zal ik ingaan in hoofdstuk 9.

De Afdeling bestuursrechtspraak is dus geneigd haar bevoegdheid ruim te zien; het besluitbegrip wordt daartoe tegenwoordig ruim uitgelegd. De Afdeling is geneigd nu meer naar de achterliggende verhouding te kijken dan naar de vorm van de beslissing. Is die achterliggende verhouding publiekrechtelijk, dan zal zij veelal een besluit aannemen. Wel zal er sprake moeten zijn van een publiekrechtelijke rechtshandeling, dus een publiekrechtelijke bevoegdheid - er dient sprake te zijn van een publiekrechtelijke titel -, maar deze hoeft niet langer te

32. ABRvS 21 oktober 1996, AB 1996, 496, m.nt. NV, JB 1996, 232, m.nt. HJS (Nanne).

33. Dorhout (1991).

34. Tweede Kamer 1991-1992, 22 495, nr. 3, blz. 246 (niet opgenomen in PG Awb II).

35. ABRvS 26 augustus 1997, AB 1997, 461, m.nt. NV, JB 19977, 265, m.nt. HJS (Samenwerkingsverband Noord-Kennemerland). 
worden gevonden in een geschreven wettelijke regeling of in het publieketaakeriterium; een dergelijke bevoegdheid kan ook worden gebaseerd op ongeschreven publiekrecht en algemene rechtsbeginselen. Met deze ontwikkeling lijkt de Afdeling steeds meer in de richting van de fundamentum petendi-leer te gaan.

\subsection{Administratie, administratieve rechtsgang en de burgerlijke rechter}

\subsubsection{Inleiding}

Met de in het vorige hoofdstuk beschreven ontwikkeling van de administratieve rechtspraak werd nog niet de beoordeling van het gehele overheidsoptreden onder de rechtsmacht van de bestuursrechter gebracht; er bleven steeds leemtes bestaan in de rechtsbescherming die die rechter kon bieden. Zo is gebleken dat bijvoorbeeld rechtshandelingen naar burgerlijk recht voor een belangrijk deel niet tot de competentie van die rechter behoren, hoewel de bestuursrechter zijn rechtsmacht wel uitbreidt; zie de in 4.2 .3 besproken jurisprudentie inzake het zuiver schadebesluit en terugvordering. Als sprake is van een rechtshandeling naar burgerlijk recht, dan kan de betrokkene zonder probleem naar de burgerlijke rechter.

Uiteraard is het de vraag of het ontstaan van administratieve rechtspraak ook in meer algemene zin invloed heeft gehad op de rechtsmacht van de burgerlijke rechter. Deze vraag zal ik hierna bespreken vanuit de optiek van de rechtsbescherming zoekende: kan deze nog bij de burgerlijke rechter terecht als een administratiefrechtelijke rechtsgang bestaat? In $4.3 .2 \mathrm{komt}$ de vraag naar de bevoegdheid van de burgerlijke rechter aan de orde en in 4.3 .3 de vraag naar de ontvankelijkheid van eiser. In 4.3.4 zal ik ingaan op het leerstuk van de formele rechtskracht. In 4.3.5 zal ik de gevolgen bekijken van de uitbouw van het bestuursrecht voor de vraag of de overheid de rechtsgang naar de burgerlijke rechter kon volgen. Ik zal mij in die paragraaf concentreren op de terugvorderingsproblematiek. De gevolgen van de 'algemene-rechtsbeginselenjurisprudentie' voor de bevoegdheid van de burgerlijke rechter zal ik hier niet behandelen; die zullen aan de orde komen in hoofdstuk 9.

\subsubsection{De invloed van het ontstaan van administratieve rechtspraak op de be- voegdheid van de burgerlijke rechter}

Had het ontstaan van administratieve rechtspraak invloed op de bevoegdheid van de burgerlijke rechter? Gelet op hetgeen in hoofdstuk 2 naar voren is gekomen zou het antwoord hierop ontkemnend moeten zijn. De Hoge Raad had immers in 1915 aangegeven dat niet de aard van partijen of de aard van de rechtsverhouding, maar de aard van de vordering bepalend was voor de bevoegdheid van de burgerlijke rechter, de zogenaamde objectum litis-leer. ${ }^{36}$

36. HR 31 december 1915, NJ 1916, 407 (Noordwijkerhout-Guldemond). Zie hierover 2.6. 
Dit bleek echter niet de visie van de wetgever te zijn, althans waar het het ambtenarenrecht betrof. Artikel 3 lid 1 Aw 1929 bepaalde dat de ambtenarenrechter 'bij uitsluiting' oordeelde over de besluiten, handelingen en weigeringen (om te besluiten of te handelen), ten aanzien van ambtenaren als zodanig door een administratief orgaan genomen, verricht of uitgesproken. Deze bepaling had ook gevolgen voor de bevoegdheid van de burgerlijke rechter op dit terrein, aldus de memorie van toelichting: de gehele rechtsbetrekking tussen overheid en ambtenaren werd als publiekrechtelijk beschouwd. Daaruit vloeide voort dat de burgerlijke rechter zich had te onthouden van de kennisneming van geschillen tussen ambtenaren en overheid. 'Het bijzondere voorschrift van dit nieuwe artikel gaat toch in ieder geval boven den algemeenen regel van het oude art. 2 R.0..$^{37}$ In de parlementaire behandeling werd nog de vraag gesteld of dit wel verenigbaar was met artikel $154 \mathrm{Gw}$ 1922, dat toch bepaalde 'dat alle twistgedingen over schuldvordering bij uitsluiting tot de kennisneming van rechterlijke macht behooren'. Het antwoord van de regering luidde als volgt:

'Art. 154 der Grondwet draagt aan de rechterlijke macht bij uitsluiting de kennisneming van twistgedingen over 'schuldvordering' op. Met schuldvorderingen worden daar bedoeld privaatrechtelijke aanspraken. Dat blijkt uit de op 'schuldvordering' volgende woorden 'en andere burgerlijke rechten". Alle geschillen, volgens de Grondwet aan den gewonen rechter ter afdoening toevertrouwd, zijn geschillen, waarvan private rechten den inzet vormen. Dat de tegenwoordige practijk op cen ander standpunt stast, valt genıakkelijk te verklaren. Zij wordt toch beheerscht, niet door artikel 154 der tegenwoordige Grondwet, maar door artikel 2 der wet op de Regterlijke Organisatie van 1827. Dit oude, op de Grondwet van 1815 steunende voorschrif belast den gewonen rechter met de beslissing van alle gedingen, dic op schuldvorderingen, onverschillig van welken aard, betrekking hebben. Krachtens artikel II Additioneele Artikelen is die bepaling van de wet op de Regterlijke Organisatie tot heden blijven gelden. Eenmaal wet geworden, zal het aanhangig ontwerp echter, voor zoover de geldelijke aanspraken van ambtenaren betreft, artikel 2 R.O. buiten werking stellen: ${ }^{39}$

De wetgever ging dus blijkbaar ervan uit dat in artikel $154 \mathrm{Gw} 1922$ de fundamentum petendi-leer was neergelegd: 'schuldvordering' moest worden gelezen als privaatrechtelijke aanspraak.

De burgerlijke rechter besliste sindsdien herhaaldelijk dat hij in ambtenarengeschillen niet meer bevoegd was. ${ }^{\text {t0 }}$ Ook de Hoge Raad deed dat. In het Ambtenarenwetarrest uit 1941 overwoog hij

'dat en blijkens de bewoordingen dezer bepaling en blijkens de geschiedenis van de totstandkoming der Ambtenarenwe! 1929 de geschillen over schuldvorderingen, welke uit de rechtsbetrekking tussehen ambtenaar en Overheid voortvloeien, voorzooverre daarbij sprake is van een klacht over een besluit of handeling of weigering der administratie, met terzijde stelling van den algemeenen regel van art. 2 R.O., aan de kennisneming van de rechterlijke macht zijn onttrokken;

37. Memorie van toelichting, Tweede Kamer 1927-1928, 392, nr. 3, blz. 17.

38. Yoorlopig verslag. Tweede Kamer 1928-1929, 91, nr. 1, blz. 1.

39. Memorie van antwoord, Tweede Kamer 1928-1929, 91, nr. 2, blz. 8. Cursivering in oorspronkelijke tekst. De minister volgde hier đus de opvatting van Thorbecke, zie 2.4.1.

40. Zie bijvoorbeeld Rb. Maastricht 25 april 1935. NJ 1935, 1285. 
$(-$,

dat mitsdien het geschil tusschen Bonneveld en den Staat $(.$.$) niet is onderworpen aan de rechtsmacht$ van den burgerlijken rechter en de Rechtbank zich onbevoegd had behooren te verklaren om van het geschil kennis te nemen', 41

In 7.2.4.3 zal blijken dat de Hoge Raad in 1992 in het Changoe-arrest is teruggekomen van deze opvatting en zich sindsdien wel bevoegd acht kennis te nemen van deze geschillen, maar de eiser niet-ontvankelijk verklaart in zijn vordering indien een met voldoende waarborgen omklede administratief-rechtelijke rechtsgang openstaat dan wel heeft opengestaan. ${ }^{42}$

De burgerlijke rechter verklaarde zich dus onbevoegd in ambtenarenaangelegenheden. Aangenomen mag worden dat de Hoge Raad dit ook zou hebben gedaan op een deel van het sociaal-economisch recht, namelijk het terrein waarop het College van Beroep voor het bedrijfsleven competent was op grond van artikel 4 lid 2 Wet arbo. Rechtspraak hierover is er niet, maar de Hoge Raad heeft zich uitdrukkelijk onbevoegd verklaard in een arrest wasrin het Scheidsgerecht voor de Voedselvoorziening, de voorloper van het College, ${ }^{43}$ bevoegd was. De bevoegdheid van dat scheidsgerecht was neergelegd in artikel 13 lid 1 Organisatiebesluit Voedselvoorziening $1941,{ }^{44}$ dat de beslissing van geschillen tussen een organisatie en een ondernemer 'bij uitsluiting' opdroeg aan een scheidsgerecht, het Scheidsgerecht voor de Voedselvoorziening. In een arrest uit 1950 overwoog de Hoge Raad dat dit artikel slechts de uitleg toeliet,

'dat alle geschillen, welke hun oorsprong vinden in de publiekrechtelijke verhouding tussen een organisatie en een ondernemer als in het artikel bedoeld, met onttrekking aan de beoordeling door den gewonen rechter in eerste instantie door een scheidsgerecht worden beslist' ${ }^{45}$

De Hoge Raad achtte de burgerlijke rechter niet bevoegd te oordelen indien een geschil op grond van artikel 13 Organisatiebesluit Voedselvoorziening 1941 onder de competentie van het Scheidsgerecht voor de Voedselvoorziening viel. Deze laatste was in dat geval exclusief bevoegd.

Het Organisatiebesluit Voedselvoorziening 1941 is in 1950 'opgegaan' in de WBO en vanaf 1 juli 1955 nam het College van Beroep voor het bedrijfsleven de werkzaamheden over van het Scheidsgerecht voor de Voedselvoorziening. Evenals het Organisatiebesluit Voedselvoorziening 1941, dat genoemde geschillen 'bij uitsluiting' opdroeg aan het Scheidsgerecht, stelde artikel 4 lid 2 Wet arbo dat het

41. HR 13 november 1941, NJ 1942, 172, AB 1942, 485. Zie ook bijvoorbeeld HR 12 januari 1951 , NJ 195i, 538 en HR 4 december 1987, NJ 1988, 295, m.nt. WHH, AB 1988, 189, m.nt. FHvdB (Du Pied). In dit laatste arrest oordeelde de Hoge Raad dat ook de president in kort geding niet bevoegd was kennis te nemen van een vordering van een ambtenaar tegen de overheid.

42. HR 28 februari 1992, NJ 1992, 687, m.nt. MS, AB 1992, 301, m.nt. FHvdB.

43. Zie hierover 8.4.2.

44. Zie over dit besluit 8.4.2.

45. HR 24 maart 1950, NJ 1950, 662. 
College 'bij uitsluiting' oordeelde over het beroep door natuurlijke of rechtspersonen ingesteld tegen de in dat artikel genoemde besluiten of handelingen. Volgens Wiersma betekende dit dat de burgerlijke rechter 'van dit terrein (is) verdrongen voor zover de geschillen hun oorsprong vinden in de publiekrechtelijke verhouding tussen het openbaar lichaam en de ondernemer. ${ }^{96}$ Ook Van Angeren trekt uit het genoemde arrest de conclusie dat in navolging van het Organisatiebesluit Voedselvoorziening 1941 ook de Wet arbo volledige rechtsbescherming biedt en dat dus de burgerlijke rechter op dit gebied onbevoegd is. ${ }^{47}$

In een aantal gevallen verklaarde de burgerlijke rechter zich dus onbevoegd; het is de vraag of hij dit deed omdat hij ook vond dat hij onbevoegd was. De Hoge Raad had immers in 1915 de objectum litis-leer als enige juiste aanvaard. Volgens Van Angeren lag de verklaring voor het feit dat de burgerlijke rechter zich desondanks onbevoegd verklaarde, daarin dat de bedoeling van de Grondwet en van artikel 2 R.O. was de rechtsbescherming van de burger, zoals de rechter die kon geven, te waarborgen tegen ingrepen door de administratie. Als deze bescherming reeds volledig door de wetgever was verzekerd in de vorm van administratieve rechtspraak, dan was een onbevoegdverklaring door de burgerlijke rechter zelf niet

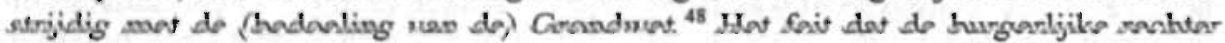
bevoegd was, betekende dus niet dat hij zich altijd bevoegd verklaarde (of moest verklaren). Het voorhanden zijn van een administratief-rechtelijke rechtsgang kon voor hem een reden zijn zich van het toneel terug te trekken, maar hij was hiertoe niet verplicht. Hiertegen kan worden aangevoerd dat zowel artikel 2 R.O. als het daarmee corresponderende grondwetsartikel de burgerlijke rechter bij uitsluiting bevoegd verklaarde indien schending van een burgerlijk recht wordt aangevoerd. De onbevoegdverklaring zou dan in strijd zijn met deze artikelen. In 2.2 is echter gebleken dat deze lezing van de woorden 'bij uitsluiting' een onjuiste is, zij gaven slechts aan dat de burgerlijke rechter, met uitsluiting van ieder ander, en vooral met uitsluiting van de administratie, over zijn bevoegdheid mocht oordelen, uiteraard binnen de grenzen van de wet. Dit betekende dat als een andere rechtsgang openstond, die de belanghebbende hetzelfde kon bieden, hij ook mocht besluiten dat voor hem geen taak was weggelegd. De betekenis van de woorden 'bij uitsluiting' in de Grondwet en in de Aw 1929 en de Wet arbo was dus niet dezelfde.

Uit de rechtspraak blijkt dat de rechter de uiterste consequentie van het bestaan van een administratief-rechtelijke rechtsgang niet snel trok; zelfs als een dergelijke rechtsgang bestond, verklaarde hij zich vrijwel nooit onbevoegd, mits uiteraard de eiser (schending van) een burgerlijk recht of een schuldvordering aanvoerde.

46. Wiersma (1958), blz. 105 .

47. Van Angeren (1968), blz. 25. Op blz. 56 (noot 1) geeft hij aan dat de Hoge Raad zich nọg niet had uitgelaten over die vorm van administratieve rechtspraak. Voor zover ik heb kunnen nagaan heeft de Hoge Raad dat daarna ook niet gedaan. Anders: Rb. 's-Gravenhage 11 januari 1973, N]: 1973,233 , welke eiser niet-ontvankelijk verklaarde omdat zij geen rechtsmacht had.

48. Van Angeren (1968), blz. 25-26. 
Hiervoor zijn twee uitzonderingen op deze 'regel' aan de orde gekomen, namelijk wanneer de ambtenarenrechter of het Scheidsgerecht voor de Voedselvoorziening (en waarschijnlijk ook in bepaalde gevallen het College van Beroep voor het bedrijfsleven) bevoegd waren. Verder oordeelde de Hoge Raad in 1925 dat de burgerlijke rechter niet bevoegd was kennis te nemen van een vordering uit onverschuldigde betaling terzake van gemeentebelasting. Eiser had een aanslag gekregen en deze betaald. Vervolgens vorderde hij dit betaalde terug als onverschuldigd betaald; de verordening, waarop de heffing steunde, zou niet rechtsgeldig zijn. De Hoge Raad verklaarde de burgerlijke rechter onbevoegd; eiser had bezwaren kunnen inbrengen bij de gemeenteraad en in beroep bij de Raad van Beroep voor de directe belastingen. Er bestond dus een bijzondere rechtsgang 'waarvoor de algemeene regel van artikel 2 R.O., krachtens welken de kennisneming en beslissing van alle geschillen over schuldvorderingen aan de rechterlijke macht is opgedragen, moet wijken'. ${ }^{49}$ En in 1928 oordeelde de Hoge Raad in een geschil tussen een provincie en de Staat dat de exclusieve bevoegdheid van de minister van Waterstaat om in een administratieve procedure te beslissen, de bevoegdheid van de burgerlijke rechter uitsloot. ${ }^{50}$

Uit deze rechtspraak kan worden afgeleid, dat de rechter zich meestal alleen onbevoegd verklaarde als er een uitputtende administratief-rechtelijke voorziening bestond. Dit was het geval als het materiële publiekrecht een volledige formeelrechtelijke uitwerking had gekregen, zoals bijvoorbeeld in de Ambtenarenwet. ${ }^{51}$

\subsubsection{De ontvankelijkheid van eiser}

Uit het voorgaande blijkt dat de bevoegdheid van de burgerlijke rechter regel, onbevoegdheid uitzondering is, mits een geschil omtrent een burgerlijk recht wordt aangevoerd. Hieruit mag echter niet de conclusie worden getrokken dat de rechter in al deze gevallen ook aan een inhoudelijke beoordeling van het geschil toekomt. Met de beantwoording van de bevoegdheidsvraag is namelijk niet tevens antwoord gegeven op de vraag of de eiser ontvankelijk is in zijn vordering.

Het lijkt erop dat de rechter zich alleen onbevoegd zal verklaren als naar zijn mening een bestuursrechter volledige rechtsbescherming kan bieden. Kan de bestuursrechter dit naar het oordeel van de burgerlijke rechter niet, dan blijft de

49. HR 6 mei 1925, NJ 1925, 756. Een paar jaar daarvoor had de Hoge Raad nog geoordeeld dat in een soortgelijk geval de burgerlijke rechter wel bevoegd was en de vordering inhoudelijk beoordeeld, HR 16 december 1920, NJ 1921, 220.

50. HR 7 december 1928 , NJ 1929, 788, m.nt. E.M.M.

51. Zoals gezegd is de Hoge Raad wat het ambtenarenrecht betreft in 1992 teruggekomen op deze opvatting in het Changoe-arrest. Hij was uit een oogpunt van rechtsbescherming van mening dat 'de burgerlijke rechter, anders dan in een stelsel van uitsluitende bevoegdheid van de administratieve rechter, (de burger) aanvullende rechtsbescherming kan bieden', HR 28 februari 1992, NJ 1992, 687, m.nt. MS, AB 1992, 301, m.nt. FHvdB, zie 7.2.4.3. M.m. geldt dan hetzelfde op de andere terreinen. De burgerlijke rechter is dan wel bevoegd, maar dient eiser niet-ontvankelijk te verklaren, aangezien een met voldoende waarborgen omklede rechtsgang bij een administratieve rechter openstaat dan wel heeft opengestaan. Zie hierover de komende paragraaf. 
laatste zichzelf competent achten. Dit kan leiden tot een positief competentiegeschil; zowel de burgerlijke als de bestuursrechter achten zich bevoegd van de vordering kennis te nemen. Net als de burgerlijke rechter beslist ook de bestuursrechter zelf over zijn bevoegdheid. In die gevallen zal de burgerlijke rechter veelal naar de achtergrond treden door eiser niet-ontvankelijk te verklaren. ${ }^{52}$

De Hoge Raad stelt zich in die gevallen op het standpunt, dat indien een rechtsgang bij de administratieve rechter openstaat of heeft opengestaan, de eiser deze weg moet of had moeten volgen. Zolang geen oordeel van deze rechter is verkregen, treedt de burgerlijke rechter terug en verklaart eiser niet-ontvankelijk. Zo besliste de Hoge Raad reeds in 1911, dus vóór het Noordwijkerhout-Guldemond-arrest, dat de burgerlijke rechter weliswaar bevoegd was kennis te nemen van een vordering tot terugbetaling van vermeend onverschuldigd betaalde premies ingevolge de Ongevallenwet, maar dat hij daarbij gebonden was aan de onaantastbaar geworden beslissing die hetzij in hoogste instantie, dus door de Centrale Raad van Beroep, hetzij door een lagere instantie, zoals bijvoorbeeld de Rijksverzekeringsbank, was genomen in het onderliggende geschil. In dit geval was de vordering uit onverschuldigde betaling gebaseerd op de stelling, dat de oorspronkelijke eiser, nu verweerder in cassatie, door de Rijksverzekeringsbank, nu eiseres in cassatie, in een verkeerde gevarenklasse was ingedeeld en hierdoor ten onrechte premies had betaald. De Hoge Raad verklaarde de oorspronkelijke eiser niet-ontvankelijk in zijn vordering. ${ }^{53}$ Overigens maakten de lagere rechters niet altijd een even scherp onderscheid tussen hun onbevoegdheid en de niet-ontvankelijkheid van de eiser. ${ }^{54}$

De burgerlijke rechter liet (en laat) de ontvankelijkheid van de eiser dus afhangen van de bevoegdheid van de administratieve rechter. Als de rechtsgang bij de administratieve rechter met voldoende rechtswaarborgen was omgeven, dan kon de burgerlijke rechter eventueel een aanvullende rol spelen, nadat het oordeel van de administratieve rechter was verkregen. Dit was het geval indien de mogelijkheden die de administratieve rechter kon bieden, niet dezelfde waren als die, welke de

52. Van Angeren (1968), blz, 49 en 52.

53. HR 30 juni 1911, W. 9197, m.nt. J.W.M. Zie ook bijvoorbeeld HR 15 december 1950, NJ 1951, 221, m.nt. Ph.A.N.H., HR 26 juni 1964, NJ 1965, 2, m.nt. G.J.S. Overigens had de RvB Leeuwarden in 1910 in een soortgelijk geval ook een vordering tot terugbetaling afgewezen. Hij overwoog hiertoe, dat de indeling 'doordat tegen die beslissing geen beroep is ingesteld, tegenover klaagster kracht van wet (heeft) gekregen met dien verstande dat zij, zoo lang die indeeling en toewijzing niet op geldige wijze zijn vervangen, dienovereenkomstig premie heeft te betalen. Van teruggave der betaalde premie, zooals door klaagster is gevorderd, kan dus geen sprake zijn, terwijl in ieder geval de raad van beroep aan geene enkele wetsbepaling de bevoegdheid ontleent, teruggave van betaalde premie te gelasten'. Er was dus volgens de RvB geen sprake van onverschuldigde betaling. De CRvB bevestigde de vitspraak op dit punt. RvB Leeuwarden 27 september 1910 en CRvB 27 januari 1911, WRSV 1911, afl. 6, ars. 3 en 4. Zie ook RvB Amsterdam 30 oktober 1908, WRSV 1909, afl. 10, nr. 13.

54. Zie bijvoorbeeld Ktr. Leeuwarden 25 juni 1946, NJ 1948, 27, welke zich onbevoegd verklaarde, waar niet-ontvankelijkheid op zijn plaats was. 
burgerlijke rechter kon bieden. Te denken valt aan de mogelijkheid tot het toekennen van schadevergoeding, het bieden van executiemogelijkheden, het opleggen van een dwangsom of het geven van een voorlopige voorziening in spoedeisende gevallen. ${ }^{55}$ De uitspraak van de administratieve rechter is in dat geval voor de burgerlijke rechter een gegeven; hij dient uit te gaan van de formele rechtskracht van het overheidsbesluit.

\subsubsection{Ontvankelijkheid en formele rechtskracht}

Met deze laatste term, de formele rechtskracht van een beshitit, is een nieuw aspect aangestipt dat van belang is bij de rolverdeling tussen de burgerlijke en de administratieve rechter. Een belangrijke vraag is, wanneer de burgerlijke rechter eiser niet-ontvankelijk moet verklaren en wanneer eiser weliswaar ontvankelijk is, maar een besluit dat in de procedure een rol speelt, voor deze rechter onaantastbaar is, voor hem dus een gegeven vormt, dat hij niet meer mag beoordelen. Kort gezegd betreft het de vraag, wanneer de ontvankelijkheid in het geding is en wanneer de formele rechtskracht van een besluit. ${ }^{56}$

Tot heden is er geen eenduidig antwoord gegeven op deze vraag. Verschillende auteurs hanteren verschillende criteria, terwijl ook de rechters, waaronder de Hoge Raad, niet consequent zijn in het gebruik van de verschillende termen. ${ }^{57}$ Volgens Damen is het bijvoorbeeld zo, dat wanneer een bestuursrechtelijke procedure openstaat of aanhangig is, de burgerlijke rechter eiser niet-ontvankelijk moet verklaren. Staat geen bestuursrechtelijke rechtsgang meer open, maar heeft deze wel opengestaan en heeft betrokkene verzuimd gebruik te maken van die rechtsgang, dan is er in beginsel sprake van formele rechtskracht van het besluit: het besluit vormt voor de burgerlijke rechter een gegeven, hij gaat ervan uit dat het zowel naar inhoud als naar wijze van totstandkoming rechtmatig is. ${ }^{58}$

Anderen hanteren als criterium voor niet-ontvankelijkverklaring de vraag of een bestuursrechtelijke rechtsgang openstaat of heeft opengestaan. ${ }^{59}$ De formele rechtskracht van een besluit komt dan aan de orde, wanneer de burgerlijke rechter niet rechtstreeks wordt gevraagd een oordeel te geven over het besluit, maar het besluit bij het beoordelen van de vordering wel een rol speelt. In dat geval heeft de burgerlijke rechter in beginsel uit te gaan van de geldigheid en rechtmatigheid

55. Van Angeren (1968), blz. 25. Overigens zijn met de komst van de Awb de mogelijkheden om via administratief-rechtelijke weg bijvoorbeeld een dwangsom op te leggen of een voorlopige voorziening te krijgen, sterk uitgebreid.

56. Zie over de leer van de formele rechtskracht onder veel meer Mok/Tjittes (1995) en Van der Linden (1998).

57. Vgl. Schueler (1997), blz. 20.

58. Onrechtmatige daad V.A.3 (Damen), aant. 71 (supplement 62, september 2001).

59. Bijvoorbeeld Van Wijk/Konijnenbelt \& Van Male (1999), blz. 716: 'Wie verzuimd heeft in bezwaar of beroep te gaan terwijl dit wel mogelijk was of is, wordt in een civielrechtelijke procedure waarin hij (ongeveer) hetzelfde probeent te bereiken, in beginsel niet ontvankelijk verklaard'. 
van het besluit; het besluit heeft in dat geval formele rechtskracht. ${ }^{60}$ Schueler spreekt met betrekking tot de ontvankelijkheidsvraag in het eerste geval van het criterium 'de bestuursrechter kan', in het tweede geval van het criterium 'de bestuursrechter kan of kon'. ${ }^{61}$ Zoals gezegd kan in de jurisprudentie van de Hoge Raad steun worden gevonden voor beide criteria. ${ }^{62}$

Naar mijn mening moet eiser niet-ontvankelijk worden verklaard indien hij via een vordering voor de burgerlijke rechter tracht iets te krijgen, dat hij ook kan of had kunnen krijgen via de bestuursrechtelijke weg, bijvoorbeeld door een aanvraag daartoe in te dienen, bezwaar te maken of beroep in te stellen bij de bestuursrechter. ${ }^{63}$ Dit is dus, onnauwkeuriger gezegd, het criterium 'de bestuursrechter kan of kon'. Deze formulering is onnauwkeuriger, nu naar mijn mening de burgerlijke rechter eiser niet alleen niet-ontvankelijk moet verklaren als een bestuursrechtelijke rechtsgang openstaat of heeft opengestaan, maar ook als de bestuursrechtelijke weg openstaat of heeft opengestaan. Het gaat dan dus niet alleen om de vraag of de bestuursrechter kan of kon, maar ook om de vraag of het bestuur mogelijk kan of kon. Laat betrokkene bijvoorbeeld na een aanvraag in te dienen ter verkrijging van iets, terwijl die mogelijkheid wel bestaat, maar gaat hij direct naar de burgerlijke rechter, dan zal deze hem niet-ontvankelijk moeten verklaren. De bestuursrechter kan op dat moment echter veelal nog niets; er ligt immers geen besluit voor warover hij bevoegd is te oordelen. ${ }^{64}$

Ook de wetgever hanteert (impliciet) het criterium 'de bestuursrechter kan of kon' in artikel $70 \mathrm{Rv}$. De tekst van deze bepaling luidt:

'1. Voor zover de rechter de aanlegger in diens vordering of verzoek niet-ontvankelijk verklaart omdat bezwaar kon worden gemaakt, administratief beroep kon worden ingesteld of beroep bij een administratieve rechter kon worden ingesteld, wordt dit in het vonnis, het arrest of de beschikking vermeld.

60. Wordt bijvoorbeeld een vordering uit onverschuläigđe betaling ingesteid voor de burgerlijke rechter, gebaseerd op de stelling dat is betaald op grond van een foutief besluit, terwijl dat besluit niet in een bestuursrechtelijke procedure is aangevallen, dan dient de burgerlijke rechter uit te gaan van de rechtmatigheid van dat besluit, dat dus formele rechtskracht heeft gekregen. Het besluit vormt in dat geval de rechisgrond voor de betaling, zodat de vordering dient te worden afgewezen. Vgl. de casus in HR 16 mei 1986, NJ 1986, 723, m.nt. MS, AB 1986, 573, m.nt. FHvdB (Heesch-Van de Akker), waarin overigens een uitzondering werd aangenomen op het beginsel van formele rechtskracht.

61. Schueler (1997), blz. 20-21. Ook Damen hanteen deze termen, Onrechtmatige daad V.A.3 (Damen), aant. 71 (supplement 62, september 2001).

62. Schueler (1997), blz. 20 en Onrechtmatige daad V.A.3 (Damen), aant. 71 (supplement 62, september 2001).

63. Uiteraard is daarmee niet gezegd dat je datgene wat je vraagt ook daadwerkelijk had gekregen via de bestuursrechtelijke rechtsgang.

64. Een voorbeeld uit de jurisprudentie waarin de Hoge Raad het 'kan of kon'-criterium hanteerde, is het Changoe-arrest. HR 28 februari 1992, NJ 1992, 687, m.nt. MS, AB 1992, 301, m.nt. FHvdB. Op het moment van dagvaarding stond geen administratieve rechtsgang meer open; de Hoge Raad overwoog dat de rechtbank Changoe niet-ontvankelijk had moeten verklaren in zijn vordering. Zie over dit arrest uitgebreid 7.2.4.3. 
2. Indien de niet-ontvankelijkheid voor de aanlegger onduidelijk kon zijn, vermeldt de rechter tevens in het vonnis, het arrest of de beschikking bij welk orgaan alsnog bezwaar kan worden gemaakt of alsnog beroep kan worden ingesteld. Het orgaan waarbij alsnog bezwaar kan worden gemaakt of alsnog beroep kan worden ingesteld, is aan die beslissing gebonden.

3. De termijn voor het alsnog indienen van het bezwaar- of beroepschrift vangt aan met ingang van de dag na die waarop het vonnis, het arrest of de beschikking onherroepelijk is geworden'.

Het eerste lid geeft aan, dat wanneer de rechter eiser niet-ontvankelijk verklaart, hij dit moet vermelden in het vonnis, het arrest of de beschikking. Tevens geeft het aan, wanneer eiser niet-ontvankelijk moet worden verklaard, namelijk wanneer bezwaar kon worden gemaakt, administratief beroep kon worden ingesteld of beroep bij een bestuursrechter kon worden ingesteld. Lid 2 geeft vervolgens aan wanneer de burgerlijke rechter in het vonnis, het arrest of de beschikking moet vermelden bij welk orgaan alsnog bezwaar kan worden gemaakt of beroep kan worden ingesteld, namelijk wanneer de niet-ontvankelijkheid voor de aanlegger onduidelijk kon zijn. In dat geval heeft de wetgever de betrokkene, die niet te verwijten valt dat hij heeft nagelaten de bestuursrechtelijke rechtsgang te volgen, een herkansing willen bieden. Lid 2 bouwt voort op lid 1: doorverwijzing naar de bestuursrechtelijke rechtsgang kan alleen als de burgerlijke rechter eiser nietontvankelijk verklaan. ${ }^{65}$

In het kader van artikel $70 \mathrm{Rv}$ is toepassing van het criterium 'de bestuursrechter kan of kon' logisch. Bij strikte toepassing van het criterium 'de bestuursrechter kan' zou het immers zo zijn dat wanneer de termijn voor het indienen van bezwaar ongebruikt is verstreken, artikel $70 \mathrm{Rv}$ geen rol meer kan spelen. In dat geval dient eiser immers niet niet-ontvankelijk te worden verklaard ${ }^{66}$ De eiser die verschoonbaar heeft nagelaten de bestuursrechtelijke procedure te volgen, kan niet alsnog naar die procedure worden verwezen, terwijl de burgerlijke rechter de vordering in het algemeen zal moeten afwijzen omdat het bestreden besluit of het besluit waarop de vordering voortbouwt formele rechtskracht heeft gekregen, tenzij deze rechter een uitzondering op die rechtskracht wil aannemen.

65. In artikel $70 \mathrm{Rv}$, dat in 2002 in werking, is getreden ${ }_{10}$ komt dit duidelijker in de tekst tot uiting dan in de voorloper van dit artikel, artikel 96a Rv. Uit de toelichting op artikel 1.8.2 Rv, het latere artike! 70, Tweede Kamer 1999-2000, 26855 , nr. 3, blz. 81, kan worden afgeleid dat met de nieuwe redactie geen inhoudelijke wijziging is beoogd ten opzichte van artikel 96a Rv. Ook onder artikel 96a Rv gold mijns inziens reeds dat doorverwijzing naar de bestuursrechter slechts mogelijk was als eiser niet-ontvankelijk was verklaard door de burgerlijke rechter. Ook zo Van Ravels (2001), blz. 200. Het probleem was echter dat de wetgever zich in de toelichting op artikel 96a niet ondubbelzinnig heeft uitgelaten over dit punt, zie de tweede nota van wijziging van de Wet voltooiing eerste fase herziening rechterlijke organisatie, waarbij artikel 96a Rv werd ingevoegd, Tweede Kamer 1992-1993, 22 495, nr. 12, blz. 67-68. Het artikel werd ingevoegd naar aanleiding van een onderzoek van de Katholieke Universiteit Brabant in samenwerking met de Erasmusuniversiteit en de Rijksuniversiteit Limburg met betrekking tot onder meer doorzenden verwijsregels, zie voor dit onderzoek Van Male/De Waard (1993).

66. Damen lijkt om dit te ondervangen lid 1 los te koppelen van lid 2; toepassing van lid 2 zou dan geen niet-ontvankelijkheid vooronderstellen, zie Onrechtmatige daad V.A.4 (Damen), aant. 98.1 (supplement 44, april 1999). Onder de redactie van artikel 96a Rv kon dit nog worden verdedigd, de nieuwe tekst van artikel 70 Rv laat naar mijn mening een dergelijke lezing niet meer toe. 
Van het geval waarin een besluit formele rechtskracht heeft gekregen, moet worden onderscheiden de situatie waarin de bestuursrechtelijke procedure is gevolgd en de bestuursrechter ${ }^{67}$ de bestuurshandeling heeft beoordeeld. In dat geval zal de burgerijke rechter dat oordeel normaliter ovememen. Voor deze situatie kan, met Bloembergen en Damen, de term bindende kracht worden gebruikt. ${ }^{68} \mathrm{Zij}$ achten het begrip formele rechtskracht hier onjuist. Het gaat volgens hen niet om de vraag of de burgerlijke rechter moet uitgaan van de rechiskracht die het besluit heeft gekregen doordat daartegen geen voorziening meer openstaat, maar het gaat om de bindende kracht van de rechterlijke uitspraak. Ook op dit punt bestaat echter geen eenduidigheid. Zo kan ook van formele rechtskracht worden gesproken, indien de bestuursrechter het besluit in stand laat. ${ }^{69}$ Duidelijk is in ieder geval wel dat wanneer de bestuursrechter het besluit vernietigt, er geen sprake meer kan zijn van formele rechtskracht van dat besluit. In het algemeen zal voor de burgerlijke rechter de onrechtmatigheid van het primaire besluit vaststaan indien de bestuursrechter dit besluit vernietigt. ${ }^{70}$ Daarbij geldt tevens de regel, dat deze onrechtmatige daad aan het bestuur kan worden toegerekend; als er al geen sprake is van schuld, dan zal toerekening plaatsvinden krachtens verkeersopvatting. ${ }^{71}$

\subsubsection{De rechtsgang naar de burgerlijke rechter door de overheid bij het bestaan van een bestuursrechtelijke regeling}

In het voorgaande is gebleken dat het bestaan van een administratieve rechtsgang gevolgen had voor de beantwoording van de vraag of de burgerlijke rechter mocht oordelen in een geschil tussen een burger en de overheid. Dit gebeurde op verschillende manieren: via de bevoegdheid van de rechter, via de ontvankelijkheid van de eiser, via de formele rechtskracht en via de bindende kracht van de rechterlijke uitspraak. In deze gevallen was het steeds de 'wederpartij' van de overheid die een vordering instelde bij de burgerlijke rechter. Had het bestaan van een bestuursrechtelijke rechtsgang ook consequenties voor het antwoord op de vraag of de overheid een vordering mocht instellen voor de burgerlijke rechter? Met andere woorden: als de overheid het publiekrechtelijk traject kon volgen door een besluit te nemen, waartegen vervolgens de belanghebbende kon ageren via het volgen van die bestuursrechtelijke rechtsgang, mocht de overheid dan in plaats daarvan de privaatrechtelijke weg kiezen door de burgerlijke rechter te adiëren?

67. Beter zou zijn: de tot beslissen geroepen instantie, aangezien dit niet altijd de bestuursrechter hoeft te zijn, hoewel dit in de praktijk vrijwel altijd het geval zal zijn.

68. Onrechtmatige daad V.A.5 (Damen), aant. 113 (supplement 55, augustus 2000).

69. In dat geval kan er zowel sprake zijn van formele rechtskracht van het besluit als van bindende kracht van de rechterlijke uitspraak.

70. Zie onder meer HR 24 februari 1984, NJ 1984, 669, m.nt. JAB, AB 1984, 399, m.nt. E.M. van Eijden (St Oedenrode/Driessen).

71. Onder meer HR 31 mei 1991, NJ 1993, 112, m.nt. CJHB, AB 1992, 290, m.nt. FHvdB onder 291 (Van Gog/Nederweert). 
Hiermee zou voor de betrokkene de bestuursrechtelijke rechtsgang worden afgesloten. Tevens moet worden bekeken in hoeverre de burgerlijke rechter een rol kon spelen indien voor het bestuursorgaan geen bestuursrechtelijke weg openstond omdat de publiekrechtelijke regeling deze weg uitdrukkelijk uitsloot. Ik zal deze vragen bekijken aan de hand van de terugvordering, nu het bij terugvordering de overheid is die het initiatief neemt, hetzij door een terugvorderingsbesluit te nemen, hetzij door een vordering in te stellen bij de burgerlijke rechter.

De periode die ik in deze paragraaf zal behandelen is die vóór en vlak na de Tweede Wereldoorlog. De latere periode komt bij de bespreking van de verschillende rechtsgebieden in de hoofdstukken 6 tot en met 8 aan de orde.

Kon de burgerlijke rechter een rol kon spelen als er een bestuursrechtelijke regeling bestond? Met betrekking tot terugvordering komt deze vraag erop neer of de overheid mocht kiezen voor de privaatrechtelijke weg als een publiekrechtelijke regeling terugvordering uitdrukkelijk toestond of juist uitdrukkelijk uitsloot. Dit laatste was bijvoorbeeld voor de Tweede Wereldoorlog het geval in vrijwel alle socialezekerheidswetten. ${ }^{72}$ In de periode die hier wordt behandeld lijkt de gemene rechtsleer, zoals gezien door onder meer Hamaker en P. Scholten, de heersende, in ieder geval onder privaatrechtelijk ingestelde juristen. ${ }^{73}$ Deze leer zag het privaatrecht als het algemene recht dat altijd en overal gold, tenzij door het publiekrecht een specifieke regeling was getroffen. In dat geval ging de publiekrechtelijike regeling voor:

'Principiecle scheiding is mogelijk tusschen staatsrecht en privaatrecht. Het overige zoogenaamd publiekrecht staat als bijzonder recht tegenover het gemeene. Grens en inhoud daarvan wordt door de positieve rechtsorde gegeven; het is niet van anderen aard dan het gemeene recht; waar het ruimte laat, gelden de gemeene regels:. ${ }^{74}$

Er zijn in de jurisprudentie geen aanwijzingen te vinden dat de burgerlijke rechter een andere opvatting buldigde. Dit betekent dat de overheid in dat geval - het publiekrecht geeft een regeling - waarschijnlijk geen gebruik mocht maken van de privaatrechtelijke weg. (Gepubliceerde) jurisprudentie van de burgerlijke rechter met betrekking tot een terugvorderingsactie ex artikel 1395 BW (oud) van een uitkering, die op grond van een socialezekerheidswet was betaald en waarbij terugvordering door die wet was uitgesloten, is er voor zover ik kan nagaan niet. $^{75}$

72. Zie hierover 6.3.

73. Zie hierover 5.2.1.

74. Asser-Scholten (1934), blz. 42. Mijn cursivering.

75. Slechts Rb. Dordrecht 11 mei 1938, NJ 1939, 571, te bespreken in 6.3 .3 , komt in de richting. maar daarbij betrof het cen vordering uit onrechtmatige daad, terwijl de rechtbank alvorens deze vordering te behandelen had vastgesteld dat de bepaling uit de Ziektewet die terugvordering uitsloot niet van toepassing was. 
Ten slotte wil ik ingaan op de vraag in hoeverre de burgerlijke rechter een rol kon spelen als geen administratiefrechtelijke weg bestond. Strikt genomen valt deze vraag buiten de in deze paragraaf behandelde materie. Toch blijkt bijvoorbeeld uit een uitspraak van de rechtbank 's-Hertogenbosch uit 1950 dat de ontwikkeling van het bestuursrecht ook hier invloed heeft gehad. ${ }^{76}$ Dit is overigens een van de weinige gepubliceerde uitspraken van de burgerlijke rechter met betrekking tot terugvordering door de overheid uit de periode tot het begin van de vijftiger jaren van de twintigste eeuw.

De minister van Oorlog had op grond van de Dienstplichtwet ${ }^{77}$ aan de zoon van Van der Meyden bij beschikking een kostwinnersvergoeding toegekend ten bedrage van $f 3,15$ per dag. In total werd een bedrag van $f 1206,45$ uitgekeerd. De Dienstplichtwet noch het op deze wet gebaseerde Dienstplichtvergoedingsbesluit $^{78}$ kenden regels met betrekking tot terugvordering van te veel of ten onrechte betaalde vergoedingen. Na controle bleek dat gedaagde geen recht had op een kostwinnersvergoeding en de Staat stelde voor de rechtbank een vordering in wegens onverschuldigde betaling. Hoewel zij zich hier niet over uitsprak, achtte de rechtbank zich wel bevoegd kennis te nemen van de vordering. Wel werd de Staat niet-ontvankelijk verklaard. De rechtbank oordeelde dat er een titel voor de betaling was, namelijk het toekenningsbesluit. Dit betekende dat er geen sprake kon zijn van onverschuldigde betaling, ook niet als bleek dat geen recht op toekenning van de vergoeding bestond. Wilde de vordering kunnen slagen, dan diende de minister eerst de toekenningsbeschikking in te trekken. De vraag of een dergelijke intrekking mogelijk was, kwam in een obiter dictum aan de orde:

'O. dat de Rechtbank deswege buiten beschouwing kan laten de, niet door partijen aangeroerde, vraag, in hoeverre het de Minister mogelijk is bij een nader Besluit, niet alleen voor de toekomst maar ook voor het verleden, met terugwerkende kracht op een reeds genomen en uitgevoerd Besluit terug te komen, en aldus aan door het eerste Besluit verkregen rechten hun rechtsgrond te ontnemen, een vraag die de Rechtbank geneigd is ontkennend te beantwoorden'.

Deze uitspraak lijkt in overeenstemming met de rechtspraak van de administratieve rechter in deze periode. ${ }^{79}$

76. Rb. 's-Hertogenbosch 13 oktober 1950, NJ 1951, 501.

77. Wet van 4 februari 1922, houdende een nieuwe regeling van den dienstplicht, Stb. 43, zoals later gewijzigd.

78. Besluit van 24 februari 1922, betreffende de uitvoering van art. 38 der Dienstplichtwet (Staatsblad 1922, no. 43), Stb. 86, gewijzigd bij het besluit van 29 september 1939, Stb. 589 C.

79. Zie bijvoorbeeld de in 7.2.3.3 te bespreken jurisprudentie die de CRvB als ambtenarenrechter heeft gewezen tot begin jaren vijftig van de twintigste eeuw. 


\subsection{Conclusie}

Het ontstaan van bestuursrechtelijke rechtsgangen heeft gevolgen voor de mogelijkheden van de burgerlijke rechter om een geschil tussen een burger en de overheid te beoordelen. Enerzijds is de burgerlijke rechter geneigd om de rechtsmacht van de bestuursrechter te erkennen en voorrang te geven. Hij doet dit veelal niet door zich onbevoegd te achten van het geschil kennis te nemen, maar door eiser niet-ontvankelijk te verklaren in zijn vordering. Zulke niet-ontvankelijkverklaring dient te worden uitgesproken indien de eiser via de rechtsgang voor de burgerlijke rechter tracht iets te verkrijgen, dat hij ook via een bestuursrechtelijke (rechts-) gang kan krijgen of had kunnen krijgen. Als de burgerlijke rechter de eiser ontvangt, kunnen de formele rechtskracht van een besluit en/of de bindende kracht van de rechterlijke uitspraak (gedaan door de bestuursrechter) een rol spelen. De formele rechtskracht van het besluit speelt een rol indien bij de beoordeling van de vordering door de burgerlijke rechter een besluit een rol speelt, dat in een bestuursrechtelijke rechtsgang kan of had kunnen worden aangevallen. Als de betrokkene die bestuursrechtelijke rechtsgang niet volgt of heeft gevolgd, gaat de burgerlijke rechter in beginsel uit van de rechtmatigheid van dat besluit. Is het besluit wel aangevallen via de bestuursrechtelijke rechtsgang, dan neemt de burgerlijke rechter in beginsel de uitspraak van de bestuursrechter hieromtrent over.

De vraag of het ontstaan van administratief-rechtelijke rechtsgangen consequenties had voor de mogelijkheid voor het bestuur om de burgerlijke rechter te adiëren, moet vooral worden beantwoord aan de hand van de heersende opvatting met betrekking tot de vraag of de overheid gebruik kon maken van het privaatrecht. Deze opvattingen zullen in het volgende hoofdstuk aan de orde komen. In de periode voor en kort na de Tweede Wereldoorlog kan de gemene rechtsleer als de heersende worden gezien; volgens deze leer was het antwoord op de gestelde vraag afhankelijk van het feit of de betrokken publiekrechtelijke regeling bepalingen bevatte.

Anderzijds diende ook de bestuursrechter zijn bevoegdheid af te bakenen. Dit leidde in bepaalde gevallen tot concurrerende rechtsmacht; de bestuursrechter hanteerde een ander criterium dan de burgerlijke rechter. Voor de bestuursrechter was dit criterium veelal de vraag, of een beschikking/besluit voorlag. Hierbij diende hij het begrip beschikking/beslttit nader uit te werken. Vooral de afbakening ten opzichte van rechtshandelingen naar burgerlijk recht was van belang. Een dergelijke rechtshandeling was namelijk geen besluit en viel dus buiten de rechtsmacht van de (algemene) bestuursrechter. In recente tijd. is de bestuursrechter het besluitbegrip steeds ruimer gaan uitleggen, zodat het door hem gehanteerde criterium steeds meer op het fundamentum petendi is gaan lijken. Dit heeft uiteraard. weer gevolgen voor de rechtsmacht van de burgerlijke rechter, althans dat zou zo moeten zijn. Hierop zal ik verder ingaan in hoofdstuk 9 en verder. 



\section{OVERHEID EN PRIVAATRECHT; VERSCHILLENDE THEORIEËN}

\subsection{Inleiding}

In de vorige hoofdstukken hebben we gezien dat drie samenhangende ontwikkelingen in de negentiende eeuw - namelijk het vrijwel ontbreken van administratief recht en administratieve rechtsbescherning, waardoor de burgerlijke rechter deze rechtsbescherming is gaan bieden, het feit dat de overheid vorderingen kon instellen bij de burgerlijke rechter en het feit dat deze rechter veelal burgerlijk recht toepaste - ertoe hebben geleid dat de overheid gebruik ging maken van het privaatrecht, ook ter verwezenlijking van publiekrechtelijke doelen, en dat het gebruik van privaatrecht door de overheid vrij algemeen werd aanvaard.

Uit dit hoofdstuk zal blijken, dat dit niet betekende dat dit gebruik onbeperkt was of zelfs onbestreden is gebleven. Wel heeft deze historische ontwikkeling ertoe geleid dat nog steeds als uitgangspunt geldt, dat de overheid publiekrechtelijke belangen in beginsel 'ook mag behartigen door gebruik te maken van haar in beginsel krachtens het privaatrecht toekomende bevoegdheden'.'

In dit hoofdstuk zal ik de theoretische onderbouwingen beschrijven die veelal achteraf - aan deze praktijk zijn gegeven. Uiteraard hebben deze theorieën op hun beurt weer de praktijk en de rechtspraak beïnvloed. Ook de manier waarop de rechter en de wetgever de verschillende theorieën hebben toegepast en uitgewerkt zullen aan de orde komen.

De beschrijvingen in dit hoofdstuk zullen in hoofdlijnen plaatsvinden. ${ }^{2}$ Globaal kunnen twee opvattingen worden onderscheiden. Aan de ene kant is er de opvatting dat de overheid gebruik mag maken van het privaatrecht. Hiermee is overigens niet gezegd dat dit gebruik ongelimiteerd en ongeclausuleerd kan plaatsvinden. Aan de andere kant zijn er geluiden uit de tegenovergestelde richting te beluisteren; het privaatrecht is niet geschreven voor de overheid en dient dus ook niet van toepassing te zijn in rechtsverhoudingen waarbij de overheid partij is. Deze tegenstelling zal in dit hoofdstuk het uitgangspunt van de beschrijving zijn.

1. HR 26 januari 1990, NJ 1991, 393, m.nt. MS onder 394, AB 1990, 408, mnt. G.P. Kleijn (Windmill).

2. Er bestaan tal van uitgebreide beschrijvingen; ik noem slechts Van der Hoeven (1989). 


\subsection{Uitgangspunt: de overheid mag gebruik maken van het privaatrecht}

Sedert het einde van de negentiende eeuw kan de stroming die vindt dat de overheid gebruik mag maken van het privaatrecht als de heersende worden beschouwd. Ik zal deze stroming dan ook als eerste bespreken. Bedacht moet worden dat eigenlijk niet gesproken kan worden van één stroming, maar van een aantal (samenhangende en op elkaar voortbouwende) stromingen.

\subsubsection{Gemene rechtsleer, eenheid van het recht en de opvatting van Van Praag}

Als theoretische bron kan worden gezien de zogenaamde gemene rechtsleer. De grondlegger van deze leer was Hamaker, die zich vooral afzette tegen de opvatting van Loeff, dat het privaatrecht afkomstig is van de staat. ${ }^{3}$ Volgens Hamaker was het privaatrecht juist het '(al)gemene recht', dat in feite niets anders was dan de inhoud van het rechtsbewustzijn. Dit privaatrecht ontstond en bestond dan ook onafhankelijk van de overheid. Het publiekrecht daarentegen was niets anders dan het overheidsbevel in de vorm van de wet. De wetgever kon hierin neerleggen hoe hij vond dat de maatschappij moest worden ingericht. ${ }^{4}$ Het publiekrecht bestond volgens Hamaker slechts voor zover het was neergelegd in een wet. ${ }^{5}$ Als dit was gebeurd, dan achtte hij het privaatrecht 'ondergeschikt' aan het publiekrecht, in die zin dat de wetgever geacht moest worden door die wetten de werking van het rechtsbewustzijn tegen te gaan, opzij te zetten. Er was geen sprake van ondergeschiktheid in die zin, dat het publiekrecht van hogere orde zou zijn dan het privaatrecht; 'over het rechtsbewustzijn heeft (de wetgever) geene macht'. ${ }^{6} \mathrm{De}$ vraag of de overheid ook gebonden was aan het privaatrecht moest bevestigend worden beantwoord, voor zover uiteraard het (in de wet neergelegde) publiekrecht geen afwijkend antwoord gaf; het privaatrecht gold immers als uiting van het rechtsbewustzijn altijd en voor iedereen - dus ook de overheid -, tenzij de overheid ervan was afgeweken in de wet. Logischerwijs betekende dit dat de overheid ook gebruik mocht maken van het privaatrecht, al heeft Hamaker dit niet met zoveel woorden gezegd. Hamaker heeft met zijn theorie de sedert 1844 bestaande praktijk voorzien van een theoretische grondslag. ${ }^{\text {? }}$

Haar populariteit heeft de gemene rechtsleer voor een groot deel te danken aan P. Scholten, die in het Algemeen deel van de Asser-serie uit 1931 schrijft:

3. Loeff (1887), blz. 32, zie hierover 5.3.1.

4. Hamaker (1894), blz. 72, Verspreide geschriften blz. 160.

5. Hij vroeg zich dan ook af of dit publiekrecht, dit overheidsbevel in de vorm van wet, wel aanspraak mocht maken op de titel 'recht', zie Hamaker (1894), blz. 51, 73, Verspreide geschriften blz. $139,161$.

6. Hamaker (1894), blz. 74, Verspreide geschriften blz. 162.

7. Hamaker stelde zelf: 'De theorie zal de praktijk moeten volgen, niet omgekeerd", Hamaker (1894), blz. 61, Verspreide geschriften blz. 149. Zie over die praktijk in de negentiende eeuw uitvoering hoofdstuk 2 . 
'Nog altijd schijnt mij, dat de kijk, die Hamaker op het vraagstuk had, het juiste inzicht geef. Het privaatrecht wijst de algemeene gedragsregelen aan, het gemeene recht is daarvoor de juiste term. In het publiekrecht worden (...) evenzeer gedragsregelen gegeven, bevelen der overheid, rechtsregels, als die van het gemeene recht, die dat recht terwille van de staatstaak aanvullen en er van afwijken. Dit kan uitodrukkelijk geschieden, de afwijking kan ook het resultaat zijn van rechtsvinding, waar de wet zwijgt (..) (E)r is een presumptic van onderworpenheid van het staatsorgaan aan het gemeene recht, doch we moeten er aan toevoegen, dat de aard der verhouding, met name het beroep op het gezag, wel niet steeds de toepasselijkheid der gewone regels moet uitsluiten, doch daartoe kan leiden'. 8

Het verschil tussen Scholten en Hamaker is dat de eerste het bestaan van ongeschreven publiekrecht erkende, ${ }^{9}$ terwijl hij voorts, uitgaande van de presumptie van onderworpenheid van de overheid aan het gernene recht, aannam dat de aard van de verhouding de toepasselijkheid van dat gemene recht kan uitsluiten. ${ }^{10} \mathrm{De}$ gemene rechtsleer, zoals verkondigd door Scholten, is lange tijd in Nedenland de heersende leer met betrekking tot de verhouding overheid-privaatrecht geweest; regelmatig wordt betoogd dat zij nog steeds de heersende leer is.

De gemene rechtsleer maakte een principieel onderscheid tussen publiek- en privaatrecht. Dit onderscheid werd echter niet door iedereen erkend. In zijn boek Die Lehre der Rechtssouveränität introduceerde Krabbe in 1906 de idee van de eenheid van het recht in Nederland. "In zijn visie bestond er weliswaar een onderscheid tussen privaat- en publiekrecht, maar hij ontkende dat dit een principieel onderscheid was; er was sprake van slechts één recht. Uitgangspunt was de rechtssoevereiniteit. Het privaatrecht was het altijd en voor eenieder, dus ook voor de overheid, geldende recht, het gemene recht, dat op sommige punten voor de overheid werd aangevuld door publiekrecht. In zoverre heeft ook deze leer haar wortels in de gemene rechtsleer. Deze leer heeft later aanhangers gevonden in onder meer Krabbe's leerling Kranenburg en G.A. van Poelje. ${ }^{12}$

De gedachte die aan de idee van eenheid van recht ten grondslag ligt, is dus

8. Asser-Scholten (1931), blz, 40. Cursivering in oorspronkelijke tekst.

9. In 1923 erkende de Hoge Raad dat ook een publieke taak bevoegdheden kon schepper, HR 12 januari 1923, NJ 1923, 307. Volgens Meijers erkende de Hoge Raad hiermee 'regels vani ongeschreven publiekrecht (...), die de overheid bevoegdheden toekennen', Meijers (1925), blz. 243, VPO III blz. 153.

10. Opvallend is dat Scholten in 1912 duidelijke vraagtekens plaatste bij de leer van Hamaker: 'Van het publiekrecht, maar ook alleen daarvan, zegt schr., ikan men zeggen, dat het te vinden is in de wet, en dat er buiten deze geen recht is. Het mag o.i. worden betwijfeld of dit laatste in allen deele juist is, voorts of de tegenstelling tusschen rechtsregels voortkomend uit het rechtsbewustzijn en rechtsregels bevelen van de overheid wel scherp te trekken is, en ten slotte of, als dit al geval is, zij dan samenvalt met die tusschen privaat- en publiekrecht', Asser-Scholten (1912), blz. 4-5. Bijna twintig jaar later gaat hij dus om. Een duidelijke aanzet daartoe was al te vinden in zijn bewerking van het Asserdeel betreffende het zakenrecht uit 1927: '(H)et privaatrecht is het gemeene recht. Het publiek recht maakt daar voortdurend inbreuk op maar stelt het niet ter zijde, het geldt ook voor de overheid, zoolang een afwijking niet kan worden aangewezen', Asser-Scholten (1927), blz. 28.

11. Krabbe (1906).

12. Zie respectievelijk Kranenburg (1927) en Van Poelje (1931). 
dat er slechts één recht bestaat. Hierbij dient wel rekening te worden gehouden met de specifieke situatie en het specifieke karakter van de rechtsverhouding. Dit betekent dat voor specifieke gevallen specifieke regels kunnen gelden, waarbij mede moet worden gekeken naar de aard van de partijen. Dit geldt niet alleen voor de overheid, waarbij het publiekrecht aanvullende regels kan geven, maar bijvoorbeeld ook voor handelsbetrekkingen, waarbij het handelsrecht aanvullend werkt of voor familierechtelijke betrekkingen, waarbij het personen- en familierecht deze functie vervult. Deze aanvullende regels vullen dan het privaatrecht, dat dus nog steeds wordt gezien als het gemene recht, aan, hetgeen ook een afwijking van dit recht kan betekenen. In zoverre sluit deze rechtseenheidgedachte aan bij en ligt zij mogelijk ten grondslag aan de gemengde rechtsleer, die vanaf de jaren zeventig van de twintigste eeuw opkomt. ${ }^{13}$ Zoals zal blijken makt het volgens deze leer niet veel uit of de overheid gebruik maakt van het privaatrecht, nu dit privaatrecht, wanneer de overheid optreedt, door de specifieke rechtsverhouding dient te worden gekleurd door publiekrechtelijke beginselen.

Sinds de gemene rechtsleer was het algemene uitgangspunt dat het privaatrecht onder omstandigheden ook van toepassing was op de overheid. Deze toepasselijkheid was niet onbegrensd. Volgens de gemene rechtsleer mocht de overheid steeds gebruik maken van het privaatrecht, tenzij er een publiekrechtelijke uitzondering was. Ook. volgens de aanhangers van de leer van de eenheid van recht mocht de overheid gebruik maken van het privaatrecht, zij het dat het publiekrecht dit privaatrecht kon aanvullen en er ook van kon afwijken.

Gelet op de jurisprudentie van de bestuursrechter met betrekking tot onder meer het zuiver schadebesluit ${ }^{14}$ is ten slotte nog de visie van Van Praag interessant. Zijn visie vertoont namelijk een aantal parallellen met de door de bestuursrechter gehanteerde constructie bij dat schadebesluit. Volgens Van Praag diende als uitgangspunt te worden genomen de rechtsverhouding: ${ }^{15}$ was deze publiekrechtelijk van aard, dan was publiekrecht van toepassing; was deze privaatrechtelijk, dan het privaatrecht. De vraag of een rechtsverhouding publiekrechtelijk van aard was, diende te worden beantwoord door te kijken in welke hoedanigheid de overheid optrad. Het criterium was daarbij of de overheid 'als zodanig' optrad, of dat zij zich wilde 'stellen op hetzelfde standpunt als een partikulier'. ${ }^{16}$

13. De idee van eenheid van recht is dan ook in die tijd weer terug te vinden in Polak (1970), blz. 15 en Bloembergen (1977). In zijn opstel, getiteld Eenheid van privaatrecht en administratief recht, pleitte Bloembergen voor een eenheid van begrippen in beide rechtsgebieden. Dit alleen zou geen eenheid van recht meebrengen, het was volgens hem wel een eerste vereiste daartoe, zie Bloembergen (1977), onder meer blz. 54, Bloembergens Werk, blz. 350-351.

14. Zie 4.2.3.

15. Van Praag (1925), blz. 131.

16. Van Praag (1923), blz. 8-10. Het was echter aan de overheid zelf om te bepalen of zij 'als zoda-

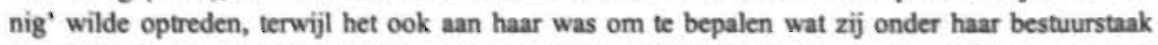
verstond. Verder was niet uitgesloten dat als de overheid 'als zodanig' was opgetreden, de regels uit het BW toch (rechtstreeks) van toepassing waren, Van Praag (1923), blz. 13-14. 
Als een bepaalde rechtsverhouding publiekrechtelijk was, dan betekende dit volgens Van Praag niet, dat de regels uit het BW niet van toepassing konden zijn. De rechter kon die regels namelijk analogisch toepassen als het publiekrecht geen regels stelde en dus een leemte bevatte. ${ }^{17}$ Ook zag Van Praag dat het mogelijk was om bepaalde algemene rechtsbeginselen te onderkennen, die hun uitwerking hadden gekregen in het BW. ${ }^{18}$ Het artikel uit het BW waarin dat rechtsbeginsel zijn uitwerking had gevonden, kon dan ook. worden toegepast in de publiekrechtelijke rechtsverhouding, al voegde hij daar onmiddellijk aan toe dat 'uit her gemeen zijn der rechtsfiguur (...) nog niet (volgt) dat ook de wetsartikelen voor beide terreinen gelden'. ${ }^{19}$ Van Praag liep hiermee vooruit op een ontwikkeling, die in de jaren vijftig door de Centrale Raad van Beroep in gang werd gezet ${ }^{20}$ en in de jaren negentig algemeen ingang heeft gevonden. ${ }^{21}$

\subsubsection{De tweewegenleer}

De tot nu toe beschreven opvattingen gingen alle uit van het uitgangspunt dat de overheid gebruik mocht maken van het privaatrecht. Hierbij gold de beperking, dat indien er (geschreven of ongeschreven) publiekrecht bestond, dit publiekrecht van toepassing was, als uitzondering, als aanvulling of omdat de overheid 'als zodanig' optrad. In 1925 introduceerde de Hoge Raad echter de tweewegenleer:

'(O)ok al had het openbaar gezag aan den eischer zijn will ter voldoening door dezen van de administratiekosten kunnen opleggen, ${ }^{2}$ geen enkel wettelijk voorschrif dit gezag belette om daarvan niet gebruik te maken, doch te dien aanzien eene regeling met den eischer te treffen en daarover eene overeenkomst aan te gaan', ${ }^{23}$

Kortom: als het privaatrecht het gemene recht is dat ook van toepassing is op de overheid, waarom kan de overheid dan niet kiezen voor toepassing van dit gemene recht als het publiekrecht een uitzondering geeft op dit gemene recht? Met andere woorden, voor de overheid staat náást de eventuele publiekrechtelijke weg ook de privaatrechtelijke weg open: de overheid kan kiezen uit twee wegen.

Hiermee werd echter het gevaar geschapen dat de overheid misbruik zou gaan maken van het privaatrecht; door te kiezen voor privaatrecht kon de overheid immers publiekrechtelijke waarborgen omzeilen. Dit werd ook geconstateerd door Huart, die zijn opstel Misbruik van burgerlijk recht door de administratie hieraan wijdde. ${ }^{24}$ Volgens Huart mocht de overheid gebruik maken van het privaatrecht,

17. Van Praag (1923), blz. 38.

18. Van Praag (1923), blz. 39.

19. Van Praag (1923), blz. 39, noot 69.

20. Zie 7.2.3.3.

21. Zie onder meer 4.2 .3 en hoofdstuk 9.

22. En wel op grond van 'de door de publiekrechtelijke macht gemaakte voorschriften'.

23. HR 16 april 1925, NJ 1925, 649. Zie ook HR 1 april 1926, NJ 1926, 577.

24. Huart (1927). 
zowel in plaats van als in combinatie met het publiekrecht, zolang maar geen sprake was van misbruik van privaatrecht. Daarvan was sprake als de publiekrechtelijke weg exclusief was bedoeld en deze weg beperkingen oplegde aan de overheid en de overheid vervolgens deze weg en de beperkingen trachtte te omzeilen door de privaatrechtelijke weg te kiezen.

Ook Donner wees in het Algemeen deel van het handboek Nederlands Bestuursrecht uit 1953 op het gevaar van misbruik van privaatrecht door de overheid. In beginsel achtte ook hij het gebruik van privaatrecht door de overheid mogelijk, maar anders dan Huart gaf hij voorrang aan de publiekrechtelijke weg. Gebruik van privaatrecht in plaats van of gecombineerd met publiekrecht wees hij af ${ }^{25}$ Voor Donner lag het primaat duidelijk bij het publiekrecht, terwijl ook bij gebruik van het privaatrecht de publiekrechtelijke normen in acht dienden te worden genomen. Met dit laatste heeft Donner ook de aanhangers van de tweewegenleer beïnvloed. Zo toonde Troostwijk zich in zijn preadvies voor de VAR uit 1956 een voorstander van de tweewegenleer, zij het dat ook hij een aantal beperkingen aanbracht op de bevoegdheid van de overheid om gebruik te maken van het privaatrecht. Zo mocht door de keuze voor het privaatrecht geen sprake zijn van misbruik van recht en diende de overheid de algemene beginselen van behoorlijk bestuur in acht te nemen. ${ }^{26}$

In de praktijk werd de tweewegenleer steeds meer toegepast. Donner spreekt van de tweepettenpraktijk: de overheid had in beginsel de keuze of zij in een bepaalde verhouding haar publiekrechtelijke dan wel haar privaatrechtelijke pet op wilde zetten. ${ }^{27}$ Ook in de rechtspraak werd in de jaren zestig de tweewegenleer tot uitgangspunt verheven. ${ }^{28}$ Uiteraard kon de tweewegenleer slechts toepassing vinden als er twee wegen bestonden: er moest in een concreet geval een publiekrechtelijke regeling voorhanden zijn. ${ }^{29}$ Het uitgangspunt van de Hoge Raad was dat privaatrechtelijk optreden door de overheid was toegestaan, ook als een publiekrechtelijk alternatief voorhanden was. Dit was slechts anders als de bewoordingen dan wel de strekking van een wettelijke publiekrechtelijke bepaling zich hiertegen verzetten, zo bleek uit het arrest Eindhoven-Staals. ${ }^{30}$ Andere arresten voegden hieraan toe dat geen sprake mocht zijn van misbruik van bevoegdheid of misbruik van feitelijke macht. ${ }^{31}$ Op deze manier werden ook in het privaatrechtelijk optreden van de overheid (steeds meer) publiekrechtelijke normen binnengebracht.

25. Donner (1953), blz. 65-66.

26. Troostwijk (1956), blz. 70-71.

27. Donner (1987), blz. 271.

28. Beurskens (1997), blz. 26.

29. Was dit publiekrechtelijk 'alternatief niet aanwezig, dan werd het privaatrecht toegepast: de gemene rechtsleer.

30. HR 19 januari 1968, NJ 1968, 166, m.nt. G.J.S., AB 1968, 585, m.nt. S.

31. Zie onder meer HR 13 april 1962, NJ 1964, 366, m.nt. H.B., AB 1962, 487, m.nt. St. (Kruseman). Zie hierover Beurskens (1997), blz. 26-35. 


\subsubsection{Verdere beperkingen op het gebruik van privaatrecht door de overheid}

Het binnenbrengen van die publiekrechtelijke normen in het privaatrechtelijk optreden van de overheid betekende dat in het gebruik van privaatrecht verdere beperkingen werden aangebracht. Troostwijk wees in zijn genoemde preadvies voor de VAR reeds op de algemene beginselen van behoorlijk bestuur. Deze beginselen zijn in eerste instantie ontwikkeld door bestuursrechtelijke juristen en 'recht'sprekende instanties. ${ }^{32}$ Zo toetste voor de inwerkingtreding van de Ambtenarenwet 1929 de Kroon op het terrein van het ambtenarenrecht aan ongeschreven behoorlijkheidsnormen. ${ }^{33} \mathrm{Na}$ de inwerkingtreding van die wet toetste vervolgens de Centrale Raad van Beroep in 1935 een beslissing aan het (ongeschreven) rechtszekerheidsbeginsel, ${ }^{34}$ nadat hij al in 1933 had laten blijken te zullen toetsen aan algemene rechtsbeginselen. ${ }^{35}$ In 1936 wees de Hoge Raad een arrest waarin hij aangaf dat schending van een ongeschreven (publiekrechtelijke) rechtsnorm een onrechtmatige daad kon opleveren. De Hoge Raad eiste van het bestuur een redelijke en billijke bevoegdheidsuitoefening, maar hij zag pas ruimte voor rechterlijk ingrijpen als de bevoegdheidsuitoefening misbruik van bevoegdheid opleverde. ${ }^{36} \mathrm{Na}$ de Tweede Wereldoorlog werd strijd met algemene beginselen van behoorlijk bestuur opgenomen als toetsingsgrond in administratieve wetten. Dit gebeurde het eerst in de Wet arbo; artikel 5 noemde als beroepsgronden strijd met een algemeen verbindend voorschrift, détournement de pouvoir (het bestuursorgaan heeft bij het geven van het besluit van zijn bevoegdheid kennelijk tot een ander doel gebruik gemakt dan tot de doeleinden, waartoe die bevoegdheid is gegeven), willekeur (het bestuursorgaan heeft bij afweging van de betrokken belangen niet in redelijkheid tot het besluit kunnen komen) en strijd met enig ander in het algemeen bewustzijn levend beginsel van behoorlijk bestuur. ${ }^{37}$ Later volgden onder meer de Wet bab en haar opvolgers, de Wet arob en de Awb. ${ }^{38}$

Ook in de jurisprudentie van de burgerlijke rechter werd in de naoorlogse periode het privaatrechtelijk optreden van de overheid steeds vaker getoetst aan deze beginselen, zij het aanvankelijk nog voorzichtig. In de eerste van de twee bekende woonruimtevorderingsarresten uit 1949, de Zandvoortse woonruimtevordering, ${ }^{39}$ besliste de Hoge Raad dat het bestuursorgaan zich slechts mag laten leiden door die motieven welke naar de strekking van de wet in aanmerking mogen komen. Laat het andere motieven meespelen, dan maakt het een ander

32. In Nederland moeten Krabbe en Struycken worden gezien als de 'aartsvaders' van deze beginselen, Nicolai (1990), blz. 23.

33. Zie Nicolaĩ (1990), blz. 40-42.

34. CRvB 31 oktober 1935, AB 1936, 168. Zie 7.2.3.3 en Nicolar (1990), blz. 45.

35. CRvB 22 juni 1933, AW 1933/K8 (niet gepubliceerd), geciteerd bij onder andere Nicolar (1990), blz. 45 .

36. HR 13 november 1936, NJ 1937, 182, m.nt. E.M.M. Zie ook Nicolar (1990), blz. 62-63.

37. Zie over de Wet arbo 3.5 en 8.4.3.

38. Zie 3.4 .

39. HR 14 januari 1949, NJ 1949, 557, m.nt. DJ.V. onder 559. 
gebruik van zijn bevoegdheid dan waarvoor deze is gegeven..$^{40}$ Het tweede arrest, de Doetinchemse woonruimtevordering, betrof het verbod op willekeur. ${ }^{11}$ Van willekeur was sprake als het bestuursorgaan bij afweging van alle betrokken belangen in redelijkheid niet tot zijn besluit is kunnen komen. Dit zal zich vooral voordoen bij discretionaire bevoegdheden.

Toetste de burgerlijke rechter het overheidshandelen ook aan de overige algemene beginselen van behoorlijk bestuur? Deze vraag werd in eerste instantie beantwoord in de Landsmeer-arresten, die ook woonruimtevordering betroffen. ${ }^{42}$ Hierin overwoog de Hoge Raad dat de burgerlijke rechter het overheidshandelen niet rechtstreeks mocht toetsen aan de algernene beginselen van behoorlijk bestuur. Wel konden deze beginselen een rol spelen in het kader van de vraag of het bestuursorgaan in redelijkheid tot zijn besluit had kunnen komen. Er was dus sprake van een indirecte toets: schending van een dergelijk beginsel kon slechts over de band van de willekeur worden gespeeld. Dit had tot gevolg dat de enkele schending van een algemeen beginsel van behoorlijk bestuur niet kon leiden tot een onrechtmatige daad, daarvoor moest deze schending zodanig zijn dat het bestuursorgaan willekeurig had gehandeld, dus in redelijkheid niet tot zijn besluit had kunnen komen.

Deze lijn - toetsing aan de algemene beginselen van behoorlijk bestuur kan slechts aan de orde komen in het kader van de willekeurtoets - heeft de Hoge Raad volgehouden tot 1987. In het arrest Amsterdam-Ikon ging hij (impliciet) om; hij overwoog dat de stelling dat het gelijkheidsbeginsel 'slechts aan de orde zou kunnen komen in het kader van de toepassing van een aan de overheid meer ruimte latende redelijkheidsmaatstaf en daarom hier een zwakkere werking dan in het bestuursrecht zou hebben', uitgaat 'van een onjuiste rechtsopvatting'. ${ }^{43}$ Vanaf dat moment werd aangenomen dat de burgerlijke rechter het (privaatrechtelijk) overheidsoptreden ten volle diende te toetsen aan de algemene beginselen van behoorlijk bestuur. De Hoge Raad heeft inmiddels duidelijk gemaakt dat dit ook zijn opvatting is. ${ }^{14}$

Uit deze jurisprudentie blijkt dat de Hoge Raad onder de tweewegenleer, zoals die werd toegepast in de jaren zestig, het gebruik van privaatrecht door de overheid in het algemeen toestond, maar dat wel tot op bepaalde hoogte rekening werd gehouden met het feit dat de overheid optrad én met het feit dat het publiekrecht zich kon verzetten tegen het gebruik van privaatrecht. Een directe toetsing aan de algernene beginselen van behoorlijk bestuur vond in die tijd nog niet plaats.

De gedachte dat de overheid steeds (mede) aan publiekrechtelijke normen was gebonden, ook als zij privaatrechtelijk optrad, begon dus steeds meer ingang te

40. Er is dan sprake van détoumement de pouvoir. Nicolar (1990), blz. 63, betwist echter dat de Hoge Raad in de Zandvoortse zaak het verbod van détournement de pouvoir hanteerde.

41. HR 25 februari 1949, NJ 1949, 558, m.nt. D.J.V. onder 559.

42. HR 4 januari 1963, NJ 1964, 202 en 204, m.nt. J.H.B. onder 204.

43. HR 27 maart 1987. NJ 1987, 727, m.nt. MS; AB 1987, 273, m.nt. FHvdB.

44. Zie bijvoorbeeld HR 24 april 1992, NJ 1993, 232, m.nt. MS, AB 1992, 542 (Zeeland-Hoondert). 
vinden. Als gezegd heeft een aantal ontwikkelingen op publiekrechtelijk terrein daaraan bijgedragen, zoals de ontwikkeling van ongeschreven publiekrechtelijke normen. Verder kan worden gewezen op de emancipatie van het bestuursrecht na de Tweede Wereldoorlog, waardoor de gemene rechtsleer steeds meer onder vuur kwam te liggen. Van belang was verder dat de burgerlijke rechter in zijn jurisprudentie steeds meer aandacht ging besteden aan de hoedanigheid van de partijen, waarbij dus het feit dat een van de partijen overheid was, mee kon spelen bij de uiteindelijke beslissing van de rechter. ${ }^{45}$

Tegelijkertijd werd het uitgangspunt van de gemene rechtsleer gehandhaafd: de overheid mag in beginsel privaatrechtelijk optreden, ook ter behartiging van publiekrechtelijke belangen. Privaatrechtelijk optreden had immers in bepaalde gevallen onmiskenbare voordelen: het was vaak praktischer, sneller, goedkoper en gaf de overheid meer slagkracht.

\subsubsection{De gemengde rechtsleer}

De in de vorige paragraaf genoemde twee uitgangspunten - de overheid mag in beginsel privaatrechtelijk optreden, maar dit optreden dient steeds (meer) te worden genormeerd door publiekrechtelijke beginselen - leidden uiteindelijk tot de gemengde rechtsleer. In deze leer is het niet zozeer de vraag of de overheid gebruik mag maken van privaatrecht, maar of het privaatrechtelijk handelen van de overheid niet (mede) publiekrechtelijk gekleurd moet zijn. Het privaatrechtelijk optreden van de overheid is dan niet meer zuiver privaatrechtelijk; er dient al naar gelang de omstandigheden van het geval in meerdere of mindere mate rekening te worden gehouden met een publiekrechtelijk inkleuring van dat optreden. Deze leer vormt dus geen breuk met de voorheen als algemeen geldend beschouwde gemene rechtsleer, maar bouwt daarop voort.

Alvorens op de gemengde rechtsleer in te gaan, zet ik de zienswijze van Van der Hoeven uiteen. Een aantal van diens ideeën is namelijk later gebruikt in de gemengde rechtsleer. In zijn bekende opstel uit 1970 De magische lijn. Verkenningen op de grens van publiek- en privaatrecht werkte Van der Hoeven zijn opvattingen uit. ${ }^{46}$ Hij verwierp de tot dan veel gehanteerde criteria, zoals de opvatting die onderscheidde tussen het privaatrecht als het algemene recht en het

45. De overheid was immers als zij privaatrechtelijk optrad gebonden aan privaatrechtelijke normen, waaronder de redelijkheid en billijkheid. Wat redelijkheid en billijkheid eisen, wordt sedert HR 19 mei 1967, NJ 1967, 261, m.nt. G.J.S. (Saladin-HBU) mede bepaald door 'de maatschappelijke positie en de onderlinge verhouding van partijen'. Weliswaar mag worden aangenomen dat de HR bij het formuleren van deze maatstaf niet het oog heeft gehad op verhoudingen waarbij de overheid is betrokken, het arrest biedt wel de mogelijkheid hiermee rekening te houden. Volgens Konijnenbelt brengt bijvoorbeeld de matschappelijke positie van de overheid mee, dat zij altijd de algemene beginselen van behoorlijk bestuur in acht heeft te nemen, Van Wijk/Konijnenbelt \& Van Male (1999), blz. 451. Zie over de betekenis van dit arrest voor contracten met de overheid Bloembergen (1976), blz. 33-34, Bloembergens werk blz. 252-253.

46. Van der Hoeven (1970). 
publiekrecht als het uitzonderingsrecht, de opvatting die het onderscheid legde bij het optreden van de overheid 'als zodanig' en ook de opvatting die geen principieell onderscheid zag tussen publiek- en privaatrecht. Van der Hoeven kende onderscheidend vermogen toe aan de vraag of een publiek belang in het geding was. ${ }^{47}$ Maakt een handeling deel uit van publieke taakvervulling, dan heeft dat gevolgen 'voor de inhoud van het recht waardoor die handeling wordt geregeerd onverschillig of dat privaatrecht of publiekrecht in de klassieke zin des woords is'. ${ }^{48}$ Wel blijft bij Van der Hoeven sprake van privaatrecht dat publiekrechtelijke elementen gaat opnemen. ${ }^{49}$ Dit is ook het geval bij Lubach, ${ }^{50}$ aan wie in het algemeen de term 'gemengde rechtsleer' wordt toegeschreven. ${ }^{51}$ Anderen zien de

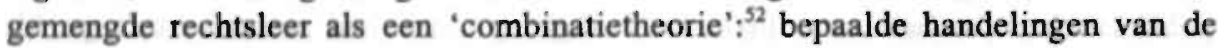
overheid worden niet meer bestempeld als 'privaatrecht met een publiekrechtelijk sausje' of als 'publiekrecht met een privaatrechtelijke inkleuring', maar er ontstaat een eigen, gemengd recht.

Uiteindelijk is ook de rechter de gemengde rechtsleer gaan toepassen, onder meer door het privaatrechtelijk overheidsoptreden rechtstreeks te gaan toetsen aan de algemene beginselen van behoorlijk bestuur. ${ }^{53}$ Ook het feit dat er in 1976 een algemene administratieve rechter kwam, de Afdeling rechtspraak van de Raad van State, droeg hieraan bij. ${ }^{54}$ Dit had namelijk gevolgen voor de wijze waarop de burgerlijke rechter het privaatrechtelijk optreden van de overheid ging beoordelen. Zo gaf deze administratieve rechter het 'goede voorbeeld' aan de burgerlijke rechter, onder meer door allerlei publiekrechtelijke beginselen te ontwikkelen en/of verder uit te werken. Daamaast was er een aantal geschillen dat zowel voor de Afdeling als voor de burgerlijke rechter kwam. De burgerlijke rechter werd hierdoor min of meer gedwongen de lijn van de bestuursrechter over te nemen. ${ }^{55}$

Onder de gernengde rechtsleer bleef het uitgangspunt dat de overheid privaatrechtelijk mag optreden. Dit betekent dat de overheid kan optreden als rechtssubject in het privaatrecht. Dit is ook het uitgangspunt dat wordt gehanteerd in de jurispru-

47. Van der Hoeven (1970), blz. 205, Staatsrecht en Bestuursrecht blz. 181.

48. Van der Hoeven (1970), blz. 218, Staatsrecht en Bestuursrecht blz. 194.

49. Of omgekeerd: 'dat publiekrecht soms het omgekeerde verschijnsel laat zien (nl. 'privaatrechtelijke' trekken gaat vertonen)', Van der Hoeven (1970), blz. 218, Staatsrecht en Bestuursrecht blz. 194. De Haan (1998-I), blz. 632, spreekt van de 'absorptietheorie'.

50. Lubach (1982), blz. 102.

51. in zijn VAR-preadvies uit 1986, Lubach (1986), zou de term voor het eerst zijn gebruikt.

52. Zie bijwoorbeeld Bloembergen (1976), blz. 63-64, Bloembergens werk blz. 282-283 en De Haan (1998-II), blz. 95.

53. Zie 5.2.3.

54. Zie 3.4.3. Zie hierover ook Beurskens (1997), blz. 39-41.

55. Het bekendste voorbeeld hiervan is de jurisprudentie inzake het uitwegvergunningenstelsel; zie achtereenvolgens HR 2 februari 1966, NJ 1966, 415, m.nt. N.J.P. (Hoogeloon), ARRvS 1 september 1977, AB 1977, 366, m.nt. v.d.V. (Uitwegvergunning Maastricht I) en HR 16 mei 1986, NJ 1986, 723, m.nt. MS, AB 1986, 573, m.nt. FHvdB (Heesch-Van de Akker). 
dentie. Zo stelt de Hoge Raad voorop dat de overheid in beginsel beschikt over haar krachtens het privaatrecht toekomende bevoegdheden. ${ }^{56}$ Dit uitgangspunt is door onder meer Bloembergen verdedigd met een beroep op de artikelen 2:1 en 2:5 BW. ${ }^{57}$ Artikel 2:1 luidt als volgt:

'1. De Staat, de provincies, de gemeenten, de waterschappen, alsmede alle lichamen waaraan krachtens de Grondwet verordenende bevoegdheid is verleend, bezitten rechtspersoonlijkheid.

2. Andere lichamen, waaraan een deel van de overheidstaak is opgedragen, bezitten slechts rechtspersoonlijkheid, indien dit uit het bij of krachtens de wet bepaalde volgt.

3. De volgende artikelen van deze titel, behalve artikel 5 , gelden niet voor de in de voorgaande leden bedoelde rechtspersonen'.

Artikel 2:5 bepaalt dat een rechtspersoon wat het vermogensrecht betreft, met een natuurlijk persoon gelijkstaat, tenzij uit de wet het tegendeel voortvloeit. Van belang is vooral artikel 2:1 lid 3, waaruit voor publiekrechtelijke rechtspersonen rechtsbevoegdheid voortvloeit, want door dit artikellid is artikel 2:5 als enige uit de titel Algemene bepalingen van toepassing. Hiermee is volgens Bloembergen de overheid 'als rechtssubject het privaatrecht binnengesluisd en is het overheidsprivaatrecht gegeven', waarbij dus ook aan de overheid vermogensrechten kunnen toekomen en waarbij de overheid ook privaatrechtelijke rechtshandelingen kan verrichten. ${ }^{58}$ Dat deze zienswijze niet onomstreden is, zal blijken in 5.3.2. ${ }^{59}$

De gemengde rechtsleer is ook doorgedrongen in de twee codificaties die hebben plaatsgevonden in het privaatrecht en het publiekrecht, het (nieuwe) BW en de Awb. In dat verband zijn van belang enerzijds de zogenaamde schakelbepalingen in het $\mathrm{BW},{ }^{60}$ die de export van privaatrecht naar publiekrechtelijke verhoudingen bevorderen, anderzijds artikel 3:1 lid 2 Awb en artikel 3:14 BW, dat respectievelijk de export dan wel de import van publiekrecht naar 'privaatrechtelijke' verhoudingen regelt. Verder kan worden gewezen op artikel 3:12 BW, dat bepaalt dat bij de vaststelling van wat redelijkheid en billijkheid eisen, rekening moet worden gehouden met algemeen erkende rechtsbeginselen, met de in Nederland levende rechtsovertuigingen en met de maatschappelijke en persoonlijke belangen.

In de schakelbepalingen wordt een aantal artikelen uit Boek $3 \mathrm{BW}$ buiten het vermogensrecht van overeenkomstige toepassing verklaard, 'voor zover de aard van de rechtshandeling of van de rechtsbetrekking zich daartegen niet verzet'. Lange tijd was onduidelijk of ook het bestuursrecht hierdoor werd bestreken. Uit de memorie van antwoord bij de Invoeringswet boeken 3, 5 en 6 van het Nieuwe Burgerlijk Wetboek (vierde gedeelte) blijkt echter duidelijk, dat deze bepalingen

\footnotetext{
56. Vgl. HR 26 januari 1990, NJ 1991, 393, m.nt. MS onder 394, AB 1990, 408, m.nt. G.P. Kleijn (Windmill).

57. Bloembergen (1992), blz. 953.

58. Bloembergen (1992), blz. 953.

59. Ik wijs haar in ieder geval af; zie hoofdstuk 11 .

60. De artikelen $3: 15,3: 59,3: 79$ en 3:326 BW.
} 
mede zien op het bestuursrecht. ${ }^{61}$ Wel dient de toepassing van de 'geschakelde' artikelen steeds te worden getoetst aan de vraag of 'de aard van de betrokken rechtsverhouding zich daartegen niet verzet'.

Verder kent het $\mathrm{BW}$ in artikel 3:14 een bepaling die buiten kijf stelt, dat ook wanneer de overheid privaatrechtelijk handelt, zij is gebonden aan regels van publiekrecht. Volgens artikel 3:14 mag 'een bevoegdheid die iemand krachtens het burgeriijk recht toekomt, (...) niet worden uitgeoefend in strijd met geschreven of ongeschreven regels van publiekrecht'. Dit artikel zou leiden tot het primaat van het publiekrecht. ${ }^{62}$ Het wordt (deels) gecomplementeerd door artikel 3:1 lid 2 Awb, dat bepaalt dat 'op andere handelingen van bestuursorganen dan besluiten de afdelingen 3.2 tot en met 3.5 van overeenkomstige toepassing (zijn), voor zover de aard van de handelingen zich daartegen niet verzet'. Volgens de wetgever dient het laatste artikel te worden beschouwd als een uitwerking van artikel 3:14 BW, voor zover zij elkaar overlappen. ${ }^{63}$ Dat beide artikelen elkaar niet geheel overlappen, blijkt uit het feit dat artikel 3:1 lid 2 Awb drie afdelingen, waarin een aantal algemene beginselen van behoorlijk bestuur is gecodificeerd, in beginsel van overeenkomstige toepassing verklaart op onder meer privaatrechtelijk handelingan van de sverheid Het gaat dus om geschreven beginselen. geschreven publiekrecht. Artikel 3:14 BW daarentegen betreft zowel geschreven als ongeschreven publiekrecht, dus ook de (nog) niet gecodificeerde algemene beginselen van behoorlijk bestuur. ${ }^{64} \mathrm{Nu}$ reeds op grond van artikel 3:14 BW het geschreven publiekrecht, dus ook de in artikel 3:1 lid 2 Awb genoemde afdelingen, bij de uitoefening van privaatrechtelijke bevoegdheden in acht dient te worden genomen, was artikel 3:1 lid 2 eigenlijk overbodig. Desalniettemin vond de wetgever het uit systematisch oogpunt noodzakelijk dit artikel in de algemene codificatie van het bestuursrecht op te nemen. ${ }^{65}$

\subsubsection{De doorkruisingsleer}

Ook onder de gemengde rechtsleer bleef de tweewegenleer haar gelding behouden. Stond slechts één weg open, ${ }^{66}$ de privaatrechtelijke, dan diende deze weg mede ingekleurd te worden door publiekrechtelijke beginselen. Stonden twee wegen open, dan was het uitgangspunt dat de overheid kon kiezen. Koos zij voor de privaatrechtelijke weg, dan werd deze weg mede ingekleurd door publiekrechtelijke beginselen. Dit kon ertoe leiden dat de privaatrechtelijke weg alsnog werd afgesneden, bijvoorbeeld omdat het gebruik van deze weg in strijd was met de wet, omdat er sprake was van détournement de pouvoir et cetera.

61. PG Inv. Boek 3 BW, blz. 1016.

62. Van der Veen (1997), blz. 360.

63. PG lnv. Boek 3 BW, blz. 1015. Zie ook Snijders (1988), blz. 50.

64. Ik. wil er overigens uitdrukkelijk op wijzen dat artikel 3:14 BW niet is beperkt tot toetsing aan de algemene beginselen van behoorlijk bestuur.

65. PG Awb 1, blz. 188.

66. Feitelijk was er in dat geval dus geen tweewegenprobleem. 
Aan het einde van de jaren tachtig en het begin van de jaren negentig werd de tweewegenleer 'vervangen' door de doorknuisingsleer. Indien een publiekrechtelijke weg openstond, was het niet meer zo evident dat de overheid desondanks de privaatrechtelijke weg mocht bewandelen. De Hoge Raad heeft in een aantal arresten de criteria ontwikkeld, aan de hand waarvan moet worden beoordeeld of de privaatrechtelijke weg openstaat. De doorkruisingsleer bekijkt dus - evenals de tweewegenleer - of het de overheid in een concreet geval vrij staat de privaatrechtelijke weg te kiezen in plaats van de publiekrechtelijke weg.

Het uitgangspunt van de doorkruisingsleer is door de Hoge Raad uiteengezet in het Windmill-arrest. ${ }^{67}$ Voorop wordt gesteld, dat de overheid beschikt over 'haar in beginsel krachtens het privaatrecht toekomende bevoegdheden'. De vraag is dan of de overheid gebruik mag maken van die privaatrechtelijke bevoegdheden ter behartiging van een belang, indien haar daartoe bij een publiekrechtelijke regeling publiekrechtelijke bevoegdheden zijn toegekend.

$\mathrm{Bij}$ de beantwoording van deze vraag moet eerst worden gekeken of de betrokken publiekrechtelijke regeling hier iets over zegt. Als deze regeling uitdrukkelijk exclusiviteit van de publiekrechtelijke weg voorschrijft, is het evident dat de privaatrechtelijke weg niet mag worden bewandeld. Overigens is het zo, dat ook de privaatrechtelijke weg exclusief kan worden voorgeschreven door de publiekrechtelijke regeling, zie bijvoorbeeld artikel 17 Onteigeningswet.

Wanneer de publiekrechtelijke regeling geen antwoord geeft op de vraag of de privaatrechtelijke weg mag worden bewandeld - en dat zal vrijwel altijd het geval zijn, nu het kennelijk gaat om de vraag of de publiekrechtelijke regeling expliciet voorziet in een antwoord op deze vraag; de inhoud en strekking van deze regeling, die mede uit de parlementaire geschiedenis kunnen blijken, spelen namelijk veelal pas een rol in de volgende fase -, zal moeten worden gekeken of het gebruik maken van de privaatrechtelijke bevoegdheden de publiekrechtelijke regeling op onaanvaardbare wijze doorkruist. Hiertoe geeft de Hoge Raad een arsenaal aan toetsingscriteria, die steeds moeten worden bekeken tegen de achtergrond van het geschreven en ongeschreven publiekrecht: inhoud en strekking van de publiekrechtelijke regeling, waarbij mede moet worden gelet op de parlementaire geschiedenis, en de rechtsbescherming die de publiekrechtelijke regeling de burger biedt - niet alleen de direct betrokkene, maar ook andere belanghebbenden. Ten slotte is van belang de vraag of de overheid door gebruik te maken van de publiekrechtelijke regeling een vergelijkbaar resultaat kan bereiken als door gebruikmaking van de privaatrechtelijke weg. Als dit zo is, is dat volgens de Hoge Raad een belangrijke aanwijzing dat de privaatrechtelijke weg is afgesneden.

De criteria, die de Hoge Raad in 'Windmill' heeft gegeven om te bepalen of gebruik mag worden gemaakt van de privaatrechtelijke weg, zijn flexibel gebleken; in latere arresten heeft de Hoge Raad ze aangepast aan de omstandigheden van het geval. Hierin zit een groot deel van de aantrekkelijkheid van de doorkrui- 
singsleer: het is een soepele leer. Afhankelijk van de feitelijke omstandigheden en de ingestelde vordering wordt de vraag, of sprake is van doorkruising van de publiekrechtelijke regeling, beantwoord, nadat uiteraard eerst is bekeken of die publiekrechtelijke regeling zelf al een uitdrukkelijk antwoord bevat op de vraag of de privaatrechtelijke weg mag worden gevolgd. De rechter kan rekening houden met het feit, dat de overheid zich beroept op haar eigendomsrecht, ${ }^{68}$ dat het verhaal van door de overheid gemaakte kosten betreft, ${ }^{69}$ dat het gaat om een onrechtmatigedaadsactie ${ }^{70}$ of dat het gaat om het niet-nakomen van voorwaarden die zijn verbonden aan een overeenkomst ${ }^{71}$ en in ieder van deze of andere gevallen de te hanteren criteria bijstellen.

Zoals gezegd stelt de Hoge Raad voorop de vraag of de wetgever heeft gesproken. Zegt de publiekrechtelijke regeling uitdrukkelijk iets over het gebruik van privaatrecht, dan is daarmee de kous af. Dit is zowel zo, wanneer de publiekrechtelijke regeling het gebruik van privaatrecht verbiedt, als wanneer deze regeling dat gebruik toestaat. In een aantal arresten heeft de Hoge Raad overwogen dat bij de vraag of de publiekrechtelijke regeling iets zegt de inhoud en strekking van de regeling, die mede kunnen blijken uit haar geschiedenis, niet aan de orde dienden te komen; deze factoren speelden immers pas een rol bij de doorkruisingsvraag. ${ }^{72}$ In Kunst- en Antiekstudio Lelystad werden de strekking en de geschiedenis van de regeling wel betrokken bij de vraag of de publiekrechtelijke regeling zelf iets zei over het gebruik van de privaatrechtelijke weg. Andere arresten laten ruimte voor beide interpretaties. ${ }^{73}$ Naar mijn mening zouden strekking en geschiedenis van de regeling aan de orde moeten komen bij de doorkruisingsvraag. Het is dan immers slechts één van de factoren die bepaalt of sprake is van onaanvaardbare doorkruising. Opvattingen over regelingen kunnen immers in de loop der tijd wijzigen, een factor waarmee de Hoge Raad tijdens de hoogtijdagen van de tweewegenleer rekening hield, ${ }^{74}$ terwijl het gevaarlijk is om

68. Zoals bijvoorbeeld in HR 26 januari 1990, NJ 1991, 393, m.nt. MS onder 394, AB 1990, 408, m.nt. G.P. Kleijn (Windmill) en HR 9 juli 1990, NJ 1991, 394, m.nt. MS, AB 1990, 547, m.nt. G.P. Kleijn (De Pina-Helmond).

69. Zoals bijvoorbeeld in HR 11 december 1992, NJ 1994, 639, m.nt. MS, AB 1993, 301, m.nt. G.A. van der Veen (Brandweerkosten), HR 14 oktober 1994, NJ 1995, 720, m.nt. MS, AB 1995, 48, m.nt. G.A. van der Veen (Wrakkenwet) en HR 15 januari 1999, NJ 1999, 306, m.nt. ARB, AB 2000, 196, m.nt. ThGD, JB 1999, 45, m.nt. ARN (De Eemshorn).

70. Zoals bijvoorbeeld in HR 22 oktober 1993, NJ 1995, 717, m.nt. MS, AB 1994, 1, m.nt. G.A. van der Veen (Staat-Magnus).

71. Zoals bijvoorbeeld in HR 8 juli 1991, NJ 1991,691, m.nt. MS, AB 1991, 659, m.nt. FHvdB (Kunst- en Antiekstudio Lelystad).

72. Zie bijvoorbeeld HR 26 januari 1990, NJ 1991, 393, m.nt. MS onder 394, AB 1990, 408, m.nt. G.P. Kleijn (Windmill) en HR 11 december 1992, NJ 1994, 639, m.nt. MS, AB 1993, 301, m.nt. G.A. van der Veen (Brandweerkosten).

73. Bijvoorbeeld HR 14 oktober 1994, NJ 1995, 720, m.nt. MS, AB 1995, 48, m.nt. G.A. van der Veen (Wrakkenwet) en HR 15 januari 1999, NJ 1999, 306, m.nt. ARB, AB 2000, 196, m.nt. ThGD, JB 1999, 45, m.nt. ARN (De Eemshom).

74. Zie bijvoorbeeld HR 19 januari 1968, NJ 1968, 166, m.nt. G.J.S., AB 1968, 585, m.nt. S (Eindhoven-Staals). 
uit het enkele stilzwijgen van de wetgever af te leiden dat deze instemt met bepaalde zaken. ${ }^{75}$ De doorkruisingsvraag biedt in dat geval nog een aantal andere toetsingscriteria, die tezamen een genuanceerder antwoord geven op de vraag of de privaatrechtelijke weg in het concrete geval openstaat.

De criteria zijn dus flexibel. Zo overwoog de Hoge Raad bijvoorbeeld in Windmill, dat het feit dat via de publiekrechtelijke weg een vergelijkbaar resultaat kan worden behaald als via de privaatrechtelijke weg, een belangrijke aanwijzing is dat deze laatste weg is afgesloten. In het Brandweerkostenarrest was juist een belangrijke factor het feit dat een bepaald resultaat (verhaal van kosten) niet via de publiekrechtelijke weg kon worden behaald; dit diende ertoe te leiden dat dat resultaat ook niet via privaatrechtelijke weg mogelijk diende te zijn.

De vraag of de tweewegenleer door de doorkruisingsleer is verdreven is niet eenduidig te beantwoorden. Naar aanleiding van onder meer het Windmill-arrest was een aantal schrijvers van oordeel dat de tweewegenleer was verlaten. ${ }^{76}$ Mijns inziens kan de doorkruisingsleer echter ook worden gezien als uitwerking van de tweewegenleer. Duidelijk is in ieder geval dat de overheid in beginsel privaatrechtelijk mag optreden, ook als er een publiekrechtelijke weg is. Tot zover kan men dus stellen dat de tweewegenleer overeind is gebleven. Daar staat echter tegenover dat de grote keuzevrijheid die de rechter de overheid gaf onder de 'traditionele' tweewegenleer, is ingeperkt. Was het oorspronkelijk zo dat de privaatrechtelijke weg mocht worden gevolgd, tenzij de publiekrechtelijke weg uitdrukkelijk als exclusief was bestempeld, tegenwoordig dient - als de publiekrechtelijke regeling niets zegt - ook te worden bekeken of het volgen van de privaatrechtelijke weg het publiekrecht niet doorkruist.

Hiermee is overigens niet gezegd dat de doorknuisingsleer de juiste benadering biedt van de vraag of de overheid gebruik mag maken van het privaatrecht. Dit is namelijk niet zo. Het uitgangspunt van de Hoge Raad dat de overheid in beginsel beschikt over haar krachtens het privaatrecht toekomende bevoegdheden kan worden betwist. ${ }^{77}$ Maar zelfs als men dit uitgangspunt wel aanvaardt, hanteert de doorknuisingsleer verkeerde uitgangspunten. Ik zal hierop ingaan in 11.5.

\subsection{Uitgangspunt: de overheid mag geen gebruik maken van het privaatrecht}

De hiervoor beschreven stromingen hebben alle als uitgangspunt dat het privaatrecht in beginsel ook van toepassing is op de overheid. Dit betekent dat de overheid in beginsel gebruik mag maken van dit privaatrecht. Hieraan werden welis-

75. Dit deed de Hoge Raad bijvoorbeeld in Kunst- en Antiekstudio Lelystad, HR 8 juli 1991, NJ 1991, 691, m.nt. MS, AB 1991, 659, m.nt. FHvdB.

76. Bijvoorbeeld Tak (1990), blz. 265-266 en Drupsteen (1990). Scheltema ziet in deze arresten de bevestiging van zijn opvatting dat de gemene rechtsleer reeds was verlaten, zie zijn noot onder HR 9 juli 1990, NJ 1991, 394 (De Pina-Helmond), blz. 1675.

77. Zie hierover $5.3 .2 \mathrm{en}$ (wat mijn eigen opvatting betreft) 11.4. 
waar in de loop der tijd grenzen gesteld, het uitgangspunt blijft intact. Dit uitgangspunt is echter ook verworpen door een aantal auteurs, vooral in de negentiende en aan het einde van de twintigste eeuw. Gedurende een groot deel van de twintigste eeuw was de heersende en vrijwel onbestreden opvatting dat het privaatrecht het 'gemene recht' was. In deze paragraaf zal ik de 'andere' stroming beschrijven. Evenals in $5.2 \mathrm{zal}$ ik hierbij ook beschrijven in hoeverre deze stromingen, en dan met name de zogenaamde invullende rechtsleer, ingang hebben gevonden in de rechtspraktijk; in de jurisprudentie en in de wetgeving dus.

\subsection{De negentiende eeuw: Thorbecke en Loeff}

De eerste die, in het midden van de negentiende eeuw, in Nederland een principieel onderscheid maakte tussen publiek- en privaatrecht was Thorbecke. Weliswaar was er een aantal auteurs dat reeds aan het begin van de negentiende eeuw een onderscheid maakte tussen deze twee gebieden, maar dat onderscheid was bij hen slechts bedoeld om de competentie van de burgerlijke rechter af te bakenen. Van een principieel onderscheid kon niet worden gesproken. ${ }^{78}$ Thorbecke was aanhanger van het constitutionalisme, ${ }^{79}$ een stroming die de Grondwet als hoogste wet in de staat zag, waarbij alle overheidsbevoegdheden dienden te kunnen worden herleid tot de Grondwet. Dit bracht in zijn visie met zich, dat de publiekrechtelijke bevoegdheden slechts bij de staat konden berusten. Deze opvatting leidde tot een scheiding tussen publiek- en privaatrecht. Het onderscheidend criterium was het onderscheid tussen algemeen en bijzonder belang. ${ }^{80}$ Aangezien het algemeen belang voor Thorbecke principieel verschilde van het bijzonder belang, was ook het onderscheid tussen publiek- en privaatrecht voor hem principieel. Volgens Thorbecke was niet uitgesloten dat overheidslichamen privaatrechtelijk optraden, maar wanneer het algemeen belang in het geding was, dan kon het overheidslichaam slechts publiekrechtelijk optreden, en diende dit optreden naar de regels van publiekrecht te worden beoordeeld; voorkomen moest worden 'dat het algemeen belang (...) wordt behartigd met behulp van bevoegdheden die gelegenheid scheppen om een bijzonder belang (...) te dienen' ${ }^{81}$ Er is dan ook een scherpe scheiding tussen publiek- en privaatrecht.

Thorbecke heeft zijn ideeên over het onderscheid tussen publiek- en privaatrecht nooit samengebracht in één, speciaal hieraan gewijd, geschrift; zij zijn verspreid over zijn gehele werk en vele antekeningen, notities en collegedictaten te vinden. De eerste die een zelfstandig werk wijdde aan dit onderscheid, waarin hij het principiële karakter van het onderscheid verdedigde, was Loeff in zijn dissertatie Pu-

78. Poortinga (1987), blz. 87-91.

79. Althans seden ongeveer 1840, zie Poortinga (1987), blz. 69-71.

80. Poortinga (1987), blz. 112.

81. Poortinga (1987), blz, 118. 
bliekrecht tegenover privaatrecht, ${ }^{82}$ waarmee hij in 1887 promoveerde bij Buys.

Uitgangspunt bij Loeff was de staatssoevereiniteit. De staat is almachtig, hij kan doen wat hem goeddunkt. Zijn wil is altijd recht, niet in de zin van aequitas (billijkheid) of justitia (rechtvaardigheid), die boven de staat staan, maar in de zin van jus. Hij zal altijd dat willen, wat in zijn belang is; hieruit bestaat dus het recht. ${ }^{83}$ Maar de staat zelf kan niet handelen, dit moet hij doen door middel van feilbare - natuurlijke en onnatuurlijke - personen, de administratie. Om er voor te zorgen dat de administratie ook daadwerkelijk de staatswil uitoefent, kan de staat regels stellen, de zogenaamde publiekrechtelijke wetten. Deze wetten creëren dus een verplichting voor de administratie; voor de staat scheppen zij een recht op naleving van die regels.

In de opvatting van Loeff is zowel het publiekrecht als het privaatrecht afkomstig van de staat. ${ }^{84}$ Het eerste regelt de verhouding tussen de staat en de staatsonderdaan; het tweede de verhoudingen tussen staatsonderdanen onderling. ${ }^{85}$ De vraag is of een staatsonderdaan subject kan zijn van publiekrecht en de staat subject van privaatrecht. Het antwoord op beide vragen luidt ontkennend. ${ }^{86}$ Loeff koppelt het zijn van subject aan het hebben van subjectieve rechten. Als een staatsonderdaan subject zou kunnen zijn van publiekrecht, zou dit betekenen dat hij subjectieve rechten zou hebben op publiekrechtelijk gebied, dus tegenover de staat. Hier tegenover zouden dan logischerwijs subjectieve rechtsplichten van de staat ten opzichte van de staatsonderdaan moeten staan. $^{87}$ Uitgaande van de staatssoevereiniteit is dit ondenkbaar. Het publiekrecht schept slechts plichten voor de staatsonderdaan en voor de administratie ten opzichte van de staat; het kan geen rechten scheppen voor de staatsonderdaan. Volgens Loeff kan de staat ook geen subject van privaatrecht zijn, de aard van de staat laat dat niet toe. Zou dit wel kunnen, dan zou hij ondergeschikt worden aan datgene, wat hij zelf heeft geschapen. Hij zou als persoon van hogere orde op een lijn komen te staan met de staatsonderdanen, waardoor hij zijn karakter als heerser verliest; de heerser zou tevens beheerste worden. Ook dit is ondenkbaar voor Loeff. Dit betekent niet dat de staat geen enkele vermogensrechtelijke handeling kan verrichten, alleen moet men deze handelingen niet beschouwen als privaatrechtelijk. De (burgerlijke) rechter kan hier dan ook niet over oordelen. ${ }^{88}$

82. Poortinga (1987), blz. 20-21.

83. Dit jus kan dus zelfs in strijd zijn met de aequitas: '(W)at de Staat wil (kan) zeer goed contra aequitatem (..) zijn, maar niet contra jus. Want juist doordat hij het wil is het jus, hoezeer het ook met de aequitas moge strijden', Loeff (1887), blz. 32, noot 1 .

84. Loeff (1887), blz. 32.

85. Loeff (1887), blz. 33.

86. Loeff (1887), blz. 50 .

87. Loeff (1887), blz. 50-51.

88. Loeff (1887), blz. 53-54. Overigens zag Loeff zelf dat zijn theorie niet in overeenstemming was met de praktijk van dat moment; voor hem was dit ook geen probleem: zijn opvattingen hadden 'louter het $o \circ g$ in abstracto op de natuur van Staat en staatsonderdanen, en maken geen oogenblik aanspraak op praktische waarde', Loeff (1887), blz. 50. Desondanks heeft hij geprobeerd zijn theorie ingang te doen vinden via de Ontwerpen-Loeff, zie 3.3. Administratieve rechtspraak 


\subsubsection{De invullende rechtsleer}

De opvatting van Loeff werd sterk bestreden, onder meer door Hamaker. ${ }^{89}$ Diens gemene rechtsleer werd vervolgens de heersende leer. Het uitgangspunt dat het privaatrecht ook van toepassing was op de overheid, ondervond als zodanig gedurende het grootste deel van de twintigste eeuw geen bestrijding. Wel werden beperkingen aangebracht op dit gebruik. Maar aan het eind van deze eeuw werd ook het uitgangspunt onder vuur genomen, en wel door een aantal mensen van de Universiteit Maastricht, hetgeen uiteindelijk heeft geleid tot de benaming 'de Maastrichtse school'. Vooral in de geschriften van Tak, Simon en Teunissen valt principiële kritiek te beluisteren op de gemene en gemengde rechtsleer en de praktische uitwerking daarvan in de tweewegen- en doorkruisingsleer. Als alternatief voor die opvattingen stelde Tak in 1993 de zogenaamde invullende rechtsleer voor. ${ }^{90}$

Het voornaamste kritiekpunt is de omstandigheid dat de heersende leren uitgaan van de opvatting dat ook de overheid in beginsel privaatrechtelijke bevoegdheden heeft. Dit uitgangspunt zou ook zijn neergelegd in de artikelen 2:1 en 2:5 BW..$^{91}$ Dit nu wordt bestreden; het BW verleent geen bevoegdheden, maar reguleert slechts (de uitoefening van) bestaande bevoegdheden. ${ }^{92}$ Bij natuurlijke personen wordt deze bevoegdheid voorondersteld; de bekwaamheid van de burger is uitgangspunt. ${ }^{93}$ Pas als de bevoegdheid problematisch wordt, treden bevoegdheidsvragen op. Voor privaatrechtelijke rechtspersonen geldt hetzelfde, zie artikel 2:5 BW: 'Een rechtspersoon staat wat het vermogensrecht betreft, met een natuurlijk persoon gelijk, tenzij uit de wet het tegendeel voortvloeit'.

Dit uitgangspunt kan echter niet worden volgehouden waar het publiekrechtelijke rechtspersonen betreft; binnen het publiekrecht bestaan bevoegdheden slechts voor zover deze uitdrukkelijk zijn verleend, althans er dient een 'positieve indicatie' te zijn voor een dergelijke bevoegdheid.94 Uitgangspunt is 'de onbekwaamheid van de overheid". ${ }^{95}$ Er dient steeds een titel te kunnen worden aangewezen, die een publiekrechtelijke bevoegdheid vestigt (legaliteitsbeginsel of vereiste van wetmatigheid van bestuur), terwijl de uitoefening van die bevoegdheid steeds dient te geschieden met inachtneming van het doel waarvoor zij is verleend (specialiteitsvereiste). ${ }^{96}$ Het uitgangspunt van de doorkruisingsleer, dat

was yoor hem dan ook niet zozeer bedoeld om de burger rechtsbescherming te bieden tegen de overheid, maar ter controle van de administratie: voerde deze de staatswil wel uit?

89. Zie 5.2.1.

90. Tak (1993).

91. Zie 5.2.4.

92. Zie Tak (1993), blz. 178, Simon (1993), blz. 190, Teunissen/Tak (1994), blz. 609, Simon/Tak (1994), blz. 178 Teunissen (1996), blz. 22 ! en Tak (1997), blz. 105 en 107.

93. Simon/Tak (1994), blz. 178. Dit blijkt volgens hen bijvoorbeeld uit artikel 3:32 lid $1 \mathrm{BW}$.

94. Tak (1993), blz. 178 .

95. Simon/Tak (1994), blz. 178.

96. Teunissen/Tak (1994), blz. 609. 
de overheid in beginsel beschikt over privaatrechtelijke bevoegdheden, is dan ook fout; het BW kan niet functioneren als 'bevoegdheidverschaffende grondslag voor handelen van de overheid dat ingrijpt in rechten en belangen van burgers'.?7

Betekent dit nu dat het BW in deze visie nooit een rol kan spelen in een verhouding waarbij de overheid is betrokken? Het moge duidelijk zijn dat in dat geval het $\mathrm{BW}$ nooit kan worden gebruikt als bevoegdheidsgrondslag. Wel kan er nog plaats zijn voor een rol voor het $\mathrm{BW}$ als er een publiekrechtelijke grondslag is voor het overheidsoptreden. Kent in dat geval narnelijk het (geschreven) publiekrecht een leemte, dan dient deze te worden opgevuld met ongeschreven publiekrecht. Dit ongeschreven publiekrecht kan mede worden gevonden in algemene rechtsbeginselen; beginselen die publiek- en privaatrecht gemeen hebben. Veel van deze beginselen zijn gecodificeerd in het BW, zoals de beginselen die ten grondslag liggen aan de schadevergoedingsplicht bij onrechtmatige daad, zaakwaarneming en ongerechtvaardigde verrijking, het beginsel dat ten grondslag ligt aan de vordering uit onverschuldigde betaling en het beginsel van gebondenheid aan het gegeven woord. In dat geval kan de in het BW vervatte regeling bruikbaar zijn 'als invullingsvorm van publiekrechtelijke bevoegdheden', zij het onder strenge condities. ${ }^{98}$ De regels uit het $\mathrm{BW}$ kunnen dan in het geschreven en ongeschreven publiekrecht bestaande leemtes invullen. Zij kunnen dit publiekrecht dus nooit vervangen. Volgens Tak is er in dat geval dan ook geen sprake van toepassing van een privaatrechtelijke regel, maar van een publiekrechtelijke regel. ${ }^{99}$ Voorop staat dus de absolute voorrang van het publiekrecht: is er een geschreven publiekrechtelijke regel, dan moet deze worden toegepast. Ontbreekt een dergelijke geschreven regel, dan dient toepassing te worden gegeven aan het ongeschreven publiekrechtelijk normenstelsel. Pas als in dat geval zich nog, steeds een leemte voordoet, kan invulling worden gegeven aan de overheidsbevoegdheid met gebruikmaking van de vormen van het $\mathrm{BW}$, waarbij deze $\mathrm{BW}$-vorm volledig onderworpen dient te zijn aan publiekrechtelijke beginselen. Hierbij kan de jurisprudentie, gewezen in geschillen tussen private rechtssubjecten geen rol spelen. Ten slotte is het laten toepassen en toetsen van die bepalingen door publiekrechtelijk geschoolde en geörienteerde rechters een vereiste. ${ }^{100}$

Elementen van deze leer zijn reeds terug te vinden in oudere literatuur. De invullende rechtsleer vertoont bijvoorbeeld overienkomsten met (delen van) de theorie van Praag. Zo zag Van Praag ruimte om regels uit het BW analoog toe te passen, indien het publiekrecht een leente bevatte, terwijl hij ook al onderkende, dat in het BW algemene rechtsbeginselen waren gecodificeerd, die ook kunnen worden toegepast in publiekrechtelijke verhoudingen. Tevens stelde hij dat uit 'het gemeen zijn der rechtsfiguur' niet zonder meer volgde, dat de wetsartikelen dan

97. Simon/Tak (1994), blz. 179 en Tak (1997), blz. 113.

98. Tak (1993), blz. 185.

99. Tak (1997), blz. 116.

100. Tak (1997), blz. 117. 
ook golden op beide terreinen (publiek- en privaatrecht). ${ }^{101}$ Het uitgangspunt van Praag dat onderscheid dient te worden gemaakt tussen de overheid 'als zodanig' en de overheid, optredende 'als een partikulier', wordt echter verworpen door de 'Maastrichtse school'; het veronderstelt immers dat de overheid ook privaatrechtelijk kan optreden. Maar de overheid kan volgens de 'Maastrichtse school' niet op voet van gelijkheid optreden ten opzichte van een particulier, omdat zij altijd en slechts in het algemeen belang dient te handelen. ${ }^{102}$

\subsubsection{De invullende rechrsleer in de jurisprudentie}

Heeft de invullende rechtsleer toepassing gevonden in de jurisprudentie? Elemen-ten, die later voorkomen in deze leer, komen we reeds tegen in 1952 . In dat jaar erkende de Centrale Raad van Beroep 'de bepaling, dat hetgeen zonder verschuldigd te zijn betaald is, kan worden teruggevorderd, in art. 1395 B.W. vastgelegd voor het burgerlijk recht, (...) als een algemeen rechtsbeginsel, van toepassing ook in het administratieve recht'. ${ }^{103}$ Deze uitspraak zal in 7.2.3.3 uitgebreid aan de orde komen, vandaar dat ik er hier kort over ben. Het betrof de vraag of ten onrechte - in dit geval te veel - betaalde bezoldiging kon worden teruggevorderd, ondanks het feit dat de Ambtenarenwet 1929 hiervoor geen wettelijke grondslag kende. Dit kon, aangezien genoemd algemeen rechtsbeginsel bestond.

De Centrale Raad van Beroep als ambtenarenrechter had al vrij vroeg de mogelijkheid om te oordelen over terugvorderingsbesluiten. De rechtsmacht van deze rechter werd namelijk afgebakend door de vraag, of sprake was van een besluit, handeling of weigering (om te besluiten of te handelen) ten aanzien van een ambtenaar als zodanig. ${ }^{104}$ Eenzelfde soort afbakening kende het College van Beroep voor het bedrijfsleven, althans waar het oordeelde op grond van zijn algemene rechtsmacht. ${ }^{105}$

De meeste andere administratieve rechters waren en zijn slechts bevoegd te oordelen over publiekrechtelijke rechtshandelingen. ${ }^{106}$ Tot voor kort was het zo, dat beslissingen van bestuursorganen, waarvoor geen uitdrukkelijke, geschreven publiekrechtelijke grondslag was, door deze rechters werden aangemerkt als rechtshandelingen naar burgerlijk recht, als privaatrechtelijke rechtshandelingen

101. Van Praag (1923), blz. 38-39. Zie hierover 5.2.1.

102. Tak (1993), blz. 180-181.

103. Crvb 30 december 1952, AB 1953, 477 (Schouten-Zonnemaire).

104. Artikel 3 Aw 1929, zie 3.5 en 7.2.3.2.

105. Artikel 4 lid 2 Wet arbo, zie 3.5 en 8.4.3. Weliswaar sloot dit artikel uitdrukkelijk rechtshandelingen naar burgerlijk recht uit van beroep bij het CBB, maar wanneer het publiekrechtelijk lichaam handelde binnen het kader van de uitoefening van zijn publiekrechtelijke taak, dan nam het CBE niet snel een dergelijke rechtshandeling aan, zie 8.4.3.

106. De term 'publiekrechtelijke rechtshandeling' is pas met zoveel woorden in de Awb geĭntroduceerd; de criteria in onder andere de Wet bab en de Wet arob kwamen feitelijk op hetzelfde neer, zie 4.2 . 
dus; dit konden derhalve geen publiekrechtelijke rechtshandelingen zijn. ${ }^{107}$ Dit was bijvoorbeeld het geval wanneer een bestuursorgaan een terugvorderingsbeslissing nam, wanneer het een beslissing nam naar aanleiding van een verzoek om schadevergoeding dan wel om nadeelcompensatic, waar het betaling van een geldsom betrof et cetera, waarvoor geen uitdrukkelijke grondslag was te vinden in een publiekrechtelijke regeling. Consequentie was dat de administratieve rechter de burger veelal niet-ontvankelijk verklaarde en dat de burgerlijke rechter bevoegd was. Zoals we hebben gezien paste de burgerlijke rechter in die gevallen vrijwel altijd burgerlijk recht toe, waarbij dit recht wel publiekrechtelijk werd ingekleurd.

Vanaf 1994 begonnen de administratieve rechters echter steeds valker beslissingen met betrekking tot deze voorheen als privaatrechtelijk aangemerkte rechtshandelingen te kwalificeren als publiekrechtelijk. ${ }^{108}$ De Afdeling bestuursrechtspraak deed dit wat betreft de terugvordering van onverschuldigd betaalde subsidie in 1996. Oordeelde zij een jaar eerder nog dat besluiten omtrent terugvordering die geen uitdrukkelijke wettelijke grondslag hadden, geen besluiten in de zin van artikel 1:3 Awb waren, maar privaatrechtelijke rechtshandelingen, ${ }_{, 09}$ in haar uitspraak van 21 oktober 1996 gaat zij orn. ${ }^{110}$

'De Afdeling ziet zich (...) geplaatst voor de vraag naar het rechtskarakter (...) van besluiten van bestuursorganen tot terugvordering van eerder door hen in het. kader van de uitoefening van hun bestuursrechtelijke taken en bevoegdheden gedane toekenningen.

De Afdeling oordeclt dienaangaande thans, anders dan zij in het verleden heeft gedaan, dat terugvorderingsbesluiten van bestuursorganen als in de vorige alinea omschreven, ook indien deze niet op uitdrukkelijk daartoe strekkende wettelijke bevoegdheden zijn gebaseerd, zijn gericht op rechtsgevolg. Dit rechtsgevolg wordt ontleend aan het algemene, ook in het bestuursrecht geldende, rechtsbeginsel volgens hetwelk hetgeen onverschuldigd is betaald, kan worden teruggevorderd.

Dit rechtsbeginsel is van bestuursrechtelijke aard, wanneer zijn werking zich doet gevoelen in door het bestuursrecht beheerste verhoudingen. Voor bestuursorganen schept het dan een bevoegdheid omtrent de aanwending waarvan per geval beslist moet worden met inachtneming van de algemene bestuursrechtelijke normen die de aanwending van discretionaire bevoegdheden beheersen. Zo een beslissing, die strekt tot voldoening aan de bestuursrechtelijke voorwaarden voor een rechtmatige terugyordering, opdat naar het bestuursrecht een betalingsverplichting ontstaat, is gericht op publiekrechtelijk rechtsgevolg'.

In deze uitspraak kan de invullende rechtsleer worden gelezen. De leemte in het publiekrecht, waar het de terugvordering betreft, leidt er namelijk niet toe dat het privaatrecht van toepassing is, zoals voorheen werd aangenomen, maar zij wordt kennelijk ingevuld door ongeschreven publiekrecht. Dit ongeschreven publiekrecht

107. Hierop bestonden uitzonderingen. Zo werd in een aantal gevallen ook een publiekrechtelijke grondslag gevonden in een publieke taak. Zie hierover 4.2.2.

108. Deze 'revolutie der rechters' (Verheij (1999), blz. 22) begon met een uitspraak van de Crvb als socialezekerheidsrechter met betrekking tot een zuiver schadebesluit, CRvB 28 juli 1994, AB. 1995, 133, m.nt. RMvM, JB 1994, 221, m.nt. ELB/ABJH, zie hierover 4.2.3.

109. Bijvoorbeeld ABRvS 2 november 1995, JB 1995, 333, m.nt. F.A.M. S.

110. ABRvS 21 oktober 1996, AB 1996, 496, m.nt. NV, JB 1996, 232, m.nt. HJS (Nanne). Zie over deze uitspraak uitgebreid $4.2 .3,8.2 .6$ en hoofdstuk 9 . 
wordt in casu gevonden in het algemene rechtsbeginsel dat hetgeen onverschuldigd is betaald, kan worden teruggevorderd. De Afdeling moet vervolgens nog bepalen wanneer dit rechtsbeginsel publiekrechtelijk is; dit is zo wanneer 'zijn werking zich doet gevoelen in door het bestuursrecht beheerste verhoudingen'. Er is in dat geval sprake van materiële connexiteit. ${ }^{111}$

Vervolgens ging de Afdeling ook om met betrekking tot het zuiver schadebesluit, zie onder meer de uitspraken inzake Alpha Kledingreinigingsbedrijf en Van Vlodrop. ${ }^{112}$ Naast het algemene rechtsbeginsel, volgens hetwelk hetgeen onverschuldigd is betaald, kan worden teruggevorderd en het algemene rechtsbeginsel, volgens hetwelk degene die door aan hem toerekenbaar onrechtmatig handelen of nalaten schade heeft veroorzaakt, is gehouden die aan de benadeelde te vergoeden, heeft de Afdeling inmiddels ook het algemene rechtsbeginsel dat hij die ongerechtvaardigd is verrijkt ten koste van een ander, verplicht is, voor zover dit redelijk is, diens schade te vergoeden tot het bedrag van zijn verrijking, erkend als ook in het bestuursrecht geldend rechtsbeginsel. ${ }^{11,114}$

Ook andere bestuursrechters gingen vervolgens soortgelijke constructies hanteren. Zij erkennen tegenwoordig alle dat een zuiver schadebesluit een besluit in de zin van artikel 1:3 Awb kan zijn. ${ }^{115}$ Hierbij wordt overigens alleen door de Afdeling de bevoegdheid van het bestuur uitdrukkelijk ontleend aan een algemeen rechtsbeginsel. Slechts in het kader van de terugvordering van onverschuldigd betaalde studiefinanciering overwoog het College van beroep studiefinanciering dat van het publiekrecht ook deel uitmaakt 'het in het algemeen rechtsbewustzijn levend beginsel dat hetgeen onverschuldigd is betaald dient te worden terugbetaald. ${ }^{116}$

111. Het enkele feit dat sprake is van een besluit in de zin van artikel 1:3 Awb wil nog niet zeggen. dat de bestuursrechter ook bevoegd is kennis te nemen van beroepen tegen dit besluit. Hiervoor stelt de Afdeling (en de overige bestuursrechters) nog het vereiste van processuele connexiteit, zie 4.2.3. Overigens zal de situatic dat wel sprake is van materiele, maar niet van processuele connexiteit zich niet snel voordoen bij terugvordering, zo ook Verheij (1999), blz. 34, noot 77.

112. ABRvS 29 november 1996, AB 1997, 66, m.nt. PvB, JB 1996, 253, m.nt. red. (Alpha Kledingreinigingsbedriif) en ABRvS 6 mei 1997, A.B 1997, 229, m.nt. PvB, JB 1997, 118, m.nt. HJS (Van Vlodrop). Zie 4.2.3.

113. ABRvS 26 augustus 1997, AB 1997, 461, m.nt. NV, JB 1997, 265, m.nt. HJS (Samenwerkingsverband Noord-Kennemeriand).

114. Daarnaast erkende de ABRvS in de uitspraak inzake Van Vlodrop, ABRvS 6 mei 1997, AB 1997, 229, m.nt. PvB, JB 1997, 118, m.nt. HJS, ook het rechtsbeginsel van 'égalité devant les charges publiques' oftewel de gelijkheid voor openbare lasten. 'Op grond van dit beginsel zijn bestuursorganen gehouden tot compensatie van onevenredige - buiten het normale maatschappelijke risico vallende en op een beperkte groep burgers of instellingen drukkende - schade die is ontstaan in een door de uitoefening van een aan het publiekrecht ontleende bevoegdheid ontstane rechtsverhouding', aldus de ABRvS. Dit beginsel is per definitie publiekrechtelijk en kent dus geen privaatrechtelijk equivalent. De ABRvS spreekt dan ook niet van een algemeen rechtsbeginsel, maar van een rechtsbeginsel, zie Teunissen (2001), blz. 90. Nu dit beginsel per definitie publiekrechtelijk van aard is, ga ik er niet verder op in.

115. Zie bijvoorbeeld CBB 19 februari 1997, AB 1997, 144, m.nt. JHvdV, JB 1997, 92, m.nt. HJS en Cbsf 23 mei 1996, JB 1996, 177, m.nt. red.

116. Cbsf 9 april 1997, JB 1997, 105, m.nt. HJS. In 8.3 .2 zal ik verder op deze uitspraak ingaan. 
Het antwoord op de aan het begin van deze paragraaf gestelde vraag - heeft de invullende rechtsleer in de jurisprudentie toepassing gevonden? - moet op grond van de hiervoor besproken uitspraken volgens een aantal auteurs, waaronder Van Ommeren, Van der Meulen en Verheij, positief worden beantwoord, althans zij vinden dat de jurisprudentie van vooral de Afdeling bestuursrechtspraak - om met Verheij te spreken - 'verdacht veel op een toepassing van Taks invullende rechtsleer' lijkt. ${ }^{117}$ Teunissen ziet in deze jurisprudentie het ontstaan van een nieuwe 'gemene rechtsleer', waarbij het gaat om aan het bestuursrecht en burgerlijk recht gemeen(schappelijk) recht. ${ }^{118}$ Damen spreekt in dit verband van de 'echte gemene rechtsleer'. ${ }^{119}$

Ook naar mijn mening kan deze jurisprudentie (deels) worden gezien als een toepassing van de invullende rechtsleer. ${ }^{120} \mathrm{Nu}$ een leemte bestaat in het geschreven bestuursrecht, wordit deze opgevuld met ongeschreven bestursrecht, dat in casu wordt gevonden in een algemeen rechtsbeginsel. Deze ontwikkeling zal er toe leiden dat als de bestuursrechter competent is en oordeelt over een geschil, hij niet licht privaatrecht zal toepassen. Weliswaar zal hij in een aantal gevallen teruggrijpen op bepalingen van het $\mathrm{BW}$, zoals dat bijvoorbeeld nu reeds gebeurt met betrekking tot de berekening van de te betalen schadevergoeding; hij zal dit slechts doen als die BW-bepalingen niet puur privaatrechtelijk zijn, maar meer een neerslag zijn van 'algemene regels', zoals de regels met betrekking tot schadevergoeding. Ook dit stemt overeen met de invullende rechtsleer.

Voor het antwoord op de vraag of de overheid gebruik kan maken van het privaatrecht is echter vooral de houding van de burgerlijke rechter van belang. Deze was het immers die in het verleden de gemene en de gemengde rechtsleer toepaste en door middel van de tweewegen- en de doorkruisingsleer het gebruik van privaatrecht door de overheid afbakende. Met betrekking tot de houding van deze rechter doen zich dan twee vragen voor. De eerste vraag is hoe hij zal reageren op de door de bestuursrechter ingeslagen weg. Leidde het feit dat de burger een zelfstandig schadebesluit kon uitlokken ertoe dat de weg naar de bestuursrechter exclusief werd, of mocht de burger kiezen voor een actie uit onrechtmatige daad voor de burgerlijke rechter? De tweede vraag is of in de jurisprudentie van de burgeriijke rechter reeds toepassing van de invullende rechtsleer kan worden ontdekt.

Wat de eerste vraag betreft, het antwoord hierop is inmiddels deels duidelijk. In het arrest Groningen-Raatgever heeft de Hoge Raad beslist dat de bevoegdheid van de bestuursrechter niet exclusief is, zodat de burger mag kiezen welke weg hij

117. Zie Van Ommeren (1998), blz. 121, Van der Meulen (1998), blz. 165, Verheij (1999), blz. 60.

118. Teunissen (1997), blz. 88.

119. Damen (1999-II), blz. 57. Damen wijst echter de door de administratieve rechter gehanteerde. constructie af: ongeschreven algemene rechtsbeginselen kunnen volgens hem geen discretionaire bestuursrechtelijke bevoegdheden scheppen. Zie hierover 9.3.2.

120. Deels, want volgens Tak kan eeh algemeen rechtsbeginsel nimmer enige overheidsbevoegdheid. verschaffen, Tak. (1997), blz. 48-49. Het beginsel kan dus niet bevoegdheidscheppend zijn. 
wil volgen. Hij verwijst hiertoe onder andere naar de toelichting op artikel 8:73 Awb, waar een dergelijke keuze uitdrukkelijk is toegestaan. ${ }^{121}$ De burger is dus niet verplicht een zuiver schadebesluit uit te lokken, waartegen hij vervolgens in voorkomend geval bezwaar en beroep kan instellen. Zoals gezegd zal ik in 9.6.1 nader ingaan op dit arrest. Het arrest betreft een vordering tot schadevergoeding; hiermee is dus nog niet gezegd dat de Hoge Raad met betrekking tot terugvordering eenzelfde koers zal varen.

Een andere vraag is, of in de jurisprudentie van de burgerlijke rechter ook iets is terug te vinden van de invullende rechtsleer. Ik heb de algemene houding van de burgerlijke rechter ten opzichte van het gebruik van privaatrecht door de overheid al beschreven: gebruikmaking van privaatrechtelijke bevoegdheden en vorderingen is mogelijk, zolang geen sprake is van doorkruising van het publiekrecht. Daarnaast is het zo dat de overheid ook gebruik kan maken van regels die zijn neergelegd in het BW. Wat de artikelen in een aantal titels uit boek 3 betreft, is dit reeds uitdrukkelijk vastgelegd in de zogenaamde schakelbepalingen, die steeds deze titels afsluiten: deze artikelen vinden ook buiten het vermogensrecht toepassing, voor zover de aard van de rechtshandeling of de rechtsbetrekking zich daartegen niet verzet. ${ }^{122}$ Maar dit wil niet zeggen dat artikelen uit andere titels of uit andere boeken niet ook van toepassing (kunnen) zijn op publiekrechtelijke rechtsbetrekkingen, althans volgens de burgerlijke rechter. Dit vloeit uiteraard voort uit de gemene rechtsleer. Zo heeft hij herhaaldelijk de regels uit het BW met betrekking tot de vordering uit onverschuldigde betaling rechtstreeks toegepast op publiekrechtelijke verhoudingen. ${ }^{123}$ Hetzelfde gebeurde met de regeling betreffende verrekening. ${ }^{124}$ In deze gevallen past de rechter de BW-bepalingen rechtstreeks toe. Een uitzondering hierop maakte de Hoge Raad in het arrest Cornelissen-Groningen van 25 oktober $1991 .{ }^{125}$ Daarin overwoog hij met betrekking tot een terugvordering van publiekrechtelijke aard - het betrof terugvordering van te veel betaalde bijstand -:

"Ingevolge art. 1395 BW - en ook ingevolge art. 6:203 NBW - is segene die zonder rechtsgrond heeft betaald, gerechtigd tot terugvordering. Deze voorschriften geven uiturukking aan een beginsel dat voor het gehele recht geldt. Dit brengt mee dat zij ook toegepast dienen te worden op betalingen van publiekrechtelijke aard, voor zover uit de wet niet he! tegendeel voortvloeit'.

Artikel $1395 \mathrm{BW}$ (oud) - en artikel 6:203 BW - kan dus slechts worden toegepast op betalingen van publiekrechtelijke aard, omdat die voorschriften uitdrukking geven aan een beginsel dat geldt voor het gehele recht. Er is in dit arrest dan ook geen sprake van toepassing van de gemene rechtsleer in de klassieke zin, waarbij

12i. PG Awb II, blz, 474.

122. Zie hierover 5.2 .4 .

123. Bijvoorbeeld HR 10 augustus 1992, NJ 1993, 636, m.nt. MS, AB 1993, 12 (M.-Roosendaal en Nispen).

124. HR 28 mei 1993, NJ 1994, 435, m.nt. HJS (Nieuwkoop-Staat).

125. HR 25 oktober 1991, NJ 1992, 299, m.nt. JBMV, AB 1992, 88, m.nt. FHvdB. 
het privaatrecht geldt als het algemene recht. De opmerking van Vranken in zijn noot onder dit arrest in de $\mathrm{NJ}$, dat dit arrest uit civielrechtelijk oogpunt geen nieuwe of verrassende gezichtspunten bevat, omdat al heel lang de heersende opvatting in literatuur en rechtspraak is dat genoemde artikelen als voorschriften van het gemene recht ook van toepassing zijn op betalingen van publiekrechtelijke aard, voor zover uit de wet niet het tegendeel blijkt, is dan ook onjuist. Hiervoor hoeven we slechts de formulering van de Hoge Raad te bekijken. In 1930 overwoog het hoogste (civiele) rechtscollege nog dat 'dit voorschrift van het gemeene recht (art. $1395 \mathrm{BW}$ (oud)) ook van toepassing is op betalingen van publiekrechtelijken aard', in 1991 overwoog hij dat artikel 1395 BW (oud) - en artikel 6:203 BW - 'uitdrukking (geeft) aan een beginsel dat voor het gehele recht geldt. Dit brengt mee dat het ook toegepast dient te worden op betalingen van publiekrechtelijke aard'. Met andere woorden: gaf artikel 1395 BW (oud) geen uitdrukking aan een beginsel dat voor het gehele recht gold, dan zou het ook niet worden toegepast op betalingen van publiekrechtelijke aard. Artikel 1395 BW (oud) is in dat geval dan ook slechts via een omweg van toepassing; het algemene rechtsbeginsel is 'toevallig' in dat artikel neergelegd. Dit is iets anders dan toepassing van de gemene rechtsleer, waarin artikel 1395 BW (oud) rechtstreeks zou worden toegepast, en niet via voormelde omweg. ${ }^{126}$ Het blijft wel de vraag of de Hoge Raad vervolgens de genoemde bepalingen uit het BW al dan niet invullend gebruikt, maar de door de Hoge Raad gehanteerde constructie is dezelfde als die, welke in de invullende rechtsleer naar voren komt. Het bleef echter bij dit ene arrest; nog geen jaar later overwoog de Hoge Raad in een geval waarin ten onrechte betaalde uitkeringen werden teruggevorderd, dat artikel $1395 \mathrm{BW}$ (oud) rechtstreeks van toepassing was. ${ }^{127}$

\subsubsection{De invullende rechtsleer in de wetgeving}

De discussie, zoals die in de jaren negentig werd gevoerd met betrekking tot de vraag of het privaatrecht ook van toepassing is op de overheid, lijkt uiteindelijk ook zijn beslag te krijgen in de wetgeving. Was tot voor kort de bij de wetgever heersende opvatting dat het BW het gemene recht was, ${ }^{128}$ tegenwoordig lijkt ook de wetgever steeds meer een principieel onderscheid te onderkennen tussen regels van privaatrecht en regels van bestuursrecht. Zo stelde regeringscommissaris Scheitema mede naar aanleiding van de jurisprudentie van de bestuursrechters:

126. Zo ook Tak in zijn noot onder dit arrest in tB/S 1991, Burgerlijke rechter, $\mathrm{mr}$. 7. Anders Scheltema (1997), blz. 273-274.

127. HR 10 augustus 1992, NJ 1993, 636, m.nt. MS, AB 1993, 12 (M.-Roosendaal en Nispen).

128. Zie bijvoorbeeld de memorie van toelichting bij de Wet boeten, maatregelen en terug- en invordering sociale zekerheid, Tweede Kamer 1994-1995, 23 909, nr. 3, blz. 29-31 met betrekking tot de toepasselijkheid van de verjaringsartikelen uit het BW in het socialezekerheidsrecht. Zie hierover ook 6.4 . 
'Er is over (de) verhouding (tussen het bestuursrecht en het burgerlijk recht) veel te zeggen, en het wordt steeds meer noodzakelijk haar goed te doordenken. Wanneer het burgerlijk recht niet meer als het gemene recht wordt beschouwd, maar men het bestuursrecht en het privaatrecht als twee rechtsgebieden ziet die worden overstegen door meer algemene regeis en rechtsbeginselen, dan vergt die benadering een nieuwe uitwerking van de onderlinge verhouding. Welke regels en beginselen zijin gemeenschappelijk? In hoeverre lenen de regels in het ene gebied - meestal het burgerlijk recht - zich voor overeenkomstige toepassing in het andere? In hoeverre volgt uit het legaliteitsbeginsel of het specialiteitsbeginsel dat er tussen beide rechtsgebieden verschil moet worden gemaakt?

Ook in de wetgeving zal de verhouding tussen het BW en de Awb duidelijker moeten worden. Misschien biedt de regeling van de geldschulden in de vierde tranche daartoe een goede gelegenheid. 129

Het voorontwerp van die vierde tranche, dat in september 1999 werd aangeboden aan de ministers van Justitie en Binnenlandse Zaken, bevat dan ook interessante beschouwingen over de verhouding tussen de Awb en het BW - en dus over de toepasselijkheid van privaatrecht in publiekrechtelijke rechtsverhoudingen. ${ }^{130}$ Twee uitgangspunten staan centraal: enerzijds zijn de regels in het $\mathrm{BW}$ primair geschreven voor privaatrechtelijke verhoudingen en kunnen daarom niet zonder meer van toepassing zijn op het terrein van het bestuursrecht, anderzijds moeten nodeloze verschillen tussen het bestuursrecht en het privaatrecht worden vermeden. ${ }^{131}$ Wat de toepasselijkheid van bepalingen uit het $\mathrm{BW}$ in het bestuursrecht betreft, wordt dit als volgt uitgewerkt. Over de toepasselijkheid van bepaalde artikelen uit het BW lijkt communis opinio te bestaan: 'de bepalingen over de onrechtmatige daad worden tegenwoordig welhaast vanzelfsprekend van toepassing geacht op onrechtmatig overheidsoptreden'. ${ }^{132}$ Maar 'bij andere onderwerpen is de toepasselijkheid van het BW minder vanzelfsprekend'. De toelichting noemt de regeling betreffende de onverschuldigde betaling, waarbij wordt verwezen naar het hiervoor behandelde arrest Cornelissen-Groningen. Ook volgens de toelichting impliceert dit arrest dat het BW in casu niet rechtstreeks van toepassing is, maar 'wél doorwerkt in bestuursrechtelijke rechtsbetrekkingen via de aan beide rechtsgebieden ten grondslag liggende algemene rechtsbeginselen'. Wel wordt uitdrukkelijk gesteld dat toepassing van een dergelijk in het BW neergelegd beginsel in een bestuursrechtelijke rechtsbetrekking in verband met de bestuursrechtelijke context soms tot andere uitkomsten kan leiden. ${ }^{133}$

Ook in de schakelbepalingen in boek 3 van het $\mathrm{BW}$ worden bepaalde titels van dat boek buiten het vermogensrecht 'van overeenkomstige toepassing'

129. Scheltema (1999), blz. 127.

130. De toelichting stelt wel uitdrukkelijk dat de verhouding tussen overheid en burger niet in alle gevallen van bestuursrechtelijke aard is; 'er zijn situaties waarin het privaatrecht rechtstreeks van tocpassing is', Voorontwerp Commissie-Scheltema Awb IV (1999), blz. 48-49.

131. Voorontwerp Commissie-Scheltema Awb IV (1999), blz. 49.

132. Voorontwerp Commissie-Scheltema Awb IV (1999), blz. 49. 'Overigens heeft de toepasselijkheid van het BW niet verhinderd dat het leerstuk van de onrechtmatige overheidsdaad altijd een speciaal leerstuk is gebleven', voegt de toelichting hieraan toe, Voorontwerp CommissieScheltema Awb IV (1999), blz. 49.

133. Voorontwerp Commissie-Scheltema Awb IV (1999), blz. 49. 
verklaard; de betrokken titels zijn dus niet rechtstreeks van toepassing op het terrein van het bestuursrecht. ${ }^{134}$ Dit zou overeenkomen met het standpunt dat de Hoge Raad heeft ingenomen in het arrest Cornelissen-Groningen. De algemene benadering dient dan ook te zijn, dat de bepalingen uit het BW en de Awb slechts gelden voor de terreinen die worden bestreken door die wetten; dit 'neemt niet weg dat regels van het ene rechtsgebied van overeenkomstige toepassing kunnen zijn in het andere rechtsgebied. ${ }^{135}$

Wel dient te worden vermeden - we komen hier op het tweede uitgangspunt dat nodeloze verschillen ontstaan of blijven bestaan tussen het BW en de Awb, waar het rechtsfiguren betreft in het privaatrecht en het bestuursrecht, die sterke onderlinge gelijkenis vertonen. Veelal zal deze rechtsfiguur reeds een regeling hebben in het $\mathrm{BW}$; de codificatie van het privaatrecht is momenteel algemener en completer dan die van het bestuursrecht. Dit betekent dat 'indien de eigen aard van het bestuursrecht geen argumenten oplevert voor een andere regeling', zoveel mogelijk moet worden aangesloten bij bestaande regelingen uit het $\mathrm{BW} \cdot{ }^{136}$

Dit alles leidt ten slotte tot de volgende regels:

'Uitgangspunt is dat de regels van het BW gelden voor het privaatrecht. Voor een aantal titels van Boek 3 is de werkingssfeer mede tot bestuursrechtelijke, verhoudingen uitgebreid voorzover de aard van de rechtsbetrekking zich daartegen niet verzet. Dit betekent dat de overige bepalingen van het BW - voorzover dit gewenst wordt - in de Awb uitdrukkelijk van overeenkomstige toepassing verklaard moeten worden. Voor de regeis van de genoemde titels van. Boek 3 geldt dat niet: het BW voorziet in. beginsel reeds zelf in die overeenkomstige toepassing. Wel kan het bij de regeling van een bepaald onderwerp uit die titels nodig zijn nader te preciseren in hoeverre die bepalingen voor het bestuursrecht de meest geschikte zijn. (...)

Voor onderwerpen waarover de wetgever zich noch in het BW noch in de Awb uitdrukkelijk uitspreekt, zal de rechter zelfstandig een oplossing moeten vinden. Uit de jurisprudentie blijkt ook dat de rechter in gevallen waarin dat goed mogelijk is, in bestuursrechtelijke verhoudingen aansluiting pleegt te zoeken bij de regels van het privaatrecht'. ${ }^{137}$

Het is, duidelijk dat in deze toelichting de gernene rechisleer wordt verworpen. De uitgangspunten van de wetgever benaderen zelfs op sommige punten sterk die van de invullende rechtsleer.

Een duidelijk voorbeeld waar de wetgever een andere koers inslaat dan de Hoge Raad, is de verrekening. De opvatting van de Hoge Raad, die de gemene rechtsleer toepaste, was dat 'vorderingen tot betaling van geldsommen die twee partijen over en weer op elkaar hebben, (...) in beginsel vatbaar (zijn) voor verrekening ongeacht de aard van de rechtsverhoudingen waaruit die vorderingen zijn ontstaan'. ${ }^{138}$ Het voorontwerp, dat onder meer een regeling bevat met

134. Voorontwerp Commissie-Scheltema Awb IV (1999), blz. 50. Dit geldt dan uiteraard ook voor de bepalingen die niet onder een schakelbepaling vallen, zoals bijvoorbeeld Boek 6 .

135. Voorontwerp Commissie-Scheltema Awb IV (1999), blz. 50.

136. Voorontwerp Commissie-Scheltema Awb IV (1999), blz. 50-51.

137. Voorontwerp. Commissie-Scheltema Awb IV (1999), blz. 51.

138. HR 28 mei 1993, NJ 1994, 435, m.nt. HJS (Nieuwkoop-Staat). 
betrekking tot publiekrechtelijke geldvorderingen, gaat uit van een tegenovergesteld standpunt: artikel 4.4.1.9 bepaalt dat geen verrekening plaatsvindt, "tenzij bij wettelijk voorschrift anders is bepaald'. De regeling uit het BW is dan ook niet van toepassing, althans zij is minder geschikt om te worden toegepast in publiekrechtelijke verhoudingen. ${ }^{139}$ De reden hiervoor is dat het ene bestuursorgaan het andere niet is, ondanks dat zij beide onderdeel van dezelfde rechtspersoon kunnen zijn en dus de vermogensrechtelijke gevolgen in beide gevallen deze rechtspersoon treffen. ${ }^{140}$ Een door de burger te betalen geldboete moet niet met een beroep op de regeling uit het $\mathrm{BW}$ kunnen worden verrekend met een huursubsidie die de burger van de staat ontvangt. ${ }^{141}$

\subsection{Conclusle}

Sedert het midden van de negentiende eeuw zijn in de Nederlandse juridische literatuur beschouwingen te vinden over de verhouding tussen het privaat- en het publiekrecht en over het gebruik van privaatrecht in publiekrechtelijke verhoudingen. De eerste die een principieel onderscheid maakte tussen publiek- en privaatrecht was Thorbecke. Volgens hem kon het algemeen belang niet worden gediend met behulp van regels die erop waren gericht bijzondere belangen te dienen; dit leidde tot een scherpe scheiding tussen privaatrecht en publiekrecht. Ook Loeff zag een scherpe scheiding. Uitgaande van de staatssoevereiniteit zag hij niet hoe de overheid, het hoogste gezag, gebonden kon zijn aan het privaatrecht, waardoor het op eenzelfde hoogte zou komen te staan als de staatsonderdanen. Dit betekende tevens dat de overheid ook geen gebruik mocht maken van privaatrecht; ook dit zou immers ertoe leiden dat de overheid zijn 'karakter als heerser verliest'.

De praktijk van die tijd was echter een andere: de overheid was in een aantal gevallen gebonden aan en maakte zelf ook gebruik van het privaatrecht. Dit werd aanvaard en ook juist bevonden. De belangrijkste theoretische onderbouwing hiervoor werd gegeven door de gemene rechtsleer: het privaatrecht was het algemene, altijd geldende recht, dat dus ook van toepassing was op de overheid. Wel werd onderkend dat de gebondenheid van de overheid aan het privaatrecht en het gebruik ervan door de overheid niet onbegrensd was. De grens werd echter door verschillende schrijvers en verschillende stromingen anders gelegd. Hamaker bijvoorbeeld achtte het privaatrecht van toepassing, tenzij er een uitdrukkelijke, wettelijke publiekrechtelijke uitzondering was gemaakt. Scholten vond dat ook ongeschreven publiekrecht de toepasselijkheid van privaatrecht kon uitsluiten.

In de praktijk bleek de burgerlijke rechter vooral na de Tweede Wereldoorlog

139. Voorontwerp Commissie-Scheltema Awb IV (1999), blz. 69.

140. Althans wanneer de wijziging van artikel 1:1 Awb zoals voorgesteld in het voorontwerp vierde tranche wet wordt. In dit voorontwerp wordt namelijk voorgesteld aan artikel 1:1 Awb een vierde lid toe te voegen, dat luidt: 'De vermogensrechtelijke gevolgen van een handeling van een. bestuursorgaan treffen de rechtspersoon waartoe het bestuursorgaan behoort'.

141. Voorontwerp Commissie-Scheltema Awb IV (1999), blz. 46. 
het gebruik van privaatrecht ruim toe te staan: de overheid mocht de privaatrechtelijke weg bewandelen, ook als een publiekrechtelijke weg aanwezig was. Deze tweewegenleer kende oorspronkelijk slechts weinig beperkingen. Door de ontwikkeling van het publiekrecht in diezelfde periode werd echter eerst de theorie, later ook de praktijk beïnvloed. In het privaatrechtelijk optreden van de overheid werden steeds meer publiekrechtelijke normen ingebouwd. Het genoemde uitgangspunt bleef gehandhaafd, maar het kon zo zijn, dat de publiekrechtelijke weg als exclusief was bedoeld, of dat door de keuze voor de privaatrechtelijke weg de overheid zich schuldig maakte aan misbruik van bevoegdheid. Ook de algemene beginselen van behoorlijk bestuur, die in deze periode tot ontwikkeling kwamen, konden hierbij een rol spelen. Door het steeds meer inbrengen van publiekrechtelijke elementen in de 'privaatrechtelijke weg' ontstond volgens een aantal auteurs uiteindelijk een soort gemengd recht. Deze stroming staat bekend als de gemengde rechtsleer. Ook de rechter ging steeds meer op deze lijn zitten; de tweewegenleer die vrij soepel tegenover het gebruik van privaatrecht stond werd 'vervangen' door de doorkruisingsleer, een leer die ten aanzien van het gebruik van privaatrecht meer toetsingscriteria inbouwt dan haar voorgangster. Uitgangspunt blijft echter nog steeds dat de overheid gebruik mag maken van het privaatrecht. Ook de wetgever hanteerde dit uitgangspunt in de twee grote codificaties, het $\mathrm{BW}$ en de Awb, hetgeen onder meer blijkt uit de artikelen 3:14 BW en 3:1 lid $2 \mathrm{Awb}$.

Het uitgangspunt dat de overheid in beginsel beschikt over privaatrechtelijke bevoegdheden, zoals ook de Hoge Raad vooropstelt in het Windmill-arrest, wordt echter bestreden door de zogenaamde 'Maastrichtse school'. Volgens deze school bestaan binnen het publiekrecht bevoegdheden slechts voor zover zij uitdrukkelijk zijn verleend of er in het publiekrecht een positieve indicatie is te vinden voor een dergelijke bevoegdheid. Dit uitgangspunt is een consequentie van het legaliteitsbeginsel. Het BW kan in ieder geval niet functioneren als 'bevoegdheidverschaffende grondslag voor handelen van de overheid dat ingrijpt in rechten en belangen van burgers". Wel erkent deze school, dat er algemene rechtsbeginselen bestaan, rechtsbeginselen die publiekrecht en privaatrecht gemeen hebben. Een aantal van deze beginselen heeft nog geen uitwerking gevonden in publiekrechtelijike regelingen, maar wel reeds in het privaatrecht. In dat geval kan de uitwerking in het privaatrecht een rol spelen indien het publiekrecht een leemte bevat; deze leemte kan dan onder strikte voorwaarden worden 'ingevuld' met behulp van de regeling uit het $\mathrm{BW}$. Dit is de zogenaamde invullende rechtsleer.

Hoewel deze leer als zodanig niet als de heersende wordt erkend, zijn in de jurisprudentie en in de wetgeving aanwijzingen te vinden dat deze leer wordt toegepast. De zogenaamde 'algemene-rechtsbeginselenjurisprudentie' van de verschillende bestuursrechter en het arrest Cornelissen-Groningen, gewezen door de Hoge Raad kunnen worden gezien als toepassing van de invullende rechtsleer. De wetgever lijkt blijkens de toelichting op het Voorontwerp van de vierde tranche van de Awb steeds meer het standpunt in te nemen dat publiekrecht en privaatrecht twee aparte rechtsgebieden zijn, en dat toepassing van regels uit het ene rechtsgebied in het andere niet zonder meer vanzelfsprekend is.

Mijn eigen opvattingen zal ik uiteenzetten in deel III van het onderzoek. 


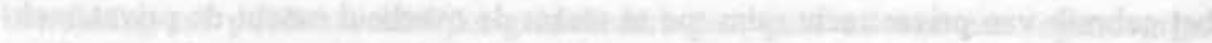

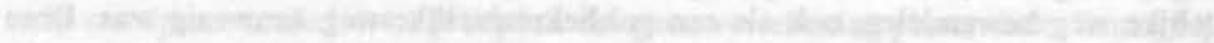

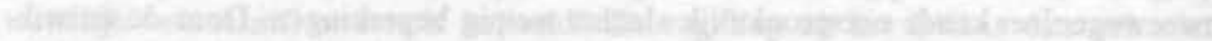

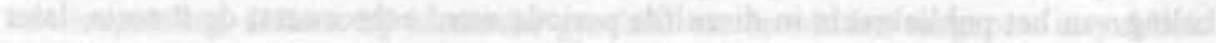

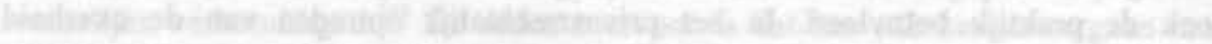

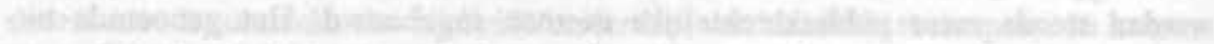

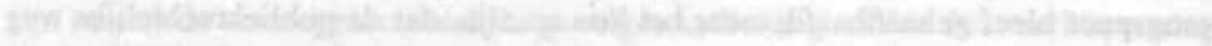

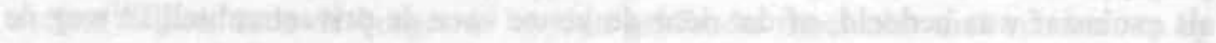

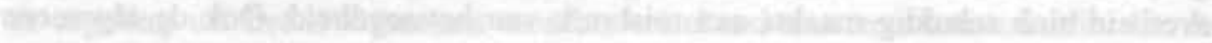

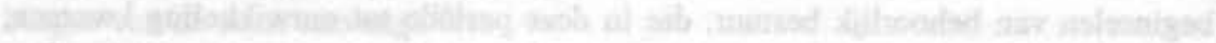

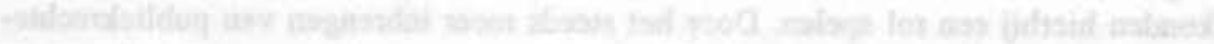

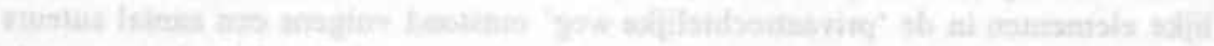

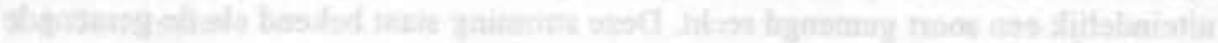

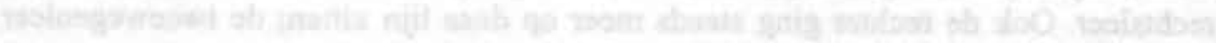

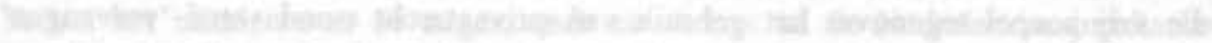

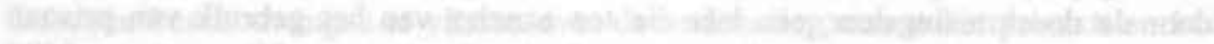

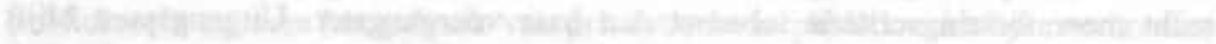

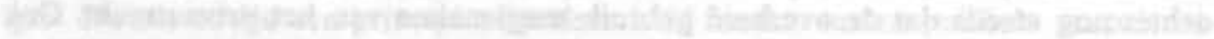

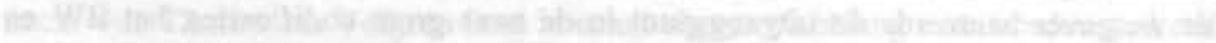

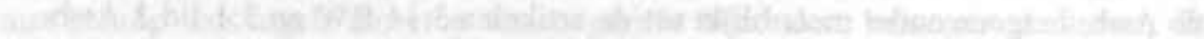

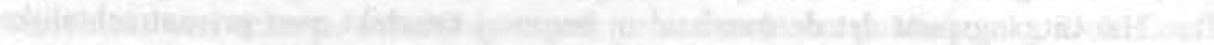

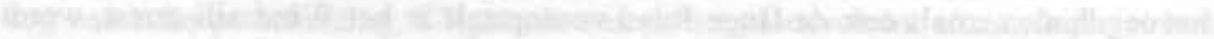

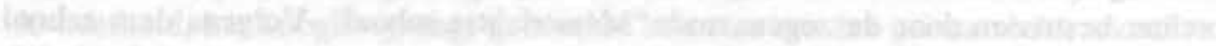

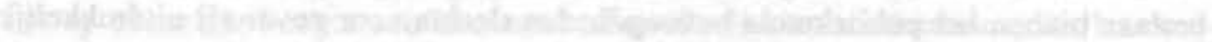

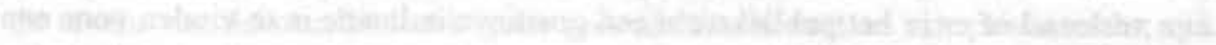

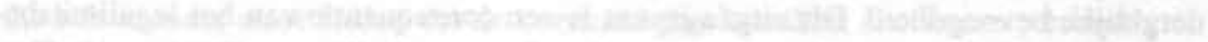

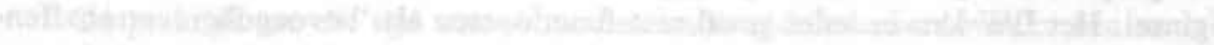

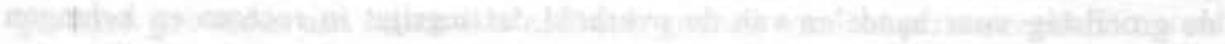

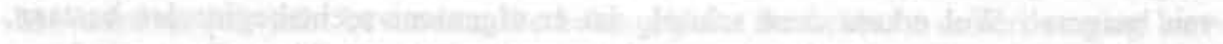

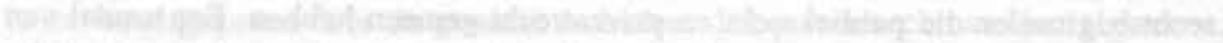

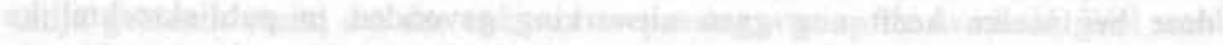

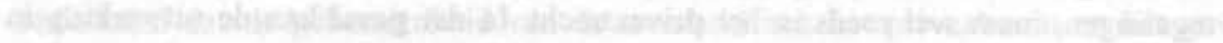

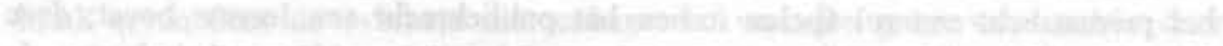

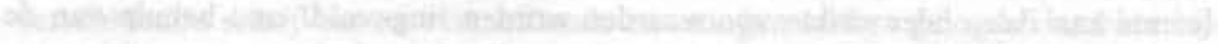

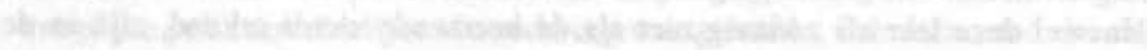

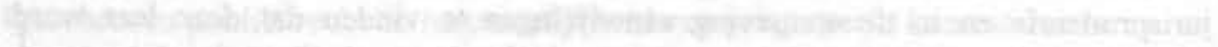

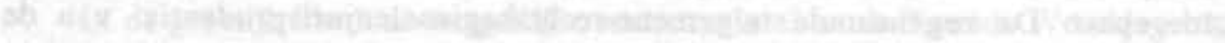

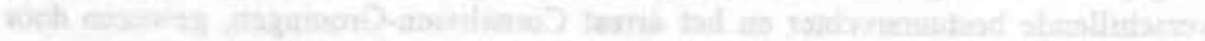

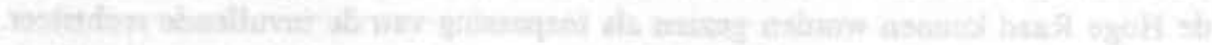

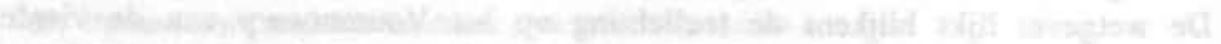

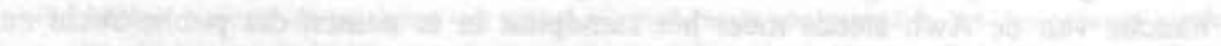

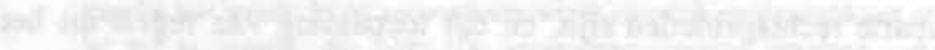




\section{DEEL II}





\section{SOCIALE ZEKERHEID}

\subsection{Inleiding}

In dit en de komende twee hoofdstukken zal ik ingaan op een aantal specifieke terreinen, waarop de overheid financieel presterend optreedt, namelijk de sociale zekerheid (dit hoofdstuk), het ambtenarenrecht (hoofdstuk 7) en de subsidies en het sociaal-economisch recht (hoofdstuk 8). Mijns inziens zijn dit de belangrijkste terreinen van financiële overheidsprestaties, waarop ook veelal een bijzondere administratieve rechter actief is. Ik zal steeds bekijken in hoeverre op die terreinen wettelijke terugvorderingsregels bestaan en, indien deze inderdaad bestaan, hoe deze regels tot stand zijn gekomen en wat de inhoud ervan is. Daarnaast is uiteraard van belang hoe de rechter met die regels is omgegaan. De jurisprudentie is vanzelfsprekend ook van belang in die gevallen, waarin geen wettelijke terugvorderingsregels bestaan. De bedoeling is om uiteindelijk te bezien of in al die wettelijke en jurisprudentiële regels een lijn kan worden ontdekt met betrekking tot de mogelijkheden en onmogelijkheden bij terugvordering. Stel dat een lijn is te ontdekken, dan rijst natuurlijk ook de vraag of deze lijn de juiste is. Die vraag zal in deel III, met name in hoofdstuk 10, aan de orde komen. Tevens zal ik in dit en de komende twee hoofdstukken bekijken in hoeverre op de behandelde terreinen nog ruimte was en is voor de burgerlijke rechter en het burgerlijk recht.

Dit hoofdstuk, gewijd aan het socialezekerheidsrecht, zal het meest uitgebreide zijn van de drie. Dit komt deels omdat in de sociale zekerheid de meest uitgebreide regelingen bestaan met betrekking tot terugvordering. Bovendien is het het terrein waarop de wetgeving het vroegst tot stand $\mathrm{kwam}$. Hierdoor zijn rechters op terreinen waar geen regeling was, mede gaan kijken naar het socialezekerheidsrecht en hebben zij bepaalde regels hieruit overgenomen. Ook de wetgever heeft dit soms gedaan op het moment dat hij op andere terreinen dan het socialezekerheidsrecht regelingen ontwierp. Dit betekent dat op de andere terreinen in een aantal gevallen kan worden volstaan met het verwijzen naar dit hoofdstuk.

In dit hoofdstuk zal, evenals in de volgende hoofdstukken, niet alleen de huidige situatie op het specifieke terrein aan de orde komen, maar ook de historie. In het vorige deel van het onderzoek is ingegaan op algemene historische ontwikkelingen; de in dit deel geschetste historische ontwikkelingen zullen meer toegespitst zijn op de specifieke terreinen. Voor een goed begrip van de huidige situatie op die verschillende terreinen is het van belang de geschiedenis te kennen. Bovendien blijken oplossingen uit het verleden vaak ook nu nog bruikbaar te zijn. Ten slotte blijken huidige regelingen in bepaalde gevallen ingegeven te zijn door pragmatische overwegingen, terwijl aan ontwikkelingen in het verleden in een aantal gevallen meer principiēle keuzes ten grondslag lagen. Een interessante 
vraag is of pragmatiek en dogmatiek met elkaar kunnen worden verenigd.

De opbouw van dit hoofdstuk is de volgende. In $6.3 \mathrm{zal}$ ik de ontwikkeling in de sociale zekerheid bespreken, zoals die heeft plaatsgevonden tot 1940. De periode na de Tweede Wereldoorlog zal in 6.4 aan de orde komen. In 6.5 zal worden bekeken in hoeverre de burgerlijke rechter en het burgerlijk recht in de sociale zekerheid een rol hebben gespeeld. Maar eerst zal ik de ontwikkeling van de Algemene bijstandswet en haar voorlopers, de Armenwetten uit 1854 en 1912 behandelen. Deze wetten kenden - en de Algemene bijstandswet kent - een zodanig eigen karakter dat bespreking in een aparte paragraaf gerechtvaardigd is.'

\subsection{De Armenwetten en de Algemene Bijstandswet tot 1997}

\subsubsection{De Armenwet 1854}

Een van de weinige publiekrechtelijke regelingen op grond waarvan de overheid in de negentiende eeuw financieel presterend optrad ten opzichte van burgers, lag op het gebied van de armenzorg. Artikel $195 \mathrm{Gw} 1848$ bepaalde dat het 'armbestuur' onderwerp van aanhoudende zorg was voor de regering; het diende door de wet te worden geregeld. Deze wet werd de Armenwet $1854,{ }^{2}$ die overigens niet moet worden gezien als 'socialezekerheidsregeling'; een belangrijke reden om deze materie te regelen, was het belang van de openbare orde, samenhangend met de bestrijding van landloperij en bedelarij - dus het staatsbelang. ${ }^{3}$

Uitgangspunt van de Armenwet was dat de armenzorg zoveel mogelijk moest worden overgelaten aan de familie van de arme, of, als deze niet tot de zorg in staat was, aan kerkelijke of particuliere instellingen. Pas als deze niet de nodige steun konden bieden, mocht de overheid inspringen. Dit is het zogenaamde subsidiariteitsbeginsel, neergelegd in artikel 20 Armenwet 1854 . Een ander beginsel was het onvermijdelijkheidsbeginsel: 'onderstand' mocht slechts door de overheid worden verstrekt indien dit onvermijdelijk was. ${ }^{4}$ Ook dan bestond geen recht op onderstand; verleende het burgerlijk armenbestuur onderstand, dan was dit een gunst. Volgens de mernorie van toelichting was het ondersteunen van armen dan ook 'een zedelijke, geen burgerlijke pligt'. 'Tegen de beslissing van het burgerlijk bestuur, of deze nu positief dan wel negatief was, was dan ook geen beroep mogelijk. ${ }^{6}$ Daarnaast kende de wet een uitgebreide regeling met betrekking tot het verhaal van verleende onderstand. Belangrijkste bepaling was artikel 52: verleende onderstand kon worden verhaald door het "burgerlijk, kerkelijk of

1. Overigens is dit eigen karakter van de Abw tegenwoordig behoorlijk verminderd, zo zal ook blijken in 6.4.5.

2. Wet van 28 juni 1854 , tot regeling van het Armbestuur, Stb. 100 .

3. Zie de memorie van toelichting, Tweede Kamer 1853-1854, bijlagen, 5le vel, blz. 196.

4. Mannoury/Asscher-Vonk (1987), blz. 46.

5. Tweede Kamer 1853-1854, bijlagen, 51 e vel, blz. 196. Cursiveringen in oorspronkelijke tekst.

6. Artike! 22 Armenwet 1854. 
bijzonder bestuur, voor welks rekening de verstrekking plaats had', en wel op de ondersteunde zelf als hij tot terugbetaling in staat was of op zijn bloed- of aanverwanten, voor zover die tot alimentatie verplicht waren. Tijdens de parlementaire behandeling werd nergens ingegaan op de achtergrond van dit verhaalsrecht. Het werd vanzelfsprekend geacht dat als iemand als gunst onderstand had gekregen, hij dit diende terug te betalen als hij later weer beschikte over voldoende middelen van bestaan. Zo oordeelde de Rechtbank Rotterdam in 1866 dat het Roomsch-Katholiek Parochiaal Armbestuur een bedrag van $f 316,70$ wegens sedert 1856 verleende onderstand en geneeskundige hulp kon verhalen op de weduwe Van Leeuwen. Aan haar was namelijk na het overlijden van haar man 'uit liefdadigheid' een bedrag geschonken van $f 1200$ om zichzelf en haar kinderen te onderhouden. De rechtbank oordeelde dat de vrouw daardoor in staat moest worden geacht om de haar verstrekte onderstand terug te betalen, zonder opnieuw armlastig te worden. ${ }^{7}$ Het verhaalsrecht werd slechts begrensd door artikel 58: er gold een verjaringstermijn van vijf jaar. ${ }^{8}$ De wetgever koos voor deze termijn omdat de bedoelde vorderingen konden worden gelijkgesteld met die, bedoeld in artikel 2012 BW (oud), zodat werd aangesloten bij de in dat artike] gestelde verjaringstermijn van vijf jaar. ${ }^{9}$ In artikel 72 werd de te volgen rechisgang geregeld indien een geschil ontstond over het verhaal: de rechterlijke macht werd competent verklaard, althans indien die geschillen 'niet door de adrninistrative magt in der minne worden afgedaan'. Zoals in 2.5 is gebleken, was volgens de regering immers sprake van een schuldvordering als bedoeld in artikel $148 \mathrm{Gw}$ 1848 en was dus de burgerlijke rechter bevoegd. ${ }^{10}$ Ook de Hoge Raad was van mening dat hierdoor de bepalingen van het BW van toepassing waren, tenzij bijzondere voorschriften waren gegeven in (in dit geval) de Armenwet $\ 854 . "$

\subsubsection{De Armenwet 1912}

In 1912 verving de Armenwet 1912 de Armenwet $18544^{12}$ Voor het verhaal van verleende onderstand bracht dit geen wijziging mee. Het subsidiariteitsbeginsel bleef gelden; eerst diende hulp te worden gezocht bij familie of andere onderhoudsplichtigen, ${ }^{13}$ bij kerkelijke of bij particuliere instellingen. Pas als dat beroep niet slaagde, kon 'ondersteuning' worden verkregen van de overheid (artikel 28 Armenwet 1912). ${ }^{14}$ Nog steeds was geen sprake van een recht op onderstand. ${ }^{15}$ Verhaal van onderstand was mogelijk (artikel 63 Armenwet 1912), waarbij nog

7. Rb. Rotterdam 3 januari 1866 , W. 2761.

8. Deze termijn ving aan op de 31 e december van het jaar waarin de onderstand werd verleend.

9. Tweede Kamer 1853-1854, bijlagen, $52 \mathrm{e}$ vel, blz. 202.

10. Memorie van toelichting, Tweede Kamer 1853-1854, bijlagen, $53 \mathrm{e}$ vel, blz. 203.

11. Verwezen zij naar het in 2.4 .2 en 2.5 behandelde arrest HR 23 november 1866, W. 2854.

12. Wet van 27 april 1912, tot regeling van het armbestuur, Stb. 165.

13. Dit was een zeer ruime categorie, zie hierover Bouwens (1996), blz. 58.

14. Zie hierover Schell (1995), blz. 20-23.

15. Schell (1995), blz. 307. 
immer een verjaringstermijn gold van vijf jaren (artikel 73 Armenwet 1912). Ook de voorgeschreven rechtsgang veranderde niet; de geschillen over verhaal werden opgedragen aan de rechterlijke macht (artikel 76 onder c Armenwet 1912). De door de burgerlijke rechter onder de wet van 1854 gewezen jurisprudentie bleef van belang.

In 1929 werd de Armenwet 1912 gewijzigd, waarbij onder meer de verhaalsbepalingen werden veranderd. ${ }^{16}$ De personen op wie verleende onderstand kon worden verhaald bleven dezelfde (artikel 63 lid 1 Armenwet 1912), wel veranderden de verjaringstermijnen. In artikel 73 werd nog slechts een verjaringstermijn opgenomen voor 'rechtsvorderingen tot verhaal van kosten van verzorging op de onderhoudsplichtigen'; deze termijn bleef vijf jaar. ${ }^{17}$ De beperking in de tijd van het verhaal van de kosten van onderhoud op de ondersteunde zelf was verdwenen. Volgens de memorie van toelichting was het voldoende om het verhaalsrecht tegen de onderhoudsplichtige aan een termijn te binden. Voor het verhaal op de ondersteunde zelf werd dit niet nodig gevonden, nu deze door de ondersteuning direct gebaat was geweest. ${ }^{18}$ Door het schrappen van de bepalingen die de verjaring van het verhaal op de ondersteunde zelf regelden, werden de verjaringstermijnen uit het BW van toepassing. Dit was in overeenstemming met de in 2.5 besproken jurisprudentie van de Hoge Raad. De wetgever was, althans in 1960, van mening dat hierdoor de verjaringstermijn van artikel $2004 \mathrm{BW}$ (oud) gold, waardoor de rechtsvordering verjaarde door verloop van dertig jaar. ${ }^{19}$ Dit is opvallend: in 1854 was hij immers nog van oordeel dat deze vorderingen konden worden gelijkgesteld met de vorderingen bedoeld in artikel $2012 \mathrm{BW}$ (oud). Om die reden was indertijd gekozen voor een termijn van vijf jaren in artikel 58 Armenwet 1854.

In 1961 werd de Armenwet gewijzigd door de Wet tot beperking van het verhaalsrecht. ${ }^{20}$ Een van de veranderingen betrof artikel 73 Armenwet, dat de verjaringstermijn regelde. De termijn bij verhaal op de onderhoudsplichtigen bleef ongewijzigd, ${ }^{21}$ maar de termijn voor verhaal op de ondersteunde zelf werd teruggebracht van dertig naar vijftien jaar. Volgens de memorie van toelichting was een zo lange nasleep - dertig jaar - van bijstand die in het verleden was verleend, in sociaal opzicht ongewenst. ${ }^{22}$ Ook het karakter van de termijn veranderde: sprak het oude artikel 73 nog van verjaren, het gewijzigde artikel 73 stelde

16. Wet van 22 juni 1929 , tot wijziging van de wet van 27 april 1912 tot regeling van het armbestuur, Stb. 326.

17. Ook hier ving de termijn aan op 31 december van het jaar waarin de 'verzorging' plaatsvond.

18. Tweede Kamer 1928-1929, 290, nr. 3, blz. 9.

19. Zie de memorie van toelichting op het wetsontwerp tot beperking van het verhaalsrecht, Tweede Kamer 1959-1960, 5864, nr. 3, blz. 8.9.

20. Wet van 12 januari 1961 tot beperking van het verhaalsrecht, bedoeld in hoofdstuk $\mathrm{V}$ der Armenwet, Stb. 9.

21. Wel werd de groep van onderhoudsplichtigen op wie verleende onderstand kon worden verhaald beperkt, zie Bouwens (1996), blz. 68-69.

22. Tweede Kamer 1959-1960, 5864, nr. 3, blz. 8-9. 
dat de rechtsvordering tot verhaal verviel. ${ }^{23}$ Het verhaal geschiedde uit kracht van een rechterlijke beschikking, waarbij de kantonrechter de bevoegde rechter was, aldus artikel 64 lid 1 en lid 2. Zoals in 6.3.2 zal blijken, was dit een duidelijk verschil met de (meeste) andere socialezekerheidswetten, waar de Raden van Beroep en de Centrale Raad van Beroep bevoegd waren.

\subsubsection{De Algemene Bijstandswet 1963}

De beperkingen op het verhaalsrecht uit 1961 kunnen worden gezien als een teken des tijds. In deze periode werd namelijk een algehele vervanging van de Armenwet voorbereid, waardoor deze zou aansluiten bij de maatschappelijke veranderingen die plaatsvonden na de Tweede Wereldoorlog. Een principiële verandering betrof het karakter van de onderstand. Was het ontvangen van onderstand eerst een gunst, het werd nu steeds meer gezien als een recht. Tegenover dit recht diende de verplichting van de overheid tot het verlenen van onderstand te staan.

Dit nieuwe uitgangspunt werd in 1963 neergelegd in artikel 1 Algemene Bijstandswet (hierna: ABW), ${ }^{24}$ zij het niet met zoveel woorden. ${ }^{25}$ Als gevolg hiervan werd de bijstandsverlening een exclusieve taak van de overheid. ${ }^{26}$ Het feit dat bijstand niet langer een gunst was, maar een recht, had ook gevolgen voor het verhaal van verleende bijstand; de uitbetaalde bijstand kon in beginsel niet meer worden verhaald op de belanghebbende (die van 'ondersteunde' 'bijstandsgerechtigde' werd). Verhaal was nog slechts mogelijk voor zover de wet dit uitdrukkelijk regelde. Het belangrijkste geval was neergelegd in artikel 58 onder a: op de betrokkene zelf konden worden verhaald kosten van bijstand, die verleend waren op grond van door de betrokkene verstrekte onjuiste of onvolledige inlichtingen. Ook werd voor het verhaal op de betrokkene zelf de verhaalstermijn ingekort: de rechtsvordering tot verhaal verviel vijf jaar nadat de kosten waren gemaakt. ${ }^{27}$ De keuze voor deze termijn werd niet verder toegelicht in de parlementaire stukken.

Ik wil vijf punten met betrekking tot het verhaal zoals geregeld in de ABW uit 1963 kort aanstippen. In de eerste plaats stelde de ABW niet als hoofdregel voorop dat een eenmaal uitbetaalde uitkering niet kon worden verhaald, zoals de meeste andere socialezekerheidswetten deden. ${ }^{28}$ Wel werd in 1970 artikel 54a toegevoegd aan de verhaalsparagraaf, dat bepaalde dat kosten van bijstand niet

23. Zie voor de consequenties hiervan Bollen (1996).

24. Wet van 13 juni 1963, houdende nieuwe regelen betreffende de verlening van bijstand door de overheid (Algemene Bijstandswet), Stb. 284. Deze wet trad in werking op 1 januari 1965, besluit van 10 juli 1964, houdende bepaling van het tijdstip waarop de Algemene Bijstandswet in werking treedt, Stb. 312.

25. Vgl. Heerma van Voss (1996), blz. 10.

26. Schell (1995), blz. 31 .

27. Artikel $70 \mathrm{ABW}$.

28. Zie 6.4.2. 
konden worden verhaald dan in de gevallen, aangegeven in die paragraaf. ${ }^{29}$ Ten tweede was sprake van een discretionaire bevoegdheid; de wet stelde dat de kosten van bijstand konden worden verhaald. In de derde plaats eiste de ABW niet dat, alvorens tot verhaal kon worden overgegaan, de toekenningsbeslissing werd ingetrokken. ${ }^{30}$ Onverschuldigde betaling was dus in de $A B W$ geen vereiste. Dit komt ook tot uitdrukking in het feit, dat werd gesproken van 'verhaal' en niet van 'terugvordering'. Ten vierde konden kosten van bijstand worden verhaald als de betrokkene onjuiste of onvolledige mededelingen had gedaan. Een verplichting tot het geven van inlichtingen kende de ABW zelf echter niet. Toch kon een dergelijke inlichtingenplicht worden afgeleid uit artikel 58. Het feit dat onjuiste of onvolledige inlichtingen waren gegeven en dus de kosten van bijstand konden worden verhaald wilde overigens niet zeggen dat er sprake was van opzettelijke fraude. ${ }^{3 t}$ Ten slotte werd de rechtsvordering tot verhaal beperkt tot vijf jaar nadat de kosten waren gemaakt. Het koppelen van - onder meer - het geven van onjuiste of onvolledige mededelingen en de vijfjarentermijn werd in 1977 overgenomen in de Wet tegengaan oneigenlijk gebruik. ${ }^{32}$

Indien de betrokkene niet wenste mee te werken aan het verhaal, dan diende de gemeente over te gaan tot verhaal in rechte. Dit geschiedde volgens artikel 62 lid $1 \mathrm{ABW}$ uit krachte van een rechterlijke beschikking. De rechtsvordering diende bij verzoekschrift te worden ingesteld bij de kantonrechter (artikel 62 lid 2 $\mathrm{j}^{\circ}$ artikel 63 lid $1 \mathrm{ABW}$ ). Hoger beroep stond open bij de arrondissementsrechtbank, tenzij het te verhalen bedrag minder was dan f 200,- (artikel 66 lid 1 $\mathrm{ABW}) .^{33}$ Zoals hiervoor al besproken bepaalde artikel 70 dat de rechtsvordering tot verhaal verviel na verloop van vijf jaar, nadat de kosten waren gemaakt. Voor de bepaling van de vijfjarentermijn was beslissend de dag van de indiening van het verzoekschrift. ${ }^{34}$ Verhaald konden worden de kosten van bijstand, die waren gemaakt tot maximaal vijf jaar voor de dag van indiening van het verzoekschrift.

De wet kende geen regeling voor verhaal indien het bestuursorgaan een administratieve vergissing had begaan. Had een dergelijke vergissing plaatsgevonden, dan stond voor het bestuursorgaan de hiervoor beschreven weg niet open. ${ }^{35}$ Had het bestuursorgaan conform de (foutieve) toekenningsbeslissing betaald, dan was de enige mogelijkheid over te gaan tot terugvordering door alsnog de toekenningsbeslissing in te trekken, gevolgd door een actie uit onverschuldigde

29. Artikel if onderdeel J Wet van 10 september 1970, houdende wijziging van de Algemene Bijstandswet, Stb. 447.

30. De Boer (1981), blz. 257.

31. Memorie van toelichting, Tweede Kamer 1961-1962, 6796, nr. 3, blz. 28.

32. Zie 6.4.3.

33. Dit bedrag is later enige malen verhoogd, uiteindelijk bedroeg het in $1995 f 2500$,-

34. Rb. Rotterdam 30 november 1981, JABW 1982, 35.

35. Artikel 54a ABW. 
betaling. ${ }^{36}$ In een in 1979 geslagen koninklijk besluit werd echter bepaald dat herstel van een administratieve vergissing mogelijk was, zij het niet met terugwerkende kracht, nu de betrokkene redelijkerwijs niet had kunnen vermoeden dat een administratieve vergissing was gemaakt en er dus op had mogen vertrouwen dat zijn uitkering niet met terugwerkende kracht zou worden gekort. ${ }^{37}$ Intrekking met terugwerkende kracht, gevolgd door een actie uit onverschuldigde betaling was bij een administratieve vergissing slechts mogelijk als de betrokkene redelijkerwijs had kunnen weten dat een dergelijke vergissing was gemaakt.

\subsubsection{De Wet terugvordering en verhaal}

Bijna dertig jaar later, in 1992, werden de verhaalsbepalingen van de ABW opnieuw gewijzigd door de Wet terugvordering en verhaal. ${ }^{38}$ Deze wet bouwde in sterke mate voort op een eerder in 1984 ingediend voorstel, houdende wijzigingen van bepalingen in de Algemene Bijstandswet die betrekking hebben op het verhaal van kosten van bijstand, ${ }^{39}$ dat door de Eerste Kamer werd verworpen. ${ }^{40}$

Vier veranderingen vallen op. In de eerste plaats werd het onderscheid ingevoerd tussen terugvordering en verhaal, met daaraan verbonden verschillende procedures. ${ }^{41}$ 'Terugvordering' was het verhaal op de betrokkene zelf, 'verhaal' het verhaal op derden. In de tweede plaats werd in de ABW het onderscheid tussen 'toedoen' en 'redelijkerwijs kunnen begrijpen' ingevoerd, met daaraan verbonden verschillende terugvorderingstermijnen. Ten derde werd de terugvorderingsprocedure ingrijpend veranderd. Ten slotte werd de bestaande bevoegdheid tot terugvordering (in de oude terminologie: verhaal) omgezet in een verplichting.

Om met het laatste punt te beginnen: stelde de wet van 1963 nog dat de kosten van bijstand op de betrokkene zelf konden worden verhaald, na de wetswijziging bepaalde artikel 55 lid 1 dat de kosten van bijstand werden teruggevorderd in de gevallen en naar de regels aangegeven in de terugvorderingsparagraaf. Volgens lid 3 kon slechts geheel of gedeeltelijk van terugvordering worden afgezien als daarvoor gelet op de omstandigheden van persoon en gezin dringende redenen aanwezig waren. Artikel 55 lid 4 ten slotte bepaalde dat buiten de in de terugvorderingsparagraaf aangegeven gevallen geen terugvordering plaats mocht vinden.

De - voor het onderzoek - belangrijkste gevallen waarin kon worden terugge-

36. De Boer (1981), blz. 257. Had het bestuursorgaan door een vergissing niet conform de toekenningsbeschikking betaald, er was dus meer uitbetaald dan waarop de betrokkene op grond van die beschikking recht had, dan diende ook een vordering uit onverschuldigde betaling te worden ingesteld, zie Schell (1995), blz. 315-316, die verwijst naar HR 25 oktober 1991, NJ 1992, 299, m.nt. JBMV, AB 1992, 88, m.nt. FHvdB (Comelissen-Groningen).

37. KB 29 november 1979, AB 1980, 177, m.nt. V.d. N.

38. Wet van 15 april 1992, houdende een nieuwe regeling voor terugvordering en verhaal van kosten van bijstand, Stb. 193.

39. Tweede Kamer 1984-1985, 18 813, nrs. 1-2.

40. Handelingen Eerste Kamer 20 mei 1986, blz. 1233.

41. Memorie van toelichting. Tweede Kamer 1987-1988, 20 598, nr. 3, blz. 1. 
vorderd stonden in artikel 57, namelijk het verstrekken van onjuiste of onvolledige inlichtingen en het niet voldoen aan de inmiddels in artikel 30 lid $2 \mathrm{ABW}$ opgenomen verplichting mededeling te doen van al datgene wat van belang was voor de verlening van bijstand of voortzetting van verleende bijstand (artikel 57 onder a en onder d) en het redelijkerwijs kunnen weten dat ten onrechte of te veel bijstand is verleend (artikel 57 onder e). ${ }^{42}$ De ABW sloot op dit punt aan bij het overgrote deel van de socialezekerheidswetten, zoals die luidden sinds in 1978 de Wet tegengaan oneigenlijk gebruik in werking was getreden. ${ }^{43}$ Ook wat betreft de terugvorderingstermijnen werd in de $\mathrm{ABW}$ aangesloten bij de termijnen die sedert 1978 vrij algemeen golden in het socialezekerheidsrecht: volgens artikel 61d lid 1 konden kosten van bijstand die meer dan vijf jaar voor de datum van verzending van de beschikking tot terugvordering waren gernaakt, niet worden teruggevorderd. Lid 2 bepaalde dat die termijn twee jaar bedroeg als werd teruggevorderd op grond van artikel 57 onder e. Over deze nieuwe terugvorderingstermijn van twee jaar zegt de toelichting slechts dat in deze gevallen (namelijk als de betrokkene redelijkerwijs had kunnen begrijpen dat de gemeente te veel of ten onrechte bijstand had uitgekeerd) een korte vervaltermijn redelijk werd geacht. ${ }^{44}$

Op het punt van de terugvorderingsprocedure onderging de $A B W$ een belangrijke wijziging. De oude situatie was zo, dat als de betrokkene niet wenste mee te werken aan het verhaal (nu: de terugvordering), de gemeente over diende te gaan tot verhaal in rechte door een verzoekschrift in te dienen bij de kantonrechter. Volgens de memorie van toelichting waren er echter geen bijzondere redenen om de tussenkomst van de rechter steeds noodzakelijk te achten. ${ }^{45}$ Artikel 60 lid 1 bepaalde dan ook dat terugvordering geschiedde door burgemeester en wethouders van de gemeente welke de bijstand had verleend. Op grond van artikel 61 lid 1 diende de beslissing tot terugvordering bij beschikking aan de betrokkene te worden medegedeeld. Tegen deze beschikking kon de betrokkene vervolgens een bezwaarschrift indienen bij burgerneester en wethouders (artikel 6la lid 1); tegen de beschikking op het bezwaarschrift stond beroep open bij gedeputeerde staten (artikel 6lb lid 1). De uitspraak van gedeputeerde staten kon door de Kroon worden geschorst of vernietigd (artikel $61 \mathrm{~b} \mathrm{j} \mathrm{j}^{\circ}$ artikel 44). Rechterlijke tussenkomst was pas vereist als de betrokkene vervolgens weigerde mee te werken aan de tenuitvoerlegging van de terugvorderingsbeschikking. In dat geval schreef artikel 6le lid 1 voor dat een verzoekschrift met betrekking tot de nakoming van de beschikking moest worden ingediend bij de kantonrechter. De

42. De terugvorderingsgronden yan artikel 57 onder b en c waren respectievelijk het niet vervuld zijn van een voorwaarde en het blijk geven van een ongenoegzaam besef van verantwoordelijkheid voor de voorziening in het bestaan.

43. Zie 6.4.3.

44. Tweede Kamer 1987-1988, 20 598, nr. 3, blz. 16.

45. Tweede Kamer 1987-1988, 20 598, nr. 3, blz. 4. 
beschikking tot terugvordering leverde dus geen executoriale titel op. ${ }^{46}$ Ook op grond van de regeling zoals neergelegd in de Wet terugvordering en verhaal kon de toekenningsbeslissing in stand blijven als de gemeente te veel of ten onrechte betaalde bijstand op grond van de artikelen 55 en verder wilde tenugvorderen. ${ }^{47,48}$

Op het moment dat de Wet terugvordering en verhaal in het Staatsblad verscheen, was net een wetsontwerp dat de $\mathrm{ABW}$ moest veranderen aangeboden aan de Tweede Kamer, de Herinrichting van de Algemene Bijstandswet. ${ }^{49}$ Dit wetsontwerp groeide vervolgens uit tot de op 1 januari 1996 in werking getreden Algemene bijstandswet (Abw). ${ }^{50}$ Het doel van deze nieuwe wet was een doeltreffender bevordering van de zelfstandige bestaansvoorziening, een zuiverder afstemming van de bijstand op de specifieke omstandigheden in het individuele geval en een verbeterde afstemming van de $\mathrm{ABW}$ op andere voorzieningen. ${ }^{31}$ Later werd naar aanleiding van drie rapporten over fraude in de bijstand hieraan nog een vierde doelstelling toegevoegd, namelijk de verbetering van de fraudebestrijding. ${ }^{52}$ Wat betreft de terugvorderingsbepalingen bracht de Abw inhoudelijk niets nieuws en werd de regeling uit de Wet terugvordering en verhaal overgenomen: de toelichting op de terugvorderingstermijnen is zelfs letterlijk hetzelfde. ${ }^{53,54}$

46. Verdere regels met betrekking tot terugvordering en invordering waren neergelegd in de Circulaire van het Ministerie van SZW van 30 september 1992 inzake uitvoeringsaspecten van de nieuwe verhaalswetgeving, gepubliceerd in S\&J-uitgave 6, Algemene bijstandswet, bewerkt door G.C.P. varı Zeijl, 2e ưruk (1998), blz. 571-580.

47. Zie bijvoorbeeld CRvB; 9 januari 2001, USZ 2001, 94, m.nt. A.E.L.T. Balkema.

48. Overigens ontstond door het feit dat een deel van de wijzigingen, waaronder de artikelen $61,61 \mathrm{a}$ en $61 \mathrm{~b}$, uitgestelde werking had (artikel $\mathrm{X}$ lid 1), een ingewikkeld web van overgangsregels, dat tot veel verwarring en rechtspraak heeft geleid. Het probleem was dat artikel $61 \mathrm{~d}$ wel in werking trad en zodoende de terugvorderingstermijn koppelde aan de verzenddatum van het terugvorderingsbesluit, terwijl het bestuursorgaan weliswaar een besluit ter zake van terugvordering moest nemen (artikel 61), maar op grond van artikel 63, dat voorlopig van toepassing bleef, voor de terugvordering zelf een verzoekschrift moest indienen bij de kantonrechter. De Hoge Raad besliste uiteindelijk dat het tijdstip van indiening van het verzoekschrift bepalend was, HR 3 maart 1995, NJ 1995, 327. Zie hierover Stijnen (1995), blz. 624-625. Hiermee in strijd lijkt mij Rb. Utrecht. 19 juli 2000, NJ 2001, 89.

49. Namelijk op 12 maart. 1992, Tweede. Kamer 1991-1992, 22 545, nrs. 1-2.

50. Wet van 12 april 1995, houdende herinrichting van de, Algemene, Bijstandswet (Algemene bijstandswet), Stb. 199 en de Wet van 12 april 1995, houdende invoering van een nieuwe Algemene bijstandswet (Invoeringswet herinrichting Algemene Bijstandswet), Stb. 200.

51. Memorie van toelichting, Tweede Kamer 1991-1992, 22 545, nr. 3, blz. 16-17. Zie ook Heerma van Voss (1996), blz. 10-11 en Schell (1995), blz. 55-58.

52. Zie Heerma van Voss (1996), blz. 11 en 14, Schell (1995), blz. 66-77.

53. Vgl. memorie van toelichting op art. 61d (Wetsontwerp terugvordering en verhaal), Tweede Kamer 1987-1988, 20 598, nr. 3, blz. 16-17 en de memorie van toelichting op art. 94 (Wetsontwerp herinrichting Algemene Bijstandswet), Tweede Kamer 1991-1992, 22545 nr. 3, blz. 174. Uiteraard is de artikelnummering een aantal malen verschillend.

54. Ook nu leidde het overgangsrecht tot grote verwarring, en wel op het terrein van de toepasselijke rechtsbescherming. Deze verwarring werd ingegeven door een uitspraak van de CRvB van 26 juli 1994, AB 1995, 229, JB 1994, 220, RSV 1995, 54 en 93, JABW 1995, 24. Zie hierover Dijkers (1995), Stijnen (1996) en De Bruijn/Klein Egelink (1996). De Hoge Raad maakte aan deze 
De inwerkingtreding van de Abw betekende niet dat de terugvorderingsbepalingen. definitief gestalte hadden gekregen. Op 1 januari 1997 vond een wijziging plaats door de Wet boeten en maatregelen. Dit komt aan de orde in 6.4.5.

\subsection{De ontwikkeling in de sociale zekerheid tot de Tweede Wereldoorlog}

\subsubsection{Inleiding}

De ontwikkeling van het huidige stelsel van sociale zekerheid begon rond 1900 . Weliswaar kende Nederland sedert 1854 een Armenwet, maar deze kan moeilijk worden getypeerd als socialezekerheidsregeling. Verlening van onderstand was immers een gunst, die een gemeente in zeer beperkte gevallen kon, maar zeker niet moest verlenen. De in 1846 tot stand gekomen Pensioenwet had meer het karakter van een socialezekerheidsregeling, ook al omdat sprake was van een recht op pensioen als was voldaan aan bepaalde vereisten. ${ }^{55} \mathrm{Bij}$ deze regeling speelden echter niet alleen de belangen van de ambtenaren een rol, een belangrijke reden om tot deze regeling te komen was dat zij in het staatsbelang werd geacht, ${ }^{56}$ evenals overigens het geval was bij de Armenwet $1854^{57}$

Tegen het einde van de negentiende eeuw groeide het besef dat de arbeiders een bescherming nodig hadden in het geval zij werden getroffen door een ongeval en (tijdelijk dan wel permanent) niet meer konden voorzien in hun levensonderhoud en dat van hun familie. Door de industrialisatie waren de risico's op bedrijfsongevallen sterk toegenomen, terwijl de arbeider voorts zijn enige bron van inkomen, zijn arbeidskracht, niet meer vrij kon exploiteren. Meestal had hij geen andere keuze dan in de fabriek te gaan werken. Daar kwam bij dat door de grote concurrentie de prijs voor de arbeid, het loon dus, laag was, zodat de arbeider geen reservepotje kon opbouwen om financiële tegenslagen op te vangen.

Tegen deze achtergrond ontstond in Europa de gedachte aan een arbeidersverzekering. In eerste instantie speelde hierbij de vraag of dit een vrijwillige dan wel een verplichte verzekering diende te zijn. De ervaring had echter geleerd dat verzekering op vrijwillige basis niet werkte; zij die de verzekering het hardst nodig hadden, zagen er vaak het belang niet van in en hadden ook vaak de financièle middelen er niet voor. Verder stapten zij er ook het eerst uit bij tegenslag. Onder meer om deze redenen werd gekozen voor een wettelijk verplicht stelsel, allereerst in Duitsland, waar onder leiding van Bismarck in 1883 het Krankenversicherungsgesetz, in 1884 het Unfallversicherungsgesetz en in 1889 het Invaliditäts- und Alterversicherungsgesetz tot stand kwamen, later in andere landen. ${ }^{58}$

verwarring cen einde in zijn arrest van 18 april 1997, NJ 1997, 499.

55. De pensioeriwetgeving zal in 7.3 aan de orde komen.

56. Zie 7.2.2.1 en 7.3.2.

57. Zie hierover 6.2.1.

58. Levenbach (1953), blz. 778, Mannoury/Asscher-Vonk (1987), blz. $48-49$ en De Leede (2001), blz. 322. 
In 6.3.2 zal ik ingaan op de ontwikkeling en uitbouw van het socialezekerheidsrecht in de jaren tussen 1901 (inwerkingtreding Ongevallenwet 1901) en 1940, waarbij vooral de terugvordering en de wettelijke bepalingen hieromtrent worden besproken. In 6.3 .3 wordt bekeken of en zo ja, in hoeverre de burgerlijke rechter een rol speelde bij de terugvordering in de sociale zekerheid in deze periode. De regelingen met betrekking tot de pensioenen zullen worden behandeld in hoofdstuk 7, aangezien de pensioenwetgeving als 'sociale zekerheid voor ambtenaren' zowel onder het socialezekerheidsrecht als onder het ambtenarenrecht valt.

\subsubsection{Terugvordering in de socialezekerheidswetten voor de Tweede Wereldoor- $\log$}

Als gezegd groeide ook in Nederland het besef dat arbeiders (financiële) bescherming nodig hadden indien hen een ongeval overkwam. De eerste wet, die deze bescherming bood, was de Ongevallenwet 1901 (OW 1901). ${ }^{59}$ Deze wet, die tot stand kwam na een voorgeschiedenis van meer dan tien jaar, ${ }^{60}$ trad op 1 juni 1901 in werking, ${ }^{61}$ behoudens artikel 1, dat bepaalde dat de werklieden, op wie de wet van toepassing was, volgens de bepalingen van de wet verzekerd waren tegen de geldelijke gevolgen van ongevallen, hun in verband met de uitoefening van het bedrijf overkomen. De inwerkingtreding van dit artikel werd in artikel 116 gekoppeld aan de inwerkingtreding van de Beroepswet. Artikel 1 trad in werking op 1 februari $1903 .^{62}$

Uitgangspunt van de wet was om de arbeider, die een ongeval was overkomen in verband met de uitoefening van het bedrijf, een schadeloosstelling te verlenen, allereerst door vergoeding van medische kosten (artikel 19 OW 1901) en voorts bij tijdelijke of blijvende arbeidsongeschiktheid door betaling van een tijdelijke uitkering (artikel 20 OW 1901) dan wel, als de verzekerde zes weken na het ongeval geheel of gedeeltelijk ongeschikt was tot werken, een geregelde uitkeriugg, rente genaamd (artikell 21 OW 1901). Tevens kende de wet de mogelijkheid van een voorlopige toekenning (artikel 67 OW 1901). Volgens artikel 42 OW 1901 dienden de middelen opgebracht te worden door de werkgevers, waarbij het hen verboden was deze kosten geheel of gedeeltelijk in te houden op het loon van de werknemers (artikel 44 OW 1901). De uitvoering van de wet werd in handen gegeven van een nieuw op te richten Rijksverzekeringsbank (artikel 13 OW 1901). Voorts was van belang artikel 75 , dat de beroepsgang regelde. Beroep kon worden ingesteld bij de Raden van Beroep, ${ }^{63}$ in hoogste ressort oordeelde een 'college voor het Rijk' (lid 1). Lid 3 bepaalde dat de samenstelling van deze colleges en de wijze van behandeling van het beroep bij nadere wet dienden te

59. Wet van 2 januari 1901, houđende wettelijke verzekering van werklieden tegen geldelijke gevolgen van ongevallen in bepaalde bedrijven, Stb. 1.

60. Zie hierover De Leede (2001), blz. 322-323 en Van Soeren (1966), blz. 10.

61. Stb. 105.

62. Stb. 1902, 225.

63. In deze Raden van Beroep hadden werkgevers en werknemers zitting, artikel 75 lid 2 OW 1901 
worden geregeld. Deze 'nadere wet' werd de Beroepswet van 1902, ${ }^{64}$ welke de Centrale Raad van Beroep in het leven riep.

De Ongevallenwet 1901 kende een aantal bepalingen met betrekking tot terugvordering. Zo bepaalde het vierde lid van artikel 67, welk artikel over de voorlopige toekenning handelde, dat uitbetalingen gedaan in dat kader niet vatbaar waren voor terugvordering. Daarnaast bevatte artikel 76 enige bepalingen over de rechtsgevolgen van het (instellen van) beroep. In het derde lid van dit artikel werd bepaald dat reeds betaalde schadeloosstellingen niet konden worden teruggevorderd indien in beroep het recht op een schadeloosstelling werd ontzegd. De achterliggende gedachte was dat in de terugvordering 'eene zekere hardheid' lag, nu 'iets teruggevorderd zou worden, waarvan men zeker weet, dat het krachtens de bestemming reeds lang verbruikt is' ${ }^{, 65}$

De Ongevallenwet bleef niet de enige socialezekerheidswet. Zo werden in 1913 de Ziektewet (ZW) en de Invaliditeitswet (IW) aangenomen. ${ }^{66}$ Beide wetten kenden bepalingen met betrekking tot terugvordering van (achteraf) ten onrechte betaalde uitkeringen. Artikel 49 lid 2 ZW 1913 bepaalde:

'Indiew sew beslwit tot aitkeering vav ziekewgeld wegens strjid met de wet, an algemeenew mantrogs' van bestuur of het algemeen belang wordt vernietigd, is het krachtens dat besluit uitgekeerde ziekengeld niet vatbaar voor terugvordering:

In het oorspronkelijk ontwerp kwam deze bepaling niet voor, zij werd ingevoegd naar aanleiding van een amendement-Patijn. ${ }^{67}$ De toelichting op dit amendement verwijst naar artikel 67 OW 1901. Het verschil echter met de Ongevallenwet en de komende Invaliditeitswet was dat deze wetten terugvordering algemeen uitsloten, terwijl artikel 49 lid 2 ZW 1913 terugvordering uitsloot als het toekenningsbesluit werd vernietigd wegens strijd met de wet, een algemene matregel van bestuur of het algemeen belang. Dit liet de mogelijkheid open dat in de andere gevallen wel kon worden teruggevorderd. In de literatuur is dit standpunt dan ook verdedigd, waarbij ervan werd uitgegaan dat onrechtmatig verkregen ziekengeld buiten de 'bescherming' van artikel 49 lid 2 bleef en kon worden teruggevorderd op grond van het 'gemene' recht, met name artikel $1395 \mathrm{BW}$ (oud) ${ }^{68}$ Om een aantal redenen werd de Ziektewet niet ingevoerd in $1913,{ }^{69}$

64. Wet van 8 december 1902, tot uitvoering van artikel 75 der Ongevallenwet 1901, Stb. 208.

65. Memorie van toelichting, Tweede Kamer 1897-1898, 182, nr. 3, blz. 25. Een ander argument was dat het terugvorderen van geringe bedragen, die in de regel toch niet verhaalbaar waren, diende te worden vermeden.

66. Respectievelijk. Wet van 5 juni 1913, tot regeling der Arbeiders-ziekteverzekering, Stb. 204 en Wet van 5 juni 1913, tot verzekering van arbeiders tegen geldelijke gevolgen van invaliditeit en ouderdom, Stb. 205. De Invaliditeitswet regelde dus ook, de ouderdomsverzekering.

67. Tweede Kamer 1911-1912, 56, nr. 19, blz. 358, Voorgestelde amendementen-Patijn, VI.

68. Zie bijvoorbeeld Van Bruggen/Van Lakerveld (1930), blz. 236.

69. Zie hierover Levenbach (1953), blz. 786-790 en De Leede (2001), blz. 324-326. 
maar pas in 1929 nadat een aantal wijzigingen waren aangebracht, ${ }^{70}$ waarna de wet in werking trad op 1 augustus 1929." Artikel 49 lid 2 ZW 1913, zoals dat in 1913 luidde, werd uiteindelijk hernummerd tot artikel 55 lid 2.

De Invaliditeitswet trad wel in 1913 in werking. ${ }^{72}$ Zij bevatte de nodige bepalingen met betrekking tot de intrekking van de invaliditeitsrente, onder meer indien na de toekenning bleek dat de verzekerde zich opzettelijk invalide had gemaakt of had laten maken, in welk geval geen aanspraak bestond op rente. ${ }^{73}$ Deze intrekking had geen terugwerkende kracht; eenmaal uitbetaalde termijnen van een ingetrokken rente werden dan ook niet teruggevorderd, aldus de artikelen 119 lid 2 en 120 IW 1913. Tevens gaf de wet een regeling met betrekking tot beroep, waarin artikel 347 was opgenomen, dat handelde over de gevolgen van het beroep. Het derde lid van dit artikel bevatte een bepaling van inmiddels bekende strekking: betaalde termijnen konden niet worden teruggevorderd indien in beroep het recht op rente werd ontzegd. De memorie van toelichting bij dit artikel was buitengewoon kort; zij verwees slechts naar artikel 76 OW 1901. ${ }^{74}$

Naast de genoemde wetten kenden ook andere socialezekerheidswetten de regel dat eenmaal uitbetaalde uitkeringen niet konden worden teruggevorderd. ${ }^{75}$ Een uitzondering vormde de Kinderbijslagwet $1939,{ }^{76}$ die geen regeling met betrekking tot terugvordering kende.

Tegen de meeste besluiten van de op grond van de verschillende socialezekerheidswetten ingestelde uitvoeringsorganen ${ }^{n}$ stond voor de betrokkene beroep open bij een administratieve rechter. Hoofdregel was dat de Raden van Beroep in eerste aanleg oordeelden, met de mogelijkheid van hoger beroep bij de Centrale Raad van Beroep te Utrecht. Het in dat geval in de regel toepasselijke formele

70. Besluit van 29 juni 1929 , ter bekendmaking van den tekst van den wet van den 5 den Juni 1913 (Staatsblad no. 204) tot regeling der Arbeiders-ziekteverzekering (Ziektewet), zooals die wet laatstelijk is gewijzigd bij de wet van 24 Juni 1929 (Staatsblad no. 329), Stb. 374.

71. Besluit van 29 juni 1929 , tot bepaling van den dag, waarop de Ziektewet, met uitzondering van de artikelen 48 en 124 in werking zal treden, Stb. 375. In artikel 2 van het besluit werd de datum van inwerkingtreding van de artikelen 21,78 en 79 bepaald op 1 maart 1930.

72. Besluiten van 12 juni 1913, Stb. 272, 19 juni 1913, Stb. 281 en 25 augustus 1913, Stb. 359.

73. Artikel $114 \mathrm{j}^{\circ}$ artikel $79 \mathrm{IW}$ 1913. Andere bepalingen met betrekking tot de intrekking van de rente waren de artikelen 107 en 115.

74. Tweede Kamer 1910-1911, 258, nr. 3, blz. 105, toelichting op artikel 332 Oorspronkelijk ontwerp. Op dat moment bevatte artikel 76 OW 1901 echter geen bepaling meer met betrekking tot de terugvordering; lid 3 van dat artikel was namelijk ongeveer een jaar eerder vervallen door een misverstand. Pas in 1921 werd deze fout hersteld bij de herziening van de OW 1901.

75. Bijvoorbeeld artikel 7 lid 4, Oorlogszeeongevallenwet 1915, Stb. 214 met betrekking tot een onverschuldigd betaalde voorlopige uitkering en artikel 61 lid 3 Besluit van 17 maart 1921 (..) tot vaststelling van een algemeene maatregel van bestuur, als bedoeld bij de artikelen (...) 23 , vierde lid (...) der Ouderdomswet 1919, Stb. 538.

76. Wet van 23 december 1939 , houdende wettelijke regelen in zake kinderbijslagverzekering (Kinderbijslagwet), Stb. 806.

77. Zie over deze uitvoeringsorganen De Leede (2001), blz. 323-326 en Schoonenberg/Vleesch Dubois (1957), blz. 11-16. 
recht was neergelegd in de Beroepswet. Op deze hoofdregel bestond een aantal uitzonderingen, waarvan die in de Ziektewet de belangrijkste was. ${ }^{78}$

\subsubsection{De bevoegdheid van de burgerlijke rechter en toepassing van het burger- lijk recht}

De tendens in de periode van 1901 tot 1940 is duidelijk: eenmaal uitbetaalde uitkeringen konden niet worden teruggevorderd. Het is dan ook niet verwonderlijk dat geen gepubliceerde jurisprudentie is te vinden van de Raden van Beroep en de Centrale Raad van Beroep met betrekking tot terugvordering in deze periode. Verder waren er wetten die niets regelden met betrekking tot de terugvordering, zoals de Kinderbijslagwet 1939.

De vraag is dan of het voor de overheid mogelijk was om een actie uit onverschuldigde betaling ex artikel $1395 \mathrm{BW}$ (oud) in te stellen bij de burgerlijke rechter om zodoende het te veel betaalde terug te krijgen. In 1930, tijdens de hoogtijdagen van de gemene rechtsleer, had de Hoge Raad uitdrukkelijk overwogen dat artikel $1395 \mathrm{BW}$ (oud) als 'voorschrift van het gemeene recht ook van toepassing is op betalingen van publiekrechtelijken aard, voorzooveel niet uit de wet het tegendeel volgt'. ${ }^{79}$ Weliswaar betrof het hier een vordering van een burger, die de overheid aansprak omdat hij van mening was dat hij onverschuldigd had betaald, maar in de overwegingen van de Hoge Raad werd geen onderscheid gemaakt tussen deze situatie en het spiegelbeeld, de overheid die onverschuldigd betaalde. De overwegingen uit dit arrest heeft de Hoge Raad later nog een aantal malen herhaald ${ }^{80}$ Een beperking die de Hoge Raad aanbracht was dat uit de wet kon blijken dat artikel $1395 \mathrm{BW}$ (oud) niet van toepassing was. Dit was ook het uitgangspunt van de heersende gemene rechtsleer: het privaatrecht gold als het (al)gemene recht, tenzij een publiekrechtelijke regeling voorhanden was. ${ }^{81}$ Algemeen werd aangenomen dat de regelingen met betrekking tot terugvordering in de sociale zekerheid als lex specialis moesten worden gezien ten opzichte van de algemene regeling van onverschuldigde betaling uit het $\mathrm{BW}$. Kende de betrokken socialezekerheidswet een (uitputtend bedoelde) regeling met betrekking tot terugvordering, dan kon deze regeling niet worden omzeild door gebruik te maken van artikel $1395 \mathrm{BW}$ (oud).

Toch trachtten uitvoeringsorganen in een aantal gevallen de voor hen ongunstige terugvorderingsbepalingen, dus de bepalingen die terugvordering verboden, te omzeilen. Een voorbeeld geeft de casus die leidde tot een uitspraak van de Rechtbank Dordrecht in $1938 .^{82}$ Hattenbach was als bierbottelaarsknecht. in dienst bij Verhoeven. Op een bepaald moment kreeg Hattenbach een uitkering

78. Ik laat hierbij de Armenwet buiten beschouwing.

79. HR 14 november 1930, NJ 1931, 222, m.nt. E.M.M.

80. Büvoorbeeld in HR 10 maart 1944, NJ 1944, 267 en HIR 24 april 1957, NJ 1957, 523. Ook in deze arresten betrof het gevallen van onverschuldigde betaling door een burger aan de overheid.

81. Zie 5.2.1.

82. Rb. Dordrecht 11 mei 1938, NJ 1939, 571 
krachtens de Ziektewet. Deze uitkering was gebaseerd op een door Hattenbach en diens baas opgegeven weekloon van $f 15$, terwijl dit in werkelijkheid slechts $f 5$ bedroeg. Uiteindelijk ontving Hattenbach in totaal $f 312$ ziekengelduitkering, terwij! hij slechts recht had op $f$ 105. De bedrijfsvereniging dagvaardde Hattenbach en Verhoeven voor de burgerlijke rechter, stellende dat zij onrechtmatig hadden gehandeld jegens haar. $\mathrm{Zij}$ hadden namelijk onjuiste mededelingen gedaan omtrent het weekloon van Hattenbach, terwijl zij wisten dat deze opgave werd gevraagd met het oog op de 'hoegrootheid van de ziekengelduitkeering'. De gedaagden voerden aan dat de Ziektewet terugvordering van te veel betaald ziekengeld uitsloot, zodat de vordering niet-ontvankelijk was. De rechtbank ging ervan uit, dat zij zich beriepen op artikel 59 lid $2 \mathrm{ZW}$, het oude artikel 49 lid 2 ZW $1913 .^{83}$ Volgens de rechtbank deden de in dat artikel genoemde gevallen zich echter in casu niet voor, zodat dat verweer niet opging. De rechtbank lichtte dit niet verder toe. $\mathrm{Zij}$ overwoog voorts dat indien kwam vast te staan dat gedaagden onjuiste opgaven hadden gedaan met betrekking tot het weekloon, terwijl zij wisten waarom die opgave werd gevraagd, zoals gesteld door eiser, zij onrechtmaltig hadden gehandeld. In dat geval dienden zij de schade die de bedrijfsvereniging had geleden, de te veel betaalde ziekengelduitkering, te vergoeden. De bedrijfsvereniging werd toegelaten te bewijzen, dat haar stellingen juist waren. ${ }^{84}$

Dat de rechtbank zich bevoegd achtte van de vordering uit onrechtmatige daad kennis te nemen, lag voor de hand. Opvallend is dat zij de bedrijfsvereniging ontvankelijk achtte. Kennelijk sloot zij aan bij de opvatting dat op onrechtmatige wijze verkregen ziekengeld niet onder de regeling van artikel 59 lid 2 viel en kon worden teruggevorderd op grond van de bepalingen van het $\mathrm{BW}:^{85}$ de Ziektewet bevatte voor die situatie geen regeling en vertoonde dus een leemte, die kon worden opgevuld door het burgerlijk recht, dat immers werd gezien als het 'gemene' recht. De rechtbank achtte het gedrag van Hattenbach en Verhoeven kennelijk zo laakbaar, dat zij vond dat dezen het te veel ontvangene moesten terugbetalen. Zo sprak zij onder meer over "leugenachtig optreden'.

De Hoge Raad was dus van mening dat artikel $1395 \mathrm{BW}$ (oud) in beginsel ook van toepassing was op publiekrechtelijke betalingen, tenzij de wet zich daartegen verzette. Problematisch waren - althans op papier - de gevallen waarin de socialezekerheidswetten geen bepaling bevatten met betrekking tot het al dan niet toestaan van terugvordering van ten onrechte uitgekeerde bedragen. De enige belangrijke wet waarbij dit .het geval was, was de Kinderbijslagwet 1939. De vraag of een vordering wegens onverschuldigde betaling ex artikel $1395 \mathrm{BW}$ (oud) kon worden ingesteld bij de burgerlijke rechter heeft zich voor zover ik kan nagaan niet voorgedaan voor de Tweede Wereldoorlog. Wel heeft de Centrale

83. Zie 6.3 .2 .

84. De bedrijfsvereniging slaagde in dit bewijs en de vordering werd toegewezen, $\mathrm{Rb}$. Dordrecht 20 december 1939, folnr. 132-1937, niet gepubliceerd.

85. Zie 6.3.2 en Van Bruggen/Van Lakerveld (1930), blz. 236. 
Raad van Beroep zich in 1950 uitgelaten over de vraag, of ten onrechte uitbetaalde kinderbijslag mocht worden verrekend met nog te betalen kinderbijslag. ${ }^{86}$ Aan S. was over een aantal kwartalen kinderbijslag betaald voor onder meer zijn dochter Geertruida, die, naar de uitkeringsinstantie later bleek, moest worden beschouwd als een 'in overspel verwekt kind'. Op grond hiervan bestond geen recht op kinderbijslag voor haar. De bedrijfsvereniging besliste vervolgens dat de reeds uitbetaalde kinderbijslag onverschuldigd was betaald, zodat tot terugvordering zou worden overgegaan en wel door inhouding op de kinderbijslag voor de andere kinderen. S. ging hiertegen in beroep bij het Scheidsgerecht der Federatie van Bedrijfsverenigingen voor Ziekengeldverzekering. Dit scheidsgerecht bevestigde de beslissing voor zover deze bepaalde dat de kinderbijslag ten onrechte was uitbetaald, maar vernietigde deze voor zover dit te veel betaalde door verrekening zou worden ingehouden. Het betrok hierbij de Kinderbijslagwet voor invaliditeits-, ouderdoms- en wezenrentetrekkers uit 1948. Deze wet gaf in artikel 9 de uitdrukkelijke bevoegdheid om op grond van die wet te veel genoten kinderbijslag terug te vorderen of te verrekenen. ${ }^{87}$ De (oudere) Kinderbijslagwet gaf een dergelijke bevoegdheid niet. Het Scheidsgerecht trok hieruit de conclusie, dat de wetgever nu kennelijk wilde dat er voor verrekening een uitdrukkelijke wetsbepaling bestond. Niet meer voldoende was 'een verwijzing naar algemene rechtsregelen, gelijk vóór het tot stand komen van art. 9 wèl geschiedde'. Het Scheidsgerecht oordeelde dan ook dat de bedrijfsvereniging niet bevoegd was tot verrekening.

De Centrale Raad van Beroep vernietigde deze uitspraak. Vast stond dat geen recht op kinderbijslag bestond voor Geertruida, terwijl S. wel recht had op kinderbijslag voor de andere kinderen. De Raad oordeelde dat het uitvoeringsorgaan terecht geen kinderbijslag voor de andere kinderen had uitgekeerd,

'aangezien volgens de algemene regel, neergelegd in artikel 1395 B.W., hetgeen zonder verschuldigd te zijn is betaald, kan worden teruggevorderd en volgens de algemene regel, vervat in artikel 1461 B.W. van rechtswege schuldvergelijking plaats vindt (...), welke regelen ook in een geval, als het onderhavige, toepassing behoren te vinden, nu noch in de Kinderbijslagwet, noch elders een bepaling staat geschreven, welke hare toepasselijkheid in zodanig geval uitsluit;

O. dat (..) algemene rechtsregelen toepassing behoren te vinden, zolang de toepassing daarvan niet bij wettelijke bepaling is uitgesloten, zodat men niet kan zeggen, dat de uitdrukkelijke erkenning van een algemene rechtsregel op het ene terrein des rechts de toepassing daarvan zou uitsluiten op een ander terrein, waarop die regel niet expressis verbis is erkend'.

Is hier nu sprake van toepassing van artikel $1395 \mathrm{BW}$ (oud) en dus van toepassing van de gemene rechtsleer? Naar mijn mening niet. Weliswaar sprak de Centrale Raad van 'de algemene regel, neergelegd in artikel 1395 BW', maar hij liet hierop volgen, dat niet kon worden gezegd 'dat de uitdrukkelijke erkenning van een algemene rechtsregel op het ene terrein des rechts de roepassing daarvan zou uitsluiten op een ander terrein'. De Raad paste dus niet artikel 1395 BW (oud) toe, maar

86. CRvB 14 december 1950, AB 1951, 257.

87. Zie 6.4.2. 
de algemene rechtsregel, die in dit geval uitdrukkelijke erkenning had gevonden in het BW. Nu deze algemene rechtsregel niet uitdrukkelijk in de Kinderbijslagwet was neergelegd, wilde dit niet zeggen dat hij hier niet van toepassing was. Twee jaar later erkende de Centrale Raad als ambtenarenrechter uitdrukkelijk dat de regel dat hetgeen onverschuldigd is betaald, kan worden teruggevorderd, een algemeen rechtsbeginsel is, dat ook van toepassing is in het administratief recht. ${ }^{88}$

\subsection{Terugvordering in de sociale zekerheid na de Tweede Wereldoorlog ${ }^{40}$}

\subsubsection{Inleiding}

Voor 1940 kenden de socialezekerheidswetten dus vrijwel allemaal de bepaling dat eenmaal uitgekeerde uitkeringen niet konden worden teruggevorderd. In die tijd was de opvatting dat in terugvordering een zekere hardheid lag, aangezien zeker was dat datgene, wat men wilde terugvorderen, reeds verbruikt was. ${ }^{90}$

Blijkens de regelingen die na de Tweede Wereldoorlog tot stand kwamen, was de opvatting hieromtrent gewijzigd. Weliswaar kenden de meeste regelingen nog wel de regel dat (ten onrechte) uitbetaalde uitkeringen niet konden worden teruggevorderd, maar vrijwel steeds volgde hierop vervolgens een uitzondering: in bepaalde gevallen kon terugvordering wel plaatsvinden. Deze uitzonderingen werden tenslotte zo belangrijk, dat feitelijk de hoofdregel werd dat ten onrechte uitbetalalde uitkeringen konden worden teruggevorderd. De gevallen waarin niet kon worden teruggevorderd werden uitzondering. In 1996 is in de Wet boeten, maatregelen en terug- en invordering sociale zekerheid (WBM) het uitgangspunt radicaal gewijzigd. De socialezekerheidswetten bepalen sinds de inwerkingtreding van die wet dat ten onrechte betalde uitkeringen altijd moeten worden teruggevorderd, tenzij er dringende redenen zijn om van terugvordering af te zien.

Deze ontwikkelingen zal ik in deze paragraaf beschrijven. In 6.4 .2 zullen de ontwikkelingen in de verschillende socialezekerheidswetten, zoals die hebben plaatsgevonden tot 1978, aan de orde komen. In dat jaar trad de Wet tegengaan van oneigenlijk gebruik van te ruime bepalingen in werking, waardoor de terugvorderingsbepalingen in het socialeverzekeringsrecht werden geharmoniseerd. Die wet, alsmede de achtergrond ervan, behande! ik in 6.4.3. In $6.4 .4 \mathrm{zal}$ ik de ontwikkelingen na 1978 bekijken, gevolgd door de behandeling van de WBM (6.4.5).

88. CRvB 30 december 1952, AB 1953, 477 (Schouten-Zonnemaire), zie hierover 7.2.3.3.

89. Zie voor een kort overzicht De Boer (1981), blz. 248-249.

90. Vgl. memorie van toelichting OW 1901, Tweede Kamer 1897-1898, 182, nr. 3, blz. 25. 


\subsubsection{De ontwikkeling tot 1978}

De eerste wet die wat terugvordering betreft een breuk vormde met het verleden, was de Noodwet Ouderdomsvoorziening, welke in 1947 in werking trad. ${ }^{91}$ Op grond van artikel 12 lid 1 was het uitvoeringsorgaan, de Raad van Arbeid, bevoegd (er was sprake van een discretionaire bevoegdheid) een ouderdomsuitkering te weigeren of een toegekende uitkering in te trekken, als de betrokkene 'min of meer' opzettelijk ${ }^{92}$ - onjuiste mededelingen had gedaan of de in artikel 23 neergelegde inlichtingenverplichting niet was nagekomen. Artikel 21 lid 2 bepaalde vervolgens dat in dat geval het te veel genotene moest worden teruggevorderd. Terugvordering was dan dus geen discretionaire bevoegdheid, maar een verplichting. Volgens de memorie van toelichting was een dergelijke verstrekkende verplichting noodzakelijk om krachtig te kunnen optreden. ${ }^{93}$ Een periode waarover kon worden teruggevorderd gaf de wet niet. Volgens de heersende opvatting betekende dit dat moest worden teruggevallen op de algemene verjaringsbepalingen uit het BW. Dit betekende dat op grond van artikel $2004 \mathrm{BW}$ (oud) een verjaringstermijn gold van dertig jaar waarbinnen kon worden teruggevorderd.

De Werkloosheidswet ${ }^{94}$ kende ook de bevoegdheid voor het bestuursorgaan om het besluit tot toekenning van de uitkering in te trekken, maar dit mocht slechts indien het besluit was genomen in strijd met deze wet en zulks was te wijten aan het toedoen van de werknemer (artikel 30 lid 6). De vraag is wat moest worden verstaan onder toedoen. De parlementaire stukken gaven hierover geen uitsluitsel. In 1954 overwoog de Centrale Raad van Beroep dat slechts sprake was van toedoen, als de werknemer iets deed of naliet wat hij niet had behoren te doen of na te laten. ${ }^{95}$ Anders dan in de Noodwet Ouderdomsvoorziening (waarin niet werd gesproken van toedoen) was (kennelijke) opzet niet vereist, zo blijkt uit een uitspraak van de Centrale Raad van Beroep uit 1955: onder toedoen viel ook niet-opzettelijk doen of nalaten. ${ }^{96}$ Was sprake van toedoen, dan kon het te veel betaalde worden teruggevorderd.

Ook in de kinderbijslagwetten verschenen bepalingen met betrekking tot terugvordering. Artikel 9 van de in 1948 tot stand gekomen Kinderbijslagwet voor

91. Wet van 24 mei 1947 houdende een voorloopige regeling ter voorziening in den nood van ouden van dagen, Stb. H 155.

92. Memorie van toelichting. Tweede Kamer 1946-1947, 362, nr. 3, blz. 7.

93. Tweede Kamer 1946-1947, 362, nr. 3, blz. 8. De memorie van toelichting gebruikte overigens het woord 'bevoegdheid', maar stelde tevens: 'in dat geval moèt terugvordering plaatshebben'. In 1954 werd deze verplichting omgezet in een bevoegdheid, artikel IX Wet van 3 februari 1954, houdende wijziging van de Noodwet Ouderdomsvoorziening, Stb. 62. Volgens de memorie van toelichting geschiedde dit om in zeer bijzondere gevallen geheel of gedeeltelijk van terugvordering te kunnen afzien, Tweede Kamer 1953-1954, 3294, nr. 5, blz. 6.

94. Wet van 9 september 1949 tot verplichte verzekering van werknemers tegen geldelijke gevolgen van onvrijwillige werkloosheid, Stb. J 423.

95. CRvB 19 oktober 1954, AB 1955, 125.

96. CRvB 12 juli 1955, AB 1956, 242. Zo ook onder meer CRvB 13 december 1955, AB 1957, 12. 
invaliditeits-, ouderdoms- en wezenrentetrekkers ${ }^{97}$ bepaalde dat te veel genoten kinderbijslag kon worden teruggevorderd of verrekend met later uit te betalen kinderbijslag of renten en uitkeringen ingevolge andere genoemde socialezekerheidswetten. Dit behoefde geen nadere toelichting volgens de memorie van toelichting. ${ }^{98}$ Intrekking was geen vereiste voor terugvordering.

De wijziging van de Kinderbijslagwet in $1950^{99}$ introduceerde een nieuwe terugvorderingsgrond. Op grond van artikel 82 lid 2 kon ten onrechte uitbetaalde kinderbijslag gedurende twee jaren na de betaalbaarstelling worden teruggevorderd, indien de betrokkene redelijkerwijze kon weten dat ten onrechte kinderbijslag werd uitbetaald. Terugvordering was dus niet slechts mogelijk als sprake was van opzettelijk toedoen door de betrokkene - in dat geval kon hij immers redelijkerwijs weten dat te veel was uitbetaald -, maar ook als bijvoorbeeld sprake was van een vergissing van het uitvoeringsorgaan, mits het feit dat ten onrechte was uitbetaald, redelijkerwijs bekend had kunnen zijn bij degene die de kinderbijslag ontving. ${ }^{100}$ De Kinderbijslagwet kende geen bepalingen met betrekking tot de intrekking van de toekenningsbeslissing. Kennelijk was intrekking niet vereist alvorens kon worden teruggevorderd. Opvallend is verder dat terugvordering werd beperkt tot een periode van twee jaren na de dag van betaalbaarstelling.

Vervolgens kregen ook de Algemene Ouderdomswet, die in 1956 de Noodwet Ouderdomsvoorziening verving, ${ }^{101}$ de Invaliditeitswet, zoals gewijzigd in $1957^{102}$ en de Algemene Weduwen- en Wezenwet ${ }^{103}$ terugvorderingsbepalingen. ${ }^{104}$ In al deze wetten kon worden teruggevorderd - er was dus sprake van een discretionaire bevoegdheid - nadat de toekenningsbeslissing was ingetrokken. Intrekking was meestal mogelijk als sprake was een schending van de inlichtingenplicht. ${ }^{105}$ Een termijn waarbinnen of waarover kon worden teruggevorderd kenden deze wetten niet.

97. Wet van 15 juli 1948 , houdende regeling tot toekenning van kinderbijslag aan invaliditeits-, ouderdoms- en wezenrentetrekkers (Kinderbijslagwet voor invaliditeits-, ouderdoms- en wezenrentetrekkers), Stb. I 309.

98. Tweede Kamer 1947-1948, 738, nr. 5, blz. 4.

99. Wet van 21 augustus 1950 tot nadere wijziging van de Kinderbijslagwet en Kinderbijslagwet voor invaliditeits-, ouderdoms- en wezenrentetrekkers, Stb. 369.

100. Tweede Kamer 1949-1950, 1332, nr. 5, blz. 6. Een geval waarin betrokkene redelijkerwijs had kunnen weten dat ten onrechte kinderbijslag werd uitbetaald, geeft CRvB 27 april 1962, RSV 1962, 120; een voorbeeld waarin dit niet zo was CRvB 9 november 1962, AB 1963, 732.

101. Wet van 31 mei 1956 inzake een algemene ouderdomsverzekering (Algemene Ouderdomswet), Stb. 281 .

102. Wet van 11 juli 1957 tot nadere wijziging van de Invaliditeitswet, Stb. 259.

103. Wet van 9 april 1959, inzake een algemene weduwen- en wezenverzekering (Algemene Weduwenen Wezenwet), Stb. 139.

104. Respectievelijk artikel 20 lid 2 AOW, artikel 120 IW en artikel 35 lid 2 AWW.

105. Bijvoorbeeld artikel 119 lid $5 \mathrm{IW}$ en artikel $49 \mathrm{AWW}$. Overigens waren er nog andere intrekkingsgronden, bijvoorbeeld als een weduwe, die op grond van de IW weduwenrente ontving. hertrouwde (artikel 119 lid 4 IW). Ook dan kon het te veel betaalde worden teruggevorderd. 
Een dergelijke termijn kende de Wet op de arbeidsongeschiktheidsverzekering ${ }^{106}$ uit 1966 wel; de terugvorderingsbevoegdheid was beperkt tot een periode van twee jaar (artikel 57 lid 2). Over deze termijn zei de toelichting slechts dat het wenselijk werd geacht een grens te stellen aan de mogelijkheid tot terugvordering. ${ }^{107}$ Ook in de WAO was de belangrijkste terugvorderingsgrond het schenden van de inlichtingenplicht (artikel 57 lid 2 onder a). Als gevolg van het in werking treden van de WAO werd de Ziektewet angepast, ${ }^{108}$ waarbij de terugvorderingsbevoegdheid werd beperkt tot een periode van twee jaren na de dag van betaalbaarstelling (artikel 33 lid 2). In de Ziektewet was terugvordering alleen mogelijk als te veel of ten onrechte ziekengeld was uitbetaald als gevolg van het verstrekken van onjuiste inlichtingen of het niet nakomen van de inlichtingenplicht. Volgens de memorie van toelichting voorkwam het stellen van een tijdslimiet van twee jaren dat de betrokkene nog vele jaren kon worden aangesproken op grond van ten onrechte of te veel ontvangen ziekengeld. ${ }^{109}$

De Algemene Arbeidsongeschiktheidswet uit $1975^{110}$ gaf vervolgens de mogelijkheid tot terugvordering indien ten onrechte of te veel was betaald als gevolg van schending van de inlichtingenplicht (artikel 48 lid 2 onder a) óf indien het de betrokkene redelijkerwijs duidelijk moest zijn geweest dat ten onrechte of te veel was uitbetaald (artikel 48 lid 2 onder b). In beide gevallen kon worden teruggevorderd gedurende twee jaren na de dag van de betaalbaarstelling. Vervolgens werd ook artikel 57 WAO in gelijke zin gewijzigd. ${ }^{11}$

Samengevat was tot 1978 het uitgangspunt in het socialezekerheidsrecht dat eenmaal uitbetaalde uitkeringen niet konden worden teruggevorderd. Op dit uitgangspunt maakten steeds meer wetten een uitzondering: terugvordering was wel toegestaan indien de betrokkene een verwijt kon worden gemaakt, ofwel omdat hij zijn inlichtingenplicht had geschonden, ofwel omdat hij wist of redelijkerwijs had kunnen weten dat hij te veel of ten onrechte kreeg uitbetaald. Wel diende in de meeste gevallen de uitkering eerst te worden ingetrokken. In een aantal gevallen werd een terugvorderingstermijn van twee jaar na betalbaarstelling opgenomen. In de andere gevallen werd aangenomen dat de verjaringstermijnen uit het $\mathrm{BW}$ van toepassing waren.

Daarnaast was terugvordering, evenals intrekking, een discretionaire bevoegd-

106. Wet van 18 februari 1966, inzake een arbeidsongeschiktheidsverzekering (Wet op de arbeidsongeschiktheidsverzekering), Stb. 84.

107. Memorie van toelichting, Tweede Kamer 1962-1963, 7171, nr. 3, blz. 63.

108. Wet van 18 februari 1966 tot wijziging van de Ziektewet (Aanpassing aan de Wet op de arbeidsongeschiktheidsverzekering), Stb. 85.

109. Tweede Kamer 1962-1963, 7171, nr. 8, blz. is.

110. Wet van 11 december 1975 tot vaststelling van een algemene arbeidsongeschiktheidsverzekering (Algemene Arbeiđsongeschiktheidswet), Stb. 674.

111. Artikel VII, onderdeel M Wet van 8 september 1976 tot aanpassing van het Wetboek van Koophandel en van een aantal wetten in verband met de Algemene Arbeidsongeschiktheidswet alsmede nadere wijziging van enkele socialeverzekeringswetten, Stb. 473. 
heid van het uitkeringsorgaan. Dit betekende dat de rechter de beslissing om tot terugvordering over te gaan marginaal kon toetsen: had het bestuursorgaan in redelijkheid tot de beslissing kunnen komen? ${ }^{112}$ Ook moest de rechter toetsen of de hantering van de bevoegdheid strijd opleverde met enig (ander) algemeen rechtsbeginsel of in het algemeen rechtsbewustzijn levend beginsel van behoorlijk bestuur. ${ }^{113}$

\subsubsection{Wet tegengaan van oneigenlijk gebruik van te ruime bepalingen}

In 1977 vond een harmonisatie van de terugvorderingsbepalingen in de socialeverzekeringswetten plaats. Aanleiding hiervoor was het kennelijk toenemend misbruik en oneigenlijk gebruik van deze wetten en samenhangend hiermee de toenemende belangstelling voor dit verschijnsel. Sinds het eind van de jaren zestig verschenen hierover steeds meer berichten, artikelen en nota's. ${ }^{114}$ Dit leidde in 1972 onder meer tot een (interim)rapport van (een werkgroep van) de Sociale Verzekeringsraad (SVR). ${ }^{115}$ Dit rapport werd in 1975 en 1976 gevolgd door een aantal rapporten van de SVR inzake het oneigenlijk gebruik van de socialeverzekeringswetten, ${ }^{116}$ waaronder het deelrapport Terugvorderingsmogelijkheden in de sociale verzekeringswetten. ${ }^{117}$ Hierin gaf de SVR zijn visie op de vraag hoe in geval van oneigenlijk gebruik, waarbij de verzekerde wist of in redelijkheid had kunnen weten dat hij ten onrechte een uitkering kreeg, terugvordering diende plaats te vinden. De raad onderkende twee mogelijkheden, namelijk het schrappen van alle terugvorderingsbepalingen, zodat artikel $1395 \mathrm{BW}$ (oud) van toepassing zou worden of het in de socialeverzekeringswetten opnemen van bepalingen als in de Kinderbijslagwet, namelijk dat tot terugvordering kon worden overgegaan als de betrokkene redelijkerwijs wist of kon weten dat te veel was uitgekeerd. ${ }^{118}$ De keuze viel op de tweede mogelijkheid. De reden hiervoor was dat geschillen in dat geval bij de Raden van Beroep en de Centrale Raad van Beroep zouden terechtkomen en deze instanties dus alle geschillen zouden berechten inzake het socialeverzekeringsrecht. Ten aanzien van de andere: mogelijkheid overwoog, hij dat sprake was van. een 'schijnbare oplossing'; er was slechts sprake van onverschuldigde betaling nadat de aan de betaling ten grondslag liggende toekenningsbeslissing

I12. Zie bijvoorbeeld RvB 's-Hertogenbosch 20 december' 1960, AB 1961, 570, CRvB 11 mei 1966, AB 1967, 578, CRvB 31 december 1970, RSV' 1971, 142 en CRvB 15' oktober 1973, RSV 1974, 112.

113. Zie bijvoorbeeld RvB Roermond 28 juli 1964, bevestigd door CRvB, 22 december 1964, RSV 1965, 22 en CRvB 30. september 1976, RSV' 1977, 36.

114. Zie voor een (kennelijk niet uitputtend) overzicht bijlage II bij het te noemen rapport van de SVR, Tweede Kamer 1972, 11 965, nr. 3, blz. 13.

115. Tweede Kamer 1972, 11 965, nr. 3.

116. Tweede Kamer 1974-1975, 13 441, nrs. 1-3, 1975-1976, nrs. 4-7 en 1976-1977, nr. 8. Wat de SVR verstond onder oneigenlijk gebruik is omschreven in de tweede paragraaf van zijn algemeen rapport, Tweede. Kamer 1974-1975, 13 .441, nr. 2, blz. 4-5.

117. Tweede Kamer 1976-1977, 13 441, nr. 8:

118. Tweede Kamer 1976-1977, 13 441, nr. 8, blz. 4. 
was ingetrokken. Of een dergelijke intrekking mogelijk was en zo ja, onder welke voorwaarden, diende te worden geregeld in de wet, waarbij de beslissing tot intrekking kon worden aangevochten voor de bestuursrechter. Pas nadat de intrekking onaantastbaar was geworden, kon een actie wegens onverschuldigde betaling bij de burgerlijke rechter worden aangespannen. ${ }^{119}$

Tevens besteedde het rapport aandacht aan de vraag of bij een verruiming van de terugvorderingsmogelijkheden een beperking in de tijd van de terugvordering wenselijk was. ${ }^{120}$ De conclusie van de SVR luidde dat de terugvorderingstermijn diende te worden beperkt, en wel tot vijf jaar als de fout bij de verzekerde lag $^{121}$ en tot twee jaar wanneer de fout niet bij de verzekerde lag, maar bijvoorbeeld bij het uitvoeringsorgaan. Uit de voorstellen van de SVR tot wijziging van de verschillende wetten blijkt dat de tweejarentermijn alleen gold als de betrokkene redelijkerwijs kon weten dat ten onrechte of te veel werd uitbetaald. ${ }^{122}$

Het belangrijkste argument voor deze beperking in de tijd werd ontleend aan de memories van toelichting bij de Ziektewet 1967 en de WAO: het was onwenselijk dat te lange tijd na de betaling kan worden teruggevorderd. Een argurnent tegen een beperking in de tijd was dat door onbeperkte terugvorderingsmogelijkheden extreme gevallen konden worden aangepakt. ${ }^{123}$ Vervolgens concludeerde de SVR dat de voornoemde beperking diende te worden aangebracht. Over de afwegingen die tot deze conclusie leidden, is niets terug te vinden in het rapport.

Naar aanleiding van deze rapporten diende de regering op 3 december 1976 het ontwerp in voor de wet tegengaan van oneigenlijk gebruik als gevolg van te ruime bepalingen (hierna: Wet tegengaan oneigenlijk gebruik), ${ }^{124}$ die onder meer de terugvorderingsregels en -termijnen in de socialeverzekeringswetten moest harmoniseren. In dit wetsontwerp werden de voorstellen en de toelichting van de rapporten van de SVR overgenomen. Het ontwerp werd eind 1977 aangenomen en trad begin 1978 in werking. ${ }^{125}$ Hierdoor werden de terugvorderingsbepalingen in de $A O W, A W W, A A W, W W, Z W, W A O$ en de kinderbijslagwetten geünificeerd. Uitgangspunt was dat terugvordering niet kon plaatsvinden, tenzij de uitkeringsgerechtigde redelijkerwijs kon weten dat ten onrechte of te veel was uitbetaald. In dat laatste geval kon worden teruggevorderd (er was dus sprake van een discretionaire bevoegdheid), maar slechts gedurende twee jaar, wanneer de fout niet bij de verzekerde lag, maar bijvoorbeeld bij het uitvoeringsorgaan, of vijf jaar, wanneer

119. Tweede Kamer 1976-1977, 13 441, nr. 8, blz. 4.

120. Tweede Kamer 1974-1975, 13 441, nr. 8, blz. 4-5.

121. Deze termijn van vijf jaar werd overgenomen uit de Algemene Bijstandswet, zie 6.2.3.

122. Tweede Kamer 1974-1975, 13 441, nr. 8, blz. 7-11.

123. Tweede Kamer $1974-1975,13441$, nr. 8, blz. 5.

124. Nadere wijziging van een aantal sociale verzekeringswetten, enkele belastingswetten en de Wet Werkloosheidsvoorziening (tegengaan van oneigenlijk gebruik als gevolg van te ruime bepalingen), Tweede Kamer 1976-1977, 14 280, nrs. 1-2.

125. Wet van 14 december 1977, Stb. 570. De inwerkingtreding werd geregeld in artikel XVII. 
de fout lag bij de verzekerde. ${ }^{126}$ Deze termijnen waren vervaltermijnen. ${ }^{127}$

De regering deelde dus het standpunt van de SVR dat niet moest worden aangesloten bij artikel $1395 \mathrm{BW}$ (oud). De memorie van toelichting gaf hiervoor nog een tweede argument, naast dat van de SVR:

'(W)anneer ten aanzien van sociale verzekeringsuitkeringen zonder meer zou worden aangesloten bij artike! 1395 van het Burgerlijk Wetboek, (zou) terugvordering van hetgeen ten onrechte of tot een te hoog bedrag is uitbetaald, in alle gevallen mogelijk (...) zijn, ook in die gevallen, waarin sprake is van een fout van een uitvoeringsorgaan en het de uitkeringsgerechtigde redelijkerwijs niet duidelijk kan zijn geweest, dat hij ten onrechte of te veel heeft ontvangen. In deze gevallen zou naar de mening van de eerste ondergetekende terugvordering onbillijk zijn. In verband hiermede is in de sociale verzekeringswetten gekozen voor een ander systeem, waarbij de hoofdregel is, dat eenmaal uitbetaalde termijnen van sociale verzekeringsuitkeringen in beginsel niet vatbaar zijn voor terugvordering. behoudens in bepaalde bij de wet omschreven gevallen'. ${ }^{128}$

Kennelijk was zij van mening dat als de betreffende wetten geen terugvorderingsbepalingen zouden bevatten, artikel $1395 \mathrm{BW}$ (oud) van toepassing zou zijn. ${ }^{129}$

\subsubsection{De situatie in de socialeverzekeringswetten vanaf 1978}

\subsubsection{Inleiding}

Nadat in 1978 de Wet tegengaan oneigenlijk gebruik in werking was getreden, kenden nagenoeg alle socialeverzekeringswetten vrijwel eenzelfde procedure op het terrein van de terugvordering. Deze procedure werd vervolgens verder uitgewerkt (en geharmoniseerd) door de jurisprudentie.

Binnen de terugvorderingsprocedure viel een aantal stappen te onderscheiden. Zo kreeg de betrokkene pas een financiële aanspraak op het overheidsorgaan dat de betreffende socialezekerheidswet uitvoerde nadat dit een toekenningsbeslissing had genomen. Deze beslissing kon echter om verschillende redenen onjuist zijn. Zoals in de vorige paragraaf beschreven, was het uitgangspunt dat eenmaal uitbetaalde uitkeringen niet konden worden teruggevorderd. Op dit uitgangspunt werd een uitzondering gemaakt als door toedoen van de betrokkene ten onrechte of te veel was uitbetaald of als sprake was van een administratieve vergissing en de

126. Kennelijk ging men ervan uit, dat bij een fout van de betrokkene deze tevens redelijkerwijs kon weten dat te veel was betaald. Dit hoeft niet zo te zijn. Zie hierover De Boer (1981), blz. 252.

127. Vgl. memorie van antwoord "Tweede Kamer 1976-1977, 14 280, nr. 5, blz. 36.

128. Tweede Kamer 1976-1977, 14 280, nr. 3, blz. 20.

129. In het voorlopig verslag verwierpen de P.P.R. en P.S.P.-fracties deze opvatting: 'De Regering (..) wijst erop dat (artikel 1395 BW) automatisch in werking zou treden, wanneer de huidige bepaling in de diverse sociale wetten, dat uitkeringen niet terugvorderbaar zijn, zouden worden geschrapt. Maar (...) die bepalingen zijn bij het vaststellen van de betreffende wetten toch niet voor niets opgenomen? Artikel 1395 BW ziet op civiel-rechtelijke verbintenissen tussen in principe gelijkwaardige partijen. (...) De aan het woord zijnde leden vonden het dan ook absurd dat artikel 1395 BW aberhaupt in de discussie is betrokken', Tweede Kamer 1976-1977, 14280 , $\mathrm{nr} .4$, blz. 18. De regering deelde blijkens de memorie van antwoord dit standpunt niet, Tweede Kamer 1976-1977, 14 280, nr. 5, blz. 34. 
betrokkene dit redelijkerwijs had kunnen weten. Alvorens in die gevallen tot terugvordering te kunnen overgaan, moest vaststaan dat onverschuldigd was betaald. Dit was niet zo zolang de toekenningsbeschikking in stand bleef; deze moest dus eerst worden ingetrokken. ${ }^{130}$ Hiertoe diende het bestuursorgaan een intrekkingsbesluit te nemen. Vervolgens diende het een terugvorderingsbesluit en een invorderingsbesluit te nemen. Op deze verschillende stappen zal ik ingaan.

\subsubsection{De toekenningsbeslissing}

Alvorens een uitkering werd toegekend, diende het uitvoeringsorgaan over de nodige informatie te beschikken om te kunnen vaststellen of een recht op uitkering bestond. Op de betrokkene rustte de plicht alle inlichtingen te geven, waarvan hij wist of kon vermoeden dat zij van invloed waren op het recht op of de hoogte van de uitkering. Deze informatieplicht bestond niet alleen op het moment van de aanvraag, maar ook daama. Schending ervan gaf in vrijwel alle gevallen het bestuursorgaan een grond het te veel of ten onrechte betaalde terug te vorderen. In dat geval was sprake van 'toedoen' door de betrokkene. Dit werd in een circulaire van de Federatie van Bedrijfsverenigingen (FBV) omschreven als 'een verwijtbaar, laakbaar, toerekembaar handelen of nalaten, bestaande in het verstrekken van geen of onjuiste inlichtingen dan wel het achterhouden van gegevens waarvan de mededelingsplichtige redelijkerwijs kan weten dat deze van belang zijn voor het recht op, de hoogte van of de uitbetaling van de uitkering of de voorziening'. ${ }^{131}$ Het maakte geen verschil of de schending opzettelijk geschiedde of niet. ${ }^{132}$

Ook kon het bestuursorgaan een fout maken, waardoor de betrokkene meer kreeg uitbetaald dan waarop hij volgens de wettelijke regeling recht had. Hierbij moesten twee gevallen worden onderscheiden: het bestuursorgaan had een feitelijke fout gemaakt en meer uitbetaald dan waarop de betrokkene aanspraak had volgens de (correcte) beschikking of het bestuursorgaan had een foutieve beschikking genomen waardoor de betrokkene aanspraak kreeg op een hoger bedrag dan waarop hij recht had. Hier is slechts het laatste geval van belang. ${ }^{133}$ Een dergelijke administratieve vergissing leverde een terugvorderingsgrond op als tevens sprake was van tekortschieten door de betrokkene; deze had redelijkerwijs kunnen of moeten ${ }^{134}$ begrijpen dat een vergissing was gemaakt. Of dit zo was, moest van geval tot geval worden bekeken, waarbij in de rechtspraak een aantal criteria is

130. Onder intrekken versta ik mede herzien met terugwerkende kracht, zie I.7.

131. Circulaire FBV inzake terugvorderingsbeleid bedrijfsverenigingen, $\mathrm{nr}$. C 820 d.d. 28 september 1992, gepubliceerd in: Documentatie orgaan Sociale Verzekering, 24 oktober 1992, blz. 216.

132. Dit bleek al uit CRvB 12 juli 1955, AB 1956, 242, zie 6.4.2. Uit CRvB 4 april 1989, RSV 1989 , 269 bleek dat het feit dat er geen sprake was van opzet of kwade trouw wel kon meespelen bij de vraag of het bestuursorgaan in redelijkheid het te veel betaalde bedrag volledig kon terugvorderen. Vooral als het bestuursorgaan ook een verwijt kon worden gemaakt, kon dit in de weg staan an volledige terugvordering. Zie bijvoorbeeld ook CRvB 15 februari 1989, RSV 1989, 227 en CRvB 20 december 1989, RSV 1990, 315.

133. In het andere geval kon het bestuursorgaan meteen tot terugvordering overgaan, zie 6.5.5.

134. Bijvoorbeeld CRvB 30 januari 1991, RSV 1992, 17. 
ontwikkeld. Zo moest het op het moment van uitbetaling redelijkerwijs duidelijk (kunnen) zijn dat de uitbetaling ten onrechte plaatsvond. ${ }^{135}$ Als de betrokkene een specificatie van de betaling ontving, leidde dit eerder tot het oordeel dat hij dit redelijkerwijs had kunnen weten. ${ }^{136}$ Hierbij speelde zijn maatschappelijke positie en de ingewikkeldheid of duidelijkheid van de specificatie mee. Ook mocht soms van betrokkene enige activiteit worden verwacht, bijvoorbeeld door te informeren of een uitkering terecht werd betaald als hij hiervan niet zeker was. ${ }^{137}$

Deze criteria kwamen voor wat betreft de werknemersverzekeringen terug in de genoemde circulaire van de FBV. Volgens deze circulaire speelde een rol: de verhouding tussen hetgeen belanghebbende had behoren te ontvangen en hetgeen hij ontving, ${ }^{138}$ de verhouding tussen hetgeen hij voorheen aan uitkering genoot en hetgeen hij ontving, de lengte van de periode waarover te veel of ten onrechte werd betaald, de door het uitkeringsorgaan verstrekte informatie over het recht op en de hoogte van de uitkering, ${ }^{139}$ de maatschappelijke positie van betrokkene, zijn opleidingsniveau en zijn verstandelijke vermogens en de mate van wetskennis die van hem kon worden verwacht ${ }^{140}$ of de eerdere ervaringen die iemand had gehad met verhoging of verlaging van zijn uitkering.

\subsubsection{De intrekkingsbeslissing}

Alvorens het bestuursorgaan kon overgaan tot terugvordering van het te veel betaalde, moest vaststaan dát onverschuldigd was betaald. In de regel moest hiertoe de toekenningsbeschikking worden ingetrokken. ${ }^{14 !}$ Eerst daarna was de rechtsgrond aan (een deel van) de betaling ontvallen en stond de onverschuldigdheid ervan vast, zodat het bestuursorgaan kon overgaan tot terugvordering indien zich een van de twee hiervoor omschreven terugvorderingsgronden voordeed. ${ }^{142}$

Bij de vraag of de toekenningsbeschikking kon worden ingetrokken, speelden de algemene beginselen van behoorlijk bestuur een belangrijke rol. Zo kon als algemene regel worden gesteld dat intrekking van een begunstigende beschikking in beginsel niet toelaatbaar was als de betrokkene geen verwijt kon worden ge-

135. CRvB 23 mei 1991, RSV 1992, 290.

136. Bijvoorbeeld CRvB 9 februari 1995, RSV 1995, 228.

137. CRvB 16 februari 1993, RSV 1994, 22, m.nt. A. Rutten.

138. Bijvoorbeeld ook CRvB 6 juli 1988, RSV 1989, 54 en CRvB \& februari 1995, RSV 1995, 228.

139. Zie bijvoorbeeld ook CRvß 12 oktober 1990, RSV 1991, 235 en CRvB 10 januari 1992, RSV 1992, 292. Dat de door een bestuursorgaan verstrekte informatie er toe kon leiden dat het betrokkene niet redelijkerwijs duidelijk kon zijn dat te veel werd uitbetaald, bleek bijvoorbeeld in CRvB 19 september 1990, RSV 1992, 63.

140: Zo ook CRvB 2 november 1988, RSV 1989, 185: 'Van een aanvrager van kinderbijslag mag in het algemeen worden verwacht dat hij zicht heeft op de hoofdlijnen van de kinderbijslagwetgeving'.

141. Als er ten tijde van de betaling reeds geen rechtsgrond voor deze betaling was; - het bestuursorgaan had bijvoorbeeld meer uitbetaald dan waarop de betrokkene op grond van de (correcte) beschikking recht had -, hoefde deze beschikking uiteraard niet te worden ingetrokken.

142. CRvB 29 december 1994, RSV 1995, 197 sprak van een 'moederbeslissing', die aan de terugvorderingsbeslissing vooraf dient te gaan. 
maakt. ${ }^{143}$ De algemene beginselen van behoorlijk bestuur, met name het vertrouwensbeginsel, verzetten zich tegen een dergelijke intrekking. ${ }^{144}$ Dit betekende dus dat intrekking well mogelijk was indien de betrokkene er niet op mocht vertrouwen dat de toekenningsbeschikking in stand bleef. Dit was zo, als het feit dat de toekenningsbeschikking onjuist was, te wijten was aan een factor die voor rekening van de betrokkene kwam, ${ }^{145}$ bijvoorbeeld als deze redelijkerwijs had behoren te begrijpen dat een fout was gemaakt ${ }^{146}$ of de betrokkene de intrekking aan zichzelf had te wijten. ${ }^{147}$ Een volgende vraag was gedurende welke tijd een beschikking mocht worden ingetrokken. In het algemeen speelde ook hier weer de mate van verwijtbaarheid een rol. Hoe groter het verwijt dat de betrokkene kon worden gemaakt, hoe minder hij erop mocht vertrouwen dat het bestuursorgaan niet meer tot correctie zou overgaan. In de sociale zekerheid leek de vraag gedurende welke tijd mocht worden ingetrokken niet van groot belang nu aan de terugvordering grenzen waren gesteld. Volgens Levelt-Overmars kon uit de jurisprudentie de regel worden gedistilleerd dat een besluit kon worden ingetrokken als aan de van toepassing zijnde terugvorderingsvoorwaarden was voldaan. ${ }^{148}$

\subsubsection{De terugvorderingsbeslissing}

Door de intrekkingsbeslissing werd de betrokkene in de juiste juridische situatie geplaatst, namelijk die situatie waarin hij zich zou hebben bevonden als alle relevante gegevens bekend waren geweest bij het bestuursorgaan of als dit bestuursorgaan geen vergissing had gemaakt. De enkele intrekking had echter nog niet tot gevolg dat het bestuursorgaan direct kon terugvorderen. Daarvoor was een tweede beslissing nodig, de terugvorderingsbeslissing. Deze moest in elk geval het bedrag dat werd teruggevorderd en de grond waarop dit gebeurde, bevatten. Uiteraard speelden in het besluitvormingsproces hieromtrent de algemene beginselen van behoorlijk bestuur een rol. ${ }^{149} \mathrm{Nu}$ sprake was van een (discretionaire) bevoegdheid tot terugvordering, diende de rechter deze beslissing marginaal te toetsen.

In een lange reeks van uitspraken heeft de rechter geoordeeld dat van het bestuursorgaan mocht worden verwacht dat het de nakoming van de verplichtingen door de betrokkene effectief controleerde - bijvoorbeeld door het regelmatig toezenden van vragenformulieren of inkomstenbriefjes -, dat het alert reageerde op gebleken of vermoede onregelmatigheden - bijvoorbeeld indien vragen onbeant-

143. Rapport ABAR (1984), blz. 218 en 230-231.

144. Bijvoorbeeld Rapport ABAR (1984), blz. 223-225 en Van Wijk/Konijnenbelt \& Van Male (1999), blz. 431 en 432 . Donner (1974), blz. 266 spreekt in dit verband van het rechtszekerheidsbeginsel. Zie met betrekking tot deze terminologie 1.5.1.

145. Van Wijk/Konijnenbelt \& Van Male (1999), blz. 432. Een uitzondering hierop bestaat indien het bestuursorgaan zijn 'terugnemingsrecht' heeft verwerkt, Konijnenbelt (1975), blz. 79.

146. Rapport ABAR (1984), blz. 221 en Verheij (1997), blz. 69-70.

147. Hij heeft bijvoorbeeld onjuiste of onvolledige gegevens verstrekt.

148. Levelt-Overmars (1997), blz. 110.

149. Bijvoorbeeld CRvB 20 juli 1989, AB 1989, 42 I, RSV 1989, 305 en CRvB 19 september 1989. RSV 1989, 334, m.nt. J.L.M. Schell. 
woord waren gelaten - en dat het de ingevulde gegevens correct verwerkte. ${ }^{150}$ Deed het dit niet, dan kon dit er toe leiden dat het volledig terugvorderen van het te veel betaalde in strijd was met het zorgvuldigheidsbeginsel. ${ }^{151}$ Hierbij speelde de in de jurisprudentie ontwikkelde zogenaamde zesmaandentermijn een rol: in het algemeen mochten slechts bedragen, betaald tot maximaal zes maanden na binnenkomst van het eerste signaal dat ten onrechte of tot een te hoog bedrag werd betaald, worden teruggevorderd. De Centrale Raad van Beroep ging er namelijk van uit dat een tijdvak van zes maanden het bestuursorgaan redelijkerwijs voldoende gelegenheid bood om de gegevens te verwerken en maatregelen te treffen om verdere toename van het ten onrechte betaalde te voorkomen. Miste het bestuursorgaan een dergelijk signaal, dan diende dit voor zijn rekening te blijven, ${ }^{152}$ tenzij er sprake was van opzet aan de kant van de betrokkene. ${ }^{153}$

De financiële en sociale omstandigheden van de betrokkene speelden in het besluitvormingsproces omtrent de terugvorderingsbeslissing geen rol. Deze aspecten speelden pas mee bij de beslissing tot effectuering van de terugvordering, de invorderingsbeslissing. ${ }^{154}$

Als sprake was van toedoen door de betrokkene kon het te veel of ten onrechte betaalde gedurende vijf jaren na de betaalbaarstelling worden teruggevorderd. Was sprake van een administratieve vergissing en had de betrokkene dit redelijkerwijs kunnen weten, dan was deze termijn twee jaar. In de jurisprudentie werden deze termijnen gezien als uitwerking van het rechtszekerheidsbeginsel. ${ }^{155}$

Deze terugvorderingstermijnen zijn niet onbestreden gebleven. Volgens De Boer was het onderscheid in een tweejaren- en een vijfjarentermijn zelfs verwerpelijk. Hij ging ervan uit dat de ratio achter het onderscheid wel zal zijn geweest dat het geven van onjuiste inlichtingen of het niet-geven van inlichtingen meer verwijtbaar was dan het (alleen maar) redelijkerwijs weten dat men teveel kreeg. Volgens hem was dit niet zo. Het welbewust jarenlang toucheren van door een administratieve fout te hoge bedragen kon meer laakbaar zijn dan bijvoorbeeld het per ongeluk vergeten een mededeling te doen. Maar hij vond het onderscheid ook principieel onjuist, nu het bij terugvorderen in het administratieve recht om het vertrouwen draaide, en niet om de oorzaak van het mislopen. ${ }^{156}$

150. Bijvoorbeeld CRvB 27 december 1985, RSV 1986, 168, CRvB 20 februari 1986, RSV 1986, 198, CRvB 20 januari 1989, RSV 1989, 212 en CRvB 20 februari 1990, RSV 1990. 248.

151. Bijvoorbeeld CRvB 18 maart 1987, RSV 1988, 7.

152. Overschrijding van de zesmaandentermijn leidde niet altijd tot overschrijding van de grenzen van de zorgvuldigheid, zie bijvoorbeeld CRvB 4 oktober 1989, RSV 1990, 109.

153. Zie bijvoorbeeld CRvB 20 februari 1986, RSV 1986, 198, CRvB 16 februari 1993, RSV 1994, 22, m.nt. A. Rutten, CRvB 14 mei 1993, RSV 1994, 21, CRvB 21 oktober 1994, RSV 1995, 122, CRvB 25 oktober 1994, RSV 1995, 123 en de Circulaire FBV.

154. CRvB 19 september 1989, RSV 1989, 334, m.nt. J.L.M. Schell.

155. Bijvoorbeeld CRvB 23 mei 1991, RSV 1992, 112. Overigens hoefde de socialezekerheidsrechter veelal slechts de wettelijke termijnen toe te passen en hoefde hij zich dus niet uit te laten over de rechtsgrond van die termijnen. Dit deed bijvoorbeeld de CRvB als ambtenarenrechter wel, onder verwijzing naar het socialezekerheidsrecht, CRvB 26 april 1990, AB 1991, 157, m.nt. HH, TAR 1990, 138, zie 7.2.4.2.

156. De Boer (1981), blz. 262. 
Naar mijn mening miskent De Boer in zijn principiële verwerping dat de vertrouwensvraag van belang was bij de vraag of überhaupt kon worden teruggevorderd. Als kan worden teruggevorderd, is een andere vraag echter, gedurende welke termijn dit kan. Hierbij speelt het rechtszekerheidsbeginsel een rol. De Boer maakt tussen deze twee vragen geen onderscheid. Maar geheel onterecht was zijn kritiek niet. Als in het onderscheid tussen de termijnen de mate van verwijtbaarheid een rol speelde, dan had het criterium voor de verschillende termijnen niet moeten zijn het 'toedoen' respectievelijk het 'redelijkerwijs kunnen weten', maar had de mate van verwijtbaarheid het doorslaggevende criterium moeten zijn. In dat geval zou de vijfjarentermijn moeten gelden, daar waar de betrokkene bewust verkeerde inlichtingen had gegeven of bewust van belang zijnde inlichtingen had verzwegen en wanneer de betrokkene bewust profiteerde van een administratieve vergissing. De tweejarentermijn zou dan moeten gelden als het geven van verkeerde inlichtingen dan wel het niet-geven van relevante inlichtingen onopzettelijk geschiedde en wanneer de betrokkene niet wist dat een administratieve vergissing was begaan, maar hij dit redelijkerwijs wel had moeten of behoren te begrijpen. ${ }^{157}$

Volgens de Centrale Raad van Beroep begonnen de termijnen te lopen op het moment van de eerste terugvorderingshandeling. Deze moest de vorm hebben van een ondubbelzinnige schriftelijke mededeling dat tot terugvordering zou worden overgegaan. ${ }^{158}$ De enkele intrekking van de toekenningsbeslissing was hiervoor niet voldoende. Relevant voor de bepaling van de termijn was het tijdstip van betaalbaarstelling en dus niet de periode waarop de bedragen die betaalbaar waren gesteld, betrekking hadden. ${ }^{159}$ Van belang was dat deze termijnen vervaltermijnen waren en geen verjaringstermijnen. ${ }^{160}$ Dit had tot gevolg dat na het verstrijken van de termijn de terugvorderingsbevoegdheid zelf teniet ging; verval heeft sterke werking. ${ }^{161}$ Dit betekende dat na verloop van die termijn geen natuurlijke verbintenis ontstond. ${ }^{162}$ Daarnaast diende de rechter deze termijn ambtshalve toe te passen; men hoeft zich in rechte niet op een vervaltermijn te beroepen. ${ }^{163}$

157. Zie ook 10.4.2.

158. CRvB 12 juli 1985, RSV 1987, 96, CRvB 14 mei 1987, RSV 1988, 35, CRvB 20 februari 1990, RSV 1990, 248 en CRvB 23 december 1993, RSV 1994, 196.

159. CRvB 23 december 1993, RSV 1994, 196. Zie ook De Boer (1981), blz. 253.

160. Zie hierover Bollen (1996).

161. Asser-Hartkamp I (2000), nr. 686, Koopmann (1993), blz. 114-116 en 119-120. Een (hier niet ter zake doende) uitzondering is het geval dat een beroep op schuldverrekening mogelijk is, zie Koopmann (1993), blz. 119.

162. Zo ook Stijnen (1995), blz. 624. Volgens De Boer (1981), blz. 253, was dit in het socialezekerheidsrecht anders. Volgens hem was hier sprake van een vervaltermijn met zwakke werking. Ook de minister van Sociale Zaken en Werkgelegenheiō leek in zijn antwoord op hieromtrent gestelde kamervragen ervan uit te gaan dat door het verstrijken van de vervaltermijn een natuurlijke verbintenis ontstond, Tweede Kamer 1995-1996, Aanhangsel van de Handelingen, blz. 21732174. Weliswaar hadden deze vragen betrekking op de ABW, maar dit makt voor dit punt geen verschil. Ik deel de mening van De Boer en de minister niet. Voor een uitgebreidere behandeling en bestrijding van hun opvattingen verwijs ik naar Bollen (1996).

163. Asser-Hartkamp I (2000), nr. 688 en Koopmann (1993), blz. 118. 


\subsubsection{De invorderingsbeslissing en de executie}

Nadat het bestuursorgaan eerst een intrekkingsbeslissing en vervolgens een terugvorderingsbeslissing had genomen, stond vast dat het bestuursorgaan onverschuldigd had betaald, dat het zou gaan terugvorderen en hoeveel. Hiermee stond nog niet vast op welke wijze de tenugvordering zou worden tenuitvoergelegd, hoe deze bedragen daadwerkelijk ingevorderd zouden gaan worden. Hiertoe diende het bestuursorgaan een afzonderlijke invorderingsbeslissing te nemen. ${ }^{164} \mathrm{Bij}$ het nemen van de invorderingsbeslissing diende het bestuursorgaan rekening te houden met onder meer de financiële en sociale omstandigheden van de betrokkene. ${ }^{165}$ Als het dit niet deed, dan kon dit leiden tot vernietiging van de beslissing wegens strijd met het zorgvuldigheidsbeginsel. ${ }^{166}$

Uitgangspunt voor het bestuursorgaan diende te zijn dat de betrokkene $90 \%$ van de voor hem geldende bijstandsnorm moest overhouden voor zijn maandelijks levensonderhoud. ${ }^{167}$ Deze ' $90 \%$ '-norm was gelijk aan de beslagvrije voet zoals die was neergelegd in artikel $475 \mathrm{~d} R v$. Afwijking van deze norm ten nadele van betrokkene was mogelijk, maar diende deugdelijk te worden gemotiveerd. ${ }^{168}$ Maar ook als het bestuursorgaan de '90\%'-grens in acht had genomen, kon er sprake zijn van willekeur. ${ }^{169}$ Dat het bestuursorgaan de ' $90 \%$ '-grens had gehanteerd, moest duidelijk blijken uit de beslissing of uit de stukken die aan de beslissing ten grondslag lagen. Was dit niet het geval, dan werd de beslissing vernietigd wegens strijd met het zorgvuldigheidsbeginsel. ${ }^{170}$

Als de invorderingsbeschikking onaantastbaar was geworden, stond vast dat het bestuursorgaan ging terugvorderen en op welke wijze het dit wilde gaan doen. Dit betekende echter niet dat het nu ook tot executie kon overgaan. Hiertoe diende het over een executoriale titel te beschikken. Dit was slechts anders als de betrokkene vrijwillig terugbetaalde of een minnelijke schikking werd getroffen. Een dergelijke executoriale titel verkreeg het bestuursorgaan door een rechterlijke beschikking. De bevoegde rechter was de civiele rechter.

164. CRvB 20 juli 1989, AB 1989, 421, RSV 1989, 305. De CRvB had reeds op 22 juni 1989, RSV 1990,51 geoordeeld dat 'de beslissing om tot verrekening over te gaan niet (...) vereenzelvigd kan worden met een daaraan voorafgaande terugvorderingsbeslissing, doch, mede gelet op de afzonderlijke aan de verrekening verbonden consequenties, als een afzonderlijke aan beroep onderworpen beslissing dient te worden beschouwd'. Dit is vervolgens vaste jurisprudentie geworden, zie onder andere CRvB 19 september 1989, RSV 1989, 334, m.nt. J.L.M. Schell, CRvB 18 december 1991, RSV 1992, 291, CRvB 21 april 1993, RSV 1994, 52 en CRvB 2 augustus 1995, NJB katern 1996, blz. 108, nr. 5.

165. Bijvoorbeeld CRvB 20 juli 1989, AB 1989, 421, RSV 1989, 305 en CRvB 4 oktober 1989, RSV $1990,109$.

166. Bijvoorbeeld CRvB 18 maart 1987, RSV 1988, 7 en CRvB 13 januari 1989, RSV 1989, 209. Dat de genoemde afweging had plaatsgevonden, moest uit de bestreden beslissing blijken, CRvB 2 januari 1989, RSV 1989, 178. Deze uitspraak liet ruimte voor de mogelijkheid dat de CRvB het voldoende achtte dat uit de gedingstukken bleek dat de afweging had plaatsgevonden.

167. Zie ook de circulaire FBV.

168. CRvB 18 december 1991, RSV 1992, 291.

169. CRvB 22 september 1993, RSV 1994, 80.

170. CRvB 12 maart 1987, RSV 1988, 6. 
De invordering kon op verschillende wijzen plaatsvinden. Zo kon de betrokkene het onverschuldigd ontvangene in een keer dan well in termijnen terugbetalen, of kon het bestuursorgaan een dergelijke betaling vorderen. ${ }^{171}$ Verder kon de laatste de verschuldigde bedragen verrekenen met lopende en toekomstige uitkeringen op grond van dezelfde rechtsverhouding of eventueel met een andere uitkering. Was dit niet mogelijk, dan moest het bestuursorgaan de normale wijze van executeren, zoals neergelegd in het Wetboek van Burgerlijke Rechtsvordering toepassen. $^{172}$

\subsubsection{Samenvatting}

Uit de jurisprudentie blijkt dat het terugvorderingstraject drie beslissingen diende te omvatten: de intrekkingsbeslissing, de terugvorderingsbeslissing en de invorderingsbeslissing. Deze drie beschikkingen konden in één beslissing worden genomen. ${ }^{173}$ Was dit het geval, dan kon de belanghebbende tegen ieder element bezwaar en beroep instellen. Werden zij afzonderlijk genomen, dan was ieder van deze beslissingen een beschikking en diende tegen ieder ervan bezwaar dan wel beroep te worden ingesteld als de betrokkene het niet eens was met de beslissing. Als een van die beschikkingen rechtens onaantastbaar was geworden, dan was zij voor de rechter of het bestuursorgaan een gegeven binnen een procedure tegen een andere beschikking. Zo kon een beroep tegen de invorderingsbeschikking niet meer de intrekkings- of terugvorderingsbeschikking aantasten als deze rechtens onaantastbaar was geworden. Een invorderingsbeschikking kon dus niet worden aangevallen door te trachten alsnog de intrekkingsbeschikking te vernietigen. Was uiteindelijk de invorderingsbeschikking onaantastbaar geworden, dan kon het bestuursorgaan niet zonder meer tot executie overgaan indien de betrokkene weigerde te betalen. Hiertoe moest het eerst over een executoriale titel beschikken. Daarvoor was een uitspraak van de burgerlijke rechter nodig.

\subsubsection{Wet boeten, maatregelen en terug-en invordering sociale zekerheid}

\subsubsection{Inleiding}

In 1996 en 1997 heeft het socialezekerheidsrecht op onder meer het terrein van de terug- en invordering een metamorfose ondergaan door de inwerkingtreding van de Wet boeten, maatregelen en terug- en invordering sociale zekerheid (hierna: WBM) ${ }^{174}$ Het doel van deze wet is het bestrijden en voorkomen van oneigenlijk

171. Uiteraard gold in dat geval de ' $90 \%$ '-norm.

172. Een duidelijke samenvatting van de jurisprudentie van de CRvB met betrekking tot invordering in casu verrekening - is te vinden in CRvB 17 mei 1990, RSV 1990, 333.

173. Zie bijwoorbeeld (impliciet) CRvB 29 december 1994, RSiV 1995, 197 en CRvB 13 december 1994, RSV 1995, 227. De uitspraak van de CRvB van 6 januari 1995, AB 1995, 388 lijkt er op. te duiden dat de intrekking zelfs impliciet kan worden genomen.

174. Wet van 25 april 1996 tot wijziging van de sociale zekerheidswetten in verband met de nadere vaststelling van een stelsel van administratieve sancties, alsook tot wijziging van de daarin. vervatte regels tot terugvordering van ten onrechte betaalde uitkeringen en de invordering 
gebruik van de sociale zekerheid. Dit dient te geschieden door het versterken van de handhavingsmogelijkheden, onder meer door de terugvorderingsmogelijkheden te verruimen en, in navolging van onder meer de $\mathbf{A b w}$, de in de meeste socialezekerheidswetten bestaande bevoegdheid tot terugvordering van onverschuldigd betaalde uitkeringen om te zetten in een verplichting. Tevens is het invorderingsbeleid aangescherpt. Ook heeft een uitbreiding en aanscherping van de sancties plaatsgevonden door de uitvoeringsorganen te verplichten een boete op te leggen, indien de belanghebbende zijn verplichting om alle inlichtingen te geven die van belang kunnen zijn voor het recht op uitkering of de hoogte daarvan, niet of niet behoorlijk is nagekomen. ${ }^{175}$

In deze paragraaf zal ik het terugvorderingstraject beschrijven, zoals dat sinds de inwerkingtreding van de WBM geldt. Ook in dit traject kunnen de reeds in 6.4.4 beschreven stappen worden onderscheiden; in zoverre biedt de WBM niets nieuws. Ook nu zal het bestuursorgaan eerst een toekenningsbeslissing moeten nemen, waardoor de betrokkene een financiële aanspraak krijgt op het orgaan. De terugvordering valt vervolgens weer uiteen in drie verschillende beslissingen, namelijk de intrekkingsbeschikking, de terugvorderingsbeschikking en de invorderingsbeschikking. ${ }^{176} \mathrm{De}$ WBM heeft de terugvorderingsregelingen in het socialezekerheidsrecht verder geüniformeerd. Slechts de Abw kent op een enkel punt een afwijkende regeling. Ook aan deze afwijkingen zal aandacht worden besteed. ${ }^{177}$

De verschillende socialezekerheidswetten kenden voor de inwerkingtreding van de WBM de regel dat eenmaal uitbetaalde uitkeringen niet konden worden teruggevorderd. Slechts indien te veel of ten onrechte was betaald door toedoen van de betrokkene of door een administratieve vergissing, hetgeen de betrokkene redelijkerwijs duidelijk had kunnen zijn, was dit anders. Sinds de inwerkingtreding van de WBM is het uitgangspunt echter dat onverschuldigd betaalde uitkeringen moeten worden teruggevorderd, ongeacht de oorzaak waardoor te veel is betaald. ${ }^{178}$ De verantwoordelijke bewindslieden zagen hierin geen strijd met de algemene beginselen van behoorlijk bestuur, ook niet met het vertrouwensbeginsel. ${ }^{179}$

Op het hiervoor beschreven uitgangspunt dat alle onverschuldigd betaalde uitkeringen moeten worden teruggevorderd, onverschillig of de betrokkene een ver-

daarvan (wet boeten, maatregelen, en terug- en invordering sociale zekerheid), Stb. 248. De wet trad in werking op 1 augustus 1996, behalve voor de Awb, de IOAW en de IOAW, voor welke wetten de inwerkingtreding was bepaald op 1 januari 1997, Besluit van 4 juni 1996, Stb. 295. In de wandeling wordt ook. wel' gesproken van de Wet Boeman, zie. Verheij (1997), blz. 70, noot 72. Waarschijnlijk zal in deze paragraaf wel duidelijk worden waarom dit is.

175. Memorie van toelichting, Tweede Kamer 1994-1995, 23. 909, nr. 3, blz. I.

176. Memorie van toelichting. Tweede Kamer 1994-1995, 23 909, nr. 3, blz. 26-27.

177. Zie over de terugvorderingsbepalingen in de Abw Kooijman (1998).

178. Memorie van toelichting, Tweede Kamer 1994-1995, 23 909, nr. 3, blz. 26. Dit betekent dat zelfs in gevallen waarin de betrokkene niet wist of kon weten dat te veel is betaald, moet worden overgegaan tot terugvordering, ook als sprake is van een administratieve vergissing.

179. Memorie van antwoord, Eerste Kamer 1995-1996, 23 909, nr. 114b, blz. 7. De memorie sprak overigens van strijd met het rechtszekerheidsbeginsel. 
wijt kan worden gemaakt, zou een uitzondering worden gemaakt in de Abw. ${ }^{180}$ De bedoeling was dat door een administratieve vergissing te veel betaalde bijstand slechts kon worden teruggevorderd indien de betrokkene redelijkerwijs had kunnen begrijpen dat te veel werd betaald. Dit had in artikel 81 lid 2 moeten worden opgenomen. Voorts zou terugvordering op deze grond slechts kunnen plaatsvinden, indien de betreffende kosten van bijstand niet meer dan twee jaren voor de datum van verzending van het besluit tot terugvordering zijn gemaakt (artikel 81 lid 3). De reden voor deze uitzondering was dat de bijstand het laatste sociale vangnet vormt voor mensen, die niet zelf in hun levensonderhoud kunnen voorzien en dat het niet aangaat om deze mensen de dupe te laten worden van fouten, door het bestuursorgaan gemaakt. Deze bedoeling is echter niet in de wet neergelegd. Het eerste lid van artikel 81 geeft - onder meer - aan dat ten onrechte verleende bijstand kan worden teruggevorderd als een intrekkingsbeslissing als bedoeld in artikel 69 lid 3 of 4 is genomen. Artikel 69 lid 3 stelt dat de toekenningsbeslissing onder meer wordt ingetrokken als de betrokkene zijn inlichtingenverplichting heeft geschonden (artikel 69 lid 3 aanhef en onder a) of als de bijstand anderszins ten onrechte of tot een te hoog bedrag is verleend (artikel 69 lid 3 aanhef en onder b). Dat laatste is onder meer het geval als een administratieve vergissing is gemaakt. Deze situatie valt dus onder artikel 81 lid 1. Artikel 81 lid 2 stelt dat hetgeen anderszins (dan lid 1, dus anderszins dan door - eenvoudig gezegd - toedoen of door een administratieve vergissing) onverschuldigd is betaald, kan worden teruggevorderd voor zover het voor de betrokkene redelijkerwijs duidelijk had kunnen zijn dat onverschuldigd werd betaald. ${ }^{18 .}$

\subsubsection{Intrekking}

Met de WBM is de in de rechtspraak ontstane scheiding in het terugvorderingstraject tussen intrekking, terugvordering en invordering terechtgekomen in de diverse socialezekerheidswetten. Ik zal deze drie beslissingen afzonderlijk behandelen.

Het uitgangspunt in het socialezekerheidsrecht is dat ten onrechte betaalde uitkeringen moeten worden teruggevorderd. Alvorens echter kan worden teruggevorderd moet vaststaan dat onverschuldigd is betaald. Hiertoe moet, net als onder het oude recht, ${ }^{182}$ eerst de toekenningsbeschikking worden ingetrokken. Dit is slechts anders, indien de betrokkene meer krijgt uitbetaald dan waarop hij op grond van de correcte toekenningsbeslissing recht heeft. Door de WBM is de verplichting tot intrekking opgenomen in de verschillende wetten. ${ }^{183}$ Het in het

180. Deze uitzondering is een gevolg van het nader gewijzigd amendement Noorman, Tweede Kamer 1995-1996, 23 909, nr. 21.

181. Om artikel 81 in overeenstemrning te brengen met de bedoeling van het amendement volstaat het om in lid 1 de verwijzing naar artikel 69 lid 3 te wijzigen in een verwijzing naar artikel 69 lid 3 aanhef $\mathrm{en}$ onder $\mathrm{a}$.

182. Hierop bestonden uitzonderingen, onder andere in de Abw.

183. Ik zal hierna steeds đe WW als voorbeeld gebruiken. Ik verwijs hierbij eerst naar de nummering van de artikelleden, zoals die luidde bij de inwerkingtreding van de WBM; tussen haakjes vermeld ik de nummering zoals die sinds 1 januari 1999 geldt indien deze afwijkt van de oorspron- 
bestuursrecht geldende algemene uitgangspunt, dat intrekking van een begunstigende beschikking in beginsel niet toelaatbaar is als de betrokkene geen verwijt kan worden gemaakt, lijkt hiermee verlaten in het socialezekerheidsrecht. Het is echter niet ondenkbaar dat via de zogenaamde 'dringende reden'-bepaling de algemene beginselen van behoorlijk bestuur de intrekkingsverplichting zullen beperken. Het bestuursorgaan mag namelijk van intrekking afzien indien daartoe dringende redenen aanwezig zijn. ${ }^{184}$ De regering heeft niet aangegeven wat dringende redenen zijn. Wel stelde zij dat er iets bijzonders en uitzonderlijks aan de hand moet zijn, waarbij het om incidentele gevallen moet gaan, gebaseerd op een individuele afweging van alle relevante omstandigheden. Er kan dan ook geen sprake zijn van algemene of categoriale afwijkingen. Verder dient niet primair of uitsluitend aan financiële redenen te worden gedacht, ook immateriële redenen kunnen een rol spelen. Wel dient de toepassing van dringende redenen te geschieden met inachtneming van de algemene beginselen van behoorlijk bestuur. ${ }^{185}$ Volgens de regering betekent dit laatste dat bij toepassing van de dringende redenbepaling de eventuele tekortkomingen van het uitvoeringsorgaan en de mogelijke wetenschap van de betrokkene moeten worden betrokken. Zij ziet dan ook in de verplichting tot intrekking geen strijd met het vertrouwensbeginsel. ${ }^{186}$ Dit zal naar mijn mening slechts zo zijn als de uitvoeringsorganen de regels, zoals in de jurisprudentie gevormd op basis van de algemene beginselen van behoorlijk bestuur, in acht zullen nemen. ${ }^{187}$

Dit lijkt ook de opvatting van het Landelijk instituut sociale verzekeringen (hierna: Lisv), het bevoegde orgaan voor de sociale verzekeringen. In zijn Besluit herziening en intrekking uitkeringen ${ }^{188}$ heeft het Lisv zijn beleid bij de toepassing van de wettelijke regelingen inzake de intrekking van toekenningsbeslissingen neergelegd. Hierin maakt het Lisv een onderscheid tussen gevallen waarin sprake is van 'toedoen of redelijkerwijs duidelijk' en gevallen waarin sprake is van 'niet redelijkerwijs duidelijk'. Het beleid is, dat in geval van toedoen intrekking plaatsvindt tot de datum van toekenning of, in voorkomend geval, de datum waarop de uitkering zou zijn ingetrokken als de betrokkene aan zijn verplichting zou hebben voldaan. Had het betrokkene redelijkerwijs duidelijk kunnen zijn dat ten onrechte of te veel werd betaald, dan dient in beginsel de toekenningsbeslissing te worden ingetrokken tot het moment waarop hem dit redelijkerwijs duidelijk was of had kunnen zijn. Als het betrokkene daarentegen niet redelijkerwijs duidelijk was of

kelijke nummering. Zie voor de verplichting tot intrekking bijvoorbeeld artikel $22 \mathrm{a} W W$.

184. Bijvoorbeeld artikel $22 \mathrm{a}$ lid 2 ww.

185. Memorie van toelichting. Tweede Kamer 1994-1995, 23 909, nr. 3, blz. 68.

186. Memorie van antwoord, Eerste Kamer 1995-1996, 23 909, nr. 114b, blz. 6-7.

187. Levelt-Overmars (1997), blz. 110 lijkt er ook zo over te denken. Het feit dat een handeling in strijd zou komen met de algemene beginselen van behoorlijk bestuur ziet zij in ieder geval als cen dringende reden om van die handeling af te zien.

188. Besluit herziening en intrekking uitkeringen, 4 december 1997, Stert. 245, gewijzigd door Besluit tot wijziging van het Besluit herziening en intrekking uitkeringen, 22 april 1998, Stcrt. 89. 
kon zijn dat hij te veel of ten onrechte uitbetaald kreeg, ${ }^{189}$ dan wordt de toekenningsbeslissing ingetrokken met ingang van de datum waarop het uitvoeringsorgaan de betrokkene voor het eerst kenbaar heeft gemaakt dat te veel of ten onrechte is betaald. Deze regels zijn in overeenstemming met de voorheen geldende jurisprudentie.

\subsubsection{Terugvordering en terugvorderingstermijnen}

Nadat de toekenningsbeslissing is ingetrokken, dient het bestuursorgaan een terugvorderingsbesluit te nemen. ${ }^{190}$ Ook indien sprake is van een (uitkerings)relatie tussen de betrokkene en het bestuursorgaan en de laatste meer heeft uitbetaald dan waarop de betrokkene recht heeft op grond van de correcte toekenningsbeslissing, dient het bestuursorgaan een terugvorderingsbesluit te nemen alvorens het kan overgaan tot terugvordering. ${ }^{191}$ In dit besluit moet onder meer worden vermeld wat wordt teruggevorderd van betrokkene. ${ }^{192}$ Het bestuursorgaan kan besluiten geheel of gedeeltelijk af te zien van terugvordering indien daarvoor dringende redenen aanwezig zijn. ${ }^{193} \mathrm{Bij}$ de beantwoording van de vraag of dringende redenen om af te zien van terugvordering aanwezig zijn, dienen dezelfde criteria te worden gehanteerd als bij de vraag of er dringende redenen zijn om van intrekking af te zien. ${ }^{194}$ Door de WBM zijn niet alleen de terugvorderingsgronden geschrapt, maar ook de daaraan gekoppelde terugvorderingstermijnen. De implicatie hiervan is volgens de regering dat nu het gemene recht van toepassing is: de verjaringstermijn van de vordering uit onverschuldigde betaling uit het $\mathrm{BW}$ geldt nu. ${ }^{195}$ Volgens artikel 3:309 $\mathrm{BW}$ verjaart deze vordering

'door verloop van vijf jaren na de aanvang van de dag, volgende op die waarop de schuldeiser zowel met het bestaan van zijn vordering als met de persoon van de ontvanger is bekend geworden en in ieder geval twintig jaren nadat de vordering is ontstaan".

Slechts de Abw zou op dit punt moeten afwijken van de overige regelingen. Zoals in 6.4.5.1 besproken, is dit niet weergegeven in de tekst van de wet. De implicatie van het feit dat de verjaringstermijnen uit het BW van toepassing zijn, is dat de termijn waarover kan worden teruggevorderd, aanzienlijk is verlengd. Of dit in de praktijk ook zo zal zijn, betwijfel ik. Ik zal dit in 6.5.2 uitwerken.

Overigens heeft in 1998 al een versoepeling van de terugvorderingsbepalingen plaatsgevonden. De Wet terugvordering en verhaal in verband met herziening van

189. En er viteraard geen sprake was van 'toedoen'.

190. Bijvoorbeeld artikel 36 lid $1 j^{\circ}$ lid 3 WW (artikel 36 lid 1 jo lid 5 WW).

191. Bijvoorbeeld artikel 36 lid $1 j^{\circ}$ lid $3 \mathrm{WW}$ (artikel 36 lid $1 \mathrm{j}^{\circ}$ lid $5 \mathrm{WW}$ ):

192. Elijvoorbeeld artikel 36 lid 3 WW (artikel 36 lid 5 WW).

193. Bijvoorbeeld artike! 36 lid 2 WW (artikel 36 lid 4 WW). Zie voor een geval waarin de rechter een dergelijke dringende reden aanwezig achtte Pres. Rb. 's-Hertogenbosch 3 september 1997, USZ 1997, 296, m.nt. G.C. Boot. Het betrof een voorlopige voorziening.

194. Vgl. Rb. 's-Gravenhage 26 februari 1998, USZ 1998, 126, mnt. MD.

195. Tweede Kamer 1994-1995, 23 909, mr. 3, blz. 29-31. 
het debiteurenbeleid ${ }^{196}$ opent voor de uitvoeringsorganen de mogelijkheid om onder bepaalde voorwaarden na vijf jaar van (verdere) terugvordering af te zien, namelijk als de betrokkene vijf jaar aan zijn betalingsverplichting heeft voldaan ${ }^{197}$ of, als dat niet het geval is, alsnog het achterstallige bedrag betaalt, ${ }^{198}$ als ondanks de nodige inspanningen door het uitvoeringsorgaan nog geen aflossing heeft plaatsgevonden en niet aannemelijk is dat dit op enig moment wel zal gebeuren $^{199}$ of als betrokkene een bedrag overeenkomend met ten minste $50 \%$ van het restbedrag in een keer aflost. ${ }^{200}$ In die gevallen krijgen de uitvoeringsorganen de bevoegdheid van verdere terugvordering af te zien, waarbij zij van geval tot geval moeten bekijken of er redenen hiertoe zijn. ${ }^{201}$ Wel is er op gewezen dat het uitgangspunt blijft dat ten onrechte betaalde uitkeringen zoveel mogelijk moeten worden teruggevorderd en dat niet de gewoonte mag ontstaan dat als men maar gedurende vijf jaar keurig aflost, min of meer automatisch zal worden afgezien van verdere terugvordering. ${ }^{202}$

\subsubsection{Invordering en executie}

In aansluiting op de verplichting tot tengvordering stelt de WBM ook de invordering verplicht, ${ }^{203}$ althans in beginsel. Waarschijnlijk kan worden afgezien van invordering, indien daarvoor dringende redenen zijn, waarbij de algemene beginselen van behoorlijk bestuur een rol zullen spelen. ${ }^{204}$ In de socialezekerheidswetten is tevens een bepaalde voorkeur aangegeven voor een volgorde van de te hanteren wijzen van executie. De volgorde van mogelijke wijzen van executie van de administratieve boete is van overeenkomstige toepassing verklaard. ${ }^{205}$ Uiteraard zal de betrokkene eerst in de gelegenheid moeten worden gesteld het onverschuldigd

196. Wet van 9 april 1998, houdende wijziging van de Algemene bijstandswet, de Wet inkomensvoorziening oudere en gedeeltelijk arbeidsongeschikte werkloze werknemers, de Wet inkomensvoorziening oudere en gedeeltelijk arbeidsongeschikte gewezen zelfstandigen, de Werkloosheidswet, de Ziektewet, de Wet op de arbeidsongeschiktheidsverzekering, de Algemene Arbeidsongeschiktheidswet, de Toeslagenwet, de Algemene Ouderdomswet, de Algemene Kinderbijslagwet, de Algemene nabestaandenwet, de Wet arbeidsongeschiktheidsverzekering zelfstandigen en de Wet arbeidsongeschiktheidsvoorziening jonggehandicapten met betrekking tot terugvordering en verhasl, Stb. 278.

197. Bijvoorbeeld artikel 36 lid 2 onder a WW. In bepaalde gevallen kan na drie jaar van (verdere) terugvordering worden afgezien, zie artikel 36 lid 3 WW.

198. Bijvoorbeeld artikel 36 lid 2 onder b WW. Ook hier kan in bepaalde gevallen na drie jaar van (verdere) terugvordering worden afgezien, artikel 36 lid 3 WW.

199. Bijvoorbeeld artikel 36 lid 2 onder c WW.

200. Bijvoorbeeld artikel 36 lid 2 onder d WW.

201. Memorie van toelichting, Tweede Kamer 1997-1998, 25 661, nr. 3, blz. 5 en 12.

202. Memorie van toelichting, Tweede Kamer 1997-1998, 25, 661, nr. 3, blz. 6.

203. Tweede Kamer 1994-1995, 23 909, nr. 3, blz. 26.

204. Zo ook Kooijman (1997), blz. 11-12. Een andere uitzondering vormde het invorderen van zogenaamde kruimelbedragen, bedragen onder $f 250,-$ op jaarbasis, Brief van de staatssecretaris van Sociale Zaken en Werkgelegenheid, Tweede Kamer 1995-1996, 23 909, nr. 24, blz. 1.

205. Bijvoorbeeld artikel $36 \mathrm{a}$ lid $2 \mathrm{f}$ artikel $27 \mathrm{~g}$ WW. 
betaalde vrijwillig terug te betalen. ${ }^{206}$ Werkt hij hier niet aan nee, dan zal het bestuursorgaan moeten kijken of de betrokkene nog steeds eenzelfde uitkering ontvangt. In dat geval moet het overgaan tot verrekening. Is dat niet het geval dan dient de mogelijkheid van 'pseudo-verrekening' te worden bekeken, waarbij inhouding plaatsvindt door een ander uitvoeringsorgaan met afdracht aan het orgaan dat de terug te vorderen uitkering heeft betaald. Als dit ook niet kan leiden tot het gewenste resultaat, dient de executie plaats te vinden met de middelen die het Wetboek van Burgerlijke Rechtsvordering biedt. ${ }^{207}$ De wetgever noemt de mogelijkheid van verrekening tussen dezelfde partijen met een andere uitkering niet in de toelichting. Deze wijze van verrekening wordt in de verschillende wetten wel geregeld en verdient de voorkeur boven de pseudo-verrekening. De genoemde volgorde wordt imperatief voorgeschreven, maar afwijking van deze volgorde of het tegelijkertijd dan wel achtereenvolgens toepassen van de verschillende vormen is mogelijk en soms zelfs wenselijk. ${ }^{208} \mathrm{Bij}$ de invordering dient de beslagvrije voet te worden gehanteerd, hetgeen betekent dat $90 \%$ van de voor betrokkene geldende bijstandsnorm moet worden vrijgelaten. Voor de 'echte' verrekening volgt deze ondergrens volgens de wetgever rechtstreeks uit de wet, namefijk uit de artikefen 6:135 aanhef en onder a $B W \mathrm{j}^{5} 475 \mathrm{c}$, $475 \mathrm{~d}$ en $479 \mathrm{i}$ lid 2 $\mathrm{Rv}^{209}$ De wetgever gaat er dus van uit dat op de verrekening van sociale uitkeringen met lopende uitkeringen de bepalingen van het BW toepasselijk zijn. ${ }^{210}$

Overigens is het zo dat het duidelijke onderscheid dat de memorie van toelichting maakt tussen het terugvorderingsbesluit en het invorderingsbesluit, in de tekst van de wettelijke bepalingen niet uit de verf komt. In een aantal gevallen wordt van (een besluit tot) terugvordering gesproken als duidelijk (tevens) (een besluit tot) invordering wordt bedoeld. Zo stelt bijvoorbeeld artikel $36 \mathrm{WW}$, het terugvorderingsartikel, in lid 5 dat het besluit tot terugvordering niet alleen vermeldt hetgeen wordt teruggevorderd, maar ook de termijn(en) waarbinnen moet worden betaald en dat bij niet tijdige betaling het besluit zal worden tenuitvoergelegd op de wijze als omschreven in artikel $36 \mathrm{a}$ WW. Deze laatste aspecten zien op de invordering. Dit blijkt ook duidelijk uit artikel 36a. Lid 2 van dat artikel bepaalt onder meer dat de bepalingen uit artikel $27 \mathrm{~g}$ WW betreffende de invordering van een boete van overeenkomstige toepassing zijn. In die bepalingen wordt onder meer de verrekening geregeld. Daarnaast stelt artikel 36a lid $1 \mathrm{WW}$ dat het besluit tot terugvordering een executoriale titel oplevert; dit moet naar mijn mening het besluit tot invordering zijn. De rechter volgt in deze overigens de wetstekst. Hij eist dan ook dat in het besluit tot terugvordering tevens wordt vermeld de betalingstermijn(en) en het feit dat het bij niet-tijdige betaling ten

206. Memorie van toelichting. Tweede Kamer 1994-1995, 23 909, nr. 3, blz. 27.

207. Memorie van toelichting, Tweede Kamer 1994-1995, 23 909, nr. 3, blz. 27-28 en blz. 63.

208. Memorie van toelichting. Tweede Kamer 1994-1995, 23 909, nr. 3, blz. 63.

209. Memorie van toelichting. Tweede Kamer 1994-1995, 23 909, nr. 3, blz. 29 en blz. 65.

210. In artikel 4.4.1.9 van het voorontwerp voor de vierde tranche van de Awb wordt gekozen voor het uitgangspunt dat verrekening niet plaatsvindt, tenzij bij wettelijk voorschrift anders is bepaald, zie 5.3 .4 . 
uitvoer zal worden gelegd als in de wet omschreven. ${ }^{211}$ Het terugvorderingsbesluit moet dus in beginsel tevens het invorderingsbesluit bevatten.

Een verschil met het voorheen geldende recht is dat het terugvorderingsbesluit een executoriale titel oplevert. ${ }^{212}$ Dit is volgens de memorie van toelichting 'een belangrijke verbetering', ${ }^{213}$ nu hierdoor een lange procedure voor het verkrijgen van een executoriale titel wordt vermeden. Het is aan de betrokkene om stappen te ondernenen als hij het niet eens is met die executie. Dit kan bijvoorbeeld door het indienen van een verzoek om een voorlopige voorziening op grond van artikel 8:81 Awb bij de president van de (bestuurskamer van de) rechtbank of door zich te verzetten tegen executie met behulp van de mogelijkheden die het Wetboek van Burgerlijke Rechtsvordering biedt. ${ }^{214}$ De staatssecretaris wees erop dat als de betrokkene de president om schorsing van het besluit en de uitvoering daarvan vraagt, rekening moet worden gehouden met de algemene beginselen van behoorlijk bestuur. ${ }^{215}$ Het instellen van bezwaar of beroep heeft geen schorsende werking op de tenuitvoerlegging. ${ }^{216}$ Volgens de regering hoeft er niet altijd direct gebruik te worden gemaakt van de executoriale titel. Het kan het verstandig zijn enige tijd te wachten met executeren omdat het bestuursorgaan anders aansprakelijk kan worden gesteld voor de kosten die voortvloeien uit de onterechte executie als de betrokkene later in het gelijk wordt gesteld in een beroepsprocedure. ${ }^{217}$ Een ander verschil met de oude regelingen is dat indien de betrokkene niet tijdig betaalt, het verschuldigde bedrag wordt verhoogd met de wettelijke rente en de kosten die worden gemaakt met betrekking tot de invordering. ${ }^{218}$

Inmiddels is het voorontwerp voor de vierde tranche van de Awb gepubliceerd. Hierin worden onder meer algemene regels gegeven met betrekking tot invordering en executie van publiekrechtelijke geldschulden. Ik zal deze regels bespreken in 10.6. Daar zal ik ook ingaan op de verschillen tussen deze algemene regeling en de $\mathrm{nu}$ in de sociale zekerheid bestaande regels en op de vraag of de socialezekerheidswetten op dit punt dienen te worden aangepast.

211. Zie onder meer Pres. Rb. 's-Hertogenbosch 3 september 1997, USZ 1997, 296, m.nt. G.C. Boot (voorlopige voorziening) en CRvB 17 maart 2000, USZ 2000, 115. Uit CRvB 19 juli 2000, nr. 98/4833 WW (niet gepubliceerd) en CRvB 8 november 2000, USZ, 2001, 19, m.nt. Red. blijkt wel dat de rechter het terugvorderingsbesluit niet ambtshalve mag vernietigen als het niet aan de gestelde vereisten voldoet; er moet dus door de betrokkene, een beroep op. worden gedaan. Voorts. heeft de CRvB aangegeven dat wanneer omtrent de invordering nog niet is beslist in het primaire (terugvorderings)besluit, dit onder omstandigheden alsnog mogelijk is in de beslissing op bezwaar, CRvB 21 september 1999, AB 1999, 464, m.nt. HBr.

212. Bijvoorbeeld artikel 36a lid 1 WW. Naar mijn mening wordt het invorderingsbesluit bedoeld.

213. Tweede Kamer 1994-1995, 23 909, nr. 3, blz. 28.

214. Bijvoorbeeld artikel 438 Rv, memorie van toelichting. Tweede Kamer 1994-1995, 23 909, nr. 3, blz. 29.

215. Handelingen Tweede Kamer 23 november 1995, blz. 2276.

216. Memorie van toelichting, Tweede Kamer 1994-1995, 23 909, nr. 3, blz. 64. Vgl. art. 6:16 Awb.

217. Memorie van toelichting. Tweede Kamer 1994-1995, 23 909, nr. 3, blz. 63.

218. Bijvoorbeeld artikel $36 \mathrm{a}$ lid $2 \mathrm{j}^{\circ}$ artikel $27 \mathrm{~g}$ lid 7 WW (artikel $36 \mathrm{a}$ lid $2 \mathrm{j}^{\circ}$ artikel $27 \mathrm{~g}$ lid $6 \mathrm{WW}$ ). 
In de socialezekerheidswetten is de terugvorderingsprocedure dus opgedeeld in drie stappen: eerst moet intrekking van de toekenningsbeslissing plaatsvinden, ${ }^{219}$ vervolgens moet een terugvorderingsbeslissing worden genomen, gevolgd door een invorderingsbeslissing. Deze beslissingen zijn ieder een besluit in de zin van de Awb, waartegen bezwaar en beroep open staat en waarop de procedure van deze wet van toepassing is. Evenals voorheen krijgen de afzonderlijke beslissingen formele rechtskracht als de betrokkene binnen de bezwaar- of beroepstermijn geen bezwaar of beroep instelt tegen die beslissing. Het bezwaar of beroep tegen een terugvorderingsbeslissing kan dus niet worden gegrond op de stelling dat het intrekkingsbesluit niet in stand kan blijven, wanneer dat intrekkingsbesluit rechtens onaantastbaar is geworden omdat de bezwaar- en beroepstermijn is verstreken. ${ }^{220}$ Overigens heeft het volgens de wetgever de voorkeur deze afzonderlijke beslissingen in één beschikking op te nemen. ${ }^{221}$

\subsection{Sociale zekerheid, burgerlijk recht en de burgerlijke rechter}

\subsubsection{Inleiding}

In de meeste socialezekerheidsregelingen zijn dus specifieke bepalingen opgenomen met betrekking tot terugvordering. Voor de Tweede Wereldoorlog sloten de meeste wetten terugvordering uit, na deze oorlog werd geleidelijk in steeds meer wetten de regel opgenomen dat terugvordering niet mocht plaatsvinden, tenzij het bestuursorgaan te veel had uitbetald door toedoen van de betrokkene of door een administratieve vergissing. In het laatste geval moest dit wel redelijkerwijs duidelijk (kunnen) zijn geweest voor betrokkene. In 1996 brak de WBM ook met dit systeem. Uitgangspunt werd vanaf nu dat ten onrechte gedane betalingen altijd kunnen en moeten worden teruggevorderd, ongeacht de oorzaak van de fout of vergissing. Slechts wanneer zich dringende redenen voordoen, kan een uitzondering worden gemaakt op dit uitgangspunt.

In deze paragraaf zal ik de vraag behandelen, of er bij terugvordering ruimte was of nog steeds is voor toepassing van de regeling van de onverschuldigde betaling uit het BW. Ook zal ik bekijken of de opvatting van de wetgever in de WBM dat door het schrappen van de terugvorderingstermijnen in de socialezekerheidswetten het 'gemene recht', de verjaringstermijnen uit het BW, van toepassing is, juist is.

Bij de beantwoording van de eerste vraag - bestond en bestaat bij tengvordering ruimte voor toepassing van de privaatrechtelijke regeling van de onverschul-

219. Tenzij de uitbetaling niet conform de correcte toekenningsbeslissing was geschied.

220. Hierop zijn uitzonderingen mogelijk volgens de CRvB, zie CRvB 15 augustus 2000, JB 2000, 277, m.nt. C.L.G.F.H. A, USZ 2000, 257.

221. Memorie van toelichting, Tweede Kamer 1994-1995, 23 909, nr. 3, blz. 23. Volgens de CRvB moet dit dus ook deels gebeuren. 
digde betaling? - moet een onderscheid worden gemaakt tussen een aantal situaties. Daarbij moet dan weer worden bedacht, dat een aantal van die situaties die zich in het verleden kon voordoen, na de inwerkingtreding van de WBM niet (snel) meer aan de orde zal zijn. De te onderscheiden situaties zijn de volgende.

De eerste situatie is die waarin het bestuursorgaan door gebruik te maken van de privaatrechtelijke weg tracht de specifieke terugvorderingsbepalingen in de betrokken socialezekerheidswet te omzeilen.

Een andere situatie doet zich voor wanneer de betrokken wet geen regeling met betrekking tot terugvordering kent of weliswar een dergelijke regeling bevat, maar deze regeling niet uitputtend is, zodat bepaalde gevallen hier buiten vallen. In deze gevallen is er dus weliswaar betaald conform een toekenningsbeslissing, maar blijkt deze toekenningsbeslissing (achteraf) onjuist en biedt de betrokken wet geen expliciet antwoord op de vraag of mag worden teruggevorderd. Deze situatie zal zich overigens niet vaak meer voordoen na de inwerkingtreding van de WBM, nu vrijwel alle wetten uitputtende regelingen bevatten.

De derde situatie is die waarin er weliswaar een regeling bestaat met betrekking tot terugvordering, maar het de vraag is of die regeling op het voorliggende geval van toepassing is. Deze vraag kan rijzen wanneer het bestuursorgaan meer heeft uitbetaald dan waarop betrokkene op grond van de toekenningsbeschikking recht had, of wanneer aan een ander dan de (rechtstreeks) betrokkene is uitbetaald. De vraag naar de titel van de betaling en de hoedanigheid van de ontvanger spelen in dat geval een rol. Het eerste geval, waarin dus de vraag naar de titel van betaling een rol speelt, zal na de inwerkingtreding van de WBM aan belang hebben ingeboet, nu vrijwel alle wetten de regeling bevatten dat niet alleen de uitkering die als gevolg van een intrekkingsbesluit onverschuldigd is betaald, kan worden teruggevorderd, maar ook hetgeen anderszins onverschuldigd is betaald.

Ten slotte is er de situatie dat op grond van de publiekrechtelijke regeling een terugvorderings(- en invorderings)beslissing is genomen en de betrokkene vervolgens weigert mee te werken aan de executie. In die gevallen diende het bestuursorgaan voor de inwerkingtreding van de WBM een vordering in te stellen bij de burgerlijke rechter teneinde een executoriale titel te verkrijgen. De rechtsgrond voor deze titel was de vordering uit onverschuldigde betaling. Na de inwerkingtreding van de WBM levert het terugvorderingsbesluit een executoriale titel op.

Ik wijs erop, dat de scheidslijn tussen de verschillende situaties niet altijd glashelder is. Bepaalde gevallen kunnen dan ook worden ondergebracht in meer dan een categorie. Zo kan bijvoorbeeld de situatie, waarin iemand twee keer een uitkering krijgt uitbetaald, terwijl hij op grond van de toekenningsbeslissing slechts recht heeft op één keer uitbetaling, en de betreffende regeling geen bepalingen bevat met betrekking tot terugvordering van hetgeen meer wordt uitbetaaid dan is toegekend, zowel worden ondergebracht bij de situatie dat er een leemte bestaat in de terugvorderingsbepalingen als bij de situatie waarin het de vraag is of er een titel voor de betaling bestaat.

Ik zal deze vier situaties in de paragrafen 6.5.3 tot en met 6.5.6 uitwerken. In 6.5.7 zal ik 'als toegift' een drietal zaken bespreken, waarin werd getracht ten onrechte betaalde uitkeringen of daarmee verband houdende kosten terug te vorde- 
ren, niet via de weg van onverschuldigde betaling, maar via andere wegen. Ik begin met de bespreking van de toepasselijkheid van de verjaringstermijnen uit het $\mathrm{BW}$ in de sociale zekerheid.

\subsubsection{De toepasselijkheid van de verjaringstermijnen uit het $B W$}

In 6.4.5.3 is gebleken dat bij de inwerkingtreding van de WBM de op dat moment in de socialezekerheidswetten opgenomen terugvorderingstermijnen zijn geschrapt. Volgens de wetgever is de implicatie hiervan, dat nu de verjaringstermijn van de vordering uit onverschuldigde betaling uit het $\mathrm{BW}$ geldt. ${ }^{222}$ Het is echter de vraag of deze verjaringstermijn van toepassing is. Mijns inziens is dit niet zo. Ik zal dit in deze paragraaf uitwerken. Het karakter van deze paragraaf zal dan ook minder beschrijvend zijn dan de rest van dit hoofdstuk.

Artikel 3:309 BW valt onder het bereik van de schakelbepaling in artikel 3:326 BW, die bepaalt dat onder meer artikel 3:309 BW ook buiten het vermogensrecht overeenkomstige toepassing vindt, voor zover de aard van de betrokken rechtsbetrekking zich daartegen niet verzet. Blijkens de parlementaire geschiedenis ziet deze schakelbepaling mede op het bestuursrecht. ${ }^{223}$ Bekeken moet dus worden of de aard van de betrokken rechtsverhouding zich verzet tegen overeenkomstige toepassing.

Eerder heb ik betoogd dat dit het geval is. ${ }^{224} \mathrm{Ik}$ baseer mij hiertoe mede op een uitspraak van de Centrale Raad van Beroep in een ambtenarenzaak, waarin een gewezen arts bij de GG \& GD meer dan zes jaar na het ontslag de gemeente Amsterdam om uitbetaling van bezoldiging bij ziekte na ontslag verzocht. De gemeente - in casu het college van B en W - beriep zich op artikel 1 lid 1 van de uit 1924 stammende Wet houdende voorschriften nopens de verjaring van geldvorderingen ten laste van het Rijk, de provinciën, de gemeenten en waterschappen, veenschappen en veenpolders. ${ }^{225}$ Dit artikel bepaalde dat rechtsvorderingen ten laste van een openbaar lichaam in iedere geval vervielen door verloop van vijf jaar na de 31 e december van het jaar waarin de vordering opeisbaar was geworden. De Centrale Raad betrok in zijn overwegingen uitdrukkelijk ook de verjaringsbepalingen uit het $\mathrm{BW}$, nu zowel in de wet van 1924 als in de bepalingen uit het BW de verjaring werd gekoppeld aan de rechtsvordering, 'dat wil zeggen de mogelijkheid de rechter te adiëren'. De verjaringstermijn werd volgens de Centrale Raad gekoppeld aan de mogelijkheid naar de rechter te stappen. Een dergelijke koppeling kwam de Raad op het terrein van het bestuursrecht vreemd voor; 'immers, anders dan in het burgerlijk procesrecht, is de mogelijkheid om de rechter te benaderen in het bestuursrecht eerst aanwezig als sprake is van een

222. Memorie van toelichting, Tweede Kamer 1994-1995, 23 909, nr. 3, blz. 29-31, zie 6.4.5.3.

223. PG Inv. Boek 3. BW, blz. 1016-1017. Zie 5.2.4.

224. Bollen (1997).

225. Wet van 31 oktober 1924, Stb. 482. 
appellabel besluit'. ${ }^{226}$ De rechtsvordering ontstond volgens de Raad op het moment dat de gemeente positief zou beslissen op de aanvraag van de gewezen ambtenaar. Pas op dat ogenblik zou de verjaringstermijn aanvangen. $\mathrm{Nu}$ de gemeente geen (positief) besluit had genomen op de aanvraag was er geen sprake van een rechtsvordering van de ex-ambtenaar op de gemeente en kon de verjaringstermijn niet zijn verstreken. Dit kwam de Centrale Raad onwenselijk voor, nu dit zou 'meebrengen, dat met betrekking tot een financiële aanspraak nog lang na het verstrijken van vijf jaren een besluit kan worden verzocht en dat vervolgens pas na het nennen van een besluit op dat verzoek de verjaringstermijn een aanvang neemt'. De conclusie van de Raad was onder meer dat om deze reden geen toepassing diende te worden gegeven aan de wet van 1924. Hieruit volgt logischerwijs tevens dat de verjaringsbepalingen uit het $\mathrm{BW}$ ook niet van toepassing waren. Dit leidde er volgens de Raad niet toe, dat het realiseren van financiële aanspraken zonder enige begrenzing naar tijd mogelijk moest zijn. Een begrenzing vond hij in het beginsel van de rechtszekerheid, dat in een ambtelijke rechtsverhouding zowel ten gunste als ten nadele van de ambtenaar kan werken, waarna hij aansloot bij de jurisprudentiële norm die was ontwikkeld met betrekking tot terugvordering van onverschuldigde betalingen aan een ambtenaar en waarbij terugvordering van meer dan vijf jaar geleden betaalde bezoldiging was uitgesloten. ${ }^{227}$ In de voorliggende casus betekende dit dat de ambtenaar financiêle aanspraken jegens de overheid niet meer geldend kon maken na het verstrijken van vijf jaar.

De redenering van de Centrale Raad kan ook worden gevolgd in het socialezekerheidsrecht. De verjaringstermijn van artikel 3:309 BW is immers gekoppeld aan een rechtsvordering; het is de rechtsvordering die verjaart. Maar alvorens deze rechtsvordering ontstaat, $\mathrm{zal}$ in de meeste gevallen eerst de toekenningsbeslissing moeten worden ingetrokken. Eerst dan ontvalt de rechtsgrond aan de betaling en staat vast dat onverschuldigd is betaald en kan de verjaringstermijn van artikel. 3:309 BW aanvangen. Door het uitstellen van de intrekkingsbeslissing kan het bestuursorgaan het moment van ontstaan van de rechtsvordering en dus de aanvang van de verjaringstermijn vitstellen. Naar aanleiding van een artikel van Sluijs $\mathrm{s}^{228}$ is dit punt in de Eerste Kamer uitdrukkelijk aan de orde gesteld. ${ }^{229}$ Volgens de verantwoordelijke bewindslieden is echter de dag waarop het uitvoeringsorgaan bekend is geworden met het bestaan van de vordering, beslissend voor de terugvorderingstermijn. Dit hoeft niet perse de datum van de intrekkingsbeslissing te zijn. Volgens hen is dit de regeling die uit artikel 3:309 BW voortvloeit. ${ }^{230}$ Deze opvatting is, als hiervoor uiteengezet, onjuist. De opvatting van

226. CRvB 19 oktober 1995, JB 1996, 11. Zie ook CRvB 14 december 1995, TAR 1996, 32 en CRvB 23 januari 1997, TAR 1997, 42. Een vergelijkbare redenering volgde ook de Afdeling bestuursrechtspraak, ABRvS 30 oktober 1995, AB. 1996, 310, m.nt. AFMB.

227. CRvB 26 april 1990, AB 1991, 157, m.nt. HH, TAR 1990, 138.

228. Sluijs (1995), blz. 341.

229. Nader voorlopig verslag van de vaste commissie voor sociale zaken en werkgelegenheid, Eerste Kamer 1995-1996, 23 909, nr. 114c, blz 2.

230. Nadere memorie van antwoord, Eerste Kamer 1995-1996, 23 909, nr. 114d, blz. 3. 
Kooijman, dat de vordering met terugwerkende kracht in het leven wordt geroepen, ${ }^{231}$ mag juist zijn, maar sllechts wat betreft de aanvang van de verjaringstermijn van twintig jaar, die in artikel 3:309 BW is neergelegd. De termijn van vijf jaar, waarbinnen de schuldeiser actie moet ondernemen begint immers pas te lopen vanaf het moment dat de schuldeiser bekend is met zowel het bestaan van de vordering als de persoon van de schuldenaar. Om bekend te kunnen zijn met het bestaan van de vordering is natuurlijk wel vereist, dat er een vordering is. Deze ontstaat door de intrekking. ${ }^{232}$ De stelling van Kooijman (en de bewindslieden) dat het uitvoeringsorgaan geacht moet worden bekend te zijn met de vordering zodra het op de hoogte raakt van feiten en omstandigheden die aanleiding geven tot aantasting van de toekenning, is dan ook onjuist. ${ }^{233}$

Er zijn nog andere argumenten om artikel 3:309 BW niet van toepassing te achten. $\mathrm{Zo}$ is een verjaringstermijn van twintig jaar in het socialezekerheidsrecht ongewenst lang. Volgens de memorie van toelichting op de WBM was de oude regeling, waarbij een verjaringstermijn van vijf of twee jaar gold, te zien als een bijzondere regeling ten opzichte van de verjaringsbepalingen uit het (oude) BW. $\mathrm{Bij}$ de totstandkoming van die bijzondere regeling was bewust afgeweken van die verjaringsbepalingen omdat een verjaringstermijn van dertig jaar waarbinnen dan wel waarover kon worden teruggevorderd niet wenselijk werd geacht in het socialezekerheidsrecht. $\mathrm{Nu}$ in het (huidige) BW de verjaringstermijn volgens de minister en staatssecretaris van SZW aanzienlijk is bekort, zien zij aanleiding aan te sluiten bij die termijn. ${ }^{234}$ De toepasselijkheid van artikel 3:309 BW betekent echter in tweeërlei opzicht een forse verruiming ten opzichte van de oude regeling. In de eerste plaats is de termijn waarbinnen tot terugvordering mag (moet) worden overgegaan, niet langer beperkt tot vijf (of twee) jaar na de betaalbaarstelling, maar moet het bestuursorgaan actie ondernemen binnen vijf jaar nadat het bekend is geworden met het bestaan van de vordering en de persoon van de ontvanger. Het is dus mogelijk dat het bestuursorgaan pas enkele jaren na de betaalbaarstelling bekend wordt met het feit dat te veel is betaald en vervolgens de toekenningsbeschikking intrekt. Op dat moment gaat de vijfjarentermijn van artikel 3:309 BW pas lopen. In de tweede plaats is de termijn waarover kan worden teruggevorderd, niet langer beperkt tot de vijf (dan wel twee) jaar voorafgaande aan de eerste, ondubbelzinnige terugvorderingshandeling, maar verjaart de vordering pas twintig jaar na haar ontstaan. Dat betekent, dat alles wat gedurende twintig jaar voor het moment dat daadwerkelijk wordt teruggevorderd, onverschul-

231. Kooijman (1997), blz. 17, noot 51 .

232. Zie 1.5.2 en de daar vermelde literatuur.

233. Overigens gaat de Afdeling bestuursrechtspraak nog verder. Volgens haar ontstaat zelfs door de intrekkingsbeschikking geen rechtsvordering. Hiertoe is vereist dat eerst een terugvorderingsbesluit wordt genomen: 'Zo een beslissing, die strekt tot voldoening aan de bestuursrechtelijke voorwaarden voor een rechtmatige terugvordering, opdat naar het bestuursrecht een betalingsverplichting ontstaat, is gericht op publiekrechtelijk rechtsgevolg', ABRvS 21 oktober 1996, AB 1996, 496, m.nt. NV, JB 1996, 232, m.nt. HJS (Nanne). Mijn cursivering.

234. Tweede Kamer 1994-1995, 23 909, nr. 3, blz. 29-30. 
digd is betaald, kan worden teruggevorderd. Waar dus eerst kon worden teruggevorderd over maximaal vijf dan wel twee jaar, is dit nu maximaal twintig jaar geworden. Volgens de memorie van toelichting is een dergelijke lange verjaringstermijn gewenst nu het, mede door het feit dat de methoden om te frauderen steeds vernuftiger worden, kan voorkomen dat het uitvoeringsorgaan pas na veel langere tijd dan vijf jaar op de hoogte komt van het bestaan van het feit dat ten onrechte of te veel is betaald. Fraude mag immers niet lonend zijn. ${ }^{235}$ Naar mijn mening is de regeling doorgeschoten. Er zal immers niet altijd sprake zijn van fraude, terwijl de regeling daar wel van lijkt uit te gaan. De betrokkene kan ook onopzettelijk onjuiste inlichtingen geven of onopzettelijk bepaalde inlichtingen niet geven of er kan sprake zijn van een administratieve vergissing, waarvan de betrokkene niet eens kon weten dat deze was gemaakt. In die gevallen is, mede gelet op het feit dat de sociale zekerheid vaak als laatste vangnet fungeert, een mogelijke terugvorderingstermijn van twintig jaar onaanvaardbaar.

Daarnaast is de termijn van vijf jaar, waarbinnen het bestuursorgaan actie moet ondernemen nadat het met het bestaan van de vordering en de persoon van de ontvanger is bekend geworden, in strijd met het zorgvuldigheidsbeginsel. Van het bestuursorgaan mag immers worden verwacht dat het alert reageert op gebleken onregelmatigheden. Dit uitgangspunt is door de Centrale Raad van Beroep dan ook neergelegd in de zogenaamde 'zesmaandenjurisprudentie'. ${ }^{236}$ Slechts bij opzet aan de kant van betrokkene kan dat anders zijn. De vijfjarentermijn zal dan ook regelmatig in strijd hiermee zijn. In eerste instantie was dit ook de opvatting van het Lisv. In zijn Besluit herziening en intrekking uitkeringen uit $1997^{237}$ gaf het uitdrukkelijk aan dat het uitvoeringsorgaan de zesmaandenjurisprudentie diende toe te passen: in de gevallen waarin het uitvoeringsorgaan op de hoogte was van het feit dat ten onrechte een uitkering werd verstrekt en daar niet adequaat op reageerde, diende de op de intrekkingsbeslissing volgende terugen invordering te worden beperkt tot zes maanden nadat het het uitvoeringsorgaan duidelijk was dat er redenen waren om de beslissing in te trekken. Deze passage is echter een aantal maanden later vervallen. ${ }^{238}$ In de Beleidsregels terug- en invordering uit 1998 en $1999^{239}$ gaf het Lisv vervolgens uitdrukkelijk aan dat de in de jurisprudentie ontwikkelde zesmaandentermijn vervalt. Zoals gezegd is dit mijns inziens in strijd met het zorgvuldigheidsbeginsel. ${ }^{240}$ De Centrale Raad heeft inmiddels echter anders geoordeeld. De zesmaandenjurisprudentie heeft zich ontwikkeld "in het kader van de rechterlijke toetsing van de wijze waarop

235. Tweede Kamer 1994-1995, 23 909, nr. 3, blz. 30.

236. Zie 6.4.4.4.

237. Besluit herziening en intrekking uitkeringen, 4 december 1997, Stert. 245.

238. Besluit tot wijziging van het Besluit herziening en intrekking uitkeringen, 22 april 1998, Stert. 89.

239. Beleidsregel terug- en invordering, 22 april 1998, Stert. 90, vervangen door Beleidsregel terugen invordering, 31 maart 1999, Stert. 75.

240. Anders: Rb. Maastricht 14 maart 2000, USZ 2000, 138, m.nt. E.E.V. Lenos. Vgl. Rb. Groningen 4 augustus 2000, JABW 2000, 143, Gst. 7133, 13, m.nt. WdB. 
bestuursorganen tot 1 augustus 1996 van de discretionaire bevoegdheid tot terugvordering gebruik maakten'. Nu momenteel geen sprake meer is van een discretionaire bevoegdheid, maar van een verplichting tot terugvordering, is de grondslag voor de toepasselijkheid van die jurisprudentie komen te vervallen, aldus de Raad. ${ }^{241}$

Dit alles zal naar mijn mening ertoe (moeten) leiden dat ook de socialezekerheidsrechter zal oordelen dat de aard van de betrokken rechtsverhouding zich verzet tegen toepassing van de verjaringstermijn van artikel 3:309 BW. Als dit inderdaad gebeurt, zal het gevolg zijn dat de rechter - en dit is in hoogste instantie de Centrale Raad van Beroep - de constructie zoals toegepast door de Centrale Raad van Beroep als ambtenarenrechter zal overnemen. Dit betekent dat de terugvorderingstermijn dient te worden begrensd door het rechtszekerheidsbeginsel. Voor de hand ligt dan ook dat de terugvorderingstermijnen, zoals die golden voor de inwerkingtreding van de WBM, zullen worden toegepast. Deze moeten immers worden gezien als een uitwerking van dit beginsel. ${ }^{242}$

Andere schrijvers komen via een andere, minder principiële, weg ook tot de conclusie dat de verjaringsbepalingen uit het $\mathrm{BW}$ niet onverkort zullen worden toegepast. De 'dringende redenen'-clausule zou de nieuwe wet namelijk weer een eindje in 'oude' richting buigen. ${ }^{243}$

\subsubsection{Het omzeilen van de terugvorderingsbepalingen via de regeling van onverschuldigde betaling in het $\mathrm{BW}$}

Mocht een bestuursorgaan door gebruik te maken van de privaatrechtelijke weg de specifieke terugvorderingsbepalingen in de betrokken wet omzeilen? In 1930 had de Hoge Raad uitdrukkelijk overwogen, dat artikel 1395 BW (oud) ook van toepassing was op betalingen van publiekrechtelijke aard, 'voorzooveel niet uit de wet het tegendeel volgt'. ${ }^{244}$ Kende de betrokken socialezekerheidswet een (uitputtend bedoelde) regeling met betrekking tot terugvordering, dan kon deze regeling niet worden omzeild door gebruik te maken van artikel $1395 \mathrm{BW}$ (oud). ${ }^{245}$

Een aantal voorbeelden hiervan biedt de jurisprudentie met betrekking tot terugvordering van uitkeringen op grond van de Wet Werkloosheidsvoorziening. (WWV). ${ }^{246}$ De WWV vormde een soort 'overbruggings'-uitkering voor werklo-

241. CRvB̈ 25 september 2001, USZ 2001, 299, m.nt. Red.

242. Zie 6.4 .4 .4 .

243. Bijvoorbeeld Verheij (1997), blz. 76.

244. HR 14 november 1930, NJ 1931, 222, m.nt. E.M.M. Zie 6.3.3.

245. Vgl. Simon (1993), blz. 198.

246. Wet van 10 december 1964, houdende regelen inzake overheidsuitkeringen aan werkloze werknemers (Wet Werkloosheidsvoorziening), Stb. 485. In artikel 3 Invoeringswet Stelselherziening Sociale Zekerheid, Stb. 1986, 567, is bepaald dat vanaf 1 januari 1987 geen nieuw recht op cen uitkering op grond van die wet kon ontstaan, aangezien de op die datum in werking getreden herziene WW de functie van de WWV overnam. Reeds voor die datum ontstane rechten bleven bestaan. Dit betekende dat het aantal mensen dat een uitkering op grond van de WWV genoot. langzaam maar zeker terugliep, aangezien het recht op een WWV-uitkering aan een in de wet. 
ze werknerners die geen recht (meer) hadden op een WW-uitkering. Alvorens deze werknemers terugvielen op een (meestal veel lagere) bijstandsuitkering hadden zij gedurende een bepaalde tijd recht op een uitkering ingevolge de WWV, die lager was dan een WW-uitkering, maar over het algemeen hoger dan een bijstandsuitkering. Uitkerende instantie was de gemeente waar de werknemer zijn woonplaats had. De WWV kende geen regels met betrekking tot terugvordering. Wel kon een beslissing tot toekenning van een uitkering worden ingetrokken ${ }^{247}$ als door toedoen van de betrokkene ten onrechte of tot een te hoog bedrag een uitkering was toegekend, of als de intrekking haar grond vond in het feit dat de betrokkene na de toekenning van de uitkering over dezelfde periode bepaalde inkomsten had genoten (artikel 27 lid 1 WWV). Andere intrekkingsgronden kende de WWV niet. Vond intrekking plaats, dan kon de betrokkene hiertegen bezwaar maken bij het gemeentebestuur (artikel 31 WWV). Tegen de beslissing op het bezwaarschrift kon betrokkene beroep instellen bij de Raad van Beroep, met eventueel hoger beroep bij de Centrale Raad van Beroep (artikel 34 WWV).

Nu de WWV geen terugvorderingsbepalingen kende, moest de gemeente die ten onrechte een uitkering had betaald, naar de burgerlijke rechter om via een actie uit onverschuldigde betaling deze uitkering terug te vorderen. ${ }^{248}$ Hierbij is een aantal malen geprobeerd de intrekkingsbepalingen van de WWV te omzeilen. Zo ook in het geval van C., die een WWV-uitkering ontving van de gemeente Wieringen. C. ontving deze uitkering deels ten onrechte, nu hij tevens een WAOuitkering kreeg die verrekend diende te worden met de WWV-uitkering. C. had dit medegedeeld aan de gemeente. Door een administratieve fout vond geen verrekening plaats. C. vermeldde niet op het inkomstenformulier dat hij nog inkomsten uit arbeid, de WAO-uitkering, had. De gemeente ontdekte de fout en deelde aan $\mathrm{C}$. mee dat het te veel betaalde werd teruggevorderd en zij verzocht hem dit over te maken. $\mathrm{C}$. voldeed hier niet aan. De gemeente begon vervolgens een procedure voor de rechtbank, welke de vordering uit onverschuldigde betaling toewees. C. ging in hoger beroep. Hier stelde hij onder meer dat de gemeente niet onverschuldigd had betaald, nu vaststond dat de gemeente de toekenningsbeslissing niet had ingetrokken met toepassing van artikel $27 \mathrm{WWV}$. Uit het stelsel van de WWV volgde dat de gemeente deze stap niet had mogen overslaan. C. stelde voorts dat hij hierdoor werd beroofd van de mogelijkheid beroep in te stellen bij de administratieve rechter. Het beroep werd verworpen. Volgens het Hof Amsterdam hoefde geen wijziging plaats te hebben wanneer op de op zichzelf ongewijzigde uitkering alsnog een korting werd toegepast die - onbetwist - had moeten worden toegepast, hetgeen ten onrechte was verzuimd. In dat geval stond geen

bepaalde maximum-termijn was gebonden.

247. De WWV sprak van in het nadeel van belanghebbende met terugwerkende kracht wijzigen.

248. Als het bestuursorgaan een beslissing had genomen de toekenningsbeslissing in te trekken en de te veel betaalde WWV-uitkering terug te vorderen op grond van artikel $1395 \mathrm{BW}$ (oud), dan kon de betrokkene tegen dat laatste deel van de beslissing geen beroep instellen bij de socialezekerheidsrechter. Deze is 'ten aanzien van die terugvordering niet de tot oordelen bevoegde rechter", aldus RvB Roermond 13 september 1989, JSV 1990, 1. 
rechtsregel eraan in de weg terugbetaling te vorderen zonder voorafgaande intrekking. Wel diende in dat geval de burgerlijke rechter de beslissing tot terugvordering te beoordelen. ${ }^{249}$ Tegen dit anrest werd geen cassatie ingesteld.

Drie maanden later overwoog de Rechtbank 's-Hertogenbosch daarentegen in een ander geval dat nu de WWV-uitkering kennelijk was verstrekt op grond van een toekenningsbeslissing en nu noch gesteld noch gebleken was dat die beslissing was ingetrokken, er geen sprake kon zijn van onverschuldigde betaling. De vordering van de gemeente diende dan ook op die grond te worden afgewezen. ${ }^{250}$

Dit was ook de opvatting van de Hoge Raad, zo bleek uit een arrest uit 1985 waarin cassatie was ingesteld tegen een arrest van het Hof Amsterdam, dat een soortgelijke uitspraak had gedaan als in de hiervoor besproken zaak van C. tegen de gemeente Wieringen. P. kreeg van de gemeente Amsterdam een WWV-uitkering, terwijl hij reeds een AAW/WAO-uitkering genoot, hetgeen hij had meegedeeld. Tevens vermeldde hij deze uitkering op de weekbriefjes die hij moest inleveren. Desalniettemin werd gedurende meer dan een jaar bij de berekening van de uitkering geen rekening gehouden met de AAW/WAO-uitkering, zodat P. een ongekorte uitkering genoot. Toen de gemeente hier achter kwam, besloot zij het naar haar oordeel te veel betaalde in te houden op de uitkering van P. Een beschikking tot wijziging van de toegekende uitkering werd door het gemeentebestuur niet genomen. P. vorderde vervolgens in kort geding dat aan de gemeente werd verboden meer op zijn WWV-uitkering in te houden dan hij ontving aan AAW/WAO-uitkering, dus dat de gemeente de in het verleden ten onrechte niet verrekende AAW/WAO-uitkering niet meer op de lopende WWV-uitkering mocht inhouden. De president wees de vordering toe. Het hof weigerde de gevraagde voorziening alsinog: een deel van de uitkering was onverschuldigd betaald en kon dus worden verrekend. De Hoge Raad casseerde; er was niet onverschuldigd betaald nu de uitkeringen waren gedaan overeenkomstig de toekenningsbeslissing. In dat geval betaalt de gemeente 'ter voldoening aan de in de beslissing vastgestelde aanspraak op een uitkering'. ${ }^{251}$ Dit strookte volgens de Hoge Raad ook met artikel 27 lid 1, waarin een aantal limitatieve gronden was opgenomen voor intrekking. Als ten onrechte was verzuimd rekening te houden met genoten inkomsten of uitkeringen, kon de toekenningsbeslissing worden ingetrokken op grond van artikel 27 lid 1 onder $b .{ }^{252}$ Verder zou de bevoegdheid tot terugvordering zonder veorafgaande intrekking tot het onwenselijke gevolg leiden dat de burgerlijke rechter zou moeten oordelen over de vaststelling van de WWV-uitkering, waaromtrent nu juist de socialeverzekeringsrechter bevoegd was. In zijn noten stelde Riphagen dat met dit arrest het toepassingsgebied van artikel 1395 BW (oud) binnen de sociale zekerheid vrij ver was teruggedrongen.

249. Hof Amsterdam 23 februari 1984, RSV 1984, 160, m.nt. J. Riphagen.

250. Rb. 's-Hertogenbosch. 1 juni 1984, Jurisprudentie WWV/WSW 1986, 36.

251. HR 11 januari 1985, AB 1986, 416, m.nt. J. Riphagen, RSV 1985, 112, m.nt. J. Riphagen.

252. Het ging dan namelijk om een wijziging die haar grond vond in de omstandigheid dat de betrokikene inkomsten had als bedoeld in artikel 17, die niet in mindering waren gebracht. 
Ook de administratieve rechter volgde deze lijn. Zo moest de Centrale Raad van Beroep in 1986 oordelen over een geval, waarin aan K. (in 1969) twee maal een volledig ongehuwden-ouderdomspensioen ingevolge de $\mathrm{AOW}$ was toegekend. Nadat dit bekend was geworden besloot de SVB het volledige ten onrechte betaalde bedrag over de periode 1969-1982 terug te vorderen op grond van artikel 1395 BW (oud). K. vroeg vervolgens ter zake van de terugvordering om een voor beroep vatbare beslissing, maar werd in dit verzoek niet-ontvankelijk verklaard. Zij ging hiertegen in beroep bij de Raad van Beroep. De SVB stelde dat al hetgeen meer was betaald dan hetgeen aan $\mathrm{K}$. was voldaan uit hoofde van haar aanspraak op (éen) ouderdomspensioen, niet kon worden beschouwd als ouderdornspensioen ingevolge de AOW. Nu het niet het rechtskarakter had van ouderdomspensioen, viel het niet onder de bijzondere terugvorderingsbepaling van de AOW en waren op de terugvordering de bepalingen van het gemene recht van toepassing. Er was dan ook geen sprake van een beslissing ingevolge de AOW, waartegen bezwaar en beroep openstond. De Raad van Beroep was daarentegen van mening dat er wel sprake was van een beslissing tot toekenning van ouderdomspensioen krachtens de AOW. Weliswaar was de Raad van Arbeid, die de (tweede) uitkering had toegekend, daartoe onbevoegd, maar dit betekende niet dat die toekenning nietig was. Evenmin betekende dit dat aan de beslissing het rechtskarakter van een beslissing tot toekenning kon worden ontnomen. De betalingen die op grond van de toekenningsbeslissing waren gedaan, moesten dan ook worden beschouwd als betalingen ten titel van ouderdomspensioen. De terugvorderingsbeslissing had dan ook in een voor beroep vatbare vorm moeten worden afgegeven, zodat $\mathrm{K}$. ten onrechte niet-ontvankelijk was verklaard in haar verzoek. Ook de Centrale Raad van Beroep kwam tot de slotsom dat op de terugvordering van het 'tweede' AOW-pensioen de regels uit de AOW van toepassing waren. De Centrale Raad ging echter verder dan de Raad van Beroep. Het maakte volgens hem zelfs niet uit of overeenkomstig een (onjuist) toekenningsbesluit was uitbetaald of dat de fout was gelegen in de uitbetaling zelf, waarbij dus niet conform de (correcte) toekenningsbeslissing werd betaald. In beide gevallen moesten de publiekrechtelijke terugvorderingsbepalingen worden gevolgd. ${ }^{253}$ Verschil was dat in het eerste geval de onjuiste toekenningsbeslissing eerst moest worden gecorrigeerd, moest worden ingetrokken dus. In het tweede geval was de toekenningsbeslissing correct, intrekking was dan niet atan de orde. ${ }^{254}$

De conclusie luidt dan ook dat de weg van artike! 1395 BW (oud), nu 6:203 $\mathrm{BW}$, niet mag worden bewandeld door de uitkerende instantie, als aan deze instantie wettelijke terugvorderingsbepalingen ten dienste staan. De publiekrechtelijke terugvorderingsbepalingen gelden als lex specialis ten opzichte van de algemene regeling dat heigeen onverschuldigd is betaald, kan worden teruggevorderd. Ook als men vindt dat de overheid in beginsel gebruik mag maken van het privaatrecht, is deze uitkomst terecht: het gebruik van de privaatrechtelijke weg 
vormt een onaanvaardbare doorkruising van de publiekrechtelijke regeling. ${ }^{25 s}$

\subsubsection{Invullen van een leemte in de terugvorderingsbepalingen met behulp van de regeling van onverschuldigde betaling in het $B W$}

Een situatie die van het hiervoor beschreven geval moet worden onderscheiden, is die waarin de wettelijke regeling geen regeling kende met betrekking tot terugvordering, dan wel een regeling die hiaten bevatte. ${ }^{256}$ De betrokken wet gaf in dat geval geen expliciet antwoord op de vraag of mocht worden teruggevorderd. Het bestuursorgaan kon zich in die gevallen in ieder geval niet beroepen op een publiekrechtelijke terugvorderingsregeling. Deze situatie deed zich bijvoorbeeld oorspronkelijk voor bij de Kinderbijslagwet 1939. ${ }^{257}$

Sinds de inwerkingtreding van de Wet tegengaan oneigenlijk gebruik in 1978 kenden alle socialeverzekeringswetten uitputtende bepalingen met betrekking tot terugvordering. ${ }^{258}$ Andere socialezekerheidswetten bevatten nog wel hiaten op dat gebied. Dan bleef de vraag relevant of te veel betaalde uitkeringen via de weg van artikel $1395 \mathrm{BW}$ (oud) konden worden teruggevorderd. In de vorige paragraaf is reeds de WWV aan de orde geweest. Deze regeling kende geen terugvorderingsbepalingen, maar te veel betaalde uitkeringen konden worden teruggevorderd met behulp van artikel 1395 BW (oud), althans als die uitkering onverschuldigd was betaald, als er dus geen rechtsgrond (meer) was voor de betaling.

Een andere regeling die hiaten bevatte in de terugvorderingsbepalingen was de $A B W$, die immers voor 1992 niet de bepaling kende dat door een administratieve vergissing ten onrechte betaalde bijstand kon worden teruggevorderd. ${ }^{259}$ Had de gemeente in dat geval conform de foutieve toekenningsbeslissing betaald, dan diende zij deze toekenningsbeslissing in te trekken, gevolgd door een actie uit onverschuldigde betaling. Was het echter betrokkene niet duidelijk dat een administratieve vergissing was begaan en kon hem dit redelijkerwijs ook niet duidelijk zijn, dan was intrekking in strijd met het vertrouwensbeginsel. ${ }^{260}$

In 1984 moest de kantonrechter in Utrecht oordelen over een terugvordering. door een gemeente van een onverschuldigd betaald bedrag. ${ }^{261}$ Door een "computerfout' was te veel vakantiegeld uitbetaald aan B. De gemeente stelde zich op het

255. Zie 5.2.5. Hetzelfde uitgangspunt zou overigens gelden bij hantering van de (klassieke) gemene rechtsieer, nu in een publiekrechtelijke regeling een uitzondering op het gemene recht is. neergelegd, zie 5.2.1.

256. Als gezegd in 6.5.1 zal deze situatie zich na de inwerkingtreding van de WBM niet (snel) meer voordoen.

257. Zie 6.3.3. Aldaar is ook de uitspraak van de CRvB 14 december 1950, AB 1951, 257 aan de orde gekomen met betrekking tot de vraag of in dat geval kon worden teruggevorderd met. behulp van artikel 1395 BW (oud).

258. Althans waar het terugvordering van de uitkeringsgerechtigde zelf betrof, waarbij conform de toekenningsbeschikking was betaald.

259. Zie 6.2 .3 .

260. KB 29 november 1979, AB 1980, 177, m.nt. V.d. N., zie 6.2.3.

261. Ktr. Utrecht 20 november 1984, JABW 1986, 4. 
standpunt dat geen sprake was van te veel betaalde bijstand. B. daarentegen voerde aan dat hij een bijstandsuitkering ontving ingevolge een beschikking van $\mathrm{B}$ en W. Het bedrag was hem dan ook uit hoofde van die beschikking betaald. De kantonrechter overwoog dat indien door een administratieve vergissing te veel was uitbetaald, van geval tot geval moest worden bekeken of sprake was van bijstandsverlening dan wel van onverschuldigde betaling. In het eerste geval moest de 'verhaalsprocedure' worden toegepast, in het tweede geval kon een 'contradictoire procedure' worden ingesteld. Volgens de rechter was in casu geen sprake van bijstandsverlening maar van onverschuldigde betaling nu de vergissing onmiddellijk was ontdekt en reeds de dag nadat de foutieve berekening aan B. was verzonden een brief was verstuurd dat het eerder vermelde bedrag onjuist was en dat spoedig het juiste bedrag zou worden medegedeeld. Ongeveer een jaar later bevestigde hetzelfde kantongerecht deze uitspraak in een overweging ten overvloede. ${ }^{262}$ In beide gevallen was het de kantonrechter die als burgerlijke rechter oordeelde, niet de kantonrechter als administratieve rechter in bijstandszaken.

Naar mijn mening had in deze gevallen de administratieve weg, zoals aangegeven door het koninklijk besluit van 29 november 1979, moeten worden gevolgd. Uit het feit dat aan B. een brief werd gestuurd waarin stond dat het aan hem vermelde bedrag onjuist was en dat spoedig het juiste bedrag zou worden medegedeeld, leid ik af dat de na deze brief gedane betalingen berustten op de nog niet gecorrigeerde toekenningsbeslissing. Doordat de gemeente de vergissing reeds voor de uitbetaling mededeelde, kon bij B. niet het vertrouwen zijn gewekt dat hij het geld mocht behouden. Intrekking was in dat geval dan ook geen probleem. De situatie dat de mededeling dat een fout was gemaakt als correctiebeschikking moest worden gezien, zodat meer was betaald dan waarop de betrokkene recht had, zal hierna worden behandeld.

Ook met betrekking tot de AAW deed zich een geval voor, waarvoor de wettelijke regeling zelf geen oplossing bood. Betrokkene had op grond van die wet een voorziening gekregen omdat hij gedurende een bepaalde tijd was tewerkgesteld in het kader van de Wet Sociale Werkvoorziening. Nadat die tewerkstel. ling was beëindigd, had ook uitbetaling van de voorziening moeten worden beëindigd, maar dit was niet gebeurd. Pas enige tijd later kreeg de betrokkene een brief dat de voorziening met terugwerkende kracht werd beëindigd en werd hem verzocht het te veel betaalde terug te betalen. De Raad van Beroep verklaarde het beroep tegen de beëindiging met terugwerkende kracht ongegrond. Het beroep tegen het verzoek om terugvordering werd niet-ontvankelijk verklaard. De Centraie Raad van Beroep bevestigde deze uitspraak. Vervolgens deelde de uitkerende instantie mee dat het te veel betaalde zou worden verrekend met de lopende uitkering. Betrokkene vorderde vervolgens in kort geding voor de president van de rechtbank dat het het uitkeringsorgaan zou worden verboden het teruggevorderde bedrag te verrekenen. Van belang is de primaire grondslag van de vordering: ingevolge de AAW was de uitkerende instantie niet bevoegd tot terugvordering van 
voorzieningen. Er bestond dus geen terugbetalingsverplichting zodat betrokkene niets verschuldigd was. De president verstond deze vordering aldus dat betrokkene stelde dat de genoten voorzieningen niet konden worden aangemerkt als onverschuldigd betaald in de zin van artikel 1395 BW (oud), daar de AAW een uitputtende en exclusieve terugvorderingsregeling bevatte. Artikel $48 \mathrm{AAW}$, de terugvorderingsbepaling, gaf slechts een regeling met betrekking tot terugvordering van uitkeringen, en niet van voorzieningen, zodat volgens betrokkene de wetgever er kennelijk voor had gekozen een dergelijke terugvordering uit te sluiten. Het feit dat de $\mathrm{AAW}$ geen regeling voor terugvordering van voorzieningen kende, was kennelijk ook de reden dat de Raad van Beroep betrokkene niet-ontvankelijk verklaarde in zijn beroep tegen het verzoek om terugbetaling. Hij had namelijk overwogen dat de vraag in hoeverre een bevoegdheid bestond om op grond van artikel $1395 \mathrm{BW}$ (oud) tot terugvordering over te gaan, niet door hem kon worden beoordeeld. Wel overwoog hij dat het hem ongerijmd voorkwam dat de AAW precieze - beperkte - regels kende met betrekking tot terugvordering van uitkeringen, terwijl het ontbreken van een dergelijke regeling met betrekking tot voorzieningen tot een veel ruimere terugvorderingsbevoegdheid op grond van het $\mathrm{BW}$ Lou' itrutur.

De president concludeerde dat niet mocht worden aangenomen dat ten onrechte uitbetaalde voorzieningen nimmer konden worden teruggevorderd. Hij zag twee denkbare oplossingen: analoge toepassing van de bepalingen betreffende terugvordering van uitkeringen dan wel teruggrijpen naar de algemene terugvorderingsmogelijkheid volgens burgerlijk recht. In beide gevallen faalde de primaire grondslag. De president koos - ongemotiveerd - voor de laatste optie, ${ }^{263}$ een naar mijn mening minder juiste keuze, nu analoge toepassing van de bepalingen van de AAW de betrokkene een betere rechtsbescherming zou hebben geboden. Volgens annotator Kooijman lijkt artikel 1395 BW (oud) op het eerste gezicht ruimere (terugvorderings)mogelijkheden te bieden dan artikel $48 \mathrm{AAW}$, maar dit was volgens hem grotendeels schijn nu aan de terugvordering een intrekkingsbeslissing moest voorafgaan, die kon worden getoetst door de administratieve rechter. Het enkele feit dat de ruimere mogelijkheid die artikel 1395 BW (oud) bood, grotendeels schijn was, lijkt mij echter al voldoende reden om in die gevallen de bepalingen uit de AAW analoog toe te passen. Zo kenden die bepalingen onder meer niet de mogelijkheid wettelijke rente te vorderen, terwijl voorts uit de jurisprudentie blijkt dat bij een beroep tegen een terugvorderingsbeslissing andere aspecten een rol spelen bij de vraag of deze beslissing in stand kan blijven dan bij een beroep tegen een intrekkingsbeslissing. Te denken valt bijvoorbeeld aan de zogenaamde zesmaandentermijn. ${ }^{264}$

Een soortgelijk geval deed zich enkele jaren later weer voor, zij het dat degene aan wie de voorziening was toegekend, was overleden. Vervolgens werd de voorziening nog enkele jaren uitbetaald aan de weduwe. De beslissing tot 
toekenning werd ingetrokken, zodat voor de (burgerlijke) rechter vaststond dat onverschuldigd was betaald. Nu de AAW geen regeling met betrekking tot terugvordering van voorzieningen kende, kon de terugvordering enkel op artikel 1395 BW (oud) berusten, aldus de rechter. ${ }^{265}$

De burgerlijke rechter was dus geneigd om in de gevallen waarin de publiekrechtelijke regeling een leemte bevatte, waardoor deze regeling geen direct antwoord gaf op de vraag of het te veel betaalde kon worden teruggevorderd, artikel 1395 BW (oud) toepasselijk te achten. De bestuursrechter leek voorzichtiger. Weliswaar oordeelde bijvoorbeeld de Kroon ook dat door een administratieve vergissing te veel of ten onrechte betaalde bijstand moest worden teruggevorderd via een actie uit onverschuldigde betaling, maar indien conform de toekenningsbeslissing was betaald moest deze actie wel zijn voorafgegaan door intrekking van de toekenningsbeslissing. Deze intrekking kon vervolgens wel door de bestuursrechter worden beoordeeld. De Centrale Raad van Beroep paste in deze gevallen het algemene rechtsbeginsel dat hetgeen onverschuldigd is betaald, kan worden teruggevorderd, toe. Deze laatste weg heeft mijn voorkeur, nu in dat geval rechtstreeks ten volle rekening kan worden gehouden met de specifieke omstandigheden van het geval, waarmee de regeling zoals neergelegd in artikel $1395 \mathrm{BW}$ (oud) naar zijn aard geen rekening houden kan, zodat in dat geval deze omstandigheden via allerlei omwegen meegenomen moeten worden. Bovendien biedt de weg van de Centrale Raad van Beroep de mogelijkheid dat de administratieve rechter over deze terugvordering kan oordelen. Hierop zal ik in hoofdstuk 12 terugkomen.

\subsubsection{De titel van betaling en de hoedanigheid van de ontvanger}

In de derde te behandelen situatie kent de betrokken regeling weliswaar terugverderingsbepalingen, maar staat ter discussie of die bepalingen van toepassing zijn, omdat het bestuursorgaan meer heeft betaald dan waarop betrokkene op grond van de toekenningsbeslissing recht had of omdat het bestuursorgaan aan een ander dan de (rechtstreeks) betrokkene heeft uitbetaald. In het eerste geval speelt de titel van de betaling een rol, in het tweede de hoedanigheid van de ontvanger. Ik zal deze beide aspecten in deze volgorde afzonderlijk behandelen. Hierbij moet overigens worden bedacht dat in bepaalde gevallen de conclusie kan zijn dat zowel de titel van betaling 'in het geding' is als de vraag of er een leemte is in de terugvorderingsbepalingen. De vorige en deze paragraaf kumnen elkaar dus deels overlappen.

\subsubsection{De titel van betaling}

De vraag of de weg van de onverschuldigde betaling ex artikel 1395 BW (oud) nu 6:203 BW - mocht worden gevolgd of dat het bestuursorgaan de bestuursrechtelijke weg moest volgen als het meer uitbetaalde dan waarop de betrokkene op grond van de correcte toekenningsbeslissing recht had, heeft voor de nodige rechtspraak gezorgd. Uit deze rechtspraak kan geen eenduidige lijn worden gehaald. 
Zo moest de Raad van Beroep Rotterdam in 1984 oordelen over een geval waarin een gemeente, die een WWV-uitkering verstrekte aan betrokkene, een aantal malen ten onrechte meer had uitgekeerd dan waarop de betrokkene op grond van de toekenningsbeslissing recht had. De gemeente vorderde dit te veel betaalde terug op grond van artikel 27 lid 1 WWV. ${ }^{266}$ Betrokkene tekende hiertegen bezwaar aan, maar het bezwaarschrift werd ongegrond verklaard. In de beslissing op het bezwaar werd onder meer overwogen dat sprake was van toedoen als bedoeld in artikel 27 lid $1 \mathrm{WWV}$. Het hiertegen ingestelde beroep werd niet-ontvankelijk verklaard, waarna hij tegen deze beschikking verzet aantekende. Vervolgens stelde B en W zich op het standpunt dat geen sprake was van toepassing van artikel 27 WWV, maar van een vordering wegens onverschuldigde betaling ex artikel 1495 (bedoeld werd: artikel 1395) BW (oud). De Raad van Beroep overwong dat geen sprake kon zijn van (toepassing van) artikel $27 \mathrm{WWV}$, nu de beslissing tot toekenning van de uitkering geen wijziging had ondergaan; er was slechts sprake van een onverschuldigde betaling bovenop de uitkering krachtens de WWV. ${ }^{267}$ Betrokkene werd wederom niet-ontvankelijk verklaard. Bij deze uitspraak moet de kanttekening worden geplaatst, dat het hier een geschil betrof over een WWVuitkering. Zoals in 6.5 .3 beschreven kende de WWV slechts een regeling met betrekking tot intrekking en niet met betrekking tot terugvordering. Intrekking was niet aan de orde, nu de toekenningsbeslissing correct was.

De opvatting van de Centrale Raad van Beroep is hiervoor al aan de orde geweest. ${ }^{268}$ In zijn uitspraak van 7 april 1986, betreffende de dubbele toekenning en uitbetaling van een AOW-pensioen, had hij overwogen dat de terugvorderingsbepalingen uit de AOW moesten worden toegepast, ook als (anders dan in casu) sprake was van een fout bij de uitbetaling, waardoor die uitbetaling meer beliep dan waarop naar de regels van de AOW (en de toekenningsbeslissing) aanspraak kon worden gemaakt. In dat geval hoefde slechts ten aanzien van de toekenningsbeslissing tevoren niets te geschieden. Wel moest sprake zijn van een betaling ten titel van AOW-pensioen. Daarvan was volgens de Centrale Raad sprake nu er twee toekenningsbeslissingen waren genomen, op grond waarvan werd uitbetaald. De 'tweede' betalingen, waarop betrokkene uiteraard geen aanspraak had, waren gedaan ten titel van ouderdomspensioen in de zin van de AOW en dienden dus ook te worden aangemerkt als ouderdomspensioen in de zin van die wet. ${ }^{269}$

De 'bijstandsrechter' volgde een andere koers. Zo overwoog de kantonrechter te Utrecht dat het door de gemeente ingediende verzoekschrift tot terugvordering ontvankelijk was nu ten tijde van de betaling van het ten onrechte betaalde bedrag sprake was van een uitkering op grond van de $A B W$. Het verzoekschrift betrof dan ook terugvordering van betaalde bijstand en niet terugvordering van een bedrag dat onverschuldigd was betaald en waarover de gewone burgerlijke rechter

266. Zie over dit artikel 6.5.3.

267. RvB Rotterdam 13 september 1984, Jurisprudentie WWV/WSW 1984, 165.

268. Zie 6.5.3.

269. CRvB 7 april 1986, RSV 1986, 207. 
had te oordelen. De kantonrechter als verhaalsrechter was dan ook bevoegd over de vordering tot terugbetaling te oordelen. De rechter liet hier in een overweging ten overvloede op volgen dat dit alles niet meebracht dat de burgerlijke rechter onbevoegd zou zijn als sprake was van een 'echte' onverschuldigde betaling, waarbij hij als voorbeeld van een dergelijke 'echte' onverschuldigde betaling noemde het geval dat na beëindiging van de uitkering toch nog werd uitbetaald. 270

Een andere belangrijke situatie was die waarin de betrokkene nog steeds recht had op een bijstandsuitkering, maar meer uitbetaald kreeg dan waarop hij op grond van de correcte toekenningsbeslissing recht had. De Centrale Raad van Beroep had in zijn hiervoor besproken uitspraak van 7 april 1986 beslist dat ook in dat geval sprake was van betaling ten titel van AOW en dat de terugvorderingsbepalingen van die wet daarop van toepassing waren en dus niet artikel $1395 \mathrm{BW}$ (oud). Het oordeel van de bijstandsrechter luidde anders.

Cornelissen ontving van de gemeente Groningen een bijstandsuitkering. Daarnaast had zij neveninkomsten. Nu zij dit had gemeld, was hiermee rekening gehouden in de toekenningsbeslissing bij de bepaling van de hoogte van de uitkering. Door een vergissing werden deze inkomsten gedurende drie maanden niet 'meegenomen" waardoor zij gedurende deze tijd een ongekorte uitkering en dus meer ontving dan waarop zij recht had op grond van de toekenningsbeslissing. Cornelissen had de fout bemerkt en medegedeeld aan de gemeente. De vraag was vervolgens of de terugvorderingsbepalingen uit de $\mathrm{ABW}$ van toepassing waren of niet, dus of al dan niet was betaald ten titel van bijstand. De gemeente volgde de procedure zoals neergelegd in artikel $59 \mathrm{ABW}$ en diende een verzoekschrift in bij de kantonrechter. Comelissen stelde zich echter op het standpunt dat artikel 59 niet van toepassing was. De kantonrechter achtte het artikel wel toepasselijk; het diende juist in het belang van personen in de positie van Cornelissen niet te eng te worden geïnterpreteerd. Als argumenten voerde de kantonrechter aan dat deze procedure goedkoop was, geen kostenveroordeling kende en de rechter een matigingsrecht gaf. De rechtbank vemietigde deze beschikking. Uit de artikelen 58 en 59 ABW volgde dat de kosten van bijstand slechts op Comelissen konden worden verhaald in de gevallen als aangegeven in die artikelen. Buiten die gevallen had de gemeente in het geheel geen verhaalsvordering. Nu er sprake was van een administratieve vergissing waren genoemde artikelen niet van toepassing en werd de gemeente niet-ontvankelijk verklaard in haar vordering. ${ }^{271}$ Deze zaak kreeg een vervolg bij de burgerlijke rechter, dat ik hierna zal bespreken. Eerst zal ik ingaan op een aantal andere uitspraken van deze rechter op dit punt.

De eerste te bespreken uitspraak werd in 1985 gewezen door de Rechtbank Amsterdam. De SVB had aan betrokkene een verminderd weduwepensioen op grond van de AWW toegekend. De reden voor deze vermindering was gelegen in het feit dat betrokkene ook een uitkering ontving in Duitsland en deze diende te worden verrekend. Gedurende bijna twee jaar werd echter abusievelijk het gehele,

270. Ktr. Utrecht 6 november 1984, JABW 1986, 3.

271. Rb. Groningen 29 november 1988, JABW 1990, 16. 
ongekorte, weduwepensioen overgemaakt. Volgens de SVB had het te veel betaalde niet het karakter van weduwepensioen en diende het als onverschuldigd te worden terugbetaald op grond van artikel $1395 \mathrm{BW}$ (oud). Betrokkene was echter van mening dat artikel $1395 \mathrm{BW}$ (oud) niet van toepassing was, omdat het gehele uitgekeerde bedrag diende te worden aangemerkt als pensioen, nu alleen ten onrechte de korting niet in mindering was gebracht. De rechtbank was het hiernee eens; er was sprake van een 'betaling ten titel van weduwepensioen, zij het dat aan gedaagde gedurende 22 maanden teveel is uitbetaald'. Voor terugvordering van te veel betaald weduwepensioen bevatte de AWW voorschriften. 'Uitsluitend aan de hand van die - administratief-rechtelijke - voorschriften moet worden beoordeeld of, en zo ja, in hoeverre gedaagde gehouden is het teveel ontvangene terug te betalen'. ${ }^{272}$ De vordering van de SVB werd niet-ontvankelijk verklaard.

In 1991 oordeelde het Hof Arnhem op gelijke wijze in een bijstandszaak. ${ }^{273}$ B. had in oktober 1983 een aanvraag tot verlening van bijstand ingediend. Bij brief van 16 mei 1984 deelde de gemeente hem mee dat hem deze bijstand werd verleend en dat de uitkering per 1 februari 1984 werd beëindigd. Vervolgens betaalde de gemeente nog ongeveer anderhalf jaar bijstand door. Nadat zij de fout had opgemerkt, stelde zij een vordering vit onverschuldigde betaling in bij de rechtbank; een oorzaak tot betaling van het bedrag ontbrak. B. stelde zich daarentegen op het standpunt dat het bedrag hem was betaald als verleende bijstand en dat dus de verhaalsprocedure van de $\mathrm{ABW}$ moest worden gevolgd, zodat een verzoekschrift bij de kantonrechter had moeten worden ingediend. Het hof oordeelde - kort gezegd - dat de betalingen niet uitsluitend het gevolg waren van een administratieve vergissing (dus waarschijnlijk ook het gevolg van het niet volledig informeren van de gemeente door B.) en dat B. de betreffende betalingen mocht beschouwen als betalingen van bijstand ingevolge de $\mathrm{ABW}$. Dit betekende dat de gemeente niet werd ontvangen in haar vordering; de strekking van de $\mathrm{ABW}$ bracht mee 'dat B. de bescherrning geniet tegen terugvordering van de zijde van de gemeente overeenkomstig de verhaalsregels van de ABW'.

Het (civiel-rechtelijke) vervolg in het geschil tussen Cornelissen en de gemeente Groningen eindigde anders. Nadat de gemeente nul op het rekest had gekregen bij de rechtbank in de verzoekschriftprocedure, stelde zij een vordering in bij de kantonrechter op grond van artikel $1395 \mathrm{BW}$ (oud). Cornelissen stelde dat reeds definitief was beslist op de vraag of zij het te veel uitgekeerde moest terugbetalen. $\mathrm{Zij}$ beriep zich onder meer op het feit dat de verhaalsbepalingen in de $\mathrm{ABW}$ een lex specialis vormden ten opzichte van artikel $1395 \mathrm{BW}$ (oud). Dit verweer werd verworpen. De kantonrechter overwoog dat in een geval waarin geen verhaal mogelijk was op grond van de verhaalsbepalingen uit de $\mathrm{ABW}$, omdat sprake was van een kennelijke vergissing, de rechtbank (als bijstanđsrechter) niet had uitgesloten dat terugvordering plaatsvond op grond van artikel 1395 BW (oud). 'Het door de gemeente betaalde bedrag moet niet als bijstandsverle-

272. Rb. Amsterdam 8 mei 1985, AB 1987, 212, m.nt. JHS onder 213.

273. Hof Amhem 5 maart 1991, JABW 1991, 164. Het hof oordeelde hier als burgerlijke rechter, niet als bijstandsrechter. 
ning maar als onverschuldigde betaling worden aangemerkt'. ${ }^{274}$ De vordering van de gemeente werd vervolgens - inclusief de gevraagde wettelijke rente toegewezen. Cornelissen ging in hoger beroep, maar de rechtbank bekrachtigde het vonnis van de kantonrechter. De betaling van het hogere bedrag was niet gedaan ten titel van bijstand ingevolge de $A B W$, maar was onverschuldigd betaald en dus kwam aan de gemeente het recht toe dit te veel betaalde terug te vorderen op grond van artikel $1395 \mathrm{BW}$ (oud). ${ }^{275}$

Cornelissen stelde cassatie in bij de Hoge Raad. $\mathrm{Zij}$ voerde aan dat de betaalde bedragen wel degelijk waren verstrekt ten titel van bijstand, nu vaststond dat zij in principe recht had op een uitkering krachtens de $A B W$, maar dat deze uitkering werd verminderd met bepaalde inkomsten. Nu ten titel van bijstand was betaald, werd de grond waarop de gemeente tot terugvordering wilde overgaan relevant, aldus Cornelissen. De ABW bood geen mogelijkheid het te veel betaalde terug te vorderen, terwijl ook de omweg van artikel $1395 \mathrm{BW}$ (oud) niet kon worden gevolgd: het puur civielrechtelijk leerstuk van de onverschuldigde betaling kon geen toepassing vinden in het publiekrecht. De HR overwoog dat geen sprake was van betaling ten titel van bijstand:

'Ingevolge art. $1395 \mathrm{BW}$ - en ook ingevolge art. 6:203 NBW - is degene die zonder rechtsgrond heef betaald, gerechtigd tot terugvordering. Deze voorschriften geven uitdrukking aan een beginsel dat voor het gehele recht geldt. Dit brengt mee dat zij ook toegepast dienen te worden op betalingen van publiekrechtelijke aard, voor zover uit de wet niet het tegendeel voortvloeit.

Uit de ABW vloeit het tegendeel niet voort. Wel bepaalt art. 54a, opgenomen in $\S 3$ van Hoofdstuk IV, dat kosten van bijstand niet kunnen worden verhaald dan in de gevallen aangegeven in deze paragraaf. Maar bij verhaal in de zin van par. 3 van Hoofdstuk IV gaat het om terugvordering van bijstand die op grond van een beschikking tot verlening van bijstand en derhalve niet zonder rechtsgrond is betaald en niet om terugvordering van bedragen die niet op grond van zulk een beschikking zijn betaald, maar bijvoorbeeld - zoals hier - bij vergissing boven het bedrag dat volgens de beschikking is verschuldigd en derhalve zonder rechtsgrond zijn voldaan.

Ook een vordering uit onverschuldigde betaling is niet toewijsbaar, voor zover dit in de gegeven omstandigheden naar maatstaven van redelijkheid en billijkheid onaanvaardbaar zou zijn. Gaat het om een vordering, van een overheidslichaam, dan moet bij de vaststelling van wat redelijkheid en billijkheid eisen rekening worden gehouden met de algemene beginselen van behoorlijk bestuur, waaronder het beginsel dat gerechtvaardigd vertrouwen moet worden beschermd. Maar hierop heeft Cornelissen, die de vergissing van de gemeente heeft bemerkt, zich niet beroepen'. ${ }^{276}$

Dus: artikel 1395 en artikel 6:203 geven uitdrukking aan een beginsel dat voor het gehele recht geldt. Dit brengt mee dat zij ook toegepast dienen te worden op betalingen van publiekrechtelijke aard, voor zover uit de wet niet het tegendeel voortvloeit. Het is dan ook de vraag of de Hoge Raad artikel 1395 BW (oud) rechtstreeks toepaste. ${ }^{277}$

274. Ktr. Groningen 8 november 1989, JABW 1990, 37.

275. Rb. Groningen 2 november 1990, JABW 1991, 5.

276. HR 25 oktober 1991, NJ 1992, 299, m.nt. JBMV, AB 1992, 88, m.nt. FHvdB.

277. Zie voor een uitgebreidere bespreking van dit arrest en de vraag of hierin mogelijk een toepassing van de invullende rechtsleer kan worden gezien 5.3.3. In ieder geval past de HR hier niet de gemene rechtsleer toe, zoals Vranken in zijn noot onder het arrest stelt. Overigens. 
Het arrest leidde er toe, dat in de rechtspraak van de twee hoogste rechters op dit gebied - de Centrale Raad van Beroep en de Hoge Raad - een tegengesteld standpunt werd ingenomen. De wetgever heeft in de WBM de weg van de Centrale Raad gevolgd. In de socialezekerheidswetten is nu ook de verplichting tot (en dus voor het bestuursorgaan de grondslag voor) terugvordering opgenomen als meer is betaald dan waarop krachtens de toekenningsbeslissing recht bestaat. ${ }^{278}$ In dat geval moeten dus de publiekrechtelijke terugvorderingsbepalingen worden toegepast. Dit lijkt mij de juiste weg. Mijns inziens zou het criterium moeten zijn de vraag of sprake is (geweest) van een publiekrechtelijke relatie tussen betaler en ontvanger. Is die er, dan dient de betrokkene een optimale bestuursrechtelijke bescherming te worden geboden door de publiekrechtelijke regeling te volgen. Bestaat er geen publiekrechtelijke verhouding tussen het betalende bestuursorgaan en de ontvanger van deze betaling - iemand die nooit een uitkering heeft gehad, krijgt op zijn bankrekening een bedrag gestort onder vermelding "bijstandsuitkering december' - dan kan de weg van artikel 6:203 BW worden gevolgd. Er zullen echter altijd grensgevallen blijven, bijvoorbeeld iemand die een uitkering heeft gehad, vervolgens enige maanden 'uit de uitkering' is waardoor de publiekrechtelijke relatie is verbroken en dan ten onrechte door een fout toch nog een maand uitkering overgemaakt krijgt, die voor iemand anders is bedoeld. Hierbij zal naar mijn mening het tijdsverloop tussen het beëindigen van de relatie en de betaling beslissend moeten zijn, in die zin, dat moet worden gekeken of de ontvanger erop mocht vertrouwen dat de betaling ten titel van de uitkering was gedaan. Zo zullen mijns inziens de publiekrechtelijke terugvorderingsbepalingen van toepassing zijn als bijvoorbeeld de betrokkene een beschikking krijgt dat de uitkering wordt beëindigd op een bepaalde datum, maar hem vervolgens door een administratieve fout toch nog een aantal uitkeringstermijnen wordt uitbetaald. ${ }^{279}$

\subsubsection{De hoedanigheid van de ontvanger}

Hiermee zijn we gekomen aan de vraag of de terugvorderingsregeling uit de betrokken wet dan wel artikel 1395 BW (oud) van toepassing is, indien is betaald aan een ander dan betrokkene. Is die ander een willekeurige derde, dan geldt de hiervoor geformuleerde regel: er is geen sprake van een bijzondere - publiekrechtelijke - verhouding tussen betaler en ontvanger, zodat in dat geval weinig bezwaar bestaat tegen toepassing van artikel 6:203 $\mathrm{BW}$. Wel dient in dat geval de overheid de algemene beginselen van behoorlijk bestuur in acht te nemen. ${ }^{280}$

overwoog de HR nog geen jaar later in een soortgelijk geval dat artikel 1395 BW (oud) rechtstreeks van toepassing was, HR 10 augustus 1992, NJ 1993, 636, mnt. MS, AB 1993, 12 (M.-Roosendaal en Nispen).

278. Zie bijvoorbeeld artikel 36 lid 1 WW: 'De uitkering die als gevolg van een besluit als bedoeld in artikel $22 \mathrm{a}$ of 27 [het intrekkingsbesluit, CB] onverschuldigd is betaald, alsmede hetgeen anderszins onverschuldigd is betaald, wordt door het Landelijk instituut sociale verzekeringen van de betrokken werknemer teruggevorderd'. Mijn cursivering.

279. Zie hierover uitgebreider hoofdstuk 11.

280. Zie hierover verder hoofdstuk 11. 
Die derde hoeft echter niet altijd een willekeurig iemand te zijn. Te denken valt bijvoorbeeld aan zogenaarnde 'doorgeschoten' uitkeringen, bijvoorbeeld indien de betrokkene overleden is, maar de uitkering werd doorbetaald, zodat de weduwe of erfgenamen uiteindelijk het geld hebben gekregen. Ook hierover heeft de rechter zich een aantal malen moeten buigen.

Een bekend arrest werd door de Hoge Raad gewezen in 1978 in een geschil tussen de SVB en de stichting St. Jansgeleen. ${ }^{281}$ Gulikers, die een uitkering had op grond van de AOW en de IW, werd verpleegd in een kliniek van deze stichting. De uitkeringen werden maandelijks uitbetaald aan de stichting. Na het overlijden van Gulikers werd deze uitbetaling nog enkele maanden voortgezet omdat de stichting dit overlijden pas later mededeelde aan de SVB. De SVB vorderde vervolgens het ten onrechte betaalde terug van de stichting. Deze vordering baseerde zij (primair) op onverschuldigde betaling, nu rechtens geen verplichting bestond tot betaling van de uitkering. De stichting voerde aan dat zij eerst optrad als gemachtigde van Gulikers en na diens dood van de erven en dat zij het geld had overgemaakt aan die erven. De Hoge Raad oordeelde dat sprake was van een onverschuldigde betaling ex artikel 1395 BW (oud). Door het overlijden van Gulikers hield namelijk de verplichting tot uitbetaling der uitkeringen op. Voorts was van belang dat de terugvorderingsbepalingen uit de AOW en de IW niet van toepassing waren. Waarom dit zo was motiveerde de Hoge Raad niet. Hij stelde slechts vast dat in cassatie ervan moest worden uitgegaan dat door het overlijden van Gulikers de volmacht eindigde en dat de stichting noch krachtens volmacht, noch krachtens zaakwaarneming bevoegd was de bedragen in ontvangst te nemen.

Deze vaststelling was volgens een uitspraak van de Centrale Raad van Beroep uit 1980 tevens de verklaring waarom de terugvorderingsbepalingen uit de AOW en IW' niet van toepassing waren. In deze zaak had de echtgenote van een man, die een AOW-uitkering genoot, verzuimd mededeling te doen van diens overlijden aan de Raad van Arbeid. Deze laatste vorderde het onverschuldigd betaalde terug van de weduwe. Volgens de Centrale Raad van Beroep was de vrouw bevoegd de betaling te ontvangen, zodat ten aanzien van haar - de Centrale Raad spreekt over 'de kategorie van personen, (...) die bevoegd zijn tot het ontvangen van betalingen terzake van krachtens de Wet toegekend ouderdomspensioen' - de terugvorderingsbepalingen van de $\mathrm{AOW}$ van toepassing waren. Het feit dat haar echtgenoot was overleden en dat zij op grond van artikel $15 \mathrm{AOW}$ slechts gedurende enkele maanden aanspraak kon maken op uitbetaling van het zogenaamde gehuwdenouderdomspensioen, bracht niet mee, dat na die datum ten titel van gehuwdenpensioen krachtens de wet betaalde termijnen voor toepassing van artikel 20 (het terugvorderingsartikel) niet zouden mogen worden aangemerkt als ouderdomspensioen. De Centrale Raad betrok het arrest. SVB-Stichting St. Jansgeleen in zijn overwegingen en kwam tot de slotsom dat de meest voor de hand liggende verklaring voor het feit dat in dat geval de terugvorderingsbepalingen uit onder meer de AOW niet van toepassing waren, was dat bij gebreke van volmacht of zaakwaar-

281. HR 31 maart 1978, NJ 1978, 363, m.nt G.J.S. 
neming de stichting onbevoegd was de betalingen in ontvangst te nemen. ${ }^{282}$

De Centrale Raad achtte echter niet iedere na de dood van betrokkene doorgeschoten betaling een betaling ten titel van de betrokken uitkering. Dit kon al worden opgemaakt uit de hiervoor beschreven uitspraak. De ontvanger van de uitkering moest bevoegd zijn de betaling te ontvangen. Een rechtsopvolger onder algemene titel, die na het overlijden van de rechthebbende over diens gelden beschikt, viel daar niet onder, zo blijkt uit een uitspraak uit 1989. Na het overlijden van R. vond door geautomatiseerde betaling nog een betaling plaats op zijn rekening, hoewel door het overlijden het recht op pensioen krachtens de AOW was geëindigd. De SVB vorderde vervolgens dit bedrag terug van $\mathrm{H}$., dochter van R. De rechtsgrond voor deze vordering was artikel 1395 BW (oud); artikel 24 AOW (het terugvorderingsartikel) en het hierin neergelegde vertrouwensbeginsel was niet van toepassing nu niet kon worden gesproken van een bijzondere administratieve relatie tussen de SVB en $\mathrm{H}$., aldus de SVB. De Raad stelde, eerst vast dat geen betaling had plaatsgevonden aan $\mathrm{H}$., maar dat deze betaling van de AOW had plaatsgevonden op de rekening van haar vader. Zij had als rechtsopvolgster onder algemene titel beschikt over het saldo van de rekening van haar vader. Hij vervolgde met te stellen dat artikel $24 \mathrm{AOW}$ 'geen beschermende werking (heeft) ten aanzien van betalingen die na het overlijden van de AOWgerechtigde over daama gelegen tijd toen er geen aanspraak op verdere betaling meer bestond, zijn gedaan'. De vraag of het betaalde kon worden teruggevorderd van de nalatenschap, moest dan ook worden beantwoord op grond van artikel $1395 \mathrm{BW}$ (oud). ${ }^{283}$

Een verklaring voor het verschil tussen deze uitspraak en de uitspraak inzake de terugvordering van de weduwe ligt mijns inziens in het feit dat de weduwe na het overlijden van haar - uitkeringsgerechtigde - echtgenoot gedurende enige tijd een zelfstandig recht op pensioen kreeg. De rechtsopvolgster onder algemene titel kreeg - en krijgt - een dergelijk recht niet. ${ }^{284}$

\subsubsection{Artikel $1395 \mathrm{BW}$ (oud) en het verkrijgen van een executoriale titel}

Ten slotte speelde artikel $1395 \mathrm{BW}$ (oud) - en ook artikel 6:203 BW - nog een rol bij de executie van teruggevorderde bedragen. Onder het recht zoals het gold voor de inwerkingtreding van de WBM, leverde de invorderingsbeslissing immers geen executoriale titel op. Teneinde een dergelijke titel te verkrijgen diende het bestuursorgaan zich tot de burgerlijke rechter te wenden. Hierbij is een aantal malen door de betrokkene van wie werd teruggevorderd, gepoogd de burgerlijke rechter (nogmaals) over de beslissing tot terugvordering of intrekking te laten oordelen. De burgerlijke rechter heeft zich. in die gevallen altijd op het standpunt gesteld dat de administratieve beslissing waartegen een administratief-rechtelijke

282. CRvB 15 mei 1980, RSV 1980, 261.

283. CRvB 13 september 1989, AB 1990, 147, m.nt. de L., RSV 1990, 237, m.nt. J.J.A. Kooijman.

284. Zie hierover ook de noot van Kooijman onder de uitspraak in de RSV. 
rechtsgang heeft opengestaan, waarvan de betrokkene geen gebruik heeft gemaakt, voor hem een gegeven vormt, evenals de beslissing van de administratieve rechter als deze onherroepelijk heeft geoordeeld over die administratieve beslissing. De Hoge Raad overwoog in een geval waarin een gemeente ten onrechte een WWVuitkering had betaald (waarbij dus moet worden bedacht dat er slechts een intrekkingsbesluit hoefde te worden genomen door het bestuur), dat het intrekkingsbesluit reeds was getoetst aan de algemene beginselen van behoorlijk bestuur door de bestuursrechter en door deze in stand was gelaten. Daarmee was de bevoegdheid van de gemeente gegeven de ten onrechte betaalde uitkeringen terug te vorderen op grond van artikel $1395 \mathrm{BW}$ (oud). Weliswaar kon de burgerlijke rechter het besluit tot terugvordering ook nog toetsen aan deze algemene beginselen, nu een dergelijke toetsing nog niet had plaatsgevonden, en wel 'in het kader van hetgeen naar maatstaven van redelijkheid en billijkheid in de gegeven omstandigheden aanvaardbaar is', uitgangspunt diende te zijn dat de uitkering met terugwerkende kracht was ingetrokken. Bij de toetsing van het terugvorderingsbesluit en 'van hetgeen in vervolg daarop heeft plaatsgevonden', de invordering dus, mocht de rechter slechts omstandigheden meenemen, die niet reeds door de bestuursrechter waren of hadden kunnen worden meegenomen bij de toetsing van het intrekkingsbesluit. Dit gold ook als de bestuursrechtelijke procedure niet was gevolgd. ${ }^{285}$

\subsubsection{Het omzeilen van de publiekrechtelijke terugvorderingsregeling anders dan via onverschuldigde betaling}

Als afsluiting van deze paragraaf wil ik nog kort ingaan op drie zaken waarbij niet werd getracht via de weg van de onverschuldigde betaling ten onrechte betaalde uitkeringen of andere daarmee verband houdende kosten terug te vorderen, maar via andere wegen.

In de eerste zaak vorderde een gemeente van de betrokkene een bedrag van bijna. $f 30.000$,- ter zake van ten onrechte gedane uitkeringen. Over dit bedrag vorderde zij voorts de wettelijke rente. Daarnaast vorderde zij kosten van gemaakte rechtskundige bijstand en incassokosten. Deze laatste vorderingen grondde zij op een door betrokkene jegens haar gepleegde onrechtmatige daad. De kantonrechter wees de verhaalsvordering toe; de overige vorderingen werden afgewezen. De rechter overwoog dat artikel $1401 \mathrm{BW}$ (oud), het onrechtmatigedaadsartikel, toepassing miste omdat de verhaalsbepalingen uit de $\mathrm{ABW}$ als lex specialis golden; de incassokosten konden dus niet op grond van artikel $1401 \mathrm{BW}$ (oud) worden gevorderd. $\mathrm{Zij}$ konden ook niet worden gevorderd op grond van die verhaalsbepalingen uit de $\mathrm{ABW}$, nu op grond van die bepalingen slechts de kosten van bijstand, en dus niet tevens van rechtsbijstand, konden worden verhaald.

285. HR 10 augustus 1992, NJ 1993, 636, m.nt. MS, AB 1993, 12 (M-Roosendaal en Nispen). Zie bijvoorbeeld ook Rb. Utrecht 2 oktober 1959, NJ 1960, 309, Rb. 's-Gravenhage 16 februari 1971, NJ 1971, 225 en Hof Leeuwarden 1 juni 1994, JSV 1994, 134. 
Hetzelfde gold voor de gevorderde wettelijke rente. Een veroordeling in de proceskosten was ook niet aan de orde, artikel $429 \mathrm{k} \mathrm{Rv}$, waarin deze veroordeling was geregeld, was niet van toepassing. ${ }^{286}$ Overigens was het onder omstandigheden wel mogelijk om de partner van de uitkeringsgerechtigde, met wie deze (ongehuwd) samenwoonde, aan te spreken op grond van een door hem gepleegde onrechtmatige daad als hij welbewust en stelselmatig had geprofiteerd van het feit dat aan betrokkene ten onrechte een uitkering was betaiald. ${ }^{287}$

In de tweede te behandelen zaak had de vader van Posthuma van de gemeente Tytsjerksteradiel een ABW-uitkering gekregen. Kennelijk was de gemeente van mening dat deze uitkering ten onrechte was verleend. Nadat zijn vader was overleden, sloot de gemeente een overeenkomst met Posthuma met de (kennelijke) inhoud dat deze, dan wel de nalatenschap van zijn vader de gemaakte kosten van bijstand zou terugbetalen. Vervolgens stelde de gemeente een vordering in bij de burgerlijke rechter, die was gegrond op deze overeenkonnst. Posthuma betoogde dat de gemeente niet kon worden ontvangen in haar vordering, nu het verlenen en terugvorderen van bijstand een publiekrechtelijke bevoegdheid was, die niet kon worden uitgeoefend via de privaatrechtelijke weg. Het Hof Leeuwarden plaatste zijn oordeel in het kader van de Windmill-leer, waarbij het als uitgangspunt nam dat de gemeente privaatrechtelijke bevoegdheden had. ${ }^{283}$ De eerste vraag was dan of de betrokken regeling, de $\mathrm{ABW}$ dus, een antwoord gaf op de vraag of de overheid gebruik mocht maken van de haar in beginsel toekomende privaatrechtelijke bevoegdheden. Volgens het hof was van belang dat de regeling van verhaal in de $\mathrm{ABW}$ exclusief was bedoeld en dus reeds een antwoord gaf op de vraag of de gemeente haar belangen mocht behartigen door gebruik te maken van haar bevoegdheid een overeenkomst naar burgerlijk recht te sluiten. Uit artikel 54a ABW volgde dat de kosten van bijstand niet konden worden verhaald dan in de gevallen in de $\mathrm{ABW}$ aangegeven en hieruit vloeide voort 'dat de wetgever verhaal van kosten van bijstand in de $A B W$ limitatief heeft willen regelen en verhaal via de privaatrechtelijke weg heeft willen uitsluiten'. Het hof oordeelde vervolgens ten overvloede dat, als dat niet zo was, in dit geval het gebruik maken van de privaatrechtelijke weg een onaanvaardbare doorkruising van de $\mathrm{ABW}$ opleverde. Uit de inhoud en strekking van de verhaalsbepalingen van de $A B W$ vloeide voort dat die regeling exclusief was bedoeld. Voorts speelde de bescherming van de belangen van de burger in de $A B W$, zoals onder meer tot uitdrukking komende in de beperking in de tijd van de verhaalsvorderingen, een rol. De verhaalsbepalingen vain de $\mathrm{ABW}$ gaven de gemeente destijds - voor het overlijden van de vader van Posthuma - geen bevoegdheid het te veell betaalde op Posthuma (de zoon) te verhalen. Verder was op het moment dat de vordering (uit de overeenkomst) werd ingesteld de verhaalsternijn zoals neergelegd in - toen - artikel $70 \mathrm{ABW}$ verstreken, zodat ook op die grond geen verhaal kon worden gezocht op Posthuma, noch 
op de nalatenschap van zijn vader. Dit alles bracht mee dat toekenning van de vordering zou betekenen dat de gemeente via 'de privaatrechtelijke weg alsnog zou bereiken hetgeen zij middels de publiekrechtelijke weg niet (meer) kan bereiken'. De conclusie was dan ook dat het gebruik van de privaatrechtelijke weg, in casu het sluiten van een overeenkomst naar burgerlijk recht, in ieder geval 'als een onaanvaardbare doorkruising van de in de Algemene Bijstandswet neergelegde regeling tot verhaal van kosten van bijstand dient te worden aangemerkt'. De grief van Posthuma slaagde dan ook. Tegen het arrest van het hof werd geen cassatie ingesteld. ${ }^{289}$

De laatste zaak betrof een strafzaak. Van den B. werd verdacht van uitkeringsfraude. Hij had namelijk ten onrechte opgegeven dat hij geen vermogen had. De gemeente kwam hier achter en deed aangifte van valsheid in geschrifte. Tot verhaal van de ten onrechte uitbetaalde RWW-uitkering, in total ongeveer $f 25.000,-$, was de gemeente niet overgegaan, ondanks het feit dat de verhaalstermijn nog niet geheel was verstreken. Wel had Van den B. de gemeente een bedrag terugbetaald van $f 6.500,-$. Voor wat betreft de terugvordering was hiermee de kwestie voor de gemeente afgedaan, ook al omdat de vordering was verjaard, aldus een brief van het hoofd van de gemeentelijke sociale dienst. Het Hof 's-Hertogenbosch veroordeelde Van den B. vervolgens tot een voorwaardelijke gevangenisstraf van 2 maanden wegens valsheid in geschrifte. Aan die veroordeling was de bijzondere voorwaarde verbonden, dat Van den B. binnen de eerste zes maanden na aanvang van de proeftijd een bedrag van $f 18.500$,- betaalde aan de gemeente. Deze voorwaarde was gebaseerd op artikel $14 \mathrm{c} \mathrm{Sr}$. Dit bedrag was het bedrag dat Van den B. te veel had ontvangen minus de reeds betaalde $f 6.500$,Van den B. ging in cassatie. Hij betoogde onder meer dat het hof een bijzondere voorwaarde had opgelegd, waarvoor de wetgever elders - in de ABW - een minutieuze en met waarborgen omklede regeling had getroffen. Dit middel werd verworpen; het bestaan van de verhaalsregeling in de ABW stond niet in de weg aan het opleggen van een bijzondere voorwaarde 'ten einde de veroordeelde te nopen tot het vergoeden aan de benadeelde gerneente van de door deze als gevolg van het plegen door de veroordeelde van een strafbaar feit als het onderhavige geleden schade'. Ook het verweer dat een dergelijke voorwaarde niet kon worden opgelegd als de rechtsvordering tot verhaal was vervallen door verloop van vijf jaren, werd verworpen. De middelen die betoogden dat de gemeente had afgezien van verdere actie om het restant-bedrag te innen, troffen wel doel; het stellen van bedoelde voorwaarde was niet mogelijk als de gemeente inderdaad afstand had gedaan 'van elke aanspraak op verdere vergoeding van de door haar geleden schade'. ${ }^{290}$

De door de Hoge Raad ingeslagen weg lijkt mij onjuist. De wetgever heeft uitdrukkelijk de verhaalsvordering willen beperken. Dit was mede gebeurd vanwege het karakter van de bijstand. De burgerlijke rechter achtte het dan ook 
niet mogelijk de terugvorderingsbepalingen te omzeilen door een civiele actie te entameren. De bijstandsrechter kon bovendien meer dan de andere rechters rekening houden met de specifieke situatie waarin betrokkene zich bevond, bijvoorbeeld bij de beoordeling of de invordering de toets aan de algemene beginselen van behoorlijk bestuur kon doorstaan. Ik zou de door de strafrechter ingeslagen weg dan ook willen betitelen als doorkruising van de publiekrechtelijke regeling, deze keer niet door het bestuur, maar door de rechter. Rechtsstatelijk lijkt het arrest mij ook niet correct; de rechter gaat immers op de stoel van het bestuur zitten. Ook annotator Corstens is geen voorstander van de gevolgde weg. Hij heeft hiervoor onder meer een praktisch argument: slaagt het bestuur er niet in om het verhaal binnen de termijn rond te krijgen, dan kan het nu alsnog aangifte doen en op die manier proberen zijn geld terug te krijgen. 'Dan wordt de strafrechtspleging voor een ander doel gebruikt dan waarvoor zij is bestemd'.

\subsection{Conclusie}

Het stelsel van sociale zekerheid, zoals wij dat momenteel kennen, vindt zijn oorsprong in het begin van de twintigste eeuw. Dit stelsel is in de loop van de tijd sterk uitgebouwd, waarbij de opvattingen met betrekking tot (de mogelijkheden en onmogelijkheden betreffende) terugvordering zijn gewijzigd. Dit is terug te zien in de terugvorderingsbepalingen.

De huidige situatie bestaat sinds 1996, het jaar waarin de WBM in werking trad. Het uitgangspunt is dat ten onrechte gedane betalingen kunnen en moeten worden teruggevorderd, ongeacht de oorzaak van de onterechte betaling. Slechts wanneer zich dringende redenen voordoen, kan van terugvordering worden afgezien. De verschillende socialezekerheidswetten bevatten geen bepalingen met betrekking tot de tijd gedurende welke onterecht gedane betalingen kunnen worden teruggevorderd. Volgens de regering zijn de algemene verjaringsregels uit het $\mathrm{BW}$ van toepassing. Op grond van artikel 3:309 $\mathrm{BW}$ betekent dit, dat de vordering verjaart vijf jaar nadat het bestuursorgaan is bekend geworden met het bestaan van de vordering en met de persoon van de ontvanger. In ieder geval verjaart de vordering twintig jaar nadat zij is ontstaan.

Ik ben van mening dat deze regeling te ver is doorgeschoten. Fraudebestrijding lijkt het hoofddoel te zijn, waaraan andere belangen ondergeschikt (b)lijken te worden gemaakt. lk heb dan ook aangegeven dat de algemene lijn zoals die met betrekking tot terugvordering bestond sinds 1978 de voorkeur heeft. Sinds dat jaar was de hoofdregel dat terugvordering niet mogelijk was, tenzij te veel was betaald door toedoen van de betrokkene of een administratieve vergissing was begaan en dit redelijkerwijs duidelijk had kunnen zijn voor betrokkene; in het eerste geval kon het te veel betaalde gedurende een periode van vijf jaar worden teruggevorderd, in het tweede geval was deze periode twee jaar. De hoofdregel, dat niet kon worden teruggevorderd, was een uitwerking van het vertrouwensbeginsel; de beperkingen in de tijd in het geval wel kon worden teruggevorderd waren een uitwerking van het rechtszekerheidsbeginsel. Voorts kon het volledig terugvorde- 
ren van het te veel betaalde in strijd zijn met het zorgvuldigheidsbeginsel.

Het was (in ieder geval tot op bepaalde hoogte) mogelijk geweest dit stelsel voort te zetten. De regering heeft immers constant aangegeven dat bij toepassing van de nieuwe bepalingen de algemene beginselen van behoorlijk bestuur in acht dienen te worden genomen. Nu waren de regels, zoals die golden voor de inwerkingtreding van de WBM grotendeels een uitwerking van deze beginselen, met name het vertrouwens-, het rechtszekerheids- en het zorgvuldigheidsbeginsel, zodat de mogelijkheid bestond dat in de praktijk de harde kanten van de regeling zouden worden afgeslepen. In de praktijk blijken de uitvoeringsinstanties en de rechter niet snel geneigd dit te doen.

Speelden en spelen het burgerlijk recht - en dan vooral de regeling betreffende onverschuldigde betaling - en de burgerlijke rechter een rol in het socialezekerheidsrecht? Zoals aangegeven kenden de meeste wetten voor de Tweede Wereldoorlog bepalingen met betrekking tot terugvordering, waarbij terugvordering veelal werd uitgesloten. Deze bepalingen werden gezien als lex specialis. In die gevallen leek er geen ruimte te zijn voor het burgerlijk recht of de burgerlijke rechter. Na de Tweede Wereldooriog werd steeds vaker terugvordering onder omstandigheden toegestaan. De wettelijke regelingen bleken echter herhaaldelijk hiaten te bevatten, terwijl bestuursorganen in een aantal gevallen ook probeerden de voor hen ongunstige terugvorderingsbepalingen te omzeilen via het gebruik van privaatrecht. Over dit laatste lijkt overeenstemming te bestaan; de weg van artikel 6:203 BW (voorheen artikel 1395 BW (oud)) mag en mocht niet worden bewandeld wanneer wettelijke terugvorderingsbepalingen bestonden, welke regels bevatten met betrekking tot de voorliggende terugvordering. Dit was anders wanneer de wettelijke regeling een leemte bevatte. In die gevallen leek de burgerlijke rechter geneigd eiser, het bestuursorgaan, te ontvangen in zijn vordering en de privaatrechtelijke bepalingen toe te passen. De bestuursrechter was in die gevallen terughoudender; hij wilde nog wel eens de wel bestaande bepalingen anajoog toepassen, waarbij de Centrale Raad van Beroep is teruggevallen op het algemene rechtsbeginsel dat hij die onverschuldigd heeft betaald, dit kan terugvorderen, het rechtsbeginsel dat ook ten grondslag lag en ligt aan de regeling van de onverschuldigde betaling in het $\mathrm{BW}$. Na de inwerkingtreding van de WBM voorzien de wettelijke regelingen ook in deze leemtes; toepassing van artikel 6:203 BW is dan ook niet meer aan de orde indien er een publiekrechtelijke titel aan de betaling ten grondslag ligt. Geconcludeerd kan dan ook worden, dat er vrijwel geen ruimte meer is voor de burgerlijke rechter of voor toepassing van artikel 6:203 BW in het socialezekerheidsrecht. 



\section{AMBTENARENSALARISSEN EN OVERHEIDSPENSIOENEN}

\subsection{Inleiding}

In het vorige hoofdstuk heb ik de overheidsuitgaven in de vorm van sociale zekerheid bekeken. Een ander belangrijk terrein waarop de overheid financieel presterend optreedt, is waar het de betaling van haar ambtenaren betreft, de ambtenarensalarissen. In dit hoofdstuk komt de terugvordering van deze betalingen aan de orde. Daarnaast zal ik ingaan op de terugvordering van overheidspensioenen. Deze pensioenen nemen een aparte plaats in; zij betreffen namelijk vrijwel allemaal pensioenen van ambtenaren. ${ }^{1} \mathrm{Zij}$ kunnen daarnaast worden gezien als socialezekerheidsregeling. Zij vallen dan ook binnen zowel het socialezekerheidsrecht als het ambtenarenrecht. Aangezien de meeste pensioenwetten meer raakvlakken hebben met het ambtenarenrecht - zo was de ambtenarenrechter vanaf 1966 veelal bevoegd over geschillen met betrekking tot pensioenen te oordelen - dan met het socialezekerheidsrecht, is ervoor gekozen deze wetten in dit hoofdstuk te behandelen. Uiteraard zijn er ook verschillen met het ambtenarenrecht, vandaar dat de overheidspensioenen zullen worden behandeld in een aparte paragraaf.

Het hier te behandelen terrein, ambtenarensalarissen en overheidspensioenen, kent de langste historie van de te behandelen bijzondere rechtsgebieden. Niet alleen heeft de overheid (in ieder geval sinds 1815) altijd ambtenaren in dienst gehad, de oudste te behandelen regeling ligt ook op dit terrein. Zo dateert de oudste pensioenregeling reeds van 1798, terwijl de eerste pensioenwet op 1 juli 1846 in werking trad. De regelingen op het terrein van het ambtenarenrecht zijn van recenter datum; de Ambtenarenwet dateert van 1929 en trad pas in 1933 in werking. Door deze wet werd de Centrale Raad van Beroep, die reeds actief was als socialezekerheidsrechter, bevoegd in geschillen tussen de overheid en haar ambtenaren. Zoals we zullen zien heeft de jurisprudentie van de Centrale Raad een belangrijke bijdrage geleverd aan de zogenaamde 'algemene-rechtsbeginselenjurisprudentie'.

Uiteraard zal ook in dit hoofdstuk. weer aandacht worden besteed aan de ontwikkelingen op het gebied van wetgeving op de genoemde terreinen. Hierbij zal ik bekijken of deze wetten terugvorderingsbepalingen bevatten en hoe de rechtsbescherming was en is geregeld. Daamaast zal ik de vraag behandelen, of er nog ruimte is voor toepassing van het burgerlijk recht en in hoeverre de burgerlijke rechter nog een rol kan spelen. In 7.2 zullen de ambtenarensalarissen aan de orde komen, in 7.3 de overheidspensioenen.

1. Uitzonderingen zijn onder meer de pensioenen voor mensen die zich in bijzondere situaties hadden ingespannen voor Nederland, zoals verzetsmensen tijdens de Tweede Wereldoorlog. 


\subsection{Ambtenaren}

\subsubsection{Inleiding}

In deze paragraaf zal ik de terugvordering van ambtenarensalarissen (en andere aan een ambtenaar gedane betalingen) behandelen. De ontwikkelingen op dit terrein, zoals deze zich hebben voorgedaan tot 1933, het jaar waarin de Ambtenarenwet 1929 in werking trad, zal ik in 7.2 .2 bespreken. Een van de belangrijkste gevolgen van de Ambtenarenwet 1929 was dat er een aparte ambtenarenrechter in het leven werd geroepen. De consequentie hiervan was, zoals we hebben gezien in 4.3.2, dat de burgerlijke rechter ophield competent te zijn in geschillen tussen een ambtenaar en de overheid. De ambtenarenrechter is vervolgens in de periode tussen 1933 en 1952 een eigen terugvorderingsregime gaan ontwikkelen; de Ambtenarenwet 1929 bevatte namelijk geen regeling met betrekking tot terugvordering. Dit zal in 7.2.3 worden behandeld. Na 1952 heeft een verdere verfijning van de terugvorderingsjurisprudentie plaatsgevonden, waarbij onder meer regels, ontwikkeld in de sociale zekerheid, werden overgenomen. Deze ontwikkelingen zal ik in 7.2.4 bekijken. In die paragraaf wordt ook ingegaan op de omslag die de Hoge Raad in 1992 heeft gemaakt in zijn jurisprudentie met betrekking tot de competentie van de burgerlijke rechter in ambtenarenzaken.

\subsubsection{De ontwikkeling van het ambtenarenrecht tot de Ambtenarenwet 1929}

\subsubsection{De negentiende eeuw}

Op het terrein van de ambtenarensalarissen bestond lange tijd geen wettelijke regeling, ondanks het feit dat daar al sedert 1848 over werd gesproken. ${ }^{2}$ De voorstanders van een dergelijke regeling, waaronder Thorbecke, vonden dat de ambtenaar, die een belangrijke rol speelde binnen de administratie, diende te worden beschermd tegen de willekeur van diezelfde administratie.

In de literatuur over de ambtenaar en zijn dienstbetrekking uit de negentiende eeuw valt voor zover ik heb kunnen nagaan niets te vinden met betrekking tot de terugvordering van te veel betaalde bezoldiging. ${ }^{3}$ Ook de jurisprudentie zwijgt. Vermoedelijk speelde het probleem van de terugvordering niet, althans in veel mindere mate dan tegenwoordig. Zo bestond tot 1918 geen algemene bezoldigingsregeling, ${ }^{4}$ wel waren bij koninklijke besluiten de bezoldigingen voor bepaalde rangen vastgesteld, maar deze besluiten lieten de overheid een grote vrijheid

2. Zie hierover Faber (1992), blz. 10-14.

3. Bijvoorbeeld Ferf (1864), Krabbe (1883) en Krabbe (1897) zwijgen allen over dit onderwerp. Dok het Rapport Staatscommissie-Kranenburg (1958) gat hier niet op in, noch in de historische beschouwingen, noch in het tweede deel van het rapport, waarin de vraag 'Is een bijzondere reglementering van de rechtspositie der ambtenaren nog steeds gemotiveerd?' aan de orde komt.

4. In dat jaar trad het Bezoldigingsbesluit Burgerlijke Rijksambtenaren (BBRA) in werking, Besluit van 3 september 1918 tot vaststelling van regeien ten aanzien van de bezoldiging van burgerlijke Rijksambtenaren, Stb. 541 . 
om af te wijken van de (meestal in die beslaiten genoemde) minima en maxima. ${ }^{5}$

Voorts werd de aard van de bezoldiging veelal gezien als een "onderhoudsrente'. ${ }^{6}$ De Staat eiste van de ambtenaar volledige toewijding en verbood hem in de regel nevenwerkzaamheden te vervullen. Deze zouden immers kunnen strijden met het staatsbelang; in ieder geval zouden zij de aandacht van de ambtenaar afleiden van de vervulling van zijn diensitplichten. Hiermee strookte, dat de Staat van zijn kant ervoor had te zorgen dat de ambtenaar zich geen zorgen hoefde te maken omtrent zijn eerste levensbehoeften, en dus dat de Staat de ambtenaar zodanig beloonde dat deze in zijn onderhoud en dat van zijn gezin kon voorzien.?

Ook werd de ontwikkeling van een ambtenaar als een zo specifieke gezien, dat hij ongeschikt werd geacht andere werkzaamheden te vervullen nadat zijn actieve ambtenarenloopbaan was beëindigd. Dit hield in, dat hij van een inkomen verzekerd diende te zijn op het moment dat hij zijn actieve loopbaan als ambtenaar beêndigde. Tevens was het niet in het belang van de Staat als cen ambtenaar, die door zijn leeftijd of lichamelijke dan wel geestelijke staat niet meer in staat werd geacht zijn werk naar behoren te vervullen, desondanks in dienst bleef omdat hij anders zonder inkomsten kwam te zitten. Ook hierin voorzag de onderhoudsrente: de bezoldiging duurde voort bij ziekte of verlof, er was een wachtgeldregeling en een pensioenregeling voor de ambtenaren. Vermoedelijk zorgde de status van de bezoldiging als onderhoudsrente, tezamen met het feit dat het ambtenarenapparaat nog vrij beperkt was, er voor dat de terugvordering een redelijk onbekend verschijnsel was, althans geen problemen veroorzaakte.

Daamaast speelde in de verhouding tussen de Staat en de ambtenaar de vraag, welke rechter in geval van een conflict bevoegd was over dit geschil te oordelen. Zoals gezegd bestond halverwege de negentiende eeuw de opvatting dat de ambtenaar diende te worden beschermd tegen de willekeur van de adiministratie. Aangezien echter in ambtenarenzaken steeds mede openbare belangen in het geding waren, heerste bij de administratie de opvatting dat de beslechting van geschillen tussen haar en de ambtenaren niet aan de gewone rechter diende te worden overgelaten; er was sprake van een inteme administratieve aangelegenheid.

De burgerlijke rechter daarentegen beoordeelde, zoals we hebben gezien, de vraag of hij bevoegd was aan de hand van de artikelen $165 \mathrm{Gw} 1815$ en 2 R.O. We hebben gezien dat de Hoge Raad hierbij in de negentiende eeuw nu eens het fundamentum petendi (de aard van de rechtsverhouding), dan weer het petifum (de aard van de vordering) beslissend achtte voor de bevoegdheid." Volgens de Staatscommissie-Kranenburg verklaarde de Hoge Raad zich aanvankelijk onbevoegd kennis te nemen van iedere vordering, welke voortsproot uit de rechtsverhouding tussen de Staat en een ambtenaar. Behandeling van een dergelijke

\footnotetext{
5. Zie hierover het Rapport Staatscommissie-Kranenburg (1958), blz. 13-15.

6. Anders Krabbe (1883), blz. 147-152 en (1897), blz. 87, die de bezoldiging deels als onderhoudsrente, deels als beloning zag.

7. Ferf (1864), blz. 76-77, die echter het woord onderhoudsrente niet gebruikt.

8. Zie 2.2 en 2.4 .

9. Rapport Staatscommissie-Kranenburg (1958), blz. 44-45.
} 
vordering zou namelijk leiden tot beoordeling van de bestuursdaad: de leer van het fundamentum petendi.

Een voorbeeld hiervan biedt een arrest uit 1875 waarin eiser, een voormalig lid van het Hoog Geregtshof van Nederlands Indië, van de regering van Nederlands Indië schadevergoeding vorderde ter zake van een onrechtmatige daad, namelijk een onbevoegd door de gouverneur-generaal verleend eervol ontslag. De Hoge Raad overwoog dat de burgerlijke rechter onbevoegd was kennis te nemen van de vordering: het benoemen, ontslaan enzovoorts van ambtenaren was opgedragen aan het 'administratief gezag'. Dit betekende dat geschillen hieromtrent, waaronder het geschil over de rechtmatigheid van het ontslag, niet behoorden tot de geschillen, die artikel $148 \mathrm{Gw} 1848$ en artikel 2 R.O. aan de burgerlijke rechter had opgedragen. Het enkele feit dat niet het ontslag werd aangevallen, maar schadevergoeding werd gevraagd, veranderde dit niet, 'nu die vordering onafscheidelijk is van haren grondslag', de onrechtmatigheid van het ontslag. ${ }^{10}$

Tien jaar eerder had de Hoge Raad anders geoordeeld. Een hoofdonderwijzer vorderde van de gemeente Finsterwolde betaling van een bedrag van $f \mathbf{7 2 5}$,zijnde een jaar traktement. De gemeente verweerde zich door te stellen dat zij slechts een deel van het traktement hoefde te betalen, namelijk $f \hat{3} 2 \hat{5}$,-; de overige $f 400$,- was door de kerkelijke gemeente toegezegd. De gemeente bestreed niet dat de vordering tegen haar ingesteld tot betaling van $f 325,-$ tot de kennisneming van de rechterlijke macht behoorde. Maar de vraag of de gemeente ook voor het deel, dat volgens haar door de kerkelijke gemeente diende te worden betaald, aansprakelijk was, stond niet ter beoordeling van de rechterlijke macht, aldus de gemeente. De Hoge Raad oordeelde anders. Een eis tot betaling van de bezoldiging betreft een twistgeding over schuldvordering als bedoeld in artikel $148 \mathrm{Gw} 1848$. De vraag of die bezoldiging 'door de burgerlijke gemeente al dan niet in haar geheel is verschuldigd', viel dan ook onder de competentie van de burgerlijke rechter. De Hoge Raad verwierp vervolgens het door de gemeente ingestelde beroep, na de vordering inhoudelijk te hebben beoordeeld; de betaling van $f 400$,was een subsidie van de kerkelijke aan de burgerlijke gemeente en dus was de gemeente gehouden tot betaling van $f 725$,- aan de onderwijzer "behoudens haar verhaal op de kerkelijke gemeente voor de haar toegezegde bijdrage'."

Het verschil in beide uitspraken lijkt hierin gelegen dat de rechter om de vordering, zoals die in 1875 in de zaak van de voormalige raadsheer uit Nederlands Indie was ingesteld, te kunnen beoordelen, eerst de rechtmatigheid van de administratieve daad moest beoordelen; de vordering tot schadevergoeding wegens onrechtmatige daad kon alleen worden toe(- dan we! af)gewezen als de onderliggende administratieve daad (al dan niet) onrechtmatig was. Dit oordeel nu kwam niet toe aan de burgerlijke rechter: een oordeel over deze voorvraag was voorbehouden aan de administratie. In de zaak die in 1865 speclde, was een dergelijke voorvraag niet in het geding; er hoefde geen administratieve daad te worden 
beoordeeld.

Volgens de Staatscommissie-Kranenburg achtte de burgerlijke rechter zich tot oordelen bevoegd, mits de rechter in staat was de gevraagde middelen toe te passen. Dit betekende dat 'de rechter niet bevoegd werd geoordeeld een veroordeling uit te spreken, welke zou moeten leiden tot een bestuursdaad'. ${ }^{12}$ Uit het vervolg van het rapport blijkt dat de staatscommissie met de woorden 'niet bevoegd werd geoordeeld' niet (alleen) het oog had op de bevoegdheidsvraag, maar (tevens) op de ontvankelijkheidsvraag en de vraag of de vordering al dan niet kon worden toegewezen. Gelet op de in 2.4 .2 besproken rechtspraak met betrekking tot 'twistgedingen over schuldvordering' was dit conform de algemene jurisprudentie van de burgerlijke rechter.

In het oog moet worden gehouden, dat het in de genoemde gevallen de ambtenaar was die de overheid aansprak. Het spiegelbeeld, de overheid die de ambtenaar aansprak en stelde dat sprake was van een schuldvordering, bijvoorbeeld door een vordering uit onverschuldigde betaling in te stellen, zou vermoedelijk steeds tot de competentie van de rechterlijke macht behoren; de bestuursdaad had al plaatsgevonden. Deze vormde namelijk de grondslag voor de schuldvorde-

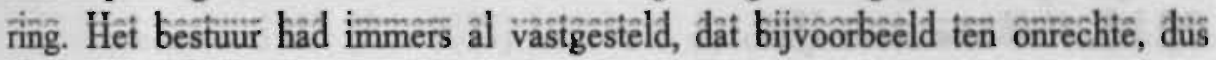
onverschuldigd, salaris was uitbetaald. Aangenomen mag worden dat in dat geval de bepalingen uit het BW van toepassing zouden zijn. ${ }^{13}$ Jurisprudentie uit de negentiende eeuw op dit gebied heb ik echter niet gevonden.

\subsubsection{De twintigste eeuw}

De twintigste eeuw bracht hierin aanvankelijk geen wijziging: een vordering uit onverschuldigde betaling was een schuldvordering, waarover de burgerlijke rechter bevoegd was te oordelen en, als gevolg hiervan, waarop volgens de rechtspraak de bepalingen uit het BW van toepassing waren. ${ }^{14}$ Dit gold tot 1933 , het jaar waarin de Ambtenarenwet 1929 in werking trad, ook voor de ambtenarensalarissen.

Ik heb in de NJ uit de periode tot 1933 slechts één arrest van de Hoge Raad gevonden op het terrein van terugvordering van te veel betaalde bezoldiging. Het betrof terugvordering door de gemeente Harlingen van te veel uitbetaald salaris an een onderwijzeres. Geesje Jacobus was in 1919 onderwijzeres aan de Iste gemeenteschool te Harlingen. Zij genoot een salaris van $f 2980_{\xi}$ - per jaar, waarin een verhoging was opgenomen van $f 800$,- omdat $\mathrm{zij}$ in het bezit was van vier akten voor speciale vakken. Het wettelijke bedrag van deze verhoging bedroeg $f$ 200,- per akte, althans wanneer Geesje Jacobus werkzaam zou zijn aan een M.U.L.O.-school. Achteraf bleek de school niet te voldoen aan de vereisten omi te worden beschouwd als een M.U.L.O.-school, met als gevolg dat Jacobus slechts recht had op $f 100$,- per akte. Zowe! de Wet tot regeling van het lager onderwijs,

12. Rapport Stantscommissie-Kranenburg (1958), blz. 45.

13. Zie 2.5 .

14. Zie 2.4.2 en 2.5 . 
als een latere wijziging van deze wet uit $1919,{ }^{15}$ welke vooral de artikelen betrof die betrekking hadden op de jaarwedde, bevatten geen bepalingen met betrekking tot de terugvordering. De burgemeester van Harlingen vorderde namens de gemeente het verschil, zijnde - na verrekening van allerlei toeslagen en pensioenbijdragen - een bedrag van $f 372,40$, terug als onverschuldigd betald. De vordering werd door de rechtbank toegewezen en het door Jacobus ingestelde cassatieberoep werd door de Hoge Raad verworpen. ${ }^{16}$

Opvallend in deze procedure, maar gelet op de in 2.6 besproken jurisprudentie niet geheel verrassend, is dat de bevoegdheid van de burgerlijke rechter nergens ter discussie werd gesteld. Het cassatiemiddel voerde aan dat de school wel moest worden gezien als een M.U.L.O.-school, zodat Jacobus wel recht had op een verhoging van $f$ 200,- per akte. Door dit te miskennen en de vordering van de gemeente toe te wijzen, had de rechtbank onder meer de artikelen 1395 en $1396 \mathrm{BW}$ (oud) geschonden dan wel verkeerd toegepast. Ook over de algemene toepasselijkheid van de bepalingen uit het BW hoefde de Hoge Raad dus geen oordeel te geven, aangezien het cassatiemiddel daartoe niet verplichtte.

\subsubsection{De Ambtenarenwet 1929}

\subsubsection{Inleiding}

Reeds sedert 1848 leefde dus de opvatting, dat de rechtstoestand van de ambtenaar wettelijk diende te worden geregeld. Centraal punt was dat de ambtenaar met betrekking tot zijn rechtspositie bescherming diende te krijgen tegen de willekeur van de administratie. Aangezien in ambtenarenzaken steeds mede openbare belangen een rol spelen, diende de beslechting van geschillen tussen ambtenaren en de administratie niet aan de gewone rechter te worden overgelaten. Dit was (een van) de belangrijkste reden(en) dat de wettelijke regeling niet van de grond kwam.

In 1897 wijdde de Nederlandsche Juristen-Vereeniging haar jaarvergadering aan dit onderwerp. Krabbe en Fokker preadviseerden over de vraag of de rechtsverhouding van de Staat tot zijn ambtenaren wettelijk moest worden geregeld." De vragen of de verhouding van de Staat tot de ambtenaren publiekrechtelijk van aard was, en of bij wet algemene regels omtrent die verhouding dienden te worden gesteld, werden door de algemene vergadering bevestigend beantwoord. ${ }^{18}$

15. Wet van 17 augustus 1878 , houdende herziening, der wet van 13 augustus 1857 tot regeling van: het lager onderwijs, Stb. 127, zoals bekendgemaakt bij besiuit van 26 juni 1905, Stb. 219 en Wet. van 14 juni 1919, tot wijziging van de wet tot regeling van het lager onderwijs, Stb. 493.

16. HR 19 juni 1925, NJ 1925, 933.

17. Krabbe (1897) en Fokker (1897).

18. Verslag NJV (1897), biz. 103. Ook de Hoge Raad zag de rechtsverhouding tussen overheid ent ambtenaar als publiekrechtelijk, zo blijkt uit de jurisprudentie. Deze rechtsverhouding kon namelijk eenzijdig worden gewijzigd, zie HR 29 januari 1926, NJ 1926, 231, m.nt. E.M.M. en HR 25 maart 1927, NJ 1927, 385, m.nt. E.M.M. Bedacht moet worden, dat deze jurisprudentie is gewezen op het moment dat reeds werd gewerkt aan een wettelijke regeling met betrekking tot de rechtstoestand van de ambtenaren. 
Toch duurde het tot 1917 eer een staatscommissie onder voorzitterschap van Dresselhuys werd ingesteld, de Staatscommissie ter voorbereiding van algemene wettelijke regelen betreffende den rechtstoestand van ambtenaren. ${ }^{19} \mathrm{Zij}$ bracht in 1919 haar verslag uit. ${ }^{20}$ In 1920 werd vervolgens een wetsontwerp Rechtstoestandenwet ingediend, ${ }^{21}$ waarin zowel het materiële als het formele ambtenarenrecht werd geregeld. Uitgegaan werd van een rechtsgang in eerste instantie bij zogenaamde Rijksscheidsgerechten met hoger beroep bij de Centrale Raad van Beroep. Voor de procedurele regels werd de regeling uit de Beroepswet 1902 gevolgd, voor zover afwijkingen niet vereist waren door de verschillende aard van de materie. Uiteindelijk sneuvelde het ontwerp in de parlementaire behandeling; het zou in de behandelde vorm te hoge lasten voor zowel het rijk als de lagere overheden meebrengen. Maar op het moment dat het werd ingetrokken was reeds een nieuw wetsontwerp ingediend, dat uiteindelijk de Ambtenarenwet 1929 zou worden. $^{22}$

In 7.2.3.3 zal ik de ontwikkeling van de rechtspraak met betrekking tot terugvordering van (voornamelijk) de Centrale Raad van Beroep bespreken. Alvorens hiertoe over te gaan zal ik in 7.2.3.2 kort ingaan op de vraag welke gevolgen de Ambtenarenwet 1929 (Aw 1929) had voor de competentie van de burgerlijke rechter in ambtenarenzaken. ${ }^{23} \mathrm{De}$ in deze paragraaf behandelde periode loopt tot 1953. De reden hiervoor is dat de jurisprudentie met betrekking tot de terugvordering in 1953 haar huidige vorm kreeg.

\subsubsection{Competentieverdeling in de Ambtenarenwet 1929}

In 3.5 heb ik reeds aangegeven dat de Ambtenarenwet 1929 zich voomamelijk richtte op het formele recht. Artikel 3 lid 1 Aw 1929 bepaalde:

'Onverminderd de wettelijke regelen ontrent de rechtspraak in pensioenzaken bestaande, oordeeien bij uitsluiting over de besluiten, handelingen en weigeringen (om te besluiten of te handelen), ten aanzien van ambtenaren als zoodanig, hunne nagelaten betrekkingen en rechtverkrijgenden door een administratief orgaan genomen, verricht of uitgesproken, in eersten aanleg de Ambtenarengerechten en in hooger beroep de Centrale Raad van Beroep te Utrecht' ${ }^{24}$

De gelijkenis met de artikelen 15 lid 1 en 74 lid 1 Ontwerp WAR van het ontwerp-Loeff is opvallend. ${ }^{25}$ Overigens vielen de militaire ambtenaren niet onder

19. Staatscommissie ingesteld bij KB van 21 mei 1917, no. 27.

20. Verslag Staatscommissie-Dresselhuys (1919).

21. Tweede Kamer 1919-1920, 357, nrs. 1-2.

22. Wet van 12 december 1929, houdende regelen betreffende den rechtstoestand van ambtenaren, Stb. 530. Het duurde vervolgens tot 1 maart 1933 voor de wet in werking trad, Besluit van 26 januari 1933, betreffende het tijdstip van inwerkingtreding van een aantal artikelen van de Ambtenarenwet 1929 en van de Militaire Ambtenarenwet 1931, Stb. 32.

23. Dit is reeds aan de orde geweest in 4.3.2.

24. Op grond van artikel 3 lid. 2 Aw 1929 was de CRvB in een aantal gevallen in eerste en enige aanleg competent.

25. Zie over deze artikelen 3.3 . 
de Ambtenarenwet 1929, voor hen werd een afzonderlijke wet ontworpen, de Militaire Ambtenarenwet $1931^{26}$ In deze wet werden de meeste bepalingen van de Ambtenarenwet 1929 van overeenkornstige toepassing verklaard, waarbij echter bepaalde specifieke regels werden gegeven met het oog op de aard van de materie. Zo werden bijvoorbeeld aanvullende regels gegeven met betrekking tot de samenstelling van en behandeling van militaire zaken door de Ambtenarengerechten en de Centrale Raad van Beroep. Ook pensioenzaken bleven uitdrukkelijk buiten de competentie van de ambtenarenrechter, aldus artikel 3 lid 1 Aw 1929.7

Zoals al in 4.3.2 aan de orde is geweest, had artikel 3 Aw 1929 volgens de wetgever ook consequenties voor de bevoegdheid van de burgerlijke rechter in ambtenarenzaken. De wetgever had namelijk uitdrukkelijk aangegeven, dat hij de gehele rechtsbetrekking tussen de overheid en de ambtenaar als een publiekrechtelijke rechtsbetrekking zag. Het gevolg hiervan was, dat de bevoegdheid van de ambtenarenrechter een exclusieve bevoegdheid was, waardoor de burgerlijke rechter ophield bevoegd te zijn ten aanzien van ambtenarengeschillen ${ }^{23}$ Hiertoe had hij ook de woorden 'bij uitsluiting' opgenomen in artikel 3 lid 1. Aan deze woorden diende dus een andere betekenis te worden toegekend dan aan dezelfde woorden in artikel 2 R.O. en het daarmee corresponderende grondwetsartikel. ${ }^{29}$ Werd in deze laatste artikelen bedoeld dat de rechter in de in die artikelen genoemde gevallen zelf zijn bevoegdheid diende vast te stellen, in artikel $3 \mathrm{Aw}$ 1929 werd bedoeld, dat de ambtenarenrechter exclusief bevoegd was. De burgerlijke rechter heeft zich vervolgens ook daadwerkelijk onbevoegd verklaard om kennis te nemen van genoemde besluiten, handelingen en weigeringen. ${ }^{30}$

\subsubsection{De jurisprudentie van de ambtenarenrechter met betrekking tot terug- vordering}

De Ambtenarenwet 1929 bevatte geen algemene bepaling met betrekking tot terugvordering van onverschuldigd betaalde bezoldigingen of andere bedragen. Wel bevatte zij twee artikelen die een regeling gaven met betrekking tot verrekening met komende uitbetalingen, indien de ambtenaar nog steeds in dienst was. Artikel 116 lid 1 bepaalde dat op de verschuldigde bezoldigingen en pensioenen mocht worden ingehouden hetgeen de ambtenaar verschuldigd was aan de uitbeta-

26. Wet van 19 december 1931, houdende regelen betreffende den rechtstoestand van de militaire ambtenaren, Sib. 519 , welke gelijktijdig met de Aw 1929 in werking trad, besluit van 26 januari 1933, Stb. 32.

27. Zie 7.3.3.

28. Zie de memorie van toelichting. Tweede Kamer 1927-1928, 392, nr. 3, blz. 17 en de memorie van antwoord, Tweede Kamer 1928-1929, 91, nr. 2, ble. 8 .

29. In 1933: artikel $154 \mathrm{Gw} 1922$.

30. Zie onder meer HR 13 november 1941, NJ 1942, 172, AB 1942, 485 (Ambtenarenwetarrest), HR 12 januari 1951, NJ 1951, 538 en HR 4 december 1987, NJ 1988, 295, m.nt. WHH, AB 1988, 189, m.nt. FHvdB (Du Pied). De Hoge Raad is in 1992 op deze jurisprudentie teruggekomen, HR 28 februari 1992, NJ 1992, 687, m.nt. MS, AB 1992, 301, m.nt. FHvdB (Changoe). Dit arrest zal aan de orde komen in 7.2.4.3. 
lende overheidsinstantie. Volgens artikel 120 gold een aantal in de wet opgenomen beperkingen ten aanzien van inhoudingen, beslag of korting niet als die inhouding of korting plaatshad 'tot verhaal van hetgeen op de bezoldiging of het pensioen is vooruitbetaald of voorgeschoten of ten gevolge van onjuiste opgaven van den ambtenaar daarop teveel is betaald: ${ }^{31}$ Uit de hierna te bespreken jurisprudentie blijkt, dat echter alvorens tot verrekening kon worden overgegaan, vast moest staan dat het te veel betaalde mocht worden teruggevorderd. De artikelen gaven dus regels met betrekking tot invordering. Voor het overige was niets geregeld met betrekking tot terugvordering. Voorheen was de opvatting dat deze betalingen via een actie uit onverschuldigde betaling ex artikel $1395 \mathrm{BW}$ (oud) voor de burgerlijke rechter konden worden teruggevorderd, zie het in 7.2.2.2 besproken arrest van de Hoge Raad. ${ }^{32}$ De wetgever was echter duidelijk geweest: het instellen van een vordering bij de burgerlijke rechter was na de inwerkingtreding van de Ambtenarenwet 1929 niet meer mogelijk; de gehele rechtsbetrekking tussen overheid en ambtenaar was een publiekrechtelijke, waaruit tevens voortvloeide dat de burgerlijke rechter niet bevoegd was kennis te nemen van geschillen tussen de overheid en de ambtenaar. Uit het feit dat de rechtsbetrekking uitdrukkelijk als een publiekrechtelijke werd gezien, kan tevens de conclusie worden getrokken dat in deze rechtsbetrekking geen plaats meer was voor (rechtstreekse) toepassing van de bepalingen uit het $\mathrm{BW}$.

Betekende dit nu dat de overheid te veel uitbetaalde salarissen niet kon terugvorderen? In de praktijk zal het zijn voorgekomen dat overheidslichamen, die te veel bezoldiging hadden betaald (of andere betalingen aan een ambtenaar als zodanig) dit ofwel terugvorderden ofwel verrekenden. Het was dan aan de ambtenaar om naar de rechter te stappen, nadat tegen het terugvorderings- of verrekeningsbesluit bezwaar was aangetekend. Artikel 58 lid 1 Aw 1929 kende twee limitatief opgesomde beroepsgronden: het besluit, de handeling of de weigering te besluiten of te handelen streed 'feitelijk of rechtens met de toepasselijke algemeen verbindende voorschriften' en 'bij het nemen, verrichten of uitspreken daarvan (heeft) het administratief orgaan van zijne bevoegdheid kennelijk een ander gebruik gemaakt dan tot de doeleinden, waarvoor die bevoegdheid is gegeven'. Kortom: strijd met een algemeen verbindend voorschrift of détoumement de pouvoir.

Hoe werd dit in de rechtspraak uitgewerkt? In 1935 moest de Centrale Raad van Beroep oordelen in een zaak, waarin Burgemeester en Wethouders van Utrecht. achteraf de jaarwedde van gemeentesecretaris De Lange lager vaststelden. Deze verlaging was gebaseerd op een besluit van gedeputeerde staten. De Lange stelde dat sprake was van strijd met een algemeen verbindend voorschrift, aangezien het

31. Artikel 1.20 lid 1 aanhef en onder e. Mijn cursivering. In 1936 werd artikel 120 Aw 1929 gewijzigd, waarbij lid 1 onder e verviel en lid 2 ging luiden: 'Bezoldiging en pensioen zijn tot de helft vatbaar voor inhouding, beslag en korting tot verhaal van hetgeen op de bezoldiging of het pensioen is vooruitbetaald, voorgeschoten of te veel betaald. (...)", Wet van 11 september 1936. tot wijziging van de Ambtenarenwet 1929, Stb. 205.

32. HR 19 juni 1925, NJ 1925, 933 (Geesje Jacobus). 
besluit van GS rechtskracht miste voor zover aan deze verlaging terugwerkende kracht was verleend. De klacht was gegrond. De Centrale Raad van Beroep was van oordeel dat GS inderdaad niet bevoegd was het besluit terugwerkende kracht te geven. Weliswaar bestond er geen uitdrukkelijk wettelijk verbod op de mogelijkheid tot het verlenen van terugwerkende kracht aan besluiten van GS, maar daaruit mocht zeker niet worden afgeleid dat zij in dat opzicht vrijheid van handelen zou bezitten. Zo wees de Centrale Raad er op dat volgens de Wet houdende algemeene bepalingen der wetgeving van het koninkrijk de wet alleen voor het toekomende verbindt en geen terugwerkende kracht heeft. Eenzelfde voorschrift bestond met betrekking tot algemene maatregelen van bestuur. De Centrale Raad overwoog vervolgens:

'dat rechtszekerheid voor den ambtenaar, ook met betrekking tot de rechtmatig door hem genoten jaarwedde, een zoo kostbaar goed is, dat deze niet mag worden aangetast door een regeling, welke: ingrijpt in de periode, waarover hij krachtens rechtsgeldige voorschriften zijn jaarwedde heeft ontvangen en welke in die voorschriften met terugwerkende kracht een voor hem ongunstige wijziging: zoude brengen;

o. dat het algemeene rechtsbeginsel, hetwelk zoodanige aantasting van hetgeen rechtmatig is verworven, verbiedt, moet worden geterbiedigd, ook al is het niet in een uitdrukkelijken wettekst neergelegd' ${ }^{33}$

Het besluit van $B$ en $W$ werd gedeeltelijk vernietigd, namelijk voor zover het terugwerkende kracht had. Niet geheel duidelijk was wat nu precies de vernietigingsgrond was. De Lange had aangevoerd dat het besluit van GS terugwerkende kracht miste, zodat over die periode nog steeds de oude salarisregeling gold. Het besluit van $B$ en $W$ was dan in strijd met een algemeen verbindend voorschrift, namelijk die oude salarisregeling, zo betoogde hij. De Centrale Raad liet zich niet uit over de vernietigingsgrond. Wel was duidelijk dat de Centrale Raad van Beroep met deze uitspraak het rechtszekerheidsbeginsel had geïntroduceerd; als eerste rechter had hij een salarisregeling onverbindend geacht wegens strijd met dit algemeen rechtsbeginsel. ${ }^{34}$

In 1937 oordeelde de Centrale Raad van Beroep dat een besluit van de Raad van Arbeid, waarbij een nieuwe berekening van wachtgeld met terugwerkende kracht plaatsvond, nietig was, voor zover het betrekking had op wachtgeld dat was uitbetaald over de maanden, die geheel waren verstreken op de dag dat het besluit werd genomen. Het verstrijken van de beroepstermijn betekende dat de tockenningsbeslissing onaantastbaar was geworden, niet alleen voor de betrokkene, maar ook voor het bestuursorgaan. Volgens de Centrale Raad bonden onaantastbaar geworden besluiten de betrokkenen, zodat, 'tenzij in de desbetreffende algerneen verbindende voorschriften uitdrukkelijk het tegendeel is bepaald', fouten niet met terugwerkende kracht kunnen worden hersteld 'zonder medewerking van hem, op

34. Nicolat (1990), blz. 45. Overigens had de Kroon reeds eerder aan het rechtszekerheidsbeginsel getoetsi, zie Nicolar (1990), blz. 40-42. 
wien het besluit betrekking heeft'. ${ }^{35}$

In 1948 overwoog de Centrale Raad van Beroep in een geval, waarin in strijd met het terzake geldende Besluit een te hoge kledingtoelage was toegekend, dat wanneer een toekenningsbeslissing onherroepelijk was geworden het te veel betaalde niet kon worden teruggevorderd. Dit gold dus zelfs als de toelage in strijd met het destijds geldende besluit tot een te hoog bedrag was vastgesteld; de toelage was immers onherroepelijk vastgesteld. ${ }^{36}$ Uit een uitspraak van de Centrale Raad van Beroep uit 1950 bleek vervolgens dat wanneer nog geen uitvoering aan het besluit was gegeven, de bovengenoemde regel mank ging. ${ }^{37}$

Een uitspraak uit 1951 bracht duidelijkheid over de grond waarop een besluit kon worden vernietigd, indien sprake was van strijd met het rechtszekerheidsbeginsel. De gemeente Wonseradeel wilde op grond van artikel 116 Aw 1929 te veel an een onderwijzeres betaald salaris inhouden op het salaris van haar man, Hoitsma, die ook als onderwijzer in dienst was van de gemeente. De Centrale Raad hoefde niet in te gaan op de vraag of dit artikel van toepassing was, aangezien hij, evenals het Ambtenarengerecht, van oordeel was dat de echtgenote het bedrag niet verschuldigd was aan de gemeente. De aan haar gedane betalingen berustten namelijk op een bevoegdelijk genomen besluit en er bestond voor haar geen reden om te twijfelen aan de juistheid van het vastgestelde en uitbetaalde bedrag. Het verweer van de gemeente, dat in het benoemingsbesluit geen aanduiding voorkwam omtrent het salaris en dat deze aanduidingen niet meer werden opgenomen in de benoemingsbesluiten, aangezien zij op eenvoudige wijze konden worden berekend aan de hand van bepaalde salaristabellen werd verworpen; kennelijk was die berekening niet zo eenvoudig, nu de gemeente in de fout was gegaan bij die berekening. De Centrale Raad liet vervolgens in het midden of het uitbetaalde salaris al dan niet in overeenstemming met die salaristabellen was vastgesteld:

'O. dat de Raad het $\mathrm{nl}$. in strijd acht met het algemeen rechtsbeginsel der rechtszekerheid, waarop de ambtenaar aanspraak heef indien in een geval als het onderhavige de besluiten tot vaststelling van zijn salaris met terugwerkende kracht te zijnen ongunste worden herzien;

0 . dat het ambtenarengerecht eisers bestreden besluit tot inhouding op gedaagde's salaris daarom terecht nietig heeft verklaard wegens strijd met een algemeen rechtsbeginsel, te rekenen tot de toepasselijke algemeen verbindende voorschriften' ${ }^{38}$

35. CRvB 25 maart 1937, AB 1937, 497. In casu had de betrokkene overigens de Raad van Arbeid ingelicht met betrekking tot de wijziging van de situatie, die leidde tot herberekening van het wachtgeld, namelijk het overlijden van zijn vrouw. De RvB Amsterdam had in 1908 in een socialezekerheidszaak al eerder een soortgelijke uitspraak gedaan: 'Een vroegere beslissing, zij moge onjuist gebleken zijn, was rechtsgeldig en stelde derhalve tot op het tijdstip waarop zij herzien werd (...) de rechtsverhouding vast tusschen de Bank en den belanghebbende, behoudens diens bevoegdheid tot het instellen van beroep binnen den daarvoor bepaalden tijd', Rvi Amsterdam 30 oktober 1908, WRSV 1909, aff. 10, nr. 13.

36. CRvB 19 oktober 1948, AB 1949, 137.

37. CRvB 19 december 1950, AB 1951, 196.

38. CRvB 2 oktober 1951, AB 1952, 190 (Hoitsma-Wonseradeel). Mijn cursivering. 
Het rechtszekerheidsbeginsel behoorde dus tot de algemeen verbindende voorschriften. Handelen in strijd met dit beginsel was handelen in strijd met een algemeen verbindend voorschrift en leverde dus een beroepsgrond op. Voorts bleek van belang het feit dat voor de echtgenote van Hoitsma 'geen reden bestond om de juistheid van het vastgestelde en uitbetaalde bedrag in twijfel te trekken'.

Dit laatste punt werd verder uitgewerkt in een uitspraak, die dateerde van 25 maart 1952. ${ }^{39}$ Op het salaris van mejuffrouw C. had ten onrechte geen pensioenverhaal plaatsgevonden, zodat zij te veel salaris had ontvangen. Zij kreeg dan ook het verzoek een bedrag van $f 37,05$ terug te betalen aan de gemeente. Het Ambtenarengerecht vernietigde dit besluit, waarna de gemeente in hoger beroep ging bij de Centrale Raad van Beroep. Deze overwoog eerst dat de verplichting tot verhaal van pensioenbijdragen in beginsel niet van andere aard was dan de verplichting tot salarisbetaling volgens de daarvoor vastgestelde voorschriften, zodat met betrekking tot dit verhaal hetzelfde gold als moest worden aangenomen met betrekking tot een onjuiste vaststelling en uitbetaling van salaris. Vervolgens stelde hij vast dat de betalingen moesten worden aangemerkt als te berusten op bevoegdelijk namens de gemeente genomen besluiten, welke in rechte onaantastbaar waren geworden. De Raad nam vervolgens aan dat mejuffrouw C. geen reden had om aan de juistheid van de oorspronkelijk vastgestelde en uitbetaalde salarisbetalingen te twijfelen. Met name had zij geen reden om aan te nemen dat het verplichte verhaal was achterwege gebleven. De Raad gaf hiervoor twee redenen: er was geen specificatie verschaft van de betaalde (en meermaals gewijzigde) bedragen en het berekenen van die bedragen was dermate ingewikkeld, dat redelijkerwijs niet mocht worden verwacht dat deze bedragen werden nagerekend; integendeel, mejuffrouw C. mocht vertrouwen op de berekening van de gemeente. Verder nam de Raad mee, dat het salaris maandelijks placht te worden besteed, zodat ambtenaren 'er redelijkerwijs op moeten kunnen vertrouwen, dat ze niet geruime tijd later worden verplicht een deel der ontvangen bedragen terug te betalen'. Hierop maakte de Raad ten slotte een uitzondering in het geval dat de betalingen werden gedaan onder voorbehoud of bij wijze van voorschot. De Centrale Raad ging vervolgens nog in op de betekenis van artikel 120 lid 2 Aw 1929, het voormalige artikel 120 lid 1 aanhef en onder e. Hij stelde vast dat daar weliswaar een regeling was gegeven met betrekking tot verrekening, maar dat daarmee niet was voorgeschreven dat 'verhaal van hetgeen op bezoldiging en pensioen te veel is betaald te allen tijde en in elk geval mag plaats hebben'. Dit artikel gaf slechts aan, dat de wetgever verhaal mogelijk achtte. Uitdrukkelijk stelde de Raad dat ook hij die mogelijkheid erkende, bijvoorbeeld als de ambtenaar redelijkerwijs had kunnen begrijpen, dat hem te veel aan bezoldiging werd uitbetaald.

De Centrale Raad erkende in deze uitspraak dus dat als voorschot gedane betalingen wel terugvorderbaar waren. ${ }^{40}$ Dit leidde er toe dat gemeenten ertoe

39. CRvB 25 maart 1952, AB 1952, 698. Zie over deze uitspraak (en over de tot nu geschetste ontwikkeling) ook Nuver (1952).

40. Zie ook CRvB 28 oktober 1952, AB 1953, 358. 
overgingen de bezoldigingen niet meer uit te betalen, maar voorschotten daarop gingen geven. De bezoldiging werd dan pas definitief vastgesteld na ongeveer een jaar, op het moment dat de gemeente de vergoedingen voor de betaalde bezoldigingen van het Rijk hadden ontvangen, en vervolgens verrekend met de betaalde voorschotten. Op die manier was het mogelijk bij een foutieve berekening de te veel betaalde voorschotten terug te vorderen. De Centrale Raad maakte vrij snel een einde aan die praktijk; in zijn uitspraak van 16 december 1952 verklaarde hij deze constructie niet geoorloofd. ${ }^{41}$ Verder gaf hij in die uitspraak uitdrukkelijk aan, dat terugvordering van te veel betaald salaris mogelijk was als de ambtenaar in redelijkheid een verwijt kon worden gemaakt. Dat kon het geval zijn als er een behoorlijke specificatie was verstrekt, zodat hij de juistheid van het uitbetaalde bedrag kon nagaan 'en hij hiertoe, ondanks een zekere ingewikkeldheid der salarisvoorschriften, dan redelijkerwijs ook in staat moet worden geoordeeld'.

De ontwikkeling van de jurisprudentie op het gebied van de terugvordering werd (voorlopig) afgerond op 30 december 1952. Op die dag deed de Centrale Raad van Beroep uitspraak in een geschil tussen onderwijzeres Schouten en de gemeente Zonnemaire. ${ }^{42}$ Schouten had op grond van het Toelagebesluit 1951 een toelage gekregen op haar salaris. Achteraf bleek dat deze toelage was berekend als ware zij kostwinner, hetgeen zij niet was. De gemeente vorderde de te veel betaalde toelage terug. Het door Schouten hiertegen ingestelde beroep werd door het Ambtenarengerecht ongegrond verklaard. De stelling dat de terugvordering in strijd was met het rechtszekerheidsbeginsel werd verworpen.

0. dat - nog daargelaten of dit beginsel geacht kan worden te behoren tot de algemeen verbindende voorschriften als bedoeld in art. 58 der Ambtenarenwet-1929 (..) -, aan genoemd beginsel niet een zodanig ruime interpretatie mag worden gegeven, dat het in het merendeel der gevallen in de weg zou stan aan de toepassing van de in de Wet neergelegde bepaling, dat hetgeen onverschuldigd is betaald kan worden teruggevorderd, en de daarin tot uitdrukking komende regel, dat ongerechtvaardigde verrijking moet worden gerestitueerd'.

Het gerecht achtte het zelfs in strijd met de rechtsgelijkheid 'en met de sedert eeuwen op het stuk der ongerechtvaardigde verrijking in de jurisprudentie en de rechtsovertuiging verankerde begrippen' om een onderscheid te maken tussen een terugvorderende overheid en een terugvorderende particulier. Bij de particulier was de vraag of er sprake was van een verzuim aan zijn kant niet relevant voor de vraag of onverschuldigd gedane betalingen konden worden teruggevorderd; als dit bij de overheid wel relevant zou zijn, was dit discriminerend.

$\mathrm{Bij}$ de beslissing van het Ambtenarengerecht kunnen twee opmerkingen worden gemaakt. Allereerst plaatste het gerecht kennelijk een vraagteken bij de vraag of het beginsel van de rechtszekerheid behoorde tot de algemeen verbindende voorschriften als bedoeld in artikel 58 Aw 1929. De Centrale Raad van Beroep had dit echter uitdrukkelijk vastgesteld in zijn uitspraak van 2 oktober 1951, ruim 
een jaar eerder dan deze uitspraak van het gerecht, welke dateerde van 6 oktober 1952. ${ }^{43}$ Verder sprak het Ambtenarengerecht van 'de in de Wet neergelegde bepaling, dat hetgeen onverschuldigd is betaald kan worden teruggevorderd'. Niet duidelijk is welke 'Wet' het gerecht bedoelde. Werd hier gedoeld op de Ambtenarenwet? Dit is onwaarschijnlijk; deze wet bevatte geen bepaling dat hetgeen onverschuldigd was betaald kon worden teruggevorderd. Waarschijnlijk werd het woord 'Wet' algemeen bedoeld, namelijk als 'de Nederlandse wetten' en werd meer specifiek verwezen naar de bepaling betreffende de onverschuldigde betaling in het BW. De verdere overwegingen van het gerecht wijzen daar ook op.

Schouten ging tegen deze uitspraak in beroep bij de Centrale Raad van Beroep. Deze gaf eerst de door het gerecht gegeven grond om tot afwijzing van het beroep op het rechtszekerheidsbeginsel te komen weer, en vervolgde:

' $O$. dienaangaande, dat de Raad de bepaling, dat hetgeen zonder verschuldigd te zijn betaald is, kan worden teruggevorderd, in art 1395 B.W. vastgelegd voor het burgerlijk recht, erkent als een algemeen rechtsbeginsel, van toepassing ook in het administratieve recht, en wel als een algemeen rechtsbeginsel, in principe van gelijke waarde als dat van de rechtszekerheid (...);

0 . dat, indien beide rechtsbeginselen in een bepaald geval niet met elkaar verenigbaar zijn, van de bijzondere omstandigheden van het geval afhangt aan welk beginsel de voorrang moet worden gegeven, en de Raad aan het beginsel, dat kan worden teruggevorderd hetgeen onverschuldigd is betald, zeker de voorrang geeft, indien de ontvanger der betaling de onverschuldigdheid ervan kende of redelijkerwijs had kunnen onderkennen'.

De Raad kwam vervolgens tot de conclusie dat dit laatste niet het geval was. Hierbij betrok hij (wederom) het feit dat een behoorlijke specificatie ontbrak en dat de bezoldigingsvoorschriften zo ingewikkeld waren, dat het 'geenszins eenvoudig' was na te gaan of het salaris juist was vastgesteld, zeker niet voor een 'jeugdige onderwijzeres'. Voorts overwoog hij dat de vaststelling van de wedde 'niet met voldoende zorgvuldigheid' had plaatsgevonden en dat het periodieke betalingen betrof, die in de regel periodiek werden verbruikt. Het besluit werd in strijd bevonden met het rechtszekerheidsbeginsel en vernietigd.

Volgens de Centrale Raad was dus het beginsel dat hetgeen onverschuldigd is betaald, kan worden teruggevorderd een algemeen rechtsbeginsel, ook geldend in het bestuursrecht. Dit betekende kennelijk, dat zelfs in het geval dat de publiekrechtelijke regeling geen bepalingen met betrekking tot terugvordering bevatte, onverschuldigd betaalde bedragen konden worden teruggevorderd. Althans, in beginsel. De eerste (logische) uitzondering is dat de publiekrechtelijke regeling terugvordering uitdrukkelijk uitsluit; in dat geval heeft de wetgever uitdrukkelijk willen afwijken van het genoemde beginsel. Een tweede uitzondering gaf de Centrale Raad in deze uitspraak: er kan sprake zijn van een botsing tussen algemene rechtsbeginselen. In dat geval zullen de concrete omstandigheden van het geval de doorslag geven, aan welk beginsel voorrang moet worden gegeven. $\mathrm{Zo}$ zal het rechtszekerheidsbeginsel de voorrang krijgen als de betrokkene niet wist en 
redelijkerwijs niet had kunnen weten dat onverschuldigd werd betaald. ${ }^{44}$ Als hij wel wist of redelijkerwijs had kunnen weten dat te veel werd betaald, moet kennelijk voorrang worden gegeven aan het beginsel dat hetgeen onverschuldigd is betaald, kan worden teruggevorderd. In dat geval is er ook geen strijd met de rechtszekerheid. De Centrale Raad noemde in de uitspraak voorts artikel $1395 \mathrm{BW}$ (oud). Het is echter duidelijk dat hij dit artikel niet toepaste; hij gebruikte het slechts om aan te tonen dat sprake was van een algemeen rechtsbeginsel, dat als zodanig reeds was gecodificeerd in het Nederlandse recht.

Deze uitspraak van de Centrale Raad is vaste jurisprudentie geworden, die verder is uitgewerkt en verfijnd. ${ }^{45}$ Hierop zal in 7.2.4.2 worden ingegaan. Met de uitspraak is een 'gemeen recht' in een nieuwe betekenis geîntroduceerd: algemene beginselen, die burgerlijk recht en administratief recht gemeen hebben, ofwel het aan burgerlijk recht en administratief recht gemeenschappelijke recht. ${ }^{46}$

Ruim 45 jaar later zijn ook de andere administratieve rechters deze constructie gaan toepassen, niet alleen op het gebied van de onverschuldigde betaling, ${ }^{47}$ maar ook bij onder meer de schadevergoeding uit zowel onrechtmatige als rechtmatige overheidsdaad. ${ }^{48}$ Deze jurisprudentie heeft in bestuursrechtelijk kringen voor nogal wat opwinding en opschudding gezorgd. Hierop zal worden ingegaan in hoofdstuk 9, alwaar deze jurisprudentie kritisch zal worden bekeken.

\subsubsection{Terugvordering van betalingen aan ambtenaren}

\subsubsection{Inleiding}

Samengevat was de stand van zaken halverwege de jaren vijftig de volgende. Ondanks het feit dat de Ambtenarenwet geen bepalingen bevatte met betrekking tot terugvordering, konden onverschuldigd betaalde bezoldigingen of andere ten onrechte aan ambtenaren betaalde bedragen onder omstandigheden worden teruggevorderd. Het algemeen rechtsbeginsel dat hetgeen is betaald zonder verschuldigd te zijn, kan worden teruggevorderd, was ook van toepassing in het administratieve recht. Het algemene beginsel van de rechtszekerheid kon zich echter onder omstandigheden tegen terugvordering verzetten.

44. Naar mijn mening speelt hier niet het rechtszekerheidsbeginsel, maar het vertrouwensbeginsel een rol. Zie hierna, 7.2 .42 .

45. Zie bijvoorbeeld Ag. Haarlem 17 februari 1959 en (in hoger beroep) CRvB 26 juni 1959, AB 1960, 469, CRvB 29 oktober 1970, AB 1971, 117 en CRvB 26 april 1990, AB 1991, 157, m.nt. HH, TAR 1990, 138.

46. Teunissen (1997), blz. 88-90.

47. Bijvoorbeeld ABRvS 21 oktober 1996, AB 1996, 496, m.nt. NV, JB 1996, 232, m.nt. HS (Nanne) en Cbsf 9 april 1997, JB 1997, 105, m.nt. HJS.

48. Zie onder meer ABRvS 29 november 1996, AB 1997, 66, m.nt. PvB, JB 1996, 253, m.nt. red. (Alpha Kledingreinigingsbedrijf), ABRvS 18 februari 1997, AB 1997, 143, m.nt. PvB, JB 1997, 47, m.nt. HJS (Beurskens), ABRvS 6 mei 1997, AB 1997, 229, m.nt. PvB, JB 1997, 118, m.nt. HJS (Van Vlodrop), Cosf 23 mei 1996, JB 1996, 177, mne. red. en CBB 19 februari 1997, AB 1997, 144, m.nt. JHvdV, JB 1997, 92, m.nt. HJS. 
Verder was van belang dat de ambtenarenrechter exclusief bevoegd was; in het Ambtenarenwetarrest uit 1941 had de Hoge Raad beslist dat

'geschillen over schuldvorderingen, welke uit de rechtsbetrekking tusschen ambtenaar en overheid voortvloeien, voorzooverre daarbij sprake is van een klacht over een besluit of handeling of weigering der administratie, met terzijde stelling van den algemeenen reget van art. 2 R.O., aan de kennisneming van de rechteriijke macht zijn onttrokken'. ${ }^{9}$

De burgerlijke rechter diende zich dan ook onbevoegd te verklaren als een dergelijk geschil te zijner kennis werd gebracht.

In deze paragraaf zal de ontwikkeling sinds de jaren vijftig worden behandeld. We zullen zien dat de jurisprudentie met betrekking tot de terugvordering verder is uitgewerkt en verfijnd. Dit komt in 7.2.4.2 aan de orde. Met betrekking tot de competentie van de burgerlijke rechter heeft de Hoge Raad zijn standpunt gewijzigd in het Changoe-arrest. Materieel-rechtelijk had dit echter weinig consequenties, zoals zal blijken in 7.2.4.3, in welke paragraaf ik de bevoegdheid van de burgerlijke rechter zal behandelen.

\subsubsection{Terugvordering}

Het algemene rechtsbeginsel dat hetgeen onverschuldigd is betaald, kan worden teruggevorderd, zag de Centrale Raad van Beroep dus als een beginsel dat ook in het administratieve recht gold. Dit beginsel was van gelijke waarde als het rechtszekerheidsbeginsel, zodat in een voorkomend geval bij strijd tussen beide beginselen een afweging moest worden gemaakt, welk beginsel voorrang kreeg. Dit was afhankelijk van de bijzondere omstandigheden van het geval. Kende de betrokkene de onverschuldigdheid van de betaling, dan ging het 'terugvorderings'beginsel voor. Dit was ook zo als de betrokkene redelijkerwijs had kunnen weten dat onverschuldigd werd betaald. Bij de beantwoording van de vraag of hij dit redelijkerwijs had kunnen weten, betrok de Centrale Raad van Beroep vaak het feit dat al dan niet een salarisspecificatie was verstrekt. Was een specificatie verstrekt, dan leidde dit meestal tot de conclusie dat betrokkene redelijkerwijs had kunnen weten dat te veel was betaald. ${ }^{50}$ Kon het bestuursorgaan de specificatie niet overleggen, dan kwam dit voor zijn risico. ${ }^{31}$ Het enkele feit dat de betrokkene inlichtingen had kunnen inwinnen, maar dat heeft nagelaten, is niet voldoende voor de conclusie dat hij redelijkerwijs had kunnen weten dat te veel werd betald. Het vragen van inlichtingen speelt eerst dan een rol als voor de betrokke-

49. HR 13 november 1941. NJ 1942, 172, AB 1942, 485. Zie 4.3.2 en 7.2.3.2.

50. Bijvoarbeeld CRvB 26 juni 1959, AB 1960, 469 en CRvB 27 januari 1978, AB 1978, 186. Het enkele feit dat een specificatie was verstrekt, is nog niet voldoende voor de conclusie dat betrokkene redelijkerwijs had kunnen weten dat te veel werd betaald. Zo kan de specificatie dermate onduidelijk zijn dat de conclusie moet luiden dat betrokkene redelijkerwijs niet kon weten dat te vee! werd uitbetaald, zie bijvoorbeeld CRvB 31 augustus 1989, AB 1989, 502, m.nt. HH.

51. CRvB 9 mei 1988, AB 1988, 455, m.nt. HH. 
ne aanleiding bestond aan de juistheid van het ontvangen salaris te twijfelen. ${ }^{52}$

Als de betrokkene wist of redelijkerwijs had kunnen weten dat een bepaald bedrag ten onrechte was betald, dan kon dit bedrag worden teruggevorderd. In het socialezekerheidsrecht was deze terugvorderingsmogelijkheid in het algemeen aan een bepaalde termijn gebonden. De Centrale Raad, optredend als ambtenarenrechter, betrok een dergelijke termijn pas halverwege de jaren tachtig in zijn cordeel. In een uitspraak uit 1987 overwoog hij, dat als betrokkene redelijkerwijs had kunnen weten dat een verkeerde inschaling had plaatsgevonden, de termijn die was verstreken tussen het moment dat de fout was begaan en het moment dat tot correctie van die fout werd overgegaan 'niet zonder belang' was. ${ }^{53}$

Dit werd uitgewerkt in een uitspraak uit 1990. Daarin concludeerde de Raad

'dat zowel het beginsel van de rechtszekerheid als het beginsel van een evenwichtige afweging van belangen meebrengt, dat ook in het ambtenarenrecht het (..) tijdsverloop een plaats dient te hebben. Op welke wijze hieraan concrete vorin kan worden gegeven zal mede worden beinnvloed door de aard van de aan de orde zijnde materie. Wat betreft het ongedaan maken van onverschuldigde betalingen door terugvordering of verrekening dient dit (...) aldus te worden geconcretiseerd, dat een administratief orgaan hetgeen aan een ambtenaar onversehuldigd is betaald in beginsel gedurende twee jaren na de dag van uitbetaling kan terugvorderen of verrekenen indien de ambtenaar wist of redelijkerwijs had kunnen weten dat hij te veel ontving, welke termijn tot vijf jaren kan worden verlengd indien de ambtenaar van de gemaakte fout niet alleen kennis droeg of redelijkerwijs had kunnen dragen maar die fout bovendien door zijn toedoen is ontstaan'. ${ }^{4}$

De Centrale Raad sloot hierbij aan bij - en verwees naar - de regeling in tal van socialeverzekeringswetten. Dit leidt tot de volgende conclusies: terugvordering was niet mogelijk als betrokkene niet wist en niet had behoren te weten dat te veel was uitbetaald. Werd te veel uitbetaald als gevolg van een administratieve vergissing en wist betrokkene dit of had hij dit redelijkerwijs behoren te weten, dan was terugvordering mogelijk gedurende twee jaren na de dag van uitbetaling. Was het feit dat te veel was betaald te wijten aan betrokkene, dan werd deze periode verlengd tot vijf jaren.

In zijn noten onder een aantal van deze uitspraken stelde Hennekens de vraag of het wel correct was van de Centrale Raad om te stellen dat hij het rechtszekerheidsbeginsel afwoog tegen het 'terugvarderings'beginsel. ${ }^{55}$ Volgens hem bood niet het algemene rechtsbeginsel van de rechtszekerheid, maar het vertrouwensbeginsel als algemeen beginsel van behoorlijk bestuur de grondslag om in een bepaald geval terugvordering onrechtmatig te achten; "het door de adrninistratie opgewekte vertrouwen dient jegens de ambtenaar in acht genomen te worden'. Hierbij gaat het 'niet om afweging van beginselen, doch om gehoudenheid aan

52. CRvB 26 februari 1987, AB 1987, 438.

53. CRvB 17 september 1987, TAR 1987, 245.

54. CRvB 26 april 1990, AB 1991, 157, m.nt. HH, TAR 1990, 138.

55. Zie met name zijn noten onder CRvB 31 augustus 1989, AB 1989, 502 en CRvB 26 april 1990, AB 1991, 157. 
zijn gedragingen door het administratief orgaan'.56 Hennekens betrok het vertrouwen op zowel de vraag of als de vraag hoelang, gedurende welke termijn, kan worden teruggevorderd. Als (extra) argument orn uit te gaan van het vertrouwensbeginsel en niet van het rechtszekerheidsbeginsel voerde hij aan dat het eerste een algemeen beginsel van behoorlijk bestuur was en het laatste een algemeen rechtsbeginsel. Algemene rechtsbeginselen werken zowel voor de overheid (en in dat geval dus tegen de burger) als voor de burger (en dus in dat geval tegen de overheid). Als dit beginsel van toepassing was, zou dit er toe leiden dat als een ambtenaar te weinig uitbetaald had gekregen, de vraag of en gedurende welke termijn een nabetaling plaats diende te vinden, zou moeten worden beantwoord aan de hand van de hiervoor weergegeven criteria. Volgens Hennekens is het evident dat dit niet het geval is. Algemene beginselen van behoorlijk bestuur dienen slechts ter bescherming van de burger; zij moeten door de overheid in acht worden genomen en kunnen niet tegen de burger worden gehanteerd.

Voor zover Hennekens stelt dat niet aan de hand van het rechtszekerheidsbeginsel moet worden bekeken of kan worden teruggevorderd, maar dat hier het vertrouwensbeginsel doorslaggevend is, ben ik het met hem eens. De ambtenaar moet er immers in beginsel op mogen vertrouwen dat hetgeen hij uitbetaald krijgh, correct is. Het door de uitbetaling bij de ambtenaar opgewekte vertrouwen dat hetgeen is uitbetaald hem ook toekomt, moet in beginsel worden gehonoreerd. In beginsel, want er zal wel sprake moeten zijn van gerechtvaardigd vertrouwen. Bij de beantwoording van de vraag of sprake is van gerechtvaardigd vertrouwen, kan vervolgens het door de Centrale Raad van Beroep gehanteerde criterium worden gebruikt: wist de betrokkene dat te veel werd uitbetaald of had hij dit redelijkerwijs behoren te weten? Luidt het antwoord hierop bevestigend, dan is er geen sprake van gerechtvaardigd vertrouwen en kan in beginsel worden overgegaan tot terugvordering. Wederom: in beginsel. De volgende vraag is dan immers of het gehele te veel betaalde bedrag kan worden teruggevorderd. Hierbij zal het rechtszekerheidsbeginsel een rol spelen. Op grond van dit algemene rechtsbeginsel speelt het tijdsverloop, dat zit fussen het ontstaan van een situatie en het ondernemen van actie tegen deze situatie, een rol; partijen zullen op een bepaald moment moeten weten 'waar zij aan toe zijn'. Het rechtszekerheidsbeginsel ligt in bijvoorbeeld het privaatrecht ten grondslag aan de verjarings- en vervaltermijnen. Ook volgens de Centrale Raad van Beroep dient op een bepaald moment duidelijkheid te worden verkregen over de positie van partijen, waarbij speelt dat die positie 'begroeit' naarmate zij langer 'onbestreden in stand is gelaten'. Hiermee moet rekening worden gehouden. ${ }^{57}$ De uitwerking van het rechtszekerheidsbeginsel leidde vervolgens in het ambtenarenrecht (en tot voor kort in het socialezekerheidsrecht) tot de terugvorderingstermijnen van twee respectievelijk vijf jaren.

De werking van de beginselen is duidelijk: aan de hand van het vertrouwensbeginsel wordt eerst bepaald of überhaupt kan worden teruggevorderd. Is het 
antwoord hierop bevestigend, dan wordt aan de hand van het rechtszekerheidsbeginsel bepaald over welke termijn kan worden teruggevorderd.

Door de eerste vraag te beantwoorden aan de hand van het vertrouwensbeginsel, een algemeen beginsel van behoorlijk bestuur, bestaat ook niet het gevaar dat Hennekens signaleerde, namelijk dat het bestuursorgaan in een tegenovergestelde situatie, wanneer de betrokken ambtenaar gedurende bepaalde tijd te weinig uitbetaald heeft gekregen, zich zou kunnen beroepen op het feit dat het niet wist noch redelijkerwijs had behoren te weten dat te weinig werd uitbetaald en dus dat het niet tot nabetaling hoefde over te gaan. Het vertrouwensbeginsel kan immers als algemeen beginsel van behoorlijk bestuur niet door het bestuur worden ingeroepen. De vraag, gedurende welke termijn de ambtenaar vervolgens nabetaling kan vorderen, wordt wel begrensd door het rechtszekerheidsbeginsel, een algemeen rechtsbeginsel dat zowel ten nadele als ten voordele van ieder der partijen kan werken. Dat het ten nadele van de ambtenaar kan werken en dat aanspraken op bezoldiging of andere daarmee verband houdende uitbetalingen in de tijd worden begrensd, heeft de Centrale Raad van Beroep uitdrukkelijk beslist. ${ }^{58}$

In 1997 nam ten slotte de bestuurskamer van de Rechtbank 's-Gravenhage in een zaak waarin een ambtenaar te veel wachtgeld had ontvangen, ook de zesmaandenjurisprudentie over van de Centrale Raad als socialezekerheidsrechter. Volgens de rechtbank was het in strijd met de zorgvuldigheid om uitkeringen - wachtgeld terug te vorderen, die werden betaald meer dan zes maanden na het tijdstip waarop het bestuursorgaan een signaal had ontvangen dat ten onrechte werd betaald. De rechtbank verwees expliciet naar de rechtspraak van de Centrale Raad als socialezekerheidsrechter. ${ }^{59}$ Inmiddels heeft ook de Centrale Raad als ambtenarenrechter de zesmaandenjurisprudentie geaccepteerd, waarbij hij heeft aangegeven dat hij geen aanleiding zag 'om de door hem gevormde vaste jurisprudentie in sociale verzekeringszaken in beginsel niet eveneens van toepassing te achten in ambtenaarrechtelijke terugvorderingsgeschillen'. ${ }^{60}$ De Centrale Raad als socialezekerheidsrechter heeft inmiddels aangegeven dat de zesmaandenjurisprudentie in de sociale zekerheid niet meer van toepassing is na de inwerkingtreding van de WBM. ${ }^{61}$ De ambtenarenrechter heeft duidelijk aangegeven dat hij de zesmaandenjurisprudentie ziet als een uitwerking van het zorgvuldigheidsbeginse!. Dit onderbouwt mijn conclusie dat ook de Centrale Raad als socialezekerheidsrechter onder het huidige socialezekerheidsrecht zijn jurisprudentie had moeten voortzetten. Ook onder het huidige socialezekerheidsrecht is het bestuursorgaan immers gebonden aan de algemene beginselen van behoorlijk bestuur.

58. CRvB 19 oktober 1995, JB 1996, 11, CRvB 14 december 1995, TAR 1996, 32 en CRvB 23 januari 1997, TAR 1997, 42. Zie over deze uitspraken 6.5.2.

59. Rb. 's-Gravenhage 5 november 1997, TAR 1998, 35.

60. CRvB 3 augustus 2000, AB 2000, 413, m.nt. HH. In CRvB 24 juni 1999, AB 1999, 406, m.nt. $\mathrm{HH}$ had hij reeds impliciet de zesmaandentermijn toegepast.

61. CRvB 25 september 2001, USZ 2001, 299, m.nt. Red. Zie 6.5.2. 


\subsubsection{Bevoegdheid van de burgerlijke rechter}

In 1941 had de Hoge Raad beslist dat geschillen over schuldvorderingen welke voortvloeiden uit de rechtsbetrekking tussen de overheid en ambtenaren aan de kennisneming van de burgerlijke rechter waren onttrokken; deze rechter was niet bevoegd van deze geschillen kennis te nemen. Verrassend was dit niet; in de memorie van toelichting op de Ambtenarenwet had de wetgever immers uitdrukkelijk overwogen dat de gehele rechtsbetrekking tussen overheid en ambtenaar als publiekrechtelijk moest worden beschouwd, waardoor de burgerlijke rechter ophield bevoegd te zijn ten aanzien van ambtenarenkwesties. ${ }^{62}$ Een en ander heb ik meer uitgebreid besproken in hoofdstuk 4, met name in 4.3.2.

Deze exclusieve bevoegdheid van de ambtenarenrechter en daaraan gekoppeld de onbevoegdheid van de burgerlijke rechter werd in 1987 door de Hoge Raad in het Du Pied-arrest ook aangenomen voor wat betreft voorlopige voorzieningen. ${ }^{63}$ Volgens de Hoge Raad bood artikel 102 Aw de mogelijkheid om zonodig een onverwijlde voorziening te vragen aan de voorzitter van het Ambtenarengerecht of (in hoger beroep) van de Centrale Raad van Beroep. Nu Du Pied een voorlopige voorziening vroeg, die hij ook had kunnen krijgen op grond van artikel $102 \mathrm{Aw}$, had hij die weg moeten volgen. De Hoge Raad oordeelde dat de burgerlijke rechter, en dus ook de president van de rechtbank in kort geding niet bevoegd was de gevorderde voorziening te geven. Uit het arrest kan de conclusie worden getrokken, dat als de Ambtenarenwet de mogelijkheid voor de gevraagde voorziening niet had geboden, de kortgedingrechter waarschijnlijk wel bevoegd was geweest.

Ook de Centrale Raad van Beroep ging er vanuit dat de burgerlijke rechter bevoegd bleef om in bepaalde gevallen aanvullende rechtsbescherming te bieden, namelijk in die gevallen waarin de Ambtenarenwet niet voorzag en waarin de ambtenarenrechter dus niet op grond van artikel 3 Aw een voorziening kon bieden. Deze wet kende bijvoorbeeld niet de mogelijkheid om een dwangsom op te leggen indien een door de voorzitter van het Ambtenarengerecht of de Centrale Raad gegeven voorlopige voorziening niet werd uitgevoerd. In dat geval kon de voorziening door de burgerlijke rechter worden 'versterkt' door een aanvulling met een dwangsom. ${ }^{64}$ Hierbij was het volgens de Centrale Raad uitdrukkelijk niet de bedoeling dat de burgerlijke rechter nogmaals overging tot afweging van de belangen. Deze afweging was immers al gemaakt door de ambtenarenrechter.

Toen de Hoge Raad in 1992 in het Changoe-arrest zijn jurisprudentie onverwacht wijzigde, betrok hij deze uitspraak van de Centrale Raad in zijn overwegingen. Changoe was als ambtenaar werkzaam, totdat hij werd ontslagen. Hij tekende bezwaar aan tegen het besluit, hetgeen ertoe leidde dat het werd ingetrokken. In de tussenliggende tijd had hij geen bezoldiging ontvangen. Dit gederfde

62. Tweede Kamer 1927-1928, 392, nr. 3, blz. 17. Dit gold sinds 1966 ook met betrekking tot ambtenarenpensioenen, zie 7.3.4.2.

63. HR 4 decernber 1987, NJ 1988, 295, m.nt. WHH, AB 1988, 189, m.nt. FHvdB.

64. CRvB 11 april 1991, AB 1991, 469, m.nt. HH. Zie ook de annotatiekroniek van Hirsch Ballin in TAR, Hirsch Ballin (1986). 
salaris werd alsnog uitbetaald. Changoe vroeg vervolgens om vergoeding van de schade, die hij had geleden doordat hij gedurende een tijd geen salaris had ontvangen. Bij brief deelde de staatssecretaris mee, dat hij zich niet aansprakelijk achtte voor enige schade. Changoe dagvaardde vervolgens de Staat op grond van een onrechtmatige daad en hij vorderde vergoeding van zijn schade, waaronder immateriële schade. De rechtbank achtte zich niet bevoegd. De afwijzing van het verzoek om schadevergoeding diende te worden aangemerkt als een besluit of (in voorkomend geval) een weigering een besluit te nemen. Hiertegen stond beroep open ingevolge de Ambtenarenwet. Changoe ging in (sprong)cassatie; de rechtbank had zich naar zijn mening ten onrechte onbevoegd verklaard.

De Hoge Raad vatte eerst zijn vroegere jurisprudentie samen: uit artikel 3 Aw volgde dat schuldvorderingen die voortvloeiden uit de rechtsbetrekking tussen de overheid en de ambtenaar aan de kennisneming van de burgerlijke rechter waren onttrokken voor zover daarbij sprake was van een klacht over een besluit, handeling of weigering van de overheid. Volgens de Hoge Raad kwam deze rechtspraak echter in aanmerking voor heroverweging. Hij overwoog dat het in het algemeen zo was, dat de bevoegdheid van de administratieve rechter de bevoegdheid van de burgerlijke rechter op grond van artikel 2 R.O. niet uitsloot. Wel leidde de bevoegdheid van de administratieve rechter tot niet-ontvankelijkheid van de vordering voor de burgerlijke rechter als de eerste voldoende rechtsbescherming kon bieden. De consequentie hiervan was, dat de burgerlijke rechter indien nodig aanvullende rechtsbescherming kon bieden.

\footnotetext{
'Het ligt voor de hand dit stelsel van aanvullende rechtsbescherming ook te aanvaarden voor de verhouding tussen burgerlijke rechter en ambtenarenrechter, tenzij de Ambtenarenwet tot een andere opvatting zou nopen. Dit is echter niet het geval. De tekst van art. 3 dwingt niet tot een andere. opvatting. De wetsgeschiedenis, waarop de Hoge Raad in het arrest van 13 nov. $194 !$ tevens een beroep heeft gedaan, kan in het licht van de rechtsontwikkeling thans geen gewichtige factor meer zijn. De strekking van de Ambtenarenwet brengt veeleer mede dat aan de ambtenaar een zo volledig mogelijke rechtsbescherming dient te worden geboden. In dit verband dient aantekening dat ook de CRvB klaarblijkelijk ervan uitgaat dat de burgerlijke rechter bevoegd is aanvullende rechtsbescherming te verlenen (CRvB 11 april 1991, AB 1991, 469) ${ }^{\circ}{ }^{65}$
}

Het door. Changoe ingestelde middel was dus gegrond, maar kon bij gebreke van belang niet tot cassatie leiden, omdat ingevolge de Ambtenarenwet beroep had opengestaan op de ambtenarenrechter. Changoe had immers beroep kunnen instellen tegen de brief van de staatssecretaris. Hij had dan ook niet-ontvankelijk in zijn vordering moeten worden verklaard. Het enkele feit, dat de ambtenarenrechter zich ten aanzien van bepaalde: schadeposten terughoudender zou opstellen dan de burgerlijke rechter en dat bij het beroep op de eerste geen vergoeding van proces- 
kosten, noch van wettelijke rente mogelijk was, ${ }^{66}$ leidde niet tot een andere beslissing, orndat dit enkele feit (als het juist zou zijn, voegde de Hoge Raad toe) niet betekende dat de rechtsbescherming met betrekking tot schadevergoeding bij de ambtenarenrechter onvoldoende was.

Waarom de Hoge Raad zijn oude jurisprudentie heeft heroverwogen, is niet geheel duidelijk. Tak spreekt van een opzienbarende wijziging in de bevoegdheidskoers van de Hoge Raad, zeker gezien het feit dat het arrest werd gewezen aan de vooravond van de invoering van een algemene bestuursrechtelijke rechtsbescherming door de Awb. Als mogelijke verklaringen zag hij de toenemende kritiek in de literatuur op de oude jurisprudentie, ${ }^{67}$ het feit dat de Centrale Raad van Beroep zelf naar de burgerlijke rechter verwees indien executiemogelijkheden ontbraken, het feit dat steeds meer stemmen opgingen om ambtenaren geen bijzondere rechtspositie meer te geven, maar te behandelen als 'gewone' werknemers, het zich sterk maken van de burgerlijke rechter ten opzichte van de andere hoogste rechters. Uiteindelijk komt hij tot de conclusie dat de Hoge Raad zich waarschijnlijk door de jurisprudentie van het Europese Hof voor de rechten van de mens gedwongen voelde de burger - en dus ook de ambtenaar - een optimale rechtsbescherming te bieden. ${ }^{68}$

De Hoge Raad stelde zich blijkens dit arrest op het standpunt dat een. exclusieve bevoegdheid van de ambtenarenrechter in alle gevallen de bevoegdheid van de burgerlijke rechter uitsloot:

'Een en ander leidt tot het uit een oogpunt van rechtsbescherming bevredigende en in een rechtsstaat passende resultaat dat de burger een zo volledig mogelijke rechtsbescherming geniet, nu de burgerlijke rechter, anders dan in cen stelsel van uitsluitende bevoegdheid van de administratieve rechter, aanvullende rechtsbescherming kan bieden' ${ }^{69}$

Ik lees de uitspraak van de Centrale Raad van Beroep echter zo, dat de exclusieve bevoegdheid van de ambtenarenrechter niet in alle gevallen tot onbevoegdheid van. de burgerlijke rechter hoefde te leiden. De Centrale Raad had namelijk overwogen, dat het naar zijn oordeel in overeenstemming zou zijn met het systeem van de Ambtenarenwet, als een vordering in kort geding tot uitvoering van een beslissing bij voorraad wordt toegewezen onder oplegging van een dwangsom. ${ }^{70}$ Mijns inziens zou de gewenste aanvullende rechtsbescherming door de burgerlijke rechter dan kunnen worden geboden in die gevallen, waarin de Ambtenarenwet

66. Inmiddels is bij de bestuursrechter het verkrijgen van vergoeding van zowel proceskosten als wettelijke rente mogelijk. Vergoeding van kosten gemaakt in de bezwaarfase daarentegen hebben deze rechters afgewezen. Een dergelijke vergoeding is slechts in zeer beperkte gevallen mogelijk, zie hierover Bollen (2000), blz. 309-310, Hartlief (2000-I) en Hartlief (2000-II).

67. Zie bijvoorbeeld de ook in de noot in de $\mathrm{AB}$ van Van der Burg onder het Changoe-arrest aangehaalde artikelen van Korteweg-Wierts (1991), Van Eijck/Maes (1991) en. Fruytier (1991).

68. Tak (1997), blz. 143-144.

69. Mijn cursivering.

70. CRvB 11 april 1991, AB 1991, 469, m.nt. HH. 
niet voorziet. ${ }^{71}$ In alle andere gevallen zou de burgerlijke rechter zich onbevoegd hebben moeten verklaren, waar hij nu volgens de Hoge Raad eiser niet ontvankelijk dient te verklaren. Het 'omgaan' van de Hoge Raad was dan ook niet nodig.

Het Changoe-arrest vormt wel een verbetering voor de rechtspositie van ambtenaren als de Hoge Raad anders strikt zou hebben vastgehouden aan zijn opvatting, dat bij een exclusieve bevoegdheid van de ambtenarenrechter de burgerlijke rechter altijd onbevoegd is te oordelen over een geschil tussen de overheid en een ambtenaar als zodanig. ${ }^{72}$ In dat geval zou de burgerlijke rechter nooit bevoegd zijn om aanvullende rechtsbescherming te bieden, bijvoorbeeld door een door de ambtenarenrechter uitgesproken voorlopige voorziening te 'versterken' met een dwangsom. In dat geval zou onbevoegdverklaring door de burgerlijke rechter naar mijn mening ook in strijd zijn met de (vermoedelijke) bedoeling van de wetgever bij de uitsluiting van de bevoegdheid van de burgerlijke rechter in 1933. Het is aannemelijk dat in die tijd de ambtenarenrechter op grond van de Ambtenarenwet de ambtenaar een grotere rechtsbescherming kon bieden dan de burgerlijke rechter kon. Zo stelde M. Scheltema in zijn noot onder het Changoearrest, dat oorspronkelijk de exclusieve bevoegdheid van de ambtenarenrechter 'een aanzienlijke versterking van de rechtsbescherming van de ambtenaar' betekende, maar dat dit nu niet meer gold: de uitsluiting van de gewone rechter betekent nu 'de uitschakeling van de mogelijkheid van 'in een rechtsstaat passende' aanvullende rechtsbescherming. ${ }^{73}$ Maar nogmaals: mijns inziens hoefde de exclusieve bevoegdheid van de ambtenarenrechter niet in alle gevallen tot onbevoegdheid te leiden en was dus het 'omgaan' van de Hoge Raad overbodig. Als de burgerlijke rechter in bepaalde gevallen wel bescherming kan bieden waar de ambtenarenrechter dit niet kan, lijkt mij dit een argument om de burgerlijke rechter (alleen) in die gevallen bevoegd te achten.

Het zal overigens voor de betrokken ambtenaar weinig uitmaken of hij in een geding door de burgerlijke rechter niet-ontvankelijk wordt verklaard of dat deze zichzelf onbevoegd verklaart. In beide gevallen krijgt hij het door hem gewenste oordeel van deze rechter niet. G.J. Scholten sprak dan ook over formele onbevoegdheid, die tot een onbevoegdheidsverklaring van de rechter leidde, en materiële onbevoegdheid, die tot niet-ontvankelijkheid leidde, ${ }^{74}$ terwijl Van der Burg stelde dat het weinig verschil maakte voor de ambtenaar of hij werd gebeten door de kat van onbevoegdheid of de hond van niet-ontvankelijkheid. ${ }^{75}$

Volledigheidshalve moet worden vermeld dat de burgerlijke rechter zich ook in de periode voorafgaand aan het Changoe-arrest in bepaalde gevallen bevoegd heeft verklaard in ambtenarenaangelegenheden. Zo stelde de gemeente Haarlem in 1971 voor de Rechtbank Amsterdam een rechtsvordering in tegen F. tot terugbeta- 
ling van ten onrechte na ontslag doorbetaald salaris en kindertoelage. F. stelde dat de ambtenarenrechter en niet de rechtbank bevoegd was over deze vordering te oordelen. De rechtbank verwierp dit verweer; de vordering strekte immers tot terugbetaling van volgens de gemeente onverschuldigd uitbetaald salaris. Het betrof dus een op artikel $1395 \mathrm{BW}$ (oud) gegronde schuldvordering in de zin van artikel 2 R.O., dus was de rechtbank op grond van die laatste bepaling bevoegd kennis te nemen van die vordering, "nu in de wet het tegendeel niet is bepaald'. ${ }^{76}$ Dit lijkt in strijd met de toen geldende jurisprudentie van de Hoge Raad. Toch lijkt mij hier bevoegdheid van de burgerlijke rechter op haar plaats; de burgerlijke rechter speelde hier namelijk een aanvullende rol, zij het dat hij de burger geen aanvullende rechtsbescherming bood. De gemeente had namelijk aan F. bij brief verzocht het te veel betaalde terug te betalen, maar ondanks herhaalde schriftelijke en ondubbelzinnige aanmaningen voldeed $F$. niet aan dit verzoek. Het doel van de procedure was dus het verkrijgen van een executoriale titel. F. voerde inhoudelijk tegen de vordering aan dat van onverschuldigde betaling geen sprake was. De rechtbank verwierp dit verweer. De ondubbelzinnige aanmaningen, neergelegd in verschillende brieven, waren aan te merken als een besluit of handeling ten aanzien van een ambtenaar als zodanig, door een administratief orgaan genomen, zodat beroep bij de ambtenarenrechter mogelijk was. Nu F. had nagelaten beroep in te stellen en inmiddels de beroepstermijn was verstreken, had het besluit van de gemeente dan ook formele rechtskracht gekregen, zodat de onverschuldigdheid van de betaling voor de rechtbank een gegeven vormde.

Artikel 3 Aw, dat tot 1 juli $1992^{77}$ de competentie van de Ambtenarengerechten en na die datum de competentie van de bestuurskamers van de rechtbanken bepaalde, verviel op 1 januari 1994 door de inwerkingtreding van de Wet voltooiing eerste fase herziening rechterlijke organisatie. ${ }^{78}$ Tegelijkertijd werd door. dezelfde wet de tweede tranche van de Awb ingevoerd. Artikel 8:1 lid 1 Awb bepaalde dat een belanghebbende tegen een besluit beroep kon instellen bij de rechtbank. Lid 2 van dat artikel stelde met een besluit gelijk een andere handeling van een bestuursorgaan ten aanzien van een ambtenaar als zodanig, waaronder ook militaire en gepensioneerde ambtenaren werden verstaan, een dienstplichtige, hun nagelaten betrekkingen of hun rechtverkrijgenden. Was er dus sprake van een besluit of een andere handeling van een bestuursorgaan ten aanzien van een ambtenaar als zodanig, dan was de (bestuurskamer van de) rechtbank bevoegd. In dat opzicht bracht de Awb weinig nieuws. ${ }^{79}$

76. Rb. Amsterdam 15 juni 1971, AB 1972, 55.

77. Op die datum trad de Wet voorintegratie in werking, Wet van 3 juni 1992, Stb. 278, wardoor de Raden van Beroep en de Ambtenarengerechten als zodanig ophielden te bestaan, zie 3.4.4.

78. Artikel IV ondendeel $\mathbf{B}$ Wet voltooiing eerste fase herziening rechterlijke organisatie, Wet van 16 december 1993, Stb. 650. De inwerkingtreding van deze wet werd geregeld in het Besluit van 23 december 1993, Stb. 693.

79. Wel nieuw is dat de belanghebbende, alvorens de rechtbank te kunnen adiēren, op grond van artikel 7:1 Awb kennelijk eerst bezwaar moet maken tegen de handeling waarmee hij het niet eens is. 


\subsubsection{Samenvatting}

De ambtenarenrechter acht terugvordering van te veel betaald salaris (of andere onverschuldigd gedane betalingen) mogelijk, ook al ligt aan die terugvordering geen wettelijke bepaling ten grondslag. Het algemene rechtsbeginsel, dat degene die onverschuldigd heeft betaald, dit kan terugvorderen, geldt ook in het bestuursrecht. Wel kan in het concrete geval het vertrouwensbeginsel (de ambtenarenrechter spreekt over het rechtszekerheidsbeginsel) zich tegen terugvordering verzetten; dit beginsel dient onder omstandigheden de voorrang te krijgen. Of dit zo is hangt af van de omstandigheden van het geval. Beslissend is of de betrokken ambtenaar wist of redelijkerwijs had kunnen weten dat ten onrechte werd betaald. Is dat het geval, dan krijgt het algemene rechtsbeginsel dat degene die onverschuldigd heeft betaald, dit kan terugvorderen, de voorrang. Hiermee is echter niet gezegd, dat deze terugvordering onbeperkt kan plaatsvinden; het rechtszekerheidsbeginsel verzet zich hiertegen. In de jurisprudentie heeft de ambtenarenrechter bij de uitwerking van dit beginsel aansluiting gezocht bij de regelingen in het socialezekerheidsrecht. Dit leidde tot de regel, dat wanneer de ambtenaar wist of redelijkerwijs had kunnen weten dat te veel werd betaald, dit te veel betaalde kan worden teruggevorderd gedurende twee jaar; is sprake van 'toedoen' dan is deze termijn vijf jaar. Daamaast heeft de arnbtenarenrechter de zesmaandenjurisprudentie van de socialezekerheidsrechter overgenomen: terugvordering van betalingen, gedaan nadat zes maanden zijn verstreken na het tijdstip waarop het bestuursorgaan actie had kunnen ondernemen, is in strijd met het zorgvuldigheidsbeginsel.

Tot 1992 was de ambtenarenrechter exclusief bevoegd met betrekking tot geschillen waarbij een ambtenaar als zodanig was betrokken. Dit leidde tot onbevoegdheid van de burgerlijke rechter, aldus de Hoge Raad in het Ambtenarenwetarrest uit 1941. In 1992 is de Hoge Raad op deze jurisprudentie teruggekomen, mede onder invloed van de rechtspraak van de Centrale Raad van Beroep. Deze had immers in 1991 aangegeven dat hij ruimte zag voor aanvullende rechtsbescherming door de burgerlijke rechter in die gevallen, waarin de ambtenarenrechter de gevraagde rechtsbescherming niet kan bieden. De Hoge Raad overwoog dan ook in het Changoe-arrest, dat de burgerlijke rechter niet langer onbevoegd was van de vordering kennis te nemen, maar dat eiser niet-ontvankelijk diende te worden verklaard in zijn vordering indien 'de administratieve rechter voldoende rechtsbescherming biedt'. Dit laatste zal de facto vrijwel $^{80}$ altijd het geval zijn; de Hoge Raad gaf tevens aan dat het enkele feit dat de ambtenarenrechter zich ten aanzien van bepaalde schadeposten terughoudender zou opstellen dan de burgerlijke rechter en dat bij het beroep op de ambtenarenrechter geen veroordeling van proceskosten, noch van wettelijke rente mogelijk was, niet ertoe leidde, dat de rechtsbescherming als onvoldoende moest worden aangemerkt.

80. Zie voor een uitzondering de jurisprudentie inzake het zuiver schadebesluit, met name HR 17 december 1999, NJ 2000, 87, m.nt. ARB onder 88, AB 2000, 89, m.nt. PvB, JB 2000, 4, m.nt. F.A.M. S. (Groningen-Raatgever). Deze uitzondering was echter niet gebaseerd op de overweging dat de rechtsbescherming, die de bestuursrechter kon bieden, onvoldoende was. 


\subsection{Overheidspensioenen}

\subsubsection{Inleiding}

In deze paragraaf zullen de door de overheid toegekende en uitbetaalde pensioenen worden behandeld. Veelal zijn dit pensioenen aan (gewezen) arnbtenaren of ander overheidspersoneel, zoals militairen. Dit is echter niet altijd het geval; op grond van bijvoorbeeld de Wet buitengewoon pensioen 1940-1945 konden deelnemers aan het verzet tijdens de Tweede Wereldoorlog of hun nabestaanden een 'buitengewoon pensioen' krijgen. Ook zeelieden-oorlogsslachtoffers konden een dergelijk pensioen krijgen op grond van de Wet buitengewoon pensioen zeelieden-oorlogsslachtoffers. Desondanks heeft het terrein van de overheidspensioenen veel raakvlakken met het ambtenarenrecht. Dit werd mede veroorzaakt door het feit, dat sinds 1966 de ambtenarenrechter bevoegd werd inzake geschillen met betrekking tot de meeste pensioenwetten. Ook hier vormden de twee genoemde wetten met betrekking tot buitengewone pensioenen een uitzondering: de personen die in aanmerking kwamen voor deze pensioenen hoefden geen ambtenaar te zijn en dus was ook de ambtenarenrechter niet bevoegd. Toch leidde dit niet tot grote afwijkingen ten opzichte van de overige pensioenwetten, aangezien de Centrale Raad van Beroep in deze wetten werd aangewezen als bevoegde rechter.

Ik zal hierna ingaan op de ontwikkelingen, die hebben plaatsgevonden met betrekking tot de pensioenwetgeving. Wat de algemene pensioenen betreft zijn de belangrijkste wetten achtereenvolgens de Pensioenwet 1846, de Pensioenwet 1890, de Pensioenwet 1922 en de Algemene burgerlijke pensioenwet uit $1966{ }^{81}$ Daarbij zullen wederom de terugvorderingsbepalingen worden bekeken. Verder zal ik ook bespreken in hoeverre op dit terrein ruimte was en is voor de privaatrechtelijke regeling van onverschuldigde betaling en voor de burgerlijke rechter.

De opbouw is dan de volgende. In 7.3.2 zal de ontwikkeling worden besproken zoals die zich heeft voorgedaan tot de inwerkingtreding van de Pensioenwet 1922. Deze laatste wet zal in 7.3.3 aan de orde komen; de Algemene burgerlijke pensioenwet in 7.3.4. Tevens zal ik in die paragrafen ook de vraag behandelen of in de betreffende periode ruimte was voor privaatrecht of de burgerlijke rechter.

Alvorens hiertoe over te gaan nog een opmerking met betrekking tot de gehanteerde terminologie. In 1.7 heb ik aangegeven dat ik onder de term intrekking versta het intrekken met terugwerkende kracht. De term herziening ziet dan op gedeeltelijke intrekking met tenugwerkende kracht. In die paragraaf is tevens gezegd, dat waar de term intrekking wordt gebruikt, daarmee tevens herziening wordt bedoeld; voor herziening gelden immers dezelfde regels als voor intrekking. Aangezien de pensioenwetten vrijwel allemaal de termen herzien en herziening hanteren, en niet de termen intrekken en intrekking, zal ik in deze paragraaf (in afwijking van hetgeen ik heb aangegeven in 1.7) deze termen gebruiken.

81. De ontwikkeling van deze algemene pensioenwetten kwam overigens in 1996 tot een einde door de privatisering van het Aigemeen burgerlijk pensioenfonds. 


\subsubsection{Pensioenen tot de Pensioenwet 1922}

In 7.2.2.1 is reeds gebleken dat de bezoldiging van de ambtenaren werd gezien als een onderhoudsrente. Vanuit deze gedachte, die mede werd ingegeven vanuit een oogpunt van staatsbelang, werden verschillende pensioenregelingen ontworpen voor ambtenaren. De oudste hiervan dateren zelfs van $1798 .^{82}$ Deze eerste regelingen, neergelegd in koninklijke besluiten, waren zeer summier en beperkt, ook qua personeel bereik. De eerste formele regeling dateeri uit 1846 , de Pensioenwet 1846 (hierna: PW 1846). ${ }^{83}$ Het doel van de wet was 'de voorziening in het pensioen der burgerlijke ambtenaren door de Staat tegen genot ener bepaalde tegemoetkoming van de zijde dier ambtenaren'. ${ }^{84}$ Volgens artikel 2 PW 1846 waren burgerlijke ambtenaren 'zij, die, al dan niet uit krachte der wet, door of van wege den koning benoemd, van vaste aanstellingen zijn voorzien, en wier wedden of belooningen uit de staats-inkomsten gekweten worden'. Militairen en de ambtenaren in de overzeese gebieden vielen hier niet onder. Op grond van deze wet diende een onderscheid te worden gemaakt tussen ambtenaren, die reeds in dienst waren op het moment dat de wet in werking trad en ambtenaren, die daarna in dienst traden. Uit de bijdragen van deze laatste groep werd een Pensioenfonds voor burgerlijke ambtenaren gesticht (artikel 33 PW 1846), dat was bestemd voor de financiering van de aan deze ambtenaren in de toekomst toe te kennen pensioenen. De burgerlijke ambtenaren, reeds in dienst ten tijde van de invoering van de wet, werd een pensioen verleend 'ten laste van den Staat' (artikel 43 PW 1846). Recht op pensioen bestond wanneer de ambtenaar vijfenzestig jaar was én veertig dienstjaren had vervuld (artikel 3 aanhef en onder a PW 1846) of wanneer hij in de uitoefening van zijn functie 'wonden of gebreken (had) bekomen, die (hem) volstrekt ongeschikt (maakte) den Staat langer te dienen' (artikel 3 aanhef en onder b PW 1846). ${ }^{85}$ Ook kon een ambtenaar pensioen worden verleend als hij na een (minimaal) tienjarige diensttijd 'uit hoofde van ziels- of ligchaamsgebreken voor de waarneming van (zijn) ambt ongeschikt' werd (artikel 5 PW 1846).

De Pensioenwet kende wel bepalingen met betrekking tot het vervallen van pensioenen ${ }^{86}$ maar niet met betrekking tot terugvordering van ten onrechte betaalde pensioenen. Volgens het Rapport van de Subcommissie-Jansen voor de beschrijving van de burgerlijke pensioenwetgeving was herziening van beslissingen mogelijk als 'het met de toepassing der wet belast gezag daartoe termen aan-

82. Zie het Rapport Subcommissie-Jansen (1953), blz. 7. Deze commissie was een subcommissie van de Staatscommissie voor de pensioenwetgeving, ingesteld bij KB van 22. juni 1949, Stb. 12, de Staatscommissie-Van Poelje.

83. Wet van 9 mei 1846 , betreffende de burgerlijke pensioenen, Sth. 24.

84. Rapport Subcommissie-Jansen (1953), blz. 65.

85. Artikel 4 kende de weduwen en minderjarige wezen van ambtenaren, die op de wijze als in artikel 3 onder b omschreven waren omgekomen, een pensioen toe.

86. Voornamelijk de artikelen 25-28. Zie over het vervallen van het pensioen ook het Rapport Subcommissie-Jansen (1953), blz. 77-78. 
wezig achtte'. ${ }^{87}$ De Boer leidt hieruit af dat ook terugvordering mogelijk was indien dat gezag 'daartoe termen zag' ${ }^{88}$ Niet duidelijk is of bij deze terugvordering de administratieve weg werd gevolgd ${ }^{99}$ dan wel of artikel $1395 \mathrm{BW}$ (oud) werd gebruikt.

Ook latere wijzigingen in de Pensioenwet 1846 kenden geen voorschriften met betrekking tot herziening of terugvordering. Dit gold ook voor de Pensioenwet 1890, die de Pensioenwet 1846 verving. ${ }^{90}$ Pas in 1913 verschenen in deze wet de eerste bepalingen met betrekking tot herziening, maar deze zagen enkel op herziening ten voordele van de gepensioneerde..$^{11}$ Overigens waren zulke bepalingen al eerder te vinden in specifieke wetten, zoals de Weduwenwet voor de onderwijzers uit 1905. Herziening ten nadele van de betrokkene, hoewel dus niet in de wettelijke regeling opgenomen, was desondanks mogelijk, zo bleek uit een in datzelfde jaar geslagen koninklijk besluit. ${ }^{92}$

Aan weduwe Ridderhof was op grond van de genoemde Weduwenwet voor de onderwijzers 1905 met ingang van 3 augustus 1910 een pensioen toegekend, aangezien er van werd uitgegaan dat de jaarwedde van haar overleden echtgenoot was uitbetaald tot en met 2 augustus van dat jaar. Later bleek dit niet te kloppen; de wedde was uitbetaald tot en met 2 november. De Pensioenraad gaf de Kroon dan ook in overweging het koninklijk besluit waarbij het pensioen was toegekend in die zin te wijzigen, dat het pensioen eerst zou ingaan op 3 november, 'met bepaling, dat het uit dien hoofde te veel genotene door haar worde teruggegeven'. Ridderhof 'gaf het verlangen te kennen' dat over het advies van de Pensioenraad 'het gevoelen van de Raad van State mocht worden ingewonnen'. Zij erkende 'met dankbaarheid' dat zij in november een bedrag uitgekeerd had gekregen, maar zij was ervan uitgegaan dat dit een tegemoetkoming was geweest in de kosten, die waren veroorzaakt door de ziekte en het overlijden van haar echtgenoot, en dus niet een uitbetaling van de bezoldiging. Bovendien zou het haar 'hoogst bezwaarlijk vallen' als zij dit bedrag moest terugbetalen.

De Afdeling Geschillen van Bestuur van de Raad van State adviseerde de Kroon dat haar besluit diende te luiden, dat het besluit tot toekenning van het pensioen geen wijziging kon ondergaan ten nadele van de belanghebbende. Als reden gaf de Afdeling dat de betrokken wet geen bepaling bevatte op grond

87. Rapport Subcommissie-Jansen (1953), blz. 79.

88. De Boer (1981), blz. 249. Deze conclusie lijkt niet te worden gestaafd door jurisprudentic uit de negentiende eeuw; De Boer zelî geeft als voorbeeld een KB uit 1913, namelijk KB 16 juni 1913, Stb. 277, Stert. 158. Desondanks komt het aannemelijk voor dat terugvordering mogelijk was.

89. Het door De Boer genoemde KB vit 1913 zou daarop kunnen wijzen.

90. Wet van 9 mei 1890, tol regeling van de pensioenen der burgerlijke ambtenaren, Stb. 78.

91. Wet van 21 juni 1913, tot wijziging en aanvulling van de Burgerlijke Pensioenwet, Stb. 304. Zie het Rapport Subcommissie-Jansen (1953), blz. 284-285.

92. Besluit van 16 juni 1913 tot wijziging van het besluit van 7 December $1910 \mathrm{n}^{\circ} .58$, tot toekenning van pensioen aan L.L.H. Ridderhof, weduwe van J.F.L. Rietdijk, laatstelijk onderwijzer aan eene openbare lagere school te Leiden, Stb. 277, Stert. 158. 
waarvan het toegekende pensioen ten nadele van de belanghebbende kon worden gewijzigd. ${ }^{93}$ Dit advies werd niet gevolgd door de Kroon. Uitgangspunt diende te zijn dat herziening plaats diende te vinden wanneer het pensioen 'in strijd met de wet is geregeld', waarbij het onverschillig was of die herziening in het voor- of in het nadeel van de betrokkene werkte. Het besluit luidde dan ook, dat de datum van ingang van het pensioen werd gewijzigd 'met bepaling dat het te veel genotene door de gepensioneerde zal worden teruggegeven'.

Dit besluit lijkt er op te wijzen, dat indien te veel pensioen werd uitgekeerd, terugvordering hiervan via de publiekrechtelijke weg verliep, ondanks het feit dat de publiekrechtelijke regeling hieromtrent geen regels bevatte. Er werd immers geen vordering uit onverschuldigde betaling ingesteld bij de burgerlijke rechter, maar er werd door de Pensioenraad aan de Kroon gevraagd de toekenningsbeslissing met terugwerkende kracht te herzien, zodat kwam vast te staan dat een deel van het pensioen ten onrechte was betaald en dus moest worden terugbetaald.

\subsubsection{De Pensioenwet 1922}

Het genoemde koninklijk besluit volgde dus met betrekking tot de terugvordering niet de lijn, die in die tijd (1913) in de socialezekerheidswetten werd aangehouden. ${ }^{94}$ Dat deden wel de Pensioenwetten die in 1922 in het Staatsblad verschenen, althans - wat de Pensioenwet 1922 betreft - in grote lijnen. Zo kenden de Pensioenwet voor de zeemacht ${ }^{95}$ (hierna: PWZ) en de Pensioenwet voor de landmach $t^{96}$ (hiema: PWL) een gelijkluidend artikel (respectievelijk artikel 56 en artikel 58), dat terugvordering uitsloot indien het toekenningsbesluit werd herzien. Ook de Pensioenwet $1922^{97}$ (hierna: PW 1922) bevatte een aantal bepalingen met betrekking tot terugvordering. In de elfde titel, 'Van beroep', was artikel 128 opgenomen, waarvan lid 3 bepaalde dat als in beroep het recht op pensioen werd ontzegd of tot een lager bedrag werd vastgesteld, het reeds betaalde of te veel betalde niet kon worden teruggevorderd. De twaalfde titel, 'Van herziening van genomen beslissingen', bevatte bepalingen met betrekking tot herziening en de gevolgen daarvan. Vooral de artikelen 130 en 132 zijn van belang. Volgens artikel 130 lid 1 kon een beslissing van de Pensioenraad alleen in het nadeel van de betrokkene worden herzien 'op grond van gebleken onjuistheid van aan de beslissing ten grondslag gelegde feiten'. Artikel 132 bepaalde vervolgens dat reeds uitbetaalde pensioenen in dat geval niet mochten worden teruggevorderd, 'tenzij in de herzieningsbeslissing is uitgesproken dat de gebleken onjuistheid van aan de beslissing ten grondslag gelegde feiten was te wijten aan het opzet van den betrokkene zelven'. Was de onjuistheid van de feiten, waarop de beslissing was

93. Het advies van de Raad van State is opgenomen in Stert. 1913, 158.

94. Zie 6.3.2.

95. Wet van 17 februari 1922, tot regeling van de militaire pensioenen bij de zeemacht, Stb. 65 .

96. Wet van 17 februari 1922, tot regeling van de militaire pensioenen bij de Landmacht, Stb. 66.

97. Wet van 5 mei 1922, houdende pensioenregeling voor de ambtenaren en hunne weduwen en weezen, Stb. 240. 
gebaseerd, te wijten aan opzet van de betrokkene, had deze dus bijvoorbeeld opzettelijk foute mededelingen gedaan of opzettelijk feiten verzwegen, en was dit in de herzieningsbeslissing vermeld, dan kon het te veel betaalde worden teruggevorderd. $^{98}$ Later zien we een soortgelijk criterium terugkomen in vrijwel alle socialezekerheidswetten, namelijk terugvordering is onder meer mogelijk als te veel is betaald door toedoen van de betrokkene. ${ }^{99}$ Opvallend is dat de memorie van toelichting zwijgt over dit artikel.

Het is duidelijk dat als de overheid wilde overgaan tot terugvordering van te veel of ten onrechte betaalde pensioenen, de publiekrechtelijke weg diende te worden gevolgd. Het was niet geheel duidelijk of terugvordering geheel was uitgesloten als deze publiekrechtelijke weg geen uitkomst bood, bijvoorbeeld omdat niet aan de in de Pensioenwet 1922 gestelde vereisten was voldaan of omdat de betreffende pensioenwet terugvordering geheel uitsloot, zoals bij de pensioenwetten voor respectievelijk de land- en de zeemacht. Er leek geen ruimte voor de overheid om naar de burgerlijke rechter te gaan en een vordering uit onverschuldigde betaling ex artikel $1395 \mathrm{BW}$ (oud) in te stellen. Nu echter ook in de pensioenwetten de Centrale Raad van Beroep werd aangewezen als beroepsinstantie, ${ }^{100}$ is het niet onwaarschijnlijk dat deze rechter in bepaalde gevallen terugvordering mogelijk achtte op grond van het algemene rechtsbeginsel dat hetgeen onverschuldigd wordt betaald, kan worden teruggevorderd, welk beginsel de Centrale Raad sedert eind 1952 in ambtenarenzaken hanteerde. ${ }^{101}$ Aan de andere kant lijkt de tekst van de bepalingen duidelijk: een beslissing kan alleen in het nadeel van de betrokkene worden herzien op grond van gebleken onjuistheid van de aan de beslissing ten grondslag liggende feiten (artikel 130 lid 1 PW 1922). Zonder herziening is nu eenmaal (in de meeste gevallen) geen sprake van onverschuldigde betaling. Het is de vraag of de rechter, in dit geval de Centrale Raad van Beroep, op dit punt ook zo redeneerde, of dat de (uit de ambtenarenrechtspraak bekende) redenering werd gevolgd, dat kon worden teruggevorderd op grond van het zojuist beschreven beginsel indien de betrokkene het feit dat te veel werd betaald, wist of redelijkerwijs had kunnen of behoren te weten.

Nadat in 1933 de Ambtenarenwet 1929 in werking was getreden, was het mogelijk geweest de in deze wet neergelegde rechtsgang ook in pensioenaangelegenheden te volgen - de pensioenwetten betroffen immers de pensioenen van ambtenaren -, zodat in eerste aanleg het Ambtenarengerecht diende te worden geadieerd.

98. In 1935 werden ook de bepalingen in de PWL en PWZ in gelijke zin gewijzigd, zie de Wetten van 31 december 1935, Stb. 825 (PWZ) en Stb. 826 (PWL).

99. Zie 6.4.4. Hierbij was echter vaak niet vereist, dat sprake was van opzet:

100. Artikel 125 PW 1922, artikel 52 PWZ en artikel 54 PWL. De bepalingen van de Beroepswet werden van toepassing verklaard, tenzij de aard van het onderwerp anders vorderde of in een AMvB ervan werd afgeweken, artikel 129 PW 1922, artikel 54 PWZ en artikel 56 PWL. Beroep bij de CRvB kon worden ingesteld tegen besluiten van de Pensioenraad (op grond van de PW 1922) of de Kroon (op grond van de PWZ of PWL).

101. Zie 7.2.3.3. 
Dit gebeurde niet. Artikel 3 lid 1 Aw 1929 stelde expliciet dat 'onverminderd de wettelijke regelen omtrent de rechtspraak, in pensioenzaken bestaande', de Ambtenarengerechten en de Centrale Raad van Beroep bij uitsluiting oordeelden over besluiten, handelingen en weigeringen om te besluiten of te handelen, genomen ten aanzien van ambtenaren. Volgens de memorie van toefichting was in de Pensioenwetten de rechtsgang reeds geregeld, waarbij vaak beroep openstond bij de Centrale Raad. Dit betekende dat de nieuwe ambtenarenrechter niet competent werd kennis te nemen van pensioenzaken. 'De rechtsmacht van den specialen pensioenrechter sluit die van den algemeenen ambtenarenrechter uit'. Wel werd aangegeven dat de rechtsmacht van de pensioenrechter niet verder reikte 'dan tot en met de vaststelling van de aanspraak op pensioen'. Ging het bijvoorbeeld om de weigering een onherroepelijk vastgesteld pensioen uit te betalen, dan werd de ambtenarenrechter weer wel bevoegd geacht. ${ }^{102}$

\subsubsection{De Algemene burgerlijke pensioenwet uit 1966}

\subsubsection{Inleiding}

In 1966 werd de Pensioenwet 1922 vervangen door de Algemene burgerlijke pensioenwet (hierna: ABPW). ${ }^{103}$ In deze paragraaf zal ik de ontwikkelingen met betrekking tot terugvordering van pensioenen vanaf dat moment beschrijven. Met de inwerkingtreding van de $\mathrm{ABPW}$ verviel ook de uitsluiting van de competentie van de ambtenarenrechter in pensioenzaken, zoals neergelegd in artikel 3 lid 1 Aw. De ambtenarenrechter werd nu dus competent op (een belangrijk deel van) dit terrein, en wel exclusief, hetgeen ook gevolgen had voor de competentie van de burgerlijke rechter, en dus voor het gebruik van artikel $1395 \mathrm{BW}$ (oud).

In 7.3.4.2 zal ik de ontwikkeling van de terugvorderingsbepalingen in de pensioenwetten beschrijven vanaf 1966, het jaar dat de ABPW in werking trad. Deze wet is overigens in 1996 vervallen, in dat jaar vond de privatisering van deze wet plaats door de Wet privatisering ABP. Naast de ABPW zal worden stilgestaan bij een aantal militaire pensioenwetten en bij een aantal bijzondere pensioenwetten, zoals de Wet buitengewoon pensioen 1940-1945. De vraag of artikel $1395 \mathrm{BW}$ (oud) of de burgerlijke rechter nog een rol kon spelen bij de terugvordering van deze pensioenen komt in 7.3.4.3 aan de orde.

102. Tweede Kamer 1927-1928, 392, nr. 3, blz 17. Om deze laatste reden was de ambtenarenrechter bevoegd te oordelen in de in 7.2.3.3 besproken zaak van mejuffrouw C., CRvB 25 maart 1952 , AB 1952, 698. In dat geval had immers ten onrechte geen, pensioenverhaal op haar salaris plaatsgevonden, zodat zij te veel salaris uitgekeerd had gekregen. Het betrof dus niet de vaststelling van de aanspraak op pensioen, maar de inhouding van pensioenpremies op het loon.

103. Wet van 6 januari 1966, houdende nieuwe regeling van de pensioenen van de burgerlijke ambtenaren en van hun nabestaanden (Algemene burgerlijke pensioenwet), Stb. 6. 


\subsubsection{Wettelijke terugvorderingsbepalingen}

Op 1 januari 1966 trad de ABPW in werking. Ondanks het feit dat het uiterlijk van deze wet het karakter van een geheel nieuwe regeling droeg, ging het volgens de memorie van toelichting om een herziening van het op dat moment geldende recht, waarbij werd voortgebouwd op de bestaande grondslagen. ${ }^{104}$ De terugvorderingsbepalingen gaven dan ook geen wezenlijke veranderingen te zien. Artikel S 3 gaf zowel de directie als de Raad van toezicht van het nieuwe Algemeen burgerlijk pensioenfonds (hiema: $\mathrm{ABP}$ ) de bevoegdheid een genomen beslissing te herzien of te wijzigen, als aan de in dat artikel gestelde voorwaarden was voldaan. Herziening was mogelijk als aan de beslissing feitelijke onjuistheden ten grondslag lagen, wijziging kon plaatsvinden als de feiten die aan de oorspronkelijke beslissing ten grondslag lagen naderhand waren gewijzigd. ${ }^{105}$ Herziening had terugwerkende kracht tot het moment dat de feiten die tot de herziening leidden, zich hadden voorgedaan, tenzij een andere dag werd bepaald, wijziging kon terugwerkende kracht hebben tot het moment dat de wijziging van de feiten zich voordeed (artikel S 4 lid 1). Artikel S 4 lid 2 bepaalde vervolgens dat een herzieningsbeslissing niet tot terugvordering of verrekening van reeds betaalde bedragen leidde, tenzij in die beslissing was uitgesproken dat de feitelijke onjuistheid die aan de oorspronkelijke beslissing ten grondslag lag, was te wijten aan betrokkene. Een wijzigingsbeslissing leidde slechts tot terugvordering of verrekening als de betrokkene had nagelaten mededeling te doen van een wijziging van de feiten, hoewel hij daartoe verplicht was op grond van de wet $^{106}$ of het doen van een dergelijke mededeling redelijkerwijs van hem mocht worden verwacht (artikel S 4 lid 3).

De ABPW wijzigde ook artikel 3 lid 1 Aw 1929. Uit dit artikel werd de zinsnede, die de beslissing in pensioenzaken uitsloot van de competentie van de ambtenarenrechter, verwijderd (artikel W 2). Hierdoor vielen vanaf dit moment ook besluiten, handelingen en weigeringen met betrekking tot pensioenaangelegenheden onder de competentie van deze rechter, en moest de betrokkene in voorkomend geval dus in beroep bij het Ambtenarengerecht, met hoger beroep bij de Centrale Raad van Beroep. Het Ambtenarengerecht 's-Gravenhage was op grond van artikel S 2 lid 2 exclusief bevoegd.

In 1974 werden de relevante herzienings-, wijzigings- en terugvorderingsbepalingen in de ABPW gewijzigd. ${ }^{107} \mathrm{Zo}$ bepaalden de eerste drie leden van artikel S 3 dat de directie dan wel de Raad van toezicht de beslissing herzag dan wel wijzigde, terwijl voorheen werd bepaald dat de directie dan wel de Raad van toezicht bevoegd was de beslissing te herzien dan wel te wijzigen. Kennelijk werd de discretionaire bevoegdheid gewijzigd in een verplichting. Voorts introduceerden de leden 4 en 5 de mogelijkheid van herstel van een eerdere beslissing als

104. Tweede Kamer 1964-1965, 7980, nr. 4, blz. 1.

105. Memorie van toelichting, Tweede Kamer 1964-1965, 7980, nr. 4, blz. 36.

106. Bijvoorbeeld op grond van artikel J 7 ABPW.

107. Wet van 29 mei 1974 tot wijziging van de Algemene burgerlijke pensioenwet en andere overheidspensioenwetten, Stb. 330. 
daarin een onjuistheid voorkwam, die niet reeds tot herziening of wijziging kon leiden. Gedacht kon hierbij worden aan problemen met de toentertijd plaatsvindende automatisering. Ook in dit geval was de wetstekst imperatief gesteld: de directie respectievelijk de Raad van toezicht herstelt de genomen beslissing. Daarnaast werd een nieuw zevende lid ingevoegd, dat bepaalde dat de directie of de Raad van toezicht af mocht zien van herziening, wijziging of herstel indien vijf jaren waren verstreken na de dagtekening van de voor herziening, wijziging of herstel vatbare beslissing. Voorts werd artikel S 4 lid 2 gewijzigd. Het bepaalde nu dat een herzieningsbeslissing niet tot terugvordering of verrekening leidde, tenzij de betrokkene redelijkerwijs had moeten begrijpen dat hem te veel werd uitbetaald. Daarnaast konden bij een herstel van feitelijke onjuistheden of verwerking van wijzigingen te veel betaalde bedragen worden teruggevorderd of verrekend, indien de herzienings- of wijzigingsbeslissing was genomen binnen vier maanden ofwel na de dagtekening van de oorspronkelijke beslissing (in geval van herziening), ofwel nadat de directie bericht had ontvangen van de wijziging in de feiten (bij wijziging). Hierbij speelde het redelijkerwijs weten of redelijkerwijs mogen verwachten geen rol (artikel S 4 lid 4). Werd een beslissing hersteld, dan konden de te veel betaalde bedragen worden teruggevorderd of verrekend indien het herstel plaatsvond binnen vier maanden na de dagtekening van de oorspronkelijke beslissing. Was deze termijn verstreken, dan was terugvordering of verrekening slechts mogelijk als de betrokkene redelijkerwijs had moeten begrijpen dat hem te veel werd uitbetaald (artikel S 4 lid 5).

Als regel gold dus nu dat geen terugvordering plaatsvond, tenzij de betrokkene redelijkerwijs had kunnen begrijpen dat hem te veel werd uitbetaald, als hij zijn inlichtingenverplichting schond of als het bestuursorgaan binnen korte tijd, namelijk vier maanden, reageerde op een gebleken feitelijke onjuistheid, wijziging of andere omstandigheid die tot herstel kon leiden. Daarnaast had het bestuursorgaan de bevoegdheid van herziening, wijziging of herstel - en dus van terugvordering of verrekening - af te zien als vijf jaren waren verstreken na de dagtekening van de oorspronkelijke beslissing. Deze regels - zij het dat zij een aantal malen tekstueel zijn gewijzigd en zijn hernummerd tot resp. artikel S 4 en S 5 - hebben gegolden tot het moment dat de ABPW op 1 januari 1996 werd ingetrokken ten gevolge van de privatisering van het $\mathrm{ABP} .{ }^{108}$

De ABPW gaf een pensioenregeling voor de burgerlijke ambtenaren en hun nabestaanden. Daarnaast bestonden ook pensioenwetten voor andere personen in overheidsdienst, zoals (gewezen) militairen, en voor mensen die zich in bijzondere situaties hadden ingespannen voor Nederland, zoals verzetsstrijders tijdens de Tweede Wereldoorlog. In 7.3.3 is al gewezen op de pensioenwetten voor de landen zeemacht uit 1922. In 1966 trad de Algemene militaire pensioenwet ${ }^{109}$ (hier-

109. Wet van 6 oktober 1966, houdende nieuwe regeling van de pensioenen van de militairen en van hun nabestaanden (Algemene militaire pensioenwet), Stb. 445. 
na: $A M P W$ ) in werking. De bedoeling was voor alle categorieën militairen één wet te maken krachtens welke zij zouden worden gepensioneerd. ${ }^{110} \mathrm{Bij}$ het ontwerpen van deze wet is zo veel mogelijk aangesloten bij (het ontwerp van) de ABPW. Ook de AMPW bouwde voort op de grondslagen van de bestaande pensioenwetten en was volgens de wetgever niet meer dan een ingrijpende herziening van het geldeñde militaire pensioenrecht. ${ }^{\prime \prime}$ De afzonderlijke militaire pensioenwetten bleven weliswaar bestaan, maar in deze wetten werden slechts die bepalingen gehandhaafd, die specifiek op de door die wet getroffen doelgroep zagen. De regels, die al die wetten gemeenschappelijk hadden, werden verwijderd uit de specifieke wetten en opgenomen in de AMPW. Zo vervielen de artikelen 55 PWL en PWZ, welke artikelen inmiddels de herziening en terugvordering regelden. ${ }^{112}$ De AMPW kende geen bepaling met betrekking tot terugvordering, wel waren artikelen opgenomen met betrekking tot herziening. Artikel W 4 bepaalde dat de Kroon, de minister van Defensie, de directie van het ABP of de Raad van toezicht daarvan bevoegd waren een door hen genomen beslissing te herzien. Herziening in het nadeel van de betrokkene kon echter alleen plaatshebben, als aan die beslissing een feitelijke onjuistheid ten grondslag lag. Deze bepaling werd vervoigens herhaaide maien gewijzigd. Momenteel is zij vrijweí gelijk aan artikel S 4 ABPW, zoals dat luidde op het moment dat deze werd ingetrokken. De wet kent dus de mogelijkheid de beslissing te herzien, te wijzigen of te herstellen. Herziening et cetera. vindt plaats door de minister van Defensie. In voorkomend geval is herziening et cetera. imperatief voorgeschreven, zij het dat de minister van herziening et cetera. kan afzien indien vijf jaren zijn verstreken na de dagtekening van de voor herziening et cetera. vatbare beslissing. Over de mogelijkheid van terugvordering zijn nog steeds geen regels opgenomen. Beroep tegen een beslissing op grond van de AMPW was mogelijk bij de ambtenarenrechter (artikelen W 1 en W 3). Nu is op grond van artikel W 3 de bestuurskamer van de Rechtbank 's=-Gravenhage exclusief bevoegd.

De Wet buitengewoon pensioen 1940-1945 (hierna: WBP) $)^{113}$ voorziet in een recht op buitengewoon pensioen voor deelnemers aan het verzet tijdens de Tweede Wereldoorlog. Het recht op een dergelijk pensioen bestaat kort gezegd als de betrokkene in verband met het verzet gewond of verminkt is geraakt of als hij ziekten of gebreken ondervindt als gevolg van zijn werk voor het verzet. Dit laatste kan zich ook geruime tijd na de oorlog openbaren. Tevens bestaat onder bepaalde omstandigheden recht op het buitengewoon pensioen voor de weduwe of

110. Memorie van toelichting, Tweede Kamer 1964-1965, 8199, $\mathrm{nr}, 4$, blz. 1.

111. Memorie van toelichting, Tweede Kamer 1964-1965, 8199, nr. 4, blz. 1.

112. Artikel 58 PWL en artikel $56 \mathrm{PWZ}$ waren bij Besluit van 30 december 1950, Stb. 672 hernummerd tot artikel 55 PWL respectievelijk PWZ. De artikelen 55 van deze,wetten vervielen door de inwerkingtreding van artikel $\mathrm{Z} 2$ aanhef en onder G AMPW.

113. Wet van 22 augustus 1947 tot invoering van een buitengewoon pensioen voor deelnemers aan het verzet, alsmede voor hun nagelaten betrekkingen (Wet buitengewoon pensioen 1940-1945), Stb. H 313 . 
de kinderen van de deelnemer aan het verzet. Uitvoeringsorgaan was de Buitengewone Pensioenraad. Artikel 42 lid 1 WBP bepaalde dat een beslissing van deze raad door hem kon worden herzien in het nadeel van de betrokkene, maar alleen op grond van gebleken onjuistheid van aan de oorspronkelijke beslissing ten grondslag gelegde feiten. Was de beslissing met terugwerkende kracht herzien in het nadeel van betrokkene, dan leidde dat niet tot terugvordering van hetgeen volgens de oorspronkelijke beslissing was uitbetaald, tenzij in de herzieningsbeslissing was uitgesproken dat de gebleken onjuistheid van de aan die oorspronkelijke beslissing ten grondslag gelegde feiten te wijten was aan de opzet van betrokkene (artikel 42 lid 4). Een soortgelijke regeling gaf artikel 34 van de Wet buitengewoon pensioen zeelieden-oorlogsslachtoffers (hierna: WBPZ). ${ }^{114}$ Met betrekking tot beroep regelde de WBP dat beroep tegen een beslissing op bezwaarschrift van de Buitengewone Pensioenraad kon worden ingesteld bij de Centrale Raad van Beroep (artikel 38). Op het beroep waren de bepalingen van de Beroepswet van toepassing (artikel 40). De WBPZ kende oorspronkelijk geen bepalingen met betrekking tot beroep. In 1956 werd beroep op grond van deze wet mogelijk bij de Centrale Raad van Beroep. ${ }^{115}$ Overigens moet worden bedacht dat de Centrale Raad in deze wetten niet optrad als ambtenarenrechter; de deelnemers aan het verzet of de zeelieden-oorlogsslachtoffers waren als zodanig geen ambtenaren. Ook deze wetten en de herzienings- en terugvorderingsbepalingen erin werden enige malen gewijzigd. Nu kan herziening in het nadeel van betrokkene plaatsvinden op grond van gebleken onjuistheid van de aan de beslissing ten grondslag gelegde feiten, dan wel op grond van gegevens die niet bekend waren ten tijde van het geven van die beslissing en die, waren zij wel bekend geweest, tot een andere beslissing hadden geleid (artikel 42 lid 1 WBP en artikel $35 \mathrm{e}$ WBPZ). Terugvordering vindt niet plaats, tenzij in de herzieningsbeslissing is uitgesproken dat de onjuistheid van de aan de oorspronkelijke beslissing ien grondslag gelegde feiten te wijten was aan de opzet of grove nalatigheid van de betrokkene (resp. artikel 42 lid 2 en artikel 35 e lid 2).

\subsubsection{Gebruik van artikel 1395 BW (oud) en de bevoegdheid van de burgerlijke rechter}

$\mathrm{Nu}$ in verscheidene pensioenwetten regels waren neergelegd met betrekking tot terugvordering, deed zich ook hier de vraag voor of deze regels konden worden omzeild met behulp van de privaatrechtelijke regeling van onverschuldigde betaling. Ook de vraag of deze laatste regeling een oplossing bood in gevallen, waarin in de pensioenwetten niet was voorzien, komt aan de orde. De belangrijkste jurisprudentie op dit terrein is afkomstig van de bestuursrechter, meestal de Centrale

114. Wet van 11 december 1947 tot invoering van een buitengewoon pensioen voor zeelieden-oorlogsslachtoffers, alsmede voor hun nagelaten betrekkingen, Stb. H 420 . Een verschil met de WBP was dat in de WBPZ een herzieningsgrond was het feit dat de toestand welke de maatstaf vormde bij het nemen van de beslissing een verandering had ondergaan, artikel 34 lid 1 .

115. Artikel 34 WBPZ, zoals gewijzigd bij wet van 24 mei 1956, Stb. 354 . 
Raad van Beroep. Dit is niet verwonderlijk, aangezien deze rechter - behoudens in gevallen waarin de wetten met betrekking tot de buitengewone pensioenen aan de orde waren - optrad als ambtenarenrechter. In dat geval waren het Ambtenarengerecht en de Centrale Raad van Beroep tot voor kort exclusief bevoegd, terwijl de burgerlijke rechter tegenwoordig - na het Changoe-arrest van de Hoge Raad eiser niet-ontvankelijk verklaart in zijn vordering. Dit had uiteraard ook gevolgen voor de directe toepassing van artikel $1395 \mathrm{BW}$ (oud).

De ABPW bevatte pas sinds 1974 een regeling met betrekking tot herstel van administratieve vergissingen, zie 7.3.4.2. Voor die tijd bevatte de ABPW dus een leemte op dat terrein. In 1972 diende de Centrale Raad van Beroep te beslissen over een geval, waarin een administratieve vergissing had plaatsgevonden en waarbij de Raad van toezicht van het $A B P$ wilde overgaan tot terugvordering van het te veel betaalde. De Raad van toezicht beriep zich hierbij in zijn beslissing op het bezwaarschrift op het algemene rechtsbeginsel dat hetgeen onverschuldigd is betaald, kan worden teruggevorderd: op grond van artikel 1395 BW (oud) kan hetgeen onverschuldigd is betaald worden teruggevorderd; hetgeen in deze bepaling is neergelegd, geeft een ook in het bestuursrecht geldend algemeen rechtsbeginsel weer, dat van geiijke waarcie is ais het rechtszekerheidsoeginsel. In het voorliggende geval was de Raad van toezicht van mening dat voorrang diende te worden gegeven aan het eerste beginsel. De Centrale Raad van Beroep was het hier uiteindelijk niet mee cens. Hij stelde voorop dat het feit dat de ABPW geen regeling kende met betrekking tot herstel van een administratieve fout, niet wilde zeggen dat de wetgever de directie van het pensioenfonds de bevoegdheid had willen ontzeggen binnen redelijke termijn over te gaan tot herstel van de vergissing, zelfs als de betrokkene die vergissing had onderkend of redelijkerwijs had kunnen onderkennen. In geding was dan nog de vraag of dit herstel in het nadeel van betrokkene kon plaatsvinden met terugwerkende kracht. De Raad was van oordeel dat de betrokkene de vergissing redelijkerwijs had behoren te onderkennen. Aan de andere kant had het erg lang geduurd eer de directie van het ABP de vergissing had opgemerkt, namelijk tweeënhalf jaar. Kennelijk vond onvoldoende controle op de uitbetalingen plaats, waardoor de directie een zeer groot risico had genomen, aldus de Raad. De kennis en houding van beide partijen afwegende en in aanmerking nemende de beide genoemde algemene rechtsbeginselen, kwam de Raad tot de conclusie, dat de directie in de gegeven omstandigheden niet bevoegd was aan haar besluit terugwerkende kracht te verlenen. ${ }^{116}$ Ondanks het feit dat de regeling van herziening en terugvordering in de ABPW niet van toepassing was, achtte de Centrale Raad van Beroep terugvordering dus in principe wel mogelijk, en wel op grond van het algemene rechtsbeginsel dat hetgeen onverschuldigd is betaald, kan worden teruggevorderd. ${ }^{117}$ Verbazing hoeft dit niet te wekken; het was immers de Centrale Raad als ambtenarenrechter die oordeelde en 
die hier dus zijn in 1952 ontwikkelde rechtspraak toepaste. ${ }^{118}$

Een ander geval speelde zich af in 1978, toen de directie van het ABP poogde na het overlijden van de rechthebbende doorgeschoten pensioenen terug te vorderen van de erven. Deze terugvordering werd gebaseerd op 'het beginsel neergelegd in art. $1395 \mathrm{BW}$ '. De ABPW kende voor deze gevallen een regeling, artikel Q 7, waarin stond dat doorgeschoten uitkeringen konden worden teruggevorderd voor zover verrekening kon plaatsvinden van het te veel betaalde met een weduwen- of weduwnaarsuitkering. Na het overlijden van de gepensioneerde ambtenaar had diens weduwe of weduwnaar namelijk recht op een uitkering ten bedrage van het pensioen van de ambtenaar over twee maanden. De Centrale Raad van Beroep overwoog:

'Binnen het raam van de uitvoering van de Wet kunnen de organen van het ABPF dan ook niet aan het rechtsbeginsel van art. $1395 \mathrm{BW}$ - zoals dit beginsel in het administratieve recht een plaats heeft gekregen - de bevoegdheid ontlenen om in een geval als het onderhavige, waarin art. Q 7 eerste lid Wet ter zake geen basis biedt, tot terugvordering van hetgeen te veel aan pensioen is betaald, te besluiten". 119

Weliswaar bood artikel Q 7 in dit soort gevallen niet altijd de mogelijkheid het te veel betaalde terug te vorderen, maar dit was voor de Raad geen aanleiding 'om tegen de duidelijke woorden van art. Q 7 eerste lid Wet in in alle gevallen terugvordering toelaatbaar te achten'. Deze regeling, die in dit concrete geval niet tot terugvordering kon leiden, mocht niet worden omzeild via het gebruik maken van het algemene rechtsbeginsel.

De ABPW kende voorts een regeling met betrekking tot het verstrekken van voorschotten. De vraag was of, indien een voorschot was verstrekt, dit kon worden teruggevorderd. De Centrale Raad van Beroep stelde vast dat indien geen definitieve toekenning volgde, de wet geen bepalingen bevatte op grond waarvan de toekenning van de voorschotten kon worden herzien. Toch kon onder omstandigheden worden teruggevorderd, en wel op grond van het aan artikel $1395 \mathrm{BW}$ (oud) ontleende, ook in het bestuursrecht geldende inmiddels bekende algemene rechtsbeginsel. ${ }^{120}$ Uiteraard diende de toepassing van dit rechtsbeginsel te worden afgewogen tegen het vertrouwensbeginsel. ${ }^{121}$

In 7.3.4.2 is gebleken dat de AMPW geen regeling kende met betrekking tot terugvordering. Het ligt op grond van de hiervoor besproken jurisprudentie voor de hand, dat de Centrale Raad van Beroep hierin geen beletsel zag voor de uitkerende instantie om over te gaan tot terugvordering. Wel diende in voorkomend geval eerst de toekenningsbeslissing met terugwerkende kracht te zijn herzien; zie hierover ook de reeds hiervoor aangehaalde jurisprudentie inzake de ABPW. Was dit gebeurd, dan stond het bestuursorgaan het algemeen rechtsbeginsel ten dienste, 
dat hetgeen onverschuldigd is betaald, kan worden teruggevorderd. ${ }^{122}$ Uiteraard mocht het bestuursorgaan, in dit geval de minister van Defensie, niet in strijd geraken met enig algemeen beginsel van behoorlijk bestuur. De Raad gaf vervolgens enige aanwijzingen, waarbij hij allereerst wees op het feit dat de wetgever in. andere wetten beperkingen met betrekking tot terugvordering had neergelegd. De Raad noemde onder meer de $A O W$ en de $\mathrm{ABPW}^{123}$ en gaf aan dat de mogelijkheid om terug te vorderen in die wetten met het verstrijken van de tijd 'onderhevig geraakt aan strenger wordende criteria'. Zolang de AMPW geen regeling met betrekking tot terugvordering kende, moest de minister 'zich bij het vinden van. vorenbedoelde contouren kunnen spiegelen aan wetsbepalingen elders als de zoëvenbedoelde'. Nu hij - overeenkomstig uitspraken van het Ambtenarengerecht 's-Gravenhage - standaard een maximale terugvorderingstermijn van vijf jaar had gehanteerd, zonder de omstandigheden van het geval in aanmerking te nemen, had hij de vereiste zorgvuldigheid niet in acht genomen.

Ondanks het feit dat de Raad zich hier niet over uitliet, mag uit zijn jurisprudentie worden geconcludeerd dat de terugvorderingstermijn een uitvloeisel is van het rechtszekerheidsbeginsel. ${ }^{124}$ Tevens mag uit de laatste uitspraak de conclusie worden getrokken dat de Centrale Raad wilde aansluiten bij de terugvorderingstermijnen, zoals die tot voor kort waren neergelegd in de meeste socialezekerheidswetten. De Raad gaf weliswaar geen precieze termijnen, ${ }^{125}$ maar toch kan dit tussen de regels worden gelezen: de minister van Defensie kon zich immers spiegelen aan wetsbepalingen als in bijvoorbeeld de AOW. Ook gold dat hoe emstiger het verwijt, hoe langer de terugvorderingstermijn. Dit was ook het uitgangspunt in de socialezekerheidswetten: ${ }^{126}$ was sprake van toedoen, dan werd de terugvorderingstermijn beperkt tot vijf jaar, was sprake van een administratieve vergissing waarvan de betrokkene redelijkerwijs op de hoogte was of had kunnen zijn, dan was deze termijn twee jaar. Deze conclusie sluit ook aan bij de latere jurisprudentie van de Raad met betrekking tot terugvordering van ambtenarensalarissen. ${ }^{127}$ Daarnaast kan worden geconcludeerd, dat terugvordering niet slechts wordt beperkt als wordt teruggevorderd op grond van het algemene rechtsbeginsel, maar ook als dit gebeurt op grond van terugvorderingsbepalingen en deze geen terugvorderingstermijn kennen. Dit was bijvoorbeeld het geval in de ABPW.

122. CRvB 4 november 1982, AB 1983, 192.

123. Zoals hiervoor beschreven kende de ABPW echter geen beperking met betrekking tot terugvordering, slechts was een bevoegdheid opgenomen orn van herziening af te zien als vijf jaren waren verstreken na dagtekening van đe voor herziening in aanmerking komende beslissing.

124. $\mathrm{Vgl}$. met betrekking tot terugvordering van ambtenarensalarissen 7.2.4.2.

125. In latere uitspraken fit hij dit ook niet, zie bijvoorbeeld CRvB 12 september 1991, RSV 1992, 226 en CRvB 16 juli 1992, RSV 1993, 30.

126. Dat dit uitgangspunt niet helemaal opging heb ik. aangegeven in 6.4.4.4. Het weten dat een administratieve vergissing is begaan en bewust hierover zwijgen kan verwijtbaarder zijn dan het onopzettelijk niet geven van inlichtingen waar dit wel had moeten gebeuren. Ik zal hierop terugkomen in 10.4.2.

127. Zie bijvoorbeeld CRvB 26 april 1990, AB 1991, 157, m.nt. HH, TAR 1990, 138. Zie hierover 7.2.4.2. 
Ook in de jurisprudentie met betrekking tot de buitengewone pensioenen kwam de vraag naar de terugvorderingstermijn aan de orde. In 1990 oordeelde de Centrale Raad van Beroep over een terugvordering van ten onrechte uitbetaald pensioen op grond van de WBPZ. De Buitengewone pensioenraad was op grond van artikel 35 e lid 5 WBPZ overgegaan tot terugvordering van nar zijn mening ten onrechte betaalde bedragen, en had daarbij overwogen dat dat artikel geen termijnen vermeldde waarbinnen het te veel betaalde kon worden teruggevorderd. De Centrale Raad overwoog dat dit laatste op zich juist was, maar niet spoorde met de regeling van termijnen van terugvordering in onder meer de sociale zekerheid. Hij vond dat zowel het rechtszekerheidsbeginsel als het beginsel van een evenwichtige afweging van belangen meebracht dat de terugvorderingsbevoegdheid in de tijd moest worden begrensd. Hij concretiseerde dit vervolgens door de vijfjarentermijn over te nemen 'indien het ten onrechte teveel betald zijn is te wijten aan opzet of grove nalatigheid van de pensioengerechtigde'. ${ }^{128}$

Met betrekking tot de WBP kwam ten slotte de vraag an de orde of gebruik mocht worden gemaakt van artikel 1395 BW (oud), nu de WBP een herzieningsen terugvorderingsregeling kende. Zoals te verwachten vond de Centrale Raad dat dit niet mocht; als er een regeling bestaat in de betreffende wet, dan is het 'slechts in overeenstemming met het systeem van die wet te achten een beslissing tot terugvordering op (het) betreffende artikel te doen steunen'. ${ }^{129}$

\subsubsection{Samenvatting}

Geconcludeerd kan worden dat in de rechtspraak met betrekking tot pensioenen de terugvorderingsbepalingen uit de verschillende wetten moeten worden toegepast. Deze bepalingen mogen niet worden omzeild via het gebruik van artikel 1395 BW (oud) of artikel 6:203 BW, noch via het aan die artikelen ten grondslag liggende beginsel dat hetgeen onverschuldigd is betaald, kan worden teruggevorderd. Bevat de regeling echter een leemte en doet zich een situatie voor waarop de herzienings- of terugvorderingsbepalingen niet van toepassing zijn, dan betekent dat niet, dat niet mag worden teruggevorderd. In dat geval schiet het genoemde algemene rechtsbeginsel dat hetgeen onverschuldigd is betaald, kan worden teruggevorderd, te hulp. Wel zal in die gevallen dit beginsel moeten worden afgewogen tegen het vertrouwensbeginsel, hetgeen weer aan terugvordering in de weg kan staan. Verder lijkt het erop dat toetsing aan het rechtszekerheidsbeginsel leidt tot analoge toepassing van de terugvorderingstermijnen, zoals de diverse socialezekerheidswetten die tot voor kort kenden. Directe toepassing van artikel 1395 BW (oud) of artikel 6:203 BW lijkt uitgesloten. Dit komt onder meer voort uit het feit dat in pensioenzaken de ambtenarenrechter bevoegd is. Deze rechter is nooit geneigd geweest deze artikelen rechtstreeks toe te passen. De bevoegdheid van de ambtenarenrechter leidde er tot voor kort toe dat de burgerlijke rechter, die in het verleden op andere terreinen artikel 1395 BW (oud) wel direct toepaste, zich onbevoegd verklaarde, terwijl het tegenwoordig (sinds het Changoe-arrest) 
leidt tot niet-ontvankelijkheid van de vordering. Slechts met betrekking tot de buitengewone pensioenen zou dit anders kunnen zijn, maar aangezien op grond van deze wetten de Centrale Raad van Beroep bevoegd is, is het de vraag of de burgerlijke rechter hier niet dezelfde weg volgt.

\subsection{Conclusie}

Tot 1933 bestond in Nederland geen algemene wettelijke regeling op het terrein van het ambtenarenrecht. Ook ontbrak een administratieve rechter, die bevoegd was te oordelen over geschillen tussen overheid en ambtenaar. Met betrekking tot terugvordering van ten onrechte of te veel betaalde bezoldiging was dus niets geregeld. Twee vragen deden zich dan ook voor: mocht de overheid artikel 1395 BW (oud) gebruiken en was de burgerlijke rechter bevoegd te oordelen over geschillen tussen de overheid en zijn ambtenaar? Om met de laatste vraag te beginnen: in de negentiende eeuw paste de Hoge Raad nu eens de fundamentum petendileer, dan weer de leer van het objectum litis toe. Jurisprudentie uit die periode met betrekking tot terugvordering door de overtieid van een ambitenaar heb ik niet gevonden. In de twintigste eeuw werd geen punt meer gemaakt van de bevoegdheidsvraag. Werd een geschil met betrekking tot een schuldvordering aangevoerd, dan was de burgerlijke rechter bevoegd, waarbij tevens de bepalingen uit het burgerlijk recht van toepassing waren. In dat geval kon hetgeen onverschuldigd was betaald worden teruggevorderd op grond van artikel $1395 \mathrm{BW}$ (oud), zie het arrest Geesje Jacobus. ${ }^{130}$

In 1933 trad de Ambtenarenwet 1929 in werking. Deze wet bevatte voornamelijk het formele recht; bepalingen met betrekking tot terugvordering waren niet opgenomen. In artikel 3 was de rechtsgang neergelegd: de Ambtenarengerechten en in hoger beroep de Centrale Raad van Beroep werden bij uitsluiting bevoegd te oordelen over besluiten, handelingen of weigeringen te besluiten of te handelen ten aanzien van ambtenaren. Beroepsgronden waren strijd met een algemeen verbindend voorschrift en détournement de pouvoir. Deze bevoegdheid was een exclusieve, aldus de wetgever. De Hoge Raad achtte zich dan ook onbevoegd kennis te nemen van geschillen tussen de overheid en ambtenaren. In 1992 is de Hoge Raad in het Changoe-arrest hierop teruggekomen; vanaf dat moment achtte hij zich wel bevoegd kennis te nemen van de vordering, maar diende eiser nietontvankelijk te worden verklaard in zijn vordering. ${ }^{131}$ De rechtsgang naar de ambtenarenrechter werd immers gezien als een met voldoende rechtswaarborgen omklede rechtsgang. Artikel 3 Aw 1929 is in 1994 vervallen; de inhoud ervan is (grotendeels) overgenomen in artikel 8:1 lid $2 \mathrm{j}^{\circ}$ lid $1 \mathrm{Awb}$.

$\mathrm{Nu}$ de Ambtenarenwet geen bepalingen bevatte met betrekking tot terugvordering, is het de vraag of mocht worden teruggevorderd en zo ja, of hierbij gebruik 
mocht worden gemaakt van de regeling uit het BW. In eerste instantie achtte de ambtenarenrechter terugvordering in strijd met het rechtszekerheidsbeginsel. Later achtte hij terugvordering mogelijk, en wel op grond van het algemene rechtsbeginsel dat degene die onverschuldigd heeft betaald, dit kan terugvorderen. Dit rechtsbeginsel ligt ten grondslag aan de regeling van onverschuldigde betaling in het BW, maar geldt ook in het bestuursrecht. Wel moet in een concreet geval worden bekeken of hierdoor geen strijd ontstaat met een ander beginsel, namelijk het rechtszekerheidsbeginsel, waarmee naar mijn mening de Centrale Raad doelde op het vertrouwensbeginsel. In latere jurisprudentie is dit verder uitgewerkt. De conclusie luidt dat de regels zoals ontwikkeld in de jurisprudentie met betrekking tot terugvordering vrijwel gelijk zijn aan de regels, zoals die golden in het socialezekerheidsrechtvoor de inwerkingtreding van de WBM.

Met betrekking tot de overheidspensioenen bestonden reeds lange tijd wettelijke regelingen; de eerste wet dateerde zelfs al van 1846. Bepalingen met betrekking tot terugvordering kwamen in de oudste wetten niet voor, bepalingen met betrekking tot herziening met terugwerkende kracht evenmin. Toch was een dergelijke herziening niet onmogelijk, zo blijkt uit het koninklijk besluit inzake weduwe Ridderhof uit 1913. ${ }^{132}$ Uit dit besluit lijkt ook te kunnen worden geconcludeerd, dat bij herziening en terugvordering de publiekrechtelijke weg moest worden gevolgd. De Pensioenwet 1922 kende wel bepalingen met betrekking tot herziening en terugvordering. Belangrijk is vooral dat op grond van deze bepalingen slechts kon worden teruggevorderd, indien in de herzieningsbeslissing was vermeld dat de onjuistheid van de oorspronkelijke beslissing was te wijten aan de opzet van de betrokkene. Over andere gevallen zweeg de wet. Het is de vraag of in die andere gevallen toch kon worden teruggevorderd, bijvoorbeeld op grond van artikel $1395 \mathrm{BW}$ (oud) of het daaraan ten grondslag liggende algemene rechtsbeginsel. Dit laatste ligt het meest voor de hand, nu de pensioenwetten de Centrale Raad van Beroep aanwezen als beroepsinstantic. Daar staat echter tegenover, dat de tekst van de pensioenwetten duidelijk was; alleen in de in de wet genoemde gevallen kon worden teruggevorderd. Ik heb in de gepubliceerde rechtspraak geen uitdrukkelijk antwoord op deze vraag gevonden.

In 1966 trad de ABPW in werking. Een belangrijke wijziging was, dat de ambtenarenrechter bevoegd werd (exclusief, althans tot 1992) kennis te nemen van pensioengeschillen, met uitzondering van geschillen betreffende de bijzondere pensioenwetten. Vanaf ongeveer 1974 werden ook de herzienings- en terugvorderingsbepalingen uitgebreid, hetgeen tot consequentie had dat deze bepalingen strenger werden toegepast; zij konden niet worden omzeild via artikel $1395 \mathrm{BW}$ (oud) of het aan dat artikel ten grondslag liggende rechtsbeginsel. Bevatten die bijzondere bepalingen echter een leemte, dan kon deze worden ingevuld met behulp van het genoemde algemene rechtsbeginsel. Wel gold ook hier weer de afweging tegen het vertrouwens- en het rechtszekerheidsbeginsel. 


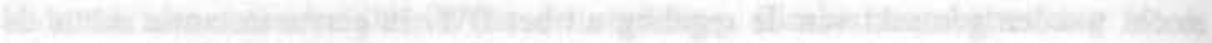

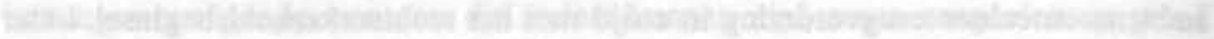

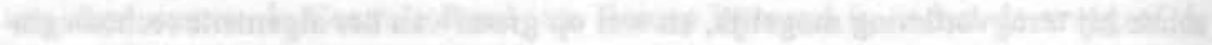

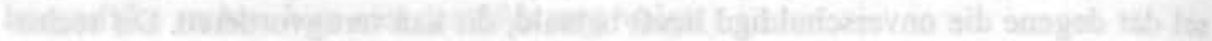

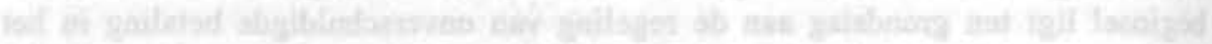

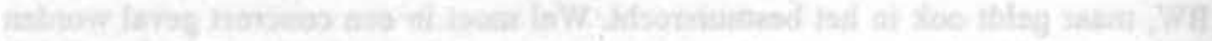

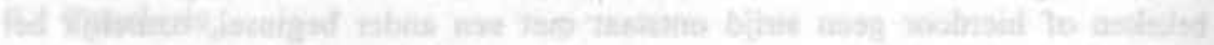

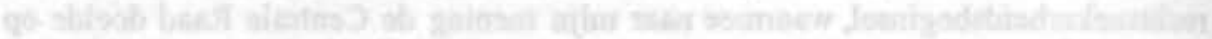

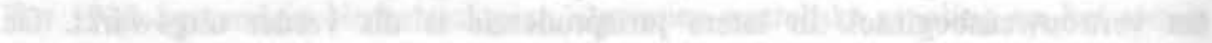

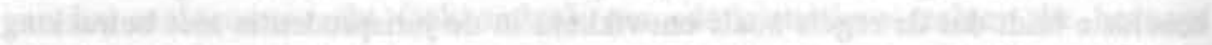

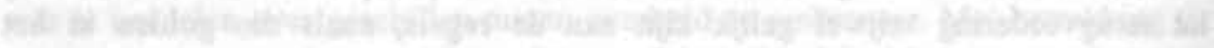

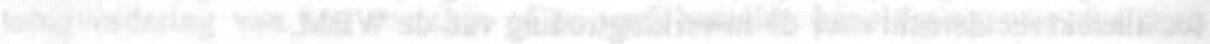

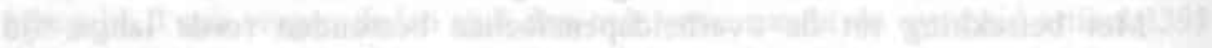

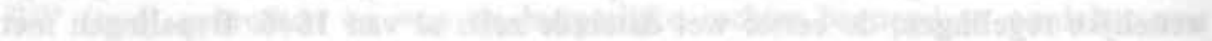

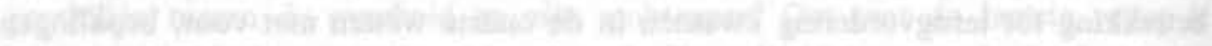

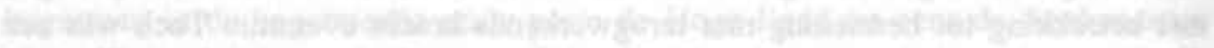

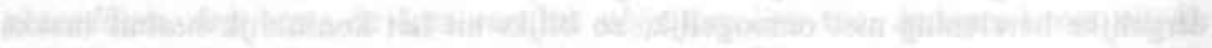

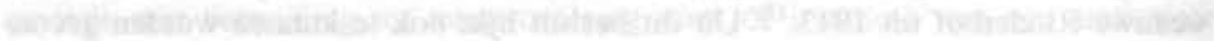

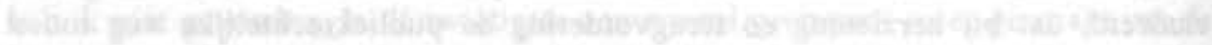

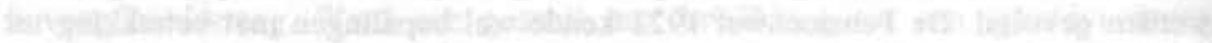

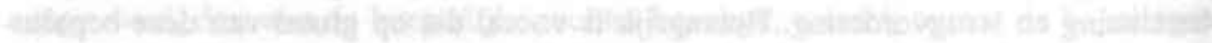

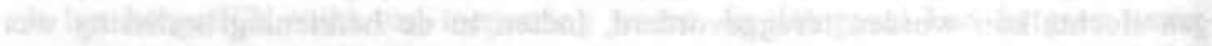

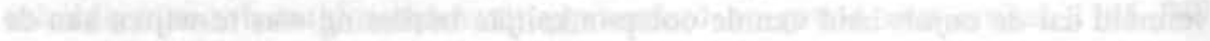

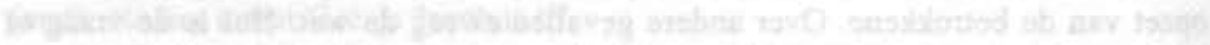

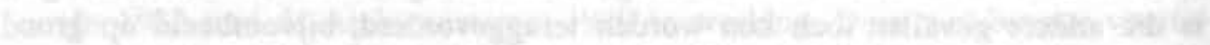

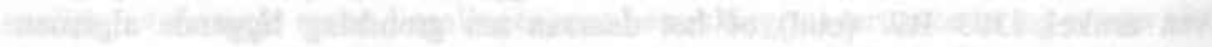

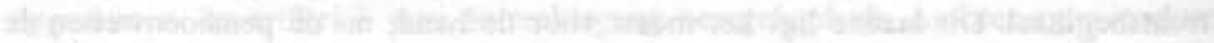

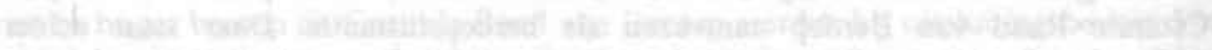

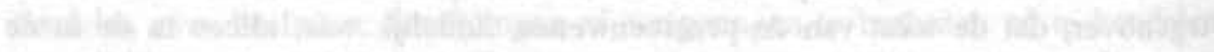

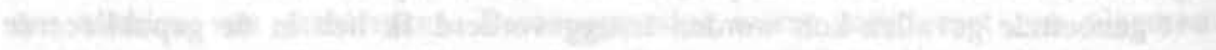

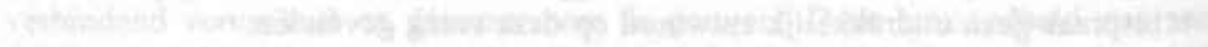

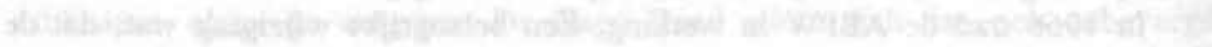

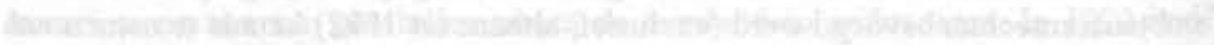

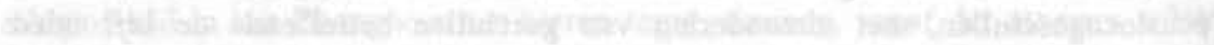

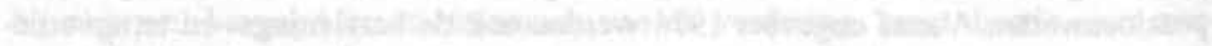

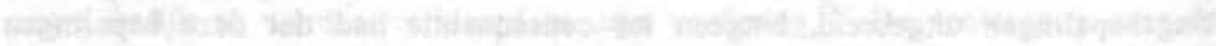

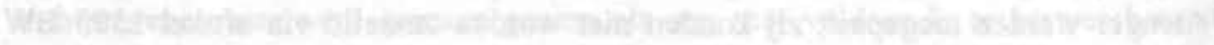

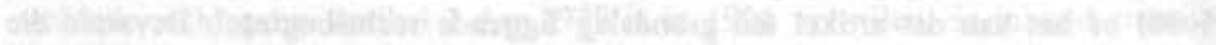

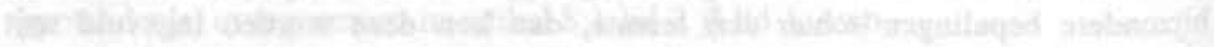

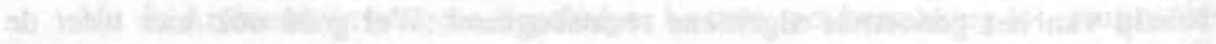

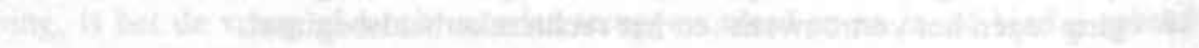




\section{HOOFDSTUK 8}

\section{SUBSIDIES EN SOCIAAL-ECONOMISCH RECHT}

\subsection{Inleiding}

Een belangrijk deel van de uitgaven die de overheid doet, vindt plaats in de vorm van subsidies of daarop gelijkende uitkeringen. Hierbij kan worden gedacht aan subsidies aan individuele, natuurlijke personen of aan rechtspersonen. Voorbeelden van subsidies aan de eerste categorie personen zijn bijdragen in de kosten voor de aanschaf van een eigen woning of de kosten voor het restaureren van een monumentale woning, en de individuele huursubsidie. Voorbeelden van de tweede categorie zijn de subsidies in het welzijnswerk, de gezondheidszorg, de sport, maar ook de steun aan bedrijven in nood en exportbevorderende belastingvoordelen.

Als belangrijk kenmerk van subsidie kan worden genoemd dat het gaat om een eenzijdige bijdrage door de overheid, waarbij zij een bepaalde activiteit subsidieert die zij in het algemeen belang noodzakelijk acht, maar die zij zelf niet (of niet efficiënt genoeg) ter hand neemt, wil nemen of kan nemen. Deze bijdragen staan in dit hoofdstuk centraal. Gelet op het feit dat het onderzoek zich richt op terugvordering zal ik mij hierbij beperken tot geldelijke subsidies.' Terugvordering van subsidies in natura, zoals bijvoorbeeld het ter beschikking stellen van een gebouw, is niet goed denkbaar. Eventueel zou waardevergoeding voor de naar achteraf blijkt ten onrechte geleverde prestatie kunnen worden gevorderd, ${ }^{2}$ maar dit valt buiten het kader van dit onderzoek.

Op 1 januari 1998 trad de derde tranche van de Awb en de daarin vervatte subsidietitel, titel 4.2, in werking. Artikel 4:21 lid 1 Awb bevat een definitie van het begrip subsidie:

'Onder subsidie wordt verstaan: de aanspraak op financiēle middelen, door een bestuursorgaan verstrekt met het oog op bepaalde activiteiten van de aanvrager, anders dan als betaling vooir aan het bestuursorgaan geleverde goederen of diensten".

Een belangrijke beperking vormen de woorden 'met het oog op bepaalde activiteiten'. Verstrekking van financiële middelen, die dienen om te voorzien in de kosten van het bestaan, vallen buiten de definitie. Volgens de toelichting vallen ook studiefinanciering en huursubsidie buiten het bereik van de regels van de subsidietitel, hoewel zij een gemengd karakter hebben: enerzijds inkomensover-

1. Zie 1.3. Vgl. de definitie van 'subsidie' in artikel 4:21 lid $1 \mathrm{Awb}$; hierover Jacobs (1999), blz. 23-26.

2. Vgl. artikel $6: 210$ lid $2 \mathrm{BW}$. 
dracht, anderzijds ook verstrekt met het oog op een bepaalde activiteit. ${ }^{3}$

In het verleden is het begrip 'subsidie' ruimer omschreven, onder andere door Van Kreveld, die subsidie zag als een overdracht van geld of op geld waardeerbare goederen of diensten waar geen directe, in economische zin gelijkwaardige, tegenprestatie jegens de overheid tegenover staat, welke overdracht ten laste komt van de openbare middelen en welke overdracht plaatsvindt om activiteiten van particuliere producenten of consumenten van bepaalde goederen of diensten in een bepaalde richting te beïnvloeden. ${ }^{4}$ Onder deze definitie zijn bijvoorbeeld ook de studiefinanciering en de individuele huursubsidie te vatten.

Uitgangspunt in dit hoofdstuk zal zijn de omschrijving van het begrip 'subsidie' zoals die te vinden is in het positieve recht, in de Awb dus. Daarnaast zal ik in dit hoofdstuk ook de huursubsidie en de studiefinanciering behandelen. In mijn visie hebben deze terreinen, als ze al niet als subsidie zijn te beschouwen, zoveel aanknopingspunten met 'echte' subsidies, dat behandeling in dit hoofdstuk voor de hand ligt. ${ }^{5} \mathrm{lk}$ stel dan ook de gerichtheid op de activiteit - het wonen respectievelijk het studeren - voorop en niet de inkomensoverdracht, hoewel dit laatste ook een rol speelt, het duidelijkst bij huursubsidie.

Op het terrein van de subsidies zijn verschillende bestuursrechters actief. Het terrein van de sociaal-economische ordening - bijvoorbeeld subsidies voor bedrijven - valt grotendeels onder de competentie van het College van Beroep voor het bedrijfsleven. Het (voormalige) College van beroep studiefinanciering was in de Wet op de Studiefinanciering, de voorloper van de Wet studiefinanciering 2000, aangewezen als bevoegde rechter. De voormalige Afdeling rechtspraak en de huidige Afdeling bestuursrechtspraak van de Raad van State speelde respectievelijk speelt als 'rest'rechter bij de meeste andere subsidies een rol. Deze verschillende rechters hebben ieder hun eigen jurisprudentie ontwikkeld, ook met betrekking tot terugvordering en de vraag of deze terugvordering als publiekrechtelijke dan wel als privaatrechtelijke rechtshandeling dient te worden gezien, en gekoppeld hieraan de vraag of publiekrecht dan wel privaatrecht van toepassing is op deze terugvordering. Om deze reden heb ik ervoor gekozen de rechtsbescherming voorop te stellen bij het maken van een indeling. Concreet betekent dit dat de terreinen waarop de Afdeling (bestuurs)rechtspraak van de Raad van State, het College van beroep studiefinanciering of het College van Beroep voor het bedrijfsleven oordelen, in afzonderlijke paragrafen worden behandeld.

Ook aan deze indeling kan een argument worden ontleend on de huursubsidie in dit hoofdstuk als subsidie te behandelen; zij kan vanuit een oogpunt van. rechisbescherming op een lijn worden gezet met een groot aantal 'echte' subsidies. Op grond van (eerst) de Wet individuele huursubsidie en (tegenwoordig) de Huursubsidiewet was de Afdeling rechtspraak en is de Afdeling bestuursrechtspraak de hoogste rechter in huursubsidiegeschillen. De jurisprudentie van deze 
rechters maakt dan ook geen onderscheid tussen huursubsidie en andere subsidies.

De indeling van dit hoofdstuk is dan de volgende. In 8.3 zal ik de studiefinanciering behandelen. De jurisprudentie van het College van Beroep voor het bedrijfsleven, grotendeels samenvallend met het recht op het terrein van de sociaal-economisch ordening, komt in 8.4 aan de orde. Begonnen wordt in 8.2 met een meer 'algemeen deel' van het subsidierecht, waarin onder andere de vraag naar de grondslag voor subsidiëring aan de orde komt, alsmede de subsidietitel uit de Awb. Voorts wordt de huursubsidie in deze paragraaf behandeld, evenals de jurisprudentie van de Afdeling (bestuurs)rechtspraak.

\subsection{Subsidies en de Afdeling (bestuurs)rechtspraak van de Raad van State}

\subsubsection{Grondslag voor subsidiëring voor de inwerkingtreding van de Awb}

Het is algemeen aanvaard dat de overheid bepaalde activiteiten, die in het algemeen belang nodig worden geacht en die beter, effectiever of efficiënter (kunnen) worden uitgevoerd door derden, financieel ondersteunt. Het feit dát de overheid subsidieert, is niet meer omstreden; het wordt zelfs gezien als een overheidstaak. ${ }^{6}$

In het verleden was het zo, dat subsidiëring vaak werd gezien als een nietjuridisch bestuursinstrument. ${ }^{7}$ Naast subsidiëring op grond van een uitdrukkelijk wettelijk voorschrift, zoals bijvoorbeeld de subsidiëring van het onderwijs, vond ook op ruime schaal subsidiëring plaats, die niet op een uitdrukkelijk wettelijk voorschrift berustte. Veelvuldig kwam subsidiëring voor die slechts berustte op zogenaamde pseudowetgeving ${ }^{8}$ - tegenwoordig wordt gesproken over beleidsregels - of zelfs een enkele begrotingspost. Uiteraard dienden de benodigde gelden, die op grond van deze pseudowetgeving werden toegekend als subsidies, wel te zijn gereserveerd op de begroting. De opname van de uitgaven op de begroting vormde voor de overheid de legitimatie voor het doen van die uitgaven. Zonder begrotingspost mochten dus geen uitgaven worden gedaan. Was het bij pseudowetgeving nog enigermate duidelijk hoe het bestuur in een bepaalde situatie zou handelen (als tenminste de regels die golden, naar buiten bekend waren gemaakt), bij subsidiëring die slechts werd gebaseerd op een begrotingspost was dat niet het geval. Toch werd ook dit algemeen aanvaard.

Op rijksniveau kan bijvoorbeeld worden gewezen op het koninklijk besluit van 19 juni 1924, ${ }^{9}$ waarvan artikel 1 bepaalde dat de 'Hoofden der Ministerieele Departementen' bevoegd waren (onder meer) subsidies toe te kennen, onder het

6. Dit is in het verleden anders geweest, zie bijvoorbeeld Bohtlingk (1958), blz. 10, die sprak over 'het droevig verschijnsel van 'bestuur door middel van subsidiering', reeds zo gewoon geworden, dat men nauwelijks, nog beseft hoe abnormaal het eigenlijk is'.

7. Ten Berge/Reinders (1984), blz. 44.

8. Deze termt is afkomstig van Van der Hoeven (1967).

9. Besluit van 19 juni 1924 tot overdracht van enkele bevoegdheden aan de Hoofden der Ministerieele Departementen, Stb. 294. 
voorbehoud 'dat de noodige gelden op de begrootingen van uitgaven beschikbaar zijn'. Ook de Comptabiliteitswet $1927^{10}$ gaf de overheid de mogelijkheid uitgaven te doen mits gelden waren gereserveerd op de begroting. Meer recent gold het koninklijk besluit van 27 juli $1950^{11}$ in samenhang met een begrotingspost als voldoende grondslag voor de subsidiëring. Artikel 1 van dit besluit gaf aan de hoofden van de departementen van algemeen bestuur dezelfde bevoegdheden als artikel 1 van het besluit uit 1924, namelijk om binnen het raam van de begroting subsidies te verlenen. ${ }^{12}$ Ook subsidiëring op grond van een gevoerd beleid, op grond van pseudowetgeving dus, ontmoette weinig bezwaar, zij het dat de burger in het algemeen minder snel aanspraak kon maken op subsidie; hij was namelijk niet altijd bekend met het gevoerde beleid. Zoals gezegd diende er ook in dat geval de benodigde ruimte voor de uitgaven te zijn op een begrotingspost.

Op lager niveau was eenzelfde situatie te zien. Zo bepaalde artikel 246 gemeentewet (oud) dat geen uitgaven konden worden gedaan welke niet bij de goedgekeurde begroting of begrotingswijziging waren geraamd. ${ }^{13}$ Subsidiëring kon plaatsvinden wanneer een bepaalde post was opgenomen op de begroting.

Bij subsidiëring was dus vaak geen wettelijke grondslag aan te wijzen. Een begrotingspost kan ook niet als zodanig fungeren, nu een dergelijke post slechts aangeeft dát en tot welk maximum er gelden zijn vrijgemaakt voor het in die post omschreven doel. Hieruit valt niet af te leiden, wie in aanmerking komt voor subsidie en aan welke voorwaarden in dat geval moet zijn voldaan. De vraag rijst of dit in strijd is met het legaliteitsbeginsel. Algemeen werd aangenomen dat dit niet zo was. Nu sprake was van een zogenaamde Leistungsverwaltung, waarbij de overheid presterend optrad, was geen wettelijke grondslag vereist. Aan het verlenen van subsidies werden echter vaak voorschriften verbonden. Ondanks het feit dat deze voorschriften als belastend konden worden gezien, werd ook hier geen wettelijke grondslag vereist; 'wie het meerdere mag (in dit geval: het weigeren van subsidie), mag ook het mindere (namelijk het verbinden van voorschriften aan de subsidieverlening)', zo was de opvatting.

Deze opvatting is sedert het begin van de jaren tachtig steeds meer bestreden. Zo eist Konijnenbelt een wettelijke grondslag als er sprake is van een Leistungs. verwaltung, namelijk voor zover de Leistungsvenwaltung tevens een Eingriffsver-

10. Wet van 21 juli 1927, houdende regeling van het beheer van 's Rijks linanciên, Sib. 259.

11. Besluit van 27 juli 1950, houdende nadere regeling van de aan de hoofden der Ministeriéle Departementen verleende bevoegdheid tot toekenning van subsidiën, bijdragen, vergoedingen, schadeleosstellingen en gratificatien, Stb. $K 320$. Het $\mathrm{KB}$ is in 1991 ingetrokken bij wijziging van de Comptabiliteitswet 1976, artikel li, onderdeel 4 Wet van 19 december 1991, Stb. 752.

12. Dit KB had oorspronkelijk een geheel andere functie. Het had namelijk betrekking op representatiekosten, overwerkwergoedingen, kledingtoelagen, gratificaties, kosten van het voeren van rechtsgedingen en het salaris van de landsadvocaat, zie Van Ommeren (1996), blz. 110 met verdere verwijzingen.

13. Artikel 246 wend ingeyoegd bij wet van 15 december 1966, Stb. 564. Overigens bevatten de artikelen 247 en 248 een aantal uitzonderingen op deze regel. 
waltung is, voor zover de begunstigende beschikking dus tevens belastende elementen bevat. ${ }^{14}$ Dit standpunt is bestreden door Damen, die de opvatting van. Konijnenbelt als 'compromisvoorstel' weinig operationeel acht. Damen concludeert dat eigenlijk 'voor heel het 'positieve' overheidsoptreden een wettelijke grondslag en regeling noodzakelijk' is. ${ }^{15}$ Ook. De Haan, Drupsteen en Fernhout stellen in Bestuursrecht in de sociale rechtsstaat dat dient te worden gestreefd naar een wettelijke grondslag voor het gehele overheidsbeleid. ${ }^{16}$

Ook bij de overheid leefde kennelijk het besef dat voor zowel de burger als het bestuur duidelijkheid gewenst was wanneer kon worden gesubsidieerd. Dit leidde in eerste instantie tot het opstellen van beleidsregels, regels waarin het bestuur zichzelf bond om in de in die regels vastgelegde gevallen over te gaan tot subsidiëring. De overheid ging de beleidsruimte die zij had, dus min of meer vastleggen. Deze beleidsregels kregen externe werking indien zij bekend waren gemaakt, bijvoorbeeld door publicatie, en dus niet langer louter intern bekendheid genoten. In een aantal gevallen kon de burger er dan ook rechten aan ontlenen.

Ging het bij beleidsregels nog om buitenwettelijke regels, daarnaast ging de overheid steeds meer wettelijke regels ten grondslag leggen aan subsidiëring. Dit kwam onder andere omdat het feit dat de bevoegdheid tot het verstrekken van subsidies vaak gebaseerd was op slechts een beleidsregel, of zelfs op slechts een begrotingspost, als onbevredigend werd ervaren. Zo werd in de jaren tachtig - na het RSV-debacle en de daarop volgende parlementaire enquête - de vraag om 'vastlegging van de steunregelingen in voor ieder kenbare vorm' steeds luider. ${ }^{17}$ Op lager niveau kan worden gewezen op de gemeentelijke en provinciale subsidieverordeningen, door de gemeenteraad of provinciale staten vastgesteld op grond van hun bevoegdheid in artikel 167 en 168 gemeentewet (oud), nu artikel 147 Gemeentewet, respectievelijk artikel 89 Provinciewet (oud), nu artikel 143 Provinciewet. Op rijksniveau werd een aantal kaderwetten aangenomen. Deze wetten vormden - zoals de naam al aangeeft - het kader, het raamwerk waarbinnen de subsidiëring diende plaats te vinden. Belangrijke kaderwetten waren de Kaderwet specifiek welzijn ${ }^{18}$ en de op het sociaal-economisch terrein belangrijke Kaderwet verstrekking financiële middelen $\mathrm{EZ},{ }^{19}$ welke wet bij de inwerkingtreding van de

14. Konijnenbelt (1982). Later heeft hij hier nog een tweede situatie aan toegevoegd waarin cen, wettelijke grondslag vereist is, namelijk voor zover personen wat hun inkoristen betreft geheei aan de overheid zijn overgeleverd, Van Wijk/Konijnenbelt (1988), blz. 41.

15. Damen (1987), blz. 296.

16. De Haan/Drupsteen/Femhout I (2001), blz. 289.

17. Aandachtspunt van de Parlementaire Enquêtecornnissie RSV, 20als weergegeven in de memorie van txelichting op de Kaderwet verstrekking financicle middelen E?, Tweede Kamer 1987-1988, 20 527, nr. 3, blz. 3. Zie ook Damen (1987), biz. 280-281.

18. Wet van 8 september 1982, houdende regelen ten aanzien van de beleidsvoorbereiding, beleidsbepaling, uitvoering en bekostiging van verraieningen op terreinen van specifiek welzijn (Kaderwet specifiek wetzijn), Stb. 539. Deze wet werd in 1987 ingetrokken door artikel 45 Welzijnswet. Zie over de (ontwerp)kaderwet Reinders (1981), in het bijzonder blz. 73-99.

19. Wet van 4 december 1991, Stb. 767. 
subsidietitel van de Awb werd vervangen door de Kaderwet EZ-subsidies. ${ }^{20}$

Naar mijn mening dient in het algemeen een wettelijke grondslag aanwezig te zijn bij subsidiëring. Zoals ik zal uitwerken in hoofdstuk 9, dienen op grond van het legaliteitsbeginsel bestuursbevoegdheden waardoor bevoegdheden, rechten en plichten van (natuurlijke of rechts)personen kunnen worden vastgesteld of gewijzigd, te berusten op een wettelijke grondslag. ${ }^{21}$ Daarnaast speelt mijns. inziens een rol, dat de overheid beperkt is in de financiële middelen die zij tot haar beschikking heeft. Voor een bepaald soort activiteiten is doorgaans een beperkt budget voorhanden. Dit betekent dat subsidiëring van een instelling consequenties kan hebben (en veelal heeft) voor andere instellingen; geld kan immers slechts eenmaal worden uitgegeven. Om die reden moet dan ook duidelijk zijn hoe met het beschikbare geld wordt omgegaan en in welke gevallen er een recht kan bestaan op subsidiëring. Dit kan slechts optimaal gebeuren als een wettelijke grondslag aanwezig is. Uiteraard leidt dit er niet toe dat er meer geld vrij komt voor subsidiëring, maar wel dat de subsidiëring doorzichtiger wordt. Het feit dat bijvoorbeeld in bepaalde gevallen subsidieplafonds gelden, waarbij een maximum bedrag beschikbaar is voor subsidiëring van een bepaalde activiteit, zal niet veranderen; wel zal eenieder duidelijk zijn dát een dergelijk plafond geldt als dit in de wettelijke regeling is vastgelegd. Potentiële aanvragers van die subsidie kunnen daar dan rekening mee houden en hun gedrag daarop afstemmen.

De wens om tot een algemene wettelijke grondslag te komen heeft uiteindelijk geleid tot het opnemen van een titel over subsidies in de Awb.

\subsubsection{De subsidietitel in de Awb}

\subsubsection{Inleiding}

Sinds 1 januari 1998 is in de Awb een regeling betreffende subsidies opgenomen: titel 4.2, Subsidies. In deze paragraaf zal ik (een aantal aspecten van) deze regeling beschrijven. Hierbij zal eerst het vereiste van een wettelijke grondslag worden behandeld (8.2.2.2), vervolgens de verschillende stappen bij subsidiëring (8.2.2.3), de intrekking en terugvordering (8.2.2.4) en ten slotte zal ik commentaar leveren op de regeling (8.2.2.5). Alvorens hiertoe over te gaan zal ik eerst een

20. Wet van 29 februari 1996, Stb 180. De reden voor deze vervanging was tweeledig. Een aantal artikelen diende te vervallen, nu de Awb reeds voorzag in de in die artikelen geregelde materie. Verder werd de grondslag die de Kadenwet bood als 'te smal' ervaren; zij beperkte zich tot het verstrekken van financiele middelen aan ondernemers. Zie de memorie van toelichting, Tweede Kamer 1995-1996, 24 416, nr. 3, blz. 1. De nieuwe Kaderwet dient de door artikel 4:23 lid 1 Awb vereiste wettelijke grondslag te geven voor alle subsidieverstrekkingen door het ministerie van Economische Zaken. Zie over de beide EZ-Kaderwetten Bollen (1999), blz. 43-45.

21. Daarnaast is het zo, dat bij subsidiêring veelal (belastende) voorschriften worden gesteld, aldus Damen (1987), blz. 296. Reeds hierom mag de eis van een wettelijke grondslag in het algemeen worden gesteld. Hoewel Damen zich beperkte tot de steunverlening aan ondememingen, gaat dit argument naar mijn mening ook daarbuiten op. 
antal begrippen kort uiteenzetten.

In het algemeen kan bij subsidiëring een aantal momenten worden onderscheiden, namelijk de subsidieverlening, de betaling en de subsidievaststelling. Voor dit onderzoek is ook de afwikkeling achteraf van belang, als blijkt dat (deels) ten onrechte is gesubsidieerd, waarbij de wijziging of intrekking en vervolgens de terugvordering aan de orde komen. Deze verschillende stappen werden ook al onderscheiden voor de inwerkingtreding van de subsidietitel in de Awb. ${ }^{22}$

Het verkrijgen van subsidie is meestal afhankelijk van het verrichten van een bepaalde activiteit. Hierbij zal niet altijd terstond duidelijk zijn hoe hoog de uiteindelijke kosten van die activiteit zullen zijn. Het lijkt dan ook logisch dat subsidiëring eerst plaatsvindt na afloop van de activiteit. Dit stuit echter in vele gevallen op onoverkomelijke bezwaren aan de kant van de gesubsidieerde. Het zal immers vaak voorkomen dat deze het benodigde geld voor het verrichten van de te subsidiëren activiteit niet heeft en niet kan krijgen. In die gevallen zou de activiteit dus niet kunnen plaatsvinden. Dit is dan weer maatschappelijk niet gewenst; het gaat immers om activiteiten die de overheid in het algemeen belang noodzakelijk acht. Om dit probleem te ondervangen wordt een onderscheid gemaakt tussen de subsidieverlening vooraf en de subsidievaststelling achteraf.

De subsidietitel in de Awb geeft ook regels voor de gevallen, waarin aan de subsidievaststelling geen subsidieverlening voorafgaat. Ook zijn er (meer algemene) bepalingen die gelden voor zowel de situatie dat de subsidievaststelling wordt vooraf gegaan door een subsidieverlening, als de situatie waarin dat niet het geval is. Denk bijvoorbeeld aan het vereiste van een wettelijke grondslag. In die gevallen, alsmede in de gevallen waarin het samenspel van subsidieverlening en -vaststelling aan de orde is, hanteert de wetgever de term (subsidie)verstrekking.

\subsubsection{Het vereiste van wettelijke grondslag}

Artikel 4:23 lid 1 Awb eist voor iedere subsidie een wettelijke grondslag; subsidie kan slechts worden verstrekt op grond van een wettelijk voorschrift dat aangeeft voor welke activiteiten deze subsidie kan worden verstrekt. De reden hiervoor is dat op die manier duidelijkheid kan worden geschapen over de rechten en plichten van subsidieverlener en -ontvanger, waarmee de rechtszekerheid is gediend. Op deze wijze wordt voorts het bestuursorgaan gedwongen na te denken over de met de subsidiëring te bereiken doeleinden, aldus de memorie van toelichting. De memorie voert verder aan dat er in de literatuur herhaaldelijk op is gewezen, dat een wettelijke grondslag op rechtsstatelijke gronden wenselijk is. De overheid grijpt via haar subsidiebeleid 'soms even diep (in) in de vrijheidssfeer van de burgers (...) als door klassieke gebods- en verbodsbepalingen', nu burgers in bepaalde gevallen 'in hoge mate afhankelijk zijn van overheidssubsidies'. ${ }^{23}$

Artikel 4:23 lid 1 brengt mee, dat er op rijksniveau voor de subsidie een grondslag in een formele wet dient te zijn, waarin in ieder geval de hoofdlijnen 
van het subsidiebeleid moeten worden geregeld. De nadere regeling kan, afhankelijk van de aard van de subsidie, deels geschieden in een lager wettelijk voorschrift, zoals een algemene maatregel van bestuur of een ministeriële regeling. ${ }^{24}$ Op provinciaal en gemeentelijk niveau zal de subsidiëring in het algemeen bij (provinciale of gemeentelijke) verordening dienen te worden geregeld. ${ }^{25}$

Het wettelijk voorschrift dient aan twee minimum-eisen te voldoen, wil het de beoogde doelmatigheid en rechtszekerheid bieden. Het moet de activiteiten omschrijven waarvoor subsidie kan worden verleend en het moet de grondslag vormen voor de verplichtingen, die het bestuursorgaan aan subsidiëring kan verbinden, voor zover die grondslag niet reeds in de Awb is opgenomen. ${ }^{26}$

Ingevolge lid 2 van artikel 4:23 kan in bepaalde gevallen (tijdelijk) worden volstaan met een grondslag in een zelfstandige algemene maatregel van bestuw. Het gaat dan vooral om subsidieregelingen met een tijdelijk of experimenteel karakter, waarvoor het tot stand brengen van een formeel-wettelijke regeling als te zwaar wordt gezien. ${ }^{27}$ Artikel 4:23 lid 3 geeft een aantal uitzonderingen op het vereiste van een wettelijke grondslag.

Tegelijk met de inwerkingtreding van deze bepalingen is een aantal kaderwetten in werking getreden, die voor subsidiëring op bepaalde terreinen de wettelijke. grondslag bieden, zoals de Kaderwet SZW-subsidies, ${ }^{28}$ de Kaderwet subsidies Verkeer en Waterstaat ${ }^{29}$ en de Kaderwet LNV-subsidies. ${ }^{30}$ In de praktijk betekent dit, dat bij subsidiëring vaak op meerdere niveaus regels worden gegeven; er is sprake van een gelaagde structuur. De algemene regels, zoals neergelegd in de Awb, zijn van toepassing, evenals de regels in de specifieke wet en de eventueel daarop gebaseerde algemene maatregel van bestuur of de ministeriële regeling, waarin de nadere regeling is neergelegd. Voor zover de hogere regeling daarvoor ruimte laat, is afwijking van de algemenere regels in de lagere regeling mogelijk.

Wordt ondanks het feit dat een wettelijke grondslag ontbreekt toch subsidie verleend (en valt deze subsidieverlening niet onder de uitzonderingen van artikel $4: 23$ lid 2 of 3 ), dan zal dat in het algemeen slechts interne gevolgen hebben, maar het kan ook externe gevolgen hebben; onder omstandigheden is intrekking van de subsidieverlening of -vaststelling 'denkbaar' als de ontvanger wist of behoorde te weten dat de subsidiëring niet was toegestaan. Het behoort echter 'primair tot de verantwoordelijkheid van het betrokken bestuursorgaan (...) na te

24. PG Awb Ili, blz. 199.

25. PG Awb III, blz. 199.

26. PG Awb III, blz. 200. Een aantal verplichtingen, dat kan worden opgelegd, is te vinden in artikel 4:37.

27. PG Awb III, blz. 200.

28. Wet van 19 juni 1997, houdende regels inzake de verstrekking van subsidies door de Minister van Sociale Zaken en Werkgelegenheid (kaderwet SZW-subsidies), Stb. 285.

29. Wet van 17 december 1997, houdende regels inzake de verstrekking van subsidies door de Minister van Verkeer en Waterstaat (Kaderwet subsidies Verkeer en Waterstaat), Stb. 724.

30. Wet van 17 december 1997, houdende regels inzake de verstrekking van subsidies door de Minister van Landbouw, Natuurbeheer en Visserij (Kaderwet LNV-subsidies), Stb. 710. 
gaan of een voldoende wettelijke basis voor subsidieverlening bestaat'. ${ }^{31}$

Dat het ontbreken van een wettelijke grondslag niet snel consequenties dient te hebben voor de ontvanger van de subsidie is ook logisch, als wordt gekeken naar de ratio van de eis van een wettelijke grondslag. Ten opzichte van de burgers is immers de bedoeling het verzekeren van de rechtszekerheid. Het gaat dan naar mijn mening te ver om het ontbreken van een wettelijke grondslag tégen de burger te gebruiken. Zowel het rechtszekerheids- als het vertrouwensbeginsel verzetten zich daartegen. Indien de subsidie-ontvanger weet dat een wettelijke grondslag ontbreekt, kan onder omstandigheden de subsidieverlening of -vaststelling worden ingetrokken en kan terugvordering plaatsvinden. Wel zal dit zeer terughoudend moeten plaatsvinden, vooral gelet op de genoemde ratio achter het vereiste van de wettelijke grondslag. Verder ben ik van mening dat het feit, dat de betrokkene behoorde te weten dat een wettelijke grondslag ontbreekt, niet voldoende rechtvaardiging is om tot intrekking en terugvordering over te gaan. Dit criterium is te vaag. ${ }^{32}$ Dit lijkt ook de opvatting van de wetgever te zijn: in de nota naar aanleiding van het verslag stelt de regering onder meer dat niet van de burger kan worden verlangd, 'dat hij steeds nagaat of het bestuursorgaan wel bevoegd is een bepaalde subsidie te verstrekken.'.

\subsubsection{Subsidieverlening en subsidievaststelling}

Bij subsidieverstrekking kan een aantal momenten worden onderscheiden, namelijk de subsidieverlening, de betaling en de subsidievaststelling. Ook onder het oude recht kon dit onderscheid veelal worden gemaakt. Hiema zal ik in grote lijnen deze verschillende stappen beschrijven, waarbij ik uitga van de situatie dat aan de subsidievaststelling een subsidieverlening voorafgaat.

Alvorens het bestuursorgaan tot subsidieverlening overgaat, moet de betrokkene een aanvraag indienen. Vervolgens zal het bestuursorgaan een beschikking. omtrent subsidieverlening geven. Als deze beschikking een positieve beslissing op de aanvraag inhoudt, kan vervolgens een voorschot worden verleend, voor zover dit is bepaald bij wettelijk voorschrift of bij de subsidieverlening. De beslissing om een voorschot te verlenen is een beschikking. Vervolgens kan de betrokkene na afloop van een bepaalde termijn of na afloop van de te subsidiëren activiteit een aanvraag tot subsidievaststelling indienen. Ook kan in bepaalde gevallen het bestuursorgaan ambtshalve de subsidie vaststellen. Ook de beslissing tot subsidievaststelling is een beschikking. Ten slotte wordt het subsidiebedrag conform de vaststelling betaald, onder verrekening van de betaalde voorschotten.

De Awb omschrijft niet wat onder subsidieverlening moet worden verstaan.

31. PG Awb III, blz. 200.

32. Zo kan men zich afvragen wanneer iemand behoort te weten dat een wettelijke grondslag ontbreekt. Moet hierbij cen onderzoeksplicht worden aangenomen? In hoeverre geldt het adagium! dat eenieder wordt geacht de wet te kennen? Ook Verheij en Lubberdink zijn van mening dat van de ontvanger niet mag worden verwacht dat hij weet of er wel een toereikende wettelijke grondslag voor de subsidie is, Verheij/Lubberdink (1996), blz. 42.

33. PG Awb III, blz. 177. 
Wel geeft de wet enkele regels met betrekking tot de inhoud van de beschikking. Zij bevat in ieder geval een omschrijving van de activiteiten waarvoor subsidie wordt verleend (artikel 4:30 lid 1) en het bedrag van de subsidie, dan wel de wijze waarop dat bedrag zal worden berekend (artikel 4:31 lid 1). Daarnaast kan zij bepalingen bevatten met betrekking tot verplichtingen van de subsidie-ontvanger, zo blijkt impliciet uit afdeling 4.2.4. De consequentie van de beschikking tot subsidieverlening is, dat als de aanvrager de gesubsidieerde activiteit verricht en zich aan de eventuele verplichtingen houdt, hij een aanspraak op financiêle middelen krijgt. Hierbij kan het zijn, dat nog niet geheel duidelijk is hoeveel hij krijgt; dit kan mede afhangen van de omvang van de te verrichten activiteit en de uitgaven en inkomsten. Dit betekent echter niet dat het bestuursorgaan in deze fase zonder meer kan terugkomen op de subsidieverlening: verricht de aanvrager de activiteiten en voldoet hij aan de voorwaarden, dan moet het bestuursorgaan subsidiëren. Door de subsidieverlening krijgt de aanvrager dus een voorwaardelijke - en niet een voorlopige of vrijblijvende - aanspraak op financiële middelen. De toelichting stelt dan ook uitdrukkelijk dat het bestuursorgaan reeds door de verlening en niet pas door de vaststelling een financiële verplichting aangaat. ${ }^{34}$

Deze voorwaardelijke aanspraak wordt definitief door de beschikking tot subsidievaststelling. In deze beschikking wordt het bedrag van de subsidie vastgesteld, waardoor aanspraak op betaling van dat bedrag ontstaat, aldus artikel 4:42. Normaal wordt de beschikking tot vaststelling genomen op aanvraag van de subsidie-ontvanger (artikel 4:44 lid 1 en 2), de wet geeft het bestuursorgaan de mogelijkheid de subsidie ambtshalve vast te stellen (artikelen 4:44 lid 4 en 4:47). Hier is vooral van belang artikel 4:47 aanhef en onder c: de subsidie kan ambtshalve worden vastgesteld als de beschikking tot subsidieverlening of -vaststelling wordt ingetrokken of ten nadele van de subsidie-ontvanger wordt gewijzigd. Alvorens tot de subsidievaststelling over te gaan zal het bestuursorgaan nagaan of de activiteit is verricht en dat de eventueel opgelegde verplichtingen zijn nagekomen. Is dit het geval, dan zal de subsidie conform de verlening moeten worden vastgesteld. Dit is ook het uitgangspunt van artikel 4:46. Is dit niet het geval, dan kan de subsidie lager worden vastgesteld, zie artikel 4:46 lid 2 aanhef en onder a en b. Ook kan de subsidie lager worden vastgesteld als de ontvanger bij de aanvraag tot subsidieverlening onjuiste of onvolledige inlichtingen heeft gegeven of bij de verlening een administratieve vergissing is gemaakt (artikel 4:46 lid 2 aanhef en onder $c$ en d). Ik zal hierop ingaan in 8.2.2.5. De beschikking tot subsidievaststelling geeft aanspraak op betaling van het vastgestelde bedrag, dat dan ook onder verrekening van eventueel betaalde voorschotten dient te worden betaald (artikel 4:52 lid 1). In beginsel is hiermee de subsidieverhouding afgerond. Het is echter mogelijk in bepaalde gevallen aan de subsidievaststelling verplichtingen te verbinden, bijvoorbeeld de verplichting om bij de koop van een nieuwbouwwoning, waarvoor subsidie is verstrekt, gedurende een aantal jaren deze woning zelf te bewonen. 


\subsubsection{Intrekking en terugvordering:}

De Awb geeft regels met betrekking tot intrekking en wijziging van zowel de beschikking tot subsidieverlening als die tot subsidievaststelling, waarbij wat de beschikking tot subsidieverlening betreft wordt onderscheiden tussen intrekking of wijziging ex tunc en ex nunc. Ik concentreer mij hier op de intrekking ex tunc. ${ }^{35}$

Ook onder het oude recht - dus voor de inwerkingtreding van de subsidietitel in de Awb - was intrekking van de beschikking tot subsidieverlening mogelijk volgens de Afdeling rechtspraak van de Raad van State, ook als de regeling waarop de subsidieverlening was gebaseerd daarover zweeg:

'Indien (...) geen wettelijke voorschriften omtrent intrekking van een begunstigende beschikking wegens het verstrekken van onjuiste of onvolledige gegevens zijn vastgesteld, kan naar het oordeel der Afdeling zodanige intrekking zonder in strijd te komen met in het algemeen rechtsbewustzijn levende beginselen van behoorlijk bestuur, met name het beginsel der rechtszekerheid, geschieden indien de juiste gegevens, waren zij eerder bekend geweest, zouden hebben geleid tot afwijzing van de desbetreffende aanvraag en de betrokkene van die onjuiste of onvolledige opgave in redelijkheid een verwijt kan worden gemaakt:.36

De door de Afdeling gegeven regel zag op het geval dat de subsidie-ontvanger onjuiste of onvolledige inlichtingen had gegeven. Twee punten vallen op. Intrekking was ook dan mogelijk als de betrokken regeling daarin niet voorzag. De algemene beginselen van behoorlijk bestuur moesten in het concrete geval een antwoord geven op de vraag of intrekking geoorloofd was. Voorts leek de Afdeling rechtspraak, anders dan in de sociale zekerheid, intrekking (en dus terugvordering) slechts mogelijk te achten als de betrokkene een verwijt kon worden gemaakt van het feit dat onjuiste of onvolledige inlichtingen waren gegeven. ${ }^{37}$ De Afdeling. bestuursrechtspraak stelde dit laatste vereiste niet; volgens haar gold 'in het administratieve recht reeds lang en algemeen' dat intrekking van het toekenningsbesluit in beginsel mogelijk was, als de verstrekte gegevens onjuist of onvolledig waren en een andere beslissing zou zijn genomen bij bekendheid van de juiste gegevens. ${ }^{38}$ Als sprake was van een administratieve vergissing, was intrekking van de beschikking tot subsidieverlening mogelijk als de ontvanger wist of behoorde te weten dat ten onrechte subsidieverlening plaatsvond. ${ }^{39}$ Op dit punt week de

35. De intrekking of wijziging ex nunc is geregeld in artikel 4:50; deze zal veelal leiden tot een verplichting voor het bestuursorgaan om de schade te vergoeden die de ontvanger lijdt doordat hij in vertrouwen op de subsidie anders heeft gehandeld dan hij zonder subsidie(verlening) zou hebben gedaan, artikel 4:50 lid 2.

36. ARRvS 10 mei 1979 , tB/S III, nr. 124, m. aant. tB/S. De Afdeling spreekt over het: "beginsel der rechtszekerheid', naar mijn mening bedoelt zij het vertrouwensbeginsel, zie 1.5.1.

37. Ook in de sociale zekerheid werd voor de inwerkingtreding van de WBM getist dat de betrokkene een verwijt kon worden gemaakt, maar het verwijt betrof dan het feit dát onjuiste of onvolledige inlichtingen waren verstrekt, niet dat verwijtbaar onjuiste of onvolledige inlichtingen waren verstrekt. Zie 6.4.2 en 6.4.4.2.

38. ABRvS 8 februari 2000, AB 2001, 118, m.nt. LD, JB 2000, 91, m.nt. C.L.G.F.H. A.

39. ARRvS 31 juli 1991, AB 1992, 76. Dit lijkt een algemene regel te zijn, zie ARRvS 29 februari 1988, AB 1989, 356, m.nt. onder 357 H.J. Simon. 
terugvordering van subsidies niet af van terugvordering op het terrein van de sociale zekerheid ${ }^{40}$ of het ambtenarenrecht. ${ }^{4 i}$ Wel week het hiervan af, waar het de termijnen voor terugvordering betrof; de twee- en vijfjarentermijn waren niet van toepassing. ${ }^{42}$ Dit betekende niet, dat de (intrekkings- en) terugvorderingsbevoegdheid onbegrensd was (waren), deze begrenzing vond plaats door het rechtszekerheidsbeginsel, waarbij van geval tot geval werd bekeken of dit beginsel was geschonden. ${ }^{43}$

Onder de Awb kan intrekking (of wijziging ten nadele van de ontvanger) van de beschikking tot subsidieverlening, geschieden zolang de subsidie niet is vastgesteld (artikel 4:48 lid 1 aanhef). Gronden voor intrekking zijn het niet verrichten van de activiteit, het niet voldoen aan de verplichtingen, het feit dat de ontvanger bij de aanvraag onjuiste of onvolledige inlichtingen heeft gegeven of het feit dat een administratieve vergissing heeft plaatsgevonden en de subsidieontvanger dit wist of behoorde te weten (artikel 4:48 lid 1). ${ }^{44}$ Intrekking van de beschikking tot subsidievaststelling is mogelijk indien de vaststelling onjuist was en de ontvanger dit wist of behoorde te weten of indien de ontvanger na de vaststelling niet aan de verplichtingen heeft voldaan (artikel 4:49 lid 1 aanhef en onder b en c). Daarnaast kan de subsidievaststelling worden ingetrokken op grond van feiten of omstandigheden waarvan het bestuursorgaan bij de vaststelling redelijkerwijs niet op de hoogte kon zijn en op grond waarvan de subsidie lager dan overeenkomstig de verlening zou zijn vastgesteld (artikel 4:49 lid 1 aanhef en onder a). Het bestuursorgaan zal dus bij de vaststelling goed moeten opletten; ziet het iets over het hoofd dat op de vaststelling van invloed is en waarvan het redelijkerwijs op de hoogte had kunnen zijn, dan kan dat feit later geen reden zijn voor intrekking van de beschikking tot vaststelling. Artikel 4:49 lid 3 bepaalt dat geen intrekking van de vaststelling kan plaatsvinden indien vijf jaren zijn verstreken sedert de dag waarop zij is bekendgemaakt. Wordt de vaststelling op grond van artikel 4:49 lid 1 aanhef en onder $c$ ingetrokken, dan vangt deze vijfjarentermijn aan op de dag waarop de handeling in strijd met de verplichting is verricht of de dag waarop aan de verplichting had moeten worden voldaan.

Ten slotte geeft artikel 4:57 een regel met betrekking tot de terugvordering:

'Onverschuldigd betalde subsidiebedragen en voorschotten kunnen worden teruggevorderd voor zover na de dag wasrop de subsidie is vastgesteld, dan wel de handeling als bedoeld in artikel $4: 49$, eerste lid, onderdeel c, heeft plaatsgevonden, nog geen vijf jaren zijn verstreken".

40. Althans voor de inwerkingtreding van de WBM. Zie 6.4.4.3 en 6.4.5.2.

41. Zie 7.2 .3 .3 en 7.2 .4 .2 .

42. Zie over deze termijnen in het socialezekerheidsrecht 6.4.4.4 en in het ambtenarenrecht 7.2.4.2.

43. Zie onder meer ABRvS 4 april 2000, AB 2000, 250, m.nt. NV, waarin de Afdeling niet wilde anticiperen op de (hierna te bespreken) regeling in de subsidietitel in de Awb.

44. Artikel 4:48 lid 1 aanhef en onder e noemt nog het geval dat een beroep wordt gedaan op het zogenaamde begrotingsvoorbehoud. Zie over dit voorbehoud onder andere Verheij/Lubberdink (1996), blz 52-54. 
Dit artikel vormt, anders dan men kan denken, niet de (publiekrechtelijke) bevoegdheidsgrondslag voor de terugvordering, zie 8.2.5. In het voorontwerp van de vierde tranche Awb wordt dan ook de volgende wijziging van het artikel voorgesteld:

१. Het bestuursorgaan kan teveel betaalde subsidiebedragen terugvorderen.

2. Het bestuursorgaan kan het terug te vorderen bedrag bij dwangbevel invorderen.

3. Terugvordering van een subsidiebedrag of een voorschot vindt niet plaats voorzover na de dag waarop de subsidie is vastgesteld, dan wel de handeling, bedoeld in artikel $4: 49$, eerste lid, onderdeel c, heef plaatsgevonden, vijf jaren zijn verstreken'.

Hiermee wordt beoogd artikel 4:57 wel een dergelijke grondslag te laten bieden. Ik zal hierop ingaan in 8.2.6.

\subsubsection{Commentaar op de regeling}

Op het eerste gezicht vormt de hiervoor beschreven regeling een logisch geheel. Bij nadere beschouwing moet worden geconcludeerd dat vooral de verhouding tussen de subsidieverlening en de subsidievaststelling onvoldoende is doordacht.

De regeling beoogt een onderscheid te maken tussen de subsidieverlening en de subsidievaststelling, maar dit onderscheid wordt bij de intrekking niet in het oog gehouden. Dit heeft ertoe geleid, dat eventuele fouten bij de verlening nog kunnen worden gecorrigeerd bij de vaststelling, terwijl omstandigheden die slechts bij de subsidievaststelling een rol mogen spelen aanleiding kunnen zijn om de subsidieverlening aan te tasten. Zo geeft artikel 4:46 lid 2 een aantal gronden om de subsidie lager vast te stellen dan bij de verlening is aangegeven. Dezelfde gronden kunnen (zolang de subsidie niet is vastgesteld) reden zijn de subsidieverlening in te trekken, zie artikel 4:48. Het betreft de volgende gronden: de te subsidiëren activiteit vindt niet plaats; de subsidie-ontvanger heeft niet aan de verplichtingen voldaan; de subsidie-ontvanger heeft onjuiste of onvolledige inlichtingen verstrekt, terwijl verstrekking van de juiste of volledige gegevens tot een andere beschikking tot verlening had geleid en ten slotte: de subsidieverlening was anderszins onjuist en de subsidie-ontvanger wist dit of behoorde dit te weten. Deze gronden zouden niet - alternatief - tot zowel intrekking van de subsidieverlening als tot het lager vaststellen van de subsidie moeten kunnen leiden. Er moet een onderscheid worden gemaakt tussen gronden, die zouden hebben geleid tot een andere beschikking omtrent subsidieverlening en gronden, die pas na de subsidieverlening spelen. Tot de eerste behoren het feit dat de aanvrager onjuiste of onvolledige inlichtingen heeft verstrekt en het feit dat de subsidieverlening anderszins onjuist was en de ontvanger dit wist of behoorde te weten. In deze gevallen is de beschikking tot subsidieverlening gebrekkig en deze gronden zouden dan ook enkel tot aantasting van die beschikking moeten kunnen leiden. Het feit dat de activiteit niet wordt verricht of dat niet aan de verplichtingen wordt voldaan, kan bij de beslissing op de aanvraag tot subsidieverlening geen rol spelen: 
dit zijn vereisten die eerst door de subsidieverlening ontstaan. ${ }^{45} \mathrm{Zij}$ zouden dan ook niet tot intrekking van de beschikking tot subsidieverlening moeten kunnen leiden; aan die beschikking kleeft immers geen gebrek. Deze feiten dienen slechts te (kunnen) leiden tot lagere vaststelling, eventueel op nihil. ${ }^{46,47}$

Volgens de memorie van toelichting krijgt de ontvanger door de vaststelling een definitief recht op financiële middelen. De vaststelling betekent dan ook een afsluiting van de subsidieverhouding. De toelichting stelt vervolgens dat na de vaststelling de subsidieverlening is uitgewerkt en daardoor haar betekenis verliest. Dit zou onder meer blijken uit de regeling van de intrekking, nu na vaststelling intrekking van de verlening niet meer mogelijk is. ${ }^{48}$ Dat de subsidieverlening door de vaststelling is uitgewerkt en haar betekenis verliest, lijkt mij niet geheel correct. Op grond van artikel 4:49 is immers intrekking van de beschikking tot vaststelling onder meer mogelijk op grond van feiten of omstandigheden waarvan het bestuursorgaan bij de subsidievaststelling redelijkerwijs niet op de hoogte kon zijn en op grond waarvan de subsidie lager dan overeenkomstig de subsidieverlening zou zijn vastgesteld (artikel 4:49 lid 1 aanhef en onder a). Het kan voorkomen dat eerst na de vaststelling blijkt dat de ontvanger de verplichtingen, neergelegd in de beschikking tot subsidieverflening, niêt is nagekomen, terwijl dit bij de vaststelling niet bekend kon zijn, bijvoorbeeld omdat de betrokkene onjuiste of onvolledige inlichtingen heeft gegeven. In dat geval kan de subsidievaststelling dus worden aangetast omdat niet is voldaan aan de bij de subsidieverlening gestelde voorschriften. De beschikking tot subsidieverlening heeft dan niet haar betekenis verloren. Hetzelfde geldt bij de intrekkingsgrond genoend in artikel 4:49 lid 1 aanhef en onder b: de subsidievaststelling was onjuist en de ontvanger wist dit of behoorde dit te weten. Uit de memorie van toelichting blijkt dat hierbij kan worden gedacht aan een kennelijke onjuistheid van de vaststelling. De memorie geeft het voorbeeld dat bij de vaststelling een rekenfout is gemaakt. ${ }^{49}$ Hierbij zal ook de beschikking tot subsidieverlening een rol kunnen spelen, bijvoorbeeld indien in deze beschikking de berekeningswijze is neergelegd.

Intrekking van de subsidieverlening is niet meer mogelijk nadat de vaststelling heeft plaatsgevonden. ${ }^{50}$ De reden hiervoor is volgens de memorie van toelichting dat de intrekking dan geen zin meer heeft, "omdat daardoor de uit de

45. Uiteraard kan het wel zo zijn, dat reeds bij de aanvraag duidelijk is dat de activiteit niet zal worden verricht. In dat geval zal geen subsidie mogen worden verleend, zie artikel 4:35 lid 1. Blijkt pas achteraf - dus na de verlening - dat de activiteit niet zal worden verricht, dan is dit reden om tot lagere vaststelling, meestal op nihil, over te gaan.

46. Vgl. CBB 9 november 1999, AB 2000, 233, m.nt. JHvdV.

47. Artikel $4: 48$ kent voorts, als intrekkingsgrond het feit dat een beroep wordt gedaan op het zogenaamde begrotingsvoorbehoud. Een beroep op dit voorbehoud zou logischerwijs ook niet moeten kunnen leiden tot intrekking van de subsidieverlening, maar zou moeten leiden tot een lagere vaststelling. De verlening was immers terecht, aan die beschikking kleeft geen gebrek.

48. PG Awb III, blz. 170.

49. PG Awb III, blz. 246-247.

50. Zie artikel 4:48 lid 1 aanhef en de memorie van toelichting, PG Awb III, blz. 170, 173 en 245. 
vaststelling voortvloeiende aanspraak op financiēle middelen niet wordt aangetast'. Het mag zo zijn dat de aanspraak op financiële middelen door de enkele intrekking van de beschikking tot subsidieverlening niet wordt aangetast, toch is intrekking van deze beschikking niet zinloos. Door intrekking van die beschikking staat immers vast dat de subsidieverlening niet had mogen plaatsvinden, althans dat de beschikking anders had moeten luiden; de verlening was immers gebrekkig. Het feit dat de aanspraak op financiēle middelen blijft bestaan zolang de subsidievaststelling in stand blijft, kan eenvoudig worden opgelost. Bij de gronden voor intrekking van de vaststelling in artikel 4:49 zou als grond kunnen worden toegevoegd, dat de beschikking tot subsidieverlening is ingetrokken op een van de gronden genoemd in artikel 4:48 lid $1 .^{52}$

Momenteel bindt slechts artikel 4:49 de mogelijkheid van intrekking - in dit geval van de vaststelling - aan een termijn. Lid 3 bepaalt dat de subsidievaststelling niet meer kan worden ingetrokken als meer dan vijf jaar zijn verstreken na de dag van bekendmaking. ${ }^{53}$ De intrekking van de subsidieverlening is niet aan een wettelijke termijn gebonden. Gelet op het voorgaande zou ook hier een wettelijke termijn moeten komen. Voorts zou ook bij de intrekking van de subsidieverlening en van de subsidievaststelling een onderscheid moeten worden gemaakt tussen de tweejaren- en de vijfjarentermijn, waarbij naar mijn mening de laakbaarheid aan de kant van de betrokkene een rol dient te spelen bij de vraag welke termijn in een concreet geval geldt. Ik zal dit uitwerken in 10.4.2. ${ }^{54}$

Dit leidt er toe, dat ook artikel 4:57 moet worden gewijzigd. Dit artikel bepaalt onder meer dat onverschuldigd betaalde subsidiebedragen en voorschotten kunnen worden teruggevorderd gedurende vijf jaar na de dag van de vaststelling. De vraag is of uit dit artikel de conclusie moet worden getrokken dat altijd een vaststelling nodig is of dat, wanneer geen vaststelling heeft plaatsgevonden, er geen wettelijke beperking aan de terugvorderingstermijn is gesteld. Zo zal bijvoorbeeld bij intrekking van de verlening, waarbij voorschotten zijn verleend, op grond van artikel 4:57 geen termijn voor de terugvordering gelden; er heeft immers geen vaststelling plaatsgevonden en dus geldt de vijfjarentermijn niet. Dit is ongewenst. Dit probleem blijft spelen onder de voorgestelde nieuwe tekst van artikel 4:57; lid 3, waarin de vijfjarentermijn is opgenomen, is immers alleen van toepassing op de vaststelling.

Het is overigens de vraag of het intrekken van de vaststellingsbeschikking aan een termijn moeten worden gebonden, als voorafgaand aan die intrekking de be-

51. PG Awb III, blz. 245. Zie ook blz. 173.

52. Waarbij artikel 4:48 lid 1 dan zodanig dient te worden gewijzigd, dat slechts de gronden genoemd onder $\mathrm{c}$ en $\mathbf{d}$ kunnen leiden tot intrekking van de subsidieverlening.

53. Wordt een verplichting, opgelegd bij de vaststelling niet nagekomen, dan begint de vijfjarentermijn te lopen op de dag waarop in strijd met de verplichting wordt gehandeld of waarop aan de verplichting had moeten worden voldaan.

54. Ook Hazewindus (1992), blz. 77, pleit voor een onderscheid in een tweejarentermijn en een vijfjarentermijn, zie ook zijn voorstel voor wijziging van de tekst van artikel 4.2.6.2, derde lid, nu artikel $4: 49$ lid 3, op blz. 81 . Hij betrekt dit echter slechts op de vaststelling. 
schikking tot subsidieverlening is ingetrokken. Mij lijkt dat onnodig in een dergelijk geval, nu immers de bevoegdheid tot het intrekken van de subsidieverlening aan een termijn is gebonden. Kan de beschikking tot verlening niet meer worden ingetrokken omdat de termijn daarvoor is verstreken, dan moet het ook niet meer mogelijk zijn om de vaststelling in te trekken, althans niet op de grond dat ten onrechte subsidie is verleend. Intrekking van de vaststelling op andere gronden, bijvoorbeeld dat verplichtingen niet zijn nagekomen, moet uiteraard wel mogelijk blijven.

\subsubsection{Huursubsidie}

In deze paragraaf zal ik de (hoofdlijnen van de regeling van) ${ }^{55}$ huursubsidie bespreken. Deze 'subsidie' valt niet onder de definitie van subsidie zoals gegeven in artikel 4:21 lid 1 Awb. Het gevolg is dat de subsidietitel uit de Awb niet van toepassing is op huursubsidies. ${ }^{56}$ Aan de orde zal komen de Huursubsidiewet (HSW). Tevens zal ik ingaan op de voorloper van deze wet, de Wet individuele huursubsidie (IHS). ${ }^{57}$ Deze verving in 1986 de Beschikking individuele huursubsidie, ${ }^{58}$ een ministerie̋le regeling die het beleid met betrekking tot huursubsidie bevatte. Deze regeling werd als grondslag voor individuele huursubsidie als te wankel ervaren, mede gelet op het grote aantal huurders dat een beroep op de Beschikking deed. ${ }^{59}$

Huursubsidie kan worden omschreven als een bijdrage uit 's Rijks kas ter tegemoetkoming in de kosten, verbonden aan het genot van de woning, zo bleek uit artikel 2 lid 1 IHS. De vraag of iemand in aanmerking kwam voor huursubsidie was onder andere afhankelijk van de huurprijs van de woning en het inkomen van de subsidie-ontvanger en bepaalde andere personen.

$\mathrm{Om}$ in aanmerking te komen voor huursubsidie - de wet sprak over een 'bijdrage' - moest de huurder een aanvraag indienen bij burgemeester en wethouders van de gemeente waarin de woning was gelegen (artikelen 26 en 27 IHS). De subsidie werd verstrekt door de minister van VROM (artikel 28 IHS), in beginsel voor een tijdvak van een jaar, aanvangende op 1 juli (artikel 2 lid 5 IHS). Het tijdvak liep normaal van 1 juli tot en met 30 juni van het daarop volgende jaar.

55. Zo zal ik bijvoorbeeld niet ingaan op de zogenaamde huurmatiging, waarbij de wet de mogelijkheid biedt om de huursubsidie maandelijks in de vorm van een voorschot rechtstreeks aan de verhuurder of de betrokken gemeente te betalen, waarbij deze voorschotten achteraf worden verrekend met de aan de huurder uit te betalen huursubsidie.

56. Dit wordt nog eens bevestigd in artikel 7 lid 3 Huursubsidiewet. Zie ook 8.1.

57. Wet van 2 mei 1986, houdende regelen omtrent het aan huurders van een woning verstrekken van bijdragen (Wet individuele huursubsidie), Stb. 265. Een belangrijke wijziging vond plaats in 1990 , Wet van 27 juni 1990, tot wijziging van de Wet individuele huursubsidie ter verbetering op onderdelen van de mogelijkheden tot een zo doelmatig mogelijke uitvoering van die wet, Stb. 326.

58. Stert. 1975, 63.

59. In 1984 ruim 700.000 huurders, aldus de memorie van toelichting IHS, Tweede Kamer 19831984,18539 , nr. 3, blz. 28. 
Onder meer door de keuze van dit tijdvak ontstonden problemen met betrekking tot de bepaling van het inkomen. Om deze problemen op te lossen werd er voor gekozen het in aanmerking te nemen inkomen te berekenen aan de hand van het inkomen over het aan 1 juli voorafgaande kalenderjaar (artikel 10 lid 1 IHS). Slechts indien de ontvanger aangaf een wijziging in het inkomen te verwachten van $15 \%{ }^{60}$ werd het geschatte inkomen in aanmerking genomen (artikel 10 lid 3 IHS). Als het in aanmerking te nemen inkomen na de verstrekking van de subsidie veranderde, leidde dit in beginsel niet tot wijziging van de verstrekte bijdrage. Hierop kende de wet drie uitzonderingen, namelijk als achteraf ten onrechte was uitgegaan van een geschat inkomen (artikel 10 lid 3 laatste volzin IHS), als terecht was uitgegaan van een geschat inkomen, maar de schatting niet correct was en als er niet was uitgegaan van een geschat inkomen, terwijl achteraf bleek dat dit wel had moeten gebeuren (artikel 10 lid 4 IHS). In deze gevallen kon de minister de vaststelling van de bijdrage bijstellen.

In deze drie gevallen werd formeel de wet in eerste instantie juist toegepast. Er was reden om al dan niet uit te gaan van een relevante wijziging in het inkomen. Daarnaast kon het zo zijn dat werd uitgegaan van onjuiste gegevens bij de beslissing tot verstrekking. In dat geval was de wet onjuist toegepast en kon de bijdrage opnieuw worden vastgesteld binnen vijf jaar na afloop van het tijdvak, waarvoor de bijdrage is verstrekt, aldus artikel 22 IHS. In 1990 werd daaraan toegevoegd, dat in dat geval 'mede (wordt) vastgesteld het bedrag dat betrokkene als gevolg van de nadere vaststelling aan de Staat verschuldigd is en de termijn waarbinnen betaling van het verschuldigde bedrag moet hebben plaatsgevonden'. ${ }^{61}$ De gevallen waarop artikel $22 \mathrm{zag}$, waren de gevallen waarin de subsidieontvanger onjuiste gegevens had verstrekt.

Het mag duidelijk zijn dat de hiervoor beschreven regeling - en dan vooral het al dan niet in aanmerking nemen van het geschatte inkomen - relatief vaak leidde tot nadere vaststelling of wijziging van de bijdragen en vervolgens tot tengvordering of verrekening van het eventueel te veel betaalde. Dit werd versterkt door de praktijk dat de minister in eerste instantie besliste op grond van de door de aanvrager verstrekte gegevens, zonder deze te controleren. Deze controle vond achteraf plaats. De Afdeling rechtspraak zag hierin geen aanleiding om een eventuele herziening of terugvordering onzorgvuldig te oordelen, dit mede gelet op het grote aantal beslissingen dat de minister op dit terrein moest nemen. ${ }^{62}$

De wet kende geen bepaling met betrekking tot herziening indien een adrninistratieve vergissing was begaan. Artikel $22 \mathrm{zag}$ immers op de situatie dat onjuiste gegevens waren verstrekt. Niettemin kon de toekenningsbeslissing ook worden in-

60. Dit was oorspronkelijk $25 \%$, maar bij de wetswijziging in 1990 is dit veranderd in $15 \%$, artikel I onderdeel D Wet van 27 juni 1990.

61. Artikel I onderdeel H Wet van 27 juni 1990.

62. Bijvoorbeeld Vz. ARRvS 24 maan 1988, JSV 1988, 111 en Vz. ARRvS 30 juni 1988, JSV $1989,65$. 
getrokken wanneer een administratieve vergissing was gemaakt. ${ }^{63}$

Opvallend is dat de Afdeling rechtspraak in haar uitspraken vaak aangaf dat zij het feit, dat de betrokkene door ondertekening van het aanvraagformulier zich had verbonden tot terugbetaling van het te veel betaalde, mocht achteraf blijken dat die bijdrage of een deel daarvan ten onrechte was betaald, in aanmerking nam. ${ }^{64}$ Wilde betrokkene in aanmerking komen voor een bijdrage, dan was hij verplicht een standaardformulier, dat een clausule met die inhoud bevatte, in te vullen en te ondertekenen. Betrokkene kon slechts kiezen uit het aanvragen van huursubsidie en zich daarbij binden aan de clausule of het niet aanvragen van huursubsidie; er was dan ook niet echt sprake van een keuze.

De hiervoor beschreven regeling was te ingewikkeld. Dit was een van de redenen voor de regering om in 1996 een wetsvoorstel, houdende nieuwe regels over het verstrekken van huursubsidies (Huursubsidiewet) ${ }^{65}$ in te dienen. Dit voorstel werd in 1997 de Huursubsidiewet. ${ }^{66}$ Volgens de considerans is het doel van deze wet onder meer vereenvoudiging van de wettelijke bepalingen. Deze vereenvoudiging vond onder meer plaats door afschaffing van het opgeven van een geschat inkomen. ${ }^{67}$ Volgens de memorie van toelichting leidde de regeling van het geschatte inkomen namelijk tot ongeveer 70.000 gevallen per jaar waarin huursubsidie moest worden teruggevorderd. ${ }^{68}$ Berekeningsgrondslag voor de financiële positie van de aanvrager is nu het 'rekeninkomen' (artikel $14 \mathrm{HSW}$ ) en het 'rekenvermogen' (artikel 15 HSW). Wat hieronder moet worden verstaan is uitgewerkt in de artikelen 3 en $4 \mathrm{HSW}$. Het in aanmerking te nemen tijdvak bij de bepaling van het inkomen is het peiljaar, het kalenderjaar dat voorafgaat aan het subsidiejaar (artikel 1 onder j HSW). Dit laatste is, evenals onder de IHS, het tijdvak dat loopt van 1 juli tot en met 30 juni (artikel 1 onder 1 HSW).

Ook onder de nieuwe wet dient de huurder een aanvraag in te dienen bij burgemeester en wethouders (artikel 28 lid 1 en lid $4 \mathrm{HSW}$ ). Vervolgens kent de minister van VROM de subsidie toe (artikel 7 lid $1 \mathrm{HSW}$ ). Subsidie wordt toegekend over het subsidietijdvak, dat in beginsel loopt van 1 juli tot en met 30 juni.

63. Althans kon niet onder alle omstandigheden de staatssecretaris de bevoegdheid worden ontzegd een besluit tot toekenning in te trekken, Vz. ARRvS 21 november 1989, JSV 1990, 8. Het betrof hier een subsidie verstrekt op basis van de Beschikking individuele huursubsidie, maar dat maakt verder geen versehil. Wel wordt de mogelijkheid tot intrekking begrensd door het vertrouwensbeginsel, door de voorzitter 'het in het algemeen rechtsbewustzijn levend beginsel van behoorlijk bestuur, dat niet te kort mag worden gedaan aan de rechtszekerheid van degene aan wie een zodanige toekenning is gedaan' genoemd. Zie ook Vz. ARRvS 24 juli 1990, JSV 1990, 237. Zie over deze terminologie 1.5.1.

64. Zie bijvoorbeeld Vz. ARRvS 24 maart 1988, JSV 1988, 111, Vz. ARRvS 30 juni 1988, JSV 1989, 65, Vz. ARRvS 21 november 1989, JSV 1990, 8, Vz. ARRvS 2 januari 1990, JSV 1990, 121, Vz. ARRvS 24 juli 1990, JSV 1990, 237.

65. Tweede Kamer 1996-1997, 25 090, nrs. 1-2.

66. Wet van 24 april 1997, Stb. 197.

67. Memorie van toelichting, Tweede Kamer 1996-1997, 25 090, nr. 3, blz. 4.

68. Tweede Kamer 1996-1997, 25 090, nr. 3, blz. 17. 
Betaling van de subsidie vindt achteraf plaats per kwartaal (artikel 31 lid 1 HSW). In artikel 33 lid $1 \mathrm{HSW}$ is een informatieplicht neergelegd: de huurder en zijn medebewoners moeten uit eigener beweging alle inlichtingen aan de minister verstrekken waarover zij redelijkerwijs kunnen beschikken en die redelijkerwijs van belang kunnen zijn voor de vaststelling van het recht op en de hoogte van de huursubsidie. Ook moeten desgevraagd gegevens worden verstrekt aan onder meer burgemeester en wethouders en de minister (artikel 33 lid 2 HSW).

De artikelen 36 en $37 \mathrm{HSW}$ bevatten regels met betrekking tot intrekking en terug-en invordering. Ten onrechte toegekende huursubsidie kan worden ingetrokken indien onjuiste of onvolledige inlichtingen zijn verstrekt en bij bekendheid van de juiste of volledige inlichtingen een ander besluit zou zijn genomen, indien de verplichting van artikel 33 lid 2 HSW niet wordt nageleefd of indien een administratieve vergissing is gemaakt en de huurder dit redelijkerwijs had kunnen begrijpen (artikel 36 lid $1 \mathrm{j}^{\circ}$ lid $2 \mathrm{HSW}$ ). Deze intrekking kan ten hoogste de vijf subsidietijdvakken betreffen, die voorafgaan aan het lopende subsidietijdvak. Het ten onrechte of te veel betaalde kan vervolgens worden teruggevorderd of verrekend (artikel 36 lid $3 \mathrm{HSW}$ ), terwijl voorts een boete kan worden opgelegd als het vraagformulier niet naar waarheid is ingevuld of als verwijtbaar niet aan de inlichtingenplicht van artikel $33 \mathrm{HSW}$ is voldaan (artikel 36 lid $4 \mathrm{HSW}$ ).

\subsubsection{Het karakter van subsidiëring en de rechtsbescherming}

Na deze korte uiteenzetting van de regels met betrekking tot huursubsidie volgt nu een bespreking van het (rechts)karakter van subsidies (zowel huursubsidie als 'gewone' subsidies). Dit (rechts)karakter is van belang bij de vraag welke rechter bevoegd is bij een conflict tussen subsidieverstrekker en -ontvanger. In 4.2 is uitgebreid ingegaan op de vraag wanneer de (algemeen aanvullende) administratieve rechter rechtsbescherming kan bieden. Daar bleek dat dit mogelijk is wanneer sprake is van - kort gezegd - een publiekrechtelijke rechtshandeling.

Na de inwerkingtreding van de subsidietitel in de Awb is met betrekking tot beslissingen omtrent subsidieverlening en -vaststelling de algernene administratieve rechter bevoegd, tenzij de wettelijke regeling die de grondslag biedt voor de subsidiëring anders bepaalt. Er is immers sprake van een beschikking - en dus ook een besluit - in de zin van de Awb. Voor de inwerkingtreding van de Awb was dat vaak anders. De vraag of rechtsbescherming open stond tegen beslissingen omtrent subsidies, diende allereerst te worden bekeken aan de hand van de regeling waarop de subsidie was gebaseerd. Gebleken is echter dat in het verleden vaak geen wettelijke grondslag voor subsidiëring aanwezig was. In die gevallen was ook niets geregeld met betrekking tot rechtsbescherming. Subsidiëring werd in die gevallen gezien als een gunst, en niet als een plicht van de overheid. Ook indien de subsidiëring wel berustte op een wettelijke grondslag, wilde dit niet zeggen dat ook een regeling met betrekking tot rechtsbescherming was gegeven.

Normaal zou in dat laatste geval sedert 1963 de aanvullende regeling van de Wet bab van toepassing zijn, althans voor wat betreft subsidiebeslissingen van de centrale overheid. Artikel 5 aanhef en onder $\mathbf{k}$ Wet bab sloot dit echter groten- 
deels uit; op grond van die bepaling stond geen voorziening open tegen "beschikkingen tot het toekennen of weigeren van geldelijke uitkeringen onder de naam tegemoetkoming, subsidie, garantie, crediet of hoe dan ook, tenzij zowel de verschuldigdheid als de hoogte van het verschuldigde bedrag bij of krachtens een algemeen verbindend voorschrift zijn bepaald'. Volgens de memorie van toelichting was het 'reeds om redenen van kwantitatieve aard' onwenselijk beroep open te stellen op grond van de Wet bab tegen deze beschikkingen. Verder leende een aantal vraagstukken, dat zich zou kunnen voordoen bij beroep, zich 'weinig voor beroep bij de Kroon' ${ }^{69}$ Wel was beroep mogelijk indien het om een gebonden subsidiebeschikking ging, indien de wettelijke regeling zowel het recht op subsidie als de hoogte ervan bepaalde. Artikel 5 aanhef en onder k Wet bab leidde ertoe, dat de (beoogde) subsidie-ontvanger de weg naar de burgerlijke rechter diende te volgen indien hij het niet eens was met een beslissing omtrent subsidiëring.

Dat dit niet als wenselijk werd gezien, blijkt uit de parlementaire geschiedenis van de Wet arob. In het regeringsontwerp was de uitsluiting van subsidiebeslissingen uit de Wet bab overgenomen. Reeds de Raad van State adviseerde deze uitsluiting te schrappen, nu de 'behoefte aan een rechterlijke controle hier steeds dringender (wordt) gevoeld, gelet op de uitbreiding van het overheidsoptreden ook op dit terrein'. ${ }^{70}$ Dit standpunt werd overgenomen door de Tweede Kamer. ${ }^{71}$ De regering stelde zich echter op het standpunt dat het van toepassing verklaren van het rechtsbeschermingsregime van de Wet arob voorshands te bezwaarlijk was, gelet op de grote verscheidenheid van subsidies en ook van de daaraan gekoppelde bevoegdheden. ${ }^{72}$ De kamer vond dit niet overtuigend en nam een amendement aan, ${ }^{73}$ waardoor de uitsluiting van subsidiebeschikkingen werd geschrapt. ${ }^{74}$

Dit betekende dat de Afdeling rechtspraak bevoegd was te oordelen over beslissingen met betrekking tot subsidies, mits geen andere rechter was aangewezen. als bevoegde rechter en mits sprake was van een beschikking, waarbij van belang was dat geen sprake mocht zijn van een rechtshandeling naar burgerlijk recht.

De vraag of dit laatste het geval was, heeft geleid tot de nodige rechtspraak. Financiële steun kan namelijk zowel via een subsidiebeschikking als via een overeenkomst worden verleend. De Afdeling rechtspraak nam bij subsidiebeslissingen in verreweg de meeste gevallen een beschikking aan, waarbij zij herhaaldelijk. verwees naar de parlementaire geschiedenis van de Wet arob; de wetgever wilde kennelijk dat een voorziening op grond van de Wet arob kon worden gevraagd tegen subsidiebeslissingen. ${ }^{75}$ Voor het aannemen van een beschikking was niet vereist dat er een expliciete wettelijke grondslag aanwezig was voor het besluit, wel

69. Tweede Kamer 1958-1959, 5363, nr. 3, blz. 14.

70. $\mathrm{PG}$ arob, blz. 177.

71. Zie onder meer het voorlopig verslag, PGi arob, blz. 180-181.

72. $P G$ arob, blz. 185 .

73. Gewijzigd amendement W. Scholten c.s., PG arob, blz. 188.

74. PG arob, blz, 192.

75. Zie bijvoorbeeld ARRvS 29 juni 1977 , tB/S V, blz, 73, m. aant. tB/S. Zie voorts Michicls (1987), blz. 152 en Verheij/Lubberdink (1996), blz. 75. 
moest het besluit zijn genomen in het kader van een publiekrechtelijke taak. ${ }^{76}$

Werd de subsidie in een duidelijk privaatrechtelijke jas gekleed, bijvoorbeeld in de vorm van een borgtochtovereenkomst, dan wilde de Afdeling rechtspraak nog wel eens een rechtshandeling naar burgerlijk recht aannemen. Echt duidelijk en eenduidig is die jurisprudentie niet. In een aantal gevallen keek de Afdeling door de privaatrechtelijke vorm heen en nam zij een beschikking aan, ${ }^{n}$ in andere gevallen deed zij dit niet. ${ }^{78}$ In eerste instantie veranderde dit niet met de inwerkingtreding van de Awb. De inwerkingtreding van de subsidietitel daarentegen leidde wel tot een belangrijke wijziging. Artikel 4:36 Awb bevat namelijk een regeling met betrekking tot subsidie-overeenkomsten. Het eerste lid van dit artikel bepaalt dat ter uitvoering van de beschikking tot subsidieverlening een overeenkomst kan worden gesloten. Het betreft hier een zogenaamde uitvoeringsovereenkomst. Er wordt in dit artikel niets expliciet geregeld met betrekking tot de zogenaamde beschikkingsvervangende overeenkomst, een overeenkomst die in plaats komt van een beschikking tot subsidieverlening. ${ }^{79}$ In het voorontwerp was dit nog wel het geval. Artikel 4.2.3.8, de 'voorloper' van artikel 4:36, bepaalde dat indien in plaats van een beschikking omtrent subsidieverlening een overeenkomst omtrent subsidieverlening werd gesloten, de titels 4.1 (over beschikkingen) en 4.2 (over subsidies) van overeenkomstige toepassing waren. Dit artikel was ingegeven door het feit dat bestuursorganen in de praktijk een voorkeur hebben voor het sluiten van een overeenkomst en wel om twee redenen: de subsidieverlening kan naar haar inhoud elementen bevatten die men gewend is bij overeenkomst te regelen en een overeenkomst biedt de mogelijkheid nakoming van de verplichtingen van de subsidie-ontvanger af te dwingen. Volgens de Raad van State kon dit ook worden bereikt door een uitvoeringsovereenkomst.

De wetgever nam deze visie over. Volgens de memorie van toelichting bestaat naast de uitvoeringsovereenkomst niet of nawwelijks behoefte aan de figuur van de beschikkingsvervangende subsidie-overeenkomst. ${ }^{80}$ In een artikel in het NJB gingen De Groot, Van der Meulen en Van Rossum nog verder. Zij stelden dat subsidieverlening in de vorm van een overeenkomst de voorgeschreven publiekrechtelijke weg doorkruist en daarom niet toelaatbaar is. ${ }^{81}$ Vervolgens werden hierover vragen gesteld in de Tweede Kamer. ${ }^{82}$ In eerste instantie antwoordde de regering dat een dergelijke overeenkomst in beginsel als doorkruising van de subsidieregeling moet worden beschouwd, ${ }^{83}$ later stelde (regeringscom-

76. Praktijkboek, Bestuursrecht (Van der Vlies), blz. IX-12.

77. Bijvoorbeeld ARRvS 29 juni 1977, tB/S V, blz. 73, m. sant. tB/S.

78. Bijvoorbeeld ARRvS 31 juli 1984, tB/S V, nr. 352, m. aant. B. Zie voor een overzicht van de jurisprudentie met betrekking tot deze materie Michiels (198.7), blz. 153-158 en Praktijkboek Bestuursrecht (Van der Vlies), blz. IX-12-14.

79. Verheij/Lubberdink (1996), blz 76.

80. Zie hierover PG Awb III, blz. $172-173$ en 224.

81. De GrootiVan der Meulen/Van Rossum (1994), blz. 1193.

82. PG Awb III, blz. 176.

83. PG Awb III, blz. 178. 
missaris) Scheltema dat de woorden 'in beginsel' kunnen worden weggelaten; het bij overeenkomst toekennen van subsidies vormt een doorkruising van de regeling in de Awb. ${ }^{24}$ Subsidieverlening via de privaatrechtelijke weg is dus niet meer toegelaten; beslissingen met betrekking tot subsidiëring zijn besluiten. Dit betekent dat altijd een bestuursrechter competent is te oordelen over deze besluiten.

\subsubsection{Terugvordering}

Voor de inwerkingtreding van de subsidietitel in de Awb werden beslissingen met betrekking tot subsidiëring veelal gezien als beschikkingen. Slechts bij een duidelijke privaatrechtelijke vorm wilde de Afdeling rechtspraak wel eens een rechtshandeling naar burgerlijk recht aannemen.

Als subsidiëring geschiedde door middel van een beschikking, dan kon (zoals we in 8.2.2.4 hebben gezien) deze beschikking achteraf worden ingetrokken, zelfs als de (eventuele) regeling hieromtrent niets regelde. Wel diende deze intrekking te worden getoetst aan de algemene beginselen van behoorlijk bestuur.

Had het bestuursorgaan de subsidie reeds betaald, dan kon zij het eventueel te veel of ten onrechte betaalde terugvorderen nadat de toekenningsbeslissing was ingetrokken. ${ }^{85}$ Deze terugvordering werd echter niet gezien als een beschikking, maar als een rechtshandeling naar burgerlijk recht. ${ }^{86}$ Een enkele keer werd het terugvorderingsbesluit wel als beschikking gezien. ${ }^{87}$ In dat geval was echter geen intrekkingsbeschikking genomen, zodat de terugvordering impliciet werd opgevat als intrekkingsbeschikking. ${ }^{88}$ Normaal gesproken zag de Afdeling rechtspraak de beslissing tot terugvordering - zolang deze niet tevens (impliciet) de intrekkingsbeslissing bevatte - als rechtshandeling naar burgerlijk recht, waarover dus de burgerlijke rechter diende te oordelen en niet de Afdeling rechtspraak.

De memorie van toelichting bij het wetsontwerp voltooiing eerste fase herziening rechterlijke macht uit 1992 gaf echter duidelijk aan dat deze terugvorderingsbeslissingen ook konden worden gezien als besluiten in de zin van artikel 1:3 Awb. ${ }^{89}$ Twee jaar later, in 1994, stelde de regering in de toelichting op artikel 4.2.7.6 (uiteindelijk artikel 4:57) Awb betreffende de terugvordering van onverschuldigd betaalde subsidiebedragen en voorschotten dat de terugvordering dient te geschieden 'langs de normale weg', en wel door het instellen van een vordering bij de burgerlijke rechter. Ook is verrekening met voor een volgend tijdvak toegekende subsidie of voorschot mogelijk. ${ }^{90}$ Uit dit laatste zou kunnen worden afgeleid, dat de regering hier het oog heeft op de invordering. Dat is echter niet het

84. PG Awb III, blz. 182.

85. Ook kon de subsidie lager worden vastgesteld; m.m. geldt dan hetzelfde.

86. Bijvoorbeeld Wnd. Vz. ARRvS 31 december 1982, tB/S V, nr. 290, m. aant. tB/S, Vz. ARRvS 5 december 1990, AB 1991, 568, m.nt. AFMB, ARRvS 1 maart 1990, JSV 1990, 101.

87. Zie bijvoorbeeld ARRvS 20 december 1981, tB/S V, blz. 1045 (aantekening 2 bij nr. 258).

88. Zie de noot van Ten Berge en Stroink onder Vz. ARRvS 18 februari 1982, tB/S V, nr. 258.

89. Tweede Kamer 1991-1992, 22 495, nr. 3, blz. 246. Zie ook 4.2.3.

90. PG Awb III, blz. 255. 
geval; zij bedoelt de terugvordering. Hieruit volgt dat artikel 4:57 niet de publiekrechtelijke bevoegdheidsgrondslag voor terugvordering vormt; de terugvordering geschiedt immers door het instellen van een vordering voor de burgerlijke rechter. Het is dus een rechtshandeling naar burgerlijk recht. ${ }^{91}$ In 8.2.2.4 heb ik reeds angegeven, dat in het voorontwerp van de vierde tranche Awb wordt voorgesteld artikel 4:57 Awb te wijzigen. Ik zal hierop ingaan in de volgende paragraaf.

\subsubsection{Afdeling bestuursrechtspraak Raad van State 21 oktober 1996}

In eerste instantie bleef de Afdeling bestuursrechtspraak met betrekking tot de terugvordering van subsidies de lijn volgen van de Afdeling rechtspraak: ontbrak een uitdrukkelijke wettelijke grondslag, dan was sprake van een rechtshandeling naar burgerlijk recht. Een enkele keer leek een rechtbank een andere koers te varen, zoals de Rechtbank Amhem in 1995, ${ }^{92}$ die zich - impliciet - bevoegd leek te achten te oordelen over de terugvorderingsbeslissing, hetgeen dan dus geen rechtshandeling naar burgerlijk recht was, maar een besluit. ${ }^{93}$ In hoger beroep besteedde de Afdeling bestuursrechtspraak een overweging ten overvloede aan de vraag of de terugvorderingsbeslissing een besluit was: ${ }^{94}$ bezwaren tegen terugvordering staan niet ter beoordeling van de bestuursrechter en de weigering om een deel van de vordering kwijt te schelden is dan ook een weigering een rechtshandeling naar burgerlijk recht te verrichten. ${ }^{95}$

Ongeveer een jaar later, op 21 oktober 1996, ging de Afdeling bestuursrechtspraak echter uitdrukkelijk om: terugvorderingsbeslissingen zijn besluiten in de zin van artikel 1:3 Awb en dus geen rechtshandelingen naar burgerlijk recht. ${ }^{96}$

Nanne kreeg op grond van de Beschikking geldelijke steun eigen woningen $1979^{97}$ een jaarlijkse bijdrage van de staatssecretaris van VROM. Artikel 9 van deze beschikking bepaalde dat '(d)e jaarlijkse bijdrage wordt verstrekt onder de voorwaarde, dat de begunstigde de woning van de aanvang der eerste bewoning af als eigenaar zal bewonen'. Op grond van artikel 28 lid 1 verviel de bijdrage onder meer indien de eigendom van de woning overging. Eventueel kon de minister van VROM van deze regel afwijken (artikel 28 lid 2). Daar Nanne niet meer voldeed aan dit eigenaarsvereiste, trok de staatssecretaris bij besluit van 14 maart 1993 de jaarlijkse steun met ingang van 11 september 1992 in, welk besluit de staatssecretaris later wijzigde in die zin, dat de intrekking plaatsvond met ingang van

91. Zie hierover Simon/Bok (1997), blz. 86-88.

92. Rb. Amhem 1 februari 1995, JB 1995, 128, m.nt. F.A.M. S.

93. Zie cok de noot van Stroink onder de uitspraak in de JB.

94. De beslissing van de rechthank was reeds op een andere grond vernietigd.

95. ABRvS 2 november 1995, JB 1995, 333, m.nt. F.A.M. S. Stroink spreeitt in zijn noot over een 'betreurenswaardige uitspraak'. Hij bestrijdt dit deel van de uitspraak dan ook, naar mijn mening op goede gronden.

96. ABRvS 21 oktober 1996, AB 1996, 496, m.nt. NV, JB 1996, 232, m.nt. HJS (Nanne).

97. Stert. 1979, 76. 
september 1991. De te veel betaalde bijdrage vorderde de staatssecretaris terug. Nanne stelde tegen onder meer de terugvordering beroep in.

Volgens de rechtbank was deze terugvorderingsbeslissing geen besluit in de zin van artikel 1:3 Awb, zodat de staatssecretaris het bezwaar van Nanne op dit punt niet-ontvankelijk had moeten verklaren. De rechtbank verklaarde dan ook het bezwaar alsnog niet-ontvankelijk. In de uitspraak op het beroep gaat de Afdeling bestuursrechtspraak uitgebreid in op het rechtskarakter van de terugvorderingsbeslissing. Gezien het belang van de uitspraak citeer ik de Afdeling uitgebreid:

'De Afdeling ziet zich (...) geplaatst voor de vraag naar het rechtskarakter en de beroepbaarheid bij de bestuursrechter van besluiten van bestuursorganen tot terugvordering van eerder door hen in het kader van de uitoefening van hun bestuursrechtelijke taken en bevoegdheden gedane toekenningen.

De Afdeling oordeelt dienaangaande thans, anders dan zij in het verleden heeft gedaan, dat terugvorderingsbesluiten van bestuursorganen als in de vorige alinea omschreven, ook indien deze niet op uitdrukkelijk daartoe strekkende wettelijke bevoegdheden zijn gebaseerd, zijn gericht op rechtsgevolg. Dit rechtsgevolg wordt ontleend aan het algemene, ook in het bestuursrecht geldende, rechtsbeginsel volgens hetwelk hetgeen onverschuldigd is betaald, kan worden teruggevorderd.

Dit rechtsbeginsel is van bestuursrechtelijke aard, wanneer zijn werking zich doet gevoelen in door het bestuursrecht beheerste verhoudingen. Voor bestuursorganen schept het dan een bevoegdheid ontrent de aanwending waarvan per geval beslist moet worden met inachtneming van de algemene bestursrechtelijke normen die de aanwending van discretionaire bevoegdheden beheersen. Zo een beslissing, die strekt tot voldoening aan de bestuursrechtelijke voorwaarden voor een rechtmatige terugvordering, opdat naar het bestuursrecht een betalingsverplichting ontstaat, is gericht op publiekrechtelijk rechtsgevolg'.

Volgens de Afdeling zijn terugvorderingsbesluiten gericht op rechtsgevolg; er is dus sprake van een rechtshandeling. Dit rechtsgevolg wordt ontleend aan het algemene rechtsbeginsel, volgens hetwelk hetgeen onverschuldigd is betaald, kan worden teruggevorderd. Dit algemene rechtsbeginsel heeft voor het privaatrecht zijn uitwerking gevonden in de artikelen 6:203 e.v. BW. Dit beginsel kan echter ook bestuursrechtelijk van aard zijn, namelijk wanneer zijn werking zich doet gevoelen in door het bestuursrecht beheerste verhoudingen. Als dat laatste tet geval is, dan vormt het beginsel de grondslag voor de (discretionaire) bevoegdheid van het bestuursorgaan om terug te vorderen. Door het terugvorderingsbesluit ontstaat naar het bestuursrecht de betalingsverplichting voor de betrokkene. De terugvorderingsbeslissing is gericht op publiekrechtelijk rechtsgevolg; er is dan ook sprake van een publiekrechtelijke rechtshandeling en dus van een besluit in de zin van artikel 1:3 $\mathrm{Awb}$.

Terugvorderingsbeslissingen zijn dus volgens de Afdeling bestuursrechtspraak besluiten in de zin van artikel 1:3 Awb, ook als de betrokken wettelijke regeling geen uitdrukkelijke grondslag kent voor de terugvordering. Dit betekent dat op deze besluiten hoofdstuk $3 \mathrm{Awb}$, het hoofdstuk Algemene bepalingen over besluiten, van toepassing is. Hierbij zullen vooral afdeling 3.2, Zorgvuldigheid en belangenafweging, afdeling 3.6, Bekendmaking en mededeling, en afdeling 3.7, Motivering, van belang zijn. In beginsel zal cook sprake zijn van een beschikking, maar nu titel 4.1, Beschikkingen, vooral regels bevat met betrekking tot beschikkingen gegeven op anvraag, zal deze tite! in de praktijk minder van belang zijn; 
terugvorderingsbeschikkingen zullen niet vaak op aanvraag worden gegeven.

Het feit dat sprake is van een besluit wil echter niet zeggen dat deze besluiten altijd aan het oordeel van de administratieve rechter kunnen worden onderworpen. Volgens de Afdeling is deze rechter slechts bevoegd over het besluit te oordelen als is voldaan aan het vereiste van processuele connexiteit: de (algemene of bijzondere) bestuursrechter is slechts bevoegd kennis te nemen van het terugvorderingsbesluit, als dat besluit 'voortvloei( $t$ ) uit een besluit inzake een bestuursrechtelijke toekenning ter zake waarvan die rechter bevoegd is'. Dit zou volgens de Afdeling passen 'in het door de wetgever gekozen stelsel', nu blijkens de wetsgeschiedenis de wetgever heeft gestreefd 'naar een in de rechtspraktijk goed hanteerbare afbakening van bevoegdheden tot beoordeling van besluiten tussen de algemene bestuursrechter, de bijzondere bestuursrechters en de burgerlijke rechter'. De Afdeling verwijst hiervoor naar (de tekst en geschiedenis van) artikel 8:3 Awb. Doel van dat artikel was 'zoveel mogelijk te voorkomen dat binnen een samenhangende reeks van uit elkaar voortvloeiende bestuursbeslissingen een cesuur zou moeten worden aangebracht wat betreft de rechter die bevoegd is tot toetsing van de onderscheiden beslissingen'.

Vervolgens past de Afdeling deze criteria toe op de voorliggende zaak. Geheel consequent is zij daarbij niet. Overweegt zij eerst dat de bestuursrechter slechts bevoegd is als het terugvorderingsbesluit voortvloeit uit een besluit inzake een bestuursrechtelijke toekenning ter zake waarvan die rechter bevoegd is, direct hierop laat zij volgen, dat nu de rechtbank in casu bevoegd is kennis te nemen van het beroep tegen het intrekkingsbesluit, het standpunt van de staatssecretaris aangaande de terugvordering 'als een bij de rechtbank beroepbaar besluit moet worden aangemerkt'. Mij lijkt dat als samenhangende reeks van uit elkaar voortvloeiende beslissingen dient te worden gezien de toekenningsbeslissing, de intrekkingsbeslissing en de terugvorderingsbeslissing. ${ }^{98}$ Voor wat betreft het rechtskarakter van de intrekkingsbeslissing en de terugvorderingsbeslissing dient dan te worden aangesloten bij het karakter van de toekenningsbeslissing.

Een opvallend punt in de uitspraak is dat volgens de Afdeling pas door de terugvorderingsbeslissing een betalingsverplichting ontstaat. Door die beslissing ontstaat pas een afdwingbare rechtsvordering. Door de intrekkingsbeslissing staat vast dat onverschuldigd werd betaald, maar pas door de terugvorderingsbeslissing ontstaat de verplichting tot terugbetaling. Verheij stelt dan ook dat het er op lijkt dat de terugvorderingsbeslissing constitutief is voor de verplichting tot terugbetaling. ${ }^{99}$ Dit is anders dan in het privaatrecht. Daar ontstaat namelijk door het enkele feit dat onverschuldigd is betaald (en aan de overige vereisten van artikel 6:203 BW is voldaan), dus door het wegvallen van de rechtsgrond voor de betaling, een afdwingbare rechtsvordering.

De consequentie van deze uitspraak is dat de terugvorderingsbeslissing vrijwel altijd een besluit in de zin van artikel 1:3 Awb is, waarover een administratieve 
rechter bevoegd is te oordelen. Op vrijwel alle gebieden waarop de overheid eenzijdig financieel presterend optreedt zal aan deze prestatie - de betaling - een beschikking ten grondslag liggen. De belangrijkste uitzondering hierop was de subsidie-overeenkomst, maar het sluiten van een dergelijke overeenkomst in plaats van het nemen van een besluit tot subsidieverlening is sinds de inwerkingtreding van de derde tranche van de Awb niet meer toegestaan; het sluiten van een dergelijke overeenkomst is immers een doorkruising van de publiekrechtelijke weg. ${ }^{100}$

Slechts indien sprake is van een 'echte' overeenkomst, waarbij de overheid onverschuldigd heeft betaald en dit terugvordert, zal geen sprake zijn van een besluit en zal de burgerlijke rechter competent zijn over de vordering uit onverschuldigde betaling te oordelen. Te denken valt bijvoorbeeld aan de overeenkomst waarbij de overheid computers koopt. Als deze overeenkomst wordt vernietigd, bijvoorbeeld omdat sprake is van bedrog, zal de overheid bij weigering om tot terugbetaling over te gaan een vordering uit onverschuldigde betaling moeten instellen bij de burgerlijke rechter. ${ }^{101}$

Op de uitspraak van de Afdeling bestuursrechtspraak is de nodige kritiek gekomen. Het belangrijkste kritiekpunt was dat algemene rechtsbeginselen geen bevoegdheden kunnen scheppen. Dit zou in strijd zijn met het legaliteitsbeginsel. Ik ga hierop nader in in hoofdstuk 9.

Op de uitspraak waren ook positieve reacties te beluisteren. Zo acht Verheij de uitspraak zowel praktisch als principieel van grote betekenis. ${ }^{102}$ En volgens Simon vormt de uitspraak 'voor het bestuursrecht een moment van monumentaal belang', die het einde van een tijdperk - namelijk het tijdperk van de gemene rechtsleer - markeert. De administratieve rechter heeft - eindelijk - de gemene rechtsleer van de troon gestoten! ${ }^{103}$

$\mathrm{Nu}$ lijkt deze juichkreet te vroeg geslaakt. De gemene rechtsleer is een leer die in eerste instantie immers vooral door de burgerlijke rechter is toegepast. De bestuursrechter kan wel oordelen dat dit soort beslissingen besluiten zijn waarover hij dient te oordelen, ovei de competentie van de burgerlijke rechter kan hij niet oordelen. Deze bevoegdheid komt alleen de burgerlijke rechter zelf toe. Of deze uitspraak het einde van de gemene rechisleer - althans voor wat beireft terugvorderingsbesluiten - markeert, zal dus moeten blijken indien een bestuursorgaan voor de burgerlijke rechter een vordering uit onverschuldigde betaling instelt nadat het een toekenningsbeslissing heeft ingetrokken of indien een burger de burgerlijke rechter adieert met betrekking tot een terugvorderingsbeslissing. Pas als de burgerlijke rechter in die gevallen de eiser niet-ontvankelijk verklaart, ofwel omdat het bestuur terzake een (appellabel) besluit kan nemen, ofwel omdat een met voldoen-

100. Zie 8.2.4.

101. Althans naar huidig recht. Het is de vraag of dit ook zo zou moeten zijn. Deze vraag gaat echier het onderwerp van het onderzoek te buiten.

102. Zie zijn noot onder de uitspraak in AB 1996, 496.

103. Simon in zijn noot onder de uitspraak in JB 1996, 232. 
de rechtswaarborgen omklede rechtsgang openstaat of heeft opengestaan, lijkt de conclusie gerechtvaardigd, dat de gemene rechtsleer op dit punt is verlaten.

De uitspraak van de Afdeling inzake Nanne was aanleiding voor de Awb-wetgever om in het voorontwerp van de vierde tranche van de Awb vooi te stellen artikel 4:57 Awb te wijzigen. De tekst van het voorgestelde artikel 4:57 heb ik in 8.2.2.4 reeds weergegeven. Van belang is hier vooral het voorgestelde artikel 4:57 lid t, waarin staat dat het bestuursorgaan te veel betaalde subsidiebedragen kan terugvorderen. De toelichting verwijst voor deze wijziging expliciet naar de uitspraak van de Afdeling inzake Nanne en stelt dat in het licht van die uitspraak aanpassing van artikel 4:57 gewenst is. Strikt genomen laat de tekst van artikel 4:57 ruimte om terugvordering van subsidie te zien als een besluit in de zin van artikel 1:3 Awb, maar de regering had aangegeven dat dit niet de bedoeling was. ${ }^{104}$ 'Ter vermijding van misverstand wordt daarom voorgesteld om de bevoegdheid tot het terugvorderen van teveel betaalde subsidiebedragen in een nieuw eerste lid van artikel. 4:57 neer te leggen'. ${ }^{105}$ Hiermee schept het gewijzigde artikel 4:57 een wettelijke grondslag voor besluiten tot terugvordering van subsidie. ${ }^{106}$

Zoals in 4.2.3 gezegd heeft de Afdeling bestuursrechtspraak het niet bij deze uitspraak gelaten. Niet alleen het beginsel dat hetgeen onverschuldigd is betaald, kan worden teruggevorderd, is een algemeen rechtsbeginsel, ${ }^{107}$ maar ook bijvoorbeeld het beginsel dat hij die onrechtmatig handelt de daardoor veroorzaakte schade moet vergoeden. In haar uitspraak van 26 augustus 1997 voegde zij daar aan toe het beginsel dat 'hij die ongerechtvaardigd is verrijkt ten koste van een ander, verplicht is, voor zover dit redelijk is, diens schade te vergoeden tot het bedrag van zijn verrijking'. ${ }^{108}$ De casus die leidde tot deze uitspraak was in het kort de volgende. Appellant had voorschotten gekregen van de minister van VROM op grond van de Regeling saneringsprogramma verkeerslawaai. Vervolgens stelde de minister het bedrag waarop appellant recht had, lager vast dan het bedrag dat hij aan voorschotten had ontvangen en vorderde hij het verschil, ruim $f 250.000$, terug. Appellant ging hiertegen in beroep. De Afdeling overwoog dat de afrekening van de voorschotten gebaseerd was op een aantal artikelen in de regeling, die ten tijde van het nemen van dat besluit reeds waren vervallen en waarbij geen overgangsbepaling was opgenomen. Zodoende kon het bepaalde in

\footnotetext{
104. Zie PG Awb III, blz. 255. Dit is aan de orde gekomen in 8.2.5.

105. Voorontwerp Commissie-Scheltema Awb IV (1999), blz. 60.

106. Voorontwerp Commissie-Scheltema Awb IV (1999), blz 59.

107. Zoals de Afdeling bestuursrechtspraak in haar uitspraak van 10 februari 1997, AB. 1997, 427, m.nt. NV nog eens heeft herhaald.

108. ABRvS 26 augustus 1997, AB 1997, 461, m.nt. NV, JB 1997, 265, m.nt. HJS (Samenwerkingsverband Noord-Kennemerland).
} 
die artikelen geen grondslag bieden voor het besluit. ${ }^{109}$ Volgens de Afdeling bood het algemene rechtsbeginsel, dat ten grondslag ligt aan onder meer de regeling van de ongerechtvaardigde verrijking in het privaatrecht, uitkomst. Ook dit beginsel kan namelijk van bestuursrechtelijke aard zijn, namelijk wanneer het zijn werking doet gevoelen in een door het bestuursrecht beheerste verhouding.

\subsubsection{De rol van de burgerlijke rechter}

Ten slotte dient nog kort te worden ingegaan op de rol van de burgerlijke rechter, zowel in het verleden, het heden en de toekomst. Deze rechter heeft in het verleden een grote rol gespeeld bij de terugvordering van subsidies, omdat de Afdeling rechtspraak en in eerste instantie ook de Afdeling bestuursrechtspraak de terugvorderingsbeslissing meestal zagen als rechtshandeling naar burgerlijk recht, waarover de burgerlijke rechter diende te oordelen. Dit was slechts anders wanneer de terugvorderingsbeslissing (impliciet) een intrekkingsbeslissing bevatte. In de gevallen die via deze weg bij de burgerlijke rechter terecht kwamen, was de toekenningsbeslissing dus reeds ingetrokken.

Ook indien een dergelijke intrekking niet had plaatsgevonden, achtte de burgerlijke rechter de overheid ontvankelijk als deze een vordering uit onverschuldigde betaling instelde, zo blijkt uit een arrest van de Hoge Raad van 11 oktober 1985. ${ }^{110}$ De casus was de volgende. Aan Stenekes was bij beschikking een sloopuitkering toegekend op grond van de Sloopregeling Binnenvaart 1976. ${ }^{\text {II }}$ Uitbetaling van de uitkering, bijna $f 28.000$ groot, zou plaatsvinden nadat was vastgesteld dat het schip, de Avanti, was gesloopt. Deze vaststelling vond plaats door ondertekening van een sloopverklaring door Stenekes en de sloper en door doorhaling van de teboekstelling van het schip in de registers. Later bleek dat het schip niet was gesloopt. De Staat eiste vervolgens de sloopuitkering terug, hetgeen Stenekes weigerde. Vervolgens dagvaardde de Staat hem voor de burgerlijke rechter met een (primaire) vordering uit onverschuldigde betaling, nu de voorwaarde waaronder de uitkering was toegezegd, niet was vervuld. De vordering werd toegewezen door zowel de rechtbank als het hof, terwijl de Hoge Raad het cassatieberoep verwierp. De uitspraak is opmerkelijk, aangezien de rechtsgrond voor de betaling - de toekenningsbeschikking - niet was ingetrokken door de Staat. Advocaat-generaal Mok stelt dat er sprake was van een onregelmatigheid aan de kant van de bestuurde, die kon leiden tot intrekking van de toekenningsbeschikking. Volgens hem hadden rechtbank en hof dit civielrechtelijk vertaald in een voorwaardelijke verbintenis waarbij niet was voldaan aan de (ontbindende) voorwaarde. ${ }^{112}$

109. Ongeveer een half jaar eerder had de Afdeling dit nog geen bezwaar gevonden om toch de betrokken regeling toe te passen, aangezien de subsidie krachtens die regeling was verstrekt, ABRvS 13 maart 1997, ABkort 1997, 262. Zie ook de noot, van Simon onder JB 1997, 265.

110. HR 11 oktober 1985, NJ 1986, 322, m.ntt. MS en G, AB 1986, 84, m.nt. FHvdB (Avanti)

111. Stert. 1976, 80.

112. Onderdeel 4 i.f. van de conclusie, NJ 1986, blz. 228. 
Ik vraag mij af of de gevolgde weg de juiste is. Een parallel kan worden getrokken met de subsidietitel in de Awb. In casu dient de toekenningsbeschikking te worden gezien als de subsidieverlening, waarbij de daadwerkelijke sloop binnen een vastgestelde periode als voorwaarde kan worden gezien. Vaststelling van het feit dat de sloop heeft plaatsgevonden door de sloopverklaring en de doorhaling van de teboekstelling in de registers, leidt dan tot de definitieve aanspraak. Terugvordering nadien kan dan slechts aan de orde komen als deze vaststelling wordt ingetrokken. Hiertegen kan de betrokkene vervolgens eventueel bezwaar en beroep instellen. Dit is - en was, zie 8.2.2 - de publiekrechtelijke weg. Dat vervolgens de terugvordering zelf in 1986 werd gezien als rechtshandeling naar burgerlijk recht en dus in voorkomend geval door de burgerlijke rechter diende te worden beoordeeld, doet daaraan niets af; de administratieve rechter had in dat geval reeds de rechtmatigheid van de intrekking beoordeeld of kunnen beoordelen.

De burgerlijke rechter gaat er in casu aan voorbij dat door de vaststelling een definitieve aanspraak is ontstaan, die slechts door aantasting van die vaststelling welke niet had plaatsgevonden - ongedaan kon worden gemaakt. Er was dus een rechtsgrond voor de betaling. De rechter hanteerde dan ook een gekunstelde, onjuiste constructie om tot een bepaald resultaat te komen, dat via de publiekrechtelijke weg - door intrekking van de vaststelling - had kunnen worden bereikt. Het. mag duidelijk zijn, mede gelet op de uitlatingen van de wetgever met betrekking tot subsidie-overeenkomsten, dat sinds de inwerkingtreding van de subsidietitel onder de Awb het volgen van de privaatrechtelijke weg - het construeren van een voorwaardelijke verbintenis - moet worden gezien als een (ongeoorloofde) doorkruising van de publiekrechtelijke weg. ${ }^{113}$

Wat de rol van de burgerlijke rechter in de toekomst zal zijn, hangt af van de wijze waarop hij zal reageren op de jurisprudentie van de bestuursrechter met betrekking tot het terugvorderingsbesluit. Aanvaardt de burgerlijke rechter deze rechtspraak en maakt hij deze tot de zijne, dan zal dit ertoe leiden dat hij de overheid niet-ontvankelijk acht als deze een vordering uit onverschuldigde betaling instelt voor de burgerlijke rechter. De overheid zal dan namelijk een terugvorderingsbesluit moeten nemen, dat door de betrokkene kan worden aangevochten bij de bestuursrechter. Ook zal het voor de betrokkene dan niet meer mogelijk zijñ zich tot de burgerlijke rechter te wenden als hij het niet eens is met de terugvorderingsbeslissing. Er is immers (meestal) sprake van een besluit in de zin van de Awb, waartegen een administratieve rechtsgang openstaat of heeft opengestaan. In dat geval zal hij niet-ontvankelijk worden verklaard, zodat geen inhoudelijke beoordeling door de burgerlijke rechter plaatsvindt. Ik zal hierop nader ingaan in 9.6.2. 


\subsection{Studiefinanciering: het College van beroep studiefinanciering}

\subsubsection{Algemeen}

Formeel gezien is de studiefinanciering geen subsidie. Materieel gezien kan zij wel als subsidie worden beschouwd. ${ }^{114}$ Grondslag voor studiefinanciering is sinds 1 september 2000 de Wet studiefinanciering 2000 (WSF 2000). ${ }^{115} \mathrm{Ik}$ zal deze wet hier niet uitgebreid beschrijven; de kans dat deze beschrijving snel achterhaald zal zijn, is groot. De wetgeving op het terrein van de studiefinanciering verandert immers met enige regelmaat. Zo heeft de Wet op de studiefinanciering (WSF), ${ }^{116}$ de 'voorganger' van de WSF 2000 , meer dan vijftig wijzigingen ondergaan in de tijd tussen haar inwerkingtreding in 1986 en 1998. ${ }^{117}$ Op het te behandelen terrein bracht de WSF 2000 geen wijzigingen ten opzichte van de WSF; de regeling met betrekking tot intrekking - de WSF 2000 spreekt van herziening; ik zal deze laatste term hier dan ook gebruiken -, terugvordering en invordering is dezelfde gebleven. Een belangrijke recente verandering is wel dat de specifieke bestuursrechter op dit terrein, het College van beroep studiefinanciering, is opgeheven per 1 januari 2001. Deze opheffing stond los van de inwerkingtreding van de WSF 2000.

Wil een studerende in aanmerking komen voor studiefinanciering, dan dient hij of zij een aanvraag tot studiefinanciering in te dienen (artikel 3.19 WSF 2000). ${ }^{118}$ Vervolgens kent de Informatie Beheer Groep (IBG) de studiefinanciering toe indien de betrokkene voldoet aan de in de wet gestelde criteria (artikel 3.19 lid 1 WSF 2000). ${ }^{119}$ Bepalend hierbij is onder meer de nationaliteit, de leeftijd en de onderwijssoort die wordt gevolgd (artikel 2.1 WSF 2000). Voorts zijn het inkomen van zowel de studerende, zijn eventuele partner als zijn ouders van belang voor het antwoord op de vraag op welke vorm(en) van studiefinanciering de betrokkene aanspraak kan maken: alleen een basisbeurs of eventueel ook een aanvullende beurs en/of een rentedragende lening. Daamaast heeft de studerende recht op een reisvoorziening, normaal in de vorm van een OV-week- dan

114. Zie hierover 8.1.

115. Wet van 29 juni 2000 , houdende intrekking van de Wet op de studiefinanciering en vervanging door de Wet studiefinanciering 2000 (Wet studiefinanciering 2000), Stb. 286.

116. Wet van 24 april 1986, houdende Wett op de studiefinanciering, Stb. 252.

117. Hieronder waren kleine, onbeduidende wijzigingen, maar ook fundamentele veranderingen, zoals de invoering van de tempobeurs in 1993 (Wet van 2 juli 1993, Stb. 403) en van de prestatiebeurs (Wet van 28 maart 1996, Stb. 227).

118. De WSF sprak over een 'verzoek om studiefinanciering'.

119. Oorspronkelijk kende onder de WSF de minister van Onderwijs en Wetenschappen de studiefinanciering roe, in 1994 werd de IBG in het leven geroepen als (verzelfstandigd) uitvoeringsorgaan, Wet van 15 december 1994, houdende regeling van de bestuurlijke verhouding tussen de Minister van Onderwijs en Wetenschappen en de Informatie Beheer Groep, voorheen de Informatiseringsbank (Wet verzelfstandiging Informatiseringsbank), Stb. 714. 
wel een OV-weekendkaart (artikel 3.7 WSF 2000). ${ }^{120}$

Op grond van artikel 7.1 lid 1 WSF 2000 kan de IBG een aantal beschikkingen herzien, zowel in het voor- als in het nadeel van de betrokkene, daaronder de beschikking waarbij studiefinanciering is toegekend. Dan moet wel een van de gronden, genoemd in lid 2, zich voordoen. ${ }^{121}$ De hier van belang zijnde gronden zijn het feit dat een beslissing is genomen waarvan de studerende wist, dan wel redelijkerwijs had kunnen weten dat deze onjuist was (artikel 7.1 lid 2 onder a WSF 2000), het feit dat te veel studiefinanciering is toegekend op basis van onjuiste of onjuist verwerkte gegevens anders dan bedoeld onder a (onder $\mathrm{c}$ ), het feit dat betrokkene heeft gehandeld in strijd met het bepaalde bij of krachtens de wet (onder d) of andere, nader gebleken feiten of omstandigheden, die, waren zij eerder bekend geweest, tot een andere beschikking zouden hebben geleid (onder g). De precieze afbakening tussen deze gronden is niet geheel duidelijk. ${ }^{122}$ In de toelichting wordt dan ook gesteld, dat veel situaties onder verschillende gronden tegelijk kunnen vallen. ${ }^{123}$ Zo kan onder de 'a-grond' zowel de administratieve vergissing vallen als het onjuiste gegevens verstrekken door de betrokkene. Verdedigd kan immers worden, dat in het laatste geval de studerende redelijkerwijs had kunnen weten dat de toekenningsbeslissing onjuist was. Vermoedelijk is dit de bedoeling van de wetgever. Het geval waarin een administratieve vergissing is gemaakt, terwijl dit de betrokkene niet redelijkerwijs duidelijk kon zijn, valt dan waarschijnlijk onder de 'c-grond'. De vraag op welke grond wordt herzien, is van belang, aangezien de herziening aan een termijn is gebonden, tenzij sprake is van bedrog, aldus artikel 7.1 lid 3 WSF 2000. De term 'bedrog' dient hierbij te worden verstaan in de betekenis die eraan wordt gegeven in het burgerlijk recht. ${ }^{124}$ De herziening als bedoeld in lid 2 onder a kan slechts geschieden binnen vijf jaren na het einde van het desbetreffende studiefinancieringstijdvak. ${ }^{125}$ In de andere genoemde gevallen kan herziening slechts geschieden binnen 18 maanden na het einde van het studiefinancieringstijdvak. ${ }^{126}$ Deze termijn geldt dus ook indien sprake is van een administratieve vergissing, terwijl

120. Ik ga in het onderstaande niet in op de problemen die kunnen ontstaan indien de reisvoorziening ten onrechte is verstrekt.

121. Volgens de memorie van toelichting zijn deze gronden limitatief, Tweede Kamer 1999-2000, $26873, \mathrm{nr} .3$, blz. 66.

122. Zie hierover onder andere de behandeling van het wetsvoorstel WSF in de vergadering van de. Vaste commissie voor Onderwijs en Wetenschappen, Handelingen II 1985-1986, UCV 42, 27 januari 1986, blz. 42-60-61 en Maas (1986), blz. 147.

123. Tweede Kamer 1999-2000, 26873 , nr. 3, blz. 66.

124. Memorie van antwoord WSF, Eerste Kamer 1985-1986, 19125 , nr. 136b, blz. 19.

125. Dit is het kalenderjaar of een gedeelte daarvan waarop de toekenning van studiefinanciering betrekking heeft, met dien verstande dat deze periode ten minste 1 kalendermaand is, aldus artikel 1.1 WSF 2000 .

126. Oorspronkelijk gold onder de WSF een termijn van 3 maanden. Deze termijn werd verlengd tot 18 maanden door artikel I onderdeel L van de reparatiewet van 19 december 1990, Stb. 660, aangezien de termijn van drie maanden te kort bleek, memorie van toelichting, Tweede Kamer 1989-1990, 21 687, nr. 3, blz. 4. 
betrokkene dit redelijkerwijs niet kon weten. Het feit dat in dat geval de toekenningsbeslissing kan worden herzien, lijkt mij in strijd met het vertrouwensbeginsel. Op de vraag welke termijn geldt als sprake is van bedrog, geeft de wet geen antwoord. De toelichting stelt, dat bij bedrog herziening ook na vijf jaar mogelijk is. ${ }^{127}$ Toch kan ook deze termijn niet onbeperkt zijn; de rechtszekerheid verzet zich daartegen. In het algemeen wordt een termijn van vijf jaren aanvaardbaar geacht om over te gaan tot herziening met terugwerkende kracht. De vraag of in geval van bedrog deze termijn langer mag zijn, behandel ik in 10.4.2.

Het na de herziening eventueel te veel betaalde dient vervolgens te worden terugbetaald door de betrokkene of wordt verrekend (artikel 7.4 lid 1 WSF 2000). Bij ministeriële regeling worden nadere redelijke terugbetalingsregels vastgesteld (artikel 7.4 lid 6 WSF 2000). ${ }^{128}$ Artikel 8.2 WSF 2000 bevat vervolgens regels met betrekking tot de invordering. ${ }^{129}$ Vindt geen terugbetaling plaats, dan maant de IBG de 'nalatige' aan om alsnog binnen twee weken te betalen. Gebeurt dit niet, dan vaardigt de IBG een dwangbevel uit, dat een executoriale titel oplevert (artikel 8.2 lid 1 WSF 2000). Tegen dit dwangbevel kan de betrokkene verzet aantekenen; dit verzet stuit de executie niet (artikel 8.2 lid 3 WSF 2000). ${ }^{130}$ Wordt toepassing gegeven aan artikel 8.2 lid 1 WSF 2000, dan kunnen tevens de gerechtelijke dan wel buitengerechtelijke kosten en de wettelijke rente worden ingevorderd, aldus artikel 8.2 lid 2 WSF 2000 . Uit de tekst kan worden afgeleid dat de invordering van deze kosten en van de wettelijke rente ook reeds kan. geschieden als een aanmaning is uitgegaan; mij lijkt de bedoeling dat deze kosten slechts kunnen worden ingevorderd als een dwangbevel is uitgevaardigd.

Tegen besluiten van de IBG staat bezwaar open. Een aantal artikelen uit de Awb is niet van toepassing als bezwaar wordt ingesteld tegen een herzieningsbesluit op grond van artikel 7.2 WSF 2000, aldus artikel 7.3 WSF 2000. Onder de WSF kon vervolgens beroep worden ingesteld bij het College van beroep studiefinanciering (artikel $118 \mathrm{j}^{\circ}$ artikel $108 \mathrm{WSF}$ ). ${ }^{131}$ Dit College besliste in eerste en. enige aanleg (artikel $120 \mathrm{WSF}$ ). Op 1 januari 2001 is dit college opgeheven. De consequentie hiervan is dat de bestuurskamers van de rechtbanken nu in eerste aanleg bevoegd zijn kennis te nemen van geschillen met betrekking tot de WSF 2000. Hoger beroep is mogelijk bij de Centrale Raad van Beroep. ${ }^{132}$

127. Tweede Kamer 1999-2000, 26873 , nr. 3, blz. 66.

128. Regeling terugbetaling teveel uitbetaalde bijdragen in de studiekosten, Stert 1986, 154. Dezte regeling werd in 1989 vervangen door de Regeling verrekening en terugbetaling teveel uitbetalde studiefinanciering, Stert. 1989, 135. Deze beschikking is een aantal malen gewijzigd, zie S\&. uitgave 9-E, Wetgeving hoger onderwijs, bewerkt door W.C.M. Beijk (1998), blz. 277.

129. Zie Spetter/Vaandrager (1992) met betrekking tot de gelijkluidende regeling in de WSF.

130. Hiervoor dient hij een voorziening bij voorraad te vragen.

131. Oorspronkelijk heette dit College de Commissie van beroep studiefinanciering.

132. Wet van 22 juni 2000 , tot wijziging van de Wet op de studiefinanciering, de Wet tegemoetkoming studiekosten, de Beroepswet en enige andere wetten, alsmede enige rechtspositionele voorzieningen in verband met de opheffing van het College van beroep studiefinanciering (Wet opheffing College van beroep studiefinanciering), Stb. 284. Deze wet is in werking getreden op 1 januari 2001, Besluit van 28 juli 2000, Stb. 336. Zie hierover Van den Berg (2000). 


\subsubsection{Terugvordering}

Zoals uit het voorgaande blijkt, bevat de WSF 2000 bepalingen met betrekking tot herziening, terugbetaling of verrekening en invordering. Wat echter ontbreekt is een bepaling met betrekking tot terugvordering. K.ennelijk gaat de wetgever ervan uit, dat de herzieningsbeschikking voldoende is om over te kunnen gaan tot terugvordering. Ook de Regeling verrekening en terugbetaling teveel uitbetaalde studiefinanciering gaat hiervan uit; deze regeling geeft namelijk niet aan wanneer mag worden teruggevorderd, maar slechts op welke wijze de terugvordering dient plaats te vinden. Dit blijkt duidelijk uit artike! 2 lid 1 Regeling, dat bepaalt dat als uit de herzieningsbeschikking blijkt dat te veel studiefinanciering is betaald, dit kan worden verrekend. De toelichting op de wijzigingsbeschikking van 8 oktober $1991^{133}$ vermeldt dan ook dat uit de tekst van artikel 2 lid 1 Regeling blijkt dat verrekening en terugbetaling van te veel uitbetaalde studiefinanciering gebaseerd is op ofwel de herzieningsbeschikking, ofwel de beschikking op bezwaar.

De WSF 2000 eist dus geen aparte terugvorderingsbeschikking, maar naar mijn mening valt uit artikel 7.4 lid 1 af te leiden dat uit de herzieningsbeschikking dan wel de beslissing op bezwaar moet blijken, dat zal worden teruggevorderd en welk bedrag. Artikel 7.4 lid 1 bepaalt immers dat het te veel betaalde wordt teruggevorderd of verrekend indien de herzieningsheschikking daurtoe aamleiding geeft. De herzieningsbeschikking zal dus tevens (expliciet dan wel impliciet) de terugvorderingsbeslissing moeten bevatten.

Ook uit de uitspraak van 9 april 1997 van het College voor beroep studiefinanciering ${ }^{134}$ kan worden afgeleid dat eerst door de terugvorderingsbeslissing de (terug)betalingsverplichting voor de betrokkene ontstaat. De casus was de volgende. Aan een studerende was een basisbeurs toegekend. Later bleek dat zijn ouders over de periode waarover de beurs was toegekend, al een tegemoetkoming in de studiekosten hadden gehad. Op grond van artikel 14 lid 4 WSF moest die tegemoetkoming in dat geval worden beschouwd als een voorschot op de studiefinanciering, waarbij dit voorschot moest worden ingehouden op de beurs. Dit voorschot, zijnde $f 91,-$, was ten onrechte één maand niet ingehouden, zodat dit bedrag diende te worden terugbetaald, aldus het besluit van de IBG. Betrokkene ging tegen dit besluit in beroep.

Het College overwoog dat het, alvorens een rechtsoordeel te kunnen geven, diende na te gaan of het bevoegd was over dit geschil te oordelen. Hiertoe stelde het eerst vast, dat op grond van artikel 14 lid 4 WSF ervan uit diende te worden gegaan dat de betrokkene al een voorschot op de toegekende studiefinanciering had ontvangen. De vraag was vervolgens of de uitbetaalde studiefinanciering kon worden teruggevorderd. Het College stelde vast, dat geen sprake was van een situatie als bedoeld in artikel 55 WSF, het latere artikel 7.1 WSF 2000, zodat artikel 58 WSF, nu artikel 7.4 WSF 2000 , niet van toepassing was. Nu zich geen 
situatie voordeed als bedoeld in artikel 55 WSF (artikel 7.1 WSF 2000), hoefde de toekenningsbeschikking niet te worden herzien om de rechtsgrond aan de betaling te doen ontvallen; er was sowieso geen rechtsgrond voor de betaling. $D_{i}$ betaling was dus onverschuldigd.

De volgende vraag die het College moest beantwoorden, was of de vaststelling, dat het te veel uitbetaalde moest worden terugbetaald, kon worden gezien als een (terugvorderings)besluit waartegen beroep kon worden ingesteld bij het College. Bij de beantwoording van die vraag diende te worden aangesloten bij het besluitbegrip uit de Awb, nu in artikel 118 lid 2 WSF was bepaald dat op de competentie van het College de artikelen 8:1 lid 3, 8:2 en 8:3 Awb van toepassing waren. Belangrijk was dus of er sprake was van een publiek- dan wel een privaatrechtelijke rechtshandeling.

'Het College benadert de vraag of een rechtsfiguur, in casu de onverschuldigde betaling, als rechtshandeling kan worden aangemerki en de vraag of een rechtsfiguur als publiekrechtelijk of privaatrechtelijk moet worden gekwalificeerd vanuit de aard van de onderliggende rechtsverhouding.

De rechtsbetrekking tussen partijen in casu $_{y}$ de toepassing van de WSF, wordt beheerst door het publiekrecht. Van dit publiekrecht maskt ook deel uit het in het algemeen rechtsbewustzijn levend rechtsbeginsel dat hetgeen onverschuldigd is betald dient te worden terugbetaald. Het feit dat dit beginsel voor het terrein van de WSF slechts ten dele is gecodificeerd in artikel 58 WSF heeft niet tot gevolg dat de toepassing van deze rechtsfiguur in andere gevallen die samenhangen met de toepassing van de WSF als privaatrechtelijk moet worden gekwalificeerd. ${ }^{135}$

Een terugvorderingsbeslissing als de onderhavige waarbij ten aanzien van een rechtmatige terugvordering wordt vastgesteld dat naar bestuursrecht een betalingsverplichting ontstaat is gericht op publiekrechtelijk rechtsgevolg".

Het College kwam tot de conclusie dat er sprake was van een publiekrechtelijke rechtshandeling; de onderliggende rechtsverhouding is publiekrechtelijk en dat betekent dat ook de terugvorderingsbeslissing publiekrechtelijk is, zelfs als geen directe grondslag voor het terugvorderingsbesluit is neergelegd in de wet. In dat geval schept het algemene, ook in het publiekrecht levende, rechtsbeginsel dat hetgeen onverschuldigd is betald, dient te worden terugbetaald de bevoegdheid om een terugvorderingsbesluit te nemen. Verder stelde het College uitdrukkelijk dat eerst door de terugvorderingsbeslissing een betalingsverplichting ontstaat, en dus niet reeds door het feit dat onverschuldigd is betaald. Weliswaar sprak het over 'een terugvorderingsbeslissing als de onderhavige', maar dit lijkt mij vooral ingegeven door het feit dat het nu eenmaal diende te oordelen over die voorliggende beslissing.

Vervolgens stelde het College nog de eis van processuele connexiteit, maar ook daaraan was in casu voldaan, nu 'de vaststelling van omvang van de studiefinanciering ingevolge de WSF en de vaststelling van een met deze aanspraak samenhangende onverschuldigde betaling' een 'zodanige samenhang weerspiegelt

135. Kennelijk ziet dus ook het College in artikel 58 WSF en dus ook in artikel 7.4 WSF 2000 de bevoegdheid tot tenugvordering neergelegd: het beginsel van onverschuldigde betaling is volgens het College immers in dat artikel 'ten dele gecodificeerd'. 
dat (...) versnippering van rechtsmacht niet gewenst is'. Het besluit van de IBG was dan ook een appellabel besluit, waartegen (na bezwaar) beroep openstond bij het College. Nadat het College had vastgesteld dat niet was gebleken dat de vereiste belangenafweging niet had plaatsgevonden, verklaarde het het beroep ongegrond; het terugvorderingsbesluit bleef in stand.

\subsection{Het College van Beroep voor het bedrijfsleven: de social-economische ordening}

\subsubsection{Inleiding}

In deze paragraaf zal worden ingegaan op het terrein van het recht dat wordt bestreken door de jurisprudentie van het College van Beroep voor het bedrijfsleven (hierna: het College) en dat grotendeels samenvalt met het sociaal-economisch recht, ook wel kortweg als economisch recht aangeduid. In hun Schets van het sociaal-economisch recht in Nederland geven Mulder en Duk de volgende omschrijving van dit begrip: het door de overheid uitgevaardigde recht, dat ten doel heeft rechtstreeks of middellijk de instelling of de werking van de markt te beinvloeden. ${ }^{136}$ Degenkamp definieert het als volgt: die onderdelen van het recht (normen en bevoegdheidsbepalingen) die overheden ten dienste staan bij het voeren van hun economisch beleid. ${ }^{137}$ Het (sociaal-)economisch recht wordt dus in beide gevallen gezien als een hulpmiddel voor de overheid om sociaal-economische ontwikkelingen te entameren of te sturen.

De competentiesfeer van het College is dus gelegen op het terrein van het sociaal-economisch recht. Weliswaar is het streven van de wetgever erop gericht het College aan te wijzen als de in beginsel te kiezen administratieve rechter in wettelijke regelingen van sociaal-economische aard, ${ }^{138}$ dit wil niet zeggen dat het ook in alle regelingen op dit terrein is aangewezen als bevoegde rechter. ${ }^{139}$ $\mathrm{Nu}$ in deze paragraaf het College centraal staat, komen dan ook alleen die regelingen aan de orde, die onder zijn competentie vallen.

Het College werd opgericht als rechtsprekende instantie op het terrein dat werd bestreken door de Wet op de Bedrijfsorganisatie; beroepen tegen de besluiten en handelingen van de door die wet opgerichte publiekrechtelijke bedrijfsorganisaties vielen onder zijn competentie, zie hierover 8.4.2 en 8.4.3. Daarnaast werd het in tal van andere wetten aangewezen als bevoegde rechter, waaronder de

136. Mulder/Duk (1985), blz. 3.

137. Degenkamp (1989), blz. 20.

138. Richtliinen voor het openstellen van beroep, op het College van Beroep voor het bedrijfsleven, vastgesteld bij besluit van de minister-president handelend in cvereenstemming met het gevoeien van de ministerraad van 13 april 1984, Stert. 1986, !24.

139. Zie voor voorbeelden op het terrein van het sociaal-economisch recht waarbij niet het CBB als bevoegde rechter was aangewezen, maar waarbij in het geheel geen bepaling met betrekking tot een bevoegde rechter was gegeven en dus de ARRvS bevoegd was Bolt (1988), blz. 521-522. 
Landbouwwet, ${ }^{140}$ de Wet investeringsrekening (Wir) ${ }^{141}$ en de Kaderwet verstrekking financiële middelen $\mathrm{EZ},{ }^{142}$ die in verband met het in werking treden van de derde tranche van de Awb is vervangen door de Kaderwet EZ-subsidies. ${ }^{143}$

In deze paragraaf zal de terugvordering in het kader van het sociaal-economisch recht worden bekeken. Als eerste zal in 8.4.2 worden ingegaan op het ontstaan, en de ontwikkeling van het sociaal-economisch recht in Nederland. Een belangrijk moment daarin was de inwerkingtreding van de Wet op de Bedrijfsorganisatie (WBO). Deze wet riep een aantal lichamen in het leven, die ook verordenende bevoegdheden hadden, welke burgers konden binden. In verband hiermee kwam er ook een regeling met betrekking tot de rechtsbescherming, die werd neergelegd in de Wet administratieve rechtspraak bedrijfsorganisatie, de Wet arbo. Deze zal aan de orde komen in 8.4.3. Zoals gezegd speelde het College hierin een grote rol. De connpetentie van het College bleef niet beperkt tot het oordelen in geschillen tussen burgers en lichamen op grond van de Wet arbo, ook in tal van andere wetten werd het aangewezen als de bevoegde rechter. Oordeelde het College op grond van zijn bevoegdheid, zoals die was neergelegd in de Wet arbo, dan was sprake van zogenaamde algemene rechtsmacht; was het bevoegd te oordelen op grond van een specifieke wet, dan sprak men van bijzondere rechtsmacht. Zoals in 8.4.3 zal blijken, was dit onderscheid van belang. In 8.4.4 zal ik vervolgens de terugvordering op het sociaal-economische terrein bekijken, waarbij ook weer het onderscheid tussen de algemene en bijzondere rechtsmacht van het College een rol speelt. Ten slotte zal in 8.4 .5 worden bekeken of er op dit terrein nog een rol is weggelegd voor de burgerlijke rechter.

\subsubsection{De ontwikkeling van het sociaal-economisch recht}

De ontwikkeling van het recht omtrent de bedrijfsorganisaties begon in de crisistijd, de tijd rond 1930. In 1933 kwam de Landbouw-Crisiswet van de grond, een crisiswet op het terrein van de voedselvoorziening. ${ }^{144}$ Zogenaamde crisisorgani-

140. Wet van 26 juli 1957, houdende nieuwe regelen ter bevordering van de voortbrenging, de afzet en een redelijke prijsvorming van voortbrengselen van de landbouw en de visserij en in verband daarmede ten behoeve van de afnemers van produkten (Landbouwwet), Stb. 342.

141. Wet van 29 juni 1978, houdende regelen ter stimulering en sturing van de investeringen (Wet investeringsrekening), Stb. 368. Deze wet was zo succesvol dat zij uiteindelijk voor de overheid niet meer te betalen was. $\mathrm{Zij}$ is dan ook herhaalde keren gewijzigd en uiteindelijk in 1989 ingetrokken, artikel VI Wet van 28 december 1989, Stb. 601.

142. Wet van 4 december 1991, houdende regels betreffende de verstrekking van financièle middelen aan ondernemers ten laste van de begroting van het Ministerie van Economische Zaken (Kaderwet verstrekking financięle middelen EZ), Stb. 767.

143. Wet van 29 februari 1996 , houdende vaststelling regels inzake de verstrekking van subsidies door de Minister van Economische Zaken (Kaderwet EZ-subsidies), Stb. 180.

144. Wet van 5 mei 1933, tot verleening van bevoegdheden tot het nemen van bijzondere maatregelen in het belang van den Landbouw (Landbouw-Crisiswet 1933), Stb. 261. 
saties werden belast met de uitvoering van deze wet. Dit waren particuliere organisaties, die zowel administratieve als tuchtrechtelijke maatregelen konden nemen. Op grond van het Crisis-Organisatiebesluit $1934^{145}$ kon men tegen administratieve besluiten, genomen door de crisisorganisaties, 'in beroep' bij 'scheidslieden als bedoeld in artikel 620 van het Wetboek van Burgerlijke Rechtsvordering' (artikel 3 onder $6^{\circ}$ Besluit). Deze scheidslieden waren de in 1934 ingestelde Crisisarbitrage-commissies. Er was dus sprake van arbitrage. In 1941 werd de Landbouw-Crisiswet vervangen door het Organisatiebesluit Voedselvoorziening. ${ }^{146}$ Door dit besluit namen openbare lichamen, de zogenaamde bedrijfsorganisaties, de taken, die voorheen werden uitgevoerd door de crisisorganisaties, over van deze laatste. Tegelijkertijd werden de Crisisarbitrage-commissies vervangen door het Scheidsgerecht voor de Voedselvoorziening, een onafhankelijke instantie van administratieve rechtspraak. ${ }^{147}$

$\mathrm{Na}$ de Tweede Wereldoorlog werd dit stelsel verder uitgewerkt, ook op terreinen buiten de voedselvoorziening. In $1950 \mathrm{kwam}$ de Wet op de Bedrijfsorganisatie tot stand. ${ }^{148}$ In deze wet werd de Sociaal-Economische Raad, de SER, geïntroduceerd. Volgens artikel 2 WBO was de taak van de SER 'een het belang van het Nederlandse volk dienende werkzaamheid van het bedrijfsleven te bevorderen, alsmede het belang van het bedrijfsleven en de daartoe behorende personen te behartigen'. Daarnaast had hij een adviserende taak, die bestond uit het gevraagd en ongevraagd advies geven aan de ministers over de uitvoering van de Wet op de Bedrijfsorganisatie 'en andere aangelegenheden van sociale of economische aard' (artikel 41 lid 1 WBO). Ter vervulling van de in artikel 2 genoemde taak kreeg de SER verordenende bevoegdheid; op grond van artikel 32 lid 1 WBO diende hij ten aanzien van de hem bij wet opgedragen onderwerpen 'de verordeningen, die hij ter vervulling van zijn (...) taak nodig oordeelt' te maken.

De wet opende verder de mogelijkheid andere openbare lichamen in het leven te roepen, namelijk product-, hoofdbedrijf- en bedrijfschappen (artikel 66 WBO). Ook zij hadden tot taak 'een het belang van het Nederlandse volk dienende bedrijfsuitoefening door de ondernemingen, waarvoor zij zijn ingesteld, te bevorderen', terwijl zij voorts het gemeenschappelijk belang van de ondernemingen en van de daarbij betrokken personen dienden te behartigen (artikel 71 WBO). De productschappen organiseerden bedrijfskolommen; zij organiseerden bedrijven die gezamenlijk een bepaald(e groep van) product(en) fabriceerden, dus de bedrijven die vanaf de grondstof tot het eindproduct bij de productie waren betrokken. De (hoofd)bedrijfschappen organiseerden bedrijfstakken, dus alle bedrijven die onder een bepaalde bedrijfstak vielen. De productschappen werden

145. Besluit van 11 april 1934 tot wijziging van het Crisis-Organisatiebesluit 1933, Stb. 144.

146. Besluit van den Secretaris-Generaal van het Departement van Landbouw en Visscherij betreffende den opbouw van een organisatie voor de voedselvoorziening (Organisatiebesluit Voedselvoorziening 1941), Verordeningenblad voor het bezette Nederlandsche gebied, jaar 1941, 69.

147. Widdershoven (1989), blz. 83-84.

148. Wet van 27 januari 1950 tot toepassing ten aanzien van het bedrijfsleven van de artikelen 80 en 152 tot en met 154 van de Grondwet (Wet op de Bedrijfsorganisatie), Stb. K 22. 
daarom wel verticale, de bedrijfschappen wel horizontale organisaties genoemd.

De instelling van een productschap diende bij wet te geschieden, van een (hoofd)bedrijfschap bij wet of algemene maatregel van bestuur (artikel 67 lid I WBO). Ten aanzien van de onderwerpen, waarvan de (nadere) regeling aan hen was overgelaten bij algemene maatregel van bestuur of wet, hadden zij verordenende bevoegdheden (artikel 93 WBO). Evenals de SER-verordeningen konden deze verordeningen "bindende regelen inhouden voor natuurlijke en rechtspersonen, die de ondernemingen, waarvoor het lichaam is ingesteld, drijven, alsmede voor personen werkzaam bij die ondernemingen' (artikel 102 WBO). De verordeningen van zowel de schappen als de SER dienden te worden afgekondigd door plaatsing in het vanwege de SER uitgegeven Verordeningenblad Bedrijfsorganisatie. ${ }^{149}$

\subsubsection{Rechtsbescherming}

Alle genoemde openbare lichamen konden publiekrechtelijke besluiten nemen en handelingen verrichten, indien de bevoegdheid daartoe was neergelegd in de verordening. Aan een regeling met betrekking tot de rechtsbescherming tegen deze besluiten en handelingen werd echter nog gewerkt, zodat in artikel 140 WBO een voorlopige regeling voor de beslechting van geschillen was opgenomen. Lid 1 van dit artikel bepaalde dat geschillen met betrekking tot besluiten, handelingen of weigeringen van een (orgaan van een) openbaar lichaam bij uitsluiting werden beslist door 'het Scheidsgerecht voor het bedrijfsleven', als hoedanig optrad het Scheidsgerecht voor de voedselvoorziening. Volgens lid 3 hield deze bepaling drie jaar na de inwerkingtreding op te werken. Er werd al gewerkt aan een regeling met betrekking tot rechtsbescherming tegen besluiten en handelingen van de operbare lichamen. In 1949 was de Commissie-Van der Grinten benoemd, die zich bezig hield met een voorstel omtrent deze rechtsbescherming. Haar verslag, uitgebracht in $1951,{ }^{150}$ leidde in 1954 tot de Wet administratieve rechtspraak bedrijfsorganisatie (Wet arbo). ${ }^{151}$ Deze wet trad in werking op 1 juli $1955 .{ }^{152}$.

Artikel 4 lid 1 van deze wet riep een nieuw administratief-rechterlijk college in het leven, het College van Beroep voor het bedrijfsleven. Op grond van lid 2 van dit artikel kon beroep worden ingesteld tegen besluiten en handelingen van 'lichamen', met uitzondering van besluiten, strekkende tot het verrichten van een rechtshandeling naar burgerlijke recht. Artikel 1 Wet arbo bepaalde wat moest worden verstaan onder lichaam: de SER, de product- en (hoofd)bedrijfschappen en lichamen, ingesteld door twee of meer product- en/of (hoofd)bedrijfschappen, ter

149. Artikelen 38 lid 3 en 106 WBO $j^{\circ}$ artikel 2 Besluit van 5 december 1950 , houdende vitvoering van de artikelen 38, eerste en derde lid, 67, derde lid, 100, eerste lid, 106 en 111 , eerste lid van de Wet op de Bedrijfsorganisatie, Stb. K. 550.

150. Verslag Commissie-Van der Grinten (1951).

151. Wet van 16 september 1954, houdende administratieve rechtspraak bedrijfsorganisatic, Stb. 416.

152. Besluit van 3 juni 1955 , houdende inwerkingtreding van de Wet administratieve rechtsprak bedrijfsorganisatie, Stb. 226. 
gemeenschappelijke behartiging van belangen. ${ }^{13}$ Het College oordeelde 'bij uitsluiting' over dit beroep. Voor wat betreft de beroepsgronden sloot de commissie (en de uiteindelijke wet) aan bij het in 3.4 .2 genoemde verslag van de Commissie-De Monchy, zij het dat de daar voorgestelde grond 'strijd met algemene beginselen van behoorlijk bestuur' werd uitgewerkt. Artikel 5 Wet arbo geeft als beroepsgronden strijd met een algemeen verbindend voorschrift, détournement de pouvoir, willekeur en strijd met enig in het algemeen rechtsbewustzijn levend beginsel van behoorlijk bestuur; dezelfde gronden die negen jaar later werden opgenomen in de Wet bab.

Op grond van artikel 4 lid 2 Wet arbo had het College wat betreft de beoordeling van de besluiten en handelingen van genoemde lichamen een algemese rechtsmacht. Met de uitbreiding van de sociaal-economische wetgeving werd cok de rechtsmacht van het College uitgebreid; op grond van vele wetten werd het belast met de rechtspraak tegen besluiten of handelingen van bestuursorganen. ${ }^{194}$ Het werd namelijk wenselijk geacht de administratieve rechtspraak op het gebied van de sociaal-economisch wetgeving te concentreren bij één rechter. ${ }^{155}$ In die gevallen was er sprake van een specifieke rechtsmacht van het College.

Dit onderscheid tussen de algemene en de specifieke rechtsmacht van het College is van belang. Werd (en wordt) het geroepen op grond van zijn algemene rechtsmacht te oordelen over een besluit of bandeling van een openbaar lichaam, dan zag het zijn competentie heel ruim. Het was dan bevoegd, tenzij sprake was van een rechtshandeling naar burgerlijk recht (of een besluit tot het verrichten van een dergelijke handeling). Hierbij interpreteerde het College het begrip rechtshandeling naar burgerlijk recht eng: handelde het lichaam binnen het kader van de uitoefening van zijn publiekrechtelijke taak, dan was niet snel sprake van een dergelijke rechtshandeling, zo blijkt uit een uitspraak uit $1963 .{ }^{156}$ En in 1975 overwoog het in een zaak waarin een hyacintenteler schadevergoeding vorderde van het Produktschap voor Siergewassen kortweg dat het beroepen besluit was genomen ter uitvoering van de aan het productschap bij de Wet op de Bedrijfsorganisatie en de Instellingswet van het schap opgedragen taak en dat mitsdien het College bevoegd was kennis te nemen van het beroep tegen het besluit. ${ }^{157}$

Werd het College daarentegen geroepen te oordelen op grond van een specifieke wet, dus op grond van zijn specifieke rechtsmacht, dan was zijn bevoegdheid meestal beperkt tot het oordelen over besluiten waarvoor een bijzondere grondslag was te vinden in die wet. Was die grondslag niet te vinden in die wet, dan verklaarde het College zich meestal onbevoegd. Bevatte de wet bijvoorbeeld een bepaling, op grond waarvan onverschuldigd gedane betalingen konden worden teruggevorderd, dan kon de betrokkene tegen een terugvorde-

153. De instelling van deze laatste lichamen werd geregeld in artikel 110 WBO.

154. Zie voor een opsomming Mulder (1980), blz. 395-396.

155. Zie ook de Richtlijnen voor het openstellen van beroep op het College van Beroep voor het bedrijfsleven, Stert. 1986, 124.

156. CBB 17 mei 1963, SEW 1963, 196 (blz. 531-533), m.nt. J.P.

157. CBB 22 april 1975, AB 1975, 149, m.nt. J.P., SEW 1975, blz. 449-452, m.nt. J.P. 
ringsbesluit in beroep bij het College (uiteraard diende deze in de wet te zijn aangewezen als bevoegde rechter). Kende de wet niet een dergelijke bepaling, dan werd de terugvorderingsbeslissing gezien als een rechtshandeling naar burgerlijk recht en was het College dus niet bevoegd over het beroep te oordelen.

Het College hanteerde dus een andere inkleuring van het begrip rechtshandeling naar burgerlijk recht al naar gelang het op grond van zijn algemene rechts. macht op grond van de Wet arbo of zijn specifieke rechtsmacht werd geroepen te oordelen. Was sprake van de specifieke rechtsmacht van het College, dain sloot het zich aan bij het beschikkingsbegrip zoals (sedert 1976) neergelegd in de Wet arob, met daarbij behorend de in die wet en de jurisprudentie gehanteerde inkleuring van het begrip 'rechtshandeling naar burgerlijk recht'. ${ }^{158}$ In 1986 werd ook deze specifieke rechtsmacht van het College in de: Wet arbo opgenomen, waarbij werd aangesloten bij de Wet arob. Aan artikel 4 Wet arbo werd namelijk een vierde lid toegevoegd, dat als volgt luidde:

'Het College is voorts belast met de beslissing van geschillen hem bij de wet opgedragen. Stelt de wet het beroep open tegen een beschikking, dan wordt daaronder verstaan: een op enig rechtsgevolg gericht schriftelijk besluit van een administratief orgaan, niet zijnde een besluit van algemene strekking of een rechtshandeling naar burgerlijk recht. Met een beschikking wordt gelijkgesteld de weigering of het uitblijven van een beschikking". ${ }^{159}$

De toelichting op dit artikellid stelde dat werd beoogd de ontwikkeling, dat in de loop der jaren het College in tal van bijzondere wetten werd aangewezen als administratieve rechter, ook in de tekst van de Wet arbo zelf tot uitdrukking te brengen. De memorie vervolgde met de opmerking dat de gegeven definitie geënt was op het beschikkingsbegrip van de artikelen 2 en 3 van de Wet arob. ${ }^{160}$

In 1993 werd de Wet arbo ingrijpend gewijzigd en werd de citeertitel van de wet veranderd in Wet bestuursrechtspraak bedrijfsorganisatie (Wbbo). Deze wijziging maakte deel uit van de voltooiing van de eerste fase van de herziening van de rechterlijke organisatie, waarvan ook de tweede tranche van de Awb deel uitmaakte. Artikel 18 Wbbo regelt de rechtsmacht van het College. Lid 1 luidt:

'Het College oordeelt, bij uitsluiting, in eerste aanleg tevens in hoogste ressort over het beroep, door een belanghebbende ingesteld tegen:

a. een besluit van een lichaam, met uitzondering van een besluit op grond van de Wet openbaarheid van bestuur en een besluit tot invordering bij dwangbevel, en

b. een andere handeling, door een lichaam ten aanzien van hem ter uitvoering van zijn bestuurstakk verricht, met uitzondering van een privaatrechtelijke rechtshandeling'.

Het derde lid bepaalt dat het College voorts is belast 'met de behandeling (...) van de bij de wet aan het College opgedragen geschillen'. Mede door de omschrijving

158. Zie over dat begrip en de inkleuring 4.2 .

159. Artikel I onder B Wet van 12 mart 1986, houdende wijziging van de Wet administratieve rechtspraak bedrijtsorganisatie, Stb. 99.

160. Tweede Kamer 1984-1985, 18 798, nr. 3, blz. 12. 
van het besluitbegrip in artikel 1:3 lid $1 \mathrm{Awb}^{161}$ is niet echt sprake van een wijziging van de rechtsmacht van het College. Aangenomen mag worden dat de uitleg van het begrip 'publiekrechtelijke rechtshandeling' in artikel 1:3 lid I Awb door het College op dezelfde wijze zal geschieden als voorheen de uitleg van het begrip 'besluit, niet inhoudende een rechtshandeling naar burgerlijk recht', waarbij dus onderscheid moet worden gemaakt tussen de algemene rechtsmacht van het College op grond van (nu) artikel 18 lid 1 Wbbo en de specifieke rechtsmacht op grond van (nu) artikel 18 lid 3 Wbbo.

In onder meer 4.2.3, 5.3.3 en 8.2.6 is gebleken, dat de Afdeling bestuursrechtspraak in haar recente jurisprudentie het besluitbegrip heeft opgerekt. Schriftelijke beslissingen op een verzoek orn schadevergoeding en schriftelijke beslissingen tot terugvordering zijn onder omstandigheden, namelijk wanneer sprake is van materiêle connexiteit, besluiten in de zin van artikel 1:3 Awb, welke appellabel zijn als is voldaan aan het processuele connexiteitsvereiste. Er is dan sprake van een zogenaamd zuiver schadebesluit of een terugvorderingsbesluit. ${ }^{162}$ Met de jurisprudentie inzake het schadebesluit volgde de Afdeling de oudere jurisprudentie van de Centrale Raad van Beroep als ambtenarenrechter ${ }^{163}$ en het College, oordelend op grond van zijn algemene rechtsmacht. ${ }^{164}$ Met betrekking tot het terugvorderingsbesluit waren deze twee rechters de Afdeling ook voorgegaan. ${ }^{165} \mathrm{Na}$ de inwerkingtreding van de Awb hebben voorafgaand aan de Afdeling ook de Centrale Raad van Beroep als socialezekerheidsrechter ${ }^{166}$ en het College van beroep studiefinanciering ${ }^{167}$ de constructie van het zuiver schadebesluit erkend. ${ }^{168} \mathrm{Im}$ pliciet deed ook het College, oordelend op grond van zijn specifieke rechtsmacht, dit. ${ }^{169}$ Op 19 februari 1997 deed het dit ook expliciet. Het overwoog dat als een verzoek om schadevergoeding werd ingediend in verband met schade geleden door een besluit, de toekenning van die vergoeding kan worden aangemerkt als een publiekrechtelijke rechtshandeling, en dus kan de toekenning of de weigering worden bestempeld als een besluit in de zin van de Awb.

161. Zie hierover 4.2.3.

162. Zie onder meer ABRvS 21 oktober 1996, AB 1996, 496, m.nt. NV, JB 1996, 232 (Nanne) (terugvorderingsbesluit), ABRvS 29 november 1996, AB 1997, 66, m.nt. PvB, JB 1996, 253, m.nt. red. (Alpha Kledingreinigingsbedrijf) en ABRvS 6 mei 1997, AB 1997, 229, m.nt. PvB, JB 1996, 118, m.nt. HJS (Van Vlodrop) (schadebesluiten).

163. Onder meer CRvB 3 mei 1972, AB 1973, 232, m.nt. v.d. H.

164. Zie onder meer de in deze paragraaf reeds genoemde uitspraken CBB 17 mei 1963, SEW 1963, 196 (blz. 531-533), m.nt. J.P. en CBB 22 april 1975, AB 1975, 149, m.nt. J.P., SEW 1975, blz. 449-452, m.nt. J.P.

165. Onder meer CRvB 30 december 1952, AB 1953, 477 (Schouten-Zonnemaire), zie 7.2.3.3, en (naar mijn mening impliciet) CBB 27 december 1977, AB 1978, 334, SEW 1978, blz. 693-696, m.nt. JHvK. In de volgende paragraaf zal ik op deze laatste uitspraak ingaan.

166. CRvB 28 juli 1994, AB 1995, 133, m.nt. RMvM, JB 1994, 221, m.nt. ELB/ABJH.

167. Cbsf 23 mei 1996, JB 1996, 177, m.nt. red.

168. Zie 4.2.3.

169. CBB 26 maart 1996, JB 1996, 135, m.nt. A.B. 
'Het, publiekrechtelijk karakter van de betrokken rechtshandeling acht het College gegeven met de aard van de schade-oorzaak. Indien de oorzaak van de schade ligt in een publiekrechteiijke rechtshandeling, het schadeveroorzakende besluit, wordt met een beslissing ter regeling van de gevolgen van die rechtshandeling niet buiten de publiekrechtelijke rechtsbetrekking getreden waarbinnen de schade is veroorzaakt'. ${ }^{170}$

Ligt met andere woorden de schade-oorzaak in een publiekrechtelijke rechtshandeling, dan is de beslissing op een verzoek om schadevergoeding ook genomen binnen de (door die rechtshandeling bestaande) publiekrechtelijke rechtsbetrekking en is er sprake van een besluit. Anders dan de Afdeling bestuursrechtspraak leidt het College de bevoegdheid tot het vergoeden van de schade niet af uit een algemeen rechtsbeginsel. Mogelijk neemt het College een impliciete bevoegdheid aan. ${ }^{17}$ Wel eist ook het College processuele connexiteit; het schadeveroorzakende besluit en het besluit waarbij wordt beslist over de vergoeding van de schade moeten niet slechts op één lijn worden geplaatst 'wat betreft hun karakterisering als besluit in de zin van de Awb doch tevens wat betreft de openstaande rechtsgang'.

Mijns inziens heeft deze uitleg van het besluitbegrip ook gevolgen voor de (specifieke) rechtsmacht van het College inzake terugvordering, ook al heeft het College zich daarover tot nu toe niet uitgelaten, althans voor zover ik kan nagaan in de gepubliceerde jurisprudentie. Deze terugvordering zal nu aan de orde komen.

\subsubsection{Terugvordering}

Zoals in 8.4.2 naar voren is gebracht, hebben de SER en de verschillende schappen verordenende bevoegdheden. In de instellingswet of $-A M v B$ is te vinden welke onderwerpen door het schap bij verordening mogen worden geregeld. ${ }^{172}$ Zo zijn er verordeningen, die restituties, subsidies, toeslagen of uitkeringen regelen. ${ }^{173}$ Ook kunnen op grond van verordeningen nadere besluiten worden genomen, waarin bijvoorbeeld het toekennen van toeslagen of subsidies wordt geregeld. ${ }^{174}$ In deze gevallen bestaat uiteraard de mogelijkheid, dat ten onrechte geld wordt betaald. In een aantal gevallen wordt in de verordening of het nadere besluit geregeld, dat dit ten onrechte uitbetaalde kan worden teruggevorderd. Ook als dit niet het geval is, is terugvordering mogelijk.

Een concreet voorbeeld uit de jurisprudentie vormt het besluit P.Z. 1963, Toeslag gecondenseerde melk met suiker van het Productschap voor Zuivel, dat de regel bevatte, dat het productschap een toeslag verleende op condens met suiker die werd uitgevoerd naar bepaalde landen. Een melkfabrikant kreeg toestemming

170. CBB 19 februari 1997, AB 1997, 144, m.nt. JHvdV, J3 1997, 92, m.nt. HJS.

171. Zie $8.4 .4 \mathrm{en}$ meer in het algemeen over impliciete bevoegdheden 9.3 .2 en 9.3 .3 .

172. Maar ook op grond van andere wetten, zoals bijvoorbeeld in artikel 14 Landbouwwet, kregen schappen verordenende bevoegdheden, Schippers (1959), blz. 333.

173. Een willekeurig voorbeeld geeft Verordening Uitvoerrestitutie mager melkpoeder verwerkt in cacaien chocoladeprodukten 1959.

174. Wederom willekeurig Besluit uitkering fokooien Waddeneilanden 1959. 
sen bepaalde hoeveelheid ingedikte melk met suiker uit te voeren en ontving hiervoor een toeslag van bijna $f 6.000$. Later bleek dat de uitgevoerde melk niet volJeed aan de specifieke vereisten om in aanmerking te komen voor deze toeslag en het productschap vorderde deze dan ook terug. De melkfabrikant stelde hiertegen jeroep in bij het College. Het College oordeelde dat de melkfabrikant had kunnen sn moeten begrijpen dat de toeslag naar de strekking van het Besluit ten onrechte was verleend; de ten onrechte betaalde toeslag kon worden teruggevorderd. ${ }^{175}$

In zijn noot onder deze uitspraak gaat Peters in op de terugvordering van ten onrechte uitbetaalde toeslagen. Hij stelt dat het vaste jurisprudentie is, dat het erugvorderingsbesluit geen rechtshandeling naar burgerlijk recht was, maar een jesluit, ongeacht de vorm waarin de eis tot terugvordering was gegoten. Het schap vas tot terugvordering bevoegd, ook al bevatte de beschikking waarop de betaling was gegrond, daarover geen regels; Peters stelt dat men kan zeggen 'dat de erugvordering van ten onrechte verleende toeslagen het noodzakelijk tegenwicht vormt van de verplichte toekenning der bijslagen en dat de rechtsgrond voor de verplichting tot betaling van de heffing een terugvorderingsrecht in zich bergt'.

Volgens Peters is het dus vaste jurisprudentie van het College, dat terugvorderingsbesluiten geen rechtshandelingen naar burgerlijk recht zijn, maar administratieve besluiten. Uitspraken hieromtrent, daterende van voor deze uitspraak, zijn voor zover ik heb kunnen nagaan niet gepubliceerd. Desalniettemin mag worden afgegaan op hetgeen Peters hierover schrijft; hij was namelijk in die periode plaatsvervangend lid van het College en als zodanig, naar mag worden aangenomen, goed op de hoogte van zijn uitspraken, ook van de ongepubliceerde. ${ }^{176}$ Peters ziet, in navolging van het Europese Hof van Justitie, ${ }^{177}$ in de rechtsgrond voor de verplichting tot betaling een impliciete bevoegdheid tot terugvordering van de betaalde bedragen, als deze achteraf ten onrechte blijken te zijn gedaan.

Een terugvorderingsbesluit werd dus door het College niet gezien als een rechtshandeling naar burgerlijk recht, althans indien het op grond van zijn algemene rechtsmacht bevoegd was te oordelen over het geschil. Indien dit niet het geval was, maar het College door een specifieke wet of regeling bevoegd werd verklaard, dan was sprake van een besluit - en dus niet van een rechtshandeling naar burgerlijk recht - als deze wet of regeling voor de terugvordering een regeling bevatte. Ik zal hieronder eerst ingaan op een uitspraak van het College waarin het oordeelde op grond van zijn algemene bevoegdheid, daarna zal (terugvorderings)jurisprudentie worden behandeld, waarbij het tot oordelen werd geroepen op

175. CBB 10 april 1964, SEW 1964, 211 (blz. 559-561), m-nt. J.P.

176. Peters was eerst, vanaf de installatie van het CBB op 1 juli 1955 tot en met 1960, lid van dill College. Vanaf 1961 tot in de jaren zeventig was hij plaatsvervangend lid. Het CBB had overigens van 1955 tot 196.5 slechts vier vaste leden, namelijk een voorzitter en drie leden, en een griffier. Daamaast had het plaatsvervangende leden. In het jaas 1964 bijvoorbeeld kende het (naast de voorzitter, $\mathrm{mr} J$. in ' $\mathrm{t}$ Veld, de drie leden en de griffier) 14 plaatsvervangende leden.

177. Hij verwijst naar HvJ EG 4 april 1960 (Mannesmann A.G. e.a.Hoge Autoriteit EGKS, gevoegde zaken 4 tot 13-59), Jurispr. 1960, blz 245. Zie hierover Bollen (1999), blz. 52-53. 
grond van zijn specifieke rechtsmacht.

In 1976 stelde de regering in de Prijzenbeschikking consumptie-aardappelen in verband met de sterk gestegen prijzen voor consumptieaardappelen een maximum consumptieprijs vast voor bintjes. Tevens werden gelden ter beschikking ge. steld voor een toeslagregeling ten behoeve van de groothandels. Deze toeslagregeling werd uitgevoerd door het Produktschap voor Aardappelen, dat in een aantal circulaires de voorwaarden had bekend gemaakt, waaraan moest zijn voldaan om voor de toeslag in aanmerking te komen, en tevens dat de uitbetaling van de toeslagen zou geschieden onder voorbehoud van nadere controle. Deze toeslagregeling was aan te merken als beleidsregel. ${ }^{178}$ De aan Loogman \& Zonen betaalde toeslagen werden later deels teruggevorderd, aangezien een aantal leveringen niet aan de voorwaarden had voldaan. Kennelijk bevatte noch de toeslagregeling, noch de circulaires een terugvorderingsregeling. Het College overwoog dat er geen algemeen verbindend voorschrift was aan te wijzen dat het productschap verbood door hem betaalde bedragen terug te vorderen. Het vervolgde dat 'een lichaam als verweerder (...) in het algemeen bevoegd (was) door hem te veel uitgekeerde geldsbedragen terug te vorderen'; bovendien was uitdrukkelijk medegedeeld dat de uitbetaling geschiedde 'onder voorbehoud van nadere controle'. Vervolgens constateerde het, dat niet was gesteld of gebleken dat het productschap van zijn bevoegdheid kennelijk anders gebruik had gemaakt dan waartoe die bevoegdheid was gegeven. Wel was het College van oordeel dat terugvordering van een deel van de bedragen in strijd was met 'het in het algemeen rechtsbewustzijn levende beginsel van behoorlijk bestuur der rechtszekerheid, welk beginsel meebrengt, dat de administratie het door haar opgewekt vertrouwen honoreert'. 179

De overweging dat er geen algemeen verbindend voorschrift was aan te wijzen dat het productschap verbood door hem betaalde bedragen terug te vorderen, wekt verbazing. Het College draaide de eis van een wettelijke bevoegdheidsgrondslag om, zo lijkt het. Er hoefde geen algemeen verbindend voorschrift te zijn dat terugvordering toestond, maar er mocht geen algemeen verbindend voorschrift zijn aan te wijzen dat terugvordering uitsloot. Op zichzelf is dit vreemd. Er zijn twee mogelijke verklaringen.

Ten eerste is het mogelijk dat het College het algemeen rechtsbeginsel dat hetgeen onverschuldigd is betaald, kan worden teruggevorderd, toepast. Dit zou feitelijk neerkomen op hetgeen de Centrale Raad van Beroep in ambtenarenzaken expliciet deed; de Ambtenarenwet gaf geen terugvorderingsregeling, maar de Centrale Raad greep terug op het genoemde algemeen rechtsbeginsel. ${ }^{180}$ Mogelijk heeft het College in deze uitspraak impliciet dezelfde redenering gevolgd: et is een algemeen, ook in het bestuursrecht geldend, rechtsbeginsel dat hetgeen onverschuldigd wordt betald, kan worden teruggevorderd. Dit is slechts anders als de wetgever terugvordering heeft uitgesloten. Een tweede mogelijkheid is dat

178. Zie Van Kreveld in zijn noot in SEW 1978, blz. 694.

179. CBB 27 december 1977, AB 1978, 334, SEW 1978, blz. 693-696, m.nt. JHvK.

180. Zie 7.2.3.3. 
bet College een impliciete bevoegdheid tot terugvordering aannam, zoals Peters reeds eerder had aangegeven: het feit dat slechts een toeslag mag worden toegelend en uitbetaald als aan bepaalde voorwaarden is voldaan, impliceert dat deze toeslag mag worden teruggevorderd als achteraf blijkt dat niet aan die voorwaarden was voldaan. ${ }^{181}$ Vervolgens moet (in beide gevallen) worden bekeken of de in beginsel bestaande terugvorderingsbevoegdheid ook in het concrete geval bestat, en wel door eerst te beoordelen of het bestuursorgaan bij het uitoefenen van de bevoegdheid in strijd handelde met een (ander) algemeen rechtsbeginsel. Dat rechtsbeginsel was dan het rechtszekerheidsbeginsel. Dit was in casu niet zo: in de circulaire was uitdrukkelijk medegedeeld dat de betalingen onder voorbehoud van nadere controle werden gedaan. Vervolgens werd bekeken of terugvordering in casu in strijd was met een algemeen beginsel van behoorlijk bestuur. Dat bleek zo te zijn; er was sprake van strijd met het vertrouwensheginsel, door het College het rechtszekerheidsbeginsel genoemd, namelijk het beginsel dat het door de administratie opgewekt vertrouwen door haar wordt gehonoreerd.

Dat het College zich bevoegd achtte over deze terugvordering te oordelen, zonder dat er een wettelijke grondslag was an te wijzen, was niet verwonderlijk. Het oordeelde namelijk op grond van zijn algemene rechtsmacht, het ging om een besluit van een productschap. Het achtte zich dus kennelijk bevoegd (en nam geen rechtshandeling naar burgerlijk recht aan), aangezien de terugvordering plaatsvond binnen het kader van de publiekrechtelijke taak van het productschap.

Een voorbeeld uit de jurisprudentie, waarin het College bevoegd was te oordelen over een terugvorderingsbesluit op grond van zijn specifieke rechtsmacht, geeft een uitspraak uit 1987. Pruvé Produktiecentrum B.V. had steunbedragen ontvangen op grond van de Beschikking steun boter met bijzonder gebruik of bijzondere bestemming $1981 .^{182}$ Hierbij had het zich ertoe verbonden te voldoen aan een aantal voorschriften. Artikel 12 lid 2 Beschikking bevatte de bepaling dat de steun onder voorbehoud werd verleend en dat terugbetaling of verrekening zou plaatsvinden indien later bleek, dat de steun ten onrechte of tot een te hoog bedrag was verleend. Nadien bleek dat Pruvé niet had voldaan aan de voorschriften en het Voedselvoorzieningsin- en verkoopbureau, dat met de uitvoering van de beschikking was belast, vorderde de verleende steunbedragen terug. Pruvé ging tegen dit besluit in beroep bij het College. Het bureau voerde aan dat Pruvé niet-ontvankelijk was, aangezien deze zich door steunovereenkomsten had verbonden aan een aantal voorschriften te voldoen. Het geschil vond dan ook zijn grondslag in de omstandigheid, dat Pruvé deze steunovereenkomsten niet was nagekomen. Het besluit betrof dan ook de uitvoering van die overeenkomsten en was dus aan te merken als een rechtshandeling naar burgerlijk recht; er stond dus geen beroep open op het College. Het College volgde het bureau hierin niet. Het bureau was immers in artikel 2 lid 3 Beschikking aangewezen als het bevoegde orgaan voor toekenning en uitkering van de steun. Dit was geschied onder meer ter uitvoering

181. Ik kom op de constructie van impliciete bevoegdheden terug in 9.3 .2 en 9.3.3.

182. Stert. $1981,168$. 
van artikel 32 Landbouwwet. Voorts wees het College op artikel 12 Beschikking. Het kwam tot de conclusie, dat 'gelet op het samenspel van voomoemde voorschriften', zowel de terugvorderingsbeslissing als de daaraan voorafgaande toekenningsbeslissingen geen rechtshandelingen naar burgerlijk recht waren; de beschikking bevatte de grondslag voor de terugvordering. Het feit, dat ter uitvoering van de beschikking een overeenkomst was gesloten, deed niet ter zake. ${ }^{183}$

Een ander geval betrof terugvordering van ten onrechte verleende steun op grond van de Beschikking tijdelijke inkomenssteun in de akkerbouw. ${ }^{184} \mathrm{De}$ Maatschap Loots had een aanvraag ingediend om inkomenssteun op grond van die beschikking. Namens de minister van Landbouw, Natuurbeheer en Visserij werd steun toegekend. Loots ging in bezwaar tegen deze toekenning, die naar haar mening te laag was. Vervolgens werd vastgesteld, dat Loots niet voor steun in aanmerking kwam, aangezien zij niet voldeed aan de voorwaarden. De reeds betaalde steun werd vervolgens teruggevorderd. Artikel 9 lid 1 van de beschikking bevatte de volgende bepaling:

'Onverminderd het in het Burgerlijk Wetboek bepaalde kan uitgekeerde inkomenssteun geheel of ten dele worden teruggevorderd in de mate waarop deze op grond var sonjuiste, doch door de aanyrager voor juist verklaarde gegevens blijkt te zijn verleend, vermeerderd met de wettelijke rente over de periode vanaf het moment van uitbetaling tot aan het moment van terugbetaling:

In casu was er geen sprake van onjuiste gegevens; er was in eerste instantie op grond van de juiste gegevens vanuit gegaan dat Loots voor steun in aanmerking kwam, maar dit bleek een vergissing. Loots ging in beroep tegen de beslissing op bezwaar. Zij stelde dat artikel 9 van de beschikking in de weg stond aan terugvordering. Volgens de minister was dit niet zo, aangezien onverschuldigd was betald en artikel 9 expliciet bepaalde dat de bepalingen van het BW onverminderd van toepassing waren. Bovendien was artikel 9 niet van toepassing, nu de bedoeling van dat artikel was de omvang van het terug te vorderen bedrag vast te stellen indien onjuiste gegevens waren verstrekt. Daarvan was geen sprake.

Het College stelde eerst vast dat niet werd betwist - en dat dus vaststond - dat Loots niet in aanmerking kwam voor steun en dat dus bij het oorspronkelijke besluit ten onrechte steun was verleend. In zoverre was de beslissing op bezwaar dus niet in strijd met het recht. (Mede) op grond van het feit, dat de oorspronkelijke beslissing was gebaseerd op juiste gegevens, oordeelde het College echter dat de oorspronkelijke (foutieve) beslissing uitsluitend het gevolg was van een fout van het bestuursorgaan, die niet was te wijten aan enige nalatigheid van Loots. De gevolgen van die fout dienden voor rekening van het bestuur te komen. Loots had namelijk tot het tijdstip van het bestreden besluit het gerechtvaardigd vertrouwen mogen hebben, dat het primaire besluit terecht was genomen, en dit vertrouwen had moeten worden gerespecteerd. Nu dit niet was gebeurd, diende de bestreden

183. CBB 2 september 1987, AB 1988, 426, m.nt. JHvK, UCB 1988, 48, m.noten KM en BO.

184. Stert. 1990, 147. 
leslissing op het bezwaar te worden vernietigd. ${ }^{185}$

De minister betoogde dat de terugvordering was gebaseerd op (de regeling in) let BW. Mijns inziens stelđe hij hiermee dat er sprake was van een rechtshantling naar burgerlijk recht. Het College gaat hier niet expliciet op in, maar inpliciet werd dit verweer verworpen. Had het de zienswijze van de minister fevolgd, dan had het zich immers onbevoegd moeten verklaren. Dit deed het niet.

Overigens mag worden aangenomen, dat het College, als het op grond van ijn specifieke bevoegdheid wordt geroepen te oordelen over een terugvorderingsleslissing, momenteel niet meer zal aannemen dat sprake is van een rechtshandeing naar burgerlijk recht, ook niet als de betrokken regeling zwijgt over de hogelijkheid van terugvordering. Met betrekking tot zuivere schadebesluiten heeft et College immers overwogen, dat indien de schade-oorzaak ligt in een publiekbchtelijke rechtshandeling - er is dan sprake van een publiekrechtelijke rechtsbetekking -, de beslissing op een verzoek om schadevergoeding ook binnen die ibliekrechtelijke rechtsbetrekking ligt en er dus sprake is van cen besluit in de in van artikel $1: 3$. Verder eist het College processuele connexiteit: het schadeeroorzakend besluit en het schadebeslnit worden niet alleen op één lijn geplaatsı wat betreft hun karakterisering als besluit, maar ook wat betreft de openstaande rechtsgang, aldus het College. ${ }^{186}$ Dezelfde redenering kan worden gevolgd met betrekking tot terugvordering. Door het samenspel van het toekennings- en (eventueel) het intrekkingsbesluit wordt een publiekrechtelijke rechtsbetrekking gecreeerd; de beslissing om tot terugvordering van het onverschuldigd betaalde over te gaan ligt dan ook binnen die publiekrechtelijke rechtsbetrekking. Is vervolgens voldaan aan het processuele connexiteitsvereiste - en dit zal vrijwel altijd het geval zijn; het toekenningsbesluit en/of het intrekkingsbesluit zullen vrijwel altijd appellabele besluiten zijn -, dan ligt het voor de hand dat het College het terugvorderingsbesluit zal kwalificeren als besluit in de zin van artikel 1:3 Awb, waarover het bevoegd is te oordelen.

\subsubsection{De burgerlijke rechter}

De laatste te behandelen vraag is in hoeverre de burgerlijke rechter bevoegd was, of beter: zich bevoegd achtte, in sociaal-economische geschillen, en dan meer in het bijzonder met betrekking tot terugvordering van verleende toeslagen of steun.

Het College van Beroep voor het bedrijfsleven was niet bevoegd als sprake was van een (besluit tot het verrichten van een) rechtshandeling naar burgerlijk recht, zie 8.4.3. In dat geval was de burgerlijke rechter bevoegd. Wannecr het College bevoegd was te oordelen op grond van de Wet arbo, als het oordeelde op grond van zijn algemene rechtsmacht, interpreteerde het het begrip 'rechtshandeling naar burgerlijk recht' eng; zolang het openbaar lichaam handelde binnen het kader van de uitoefening van haar publiekrechtelijke taak was niet snel sprake van

186. Zie CBB 19 februari 1997, AB 1997, 144, m.nt. JHvdV, JB 1997, 92, m.nt. HJS. Zie ook 8.4.3. 
een dergelijke rechtshandeling en was dus het College bevoegd.

Desalniettemin heeft het College, oordelend op grond van zijn algemene rechtsmacht, uitspraken gewezen, waarin het zichzelf onbevoegd achtte omdat sprake was van een rechtshandeling naar burgerlijk recht. Een voorbeeld geeft de volgende casus. Een aantal aardappelexporteurs, waaronder Van L., was in financiēle moeilijkheden gekomen door overheidsmaatregelen met betrekking tot de export naar Engeland. Om deze reden had het Produktschap voor Aardappelen aan hen een lening verstrekt, waarbij de overeenkomst van geldlening regels bevatte met betrekking tot terugbetaling en rente. Van L. kon echter niet aan zijn verplichtingen voldoen, waarna het Produktschap beslag legde op goederen van hem en hem dagvaardde voor de rechtbank. Partijen traden vervolgens in onderhandeling om tot een minnelijke schikking te komen. Een voorstel van Van L. werd bij brief (van de raadsman van het schap) afgewezen door het Produktschap. Van L. stelde tegen dit besluit beroep in bij het College. Het College overwoog dat 'wat er ook zij van de aard van het besluit om tot het verstrekken van geldleningen (...) over te gaan en zelfs nog wat er ook zij van het besluit om tot terugvordering door middel van een burgerrechtelijk geding met de daaraan verbonden tenuitvoerlegging over te gaan', het besluit om niet in te gaan op een schikkingsvoorstel een 'besluit naar burgerlijk recht' was, en dus was het College niet bevoegd. ${ }^{187}$

Annotator A. Mulder was van mening dat, nu pas beroep was ingesteld nadat het Produktschap een civielrechtelijke actie was begonnen en Van L. vervolgens een schikkingsaanbod had gedaan, het College in dat stadium de weigering om op dat aanbod in te gaan terecht had beschouwd als een besluit tot het verrichten van een rechtshandeling naar burgerlijk recht. Dit zou waarschijnlijk anders zijn geweest, indien het beroep zich had gericht tegen het besluit tot het opzeggen van de lening, aldus Mulder; het opzeggen van een lening, welke in wezen een uitvloeisel was van een subsidiepolitiek, kon ook worden beschouwd als een daad van beleidsvoering in het kader van de subsidiepolitiek en dus niet (zonder meer) als een rechtshandeling naar burgerlijk recht.

Het is duidelijk, dat in voomoemd geval de competentie van de burgerlijke rechter geen probleem zal opleveren. De vraag is, of de burgerlijke rechter altijd bevoegd was op het terrein van de sociaal-economische wetgeving, ook in gevallen waarin naar het oordeel van het College van Beroep voor het bedrijfsleven geen sprake was van een rechtshandeling naar burgerlijk recht. Deze vraag is reeds in $\mathbf{4 . 3 . 2}$ aan de orde geweest. De Hoge Raad heeft nooit een uitspraak gedaan met betrekking tot de vraag naar zijn bevoegdheid in de gevallen waarin het College bevoegd was. Desalniettemin mag (althans tot 1992) worden aangenomen dat de burgerlijke rechter zich onbevoegd zou achten te oordelen over besluiten of handelingen verricht door een openbaar lichaam ter vervulling van zijn publiekrechtelijke taak. ${ }^{188}$ De bevoegdheid van het College, oordelend op grond van 
zjn algemene rechtsmacht, was exclusief; evenals in de Ambtenarenwet 1929 (en in het Organisatiebesluit Voedselvoorziening 1941) was het College immers 'bij uitsluiting' bevoegd over genoemde besluiten en handelingen te oordelen. ${ }^{189} \mathrm{De}$ onbevoegdheid van de burgerlijke rechter kan mijns inziens mede worden afgeleid ut het in 4.3 .2 besproken arrest van de Hoge Raad van 24 maart 1950. ${ }^{190}$ Daarin overwoog de Hoge Raad dat de burgerlijke rechter niet bevoegd was te oordelen als een geschil op grond van artikel 13 Organisatiebesluit Voedselvoorziening $1941^{191}$ onder de competentie van het Scheidsgerecht voor de Voedselvoorziening viel. Deze laatste was in dat geval exclusief bevoegd. Het Organisatiebesluit Voedselvoorziening 1941 is vervolgens 'opgegaan' in de Wet op de Bedrijfsorganisatie en vanaf 1 juli 1955 nam het College van Beroep voor het bedrijfsleven de werkzaamheden over van het Scheidsgerecht voor de Voedselvoorziening.

Bij het voorgaande moet naar mijn mening wel de kanttekening worden geplaatst dat deze exclusieve bevoegdheid van het College alleen gold indien het tot oordelen werd geroepen op grond van zijn algemene bevoegdheid, zoals neergelegd in artikel 4 lid 2 Wet arbo. Dit artikel gaf ook aanleiding tot deze conclusie; het College was immers 'bij uitsluiting' bevoegd. Zoals gezegd werden deze woorden ook gehanteerd in artikel 3 Ambtenarenwet 1929. Daar werden zij zo uitgelegd dat de Centrale Raad van Beroep hierdoor exclusief bevoegd werd. ${ }^{192}$ Wat de specifieke rechtsmacht van het College betrof, is het zeer de vraag of ook daar exclusieve rechtsmacht mocht worden aangenomen. Veelal werd immers het College in die wetten niet 'bij uitsluiting' bevoegd verklaard. ${ }^{193}$ Jurisprudentie hierover is echter - voor zover ik kan nagaan - niet voorhanden.

Overigens mag worden aangenomen, dat na het in 7.2.4.3 besproken Changoe-arrest de civiele rechter zich niet meer onbevoegd zal verklaren, maar tot de conclusie zal komen, dat eiser niet ontvankelijk is. Dit geldt te meer, daar het Europese Hof voor de rechten van de mens in de zaak Van de Hurk tegen Nederland oordeelde "that the applicant's civil rights and obligations were not 'determined' by a 'tribunal"; er was sprake van schending van artikel 6 lid 1 EVRM. ${ }^{194}$

189. Vgl. 4.3.2. Daar heb ik ook gewezen op het feit dat aan de woorden 'bij uitsluiting' in de Aw 1929 een andere betekenis moet worden toegekend dan aan diezelfde woorden in artikel $165 \mathrm{Gw}$ 1815 en artikel 2 R.O.

190. HR 24 maart 1950, NJ 1950, 662. Zo ook Wiersma (1958), blz. 105 en Van Angeren (1968), blz. 25.

191. Artikel 13 lid 1 luidde voor zover van belang: 'Geschillen tusschen een organisatie en een of meer ondememers (...), worden bij uitsluiting in eerste instantie beslist door een scheidsgerecht, ingesteld bij den raad, waartoe de betrokken organisatie en de ondernemer behooren. Van de uitspraak van een scheidsgerecht staat binnen een maand na den dag, waarop de uitspraak. gewezen is, beroep open op den Secretaris-Generaal. Deze beslist niet dan nadat een commissie van advies, waarvan de samenstelling en werkwijze door hem worden geregeld, is gehoord".

192. Zie 4.3.2. Ook de Hoge Raad legde deze woorden zo uit, zie HR 13 november 1941, NJ 1942, 172, AB 1942, 485 (Ambtenarenwetarrest).

193. Het feit dat de burgerlijke rechter zich bevoegd kon verklaren, wilde echter niet zeggen dat ciser ook in zijn vordering kon worden ontvangen, zie 4.3.3.

194. EHRM 19 april 1994, NJ 1995, 462, m.nt. EAA. 
De reden hiervoor was dat de Wet arbo de bepaling bevatte, dat de Kroon onder omstandigheden kon besluiten dat de uitspraak van het College geen (volledig) gevolg zal hebben. ${ }^{195}$ Hierdoor werd de procedure voor het College door het Hof niet gezien als een behandeling door een onafhankelijke rechter. De Hoge Raad achtte de rechtsgang naar het College in 1998 dan ook geen volwaardige rechtsgang, althans niet tot 1 januari 1994, de datum waarop de Wbbo in werking trad. ${ }^{196}$ In de Wbbo is deze bepaling niet teruggekeerd.

Op grond van het voorgaande en op grond van recente jurisprudentie van het College kan worden gesteld, dat waarschijnlijk de rol van de burgerlijke rechter is uitgespeeld bij terugvordering. Als immers het College wordt geroepen te oordelen op grond van zijn algemene bevoegdheid, dan zal geen sprake zijn van een rechtshandeling naar burgerlijk recht, indien de terugvordering door het bestuursorgaan geschiedt binnen het kader van de uitoefening of uitvoering van zijn publiekrechtelijke taak. Als sprake is van rechtsmacht van het College op grond van een bijzondere wet, dus als sprake is van specifieke rechtsmacht van het College, dan zal deze wet vaak een (meer of minder) expliciete terugvorderingsbepaling bevatten. In dat geval speelt de burgerlijke rechter geen rol; er is wederom geen sprake van een rechtshandeling naar burgerlijk recht.

Als de betrokken wettelijke regeling daarentegen geen terugvorderingsbepaling bevat, dan kon tot voor kort worden aangenomen dat sprake was van een rechtshandeling naar burgerlijk recht, zodat niet het College bevoegd was, maar de burgerlijke rechter. Tegenwoordig zal dit zich naar mijn mening niet meer voordoen. Ik kom tot die conclusie op grond van de jongste jurisprudentie van het College met betrekking tot het zuiver schadebesluit. Ik heb deze jurisprudentie behandeld in 8.4.3. In 8.4.4 heb ik aangegeven, dat de redenering van het College met betrekking tot het schadebesluit ook kan worden gehanteerd met betrekking tot terugvorderingsbeslissingen. Het ligt voor de hand, dat het College dit ook zal doen, zodat ervan mag worden uitgegaan dat in de toekomst terugvorderingsbeshuiten, genomen binnen een publiekrechtelijke rechtsbetrekking, ${ }^{197}$ besluiten zijn in de zin van artikel 1:3 Awb, waarover het College bevoegd is te oordelen, als is voldaan aan het processuele connexiteitsvereiste. Dit laatste zal vrijwel altijd het geval zijn. Er zal dus geen sprake meer zijn van een rechtshandeling naar burgerlijk recht, zodat de burgerlijke rechter eiser niet meer zal ontvangen. ${ }^{198}$

195. Artikel 74 Wet arbo.

196. HR 23 januari 1998, Nj 1998, 525, m.nt. MS, JB 1998, 71, m.nt. EvdL.

197. Ik zal in 11.3 uitwerken wanneer daarvan sprake is. In ieder geval is dit zo, als het bestuursorgaan een toekenningsbesluit heeft genomen.

198. De uitzondering, die de Hoge Raad heeft gemaakt in het arrest Groningen-Raatgever met betrekking tot schadebesluiten, waarbij hij heeft beslist, dat de betrokkene de keuze heeft tussen de rechtsgang naar de bestuursrechter of naar de burgerlijke rechter, zie hierover 9.6 .1 , zal hij navr mijn mening niet kunnen maken met betrekking tot terugvorderingsbesluiten. De belangrijkste reden voor het maken van die uitzondering was immers dat ook de wetgever in artikel 8:73 Awb de burger uitdrukkelijk een keuzemogelijkheid had gelaten. Met betrekking tot terugvordering 
Als de wijziging van artikel 4:57 Awb, zoals voorgesteld in het voorontwerp vanı de vierde tranche, ${ }^{199}$ wordt ingevoerd, dan staat in ieder geval wat betreft subsidies in de zin van de subsidietitel uit de Awb vast, dat er een wettelijke, publiekrechtelijke grondslag is voor de terugvordering. In dat geval staat buiten kijf, dat sprake is van een (appellabel) besluit. Nu het bij de terugvordering van betalingen, die hier aan de orde zijn, vrijwel altijd zal gaan om terugvordering van onverschuldigd betaalde subsidies in de zin van de subsidietitel, is hiermee de bevoegdheid van het College sowieso gegeven, althans wanneer het College uiteraard in de betrokken wettelijke regeling is angewezen als de bevoegde rechter.

\subsection{Conclusie}

In dit hoofdstuk heb ik de subsidies en gelijksoortige overheidsbijdragen bekeken. If heb hierbij een onderscheid gemaakt tussen de studiefinanciering, het sociaaleconomisch recht en de overige, 'algemene' subsidies. Dit onderscheid werd ingegeven door het feit dat op die drie terreinen verschillende bestuursrechters actief waren dan wel zijn, namelijk het (voormalig) College van beroep studiefinanciering, het College van Beroep voor het bedrijfsleven en de Afdeling (bestuurs)rechtspraak van de Raad van State. Dit heeft geleid tot een aantal verschillen in de jurisprudentie, ook met betrekking tot terugvordering.

Waar het die terugvordering van 'algemene subsidies' betreft was de situatie 20, dat de Afdeling rechtspraak de beslissingen met betrekking tot terugvordering slechts als (appellabele) beschikkingen zag, wanneer daarvoor een uitdrukkelijke wettelijke grondslag was aan te wijzen. Was dat niet het geval, dan werden deze beslissingen gezien als rechtshandelingen naar burgerlijk recht, waarover de burgerlijke rechter bevoegd was te oordelen. Ook de Afdeling bestuursrechtspraak volgde in eerste instantie deze lijn. Inmiddels is in het voorontwerp voor de vierde tranche van de Awb een ontwerpartikel opgenomen, dat de wettelijke grondslag voor het terugvorderingsbesluit moet vormen.

In 1996 is de Afdeling bestuursrechtspraak echter uitdrukkelijk omgegaan. In de uitspraak Nanne besliste zij dat terugvorderingsbeslissingen wel besluiten in de zin van artikel 1:3 Awb waren. Het algemeen rechtsbeginsel dat hij die onverschuldigd heeft betaald dit kan terugvorderen, vormt de grondslag voor de terugvorderingsbevoegdheid. Dit beginsel is bestuursrechtelijk van aard als zijn werking zich doet gevoelen in een door het bestuursrecht beheerste verhouding. De terugvorderingsbeslissing is in dat geval gericht op een publiekrechtelijk rechtsgevolg en dus een publiekrechtelijke rechtshandeling. Dit betekent dat sprake is van een besluit. Vervolgens eist de Afdeling wel nog processuele connexiteit, maar daaraan zal vrijwel altijd zijn voldaan bij terugvordering. In dat geval is de bestuursrechter, dus in casu in hoogste instantie de Afdeling, bevoegd 
over het terugvorderingsbesluit te oordelen. De consequentie hiervan is, dat als de burgerlijke rechter deze jurisprudentie aanvaardt (en ik zie geen reden waarom hij dit niet zal doen), deze in de toekomst niet meer zal oordelen over terugvorderingsbesluiten; hij zal eiser niet-ontvankelijk dienen te verklaren in zijn vordering.

Ook op het terrein van de studiefinanciering kom ik tot dezelfde conclusie. De WSF bevatte geen (uitputtende) regeling met betrekking tot de terugvordering. Desondanks was terugvordering mogelijk en werd de terugvorderingsbeslissing gezien als een besluit door het College van beroep studiefinanciering. Het College hanteerde hierbij sinds 1997 dezelfde constructie als de Afdeling bestuursrechtspraak, inclusief het processuele connexiteitsvereiste. Onder de WSF 2000 vond geen wijziging plaats in de herzienings-, terugvorderings- en invorderingsbepalingen. Ook nu was terugvordering niet (uitputtend) geregeld. Kort na het in werking treden van deze wet werd het College van beroep studiefinanciering opgeheven. $\mathrm{Nu}$ dient na de bezwaarschriftprocedure beroep te worden ingesteld bij de bestuurskamers van de rechtbanken met hoger beroep bij de Centrale Raad van Beroep. Waarschijnlijk zal de Raad ook bij studiefinanciering terugvorderingsbeslissingen zien als besluiten in de zin van de Awb. Enige ruimte voor de burgerlijke rechter lijkt dan niet meer te bestaan bij terugvordering.

Op het terrein van het sociaal-economische recht is het College van Beroep voor het bedrijfsleven de bevoegde administratieve rechter. Wat betreft de rechtsmacht van dit College moet een onderscheid worden gemaakt tussen diens algemene rechtsmacht op grond van artikel 4 Wet arbo en diens specifieke rechtsmacht op grond van bijzondere wetten. In beide gevallen vielen rechtshandelingen naar burgerlijk recht buiten de bevoegdheidssfeer van het College, maar de uitleg van dit begrip was een andere. Het College interpreteerde het begrip rechtshandeling naar burgeriijk recht namelijk eng indien het oordeelde op grond van zijn algemene rechtsmacht; handelde het bestuursorgaan binnen het kader van de uitoefening van zijn publiekrechtelijke taak, dan was niet snel sprake van een rechtshandeling naar burgerlijk recht. Was sprake van specifieke rechtsmacht van het College, dan eiste het een uitdrukkelijke (publiekrechtelijke) grondslag voor het bestuursoptreden. Was deze er niet, dan was sprake van een rechtshandeling naar burgerlijk recht. Dit gold ook bij terugvordering. Het is echter waarschijnlijk, dat het College momenteel bij terugvordering ook een besluit zal aannemen indien het geroepen wordt te oordelen op grond van zijn specifieke rechtsmacht, aangezien het dit ook heeft gedaan met betrekking tot zuivere schadebesluiten. Naar mijn mening zal dit laatste er ook toe moeten leiden dat de rol van de burgerlijke rechter bij terugvordering is uitgespeeld. lk verwacht immers dat terugvorderingsbeslissingen door het College over de gehele linie zullen worden aangemerkt als besluiten in de zin van de Awb, zodat het bevoegd is hierover te oordelen.

Samengevat kan worden gesteld, dat in het verleden het feit dat op het terrein van subsidies verschillende bestuursrechters competent waren, ertoe heeft geleid, dat er aanzienlijke verschillen bestonden op de onderscheiden terreinen met betrekking tot de vraag of een terugvorderingsbeslissing een beschikking was dan wel een rechtshandeling naar burgerlijk recht, waarover de burgerlijke rechter bevoegd was te oordelen. Nu echter het College van beroep studiefinanciering is 
opgeheven en zowel de Afdeling bestuursrechtspraak, de Centrale Raad van Beroep als het College van Beroep voor het bedrijfsleven de terugvorderingsbeslissing (wat de Centrale Raad en het College betreft: waarschijnlijk) zien als een (veelal appellabel) besluit, lijken deze verschillen te zijn weggenomen. 


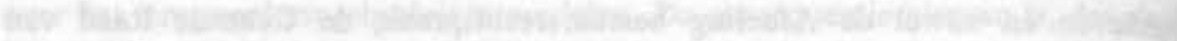

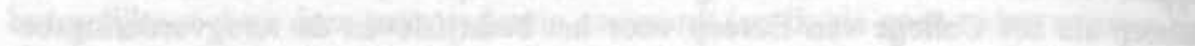

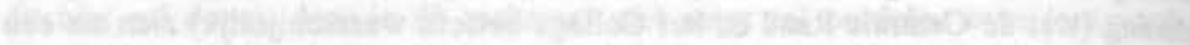

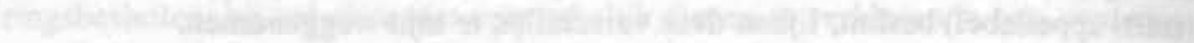

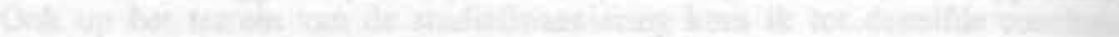

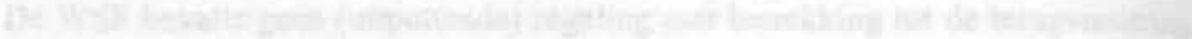

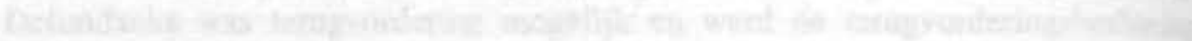

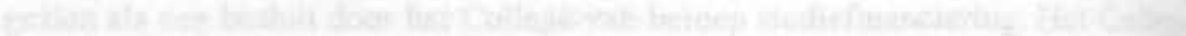

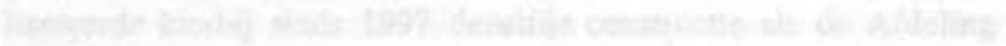

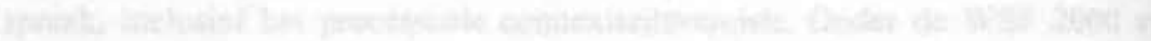

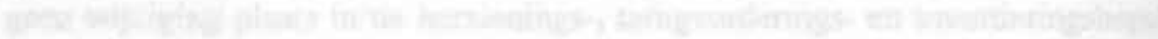

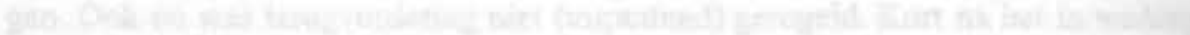

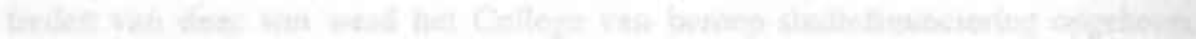

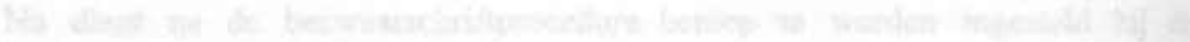

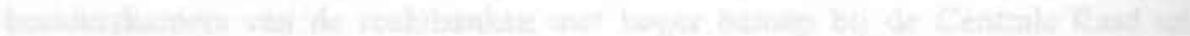

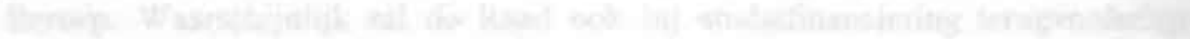

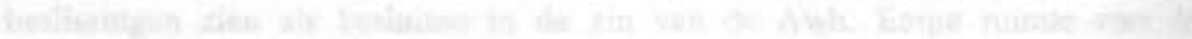

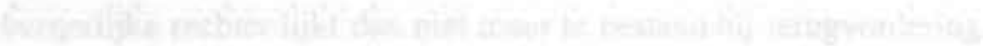

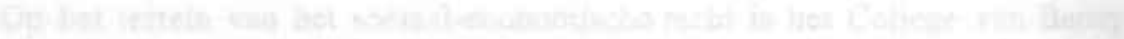

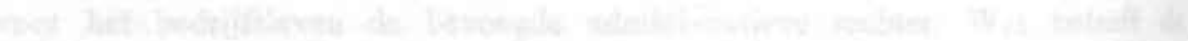

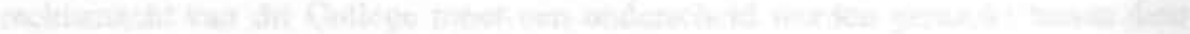

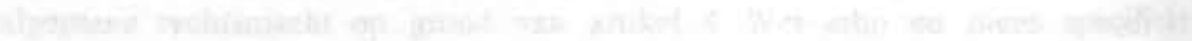

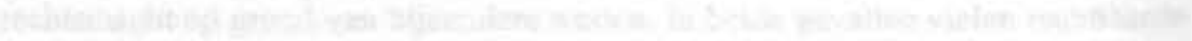
W

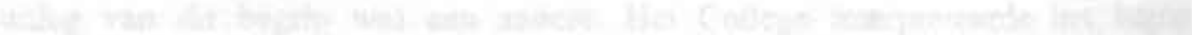

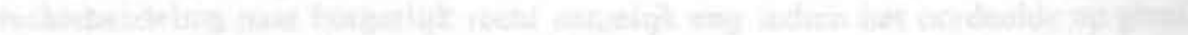

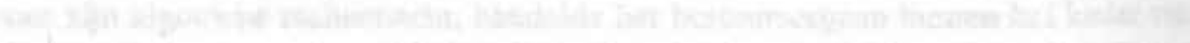

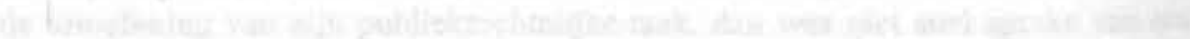

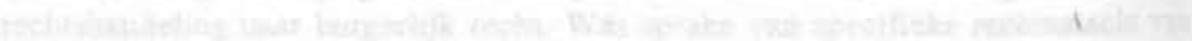

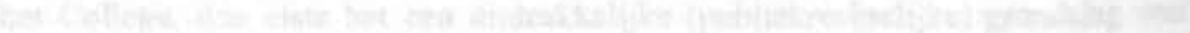

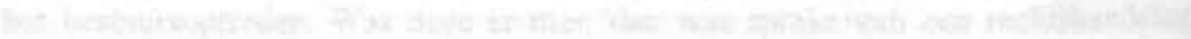

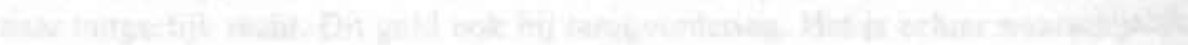

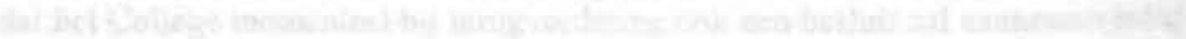

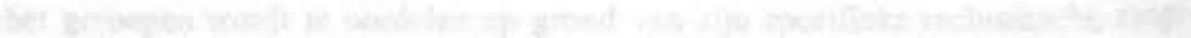

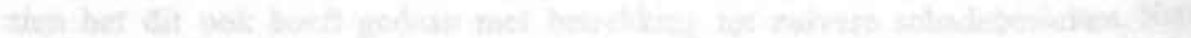

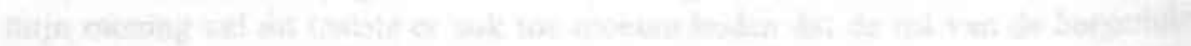

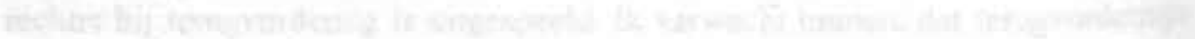

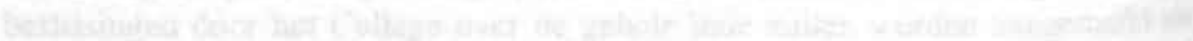

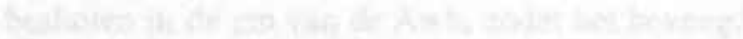

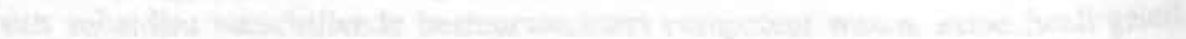

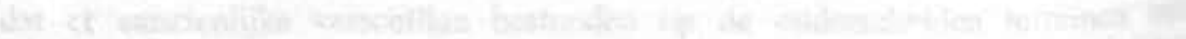

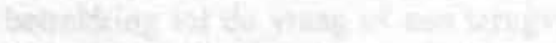

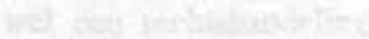

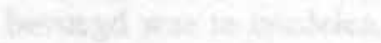


DEEL III 


\section{DE 'ALGEMENE-RECHTSBEGINSELENJURISPRUDENTIE': TERUGVORDERING EN LEGALITEIT}

\subsection{Inleiding}

In het voorafgaande is de jongste jurisprudentie van de bestuursrechters met betrekking tot onder meer het zuiver schadebesluit en het terugvorderingsbesluit behandeld. Deze behandeling is tot nu toe (voornamelijk) beschrijvend van aard geweest. Aan de hand van deze jurisprudentie kan ook een aantal principięle bestuursrechtelijke punten aan de orde worden gesteld. Zo is er de kritiek dat rechtsbeginselen, anders dan de Afdeling bestuursrechtspraak aannam, geen bevoegdheden kunnen scheppen; het legaliteitsbeginsel zou zich hiertegen verzetten. Verder zou de jurisprudentie in strijd zijn met (de rechtsmachtverdeling zoals neergelegd in) artikel 112 Grondwet. Behandeling van deze twee kwesties is van belang voor de beantwoording van de in 1.2 weergegeven probleemstelling vain dit onderzoek. Aan de hand van de reikwijdte van het legaliteitsbeginsel moet immers worden bekeken of terugvordering een wettelijke grondslag behoeft, hoe ruim die grondslag mag zijn en of er eventueel plaats is voor privaatrecht. De rechtsmachtverdeling is van belang voor het antwoord op de vraag welke rechter de terugvordering moet beoordelen: de burgerlijke of de bestuursrechter. Ik werk deze twee punten uit de bestuursrechtelijke jurisprudentie uit in dit hoofdstuk; in de volgende hoofdstukken zal ik op de bevindingen uit dit hoofdstuk voortbouwen. Om deze reden is dit hoofdstuk dan ook een overgang tussen de delen I en II en deel III van het onderzoek.

Gelet op het onderwerp van dit onderzoek zal ik mij bij de behandeling van deze punten concentreren op de terugvorderingsjurisprudentie. De constructie door de rechter van deze beslissingen als zijnde besluiten is dezelfde als bij schadebesluiten. Op sommige punten zal ik dan ook de jurisprudentie inzake het schadebesiuit bij deze behandeling betrekken, met name als in die uitspraken zaken aan de orde zijn geweest die ook voor de terugvordering van belang (kunnen) zijn.

De opbouw van dit hoofdstuk is als volgt. In 9.2 zal eerst kort de redenering van de Afdeling bestuursrechtspraak worden uiteengezet. De vraag hoe deze rechtspraak zich verhoudt tot het legaliteitsbeginsel wordt behandeld in 9.3. Vervolgens zal in 9.4 op de constitutionele aspecten van deze jurisprudentie worden ingegaan, waarna in 9.5 het door de bestuursrechter gestelde (processuele) connexiteitsvereiste aan de orde komt. Ten slotte zullen in 9.6 de reacties op deze jurispnudentiële rechtsmachtuitbreiding van de bestuursrechter worden behandeld, waronder die van de Hoge Raad in het arrest Groningen-Raatgever.'

1. HR 17 december 1999, NJ 2000, 87, m.nt. ARB onder 88, AB 2000, 89, m.nt. PvB, JE3 2000, 4, m.nt. F.A.M. S. 


\subsection{Het terugvorderingsbesluit}

In 1996 werd de Afdeling bestuursrechtspraak in het geschil tussen Nanne en de staatssecretaris van VROM geconfronteerd met de vraag of een terugvorderingsbesluit, waaryoor geen expliciete wettelijke grondslag was aan te wijzen, een besluit in de zin van artikel 1:3 Awb was. De Afdeling beantwoordde deze vraag positief. ${ }^{2}$ De kernoverwegingen van de Afdeling waren de volgende:

'De Afdeling ziet zich (...) geplaatst voor de vraag naar het rechtskarakter en de beroepbaarheid bij de bestuursrechter van besluiten van bestuursorganen tot terugvordering van eerder door hen in het kader van de uitoefening van hun bestuursrechteiijke taken en bevoegdheden gedane toekenningen.

De Afdeling oordeelt dienaangaande thans, anders dan zij in het verleden heeft gedaan, dat terugvorderingsbesluiten van bestuursorganen als in de vorige alinea omschreven, ook indien deze niet op uitdrukkelijk daartoe strekkende wettelijke bevoegdheden zijn gebaseerd, zijn gericht op rechtsgevolg. Dit rechtsgevolg wordt ontleend aan het algemene, ook in het bestuursrecht geldende, rechtsbeginsel volgens hetwelk hetgeen onverschuldigd is betaald, kan worden teruggevorderd.

Dit rechtsbeginsel is van bestuursrechtelijke aard, wanneer zijn werking zich doet gevoelen in door het bestuursrecht beheerste verhoudingen. Voor bestuursorganen schept het dan een bevoegdheid omtrent de aanwending waarvan per geval beslist moet worden met inachtneming van de algemene besturs. rechtelijke normen die de aanwending van discretionaire bevoegdheden beheersen. Zo een beslissing, die strekt tot voldoening aan de bestuursrechtelijke voorwaarden voor een rechtmatige terugvordering, opdat naar het bestuursrecht een betalingsverplichting ontstaat, is gericht op publiekrechtelijk rechtsgevolg.

Aan de art. 8:1 eerste lid en derde lid aanhef en onder a, 8:3 en 8:6 Awb ligt blijkens de wetsgeschicdenis een streven van de wetgever ten grondslag naar een in de rechtspraktijk goed hanteerbare afbakening van bevoegdheden tot beoordeling van besluiten tussen de algemene bestuursrechter, de bijzondere bestuursrechters en de burgerijike rechter. Blijkens met name de tekst en de geschiedenis van art. 8:3 Awb beoogde de wetgever in het bijzonder zoveel mogelijk te voorkomen dat binnen een samenhangende reeks van uit elkaar voortvloeiende bestuursbeslissingen een cesuur zou moeten worden aangebracht wat betreft de rechter die bevoegd is tot toetsing van de onderscheiden beslissingen.

Naar het oordeel van de Afdeling past het in dit door de wetgever gekozen stelsel de algemene dan wel de bijzondere bestuursrechter slechts bevoegd te achten tot kennisneming van beroepen tegen terugvorderingsbesluiten, indien dergelijke besluiten voortvloeien uit een besluit inzake een bestuursrechtelijke toekenning ter zake waarvan die rechter bevoegd is'.

\subsection{Het !egaliteitsbeginsel}

\subsection{Inleiding}

Op deze jurisprudentie werd fundamentele kritiek gegeven: rechtsbeginselen kunnen geen bevoegdheden scheppen. Kortmann is kort en krachtig: rechtsbeginselen kunnen wel verplichtingen creëren, maar geen bevoegdheden scheppen. Volgens hem 'is de beer los' als rechtsbeginselen bevoegdheidscheppend zouden

2. ABRvS 21 oktober 1996, AB 1997, 496, m.nt. NV, JB 1996, 232, m.nt. HJS (Nanne). Zie ook 5.3 .3 en 8.2 .6 . 
(kunnen) zijn. ${ }^{3}$ Hetzelfde geldt overigens met betrekking tot publiekrechtelijke taken. Zijn kritiek is vooral rechtsstatelijk van aard: als rechtsbeginselen en publiekrechtelijke taken bevoegdheden kunnen scheppen, is de totalitaire staat dichtbij en dus is het 'uit rechtsstatelijk oogpunt van groot belang overheidsbevoegdheden in de tang te houden'.4 Dit geschiedt onder meer door nauwkeurige attributie en delegatie van bevoegdheden. Kortmann koppelt dit (mede) aan het legaliteitsbeginsel. ${ }^{5}$ Met dit. alles verhoudt zich niet dat het ongeschreven recht als bevoegdheidsgrondslag kan dienen.

Ook Damen wijst de door de Afdeling gehanteerde constructie af:

'Een ongeschreven algemeen rechtsbeginsel kan dus volgens de Afdeling een discretionaire bestuursrechtelijke bevoegdheid scheppen. Daarmee raken we toch wel ver weg van het legaliteitsbeginsel. (...) Warom zou voor de terugvorderingsbevoegdheid geen wettelijke grondslag nodig zijn $(\ldots)^{\prime}{ }^{6}$

Hiermee geeft hij de kern van het probleem en de in deze paragraaf te behandelen vraag weer: hoe verhoudt deze jurisprudentie zich met het legaliteitsbeginsel? In 9.3.2 zal ik ingaan op de verschillende opvattingen met betrekking tot (de reikwijdte van) het legaliteitsbeginsel, waarbij ook de vraag aan de orde komt in hoeverre rechtsbeginselen bevoegdheden kunnen scheppen, in 9.3 .3 behandel ik de vraag in hoeverre terugvorderingsbesluiten een wettelijke grondslag behoeven in de verschillende opvattingen met betrekking tot het legaliteitsvereiste.

\subsubsection{Legaliteit: beginsel of vereiste?}

Volgens het legaliteitsbeginsel of het beginsel van wetmatigheid van bestuur moet het overheidsoptreden te zijn terug te voeren op wettelijke bevoegdheden. $\mathrm{Er}_{\mathrm{r}}$ is sprake van een ongeschreven beginsel: het legaliteitsbeginsel is als zodanig niet neergelegd in de Nederlandse (Grond)wet. Op een aantal terreinen is het overigens wel gecodificeerd. Zo bepaalt bijvoorbeeld artikel $104 \mathrm{Gw}$ dat 'belastingen van het Rijk worden geheven uit kracht van een wet' en dat 'andere heffingen van het Rijk (...) bij de wet (worden) geregeld'. Het beginsel is een belangrijk uitvloeisel van de rechtsstaatgedachte: ook de staat is aan het recht onderworpen. De functies die het legaliteitsbeginsel daarin heeft, zijn het bevorderen en zelfs verzekeren van rechtszekerheid en rechtsgelijkheid. Beoogd wordt willekeur van de zijde van het bestuur te voorkomen en zodoende de burger te beschermen tegen ongebreideld en ongecontroleerd overheidshandelen. Het heeft dus tevens een functie in het waarborgen van de autonomie en vrijheid van de burger. ${ }^{7}$ Daarnaast heeft het een

3. Kortmann (1997-1), blz. 1327. Kortmann uitte deze kritiek naar aanleiding van de jurisprudentie met betrekking tot het zuiver schadebesluit; aangenomen mag worden dat zij ook de 'terugvorderingsjurisprudentie' betreft.

4. Kortmann (1997-I), blz. 1327 en Kortmann (1997-II), blz. 1599.

5. Kortmann (2001), bla. 315-316.

6. Damen (1999-II), blz: 57. Cursiveringen in oorspronkelijke tekst.

7. Zie hierover Ter SpillTak (1981), blz. 45-55 en De Haan (1998-III), blz. 5-6. 
functie binnen het democratische staatsbestel: het dient ter bevordering van de democratische legitimatie van overheidsoptreden. In deze functie is het mede een uitvloeisel van de scheiding der machten.

Het is de vraag wat precies de reikwijdte van het beginsel is. Moet elk overheidsoptreden zijn terug te voeren op een wettelijke bevoegdheid of hoeft dit slechts bij bepaald optreden, bijvoorbeeld wanneer de vrijheid of eigendom van burgers in het geding is, zoals de klassieke uitleg luidde?' Verder kan men verschillend denken over het antwoord op de vraag hoe specifiek de bevoegdheidstoedeling moet zijn. Moet het overheidsoptreden direct zijn terug te voeren op een wettelijk gegeven bevoegdheid, of is het voldoende dat in een (andere) wettelijke bevoegdheid een positieve indicatie is te vinden voor de bevoegdheid tot het optreden?

Vooral de eerste vraag is hier van belang: wanneer eist het legaliteitsbeginsel een wettelijke grondslag, oftewel: wanneer is sprake van een legaliteitseis? In de literatuur wordt deze vraag verschillend beantwoord. Damen onderscheidt drie opvattingen, namelijk de opvatting dat al het overheidsoptreden een wettelijke grondslag behoeft, de opvatting dat slechts bepaald overheidsoptreden een dergelijke grondslag behoeft - hij noemt dit de 'selectieve' opvatting -, en ten slotte de 'vrije' opvatting: 'niets hoeft en anything goes'. ${ }^{10}$ Vooral de selectieve opvatting kan rekenen op veel aanhangers en kan worden gezien als de heersende. Hierbij moet worden bedacht dat tussen auteurs die tot een bepaalde stroming kunnen worden gerekend versehillen bestaan en dat voor het onderscheid tussen de 'selectieve' en de 'strenge' opvatting geen 'hard' criterium bestaat; er is sprake van een glijdende schaal waarbij de ene auteur 'meer selectief' is en de andere 'meer streng'. Daarnaast wordt aan het legaliteitsbeginsel tegenwoordig ook wel slechts een instrumentele functie toegedacht, bijvoorbeeld door Scheltema, die het keurslijf van legaliteit bij de huidige ontwikkeling van het bestuursrecht als (te) knellend ervaart. Op deze verschillende visies zal ik in het hiernavolgende ingaan.

In navolging van de Duitse opvatting werd lange tijd aarigenomen dat enkel belastende besluiten, de zogenaamde Eingriffsverwaltungen, een geschreven wettelijke grondslag dienden te hebben. Sinds de jaren tachtig gaan de meningen steeds meer in de richting van de opvatting, dat ook voor Leistungsverwaltungen, waarbij de overheid begunstigend, presterend, optreedt, veelal een wettelijke grondslag is vereist. ${ }^{11}$

Ter Spill en Tak eisen een (formeel)wettelijke grondslag wanneer zowel het democratisch als het rechtspostulaat dit vereist. ${ }^{12}$ Het democratisch postulaat

8. Overigens wordt dit laatste aspect nogal eens over het hoofd gezien, zie bijvoorbeeld de kritiek van De Haan op de dissertatie van Van Ommeren; De Haan (1998-I), blz. 634.

9. De Haan/Drupsteen/Fernhout I (2001), blz. 21.

10. Damen (1999-II), blz. 49.

11. Een zelfde ontwikkeling vond plaats in Duitsland, zie Ter Spill/Tak: (1981), blz. 45 en Schlossels (1998), blz. 107-109.

12. Ter Spill/Tak (1981), blz. 48-52. 
'vereist' een dergelijke grondslag bij beslissingen over wat als algemene belangen moeten worden aangemerkt en bij het afwegen van algemene belangen tegen elkaar; de vraag wanneer het rechtspostulaat een weitelijke grondslag vereist, is moeilijker te beantwoorden. Als algemene richtsnoeren kunnen dienen het rechtszekerheidsbeginsel en het rechtvaardigheidsbeginsel. ${ }^{13}$ Volgens Konijnenbelt dient er een wettelijke grondslag te zijn bij Leistungsverwaltungen, voor zover deze tevens Eingriffsverwaltungen zijn, voor zover het begunstigend besluit tevens belastende elementen bevat. Dit is bijvoorbeeld het geval als aan een begunstigend besluit belastende voorwaarden worden verbonden. ${ }^{14}$ Ook eist hij aliijd een wettelijke grondslag indien personen wat hun inkomsten betreft geheel aan de overheid zijn overgeleverd. ${ }^{15}$ Van der Vlies ziet de ingrijpendheid van het besluit als doorslaggevend: een wettelijke grondslag is vereist als sprake is van een ingrijpend besluit. ${ }^{16}$ Van Ommeren hanteert als criterium de vraag of sprake is van verplichtend overheidsoptreden, waarbij sprake is van betrokkenen verplichtende voorschriften; legt de overheid eenzijdig verplichtingen op aan de betrokkene, vaak burger? Slechts deze eenzijdig op te leggen verplichtingen moeten per se op een wettelijke grondslag berusten. ${ }^{17}$

Naast deze 'meer selectieve' stroming is er de 'meer strenge' stroming, die (in beginsel) voor al het overheidsoptreden een wettelijke grondslag eist. Hiertoe behoren onder meer Damen ${ }^{18}$ en Schlössels. ${ }^{19}$ Volgens hen dient in beginsel al

13. Ter Spill/Tak (1981), blz. 51 .

14. Konijnenbelt (1982), zic 8.2.1.

15. Van Wijk/Konijnenbelt (1988), blz. 41, zie 8.2.1. In de vijfde druk van dit handboek uit 1984 kwam deze eis nog niet voor.

16. Dit zijn "besluiten aangaande de eerste levensbehoeften dan wel fundamentele rechtsbeginselen (...), waardoor (nagenoeg) onontkoombare dwang zal ontstaan om conform het besluit te handelen, en waarover diepgaande meningsverschillen in de samenleving blijken te bestaan of waarbij fundamentele zaken geraakt worden die de staatsorganisatie betreffen en waarbij het bestuur een eigen belang heeft dan wel de schijn daarvan bestaat', Van der Vlies (1984), blz. 105-106. Van der Vlies ontleent haar criterium aan het Fluorideringsarrest, HR 22 juni 1973, NJ 1973, 386, m.nt. A.R.B., AB 1973, 187, m.nt. V.d.H.

17. Van Ommeren (1996), in het bijzonder deel II (zie ook de conclusies van dat deel op blz. 202203) en Van Ommeren (1999), blz. 71. In deze laatste publicatie maakt hij - mogelijk mede onder invloed van de recensie van zijn dissertatie door De Haan, zie De Haan (1998-I), blz. 634 een onderscheid tussen het zuiver juridisch legaliteitsbeginsel en de rechtspolitieke benadering van dit beginsel. Wat het zuiver juridisch legaliteitsbeginsel betreft, neemt hij het weergegeven standpunt in: is sprake van betrokkenen verplichtend overheidsoptreden? De rechtspolitieke benadering ziet hij dan als 'leidraad bij een wetgevingsprogramma'. De vraag die dan centraal slaat, is 'welke maatschappelijke problemen langs de weg van een wettelijke regeling oplossing behoeven'. Het bestaan van een wettelijke grondslag is in dat geval geen juridische plicht.

18. Zie Damen (1987), blz. 296 en Damen (1999-II), blz. 63, warin hij stelt dat we toe moeten. naar een situatie waarin voor in beginsel het gehele overheidsoptreden een zo specifiek mogelijke wettelijke grondslag nodig is' (cursiveringen in oorspronkelijke tekst).

19. Zie Schlössels (1998), blz. 113: 'Eénzijdige rechtsvorming door het bestsur dient mijns inziens, voorzover deze van invloed is op de rechispositie van rechtssubjecten, te berusten op een democratische grondslag. Deze grondslag dient in ieder geval in positieve zin, d.w.z. doelbestemd, richting te geven aan het rechtshandelen van het bestuur (de specialiteitseis). De wet biedt 
het overheidsoptreden dat de rechtspositie van betrokkenen kan beïnvloeden, een wettelijke grondslag te hebben, al zijn er situaties waarin het minder duidelijk is of onverkort aan deze eis van een wettelijke grondslag moet worden vastgehou. den. Zo is bijvoorbeeld niet geheel duidelijk of Damen bij zuivere schadebesiluiten onverkort vasthoudt aan de eis van een wettelijke grondslag. In zijn preadivies voor de Staatsrechtconferentie stelde hij dat het bestuur altijd al bevoegd werd geacht schade die door zijn onrechtmatig handelen was ontstaan, te vergoeden; er was zelfs sprake van een plicht voor het bestuur. 'In zoverre wordt er geen nieuwe bevoegdheid geschapen'. ${ }^{20}$ In zijñ referaat bij dit preadvies haakt Van Ommeren hierop in: het voorbeeld van de schadevergoeding "laat meteen zien dat naar huidig Nederlands recht niet voor alle bestuursopireden een concrete wettelijke grondslag nodig is". ${ }^{21}$ Het is mogelijk dat Damen het door Kortmann gemaakte onderscheid tussen bevoegdheden en verplichtingen van de overheid ${ }^{22}$ hanteert, waarbij bevoegdheden wél en verplichtingen in beginsel niet altijd op een wettelijke grondslag moeten berusten.

Meer in het midden van de schaal tussen de selectieve en de strenge opvatting zitten De Haan. Drupsteen en Fernhout in hun Bestuursrecht in de sociale rechtsstaai ${ }^{23}$ en Kortmann. De eersten vatten het beginsel deels op als vereiste, namelijk waar het eenzijdig door de overheid opgelegde verplichtingen betreft; deze dienen een specifieke wettelijke grondslag te hebben. ${ }^{24}$ Voor het overige zien zij het als 'rechtspolitiek desideratum', ${ }^{25}$ Hun opvatting, dat het overheidsoptreden over de gehele linie een wettelijke grondslag behoort te hebben, wordt daardoor ingegeven. Wat dit aspect betreft is er sprake van een beginsel, niet van een vereiste. ${ }^{26}$ Kortmann spreekt zich waar het belastend overheidsoptreden betreft duidelijk uit: volgens hem geldt als algemeen staatsrechtelijk beginsel 'in ieder geval dat voor de onderdaan belastende besluiten en handelingen van de

mijns: inziens uiteindelijk de beste waarborg om zen bestuursbevoegdheid inhoudelijk en procedureel te noimeren' (cursiveringen in oorspronkelijke tekst).

20. Damen (1999-II), blz. 59.

21. Van Ommeren (1999), blz. 70.

22. Zie met name Kortmann (1997-II), blz. 1599.

23. De Haan/Drupsteen/Fernhout I (2001).

24. Zie ook De Haan (1998-III), blz. 29, volgens wie het "nogal vanzelfsprekend" is dat door de overheid eenzijdig opgelegde verplichtingen een specifieke wettelijke grondslag hebben en De Haan (1998-1), blz. 634. De Haan heeft overigens ook het betreffende hoofdstuk in De Haan/Drupsteen/Fernhout voor zijn rekening genomen.

25. De Haan/Drupsteen/Fernhout İ (2001), blz. 289. De Haan (1998-III), blz. 30, stelt: 'Voor mij geldt dit beginsel in de eerste plaats als uitgangspunt dat in een democratische rechtsstast de wetgever of op lager niveau de vertegenwoordigende organen het algemeen beleid behoren te bepalen'.

26. In zoverre wijken De Haan en De Haan/Drupsteen/Fernhout niet zo veel af van het standpunt vall Van Ommeren, die voor eenzijdig opgelegde verplichtingen een wettelijke grondslag eist. Voof het overige overheidsoptreden kan de overheid een wettelijke grondslag creěren; er is dan sprake van een rechtspolitieke keuze, niet van een juridische verplichting. In bepaalde gevallen kan op rechtspolitieke gronden zelfs sprake zijn van een (niet juridische) 'verplichting', in die 2 in dat ook dan ingrepen van de wetgever 'nodig zijn', Van Ommeren (1999), blz. 71. 
overheid een grondslag moeten vinden in een geschreven wettelijke regeling'. Waar het de presterende overheid betreft, spreekt hij zich niet zo duidelijk uit. In zjn Constitutioneel recht legt hij wei duidelijk de nadruk op het feit dat het standpunt van de grondwetgever en het kabinet was dat ook dit presterend overheidsoptreden zoveel mogelijk een wettelijke grondslag dient te hebben; hij staat hier in ieder geval niet kritisch tegenover. ${ }^{27}$

Het is overigens niet zo, dat alle genoemde auteurs in de gevallen waarin zij een wettelijke gronds!ag eisen, ook eisen dat deze grondslag een uitdrukkelijke is. Zo kan er volgens onder meer Ter Spill en Tak, Van der Vlies, Van Ommeren en Teunissen onder omstandigheden sprake zijn van een impliciete bevoegdheid. Voor deze bevoegdheid bestaat dan geen uitdrukkelijke wettelijke grondslag en hoeft ook geen uitdrukkelijke wettelijke grondslag te bestaan, wel moet er een positieve indicatie voor deze bevoegdheid bestaan. De constructie van impliciete bevoegdheden kan bijvoorbeeld een roll spelen bij de terugvordering. Op dit punt kom ik in de volgende paragraaf terug.

Een opmerkelijke visie heeft M. Scheltema in 1996 naar voren gebracht in een artikel in het NJB, getiteld Van rechtsbescherming naar een volwaardig bestuursrecht ${ }^{28}$ Waar de discussie met betrekking tot het legaliteitsvereiste zich momenteel concentreert rond de vraag of al het overheidsoptreden op een wettelijke grondslag dient te berusten of dat een dergelijke grondslag slechts vereist is bij bepaald overheidsoptreden, pleit Scheltema voor "het aanzienlijk verminderen van de betekenis van het legaliteitsbeginsel'. ${ }^{29}$ Volgens hem heeft het bestuursrecht zich lange tijd geconcentreerd op de rechtsbescherming van de burger tegen de overheid. In dit kader plaatst hij het legaliteitsbeginsel: het diende de rechtszekerheid, gelijkheid en democratische legitimatie, dit alles ter bescherming van de burger tegen ongebreideld overheidsingrijpen. Maar mede doordat de rechtsbescherming tegen de overheid momenteel in voldoende mate is gegarandeerd, onder meer door de uitbouw van de administratieve rechtsbescherming, en doordat de functie van de overheid is veranderd - werd vroeger van de overheid zo veel mogelijk onthouding verlangd, tegenwoordig dient de overheid actief op te treden dient een herijking van het legaliteitsbeginsel plaats te vinden. Voor het bereiken van rechtszekerheid en rechtsgelijkheid is het beginsel weinig functioneel; vrijwel niemand leest of kent de wet, terwijl deze wet veelal abstract en algemeen is. Zekerheid en gelijkheid kan dan ook beter via goede voorlichting worden verwezenlijkt, terwijl voorts de burger ook beter gediend is met doorzichtigheid en eenheid. Nu nog moet de burger te vaak te veel loketten aflopen om (al dan niet) te krijgen wat hij wil. Dit leidt ook tot het loslaten van het specialiteitsbeginsel: wat heeft de burger aan een bouwvergunning als hij niet tevens een kapvergunning krijgt voor bomen die op de plaats staan waar het beoogde bouwwerk moet komen?

37. Kortmann (2001), blz. 316.

28. Scheltema (1996). Ik zal hier slechts ingaan op de door Scheltema met betrekking tot het legaliteitsbeginsel aangestipte punten.

2. Scheltema (1996), blz. 1355. 
Het belang van het legaliteitsbeginsel is dan volgens Scheltema nog slechts gelegen in de democratische legitimatie: de betrokkenheid van het parlement bij de wetgeving. Scheltema vindt deze betrokkenheid alleen nodig bij wat hij noemt richtinggevende besluiten. ${ }^{30}$ De voor een burger belangrijkste besluiten moeten op een afweging van de wetgever berusten. De concrete invulling en detaillering van deze regels behoeft echter niet steeds een specifieke wettelijke regeling. Een dergelijke grondslag is dan ook niet vereist; ook algemeen geformuleerde verplichtingen, zoals artikel $1.1 \mathrm{a}$ Wet milieubeheer, ${ }^{31}$ zouden de toets der kritiek kunnen doorstaan.

Scheltema neemt als uitgangspunt de wederkerigheid van de publiekrechtelijke rechtsbetrekking: tussen burger en overheid zou een wederkerige rechtsbetrekking bestaan, die voor beiden rechten en verplichtingen schept. De verhouding tussen burger en overheid is echter niet wederkerig; het betreft vrijwel altijd eenzijdig handelen van de kant van de overheid. De visie van Scheltema heeft de door hem gewenste discussie opgeleverd, waarbij zijn standpunten viijwel steeds werden verworpen. ${ }^{32}$ Damen stelt mijns inziens terecht, dat rechtszekerheid inderdaad even goed en mogelijk zelfs beter door onder meer voorlichting van de burger kan worden bereikt, maar hij ziet niet hoe het legaliteitsbeginsel daaraan in de weg kan staan. ${ }^{33}$ Het legaliteitsvereiste mag inderdaad niet aan goede voorlichting in de weg staan, omgekeerd geldt hetzelfde: goede voorlichting mag niet aan het legaliteitsbeginsel in de weg staan. Iets soortgelijks kan worden gezegd van het afstemmen van procedures op elkaar en het hierdoor scheppen van duidelijkheid bij burgers, ook dit dient te gebeuren met behoud van het specialiteitsbeginsel.

Mijns inziens houdt het legaliteitsbeginsel in dat iedere bestuursbevoegdheid waardoor bevoegdheden, rechten en plichten van burgers kunnen worden vastgesteld of gewijzigd, in beginsel een wettelijke grondslag behoeft. ${ }^{34}$ In beginsel moet voor deze bevoegdheid een uitdrukkelijke wettelijke basis bestaan. In. bepaalde gevallen kan het voldoende zijn, dat de wet een positieve indicatie bevat voor de bevoegdheid. ${ }^{35}$ Dit betekent dat in die gevallen ruimte bestaat voor impliciete bevoegdheden, waarbij deze impliciete bevoegdheden voortvloeien uit de expliciet op een wettelijke grondslag berustende (primaire) bevoegdheid. Als een bestuursorgaan bijvoorbeeld een wettelijke bevoegdheid heeft gekregen, die het (deels) naar eigen inzicht kan uitoefenen, waarbij dus beleidsvrijheid bestaat,

30. Scheltema (1996), blz. 1359.

31. Zie over zulke algemene zorgplichten Teunissen/Tak (1994).

32. Zie bijvoorbeeld Tak (1996), De Haan (1998-III), blz. 5-9. en Damen (1999-II), blz. 62.

33. Damen (1999-II), blz. 61-62.

34. In een aantal gevallen vloeit dit reeds rechtstreeks uit de Grondwet voort: de wet stelt algemene regels van bestuursrecht vast (artikel 107 lid $2 \mathrm{Gw}$ ), de wet regelt de rechtspositie van ambtena. ren (artikel $109 \mathrm{Gw}$ ), de wet stelt regels omtrent de aanspraken op sociale zekerheid (artikel 20 lid $2 \mathrm{Gw}$ ) enzovoort.

35. Ik laat de bevoegdheid om op te treden in noodsituaties hierbij buiten beschouwing. 
impliceert dit de bevoegdheid deze beleidsvrijheid uit te werken in beleidsregels. ${ }^{36}$ Hetzelfde kan worden gezegd, indien aan een bestuursorgaan een wettelijke tak is gegeven. Dit kan andere bevoegdheden impliceren, die nodig zijn om die taak te (kunnen) vervullen. ${ }^{37}$

De mogelijkheid om impliciete bevoegdheden aan te nemen is echter begrensd. Ik leg in beginsel de grens daar, waar door uitoefening van die bevoegdheid direct of indirect verplichtingen kunnen worden opgelegd aan de betrokkene(n), terwijl (de mogelijkheid tot) het opleggen van die verplichting(en) niet reeds rechtstreeks voortvloeit uit de primaire, uitdrukkelijk wettelijk geregelde, bevoegdheid of taak. ${ }^{38}$ Het verplichtende karakter van de impliciete bevoegdheid dient te kunnen worden afgeleid uit de (mogelijk) verplichtende primaire bevoegdbeid. ${ }^{39}$ De consequentie hiervan is dat bij 'verplichtend overheidsoptreden' impliciete bevoegdheden niet snel zullen bestaan, bij begunstigend of presterend optreden zal de ruimte voor deze impliciete bevoegdheden veel ruimer zijn.

Nu ik de verschillende opvattingen met betrekking tot het legaliteitsbeginsel heb weergegeven, kom ik toe aan de vraag of rechtsbeginselen bevoegdheden kunnen scheppen. Anders gezegd: is de rechtspraak van de Afdeling bestuursrechtspraak in overeenstemming met het legaliteitsbeginsel? Kortmann en Damen vinden duidelijk dat dit niet het geval is. Anderen delen deze opvatting. Van der Vlies vraagt zich bijvoorbeeld af of 'het toekennen van een scheppend vermogen aan rechtsbeginselen een gelukkige ontwikkeling is', nu op die wijze de vraag of een besluit een wettelijke grondslag had moeten hebben, wordt gepasseerd. ${ }^{40}$ Tak stelt dat een algemeen rechtsbeginsel 'onder omstandigheden zelfs een sterkere rechtsnorm' kan zijn dan een wettelijk voorschrift, maar 'het verschaft nimmer enige overheidsbevoegdheid'. '1 Ook andere auteurs geven (meer of minder uitdrukkelijk) te kennen dat rechtsbeginselen geen bevoegdheden kunnen scheppen, onder meer door te betogen dat de Afdeling de bevoegdheid niet rechtstreeks stoelt op een algemeen rechtsbeginsel, maar de constructie van de impliciete bevoegdheid hanteert, zij het dat zij zich ongelukkig uitdrukt. Ik kom hierop terug in de volgende paragraaf.

36. Zie Van Wijk/Konijnenbelt \& Van Male (1999), blz. 153. De bevoegdheid om beleidsregels vast te stellen is tegenwoordig overigens neergelegd in artikel 4:81 Awb, zodat nu geen sprake meer is van een impliciete bevoegdheid.

37. Maar deze wettelijke taak kan zo ruim worden omschreven, dat een Generalklausel ontstaat, een soort blanco bevoegdheid. Dit is naar mijn mening in strijd met het legaliteitsbeginsel en mag dus niet. Op de mogelijke gevaren hiervan is gewezen door Teunissen/Tak (1994). Zie ook De Haan/Drupsteen/Fernhout I (2001), blz. 290.

38. Ik houd hier een slag om de arm; zoals ik in 1.2 heb aangegeven, is het niet mijn bedoeling geweest om het gehele bestuursrecht te onderzoeken. Ik kan mij dan ook voorstellen dat er terreinen of gevallen bestaan, waarop toch impliciete bevoegdheden kunnen bestaan, terwijl niet (geheel) aan de door mij daarvoor gestelde voorwaarden is voldaan.

39. Ik ontleen deze formulering aan Ter Spill/Tak (1981), blz. 33.

40. Van der Vlies (1997), blz. 608.

41. Tak (1997), blz. $48-49$. 
Er zijn ook auteurs die minder moeite hebben met de opvatting dat rechtsbeginseIen bevoegdheidscheppend kunnen zijn, zoals bijvoorbeeld Nieuwenhuis. Ook hij ziet echter grenzen, die worden bepaald door het legaliteitsbeginsel. De vraag of het legaliteitsbeginsel van toepassing is en welke eisen het stelt, is onder meer afhankelijk van de ingrijpendheid van het overheidsoptreden: 'ingrijpen door de overheid in vrijheid en vermogen van de burger dient te steunen op een grondslag in de wet'. ${ }^{42}$

Gelet op de door mij aan het legaliteitsbeginsel toegekende betekenis ben ook ik van mening dat rechtsbeginselen geen bevoegdheden kunnen scheppen. Bevoegdheden dienen door de (grond)wetgever te zijn geattribueerd of gedelegeerd; er dient dan ook minimaal een positieve indicatie in de wet voor te bestaan. Dat aan bevoegdheden die aan deze eis voldoen veelal rechtsbeginselen ten grondslag liggen, betekent niet dat de stap van de wettelijke grondslag kan worden overgeslagen.

Het is de vraag of niet ook de overige bestuursrechters deze opvatting delen. Opvallend is immers dat geen enkele ander college overweegt dat het rechisbeginsel een bevoegdheid schept. ${ }^{43}$ Weliswaar verwijzen de Centrale Raad van Beroep als ambtenarenrechter en het (voormalige) College van beroep studiefinanciering naar het algemene rechtsbeginsel dat hetgeen onverschuldigd is betaald, kan worden teruggevorderd, zij overwegen nergens dat dit rechtsbeginsel bevoegdheidscheppend zou zijn. ${ }^{44}$

\subsubsection{Terugvorderingsbesluiten en legaliteit}

Na deze meer algemene uiteenzetting met betrekking tot het legaliteitsbeginsel zal $\mathrm{nu}$ de verhouding tussen het legaliteitsbeginsel en terugvorderingsbesluiten aan de orde komen. Moeten terugvorderingsbesluiten op een wettelijke grondslag berusten? En zo ja, hoe verhoudt dit zich dan met de jurisprudentie van de bestuursrechter, die in een algemeen rechtsbeginsel een bevoegdheidsgrondslag ziet?

Op grond van de in de vorige paragraaf uiteengezette opvattingen met betrekking tot het legaliteitsbeginsel zou er alleen al op grond van het feit dat terugvorderingsbesluiten belastende besluiten, Eingriffsverwaltungen, zijn, overeenstemming moeten bestaan over het antwoord op de vraag of een terugvorderingsbesluit op een wettelijke grondslag moet berusten. ${ }^{45}$ Het terugvorderingsbesluit is

42. Nieuwenhuis (1997), blz. 351.

43. Zie 5.3.3.

44. Zie onder meer CRvB 30 december 1952, AB 1953, 477 (Schouten-Zonnemaire), zie 7.2 .33 en Cbsf 9 april 1997, JB 1997, 105, m.nt. HJS, zie 8.3.2. Overigens is het de vraag of deze colleges niet toch de bevoegdheidsgrondslag zien in dit beginsel. Het feit dat zij dit niet met zoveel woorden overwegen laat echter de ruimte dat zij een andere constructie hanteren.

45. Zie bijvoorbeeld Van Ommeren (1998), blz. 117: 'Een beperkte opvatting van [de reikwijtz van, $\mathrm{CB}$ ] het legaliteitsbeginsel lijkt wel een; wettelijke grondslag yoor de beslissing tot terugvordering te verlangen', dit in tegenstelling tot zuivere schadebesluiten. 
immers een (van de) vereiste(n) om over te gaan tot terugvordering. ${ }^{46}$

Het is dan ook opvallend dat de wijze waarop de Afdeling (bestuurs)rechtspraak tot voor kort omging met terugvorderingsbesluiten die niet op een geschreven wettelijke grondslag berustten, weinig kritiek ontmoette. In de meeste gevallen nam de Afdeling namelijk aan dat sprake was van een rechtshandeling naar burgerlijk recht, waardoor een vordering voor de burgerlijke rechter diende te worden ingesteld en waardoor het privaatrecht van toepassing was. Hiermee ging de Afdeling het 'probleem' van het legaliteitsbeginsel uit de weg. Teunissen spreekt zelfs van de paradox van de legaliteit en van 'etikettenzwendel': ${ }^{47}$ er kan geen sprake zijn van een besluit omdat het bestuursorgaan niet beschikt over de (op grond van het legaliteitsbeginsel) vereiste publiekrechtelijke bevoegdheid en dus wordt er op dat optreden het etiket 'privaatrechtelijk' geplakt, waardoor het legaliteitsbeginsel geen rol meer speelt.

De jurisprudentie van de Afdeling bestuursrechtspraak inzake het terugvorderingsbesluit kan in een bepaald opzicht als een vooruitgang worden gezien: de terugvordering wordt niet langer als privaatrechtelijk gezien, maar als publiekrechtelijk. Hiermee wordit in ieder geval de (rechtstreekse) toepassing van het privaatrecht uitgesloten. Toch wordt ook op deze manier het legaliteitstekort niet opgelost.

Een aantal auteurs bepleit dan ook een andere constructie om om te gaan met terugvorderingsbesluiten waarvoor geen uitdrukkelijke wettelijke grondslag bestaat, namelijk door een impliciete of inherente bevoegdheid aan te nemen. Mogelijk kan op deze wijze wel worden voldaan aan de eisen die het legaliteitsbeginsel stelt. Karakteristiek aan een terugvorderingsbesluit is namelijk dat het (vrijwel) altijd is gekoppeld aan een of meerdere voorafgaande besluiten, namelijk het toekenningsbesluit en het intrekkingsbesluit. Bij terugvordering zouden de bevoegdheid tot intrekking van het toekenningsbesluit en de (veelal daaruit voortvloeiende) terugvorderingsbevoegdheid kunnen worden afgeleid uit de toekenningsbevoegdheid. Vrij algemeen wordt op dit moment aanvaard dat de toekenningsbevoegdheid op een uitdrukkelijke wettelijke grondslag dient te berusten. Indien is voldaan aan bepaalde, in de wettelijke regeling neergelegde criteria, dient het bestuursorgaan een toekenningsbesluit te nemen, waardoor een burger een financiêle aanspraak krijgt tegenover dit (of een ander) bestuursorgaan. Veelal zal immers sprake zijn van een gebonden bevoegdheid; indien de betrokkene aan de criteria voldoet om in aanmerking te komen voor een uitkering, subsidie et cetera, rust op het bestuursorgaan de verplichting tot het toekennen van die uitkering, subsidie et cetera. Betrokkene heeft daar recht op. Is daarentegen niet aan die criteria voldaan, dan is het bestuursorgaan ook niet bevoegd een toekenningsbesluit te nemen. Als het bestuursorgaan in eerste instantie ervan uitgaat, dat aan de voorwaarden voor het toekennen van een financiële aanspraak is voldaan, terwijl

\footnotetext{
46. Uiteraard zal in voorkomend geval eerst het tockenningsbesluit moeten worden ingetrokken en moet vervolgens, nadat een terugvorderingsbeshuit is genornen, een invorderingsbesluit volgen.

47. Teunissen (1996), blz. 233 en Teunissen (1997), blz. 97-98.
} 
later blijkt dat dit niet zo is, dan heeft het bestuur dus (achteraf gezien) onbevoegd gehandeld. Hiermee is impliciet de bevoegdheid gegeven om het toekenningsbesluit in te trekken en het daardoor onverschuldigd betaalde terug te vorderen. De intrekkings- en terugvorderingsbevoegdheid vloeien dan rechtstreeks voort uit de (begrensde) toekenningsbevoegdheid. Auteurs die deze constructie accepteren, eisen dan ook geen uitdrukkelijke wettelijke grondslag voor de intrekkingsen de terugvorderingsbevoegdheid. Deze of een soortgelijke constructie wordt bepleit door onder meer Van Ommeren, Van der Vlies en Teunissen.

Zo onderscheidt Van Ommeren originaire en accessoire bevoegdheden. Bij terugvordering (en andere, aan rechtsbeginselen te ontlenen bevoegdheden) gaat het om een accessoire bevoegdheid: een bevoegdheid die voortvloeit uit een cerdere, originaire bevoegdheid. Volgens hem is de accessoire bevoegdheid inherent aan de originaire. Zo impliceert de bevoegdheid tot subsidietoekenning de bevoegdheid tot terugvordering. Rechtsbeginsel en rechtsverhouding zijn vervolgens nodig 'om aan te geven wanneer een accessoire bevoegdheid door de originaire wordt geimpliceerd, en ook welke accessoire bevoegdheid daar dan uit volgt'. Hij constateert dat het bij accessoire bevoegdheden gaat om bevoegdheden die alleen kunnen bestaan voor zover zij voortvloeien uit eerder bestuursoptreden. Hiermee zou volgens hem het legaliteitsprobleem goeddeels zijn opgelost, want als een besluit tezamen met een rechtsbeginsel ten grondslag wil liggen aan een ander besluit, dan dient het originaire besluit rechtmatig te zijn. ${ }^{48}$

Ook Van der Vlies ziet bij terugvordering de mogelijkheid tot het aannemen van impliciete bevoegdheden. Zij wil de terugvorderingsbevoegdheid vastknopen aan de intrekkingsbevoegdheid, waarbij die besluitbevoegdheden tezamen kunnen worden gezien als een publiekrechtelijke rechtsbetrekking, 'waarvan niet meer elk facet afzonderlijk een wettelijke grondslag behoeft te hebben'.49 De wetgever kan hiertoe bijdragen door het bestuur(sorgaan) de behartiging van een bepaalde taak met inachtneming van bepaalde voorwaarden op te dragen. De bevoegdheden zoulden dan in die opdracht verdisconteerd zijn, zodat niet voor elke handeling ter uitvoering van die taak een aparte bevoegdheid moet worden verstrekt.

Volgens Teunissen is het zo, dat als een bestuursorgaan krachtens wettelijk

48. Van Ommeren (1998), blz. 119. Als (logische) uitzondering op het laatste punt, het originaire besluit dient rechtmatig te zijn, noemt hij de vergoeding van onrechtmatig toegebrachte schade. Het probleem is dat bij terugvordering niet geheel duidelijk is wat Van Ommeren ziet als het originaire besluit, het toekenningsbesluit of het intrekkingsbesluit, nu hij als voorbeeld geeft dat de bevoegdheid tot subsidietoekenning de bevoegdheid tot terugvordering impliceent. Een dergelijk toekenningsbesluit behoeft volgens hem echter niet altijd een wettelijke grondslag om rechtmatig te zijn; er is geen sprake van een betrokkenen verplichtend voorschrift, zie 9.3 .2 . In dat geval kan de gehele rechtsverhouding (inclusief de intrekkings- en terugvorderingsbvoegdheid) theoretisch zonder wettelijke grondslag bestaan.

49. Van der Vlies (1997), blz. 608. Overigens zegt Van der Vlies niet met zoveel woorden dat de terugvorderingsbevoegdheid dient te worden vastgeknoopt aan de intrekkingsbevoegdheid, maur 'aan de bevoegdheid ter zake van het besluit, waarvan het invorderingsbesluit een gevolg is'. Dir lijkt mij niet geheel correct, nu het invorderingsbesluit (mede) het gevolg is van het terugvorderingsbesluit. 
voorschrift de bevoegdheid heeft gekregen financiële middelen te verlenen, impliciet uit datzelfde voorschrift voortvloeit dat die verlening ongedaan kan worden gemaakt als achteraf blijkt dat niet (langer) is voldaan aan de voorwaarden waronder deze financiële middelen konden worden verleend. De 'terugvorderingsbevoegdheid is dus, waar zij niet uitdrukkelijk is geregeld, herleidbaar tot de bevoegdheidsgrondslag waarop ook de verlenings- en herzieningsbevoegdheid is gebaseerd. ${ }^{50}$ Hij verwijst hiervoor mede naar het Duitse recht. ${ }^{51}$ Daar is volgens hem de Erstattungsanspruch, de aanspraak van het bestuur op gehele of gedeeltelijke terugbetaling van hetgeen onverschuldigd is betaald, de keerzijde van de Leistungsanspruch, de aanspraak van de burger op bepaalde financiële middelen krachtens een (toekennings)besluit van een bestuursorgaan, de zogenaamde Kehrseitentheorie. De Erstattungsanspruch heeft dan hetzelfde karakter als de Leistungsanspruch. Alvorens een Erstattungsanspruch ontstaat, dient vast te staan dat onverschuldigd is betaald; hiertoe dient het begunstigend bestuursbesluit te worden ingetrokken. Bestaat de bevoegdheid tot intrekking, dan impliceert dit een (publiekrechtelijke) bevoegdheid tot terugvordering van het onverschuldigd betaalde. De bevoegdheid tot intrekking zou immers geen zin hebben als daaraan niet een bevoegdheid tot terugvordering zou zijn verbonden. 'Deze terugvorderingsbevoegdheid bestaat dus in beginsel óók, waar zij niet uitdrukkelijk bij wettelijk voorschrift is gepositiveerd. Sterker, de publiekrechtelijke 'Erstattungsanspruch' wordt afgeleid uit het beginsel van wetmatigheid van bestuur', aldus Teunissen. ${ }^{52}$ Dit laatste is overigens niet onomstreden in Duitsland. ${ }^{33}$

De Afdeling had dus het legaliteitsbeginsel kunnen betrekken bij haar terugvorderingsjurisprudentie door een impliciete bevoegdheid aan te nemen. Volgens Teunissen is dit zelfs de constructie die zij heeft toegepast. ${ }^{54}$ De bestuursrechter heeft volgens hem dan ook niet aangenomen dat het algemene rechtsbeginsel, dat hetgeen onverschuldigd is betaald, kan worden teruggevorderd, de bevoegdheid tot terugvordering schept. Het algemene rechtsbeginsel vormt, aldus Teunissen, de materiële rechtsgrondslag, maar dit is op zich niet voldoende om te kunnen terugvorderen. Het feit, dat kan worden teruggevorderd, zegt namelijk nog niets over wie dat kan. Hiervoor moet een formele bevoegdheidsgrondslag bestaan. Bij terugvordering kan de toekenningsbevoegdheid als een dergelijke grondslag dienen. De terugvorderingsbevoegdheid is namelijk inherent te achten aan de toekenningsbevoegdheid. Het bestuursorgaan dat bevoegd was om toe te kennen, is dan ook bevoegd om terug te vorderen. Het rechtsbeginsel (de materiële rechtsgrondslag) juncto de reeds bestaande bestuursbevoegdheid (de formele bevoegdheidsgrondslag) vormen dan de basis, de grondslag, voor de impliciete bevoegd-

50. Teunissen (1997), blz. 90.

51. Zie Teunissen (1997), blz. 131-132.

52. Teunissen (1997), blz. 132. Cursivering in oorspronkelijke tekst.

53. Zie Ossenbūhl (1998), blz. 436: 'Gegen die Kehrseitentheorie der Rechtsprechung werder! seit langem grundsătzliche Bedenken unter dem Gesichtspunkt des Grundsatzes der Gesetzmảßigkeit der Verwaltung (Gesetzesvorbehalt bei belastenden Verwaltungsakten) geltend gemacht'.

5. Teunissen (1999) en Teunissen (2001). 
heid. ${ }^{55}$ De mogelijkheid om een impliciete bevoegdheid aan te nemen, is echter niet onbeperkt. Gaat het om 'ingrepen in het eigen, private domein (het vermogen en de vrijheid) van de burgers', dan is in beginsel steeds een specifiek-wettelijke grondslag vereist, welke steeds specifieker moet zijn naarmate het overheidsoptreden ingrijpender is. Teunissen geeft als voorbeeld van een dergelijk ingrijpend overheidsoptreden belastingheffing: hiervoor is een uitdrukkelijke wettelijke basis vereist, waarin 'alle wezenlijke elementen moeten zijn vastgelegd'. ${ }^{56}$

Men kan twisten over de vraag of de Afdeling de door Teunissen geschetste redenering hanteert. Op zichzelf lijkt zij aantrekkelijk, maar het is de vraag of de constructie van impliciete bevoegdheden (in welke vorm dan ook) kan worden toegepast bij terugvordering. Er is een aantal argumenten waarom dit naar mijn mening niet zo is.

In de eerste plaats is terugvordering veelal zo ingrijpend, dat het een rechtsstatelijke eis is dat het voor de burger voldoende duidelijk moet zijn wanneer tot terugvordering mag worden overgegaan. Er dient mijns inziens dan ook een uitdrukkelijke wettelijke grondslag te bestaan voor de terugvordering. Door de uitoefening van de terugvorderingsbevoegdheid ontstaat immers voor de betrokkene de verplichting het ten onrechte betaalde terug te betalen. Hetzelfde geldt voor de intrekkingsbevoegdheid. Intrekking van het toekenningsbesluit is immers een vereiste om tot terugvordering te kunnen overgaan, althans als in eerste instantie conform het toekenningsbesluit is uitbetaald. Het intrekkingsbesluit is dan veelal een eerste vereiste om tot terugvordering te kunnen overgaan en kan dus als zodanig indirect verplichtingen creëren. Die verplichtingen vloeien niet rechtstreeks voort uit de primaire bevoegdheid, de toekenningsbevoegdheid. Daanuit vloeit immers slechts voort dat het bestuursorgaan een financiële aanspraak kan toekennen of weigeren, maar niet dat als ten onrechte wordt toegekend, er mag worden teruggevorderd. Het veel gehanteerde argument dat de toekenning niet zou hebben plaatsgevonden als het bestuursorgaan had geweten dat niet aan de criteria voor die toekenning was voldaan en dat de betrokkene in dat geval ook niets zou hebben gekregen, gaat niet op. De betrokkene heeft immers wél iets gekregen. De toekenning schept dan ook een nieuwe situatie, waarop de betrokkene zijn gedrag afstemt. Dit betekent dat de betrokkene zijn feitelijke situatie veelal zal wijzigen door de toekenning; hij zal op deze situatie voortbouwen. Terugvordering na verloop van een zekere tijd is dan ook iets anders dan het in het geheel niet toekennen.

In de tweede plaats spelen de rechtszekerheid en de rechtsgelijkheid een belangrijke rol. Betrokkenen dienen vooraf te (kunnen) weten waar zij aan toe zijn, als zij al dan niet buiten hun schuld, ten onrechte uitbetaald krijgen, waarbij willekeur (vanzelfsprekend) dient te worden voorkomen. Dit geldt te meer nu betrokkenen vaak deels en in bepaalde gevallen zelfs vrijwel geheel (denk an 
bepaalde socialezekerheidsuitkeringen en ambtenarensalarissen) afhankelijk zijn van de financiële aanspraken, die zij kunnen doen gelden tegenover de overheid. Even belangrijk, zo niet belangrijker is de democratische legitimatie. Gelet op de belangen en de afhankelijke positie van betrokkenen is het mijns inziens zo, dat in bepaalde gevallen niet mag worden overgegaan tot terugvordering en dat in de gevallen, waarin terugvordering in beginsel wel mogelijk is, deze niet onbeperkt mogelijk dient te zijn. ${ }^{57}$ Zelfs als men ervan uitgaat dat het mogelijk is om een impliciete bevoegdheid tot terugvordering aan te nemen, dan nog zal deze bevoegdheid verder moeten worden uitgewerkt: mag in alle gevallen worden teruggevorderd, gedurende welke termijn kan worden teruggevorderd, op welke wijze kan worden teruggevorderd enzovoorts. Hoe zit het verder met de situatie waarin er geen toekenningsbesluit is, omdat het bestuursorgaan door een vergissing aan een 'verkeerde' persoon heeft uitbetaald? In dat geval kan er geen sprake zijn van een impliciete bevoegdheid; er is geen toekennings- of intrekkingsbesluit waarbij kan worden aangesloten. Het is uiteindelijk aan de wetgever om de terugvorderingsbevoegdheidl op duidelijk kenbare wijze te normeren en dus om te bepalen, in welke gevallen al dan niet kan worden teruggevorderd en, in de gevallen waarin in beginsel kan worden teruggevorderd, waar de grenzen van de terugvorderingsbevoegdheid moeten worden getrokken. De afweging van de belangen, die hierbij een rol spelen, dient door de wetgever te geschieden. De terugvordering behoeft dus een uitdrukkelijke democratische legitimatie.

Uit het voorgaande volgt dat $\mathrm{ik}$ mij bij terugvordering niet kan vinden in de constructie die Teunissen meent te ontwaren in de jurisprudentie van de Afdeling, waarbij het algemeen rechtsbeginsel tezamen met de reeds bestaande bestuursbevoegdheid de basis zou vormen voor een impliciete intrekkings- en terugvorderingsbevoegdheid. Het gaat niet enkel om de vraag of het overheidsoptreden ingrijpend is, maar of het verplichtingen schept of kan scheppen. Dit zal soms samenvallen, maar niet altijd. Bovendien zal de terugvordering voor de betrokkene meestal bijzonder ingrijpend zijn, aangezien mag worden aangenomen dat hij veelal zijn feitelijke situatie zal hebben gewijzigd naar aanleiding van de toekenning. Voorts stelt Teunissen dat de terugvordering van onverschuldigd uit de openbare kas betaalde bedragen niet op één lijn kan worden gesteld met de ingrepen in het eigen vermogen of inkomen van de burger. Bij terugvordering zou het namelijk gaan 'om de ongedaanmaking van een vermogensverschuiving (...) waarvoor geen rechtsgrond (meer) aanwezig is, een herstel van de "status quo". ${ }^{56}$ Ik zie niet in, waarom betalingen uit de openbare kas, gedaan aan burgers, geen deel gaan uitmaken van hun vermogen. Dat deze betalingen vervolgens onder omstandigheden kunnen worden teruggevorderd als zijnde onverschuldigd betaald, doet daaraan niet af.

Een opvallend punt in de constructie van Teunissen is verder dat hij niet lijkt te eisen dat voor de intrekkingsbevoegdheid wel een specifieke wettelijke grond-

58. Teunissen (1999), blz. 258. Cursivering in oorspronkelijke tekst. 
slag aanwezig is. Als namelijk een rechtsgrond aanwezig is voor de betaling, dan zal het betaalde deel gaan uitmaken van het vermogen van de burger. Teunissen stelt dat het bij terugvordering gaat om een ongedaanmaking van een vermogensverschuiving waarvoor geen rechtsgrond (meer) aanwezig is. Dit betekent, dat tussen het moment van de betaling en de terugvordering de rechtsgrond aan de betaling is ontvallen, waardoor in het vermogen van de burger is ingegrepen; het betaalde maakt immers kennelijk niet langer deel uit van dat vermogen. De bevoegdheid tot het onttrekken van de rechtsgrond aan de betaling, dit is de intrekkingsbevoegdheid, is dus een ingreep in het eigen private domein van de burger, en hiervoor zou dus een specifiek-wettelijke grondslag nodig zijn.

Een andere constructie om de terugvorderingsbesluiten in overeenstemming te brengen met het legaliteitsvereiste is voorgesteld door Ruiter in zijn artikel Zelfstandige schadebesluiten: rechtschepping of rechtvaststelling? ${ }^{59} \mathrm{Hij}$ bepleit hierin het terugvorderingsbesluit niet te zien als rechtscheppend, maar als rechtvaststellend. De bevoegdheid tot terugvordering vloeit rechtstreeks voort uit het algemene rechtsbeginsel dat hetgeen onverschuldigd is betaald kan worden teruggevorderd. Dit algemene rechtsbeginsel schept dan ook geen bevoegdheid voor het bestuur om tot terugvordering over te gaan; door het terugvorderingsbesluit stelt het bestuursorgaan slechts vast dat die bevoegdheid bestaat. De bevoegdheid van het bestuursorgaan tot vaststelling van wat rechtens is, behoeft volgens Ruiter geen uitdrukkelijke wettelijke grondslag, maar berust op 'de rechtsdogmatische erkenning van een praktijk waarin bestuursorganen ten opzichte van burgers een overheersende positie innemen waar het om de vaststelling van bestuursrechtelijke rechtsverhoudingen gaat'. ${ }^{60}$ Er bestaat in dat geval geen strijd met het wetmatigheidsbeginsel, nu dit beginsel ziet op 'publiekrechtelijke rechtshandelingen die zijn gericht op het eenzijdig teweegbrengen van rechtsgevolgen' en niet zozeer op "bestuurlijke vaststellingen van 'van rechtswege ingetreden rechtsgevolgen"."61 Wel is het nemen van een dergelijke vaststelling een besluit, aangezien op die wijze de rechter kan toetsen of de vaststelling ook daadwerkelijk conform de bestaande toestand heeft plaatsgevonden, of dat de vaststelling op een verkeerde interpretatie van het toepasselijke bestuursrecht berustte.

Tegen de constructie van Ruiter kan hetzelfde bezwaar worden aangevoerd als tegen de constructie van de impliciete bevoegdheid: terugvorderingsbesluiten zijn te ingrijpend om zonder specifieke wettelijke grondslag te kunnen bestaan. Voorts is het zo, dat in de constructie van Ruiter vast moet staan dat onverschuldigd is betaald. Als dat niet zo is, dan kan uiteraard geen sprake zijn van een rechtvaststellend besluit. In de meeste gevallen zal het echter zo zijn, dat in eerste instantic conform een toekenningsbeslissing is betaald. Er zal dan pas sprake zijn van

59. Ruiter (1998).

60. Ruiter (1998), blz. 287. Deze bevoegdheidsgrondslag is echter erg vaag, zoals ook Verheil (1999), blz. 47, stelt.

61. Ruiter (1998), blz. 287. Cursivering in oorspronkelijke tekst. 
nverschuldigde betaling als deze toekenningsbeslissing met terugwerkende kracht $s$ ingetrokken. De intrekkingsbeslissing kan in elk geval niet als rechtvaststellend vorden beschouwd. Dit besluit (en waarschijnlijk ook het toekenningsbesluit) beioeft dus een wettelijke grondslag, ook volgens Ruiter; het gaat immers om 'een rubliekrechtelijke rechtshandeling die is gericht op het eenzijdig teweegbrengen an rechtsgevolgen'. ${ }^{62} \mathrm{Nu}$ dus een wettelijke regeling met betrekking tot de oekenning en de intrekking moet worden gemaakt, zie ik niet in waarom niet ook ie terugvordering wettelijk kan en moet worden geregeld. In zijn preadvies voor le VAR stelt Verheij dat hij de constructie van Ruiter 'een elegante oplossing' indt - hij had hierbij vooral het zuiver schadebesluit in gedachte $-{ }^{63}$ maar evens bepleit hij een betere oplossing om een gebrek aan wettelijke grondslag op $e$ heffen: maak gewoon een wet! ${ }^{64}$ Ook ik zou in ieder geval bij terugvordering leze oplossing willen bepleiten.

\section{9,4 Constitutionele aspecten}

\subsubsection{Inleiding}

In zijn artikel De Grondwet en de jurisprudentie inzake het zelfstandig schadebesluit heeft Kortmann een tweede fundamenteel punt van bezwaar geuit tegen de jurisprudentie van de Afdeling bestuursrechtspraak met betrekking tot het zuiver schadebesluit: zij is in strijd met de Grondwet. ${ }^{65}$ Gelet op zijn onderbouwing van deze stelling zal hetzelfde gelden voor de terugvorderingsjurisprudentie. In hoofdlijn komt zijn kritiek erop neer, dat de bestuursrechter in strijd met het grondwettelijk stelsel zich rechtsmacht heeft toegeëigend die aan de burgerlijke rechter toebehoort. In deze paragraaf zal ik bekijken of deze kritiek terecht is.

\subsubsection{Het huidige grondwettelijk systeem inzake de rechtsmachtverdeling}

Sinds 1815 bevat de Grondwet een bepaling met betrekking tot de bevoegdheid van de rechterlijke macht. In 1815 was dit artikel 165 , dat bepaalde dat 'alle twistgedingen over eigendom of daaruit voortspruitende regten, over schuldvordering of burgerlijke regten, (...) bij uitsluiting tot de kennis van de regterlijke magt' behoren. ${ }^{66}$ De tekst van deze bepaling in de verschillende versies van de Grondwet heeft tot 1983 slechts een antal kleine wijzigingen ondergaan. ${ }^{67}$ Dit bevoegdheidsartikel is in de loop van de tijd verschillend geönterpreteerd, althans is er in de loop van de tijd verschil van mening geweest met betrekking tot de juiste
62. Zie Ruiter (1998), blz. 287.
63. Verheij (1999), blz. 46.
64. Verheij (1999), blz. 47.
65. Kortmann (1997-I).
66. Zie 2.2 .
67. Zie onder meet 2.4.1. 
interpretatie. ${ }^{68}$ De Grondwetgever achtte dit niet gewenst. Bij de grondwetswijziging van 1983 heeft hij dan ook gepoogd helderheid te scheppen door de tekst van het bevoegdheidsartikel te verduidelijken. ${ }^{69}$ De competentie van de rechterlijke macht is sedertdien neergelegd in artikel 112 lid $1 \mathrm{Gw}$ :

'Aan de rechterlijke macht is opgedragen de berechting van geschillen over burgerlijke rechten en over schuldvorderingen'.

Hieronder vallen niet enkel privaatrechtelijke geschillen, maar ook geschillen over burgerlijke rechten en schuldvorderingen die voortvloeien uit publiekrechtelijke rechtsbetrekkingen. ${ }^{70}$ Het tweede lid van artikel $112 \mathrm{Gw}$ voegt aan het eerste toe:

'De wet kan de berechting van geschillen die niet uit burgerlijke rechtsbetrekkingen zijn ontstaan, opdragen hetzij aan de rechterlijke macht, hetzij aan gerechten die niet tot de rechterlijke macht behoren. De wet regelt de wijze van behandeling en de gevolgen van de beslissingen'.

Het betreft dus geschillen, die niet uit 'burgerlijke rechtsbetrekkingen' - dit is: uit nubliekrechteljike rechtshetrekkingen - zjin sntstaan Het sntstane heeld is dan als volgt. Geschillen over burgerlijke rechten en over schuldvorderingen die uit burgerlijke rechtsbetrekkingen zijn ontstaan, worden berecht door de rechterlijke macht (artikel 112 lid 1). Geschillen over burgerlijke rechten en over schuldvorderingen die uit publiekrechtelijke rechtsbetrekkingen zijn ontstaan, worden berecht door de rechterlijke macht; de berechting hiervan kan tevens bij wet worden opgedragen aan gerechten die niet tot de rechterlijke macht behoren (artikel 112 lid $1 j^{\circ}$ lid 2). De overige geschillen, niet zijnde geschillen over burgerlijke rechten en over schuldvorderingen, die uit publiekrechtelijke rechtsbetrekkingen zijn ontstaan, kan de wet opdragen aan hetzij de rechterlijke macht, hetzij aan gerechten die niet tot de rechterlijke macht behoren (artikel 112 lid 2).

Door artikel 112 lid 2 ontstaat een dubbele competentie wanneer sprake is van een geschil over een burgerlijk recht of over een schuldvordering, dat uit een publiekrechtelijke rechtsbetrekking is ontstaan en dat bij wet is opgedragen aan een bestuursrechter, die niet tot de rechterlijke macht behoort. Op grond van artikel 112 lid 1 is de burgerlijke rechter ('de rechterlijke macht') bevoegd, op grond van de desbetreffende wet de bestuursrechter. Er ontstaat dus een positief competentieconflict. $^{71}$ De situatie voor de inwerkingtreding van de (nieuwe) Grondwet in 1983 was dat de burgerlijke rechter over zijn eigen competentie oordeelde, en dus ook kon oordelen dat indien tevens een administratieve rechter bevoegd was er geen behoefte meer bestond aan optreden door de burgerlijke

68. Zie hierover deel l, in het bijzonder hoofdstuk 2 en 4.3 .

69. PG Grondwet 1983, deel VI, blz. 10 en 13-14.

70. Memorie van toelichting, PG Grondwet 1983, deel VI, blz. 10.

71. Tenzij men uit de memorie van toelichting wil afleiden, dat als gebruik wordt gemaakt van de mogelijkheid die lid 2 biedt, dit leidt tot een exclusieve competentie van de aangewezen rechler. Kortmann (1987), blz. 312, die op deze mogelijkheid wijst, heeft grote twijfels hierbij, noch uit de wetstekst, noch uit de pariementaire geschiedenis valt een zodanige lezing af te leiden. 
rechter, zodat hij zich onbevoegd dan wel eiser niet-ontvankelijk verklaarde. ${ }^{72}$ De wijziging van de Grondwet bracht in deze situatie geen verandering. Was dit wel de bedoeling geweest, dan had het op de weg van de Grondwetgever gelegen dit uitdrukkelijk aan te geven. Dit ligt temeer in de rede nu volgens de jurisprudentie van de Hoge Raad in 1983 - het jaar van de Grondwetswijziging - de burgerlijke rechter zich zelfs onbevoegd diende te verklaren indien de administratieve rechter volledige rechtsbescherming kon bieden, zoals in geschillen waarbij een ambtenaar 'als zodanig' was betrokken. Zoals in 7.2.4.3 aan de orde is gekomen, is de Hoge Raad pas, in het Changoe-arrest uit 1992 hierop teruggekomen in die zin, dat het bestaan van die rechtsgang niet diende te leiden tot onbevoegdheid van de burgerlijke rechter, maar tot niet-ontvankelijkheid van eiser. Uit het Changoe-arrest en de arresten met betrekking tot de formele rechtskracht blijkt ook dat de burgerlijke rechter zich op het standpunt stelt dat geen sprake is van een exclusieve competentie van het op grond van artikel 112 lid $2 \mathrm{Gw}$ aangewezen gerecht.

Een ander punt dat tot onduidelijkheid kan leiden, is de term 'rechterlijke macht' in artikel 112 lid 1 . Volgens artikel 116 lid $1 \mathrm{Gw}$ wijst de wet namelijk de gerechten aan die tot de rechterlijke macht behoren. Volgens de toelichting kan het begrip rechterlijke macht niet alleen betrekking hebben op de gerechten van de 'gewone rechterlijke macht', maar ook op administratieve rechters. ${ }^{73}$ Deze ruime uitleg wordt ook gehanteerd in de Grondwet. ${ }^{74}$ Van de rechterlijke macht maken in ieder geval de 'traditionele' gerechten deel uit: de rechtbanken, de gerechtshoven en de Hoge Raad, zie artikel 2 R.O. ${ }^{75}$ Sedert 1992 maken bestuurskamers deel uit van de arrondissementsrechtbanken, ${ }^{76}$ zodat buiten kijf staat dat deze kamers ook deel uitmaken van de rechterlijke macht. Hun competentie wordt bepaald door artikel 43 R.O.; zij 'nemen in eerste aanleg kennis van de bestuursrechtelijke zaken waarvan de kennisneming bij de wet aan hen is opgedragen'." Andere gerechten kunnen door de wetgever worden aangewezen als onderdeel van de rechterlijke macht. Wel is dan vereist dat zij voldoen aan de vereisten die artikel $117 \mathrm{Gw}$ stelt, zoals benoeming van de leden van het gerecht voor het leven en een wettelijke regeling van hun rechtspositie. De meeste administratieve gerechten voldoen aan deze eisen en zouden dus door de wetgever kunnen worden aangewezen als tot de rechterlijke macht behorende. Dit is (nog) niet gebeurd. Willen zij dus competent zijn wat de berechting van geschillen die niet uit

72. Zie onder meer 4.3.2.

73. PG Grondwet 1983, deel VI, blz. 8.

74. PG Grondwet 1983, deel VI, blz. 9.

75. Dit was tot 1 januari 2002 neergelegd in artikel 1 R.O.; dit artikel is bij de invoering van het nieuw burgerlijk procesrecht op 1 januari 2002 gewijzigd en hemummerd tot artikel 2; tot die datum maakten ook de kantongetechten deel uit van de rechterlijke macht. Verder maken ook deel uit van de rechterlijke macht de bijzondere rechters die binnen het raam van de genoemde rechterlijke instanties fungeren, zoals de politierechter en de kinderrechter.

76. Zie 3.4.4.

77. Tot 1 januari 2002 was dit neergelegd in artikel $55 \mathrm{~b}$ R.O 
burgerlijke rechtsbetrekkingen zijn ontstaan, dan dienen zij door de wetgever competent te zijn verklaard.

\subsubsection{De kritiek van Kortmann}

Heeft de bestuursrechter in zijn jurisprudentie met betrekking tot het zuiver schadebesluit (en het terugvorderingsbesluit) in strijd met dit grondwettelijk stelsel zich rechtsmacht toegeëigend, die (exclusief) aan de burgerlijke rechter toebehoort? Anders gezegd: heeft de wetgever de bestuursrechter op dit punt rechtsmacht gegeven? Volgens Kortmann is dit laatste niet zo; de wetgever heeft de administratieve rechter noch expliciet, noch impliciet algemeen bevoegd gemaakt inzake schadevergoedingsvragen. De conclusie moet volgens hem dan ook zijn dat de rechter op het terrein van de wetgever is getreden.

De vraag rijst of deze conclusie juist is. De rechtsmacht van de bestuursrechter wordt bepaald aan de hand van de vraag of een besluit voorligt, zie artikel

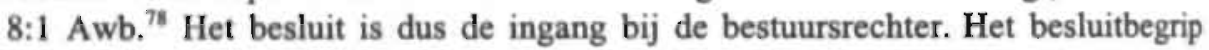
is echter een begrip dat in de wet niet duidelijk is afgebakend en dat dus door de rechter zal moeten worden ingevuld. Hierbij heeft de bestuursrechter het besluitbegrip - en voorheen onder de Wet arob het beschikkingsbegrip - voor zover het als ingang bij de bestuursrechter dient 'strategisch' uitgelegd, vooral met het oog op het bieden van rechtsbescherming. ${ }^{79}$

Het is vervolgens de vraag, wanneer nog sprake is van interpretatie en wanneer de grenzen van interpretatie worden overschreden. De bestuursrechter heeft met betrekking tot zijn jurisprudentie inzake het zuiver schadebesluit en de terugvordering de beslissing van het bestuursorgaan eerst aangemerkt als besluit, alvorens zich bevoegd te achten hierover te oordelen. De vraag is of de werkwijze van de bestuursrechter wel als interpretatie van het besluitbegrip kan worden gezien. Kortmann vindt van niet. Volgens hem heeft de Afdeling bestuursrechtspraak eerst met grote, maar verwerpelijke vindingrijkheid een besluit gecreëerd, waardoor de bestuursrechter in beginsel bevoegd wordt. De rechter gat vervolgens verder door een systeem van rechtsmachtverdeling te ontwikkelen. 'Als dit alles interpretatie mag heten, is het begrip interpretatie nagenoeg allesverslindend. ${ }^{80}$

Elders in de literatuur is een andere mening terug te vinden ${ }^{81}$ De bestuursrechter dient binnen het wettelijk kader zelf te beslissen over zijn bevoegdheid. Bovendien zijn in de parlementaire stukken aanwijzingen te vinden dat ook de wetgever de rechter ruimte wilt geven het besluitbegrip op deze wijze uit te leggen. ${ }^{82}$ Met betrekking tot terugvorderingsbeslissingen stelt de regering zelfs

78. De leden 2 en 3 van artikel 8:1 Awb geven een aantal uitzonderingen.

79. Zie hierover Schlossels (2000), die onder meer wijst op de publieketaakjurisprudentie.

80. Kortmann (1997-I), blz. 1328.

81. Bijvoorbeeld Drupsteen (1997), blz. 1597, in zijn reactie op Kortmann.

82. Zie bijvoorbeeld PG Awb II, blz. 380, Drupsteen (1997), blz. 1597 en Simon (1997), blz. 57. Zie ook 4.2.3. Anders Kortmann (1997-II), blz. 1599, die stelt dat de 'beschouwingen in kamerstukken, zeker als die wat wazig en tentatief van aard zijn' geen positief recht zijn. 
onomwonden dat het in de rede ligt dat 'terugvorderingsbeslissingen worden beoordeeld door de administratieve kamer van de rechtbank en derhalve worden gekwalificeerd als besluiten in de zin van artikel 1:3 van de Awb'. ${ }^{8}$ Ik beschouw deze jurisprudentie dan ook als een toelaatbare interpretatie en dus als grondwettig. Kortom: ik deel de opvatting van Kortmann niet.

\subsubsection{Besluit of publiekrechtelijke rechtsbetrekking?}

Een andere vraag is of het besluitbegrip wel als ingang bij de bestuursrechter zou moeten dienen. Er gaan stemmen op om de bestuursrechter niet enkel over publiekrechtelijke rechtshandelingen, maar ook over andere publiekrechtelijke rechtsfeiten te laten oordelen. Dit zou betekenen dat niet meer de publiekrechtelijke rechtshandeling (het besluit), maar de publiekrechtelijke rechtsbetrekking als rechtsingang bij de bestuursrechter zou moeten gelden. ${ }^{34}$ Het lijkt erop dat de bestuurssrechter voorzichtig deze richting op gaat. Schlössels stelt dat dit gebeurt doordat de bestuursrechter zijn rechtsmacht ontkoppelt van het besluitbegrip zoals neergelegd in artikel 1:3 Awb en een nieuw, procestechnisch besluitbegrip in de zin van artikel 8:1 Awb is gaan hanteren, waarbij aansluiting wordt gezocht bij het concept van de bestuursrechtelijke rechtsverhouding. ${ }^{85}$ Het probleem is momenteel echter dat de algemene bevoegdheid van de bestuursrechter nog altijd wordt bepaald door het voorliggen van een besluit en dat de grenzen van hetgeen de bestuursrechter onder het besluitbegrip kan brengen, langzamerhand wel in zicht komen. Het is dan ook nu aan de wetgever om de bestuursrechter algemeen bevoegd te maken bij geschillen die zijn ontstaan binnen een publiekrechtelijke rechtsbetrekking. Ik zal hierop verder ingaan in hoofdstuk 12. Daar zal ik ook aangegeven wat de gevolgen van die stap voor de bevoegdheid van de burgerlijke rechter dienen te zijn. Een voordeel van deze stap is in elk geval dat wordt voorkomen dat de bestuursrechter moet terugvallen op ongeschreven algemene rechtsbeginselen als bevoegdheidsgrondslag voor bestuurshandelen, zodat aan de publiekrechtelijke rechtshandeling - het besluit - weer strenge eisen kan worden gesteld, zoals het vereiste van een uitdrukkelijke wettelijke grondslag. Op deze wijze kan de losgeslagen beer van Kortmann weer in het gareel worden gebracht.

\subsection{Het (processuele) connexiteitsvereiste}

Een terugvorderingsbeslissing van een bestuursorgaan, genomen binnen een door het bestuursrecht beheerste verhouding, is een besluit in de zin van artikel 1:3 Awb, althans volgens de bestuursrechters. Toch vloeit hier niet automatisch uit voort dat de bestuursrechter bevoegd is het beroep tegen dit besluit te behandelen.

\footnotetext{
83. Tweede Kamer 1991-1992, 22 495, nr. 3, blz. 246. Zie ook 4.2.3.

84. Zie hierover 12.4 .

85. Schlössels (2000), blz. 4.
} 
Daarvoor is namelijk zogenaamde processuele connexiteit vereist: de algemene dan wel de bijzondere bestuursrechter is slechts 'bevoegd te achten tot kennisne. ming van beroepen tegen terugvorderingsbesluiten, indien dergelijke besluiten voortvloeien uit een besluit inzake een bestuursrechtelijke toekenning ter zake waarvan die rechter bevoegd is' ${ }^{86} \mathrm{Er}$ is dus slechts sprake van een appellabel (terugvorderings)besluit, als dit besluit voortvloeit uit een eerder appellabel toekenningsbesluit. Is dat het geval, dan is die bestuursrechter bevoegd, die ook bevoegd zou zijn geweest kennis te nemen van het beroep tegen dat toekenningsbesluit. Dit leidt ertoe dat indien geen bestuursrechter bevoegd is kennis te nemen van het toekenningsbesluit, er ook geen bestuursrechter bevoegd is kennis te nemen van het beroep tegen het terugvorderingsbesluit. ${ }^{87}$

Nu kunnen zich bij terugvordering globaal drie situaties voordoen. Ten eerste kan conform het toekenningsbesluit zijn betaald, terwijl achteraf blijkt dat dit besluit fout was. In dat geval moet het toekenningsbesluit worden ingetrokken alvorens een terugvorderingsbesluit kan worden genomen. ${ }^{88}$ Ten tweede kan er meer zijn betaald dan waarop betrokkene recht had op grond van het correcte toekenningsbesluit. Het toekenningsbesluit hoeft dan niet te worden ingetrokken; het bestuursorgaan kan direct een terugvorderingsbesluit nemen. ${ }^{89}$ Ten slotte kan zich de situatie voordoen dat tussen betrokkene en het bestuursorgaan geen relatie was, maar dat als gevolg van een vergissing is betaald aan betrokkene.

In het eerste geval is die bestuursrechter bevoegd, die ook bevoegd is kennis te nemen van een beroep tegen het toekenningsbesluit: het terugvorderingsbesluit vloeit immers voort uit het feit dat het eerdere toekenningsbesluit onjuist was. ${ }^{90}$

Het is de vraag of dit ook zo is in de tweede situatie. Het terugvorderingsbesluit vloeit dan immers niet voort uit het toekenningsbesluit, maar juist uit het feit dat niet conform dit (correcte) besluit is betaald. Betoogd kan worden, dat de betaling van het onverschuldigde in dat geval een feitelijke handeling is, ${ }^{91}$ zodat de beslissing tot terugvordering hiervan (hoewel dit een besluit kan zijn) niet kan worden aangevochten voor de bestuursrechter. Dit lijkt mij niet de bedoeling van de Afdeling bestuursrechtspraak; in dat geval kan toch worden aangenomen dat het terugvorderingsbesluit voortvloeit uit het toekenningsbesluit. Ik zie de gehele betaling (inclusief de betaling van het deel dat onverschuldigd geschiedt) dan ook als een rechtshandeling, waarbij de wil gericht is op het betalen van de schuld; de betaling van het onverschuldigde is dan ook geen feitelijke handeling. Nog beter zou zijn dat de Afdeling ook bij terugvordering het criterium gaat hanteren, dat zij

86. ABRvS 21 oktober 1996, AB 1997, 496, m.nt. NV, JB 1996, 232, m.nt. HIS (Nanne).

87. Uiteraard geldt dit slechts indien er niet reeds een. geschreven wettelijke grondslag, voor het terugvorderingsbesluit is.

88. Zie onder meer 6.4 .4 en 6.4 .5 .

89. Zie onder meer 6.4.5.3.

90. Ik ga hierbij uit van de normale situatie dat het toekenningsbesluit een besluit is in de zin van artikel 1:3 Awb.

91. in het privaatrecht wordt dit wel betoogd door een aantal schrijvers, zie hierover Asser-Hartkamp 1 (2000), blz. 140-142, met verdere verwijzingen. 
bij zuivere schadebesluiten hanteert, namelijk dat moet gaan om uit elkaar voortvloeiende of anderszins nauw met elkaar samenhangende beslissingen. ${ }^{92}$

In het laatste geval is het de vraag of sprake is van een publiekrechtelijke rechtsbetrekking: vindt de betaling plaats aan een willekeurig iemand, dan zall niet snel van een dergelijke betrekking sprake zijn. ${ }^{93}$ Men kan hierover twijfelen in. bijvoorbeeld de situatie dat sprake is van een doorgeschoten betaling: na het bečindigen van een (duur)subsidie wordt nog een termijn overgemaakt. De publiekrechtelijke rechtsbetrekking is dan beëindigd, zo kan worden betoogd. Men kan in deze situatie ook betogen dat de rechtsbetrekking nog enige tijd voortduurt. Ik zou menen dat in dit geval toch eenzelfde situatie bestaat als in het geval dat meer wordt uitbetaald dan waarop op grond van de correcte toekenningsbeslissing recht bestond. Hoe zit het echter in situaties waarin iemand een uitkering heeft gehad, deze uitkering is beëindigd en de betrokkene een half jaar later toch weer geld overgemaakt krijgt van de uitkerende instantie, omdat door een vergissing ten onrechte zijn bankrekeningnummer is ingevoerd in het computersysteem als zijnde het bankrekeningnummer van een (andere) uitkeringsgerechtigde? Ik zal hierop verder ingaan in 11.3. In de praktijk zullen dis soort gevallen zich niet vaak voordoen, de meest voorkomende situatie zal de eerste zijn.

Geconcludeerd kan worden dat het processuele connexiteitsvereiste bij terugvordering niet snel ertoe zal leiden dat de bestuursrechter onbevoegd is, zeker niet als voor het bestaan van deze connexiteit het criterium dat het besluit moet 'voortvloeien uit een besluit inzake een bestuursrechtelijke toekenning terzake waarvan die rechter bevoegd is' ruim wordt uitgelegd in de zin van het hebben van 'voldoende samenhang'.

Ook meer in het algemeen kan een vraagteken worden gesteld bij het hanteren van het processuele connexiteitsvereiste. Als reden voor het stellen van dit vereiste geeft de Afdeling dat de wetgever kennelijk heeft gestreefd naar het zoveel mogelijk bij één rechter onderbrengen van een samenhangende reeks van uit elkaar voortvloeiende bestuursbeslissingen. $\mathrm{Zij}$ beroept zich daarbij op de wetsgeschiedenis van de artikelen 8:1 lid 1 en lid 3 aanhef en onder a, 8:3 en 8:6 Awb. Op grond van artikel 8:3 kan geen beroep worden ingesteld tegen een besluit ter voorbereiding van een privaatrechtelijke rechtshandeling. Dit artikel ziet dus op een geheel andere situatie. Ook in artikel 8:6 kan geen argument worden gevonden om het processuele connexiteitsvereiste te onderbouwen, althans niet voor zover dit vereiste ertoe kan leiden dat de bestuursrechter niet bevoegd is van het beroep kennis te nemen. Volgens dit artikel kan immers geen beroep worden ingesteld tegen een besluit waartegen beroep bij een andere bestuursrechter of administratief beroep kan of kon worden ingesteld. Mogelijk kan aan dit artikel wel een argument worden ontleend om in bepaalde gevallen een specifieke bestuursrechter bevoegd te achten, namelijk wanneer die bestuursrechter ook

92. Vgl. ABRvS 29 november 1996, AB 1997, 66, m.nt. PvB, JB 19516, 253, m.ne red. (Alpha Kledingreinigingsbedrijf).

93. Zie echter 113. 
bevoegd is de achterliggende bestuurshandeling te beoordelen. Het stellen van het processuele connexiteitsvereiste is dan ook - nogmaals: althans voor zover het leidt tot onbevoegdheid van de bestuursrechter - gekunsteld en leidt tot onduidelijkheid. ${ }^{94}$ Er wordt een uitzondering gecreëerd op artikel 8:1 Awb, die niet te vinden is in de Awb. ${ }^{95}$ Het vereiste is dan ook meerdere malen bekritiseerd, onder meer door J.E.M. Polak, die stelt dat de redenering van de Afdeling eigenlijk niet klopt, nu zij eerst een besluit baseert op een algemeen rechtsbeginsel en hiermee haar bevoegdheid 'creëert', waarna zij vervolgens daalr weer afstand van doet door een uitzondering te lezen in het stelsel van de wet, die daarin niet is te vinden. ${ }^{96}$ Polak ziet meer in de lijn die de Centrale Raad van Beroep in eerste instantie volgde. Volgens dit college was pas sprake van een besluit (dat dan ook een appellabel besluit was) wanneer was voldaan an zowel het materiële als het processuele connexiteitsvereiste. ${ }^{97}$ Deze constructie is dogmatisch echter niet te verdedigen: het antwoord op de vraag of sprake is van een besluit wordt dan afhankelijk gesteld van het antwoord op de vraag of de bestuursrechter competent is of zou moeten zijn. Dit is in strijd met het uitgangspunt van de Awb, waar de competentie van de bestuursrechter juist afhankelijk wordt gesteld van de vraag of sprake is van een besluit. Mijns inziens had de Afdeling er dan ook beter aan gedaan wanneer zij had geoordeeld dat, indien op grond van de processuele connexiteit geen bijzondere bestuursrechter bevoegd is, de algemene bestuursrechter bevoegd is, de bestuurskamer van de arrondissementsrechtbank dus.

\subsection{Verdere reacties}

\subsubsection{Verdere reacties op de jurisprudentie betreffende het zuiver schadebesluit}

De jurisprudentie van de bestuursrechter heeft, zoals we in de vorige paragrafen hebben gezien, de nodige reacties uitgelokt. In deze paragraaf zal ik een aantal meer praktische punten naar aanleiding van deze reacties behandelen. Ik zal eerst ingaan op de jurisprudentie inzake het zuiver schadebesluit, waarop nogal wat kritiek te beluisteren was. De Wijkerslooth typeerde haar zelfs als 'een ramp, een absolute ramp', nu zij zou leiden tot grote onduidelijkheid en dus onzekerheid. ${ }^{98}$

94. Vooral bij zuivere schadebesluiten, waar het vereiste ook door de ABEvS wordt gesteld, nu het vaak algemeen verbindende voorschriften of feitelijke handelingen zijn die schade veroorzaken.

95. Van der Vlies (1997), blz. 609.

96. Polak (1999), blz. 75 .

97. Zie onder meer CRvB 28 juli 1994, AB 1995, 133, m.nt. RMvM, JB 1994, 221, m.nt. ELB/ABJH. Het Cbsf 23 mei 1996, JB 1996, 177, m.nt. red. volgde deze constructie van de CRvB. Het CBB volgt de lijn van de ABRvS, zie CBB 19 februari 1997, AB 1997, 144, m.nt. JHvdV, JB 1997, 92, m.nt. HJS. Zie ook 4.2.3 en 5.3.3. Inmiddels is ook de CRvB de lijn van de ABRvS gaan volgen, zic onder meer CRvB 24 september 1997, AB 1997, 431, m.nt. FP en CRvB 23 april 1998, AB 1998, 251, m.nt. HBr.

98. Zie Van Ettekoven/Schueler (1998). 
Zo wordt algemeen aangenomen dat niet iedere reactie van een bestuursorgaan op een verzoek om schadevergoeding moet worden gezien als zuiver schadebesluit. Bestuur en betrokkene moeten de gelegenheid hebben om met elkaar te corresponderen over aansprakelijkheid, hoogte van de schade enzovoorts, zonder dat elk briefje als besluit wordt gezien waartegen bezwaar moet worden gemaakt op straffe van verlies van rechtsgang. Wanneer is dan wel sprake van een zuiver schadebesluit? Mij lijkt dat dit het geval is wanneer het bestuursorgaan een als definitief bedoeld oordeel geeft. op een verzoek tot schadevergoeding. Hierbij is van belang dat het bestuursorgaan op dat moment moet aangeven dat tegen het besluit bezwaar kan worden gemaakt dan wel beroep kan worden ingesteld, zie artikel 3:45 lid $1 \mathrm{Awb}$. Bij terugvordering zal het overigens veel duidelijker zijn wanneer sprake is van een terugvorderingsbesluit, nu veelal het initiatief uitgaat van het bestuursorgaan en hier normaal geen ruimte is voor overleg, althans niet waar het de vraag betreft of wordt teruggevorderd. ${ }^{9}$

Een andere belangrijke vraag is of de publiekrechtelijke rechtsgang - bezwaar bij het bestuursorgaan, eventueel gevolgd door beroep bij de bestuursrechter exclusief is bij zuivere schadebesluiten, of dat de belanghebbende kan kiezen tussen het instellen van een privaatrechtelijke vordering voor de burgerlijke rechter en het volgen van de publiekrechtelijke rechtsgang. Een aantal schrijvers ziet de bestuursrechtelijke rechtsgang als exclusief; ${ }^{100}$ staat immers een bestuursrechtelijke rechtsgang open dan wel heeft een dergelijke rechtsgang opengestaan, ${ }^{101}$ dan dient dit bij de burgerlijke rechter op grond van diens vaste jurisprudentie te leiden tot niet-ontvankelijkheid van de eiser dan wel ongegrondverklaring van de vordering. Andere schrijvers zien een keuzemogelijkheid voor de betrokkene. ${ }^{102}$ Gelet op de onduidelijkheid die is ontstaan, vinden zij dat, zolang de wetgever geen keuze heeft gemaakt, de betrokkene mag kiezen tussen het maken van bezwaar, eventueel gevolgd door beroep bij de bestuursrechter, en het entameren van een civiele actie. Een argument hiervoor ontlenen zij aan artikel 8:73 lid $1 \mathrm{Awb}$, op grond waarvan de bestuursrechter desgevraagd schadevergoeding kan toekennen indien hij het beroep tegen het achterliggende schadeveroorzakende besluit gegrond verklaart. Het artikel laat de betrokkene een keuze: hij kan de bestuursrechter in de beroepsgang vragen om schadevergoeding toe te kennen, maar hij mag ook een separate vordering instellen uit onrechtmatige daad bij de burgerlijke rechter. ${ }^{103} \mathrm{Bij}$ een zuiver schadebesluit kan artikel 8:73 Awb geen rol spelen: kenmerk van een dergelijk schadebesluit is immers dat (althans in die procedure) om schade wordt verzocht zonder het achterliggende schadever-

\footnotetext{
99. Mogelijk kan wel overleg worden gevoerd over de wijze hoe het terug te vorderen bedrag zal worden ingevorderd.

100. Zie de schrijvers genoemd bij Van Rossum (1999), blz. 203, noot 9.

101. Hierbij moet uiteraard wel de drempel van het processuele connexiteitsvereiste zijn genomen.

102. Ook hier volsta ik met ie verwijzen naar Van Rossum (1999), blz. 203, noot 10. Van Rossum zelf ziet de bestuursrechtelijke rechtsgang overigens niet als exclusief, zie Van Rossum (1997), blz. 763.

103. Zie de memorie van toelichting op artikel 8:73, PG Awb II, blz. 474.
} 
oorzakende besluit of handelen aan te vallen. Toch wordt vaak aan dit artikel een argument ontleend om de betrokkene ook bij zuivere schadebesluiten een keuze te geven.

De Hoge Raad heeft zich hierbij aangesloten in het arrest Groningen-Raatgever. ${ }^{104} \mathrm{Hij}$ overwoog dat er 'goede grond (is) om een uitzondering op het beginsel van formele rechtskracht te anvaarden voor zuivere schadebesluiten'; ${ }^{105}$ de bedoeling van de wetgever, zoals tot uitdrukking gebracht in artikel 8:73 Awb, was de gelaedeerde een keuze te laten. Met een beroep op deze bedoeling liet de Hoge Raad voor hem beide wegen open: de betrokkene mag kiezen tussen de bestuursrechtelijke rechtsgang of de civielrechtelijke rechtsgang. Volgens de Hoge Raad zou het niet met de door de wetgever geboden keuzevrijheid stroken om voor een partij 'met een beroep op het beginsel van de formele rechtskracht de toegang tot de burgerlijke rechter te blokkeren'. Zou de bestuursrechtelijke rechtsgang exclusief moeten zijn, dan dient de wetgever dit te regelen. De keuzevrijheid van betrokkene kent volgens de Hoge Raad wel grenzen. Eén grens noemde hij uitdrukkelijk: wanneer de bestuursrechter in eerste of enige instantie het beroep tegen een schadebesluit ongegrond heeft verklaard, zal de burgerlijke rechter eiser niet-ontvankelijk moeten verklaren. ${ }^{106}$

Ilk vind het 'artikel 8:73-argument' niet overtuigend. Volgens de memorie van toelichting op artikel 8:73 Awb uit 1992 was het 'uit het oogpunt van efficiënte rechtsbedeling en rechtsbescherming aantrekkelijk, indien de burger in een en dezelfde procedure zijn schade vergoed kan krijgen'. De regering achtte het echter in 1992 nog niet wenselijk de weg naar de burgerlijke rechter af te sluiten, nu. bestuursrechters die voorheen al bevoegd waren schadevergoeding toe te kennen, in de praktijk terughoudend bleken te zijn bij het gebruikmaken van die bevoegdheid en de burgerlijke rechter een grote expertise had opgebouwd op dit terrein. De regering prefereerde dan ook 'een geleidelijke ontwikkeling waarbij de adminisistratieve rechter meer en meer zelf het schadevergoedingsaspect afdoet'. ${ }^{107}$ De ontwikkeling op het gebied van toekenning van schadevergoeding door de bestuursrechter heeft sinds 1994 - het jaar waarin de Awb en artikel 8:73 in werking traden - een stormachtige vooruitgang doorgemaakt, die door de wetgever toentertijd niet was voorzien. Daamaast lijkt het, gelet op de toelichting, de bedoeling van de wetgever om de bestuursrechter aan te moedigen vaker het schadevergoedingsaspect af te handelen. Nu deze rechter dit voortvarend aanpakt, lijkt het mij ongewenst deze ontwikkeling te vertragen. ${ }^{108}$

104. HR 17 december 1999, NJ 2000, 87, m.nt. ARB onder 88, AB 2000, 89, m.nt. PvB, JB 2000, 4 , m.nt. F.A.M. S. Voor een uitgebreider commentaar op dit arrest verwijs ik naar Bollen (2000).

105. Naar mijn mening makt de Hoge Raad allereerst een uitzondering op de regels betreffende de (niet-)ontvankelijkheid van eiser, zie 4.3.4.

106. De bestuursrechtelijke rechtsgang is dus niet exclusief, de rechtsgang naar de burgerlijke rechter is dat volgens de ABRvS ook niet, aldus ABRvS 14 december 2000, JB 2001, 29.

107. PG Awb II, blz. 474.

108. Een praktisch nadeel kan zijn dat verschillende rechters uiteenlopende vitspraken doen, zelfs in een en dezelfde zaak. Zie ook Van Buuren (1997), blz. 763. 
Narr mijn mening is het te prefereren dat de bestuursrechtelijke rechtsgang wanneer die openstaat - exclusief is. De taak van de burgerlijke rechter is historisch gezien een aanvullende: als voor de burger geen andere mogelijkheid bestond rechtsbescherming tegen de overheid te krijgen, kon hij terecht bij de burgerlijke rechter. ${ }^{109}$ Dit betekent dat tegenover de uitbreiding van de bestuursrechtelijke rechtsgangen een terugtred van de burgerlijke rechter moet staan. De burgerlijke rechter heeft deze consequentie zelf ook veelal getrokken, ${ }^{110}$ zie bijvorbeeld de door hem ontwikkelde leer van de formele rechtskracht. Het logische gevolg van de jurisprudentie van de bestuursrechter met betrekking tot het zuiver schadebesluit zou dan ook moeten zijn dat de burgerlijke rechter terugtreedt als een bestuursrechter bevoegd is. ${ }^{111}$ Op die wijze wordt de mogelijtheid om rechtsbescherming te bieden tegen de overheid steeds meer geconcentreerd bij de bestuursrechter. ${ }^{112}$

Wel zullen de bestuursrechters een nieuw, eigen bestuursrechtelijk schadevergoedingsrecht moeten ontwikkelen. Hiervoor zullen zij mijns inziens aansluiting moeten zoeken bij de regeling zoals die is neergelegd in het BW; de leemtes die in het bestuursrecht bestaan, kunnen op die manier worden ingevuld. Op dit punt kunnen de bestuurskamers van de rechtbanken een belangrijke rol spelen, zij hebben immers gemakkelijk toegang tot de deskundigheid, die op dit terrein bestaat bij de burgerlijke rechter, terwijl door het formeren van zogenaamde combi-kamers, bestaande uit rechters uit de civiele en de bestuurskamers, de expertise die aan beide kanten bestaat, optimaal kan worden benut. Voorkomen dient in ieder geval te worden, dat het administratieve en het civiele schadevergoedingsrecht te ver van elkaar verwijderd raken. Dat er verschillen zullen ontstaan is onvermijdelijk; het betreft immers twee verschillende rechtsgebieden met ieder hun eigen regels en rechtsnormen. De burger mag echter niet het gevoel krijgen dat hij veel slechter af is wanneer hij schade lijdt door een onrechtmatige overheidsdaad dan wanneer dezelfde (onrechtmatige) daad zou zijn begaan door een particulier of bedrijf.

Door het arrest Groningen-Raatgever is het nu aan de wetgever om ervoor te

109. Zie onder meer de hoofdstukken 2,3 en 4.

110. Zie bijvoorbeeld HR 28 februari 1992, NJ 1992, 687, m.nt. MS. AB 1992, 301, m.nt. FHvdB (Changoe). Zie ook 4.3.3.

III. Zo verklaarde de (civiele kamer van de) Rechtbank 's-Gravenhage een eiser niet-ontvankelijk nu sen met voldoende waarborgen omklede bestuursrechtelijke rechtsgang openstond of had opengestaan en eiser verzuimd had van die rechtsgang gebruik te maken, $\mathrm{Rb}$. "s-Gravenhage 3 september 1997, JB 1997, 247. Deze uitspraak dateert van vóór het arrest Groningen-Raatgever.

112. Hierbij zou dan wel gedurende enige tijd een overgangsregime moeten bestaan; de burger mag niet de dupe worden van de onzekerheid die zal ontstaan door deze wijziging. Daartoe biedt de wet ook de mogelijkheid. De burgerlijke rechter moet eiser immers niet-ontvankelijk verklaren nu een bestuursrechtelijke rechtsgang openstaat of heeft opengestaan. Vervolgens kan hij hem op grond van artikel 70 lid $2 \mathrm{Rv}$ alsnog doorverwijzen naar die rechtsgang. Zie over artikel $70 \mathrm{Rv}$ 4.3.4. Verder dient de bestuursrechter het processuele connexiteitsvereiste niet meer te hanteren om de bevoegdheid tussen hem en de burgerlijke rechter af te bakenen, maar slechts om de bevoegdheid tussen de verschillende bestuursrechters af te bakenen, zie 9.5 . 
zorgen dat de bestuursrechter alsnog exclusieve rechtsmacht krijgt met betrekling tot zuivere schadebesluiten. De wettelijke regeling van schadevergoeding bij zowel rechtmatige als onrechtmatige overheidsdaden staat momenteel al op de politieke agenda. In een brief aan de Tweede Kamer hebben de ministers van Justitie en Binnenlandse Zaken aangegeven dat een dergelijke regeling bovenaan staat of de prioriteitenlijst met onderwerpen, die een plaats moeten krijgen in de vifde tranche van de $\mathrm{Awb}$. In diezelfde brief gaven de bewindslieden aan, dat 'voor het ter hand nemen van nieuwe onderwerpen, en dus voor een vijfde tranche van de Awb, (...) de komende tijd maar in zeer beperkte mate ruimte (bestaat)'. ${ }^{113}$ Een dergelijke regeling zal dus nog een aantal jaren op zich laten wachten.

Inmiddels heeft de Hoge Raad een arrest gewezen, waarin hij de regel uit het arrest Groningen-Raatgever heeft uitgebreid naar een vordering in kort geding tot betaling van een voorschot op een te verwachten schadevergoeding door de orerheid. Het hof had in deze zaak geoordeeld, dat een dergelijk voorschot bij wijze van voorlopige voorziening ook aan de voorzitter van de Afdeling bestuursrechtspraak kon worden gevraagd op grond van artikel 8:81 Awb. Eiser Leers verd dan ook niet-ontvankelijk verklaard in zijn vordering. Volgens de Hoge Raad stond op grond van het in artikel 8:81 Awb vervatte connexiteitsvereiste de veg naar de voorzitter van de Afdeling slechts open, indien belanghebbende ervoor koos om voor het verkrijgen van de definitieve schadevergoeding de bestuursrechtelijke weg te volgen. Door de weg naar de burgerlijke rechter af te sluiten waar het de vordering met betrekking tot een voorschot betreft, zou eiser worden gedwongen een voorlopige voorziening te vragen aan de voorzitter van de Afdeling. Hierdoor zou hij dan weer worden gedwongen de bestuursrechtelijke weg te volgen voor het verkrijgen van de definitieve schadevergoeding. Hiermee zou de in artikel 8:73 Awb neergelegde keuzemogelijkheid teniet zijn gedaan. Dit nu vond de Hoge Raad niet aanvaardbaar; het arrest van het hof werd vernietigd. ${ }^{114}$

\subsubsection{De gevolgen voor de terugvordering}

In het voorgaande is ingegaan op de praktische gevolgen van de jurisprudentie betreffende het zuiver schadebesluit. Op deze jurisprudentie zijn veel reacties gekomen. Met betrekking tot terugvordering lijkt de jurisprudentie van de bestuursrechter minder weerstand te wekken. Dit ligt ook voor de hand, nu het gebruik van de rechtsgang naar de burgerlijke rechter door de burger minder logisch is. De betrokkene die met een terugvorderingsbesluit wordt geconfronteerd, zal dit besluit immers niet snel aanvechten bij de burgerlijke rechter. Theoretisch bestaat deze mogelijkheid wel: hij kan bijvoorbeeld een verklaring voor recht vragen dat de vordering ongegrond is. De burgerlijke rechter zal hem

113. Tweede Kamer 1999-2000, 26800 Vl, nr. 7, blz. 8.

114. HR 27 april 2001, AB 2001, 361, m.nt. ThGD, RvdW 2001, 93, JB 2001, 126, m.nt. F.A.M. S (Leers-Staat). 
in dat geval niet-ontvankelijk moeten verklaren en vervolgens artikel $70 \mathrm{Rv}$ moeten toepassen, nu gezegd kan worden dat een met voldoende waarborgen omklede bestuursrechtelijke rechtsgang openstaat en nu ook hier een onduidelijke situatie bestaat. Dit zal anders zijn, als het bestuursorgaan uitdrukkelijk heeft aangegeven dat tegen het besluit bezwaar kan worden gemaakt. Mij lijkt dat de opvatting van de Hoge Raad in het arrest Groningen-Raatgever niet voor (analoge) toepassing in aanmerking komt, nu een doorslaggevende reden voor die opvatting was, dat de wetgever kennelijk de burger bij schadevergoedingsvorderingen een uitdrukkelijke keuzemogelijkheid heeft willen geven tussen de rechtsgang naar de bestuursrechter en die naar de burgerlijke rechter. Een dergelijke keuzemogelijkheid is met betrekking tot terugvordering niet te vinden. Slechts in het uitzonderingsgeval, waarin weliswaar sprake is van een (terugvorderings)besluit, maar dit niet appellabel is omdat op grond van het processuele connexiteitsvereiste geen bestuursrechter bevoegd is over dit besluit te oordelen, komt de burgerlijke rechter in beeld. Het initiatief dient dan normaal gesproken van het bestuur uit te gaan: het enkele feit dat er een terugvorderingsbesluit ligt, wil nog niet zeggen dat dit besluit ook afdwingbaar is. Een dergelijk besluit levert immers geen executoriale titel op. ${ }^{115}$ Het bestuur zal dan ook naar de rechter dienen te stappen met een vordering uit onverschuldigde betaling.

Wel zou het bestuursorgaan in plaats van een terugvorderingsbesluit te nemen een actie uit onverschuldigde betaling kunnen instellen bij de burgerlijke rechter. Deze zal mijns inziens het bestuursorgaan dan niet-ontvankelijk moeten verklaren: het volgen van de privaatrechtelijke weg levert immers een onaanvaardbare doorkruising van het publiekrecht op. ${ }^{116}$

\subsection{Conclusie en vooruitblik}

In dit hoofdstuk heb ik een aantal publiekrechtelijke aspecten van de terugvordering behandeld naar aanleiding van de jurisprudentie van de Afdeling bestuursrechtspraak, waarbij zij de bevoegdheid tot terugvordering baseert op het algemene rechtsbeginsel dat hij die onverschuldigd heeft betaald, dit kan terugvorderen. $Z_{0}$ is onder meer de vraag aan de orde geweest of rechtsbeginselen bevoegdheden kunnen scheppen. Om deze vraag te beantwoorden heb ik mijn opvatting met betrekking tot het legaliteitsbeginsel uiteengezet: iedere bestuursbevoegdheid waardoor bevoegdheden, rechten en plichten van burgers kunnen worden vastgesteld of gewijzigd, moet in beginsel berusten op een uitdrukkelijke wettelijke grondslag. In bepaalde gevallen kan worden volstaan met een positieve indicatie in de wet voor die bevoegdheid, er is dan sprake van een impliciete bevoegdheid. Een dergelijke impliciete bevoegdheid kan echter niet bestaan wanneer door uitoefening van die bevoegdheid direct of indirect verplichtingen kunnen ontstaan

115. Mogelijk is dit anders na de inwerkingtreding van de vierde tranche van de Awb, zie 10.6.

116. Zie over de doorknuisingsleer 5.2.5. 
voor de betrokkene, terwijl deze verplichtingen niet reeds kunnen worden afgeleid uit de (mogelijk) verplichtende primaire bevoegdheid. Deze opvatting met betrekking tot het legaliteitsbeginsel leidt tot de conclusie dat rechtsbeginselen in ieder geval geen bevoegdheden kunnen scheppen.

Een andere vraag is of de bestuursrechter zich in strijd met het grondwettelijk stelsel rechtsmacht heeft toegeëigend, die aan de burgerlijke rechter toebehoort. Weliswaar is de bestuursrechter vrij ver gegaan bij het oprekken van het besluitbegrip in zijn jurisprudentie met betrekking tot het terugvorderingsbesluit (en het zuiver schadebesluit), mijns inziens is hij hierin niet te ver gegaan. Wel laat de jurisprudentie zien dat de vraag of het besluit nog wel de geëigende rechtsingang is bij de bestuursrechter, actueel is. Er wordt dan ook voor gepleit om niet langer de publiekrechtelijke rechtshandeling, het besluit, maar de publiekrechtelijke rechtsbetrekking te hanteren als ingang bij de bestuursrechter.

Ten slotte heb ik een aantal praktische vragen behandeld, die waren gerezen naar aanleiding van de 'algemene-rechtsbeginselenjurisprudentie', met name naar aanleiding van de jurisprudentie betreffende het zuiver schadebesluit. De belangrijkste vraag is of de bestuursrechtelijke rechtsgang exclusief is. De Hoge Raad heeft in het arrest Groningen-Raatgever beslist dat dit niet zo is; de betrokkene heeft een keuze. Mede gelet op de historische achtergrond van de taak die de burgerlijke rechter zich (in het verleden volkomen terecht) heeft toegeëigend met betrekking tot de rechtsbescherming tegen de overheid, had de Hoge Raad de burger, Raatgever, niet-ontvankelijk moeten verklaren en moeten doorverwijzen naar de bestuursrechtelijke rechtsgang. Een complicerende factor blijft echter het door de bestuursrechter gehanteerde processuele connexiteitsvereiste.

De jurisprudentie met betrekking tot het terugvorderingsbesluit heeft minder praktische bezwaren ontmoet. Dit is niet verwonderlijk. Het ligt niet in de lijn der verwachting dat een betrokkene, die wordt geconfronteerd met een terugvorderingsbeslissing, een vordering daaromtrent zal instellen voor de burgerlijke rechter. Zou dit overigens gebeuren, dan dient de rechter betrokkene niet-ontvankelijk te verklaren; analoge toepassing van het arrest Groningen-Raatgever is niet mogelijk. Zou het bestuursorgaan de privaatrechtelijke weg willen volgen in plaats van de publiekrechtelijke, dan zal sprake zijn van onaanvaardbare doorkruising van het publiekrecht.

Voor de terugvordering noet dus een uitdrukkelijke wettelijke grondslag aanwezig zijn; er zal een wettelijke regeling moeten zijn. Ik zal dit in het volgende hoofdstuk uitwerken, waarbij ik tevens zal bekijken aan welke vereisten deze regeling moet voldoen. Zoals gezegd wijs ik de door de Afdeling bestuursrechtspraak gevolgde constructie van bevoegdheidscheppende algemene rechtsbeginselen af. Wel vind ik het een verbetering dat de bestuursrechter steeds meer rechtsmacht krijgt. Naar mijn mening dienen bestuursrechtelijke vragen te worden behandeld door de bestuursrechter; de rechtsbescherming tegen de overheid moet worden geconcentreerd bij deze rechter. Dit zou ertoe moeten leiden, dat niet langer het besluit, maar de publiekrechtelijke rechtsbetrekking moet dienen als ingang bij de bestuursrechter. Ditt leidt onder meer tot de vraag, wanneer sprake is van een 
dergelijke publiekrechtelijke rechtsbetrekking. Dit zal aan de orde komen in hoofdstuk 11, waar tevens zal worden ingegaan op de vraag of het privaatrecht binnen een dergelijke rechtsbetrekking een rol kan spelen. Wel is voor het concentreren van de rechtsbescherming tegen de overheid bij de bestuursrechter een voorwaarde dat de organisatie van de bestuursrechtelijke rechtsgang ingrijpend wordt herzien. Ik zal dit uitwerken in hoofdstuk 12. 


$$
\text { . }
$$




\section{DE BEVOEGDHEID TOT TERUGVORDERING}

\subsection{Inleiding}

In deel II van het onderzoek heb ik onder meer bekeken in hoeverre wettelijke regelingen in het socialezekerheidsrecht, het ambtenarenrecht, het subsidierecht en het sociaal-economisch recht bepalingen bevatten met betrekking tot terugvordering, hoe deze eventuele bepalingen eruit zien en hoe rechters omgaan met terugvordering als daarvoor geen uitdrukkelijke bepalingen bestaan. Ook heb ik bekeken welke meer algemene beginselen aan de terugvordering ten grondslag liggen in de verschillende regelingen en of hierin een bepaalde consistentie valt te ontdekken. Bij vergelijking van de regelingen op verschillende terreinen, maar ook binnen een bepaald rechtsgebied, is opgevallen dat de wetgever niet altijd een eenduidige lijn heeft gehanteerd. Hetzelfde kon worden gezegd van de verschillende bestuursrechters. Inmiddels zijn de laatsten meer op één lijn komen te zitten door de jurisprudentie inzake het terugvorderingsbesluit, die ik in het vorige hoofdstuk heb behandeld. Het blijft echter een verbrokkeld geheel. Een algemene regeling met betrekking tot intrekking van toekenningsbeslissingen en met betrekking tot terugvordering bestaat niet. In grote lijnen is de huidige situatie op de genoemde terreinen de volgende.

De socialezekerheidswetten bevatten momenteel een vrijwel uitputtende regeling met betrekking tot terugvordering. Indien ten onrechte is betaald, kan het toekenningsbesluit worden ingetrokken en kan het onverschuldigd betaalde worden teruggevorderd, tenzij dringende redenen aanwezig zijn om af te zien van terugvordering. Wel is de terugvorderingsbevoegdheid beperkt in de tijd; de verjaringsbepalingen uit het $\mathrm{BW}$ zijn van toepassing.

In het ambtenarenrecht bestaat geen wettelijke regeling met betrekking tot terugvordering van onverschuldigd gedane betalingen; de Ambtenarenwet heeft dienaangaande nooit bepalingen bevat. Niettemin heeft de Centrale Raad van Beroep als ambtenarenrechter al vrij vroeg geoordeeld dat onder omstandigheden kan worden teruggevorderd: het algemeen rechtsbeginsel dat degene die onverschuldigd heeft betaald, dit kan terugvorderen, geldt ook in het bestuursrecht. Wel is deze terugvorderingsbevoegdheid niet onbeperkt, andere beginselen zoals het vertrouwensbeginsel en het rechtszekerheidsbeginsel kunnen zich in een concreet geval verzetten tegen (onbeperkte) terugvordering. Dit heeft er onder meer toe geleid dat niet mag worden teruggevorderd als de betrokken ambtenaar niet wist en ook niet kon weten dat onverschuldigd is betaald, dat de terugvorderingstermijn is beperkt tot twee jaar als er sprake was van een administratieve vergissing, hetgeen de ambtenaar wist of behoorde te weten en tot vijf jaar als de onverschuldigde betaling is veroorzaakt door toedoen van de betrokkene. Voorts geldt de zogenaamde zesmaandenjurisprudentie: de Centrale Raad acht het (als hoofdregel) 
in strijd met het zorgvuldigheidsbeginsel om betalingen terug te vorderen, die zijn gedaan zes maanden nadat een eerste signaal is binnengekomen dat ten onrechte is betaald.

Waar het terugvordering van subsidies betreft, is de situatie de volgende. De bevoegdheid tot intrekking van de subsidieverlening en/of -vaststelling is wettelijk geregeld in de Awb, waarbij in beginsel geldt dat niet mag worden ingetrokken indien de ontvanger niet wist en ook niet behoorde te weten dat geen recht op de subsidie bestond. Onverschuldigd betaalde subsidie kan worden teruggevorderd binnen vijf jaren nadat de subsidie is vastgesteld. De terugvordering zelf werd tot voor kort gezien als een rechtshandeling naar burgerlijk recht, tenzij de betrokken wettelijke regeling terugvorderingsbepalingen bevatte. In 1996 overwoog de Afdeling bestuursrechtspraak echter dat een terugvorderingsbeslissing veelal een besluit in de zin van artikel 1:3 Awb is, ook als daarvoor geen uitdrukkelijke grondslag is te vinden in de wet. ${ }^{1}$ De (publiekrechtelijke) bevoegdheid kan namelijk worden gevonden in het algemene rechtsbeginsel dat hij die onverschuldigd heeft betaald, dit kan terugvorderen. In het voorontwerp van de vierde tranche van de Awb wordt voorgesteld om in de subsidietitel een algemene terugvorderingsgrondslag op te nemen.

Binnen het terrein van subsidies nemen de subsidies op het gebied van de sociaal-economische ordening een aparte plaats in. Het College van Beroep voor het bedrijfsleven is op dit gebied de veelal bevoegde rechter. Tenzij hiervan wordt afgeweken in de specifieke wetten, zijn de bepalingen met betrekking tot intrekking uit de subsidietitel van de Awb van toepassing. Wat de terugvordering betreft, moet een onderscheid worden gemaakt tussen de situatie waarbij het College algemene rechtsmacht heeft op grond van eerst de Wet arbo, nu de Wbbo, en die waarbij sprake is van een specifieke bevoegdheid. In het laatste geval volgde het College de jurisprudentie van de Afdeling (bestuurs)rechtspraak, waarbij de terugvorderingsbeslissing tot voor kort bij het ontbreken van een uitdrukkelijke wettelijke grondslag werd aangemerkt als rechtshandeling naar burgerlijk recht. Hierover diende de burgerlijke rechter te oordelen. Aangenomen mag worden dat ook het College dergelijke terugvorderingsbeslissingen tegenwoordig zal zien als (veelal appellabele) besluiten. In het eerste geval achtte het College zich snel bevoegd over de terugvordering te beslissen, mits het bestuursorgaan maar handelde binnen de uitoefening van zijn publiekrechtelijke taak. Op de regulering van de terugvorderingsbevoegdheid is de in de vorige alinea beschreven regeling uit de Awb van toepassing, tenzij de specifieke regeling afwijkende bepalingen bevat.

In dit hoofdstuk zal ik mijn eigen opvatting uiteenzetten terzake de vraag wanneer de overheid door haar onverschuldigd betaalde gelden mag terugvorderen. Bij de beantwoording van deze vraag moet een aantal (algemene) beginseien tegen elkaar worden afgewogen, namelijk het beginsel dat hetgeen onverschuldigd is betaald, 
kan worden teruggevorderd, het vertrouwensbeginsel en het rechtszekerheidsbeginsel. De laatste beginselen zullen ook een (doorslaggevende) rol kunnen spelen bij de vraag of een toekenningsbesluit kan worden ingetrokken.

In de volgende paragrafen zal ik voortbouwen op het in het vorige hoofdstuk door mij ingenomen standpunt, dat zowel de intrekkings- als de terugvorderingsbevoegdheid een uitdrukkelijke wettelijke grondslag dienen te hebben. Dit leidt tot de in 10.3 te behandelen vraag, hoe die wettelijke regeling eruit dient te zien. Kan worden volstaan met een algemene regeling, of dient van geval tot geval een specifieke regeling te worden gemaakt? En welke criteria moeten bij een dergelijke (algemene of specifieke) regeling een rol spelen? Dit laatste komt aan de orde in 10.4. Vervolgens bespreek ik de vraag welk karakter de te hanteren terugvorderingstermijnen moeten hebben (10.5) en de invordering, waarbij ook de in het voorontwerp van de vierde tranche van de Awb voorgestelde regeling wordt bekeken (10.6).

\subsection{Een wettelijke grondslag voor terugvordering}

Ik heb in 9.3 aangegeven dat naar mijn mening zowel de intrekkingsbevoegdheid als de terugvorderingsbevoegdheid een uitdrukkelijke wettelijke grondslag moet hebben. Niet kan worden volstaan met het aannemen van een impliciete bevoegdheid. De terugvorderingsbevoegdheid kan ook niet worden gevonden in het algemene rechtsbeginsel dat hetgeen onverschuldigd is betaald, kan worden teruggevorderd. De praktische uitvoering van het vereiste van een uitdrukkelijke wettelijke grondslag voor de intrekkings- en de terugvorderingsbevoegdheid hoeft ook niet problematisch te zijn. Het vrij algemeen aanvaarde uitgangspunt is immers dat in de gevallen waarin de overheid presterend optreedt en waar burgers (of andere betrokkenen) financieel van dat overheidsoptreden (mede)afhankelijk zijn, er een wettelijke grondslag moet zijn voor dat overheidsoptreden. Voor een aantal belangrijke (zelfs de belangrijkste) terreinen waarop de overheid financieel presterend optreedt, is dit zelfs uitdrukkelijk neergelegd in de (Grond)wet. Artikel $20 \mathrm{Gw}$ bepaalt dat de wet regels stelt omtrent de aanspraken op sociale zekerheid (lid 2) en dat Nederlanders hier te lande een bij de wet te regelen recht op bijstand van overheidswege hebben, indien zij niet in hun bestaan kunnen voorzien (lid 3), artikel $109 \mathrm{Gw}$ bepaalt dat de wet de rechtspositie van ambtenaren regelt en artikel 4:23 Awb eist in het algemeen een wettelijk voorschrift als basis voor het verstrekken van subsidie.

Het zal aanstonds duidelijk zijn dat daar waar de overheid financieel presterend optreedt, dit in een aantal gevallen ten onrechte zal gebeuren. Van de wetgever mag dan ook worden verwacht, dat, nu hij in een wettelijke regeling moet neerleggen wanneer een financiële aanspraak ontstaat tegenover een bestuursorgaan, hij zich tevens erover uitlaat wat dient te gebeuren als blijkt dat deze aanspraak ten onrechte is ontstaan, ofwel omdat aan de kant van het bestuur iets is misgegaan, ofwel omdat de burger niet heeft voldaan aan bepaalde verplichtingen. 


\subsection{De wettelijke regeling met betrekking tot terugvordering: een bijzonde- re of een algemene regeling?}

De volgende vraag is dan, waar de verschillende bevoegdheden dienen te worden geregeld. Kan worden volstaan met een algemene regeling voor intrekking en terugvordering, waarbij uiteraard kan worden gedacht aan een regeling in de Awb, of dient er een specifieke regeling te komen in de wetten, waarin de toekenningsbevoegdheid is neergelegd? Mogelijk kan ook worden gedacht aan cen tussenoplossing, met name door het opnemen van de regeling in kaderwetgeving.

Ik wil vooropstellen dat naar mijn mening de toekenningsbevoegdheid een expliciete grondslag dient te hebben in een zo specifiek mogelijke regeling. In die regeling zal moeten worden aangegeven aan welke criteria moet zijn voldaan, wil de betrokkene een aanspraak krijgen tegenover het bestuur. De reden hiervoor is (wederom) de veelal bestaande afhankelijkheidspositie van de betrokkene. Rechtszekerheid en (daarmee) het voorkomen van willekeur spelen hierbij uiteraard een belangrijke rol. ${ }^{2} \mathrm{Nu}$ de vraag aan welke voorwaarden moet zijn voldaan, wil een recht bestaan op een bijdrage, afhankelijk is van het doel van de betreffende regeling, dient de toekenningsbevoegdheid in een specifieke wettelijke regeling te worden neergelegd, waarbij tevens wordt geregeld welk bestuursorgaan bevoegd is. Deze opdracht vloeit mijns inziens ook voort uit (grond)wettelijke bepalingen als de artikelen 20 en $109 \mathrm{Gw}$ en artikel 4:23 Awb.

Ook de bevoegdheid tot het intrekken van de toekenningsbeslissing dient te zijn neergelegd in de specifieke wettelijke regeling. Ook hier speelt de afhankelijkheid van de betrokkene en dus de rechtszekerheid een belangrijke rol. Bij de beantwoording van de vraag in welke gevallen het toekenningsbesluit kan worden ingetrokken, zal steeds rekening moeten worden gehouden met de specifieke omstandigheden die zich voordoen bij de wettelijke regeling. Hierbij dienen vooral aan de orde te komen de vragen, in hoeverre betrokkenen financieel afhankelijk zijn van de bijdragen en in hoeverre die bijdrage beoogt te voorzien in de primaire levensbehoeften. Dit betekent dat het afhankelijk is van het doel van de regeling in welke gevallen het toekenningsbesluit kan worden ingetrokken en hoe deze laatste bevoegdheid dient te worden begrensd. Dit brengt mee dat niet kan worden volstaan met het regelen van de intrekkingsbevoegdheid in een algemene regeling. Een dergelijke algemene regeling staat overigens wel op het programnaa van de wetgever; een van de prioriteiten voor de vijfde tranche van de Awb is een regeling met betrekking tot intrekking van begunstigende besluiten. ${ }^{3}$ A.ls deze regeling wordt gerealiseerd, is zij dus ook van toepassing op de intrekking van bijvoorbeeld vergunningen. Een dergelijke algemene regeling stond ook al als een van de eerste onderwerpen, die in de Awb dienden te worden geregeld, op het

2. Zie ook de memorie van toelichting op artikel 4:23 Awb, PG Awb III, blz. 199 en hierover 8.2.2.2.

3. Zie de brief van ministers van Justitie en Binnenlandse Zaken en Koninkrijksrelaties, Tweede Kamer 1999-2000, 26800 VI, nr. 7, blz. 9. 
programma voor de eerste tranche, maar wegens de vele moeilijkheden die optraden bij het ontwerpen van de beoogde regeling heeft dit onderwerp het nooit verder gebracht dan een (niet gepubliceerd) voorontwerp. Mocht een dergelijke algemene regeling in de vijfde tranche wel worden gerealiseerd, dan kan zij bij terugvordering om de hiervoor uiteengezette redenen de specifieke regelingen niet vervangen.

De hiervoor met betrekking tot de intrekkingsbevoegdheid aangevoerde redenen om een specifieke wettelijke regeling te verlangen, gelden evenzeer voor de terugvorderingsbevoegdheid. Ook deze dient dus te berusten op een specifieke wettelijke grondslag.

Naast de specifieke regelingen dient een algemene terugvorderingsregeling te worden opgenomen in de Awb. In de eerste plaats kunnen in een dergelijke regeling meer algemene bepalingen worden opgenomen, die als een vangnet dienen. Mocht zich een geval voordoen, waarvoor (nog) geen specifieke regeling bestaat, dan kan worden teruggevallen op de algemene regeling. Dit heeft het voordeel dat bij het ontbreken van een specifieke regeling de terugvordering in ieder geval niet wordt gezien als privaatrechtelijke rechtshandeling. Uiteraard geldt de regel dat specifieke bepalingen voor algemene bepalingen gaan. Het bestaan van een dergelijke algemene regeling ontslaat de wetgever niet van de verplichting een specifie$\mathrm{ke}$ (re) regeling te treffen, tenzij sprake is van een eenmalige, althans uitzonderlijke situatie. ${ }^{4}$ Verder dient deze algemene regeling de (publiekrechtelijke) bevoegdheid te scheppen voor de overheid om onverschuldigd gedane betalingen, die niet hebben plaatsgevonden in het kader van een publiekrechtelijke rechtsbetrekking, langs publiekrechtelijke weg terug te vorderen. Wanneer sprake is van een publiekrechtelijke rechtsbetrekking en waarom het wenselijk is om ook betalingen

4. Ook M.W. Scheltema stelt voor in de Awb een algemeen artikel met betrekking tot terugvordcring op te nemen. Waar nodig kunnen de specifieke regelingen afwijkingen bevatten. Het voordeel van een dergelijke algemene regeling is volgens hem dat de bestaande terugvorderingsbepalingen kunnen worden geüniformeerd. Zie Scheltema (1997), blz. 295-296. Hij verwijst hiervoor naar de situatie in Duitsland, waar een dergelijke algemene regeling zou zijn neergelegd in $\S 48$ Abs. 1 Verwaltungsverfahrensgesetz. $\S 48$ VwVfG betreft echter de intrekking van een besluit dat in strijd met het recht is, en niet de terugvordering. Een regeling voor terugvordering van onverschuldigde betalingen is wel neergelegd in $\$ 49 a$, waarbij de algemene regeling te vinden is in $\$ 49 \mathrm{a}$ Abs. $1 \mathrm{~S}$. 1 VwVfG. Dit is echter geen algemene terugvorderingsbepaling, maar het ziet slechts op terugvordering van betalingen gedaan op grond van een ingetrokken besluit, waarbij dit besluit in eerste instantie dus de rechtsgrond voor de betaling vormde. Het ziet dus niet op gevallen, waarin aberhaupt geen rechtsgrond aanwezig is geweest. Zie over § 49a VwVfG ook Ossenbühl (1998), blz. 419-420.

Overigens is de door Scheltema voorgestane oplossing (een algemene regeling en waar nodig een afwijking in de specifieke wet) het spiegelbeeld van het door mij voorgestane model. Ik vind immers dat et altijd een specifieke regeling moet zijn; de algemene regeling fungeert dan als een soort 'vangnet'. Dit betekent dat feitelijk, indien aan dit model wordt voldaan en er dus altijd een specifieke regeling bestaat, de algemene regeling overbodig zou zijn. Het is echter de vraag, of zich niet onvoorziene gevallen kunnen voordoen, waarop de specifieke bepalingen niet van toepassing blijken te zijn. Voor deze gevallen zou de algemene regeling dan zijn bedoeld. 
die niet hebben plaatsgevonden in het kader van een dergelijke rechtsbetrekking langs publiekrechtelijke weg terug te vorderen, zal ik behandelen in 11.3.

Eventueel zou op bepaalde terreinen kunnen worden volstaan met kaderwetgeving, waarin de intrekkingsbevoegdheid en de terugvorderingsbevoegdheid wordt gereguleerd. $Z_{0}$ is het voorstelbaar, dat op het gebied van de sociale zekerheid de criteria aan de hand waarvan moet worden bepaald of en wanneer kan worden ingetrokken dan wel teruggevorderd, bij vrijwel alle regelingen gelijk zijn. In dat geval kan in een dergelijke kaderwet een algemene regeling, die op dat gebied geldt, worden neergelegd. Dit is wat de wetgever op het terrein van de subsidies heeft gedaan; de subsidietitel in de Awb kan worden gezien als een dergelijke 'kaderregeling'. Mocht met betrekking tot specifieke wetten een uitzondering op zijn plaats zijn, dan kan deze in die specifieke wettelijke regeling worden neergelegd. Hierbij geldt uiteraard de regel, dat de specifieke wet boven de algemene wet gaat. Vanuit het oogpunt van rechtszekerheid blijft het echter te prefereren de grondslag voor de genoemde bevoegdheden neer te leggen in de specifieke wettelijke regelingen. Naar mijn mening heeft de wetgever op het terrein van de sociale zekerheid (waar reeds een bepaalde mate van harmonisatie bestond, welke werd uitgebreid door de WBM) in 1996 dan ook terecht ervoor gekozen om de terugvorderingsbepalingen in de afzonderlijke socialezekerheidswetten op te nemen en niet te volstaan met een algemene(re) regeling.

Overigens is niet op alle terreinen (algemene) kaderwetgeving mogelijk. Zo zie $i k_{\text {, }}$ anders dan de wetgever, bijvoorbeeld geen ruimte hiervoor op het gebied van subsidies. De verschillende subsidies zijn hiervoor te divers. Terugvordering van subsidies aan individuele burgers zal veelal veel ingrijpender zijn dan terugvordering van subsidies aan ondernemingen. Er zullen dan ook mogelijk andere regels moeten gelden. Bij subsidies aan ondememingen dient ook weer een onderscheid te worden gemaakt welke soort subsidie het betreft en aan welke onderneming deze wordt gegeven. Zo zal aan de ene kant van de schaal de subsidies aan kleine ondememingen, bijvoorbeeld startsubsidies, liggen en aan de andere kant subsidies aan grote multinationals. Dit betekent dat de terugvorderingsregeling in de subsidietitel van de Awb zoals die nu geldt, te ruim is, nu geen rekening wordt gehouden met de grote verscheidenheid aan subsidies.

\subsection{Uitgangspunten van de wettelijke regeling}

\subsubsection{Inleiding}

Er dient dus sieeds een zo specifiek mogelijke wettelijke regeling te zijn voor de terugvordering, waarbij wordt aangegeven in welke gevallen een toekenningsbesluit kan worden ingetrokken en in welke gevallen het (daardoor) onverschuldigd betaalde kan worden teruggevorderd. Deze regelingen zullen zo veel mogelijk maatwerk moeten zijn. Dit neemt niet weg, dat de uitgangspunten vrijwe! steeds dezelfde zullen zijn.

Twee algemene aspecten dienen in het oog te worden gehouden. In de eerste 
plaats zal in een groot aantal gevallen sprake zijn van een mate van afhankelijkheid van de betalingen aan de zijde van de ontvanger. Deze afhankelijkheid zal het grootst zijn, waar mensen wat betreft hun inkomsten en andere gelden, bedoeld om in hun levensonderhoud te voorzien, afhankelijk zijn van de bijdragen van de overheid. Te denken valt aan socialezekerheidsuitkeringen, ambtenarensalarissen, huursubsidie, studiefinanciering et cetera. Terugvordering van gelden, die naar hun bestemming veelal reeds zullen zijn verbruikt, kan bijzonder ingrijpend zijn.

In de tweede plaats moet ook in het oog worden gehouden, dat het gaat om overheidsgeld, en dus - populair gezegd - om geld van ons allemaal. De overheid heeft een begrensd budget, en dient dit optimaal te besteden. Het algemeen belang vergt dan ook dat het doen van onterechte betalingen zo veel mogelijk wordt voorkomen en dat, indien een dergelijke betaling heeft plaatsgevonden, deze zo veel mogelijk ongedaan wordt gemaakt.

Het eerst genoemde aspect wijst in de richting, dat niet kan worden teruggevorderd, althans dat de mogelijkheid tot terugvordering sterk moet worden begrensd. Het tweede aspect daarentegen wijst in de tegenovergestelde richting: ten onrechte verrichte betalingen dienen zo veel mogelijk te worden teruggevorderd. Het antwoord op de vraag, of door de overheid ten onrechte verrichte betalingen kunnen worden teruggevorderd, zal tussen deze uitersten moeten worden gevonden.

\subsubsection{Uitgangspunten}

Het eerste uitgangspunt is dat de burger mag afgaan op de juistheid van de beslissing van het bestuursorgaan. Hij mag er in beginsel op vertrouwen dat het toekenningsbesluit klopt. Ik zou nog verder willen gaan. Toekenningsbesluiten zijn naar hun aard beschikkingen, die op aanvraag worden gegeven. Alvorens op de aanvraag wordt beslist, dient de betrokkene de benodigde gegevens te overleggen. Naar mijn mening rust vervolgens op het bestuursorgaan de verplichting om het op grond van die gegevens juiste besluit te nemen. Dit leidt ertoe, dat als de betrokkene alle benodigde gegevens heeft verstrekt en deze gegevens correct zijn, het bestuursorgaan het juiste toekenningsbesluit moet nemen. Hierbij zal geen sprake zijn van een juridisch afdwingbare verplichting, maar schending van deze verplichting zou mijns inziens bij terugvordering ertoe moeten leiden dat in bepaalde gevallen de intrekkingsbevoegdheid en dus ook de terugvorderingsbevoegdheid niet ontstaat, zodat het toekenningsbesluit onaantastbaar is, althans niet op deze grond met terugwerkende kracht kan worden aangetast. Dit zal dan het geval zijn als de betrokkene niet wist en ook niet behoefde te weten dat het toekenningsbesluit onjuist is. In dat geval zal het toekenningsbesluit dus niet kunnen worden ingetrokken, zodat de rechtsgrond voor de betaling in stand blijft en er dus ook geen sprake is van onverschuldigde betaling, zodat niet kan worden teruggevorderd. Dat in dat geval het toekenningsbesluit niet met terugwerkende kracht kan worden ingetrokken, is ook het uitgangspunt dat in de subsidietitel in 
de Awb wordt gehanteerd. ${ }^{5}$ Qua resultaat komt de ambtenarenrechter tot dezelfde uitkomst, nu volgens deze rechter terugvordering in strijd is met het vertrouwensbeginsel indien een administratieve vergissing is gemaakt en de betrokkene niet wist en ook niet kon weten dat te veel of ten onrechte is betaald. ${ }^{6}$ Deze regel gold voor de inwerkingtreding van de WBM ook in de sociale zekerheid. ${ }^{7}$

Op de genoemde terreinen wordt dit resultaat bereikt door bescherming van het gerechtvaardigd vertrouwen, maar door uit te gaan van een verplichting voor de overheid wordt de positie van de burger sterker. Dit leidt tot een grotere mate van rechtsbescherming. Bij de bescherming van het gerechtvaardigd vertrouwen aan de kant van de burger zal immers de burger moeten aangeven, dat hij gerechtvaardigd mocht vertrouwen op de juistheid van de toekenningsbeslissing en dus dat hij niet wist, noch behoefde te weten dat het toekenningsbesluit niet klopte. Uitgaande van een verplichting voor het bestuur tot het nemen van een correct besluit ligt het voor de hand dat de rechter in het algemeen zal aannemen dat het het bestuur is dat moet aantonen dat de betrokkene wist of had moeten weten dat de toekenning (deels) ten onrechte was geschied. De bewijspositie van de betrokkene gaat er dus op vooruit. Nog afgezien van dit praktische voordeel voor de betrokkene acht ik de constructie van een op het bestuursorgaan rustende verplichting ook principieel juister.

Intrekking van het toekenningsbesluit is dus wel mogelijk als de betrokkene weliswaar de juiste inlichtingen heeft gegeven, maar desondanks wist of behoorde te weten dat de toekenningsbeslissing niet klopt. Dit zal bijvoorbeeld het geval zijn als hij een overzicht heeft gekregen waarop de door hem verstrekte gegevens onjuist staan vermeld. Hierbij kan worden gedacht aan het toekenningsbesluit of de salaris- of uitkeringsspecificatie. Het nalaten van het controleren en zo nodig corrigeren van deze gegevens door de betrokkene dient niet te worden beloond. Wel zullen de omstandigheden van het geval een rol spelen bij beantwoording van de vraag, of de betrokkene behoorde te weten dat de toekenningsbeslissing onjuist is. Hierbij kan worden gedacht aan de ingewikkeldheid van de specificatie, overige door het bestuursorgaan verstrekte informatie, de maatschappelijke positie van betrokkene enzovoorts. ${ }^{8}$

Intrekking is ook mogelijk indien de onjuistheid van het toekenningsbesluit te wijten is aan het feit dat de betrokkene onjuiste gegevens heeft verstrekt of geen gegevens heeft verstrekt, terwijl hij hiertoe wel verplicht was. Het feit dat het aan de betrokkene te wijten is dat een onjuist besluit is genomen, wil overigens niet zeggen dat aan de betrokkene in alle gevallen een even zwaar verwijt kan worden gemaakt. Zo bestaat veelal een vergaande inlichtingenplicht. In de socialezeker-

5. Zie artikel $4: 48 \mathrm{Awb}$ met betrekking tot het besluit tot de subsidieverlening en artikel $4: 49$ Awb met betrekking tot het besluit tot de subsidievaststelling, zie hierover 8.2.2.4.

6. Zie 7.2.3.3 en 7.2.4.2.

7. Zie 6.4 .4 .

8. Vgl. de in 6.4.4.2 genoemde circulaire FBV. Ook de ambtenarenrechter hecht belang aan deze omstandigheden, zie 7.2.3.3 en 7.2.4.2. 
heidswetten is bijvoorbeeld voor de belanghebbende de verplichting opgenomen om 'op verzoek of onverwijld uit eigen beweging' aan het bestuursorgaan mededeling te doen van alle feiten en omstandigheden waarvan hij redelijkerwijs kan weten dat deze van invloed zijn op de uitkering.' Laat de betrokkene na om een mededeling te doen van een feit waarvan hij ten onrechte maar te goeder trouw denkt dat het niet van belang is, dan kan hem weliswaar een verwijt worden gemaakt, maar het is een ander, mijn inziens minder zwaar, verwijt dan in het geval waarin hij willens en wetens gegevens verzwijgt om zodoende meer toegekend te krijgen dan waarop hij recht heeft. Ook is denkbaar dat de betrokkene is uitgegaan van de juistheid van de verstrekte gegevens, en op het moment dat hij die gegevens verstrekte daar ook van mocht uitgaan, terwijl deze gegevens achteraf niet blijken te kloppen.

In grote lijnen kunnen dan de volgende vier situaties worden onderscheiden. In de eerste situatie lokt de betrokkene opzettelijk een verkeerde beslissing uit door bewust onjuiste inlichtingen te verstrekken of door bewust van belang zijnde gegevens te verzwijgen. Het feit dat ten onrechte of te veel wordt toegekend en uitbetaald, is te wijten aan toedoen van de betrokkene. In de tweede situatie wordt de verkeerde beslissing niet uitgelokt door de betrokkene, maar profiteert hij bewust van een door het bestuursorgaan gemaakte vergissing. In dit geval is in eerste instantie geen sprake van toedoen van de betrokkene, maar van een administratieve vergissing. In de derde situatie is weliswaar sprake van het geven van onjuiste inlichtingen of het verzuimen om inlichtingen te geven, maar dit gebeurt onopzettelijk, de betrokkene heeft niet het oogmerk om een hogere bijdrage te krijgen dan waarop hij recht heeft. Ook in dit geval is het te wijten aan toedoen. van de betrokkene dat ten onrechte of te veel wordt toegekend en uitbetaald. Ten slotte kan het zo zijn dat sprake is van een administratieve vergissing, hetgeen de betrokkene redelijkerwijs had behoren te weten, maar hetgeen hij niet wist.

In alle vier hiervoor genoemde gevallen kan de betrokkenen een verwijt worden gemaakt. In dat geval is intrekking van het toekenningsbesluit mogelijk. Gelet op het feit dat het om gemeenschapsgeld gaat, zou ik zelfs een verplichting tot intrekking willen aannemen, althans als uitgangspunt. Het bestuursorgaan dient namelijk wel de bevoegdheid te hebben geheel of gedeeltelijk van intrekking af te kunnen zien, indien daarvoor dringende redenen aanwezig zijn, zoals nu ook het geval is in het socialezekerheidsrecht. ${ }^{10} \mathrm{De}$ algemene beginselen van behoorlijk bestuur moeten daarbij een rol spelen.

De intrekkingsbevoegdheid moet echter in de tijd worden beperkt. Op verschillende terreinen gebeurt of gebeurde dit ook. In bijvoorbeeld het socialezekerheidsrecht was de situatie voor de inwerkingtreding van de WBM in grote lijnen de volgende. Was sprake van toedoen, dan kon het te veel of ten onrechte betaalde worden teruggevorderd gedurende vijf jaren na de betaalbaarstelling. Was sprake van een administratieve vergissing, hetgeen de betrokkene wist of behoorde

9. Zie bijvoorbeeld artikel 25 WW en artikel 65 lid 1 Abw.

10. Zie 6.4.5. 
te weten, dan was deze periode beperkt tot twee jaren. ${ }^{11}$ De ambtenarenrechter heeft deze indeling met de termijnen overgenomen. ${ }^{12}$ In artikel 4:49 lid 3 Awb wordt de mogelijkheid tot intrekking van de subsidievaststelling in de tijd beperkt, waarbij als hoofdregel geldt dat intrekking niet meer mogelijk is als vijf jaren zijn verstreken sinds de bekendmaking van de vaststelling. Ook de mogelijkheid tot terugvordering is beperkt tot vijf jaren, zie artikel 4:57 Awb. ${ }^{13}$

Het onderscheid dat in de sociale zekerheid werd gemaakt, is bestreden door De Boer. Volgens hem is de ratio achter het onderscheid waarschijnlijk dat het geven van onjuiste inlichtingen of het niet geven van inlichtingen meer verwijtbaar is dan het (alleen maar) redelijkerwijs weten dat men te veel krijgt. Hij heeft dit bestreden. Het welbewust jarenlang toucheren van door een administratieve fout te hoge bedragen kan meer laakbaar zijn dan bijvoorbeeld het per ongeluk vergeten een mededeling te doen. ${ }^{14}$ Op dit punt deel ik zijn kritiek, die ook de rechtspraak van de ambtenarenrechter zal treffen. De Boer vindt het onderscheid echter ook principieel onjuist, nu het bij terugvorderen in het administratieve recht draait om het vertrouwen en niet om de oorzaak van het mislopen. $\mathrm{Zijn}$ conclusie luidt dat er slechts één terugvorderingstermijn moet worden gehanteerd. Deze conclusie is onjuist. Zoals ik in 6.4.4.4 heb gezegd, maakt De Boer ten onrechte geen onderscheid tussen de vraag of überhaupt kan worden teruggevorderd omdat de betrokkene een verwijt kan worden gemaakt en, als deze vraag positief wordt beantwoord, de vraag gedurende welke termijn kan worden teruggevorderd. De tweede vraag betreft de beperkingen die op de in het concrete geval bestaande terugvorderingsbevoegdheid moeten worden aangebracht.

Bij de beantwoording van deze laatste vraag moet een aantal aspecten een rol spelen. Zo zal de zwaarte van het verwijt dat de betrokkene kan worden gemaakt van belang zijn. Verder moet worden gekeken naar de aard van de regeling op grond waarvan de aanspraak bestaat. Betreft het een regeling die beoogt een bijdrage te leveren in het levensonderhoud of waarvan betrokkenen anderszins van aftankelijk zijn voor hun levensonderhoud? In dat geval zal de intrekkingsbevoegdheid verder dienen te worden beperkt dan wanneer de bijdrage louter een economisch doel heeft, zoals bijvoorbeeld bij exportbevorderende subsidies.

Het voorgaande leidt uiteindelijk tot de volgende hoofdlijnen. Als de betrokkene heeft voldaan aan zijn inlichtingenplicht (en eventuele andere verplichtingen), maar het bestuursorgaan een vergissing heeft gemaakt, dan heeft het bestuursorgaan niet voldaan aan zijn verplichting om een juist besluit te nemen en kan het de toekenningsbeslissing niet intrekken, zodat geen sprake is van onverschuldigde betaling en dus niet kan worden teruggevorderd, tenzij het weet aan te tonen dat de betrokkene wist of behoorde te weten dat te veel werd betaald.

11. Zie 6.4.4.4.

12. CRvB 26 april 1990, AB 1991, 157, m.nt. HH, TAR 1990, 138. Zie 7.2.4.2.

13. Zie hierover 8.2.2.4.

14. De Boer (1981), blz. 262. Zie ook 6.4.4.4. 
In de andere gevallen dient het toekenningsbesluit te kunnen worden ingetrokken, waardoor het te veel betaalde in beginsel kan worden teruggevorderd. De mate van verwijtbaarheid aan de zijde van de betrokkene zal dan over het algemeen van belang moeten zijn bij de beantwoording van de vraag gedurende welke termijn kan worden teruggevorderd. Hoe geringer het verwijt, hoe korter de intrekkingsen terugvorderingstermijn zal moeten zijn. Dit zal naar mijn mening vooral een rol moeten spelen in die gevallen, waarin bij de betrokkene een grote afhankelijkheid bestaat van de bijdrage. In het algemeen kan dan worden gezegd, dat bij inkomensafhankelijkheid in het geval dat er sprake is van een geringe verwijtbaaiheid een intrekkingstermijn en een terugvorderingstermijn dienen te gelden van twee jaar, terwijl deze termijnen vijf jaar dienen te zijn als het gedrag van de betrokkene in hoge mate verwijtbaar is. Het onderscheid in een tweejaren- en een vijfjarentermijn is niet nieuw. De ambtenarenrechter hanteert het, evenals vrijwel alle socialezekerheidswetten voor de inwerkingtreding van de WBM. ${ }^{15}$ Het gedrag is in hoge mate verwijtbaar als opzettelijk onjuiste inlichtingen worden verstrekt, opzettelijk gegevens worden verzwegen of bewust gebruik wordt gemakkt van een administratieve vergissing. Een geringe(re) mate van verwijtbaarheid is er dan indien weliswaar onjuiste inlichtingen worden gegeven of wordt verzuimd om inlichtingen te geven, maar dit onopzettelijk gebeurt, waarbij de betrokkene niet het oogmerk heeft om een hogere bijdrage te krijgen dan waarop hij recht heeft, en wanneer sprake is van een administratieve vergissing, hetgeen de betrokkene redelijkerwijs had behoren te weten, maar hetgeen hij niet wist. De rechter zal in een concreet geval moeten bepalen welke mate van verwijtbaarheid bestaat, en dus welke intrekkings- en terugvorderingstermijn geldt. Op grond van het vrij-bewijsbeginsel kan hij bepalen wie de aanwezigheid dan wel afwezigheid van bijvoorbeeld opzet moet aantonen. ${ }^{16} \mathrm{Er}$ is sprake van inkomensafhankelijkheid bij onder meer de socialezekerheidsregelingen, ambtenarensalarissen, studiefinanciering en huursubsidie. Daarnaast kan dit het geval zijn bij bepaalde subsidies aan kleine ondememers. Ik denk hierbij aan bijvoorbeeld startsubsidies.

Gaat het om subsidies waarbij geen sprake is van inkomensafhankelijkheid, maar waarbij voornamelijk (andere) economische motieven een rol spelen, dan zal er minder reden zijn om een onderscheid te maken tussen de genoemde twee situaties. Dit zal zich voordoen bij subsidies aan rechtspersonen met een commercieel oogmerk. In dat geval dient de toekenningsbeslissing gedurende vijf jaar te kunnen worden ingetrokken en kan dus gedurende deze periode het te veel betaalde worden teruggevorderd. Dit is wat de subsidievaststelling en de terugvordering betreft ook de regeling die is neergelegd in de Awb. Wat mij betreft kan bij het opzettelijk onjuiste inlichtingen geven of opzettelijk gegevens verzwijgen met het oogmerk om zodoende een hogere subsidie te ontvangen dan waarop recht bestaat in deze gevallen zelfs een langere termijn gelden voor intrekking en terugvordering.

15. Wel anders zijn de criteria waarin de respectievelijke termijnen moeten worden toegepast.

16. Zie 1.6. 
Eventueel kan in alle genoemde gevallen indien sprake is van het opzettelijk geven van onjuiste inlichtingen of verzwijgen van gegevens met het oogmerk om zodoende een hogere aanspraak te krijgen dan waarop recht bestaat de bevoegd. heid worden gecreëerd tot het opleggen van een boete. Daamaast kan men zich afvragen of het bestuursorgaan in dat geval niet ook (of in plaats van een boete) de schade moet kunnen verhalen op de betrokkene, bijvoorbeeld door in de regelingen de mogelijkheid op te nemen om renteschade te vorderen.

\subsubsection{Terugvordering van betalingen die niet overeenkomstig het toekennings. besluit zijn gedaan}

In het voorafgaande ben ik steeds uitgegaan van de situatie, dat conform het (onjuiste) toekenningsbesluit is betaald. Het kan ook zo zijn dat het toekenningsbesluit correct was, maar dat meer werd betaald dan waarop recht bestond. In dat geval hoeft het toekenningsbesluit niet te worden ingetrokken. De onverschuldigdheid van de betaling staat al vast. Ook dan dient de terugvorderingsbevoegdheid een wettelijke grondslag te hebben. Hiervoor kan worden aangesloten bij de regelingen, zoals die zijn neergelegd in het socialezekerheidsrecht. Zo bepaalt bijvoorbeeld artikel 36 lid $1 \mathrm{WW}$ :

'De uitkering die als gevolg van een besiuit als bedoeld in artikel 22a of 27 Thet intrekkingsbesluit, CB] onverschuldigd is betaald, alsmede hetgeen anderszins onverschuldigd is betaald, wordt foor het Landelijk instituut sociale verzekeringen van de betrokken werknemer teruggevorderd' ${ }^{77}$

Als meer wordt betaald dan waarop de betrokkene op grond van de toekenningsbeslissing recht heeft, zal sprake zijn van een (feitelijke) administratieve vergissing. In beginsel heeft het bestuursorgaan dus voldaan aan zijn verplichting om een correct besluit te nemen. Alleen is vervolgens bij de betaling iets verkeerd gegaan. De vraag is dan wanneer kan worden teruggevorderd. In dit geval zou ik het gerechtvaardigd vertrouwen bij de betrokkene de doorslag willen laten geven. Indien de betrokkene er gerechtvaardigd op mocht vertrouwen dat de betaling correct was, kan niet worden teruggevorderd. Dit zal zich in de praktijk vrijwel nooit voordoen, zeker niet als het toekenningsbesluit de hoogte van de aanspraak of de berekeningswijze hiervan vermeldt, hetgeen vrijwel altijd het geval is. In de andere gevallen kan dus worden teruggevorderd. Hierbij moet wederom een onderscheid worden gemaakt tussen de situatie dat de betrokkene niet wist dat een administratieve vergissing is gemaakt, maar dit wel behoorde te weten (hetgeen ook uitzondering zal zijn) ${ }^{18}$ en het geval dat de betrokkene dit wist en (kennelijk) bewust heeft geprofiteerd van die vergissing. Ook hier kan dit onderscheid leiden tot verschillende terugvorderingstermijnen, wederom affankelijk van het

17. Mijn cursivering.

18. Hierbij dienen de omstandigheden van het geval een rol te spelen, waarbij wederom kan worden gelet op de ingewikkeldheid van de specificatie, door het bestuursorgaan verstrekte informatie, de maatschappelijke positie van betrokkene enzovoorts. 
soort regeling waarom het gaat. Mede om deze reden dient ook de terugvorderingsbevoegdheid in de verschillende regelingen te worden gereguleerd.

\subsubsection{De algemene regeling in de Awb}

Hoe de precieze regelingen eruit dienen te zien, is afhankelijk van het doell van de wettelijke regeling op grond waarvan het toekenningsbesluit is genomen. Er dient echter ook een algemene regeling in de Awb te komen voor intrekking van toekenningsbesluiten en terugvordering. Wat betreft de terugvordering zal de regeling bepalingen moeten bevatten voor twee te onderscheiden situaties, namelijk de situatie waarin de terugvordering plaatsvindt in het kader van een publiekrechtelijke rechtsbetrekking en de situatie waarin dit niet het geval is. ${ }^{19}$ Deze laatste situatie zal uitzonderlijk zijn. Wanneer de terugvordering plaatsvindt in het kader van een publiekrechtelijke rechtsbetrekking en de specifieke wettelijke regeling (nog) geen bepalingen kent met betrekking tot intrekking en terugvordering, dan kan worden teruggevallen op de algemene regeling. Zodoende wordt voorkomen dat indien er geen specifieke regeling is, terugvordering niet mogelijk is, hetgeen maatschappelijk gezien onwenselijk is, of dat de terugvordering word gezien als privaatrechtelijke rechtshandeling, waarop de bepalingen betreffende onverschuldigde betaling uit het $\mathrm{BW}$ van toepassing zijn. Nu deze regeling dus een soort 'restregeling' wordt, kan de aard van de regeling waarop de betaling berustte, geen rol spelen bij de beantwoording van de vraag hoe deze algemene regeling eruit dient te zien. Ik zou om deze reden de bescherming van de belangen van de betrokkene voorop willen stellen. Dit leidt ertoe dat wederom op het bestuursorgaan de verplichting rust een correct besluit te nemen in die gevallen, waarin de betrokkene aan zijn inlichtingenplicht heeft voldaan. Heeft het bestuursorgaan deze verplichting geschonden, dan kan de toekenningsbeslissing niet worden ingetrokken, tenzij de betrokkene wist of behoorde te weten dat ten onrechte is toegekend. Ook kan het toekenningsbesluit worden ingetrokken en het te veel betaalde dus in beginsel worden teruggevorderd als de betrokkene onjuiste of onvolledige inlichtingen heeft verstrekt, dan wel zijn inlichtingenplicht heeft geschonden. De intrekkings- en terugvorderingsbevoegdheid dient te worden beperkt tot vijf jaar als er opzettelijk onjuiste inlichtingen zijn verstrekt, opzettelijk gegevens zijn verzwegen of bewust is geprofiteerd van een administratieve vergissing. In de andere gevallen dienen de genoemde bevoegdheden te worden beperkt tot twee jaar. Deze regeling dient niet alleen van toepassing te zijn indien conform een (achteraf onjuist gebleken) toekenningsbesluit is betaald, maar ook als meer is betaald dan waarop krachtens het oorspronkelijke toekenningsbesluit recht bestaat.

Vindt de terugvordering niet plaats in het kader van een publiekrechtelijke rechtsbetrekking, wordt bijvoorbeeld betaald aan een willekeurige derde, dan ligt

19. Zie 10.3. Als gezegd zal ik de achtergrond van dit onderscheid en het antwoord op de vraag wanneer sprake is van een dergelijke rechtsbetrekking uitwerken in 11.3. 
het voor de hand een ruime terugvorderingsbevoegdheid te creëren. In beginsel dient te kunnen worden teruggevorderd, tenzij dit in strijd is met (een of meer) algemene beginselen van behoorlijk bestuur. Het ligt in deze gevallen ook voor de hand om aansluiting te zoeken bij de regeling uit het BW waar het de terugvorderingstermijnen betreft. Toch ben ik van mening dat dit niet zonder meer moet gebeuren. Mede gelet op de maatschappelijke positie van de overheid, zullen deze termijnen namelijk snel te lang zijn. Zo zie ik niet in waarom een verjaringstermijn zou moeten gelden van vijf jaar nadat de overheid bekend is geworden met het feit dat en aan wie onverschuldigd is betaald. Ik denk dat van de overheid enige voortvarendheid mag worden gevergd, zodat een dergelijke termijn snel in strijd zal komen met het zorgvuldigheidsbeginsel. De lange verjaringstermijn van twintig jaar lijkt mij ook te lang. Naar mijn mening moet een overheidsorgaan binnen een kortere termijn erachter kunnen komen dat onverschuldigd is betaald. Hierbij speelt mee dat niet snel sprake zal zijn van fraude, veelal zal het gaan om vergissingen aan de kant van de overheid. In die gevallen lijkt een termijn van tien jaar lang genoeg.

\subsection{Bepaling van de aanvang van de termijnen en het rechtskarakter ervan}

De rechtszekerheid brengt mee dat als mag worden teruggevorderd, dit niet onbeperkt mag gebeuren. Ik heb dit in de vorige paragraaf als volgt uitgewerkt: in bepaalde gevallen kan een toekenningsbesluit slechts gedurende twee jaar worden ingetrokken en kan ook slechts gedurende deze termijn worden teruggevorderd, in andere gevallen is dit mogelijk gedurende vijf jaar. In een aantal uitzonderingssituaties is het verantwoord een nog langere termijn te hanteren, bijvoorbeeld als het subsidies aan commerciële rechtspersonen betreft en er sprake is van opzet aan de kant van betrokkene. De vraag is, hoe deze termijnen worden bepaald en wat het rechtskarakter ervan is.

Wat de bepaling van de termijnen betreft, zou ik het criterium willen aanhouden dat de socialezekerheidsrechter in het verleden hanteerde bij de terugvorderingstermijn. Volgens de Centrale Raad van Beroep was voor de bepaling van de termijn beslissend, het moment van de eerste terugvorderingshandeling. Deze moest de vorm hebben van een ondubbelzinnige schriftelijke mededeling dat tot terugvordering zal worden overgegaan. ${ }^{20}$ De enkele intrekking van de toekenningsbeslissing was hiervoor volgens de Raad niet voldoende. Mijns inziens had dit te maken met het feit dat slechts de terugvorderingsbevoegdheid aan een termijn was gebonden en de intrekkingsbevoegdheid niet. Nu ook de intrekkingsbevoegdheid in de tijd moet worden beperkt, zou ik voor de bepaling van de aanvang van de termijn voor de intrekking het moment van de eerste intrekkingshandeling willen hanteren, dit wil zeggen het moment van de eerste ondubbel-

20. CRvB 12 juli 1985, RSV 1987, 96, CRvB 14 mei 1987, RSV 1988, 35, CRvB 20 februari 1990, RSV 1990, 248 en CRvBi 23 december 1993, RSV 1994, 196. Zie hierover 6.4.4.4. 
zinnige schriftelijke mededeling dat tot intrekking zal worden overgegaan, en voor het bepalen van de aanvang van de termijn voor de terugvordering het moment van de eerste terugvorderingshandeling, het moment van de eerste ondubbelzinnige schriftelijke mededeling dat tot terugvordering zal worden overgegaan. Deze momenten kunnen uiteraard samenvallen. Mij lijkt bijvoorbeeld voor het bepalen van de termijn voor de terugvordering voldoende, dat bij de eerste, ondubbelzinnige intrekkingshandeling uitdrukkelijk wordt medegedeeld dat indien blijkt dat te veel is betalald, dit zal worden tenuggevorderd.

Ingetrokken kunnen dan worden de toekenningsbesluiten die tot maximaal de in de wet genoemde tijd, in mijn visie dus veelal twee dan wel viĵ̣f jaar, vóór de eerste intrekkingshandeling in werking zijn getreden, dus zijn bekend gemaakt aan de betrokkene. Teruggevorderd kunnen worden de bedragen die gedurende de in de wet genoemde termijn vóór de eerste terugvorderingshandeling betaalbaar zijn gesteld. Uiteraard dienen deze bedragen wel onverschuldigd te zijn betaald.

Alle genoennde termijnen dienen vervaltermijnen te zijn. De reden hiervoor is dat deze termijnen als een harde grens moeten gelden. Na ommekomst ervan dient het recht van het bestuursorgaan om de toekenningsbeslissing in te trekken, dit is dus de intrekkingsbevoegdheid, te vervallen. Hetzelfde geldt voor het recht om het te veel betaalde terug te vorderen. Deze termijnen dienen, mede vanuit een oogpunt van adequate rechtsbescherming, ambtshalve te worden toegepast door de rechter. Het karakter van de termijnen als vervaltermijnen dient uit de wettelijke bepalingen te blijken. In de sociale zekerheid waren de terugvorderingstermijnen voor de inwerkingtreding van de WBM ook vervaltermijnen. ${ }^{21}$

Op zich kan men zich afvragen of het noodzakelijk is ook de terugvorderingsbevoegdheid aan een (verval)termijn te binden. Als de toekenningsbeslissing niet meer kan worden ingetrokken, blijft dit toekenningsbesluit immers de rechtsgrond vormen voor de betaling, zodat niet onverschuldigd is betaald en dus niet kan worden teruggevorderd. Deze redenering loopt echter spaak als het toekenningsbesluit niet hoeft te worden ingetrokken, omdat het niet de rechtsgrond vormde voor de betaling, althans voor het te veel betaalde. Dit is het geval als niet conform het toekenningsbesluit wordt betaald, maar meer wordt betaald dan waarop betrokkene recht had op grond van dat besluit. Daarnaast is het ook mogelijk dat tussen het moment van de eerste, ondubbelzinnige intrekkingshandeling en de eerste, ondubbelzinnige terugvorderingshandeling enige tijd is verstreken. In dat geval beginnen de termijnen, die bepalend zijn voor de intrekkingsbevoegdheid van het toekenningsbesluit en de termijnen, die de terugvorderingsbevoegdheid bepalen, op een ander tijdstip te lopen.

Voor de inwerkingtreding van de WBM paste de Centrale Raad van Beroep als socialezekerheidsrechter naast de terugvorderingstermijnen nog een andere, door

21. Er is echter betoogd dat deze vervaltermijnen zwakke werking hadden, zodat na het verstrijken van de termijn een natuurlijke verbintenis ontstond, zie De Boer (1981), blz. 253. Zie verder hierover 6.4.4.4 en Bollen (1996). 
hem in zijn jurisprudentie ontwikkelde termijn toe: de zogenaande zesmaandentermijn. Zoais ik heb beschreven in 6.4.4.4 kwam deze jurisprudentie erop neer, dat van een bestuursorgaan mocht worden verwacht dat het adequaat reageerde op tekenen dat ten onrechte was uitbetaald. Het diende de nakoming van de verplichtingen door de betrokkene effectief te controleren en alert te reageren op gebleken of vermoede onregelmatigheden. Daarnaast diende het de op een vragenformulier of inkomstenbriefje ingevulde gegevens correct te verwerken. Gebeurde dit niet, dan kon terugvordering in strijd zijn met het zorgvuldigheidsbeginsel. De Raad hanteerde daarbij het criterium, dat in het algemeen van het bestuursorgaan mocht worden verwacht, dat het reageerde binnen een termijn van zes maanden na binnenkomst van het eerste signaal, dat ten onrechte was betaald. Een tijdvak van zes maanden bood het bestuursorgaan redelijkerwijs voldoende gelegenheid om de gegevens te verwerken en maatregelen te treffen om verdere toename van het ten onrechte betaalde te voorkomen. Miste het bestuursorgaan een dergelijk signaal, dan diende dit voor zijn rekening te blijven. Dit kwam erop neer dat terugvordering van betalingen, gedaan na verloop van zes maanden na binnenkomst van zodanig signaal, in beginsel in strijd was met het zorgvuldigheidsbeginsel, tenzij er sprake was van opzet aan de zijde van de betrokkene. Deze zesmaandenjurisprudentie is inmiddels overgenomen door de Centrale Raad van Beroep als ambtenarenrechter, ${ }^{22}$ de Centrale Raad als socialezekerheidsrechter is echter na de inwerkingtreding van de WBM op deze jurisprudentie teruggekomen. ${ }^{23}$

Naar mijn mening moet de zesmaandentermijn worden overgenomen. Van het bestuur mag voortvarendheid worden verwacht. Dit zou er mijns inziens toe moeten leiden dat toekenningsbesluiten, die de grondslag vormen voor betalingen, die zijn gedaan zes maanden nadat een eerste signal is binnengekomen dat er iets mis is, in beginsel niet kunnen worden ingetrokken. Hetzelfde geldt voor terugvordering. In uitzonderingsgevallen moet het bestuur wel de mogelijkheid hebben meer tijd te nemen, bijvoorbeeld wanneer het een bijzonder ingewikkelde zaak betreft. Ook zou ik een uitzondering willen aannemen wanneer sprake is van fraude, als opzettelijk onjuiste inlichtingen zijn verschaft of opzettelijk gegevens zijn verzwegen. Als het onderzoek hiernaar meer tijd vergt dan zes maanden, moet dit er niet toe leiden dat de intrekkings- en terugvorderingsbevoegdheid hierdoor deels vervallen. Wel zal in dat geval uiteraard het zorgvuldigheidsbeginsel een rol blijven spelen, zodat onnodige vertragingen wel leiden tot het vervallen van de intrekkingsen terugvorderingsbevoegdheid.

22. Zie onder meer CRvB 24 juni 1999, AB 1999, 406, m.nt. HH en CRvB 3 augustus 2000, AB 2000, 413, m.nt. HH, zie 7.2.4.2.

23. CRvB 25 september 2001, USZ 2001, 299, m.nt. Red. Als reden gaf de CRvB dat de zesmaandenjurisprudentie zich had ontwikkeld in het kader van de toetsing van de wijze waarop bestuursorganen van de discretionaire bevoegdheid tot terugvordering gebruik maakten. Nu na de inwerkingtreding van de WBM geen sprake meer is van een discretionaire bevoegdheid (zie 6.4.5), is de grondslag voor de toepasselijkheid van deze jurisprudentie komen te vervallen, aldus de CRvB. Zie hierover 6.5.2. 


\subsection{Invordering}

De laatste stap in het terugvorderingstraject is de invordering. Om tot invordering over te kunnen gaan, moet een invorderingsbesluit worden genomen. Ook de bevoegdheid tot het nemen van dat besluit dient te berusten op een wettelijke grondslag. De reden hiervoor is dat de invordering voor de betrokkene de facto misschien wel het meest ingrijpend is; dit is immers het moment waarop daadwerkelijk moet worden betaald. Om sociale of financiële redenen kan (een bepaalde wijze van) invordering (te) bezwaarlijk zijn. Wat bij invordering wel en niet mag, dient naar mijn mening dan ook wettelijk te worden geregeld en gereguleerd.

Anders dan bij de intrekkings- en terugvorderingsbevoegdheid kan hier wel worden volstaan met een algemene regeling; de aard en het doel van de wettelijke regeling waarop de oorspronkelijke toekenningsbeslissing berust, zal minder van belang zijn bij de vraag, hoe de invorderingsbevoegdheid moet worden gereguleerd, dan bij de genoemde bevoegdheden. Toch kan en zal op bepaalde specifieke terreinen een afwijking van de algemene regeling nodig zijn. Ik denk hierbij aan bijvoorbeeld de sociale zekerheid, waar op dit moment reeds een uitgebreide uniforme invorderingsregeling bestaat. ${ }^{24}$

In het invorderingsbesluit moet het bestuursorgaan duidelijk maken hoe het terug te vorderen bedrag zal worden ingevorderd. Het uitgangspunt moet naar mijn mening zijn dat het terugvorderingsbesluit zoveel mogelijk tenuitvoer wordt gelegd, maar dat tevens rekening wordt gehouden met de sociale en financiële omstandigheden van de betrokkene. Dit zal bij sommige regelingen eerder spelen dan bij andere. Dit kan ertoe leiden dat in sommige gevallen van (verdere) invordering moet worden afgezien, hetgeen in de bijzondere wetten moet worden geregeld. In bepaalde gevallen is dit ook al gebeurd. Zo heeft bijvoorbeeld de Wet terugvordering en verhaal in verband met herziening van het debiteurenbeleid in de meeste socialezekerheidswetten de mogelijkheid geopend om in bepaalde in de wet omschreven gevallen van invordering af te zien. ${ }^{25}$ Daarnaast moet de betrokkene voldoende geld overhouden om in zijn levensonderhoud te voorzien, indien deze betrokkene een natuurlijk persoon is. De beslagvrije voet van artikel $475 \mathrm{~d} R v$ moet worden gehanteerd. Ten slotte moet het bestuursorgaan af kunnen zien van invordering wanneer daartoe dringende redenen zijn. In grote lijnen komt dit overeen met de regeling zoals die momenteel geldt in het socialezekerheidsrecht. ${ }^{26}$

Eind 1999 heeft de Commissie wetgeving algemene regels van bestuurstecht (de Commissie-Scheltema) een voorontwerp van de vierde tranche van de Awb gepresenteerd. ${ }^{27}$ In dit voorontwerp zijn onder meer bepalingen opgenomen

24. Deze uniforme regeling is ingevoerd in de socialezekerheidswetten door de WBIM, zie 6.4.5.4.

25. Zie 6.4.5.3.

26. Zie 6.4.5.4.

27. Voorontwerp Commissie-Scheltema Awb IV (1999). 
betreffende bestuursrechtelijke geldschulden. Het is de bedoeling dat in de Awb een nieuwe titel 4.4 wordt opgenomen, waarin deze geldschulden een regeling vinden. Het betreft een algemene regeling over betaling en invordering van geldschulden door en aan de overheid. ${ }^{28}$ Van belang voor het onderzoek is uiteraard welke gevolgen deze regeling heeft voor de invordering van geldschulden door de overheid. Ik zal een aantal punten uit dit voorontwerp kort bespreken en daarbij tevens bekijken in hoeverre er voor die invordering als zodanig of voor de invordering op specifieke terreinen, bijvoorbeeld de sociale zekerheid, een afwijkende regeling moet komen en in hoeverre de op deze terreinen reeds bestaande, afwijkende regelingen moeten worden gehandhaafd. Vooropgesteld kan worden dat de door de Commissie voorgestelde regeling op hoofdlijnen voldoet.

In artikel 4.4.1.1 lid 1 wordt de reikwijdte van de regeling beperkt tot betalingsverplichtingen, die hun oorsprong vinden in het geschreven bestuursrecht. ${ }^{29}$ Dit betekent dat de regeling niet van toepassing is op betalingsverplichtingen die voortvloeien uit een zuiver schadebesluit of een terugvorderingsbesluit, waarvoor geen uitdrukkelijke wettelijke grondslag bestaat, althans deze verplichtingen worden 'voorshands niet door het voorstel (...) bestreken'. ${ }^{30}$ Waarom deze beperking is aangebracht, is mij niet geheel duidelijk. Met betrekking tot de zuivere schadebesluiten geeft de toelichting slechts aan dat in het kader van de vijfde tranche een regeling met betrekking tot het bestuursrechtelijk schadevergoedingsrecht op het programma staat, waarin zal worden bekeken in hoeverre de nu voorgestelde regeling van toepassing dient te zijn op de afhandeling van zuivere schadebesluiten. ${ }^{31}$ De bevoegdheid tot terugvordering is volgens de toelichting 'als regel' in de bijzondere wet opgenomen ${ }^{32}$ Een algemene terugvorderingsbevoegdheid bestaat echter bijvoorbeeld niet voor ambtenarensalarissen. Tenzij die bevoegdheid in een lagere wettelijke regeling is opgenomen, zal de regeling zoals nu voorgesteld niet van toepassing zijn. Ik zie echter geen reden dit soort betalingsverplichtingen uit te sluiten; het gaat immers om een bestuursrechtelijke geldvordering. ${ }^{33}$

De regeling heeft dus betrekking op (uit het geschreven bestuursrecht voortvloeiende) betalingsverplichtingen. Dit betekent dat vast moet staan dat er een betalingsverplichting is. Bij terugvordering moet dus vaststaan dat onverschuldigd

28. Vgl. Voorontwerp Commissie-Scheltema Awb IV (1999), blz. 46. Afdeling 4.4.4 Aanmaning en invordering bij dwangbevel, is beperkt tot invordering door de overheid.

29. Dit artikel luidt: 'Deze titel is van, toepassing op geldschulden die voortvloeien uit een, wettelijk voorschrift dat een verplichting tot betaling uitsluitend aan of door een bestuursorgaan regelt'.

30. Voorontwert Commissie-Scheltema Awb IV (1999), blz. 52.

31. Voorontwerp Commissie-Scheltema Awb IV (1999), blz. 52.

32. Dit geldt volgens de toelichting voor bijvoorbeeld betalingen in de sfeer van de sociale zekerheid en (na de wijziging van artikel 4:57 Awb zoals voorgesteld in het voorontwerp, zie 8.2.6) voor subsidies, Voorontwerp Commissie-Scheltema Awb IV (1999), blz. 52.

33. Uiteraard is het de vraag of een dergelijke betalingsverplichting kan ontstaan zonder wettelijke grondslag. Bij terugvordering zou dit mijns inziens niet het geval moeten zijn, zie 9.3 en 10.2 . 
is betaald - hiertoe moet in voorkomend geval het toekenningsbesluit worden ingetrokken - en dat het onverschuldigd betaalde zal worden teruggevorderd; er moet een terugvorderingsbesluit zijn genomen. Artikel 4.4.1.2 lid 1 bepaalt dat de verplichting tot betaling wordt vastgesteld bij beschikking; dit is het invorderingsbesluit. ${ }^{34}$

De hoofdlijn van de voorgestelde regeling is de volgende. Betaling dient in beginsel te geschieden binnen zes weken na bekendmaking van de beschikking (artikel 4.4.1.3 lid 1). Betaling door middel van verrekening is uitgesloten, tenzij bij wettelijk voorschrift anders is bepaald (artikel 4.4.1.9). ${ }^{35}$ Als de schuldenaar niet binnen de voorgeschreven termijn betaalt, is hij in verzuim (artikel 4.4.2.1), hetgeen onder meer de verschuldigdheid van wettelijke rente tot gevolg heeft (artikel 4.4.2.2 lid 1). Tevens heeft het verzuim tot gevolg dat het bestuursorgaan de schuldenaar moet aanmanen tot betaling; artikel 4.4.4.2 lid 1 bepaalt dat 'het bestuursorgaan (...) de schuldenaar die in verzuim is schriftelijk aan(maant) tot betaling binnen twee weken, gerekend vanaf de dag na die waarop de aanmaning is toegezonden'. De aanmaning moet verder vermelden 'dat bij niet tijdige betaling deze kan worden afgedwongen door op kosten van de schuldenaar uit te voeren invorderingsmaatregelen' (artikel 4.4.4.2 lid 3). Nadat de in de aanmaning genoemde termijn is verstreken zonder dat (volledig) is betaald, kan een dwangbevel worden uitgevaardigd, indien de bevoegdheid tot het uitvaardigen van een dergelijk bevel bij wet is toegekend (artikel 4.4.4.6 $\mathrm{j}^{\circ}$ artikel 4.4.4.4). Dit dwangbevel wordt omschreven als 'een schriftelijk bevel van een bestuursorgaan dat ertoe strekt de betaling van een geldsom als bedoeld in artikel 4.4.1.1 af te dwingen' (artikel 4.4.4.1). Het bevel levert een executoriale titel op, die met toepassing van de voorschriften van het Wetboek van Burgerlijke Rechtsvordering kan worden tenuitvoergelegd (artikel 4.4.4.5). De regeling bevat ook bepalingen met betrekking tot verjaring. Na het verstrijken van de betalingstermijn van artikel 4.4.1.3 (of de in de bijzondere regeling gegeven termijn) gaat de verjaringstermijn lopen; na verloop van vijf jaren is de rechtsvordering tot betaling verjaard (artikel 4.4.3.1 lid 1). Het voltooien van de verjaring heeft onder meer tot gevolg dat de bevoegdheden van het bestuursorgaan tot aanmaning en verrekening en tot uitvaardiging en tenuitvoerlegging van een dwangbevel vervallen (artikel 4.4.3.1 lid 2).

De verplichting tot betaling wordt dus (in beginsel) bij beschikking vastgesteld. Op dit besluit zijn de algemene regels uit de Awb van toepassing; er staat dus bezwaar en beroep open. Het instellen van bezwaar of beroep heeft geen schorsende werking (artikel 6:16 Awb): de betalingsverplichting blijft dus

34. Op grond van artikel 4.4.1.4 lid I kan in de bijzondere wet hierop een vitzondering worden gemaakt: 'Bij wettelijk voorschrift. kan worden bepaald dat een geldsom moet worden betaald zonder dat dit bij beschikking is vastgesteld".

35. Niet kan worden teruggevallen op de regeling uit het EW, zoals geschiedde in HR 28 mei 1993, NJ 1994, 435, m.nt. HJ̈S (Nieuwkoop-Staat). Zie hierover 5.3.4. 
bestaan. ${ }^{36}$ Op zich is dit te billijken, nu artikel 4.4.2.6 lid 1 bepaalt dat indien te beschikking in bezwaar of beroep wordt gewijzigd of vernietigd, het bestuurscrgaan over de termijn tussen de betaling en de terugbetaling wettelijke rente verschuldigd is over het te veel betaalde bedrag. Een probleem is dat artilel 4.4.2.2 lid 2 bepaalt dat wettelijke rente niet verschuldigd is indien deze minder dan 25 euro bedraagt. Dit zal vaak het geval zijn. Het lijkt mij niet te billijken dat wanneer de betrokkene verplicht wordt te betalen, terwijl het invorderingsbesluit nog geen formele rechtskracht heeft, de schade die hij door de betaling lijdt indien het besluit later geen stand blijkt te kunnen houden, voor zijn rekening blijft. De toepasselijkheid van artikel 4.4.2.2 lid 2 zou dan ook moeten worden uitgesloten indien artikel 4.4.2.6 lid 1 van toepassing is. Voorts is het zo, dat het bestuursagaan onder omstandigheden al een dwangbevel kan uitvaardigen voordat het invorderingsbesluit formele rechtskracht heeft. De kosten van de uitvaardiging en betekening van dit dwangbevel zijn voor rekening van degene tegen wie het is uitgevaardigd, aldus 4.4.4.9 lid 1. Deze zal dus die kosten ook moeten betalen a's het invorderingsbesluit vervolgens wordt vernietigd. Dit lijkt mij niet redelijk. Uiteraard kan de betrokkene betalen of uitstel dan wel schorsing vragen, maar het is mijns inziens beter indien ofwel een bepaling wordt opgenomen dat bij vernietging van het invorderingsbesluit de genoemde kosten voor rekening van het bestuursorgaan blijven, ofwel wordt bepaald dat geen dwangbevel kan worden uitgevaardigd zolang het invorderingsbesluit geen formele rechtskracht heeft. Blijft in het laatste geval het invorderingsbesluit in stand, dan betekent dit dat de betrokkene over de gehele periode waarin hij niet aan zijn betalingsverplichting heeft voldaan, in verzuim is geweest en dus wettelijke rente verschuldigd is.

Zoals gezegd staat tegen het invorderingsbesluit bezwaar en beroep open. Dit rechtsmiddel staat niet open tegen de aanmaning, het dwangbevel en de executie. Dat tegen de executie geen bezwaar en beroep openstaat, is in het huidige stelsel logisch; er is immers geen sprake van een besluit in de zin van artikel 1:3 Awb. Het is de burgerlijke rechter die hier rechtsbescherming moet bieden, waarbij deze de regels van het Wetboek van Burgerlijke Rechtsvordering moet toepassen. Als het dwangbevel de executoriale titel vormt, dan volgt dit rechtstreeks uit artikel 4.4.4.5; als de bevoegdheid tot het uitvaardigen van een dwangbevel niet bestaat, dan moet het bestuursorgatan sowieso naar de burgerlijke rechter om een executoriale titel te verkrijgen, waaruit voortvloeit dat die regels van toepassing zijn. De aanmaning en het dwangbevel zijn daarentegen wel besluiten in de zin van artikel 1:3 Awb, maar zij worden uitgesloten van bezwaar en beroep: aan artikel 8:4 Awb, dat een aantal besluiten uitsluit van beroep (en dus ook van bezwaar), wordt een onderdeel toegevoegd waarin de genoemde besluiten worden opgenomen. De toelichting geeft als reden om het dwangbevel van beroep uit te sluiten, dat een dergelijke beroepsmogelijkheid overbodig is omdlat reeds eerder bezwaar en beroep heeft opengestaan tegen het invorderingsbesluit, terwijl voorts ook de

36. Wel kan het bestuursorgaan uitstel van betaling verlenen (artikel 4.4.1.10 lid 1) of kan de betrokkene bij voorlopige voorziening schorsing van het besluit vragen. 
mogelijkheid bestaat een executiegeschil aanhangig te maken bij de burgerlijke rechter op grond van artikel $438 \mathbf{R v} .^{37} \mathrm{Er}$ is gekozen voor de burgerlijke rechter in verband met diens expertise op dit gebied. ${ }^{38}$

Ik zou bij deze regeling een aantal opmerkingen willen maken, naast de reeds genoemde punten. De eerste betreft de regeling van de verjaring. Zoals gezegd bepaalt artikel 4.4.3.1 lid 1 dat de rechtsvordering tot betaling van een geldsom vijf jaren nadat de voorgeschreven betalingstermijn is verstreken, verjaart. De reden voor het opnemen van deze bepaling is dat in de praktijk onzekerheid bestaat 'omtrent de reikwijdte van de schakelbepaling van artikel 3:326 van Boek $3 \mathrm{BW}$ en in het bijzonder omtrent de toepasselijkheid van de bepalingen in titel 11 van Boek 3 BW omtrent de bevrijdende verjaring in het bestuursrecht'. ${ }^{39}$ De in artikel 4.4.3.1 opgenomen verjaringstermijn is uitdrukkelijk slechts van toepassing op de invordering, en dus niet op de vraag gedurende welke termijn een terugvorderingsbesluit kan worden genomen. ${ }^{40}$ Dit betekent dus dat met betrekking tot de verjaring van de terugvorderingsbevoegdheid (en ook de intrekkingsbevoegdheid) een regeling noodzakelijk blijft, voor zover de bijzondere wet hierover geen regeling bevat. ${ }^{41}$ Op zich zelf kan worden ingestemd met de termijn van vijf jaren voor invordering, alleen is het de vraag of dit een verjaringstermijn moet zijn. Teunissen vindt van niet; er zou sprake moeten zijn van een vervaltermijn, dit gelet op het feit dat een dergelijke termijn sterke werking heeft. ${ }^{42} \mathrm{Hij}$ beroept zich hiertoe op het gelijkheidsbeginsel: op een verjaringstermijn moet een beroep worden gedaan en dit leidt ertoe dat er verschil bestaat tussen burgers die hiervan wel en burgers die hiervan niet op de hoogte zijn. ${ }^{43} \mathrm{Ik}$ zou hieraan nog een argument willen toevoegen. Door het hanteren van een vervaltermijn zou tevens misbruik door het bestuur van eventuele onwetendheid bij de betrokkene kunnen worden tegengaan. Gebleken is dat het voorkomt dat bestuursorganen, ondanks het feit dat de verjaringstermijn is verstreken, toch pressie

37. Vorrontwerp Commissie-Scheltema Awb IV (1999), biz. 88. Op diezelfde plats wordt gezegd dat de aanmaning van beroep wordt uitgezonderd in verband met het forfaitaire karakter van de in rekening te brengen vergoeding.

38. Voorontwerp Commissie-Scheltema Awb IV (1999), blz. 58

39. Voorontwerp Commissie-Scheltemal Awb IV (1999), blz. 77.

40. $\mathrm{V}$ gl. de toelichting: 'Voor de goede orde wordt opgemerkt dat het in deze afdeling niet gaat om de vraag binnen welke termijn een bestuursorgaan nog rechtsgeldig een verplichting tot betaling kan vaststellen (...). Het gaat hier om de vraag hoe lang, degene die verzuimd heeft tijdig aan een verplichting tot betaling van een bestuursrechtelijke geldschuld te voldoen, nog in rechte tot nakoming kan worden gedwongen', voorontwerp Commissie-Sichelterna Awb IV (1999), blz. 77.

41. Mijn in Bollen (1997) en in 6.5 .2 geuite kritiek op het van toepassing laten zijn van de verjaringstermijn uit het $\mathrm{BW}$ op de terugvorderingsbevoegdheid, zoals dat nu het geval is in het socialezekerheidsrecht, blijft dus overeind.

42. Zie over het verschil tussen een verjaringstermijn en een vervaltermijn Bollen (1996), blz. 265 en Asser-Hartkamp I (2000), blz. 615-6122.

43. Teunissen in: De Vierde tranche Awb (2000), blz. 64 . 
uitoefenen op de betrokkene om te betalen. ${ }^{44}$ Wordt vervolgens onder druk betaald, dan gebeurt dit niet onverschuldigd; de rechtsvordering verjaart immers, het recht zelf niet. $\mathrm{Bij}$ een vervaltermijn is dit anders; daar vervalt na onmekomst van de termijn het recht. Wordt dus vervolgens toch betaald, dan gebeurt dit onverschuldigd. ${ }^{45}$

De tweede opmerking betreft het dwangbevel. Als de bevoegdheid tot het uilvaardigen van een dergelijk bevel in de bijzondere wet is gegeven, dan levert ait bevel een executoriale titel op. Op zich kan hiermee worden ingestemd, nu bij terugvordering in het aan het uitvaardigen van dit bevel voorafgaande traject voldoende rechtsbeschermingspunten zijn ingebouwd. Belangrijk is dat niet het terugvorderings- of het invorderingsbesluit een executoriale titel oplevert, zoals bijvoorbeeld in de sociale zekerheid wel het geval is ${ }^{46}$ Mijns inziens moeten de bepalingen in de verschillende socialezekerheidswetten, waarin staat dat het terugvorderingsbesluit een executoriale titel oplevert, dan ook worden vervangen door een bepaling, waarin het bestuursorgaan de bevoegdheid krijgt een dwangbvel uit te vaardigen.

Een volgend punt betreft de vraag welke rechter bevoegd dient te zijn inzale executiegeschillen. In het voorontwerp wordt gekozen voor de burgerlijke rechter, vanwege diens expertise op dit terrein. Naar mijn mening dient de bestuursrechter bevoegd te zijn wanneer dit geschil ontstaat binnen een publiekrechtelijke rechtsverhouding. Ik zal hierop uitgebreider ingaan in de twee volgende hoofdstukken.

Ten slotte blijkt uit de regeling niet of bij invordering in het kader van een terugvorderingsprocedure sprake is van een discretionaire bevoegdheid of van een verplichting. Mij lijkt dat in beginsel sprake moet zijn van een verplichting - het algemeen belang eist immers dat onverschuldigd betaalde gelden zoveel mogelijk worden teruggevorderd en dat teruggevorderde bedragen zoveel mogelijk worden ingevorderd -, maar dit dient in de bijzondere wetten te worden neergelegd. In die wetten moeten dan ook de uitzonderingen op die verplichting worden gegeven. Wat wel in de algemene regeling kan worden opgenomen, is de bepaling dat het bestuursorgaan om dringende redenen van invordering kan afzien. Een dergelijke bepaling hoeft dan niet meer in de afzonderlijke wetten te worden opgenomen.

\subsection{Conclusie}

In dit hoofdstuk heb ik bekeken aan welke vereisten een wettelijke regeling met betrekking tot tengvordering moet voldoen. Uitgangspunt hierbij is dat zowel de intrekkings- als de terugvorderingsbevoegdheid een uitdrukkelijke wettelijke: grondslag behoeft; een impliciete bevoegdheid volstaat niet, zie 9.3.

Naar mijn mening dienen zowel de toekenningsbevoegdheid als de intrek-

44. Zie de casus die de aanleiding vormde voor mijn artikel in Sociaal Recht, Bollen (1996).

45. Zie Bollen (1996).

46. Zie 6.4.5.4. 
kings- en de terugvorderingsbevoegdheid te worden neergelegd in een zo specifiek mogelijke regeling. Bij de beantwoording van de vraag wanneer een toekenningsbesluit kan worden ingetrokken en het onverschuldigd betaalde teruggevorderd, zal moeten worden gekeken naar het doel van de wettelijke regeling, de mate van (financiële) afhankelijkheid van de betrokkenen van die regeling en de zwaarte van het verwijt dat de betrokkene kan worden gemaakt.

Het uitgangspunt bij terugvordering dient te zijn dat als de betrokkene in het geheel niets te verwijten valt, het toekenningsbesluit niet kan worden ingetrokken en dus dat niet kan worden teruggevorderd. Dit is anders als betrokkene wel een verwijt kan worden gemaakt omdat hij wist of had behoren te weten dat het toekenningsbesluit onjuist was, omdat hij onjuiste inlichtingen heeft gegeven of omdat hij gegevens heeft verzwegen. De intrekkings- en de terugvorderingsbevoegdheid zijn echter niet onbegrensd, zij moeten worden beperkt in de tijd. Deze beperking is afhankelijk van de aard van de regeling op grond waarvan de aanspraak bestaat en van de zwaarte van het verwijt dat de betrokkene kan worden gemaakt. Dit kan ertoe leiden dat in verschillende situaties verschillende termijnen moeten gelden. De intrekkings- en terugvorderingstermijnen dienen vervaltermijnen te zijn. Voorts zal in de wettelijke regelingen een bepaling moeten worden opgenomen met betrekking tot terugvordering indien het bestuursorgaan meer heeft betaald dan waarop betrokkene aanspraak kan maken op grond van het juiste toekenningsbesluit. Als de betrokken regeling intrekking en terugvordering in een concrete situatie toestaat, dan moet het uitgangspunt zijn dat het bestuursorgaan in beginsel verplicht is terug te vorderen. Wel dient de mogelijkheid te bestaan af te zien van terugvordering, indien daarvoor dringende redenen zijn of als terugvordering in strijd is met de algemene beginselen van behoorlijk bestuur.

Nadat een terugvorderingsbesluit is genomen, moet nog een invorderingsbesluit worden genomen. Daarin zal moeten worden vermeld hoe de daadwerkelijke invordering zal verlopen. Ook het invorderingsbesluit dient op een wettelijke grondslag te berusten, maar hier kan wel worden volstaan met een algemene regeling; de aard van de regeling waarop de aanspraak berust, speelt een minder grote rol. Uiteraard kunnen wel in de specifieke regelingen afwijkende bepalingen worden opgenomen indien dit gewenst is. Uitgangspunt dient te zijn dat het terugvorderingsbesluit zoveel mogelijk wordt tenuitvoergelegd. Het voorontwerp van de vierde tranche van de Awb bevat een (algemene) regeling met betrekking tot invordering. Deze regeling voldoet op hoofdlijnen. 


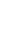




\section{OVERHEID, TERUGVORDERING EN PRIVAATRECHT}

\subsection{Inleiding}

In het vorige hoofdstuk, meer precies in 10.2, heb ik betoogd dat bij terugvordering zowel de intrekkingsbevoegdheid als de terugvorderingsbevoegdheid een uitdrukkelijke wettelijke grondslag moeten hebben. Dit vloeit voort uit (mijn invulling van) het legaliteitsbeginsel: iedere bestuursbevoegdheid waardoor bevoegdheden, rechten en plichten van burgers kunnen worden vastgesteld of gewijzigd, moet in beginsel berusten op een wettelijke grondslag. $\mathrm{Nu}$ de bevoegdheid publiekrechtelijk van aard moet zijn, dient ook de wettelijke grondslag publiekrechtelijk te zijn. Verder moet deze grondslag bij terugvordering een uitdrukkelijke zijn. ${ }^{1}$ Dit betekent dat bij terugvordering de volgende uitgangspunten gelden. Zowel de intrekkings- als de terugvorderingsbevoegdheid dienen te worden neergelegd in een zo specifiek mogelijke regeling. ${ }^{2}$ Voorts moeten deze bevoegdheden worden genormeerd, waarbij de specifieke normering afhankelijk is van de aard van de regeling. Als algemeen uitgangspunt dient te gelden dat het toekenningsbesluit niet kan worden ingetrokken en dus dat er niet kan worden teruggevorderd als de betrokkene geen enkel verwijt kan worden gemaakt. Kan betrokkene wel een verwijt worden gemaakt, dan kan in beginsel worden ingetrokken en teruggevorderd, maar deze bevoegdheden moeten in de tijd worden beperkt. ${ }^{3}$

In dit hoofdstuk zal ik bespreken wat dit betekent voor het gebruik van privaatrecht bij terugvordering. Mag de overheid bijvoorbeeld gebruik maken van de regeling betreffende onverschuldigde betaling zoals die is neergelegd in het BW, wanneer een publiekrechtelijke terugvorderingsbevoegdheid ontbreekt of de publiekrechtelijke regeling beperkingen bevat die niet worden gesteld in de privaatrechtelijke regeling? Het uitgangspunt van de Hoge Raad in het Windmillarrest is dat de overheid in beginsel beschikt over haar krachtens het privaatrecht toekomende bevoegdheden. ${ }^{4}$ Het is de vraag of dit uitgangspunt ook bij terugvordering kan worden volgehouden: beschikt de overheid in beginsel over de bevoegdheid om onverschuldigd gedane betalingen terug te vorderen op grond van de regeling betreffende onverschuldigde betaling uit bet BW? Mijn conclusie zal zijn dat dit niet het geval is.

In het inleidende hoofdstuk beb ik aangegeven dat het in het onderzoek

1. Zie 9.3 .

2. Zie 10.3 .

3. Zie 10.4 .

4. HR 26 januari 1990, NJ 1991, 393, m.nt. MS onđer 394, AB 1990, 408, m.nt. G.P. Kleijn. Zie hierover 5.2.5. 
tevens de bedoeling is om te bekijken of het mogelijk is om vanuit het terrein van de terugvordering en (de mogelijk- en onmogelijkheden van) het gebruik van privaatrecht daarbij, lijnen iets verder door te trekken naar de vraag naar het gebruik van privaatrecht door de overheid in het algemeen. Ook dit zal in dit hoofdstuk aan de orde komen. Hierbij zal ik dus ook meer in het algemeen het uitgangspunt van de Hoge Raad in het Windmill-arrest bespreken.

Dit leidt tot de volgende opbouw van dit hoofdstuk. In 11.2 en $11.3 \mathrm{zal}$ de vraag of de overheid gebruik mag maken van het privaatrecht bij terugvordering aan de orde komen. In $11.4 \mathrm{zal}$ ik bekijken of uit de bevindingen uit de genoemde paragrafen enige meer algemene conclusies kunnen worden getrokken met betrekking tot het gebruik van privaatrecht door de overheid. In deze paragraaf zal ik het uitgangspunt van de Hoge Raad in het Windmill-arrest verwerpen. Hiermee verwerp ik ook de doorkruisingsleer. Daar deze leer momenteel als heersende kan worden gezien, besteed ik (ondanks het feit dat ik deze leer verwerp) in $11.5 \mathrm{kort}$ aandacht aan de vraag of deze leer wel zo logisch is, wanneer men het 'Windmilluitgangspunt' wel zou aanvaarden.

\subsection{Het gebruik van privaatrecht bij terugvordering door de overheid}

Bij terugvordering moeten de intrekkings- en terugvorderingsbevoegdheid een uitdrukkelijke wettelijke grondslag hebben, terwijl ook de uitoefening van deze bevoegdheden in een publiekrechtelijke regeling moet worden gereguleerd. Wat betekent dit nu voor het gebruik van privaatrecht bij terugvordering? Ik beperk mij in eerste instantie tot de situatie waarin ofwel ten onrechte een aanspraak is ontstaan omdat het toekenningsbesluit onjuist was, ofwel meer is betaald dan waarop de betrokkene aanspraak had op grond van het juiste toekenningsbesluit. Mag de overheid in die gevallen naast of in plaats van de (aanwezige) publiekrechtelijke weg ook de privaatrechtelijke weg bewandelen? Mag zij gebruik maken van het privaatrecht, en meer in het bijzonder van de regeling betreffende de onverschuldigde betaling uit het $\mathrm{BW}$, als een publiekrechtelijke terugvorderingsregeling ontbreekt?

Bij de beantwoording van deze vragen dient dus een onderscheid te worden gemaakt tussen de gevallen waarin er een uitdrukkelijke publiekrechtelijke grondslag bestaat voor de intrekking van de toekenningsbeschikking en voor de terugvordering en de gevallen waarin dit niet zo is. In het eerste geval is er een (publiekrechtelijke) bevoegdheid voor de overheid, welke bevoegdheid dan ook veelal in de publiekrechtelijke regeling zal zijn afgebakend. Over een privaatrechtelijke bevoegdheid beschikt de overheid dan niet. Zij mag dus niet naast of in plaats van de 'publiekrechtelijke terugvorderingsweg' gebruik maken van de privaatrechtelijke weg, in casu de regeling van onverschuldigde betaling uit het $\mathrm{BW}$, ook niet wanneer de publiekrechtelijke regeling in het concrete geval de terugvorderingsmogelijkheid heeft afgesloten, bijvoorbeeld omdat een administratieve vergissing is gemaakt en de betrokkene dit niet wist, noch behoorde te weten of omdat de geldende terugvorderingstermijnen zijn verstreken. In die gevallen 
bestaat de publiekrechtelijke bevoegdheid in concreto niet. Zou nu een privaatrechtelijke bevoegdheid worden aangenomen, dan zou dit een onaanvaardbare uitholling betekenen van het legaliteitsbeginsel.

Dat in deze situatie geen gebruik kan worden gemaakt van het privaatrecht, is niet omstreden. Ook als men als uitgangspunt neemt dat de overheid in beginsel beschikt over privaatrechtelijke bevoegdheden, zoals de Hoge Raad doet, ${ }^{5}$ dan is het gebruik van de privaatrechtelijke weg in deze gevallen altijd een doorkruising van de publiekrechtelijke weg. Dit volgt reeds uit de inhoud en strekking van de (publiekrechtelijke) regeling, zoals die mede uit de parlementaire geschiedenis zullen blijken. ${ }^{6}$ De wetgever heeft immers duidelijk aangegeven in die gevallen geen terugvordering te willen toestaan.

Wel kan eventueel gebruik worden gemaakt van (een) regeling(en) in het BW als een publiekrechtelijke bevoegdheidsgrondslag aanwezig is voor de intrekking en de terugvordering, maar de publiekrechtelijke regeling op een of meer andere punten een leemte bevat. In dat geval kan die leemte mogelijk en onder bepaalde voorwaarden worden opgevuld met behulp van een regeling uit het BW. De regeling uit het BW vormt hierbij dus niet de bevoegdheidsgrondslag, maar het privaatrecht wordt invullend, als rechtsvindingsmethode, gebruikt. ${ }^{7}$ Dit is ook de kern van de invullende rechtsleer. ${ }^{8}$ Zoals gezegd gelden hierbij bepaalde voorwaarden. $\mathrm{Zo}$ is vereist dat de betreffende, als invulling te gebruiken bepalingen uit het $\mathrm{BW}$ uitdrukking geven aan, een uitwerking vormen van een algemene en dus niet alleen voor het privaatrecht, maar ook voor het publiekrecht geldende, rechtsregel. Deze bepalingen moeten in dat geval worden gezien als publiekrechtelijk; er moet dan ook waar nodig worden geabstraheerd van de typisch-privaatrechtelijke uitwerking ervan. Ik zie overigens in de praktijk weinig mogelijkheden voor het invullend gebruiken van het privaatrecht bij terugvordering. In de publiekrechtelijke regeling zal immers moeten worden neergelegd wanneer en gedurende welke periode de toekenningsbeschikking kan worden ingetrokken en vervolgens het onverschuldigd betaalde kan worden teruggevorderd. Mij lijkt dat niet snel een leemte zal ontstaan, die kan worden opgevuld met behulp van de regeling betreffende de onverschuldigde betaling uit het BW. Waar wel leemtes kunnen bestaan, is op het terrein van de betaling en van de effectuering van de terugvordering, de invordering dus. Deze leemtes zullen grotendeels worden opgevuld als het voorontwerp van de vierde tranche van de Awb wet wordt."

Een andere situatie is die, waarin de publiekrechtelijke regeling op grond waarvan het toekenningsbesluit is genomen, geen bepalingen met betrekking tot,

5. HR 26 januari 1990, NJ 1991, 393, m.nt. MS onder 394, AB 1990, 408, m.nt. G.P. Kleijn (Windmill). Zie hierover 5.2.5. Dit is overigens niet mijn opvatting, zie $11.3 \mathrm{en} 11.4$.

6. Zie 5.2.5.

7. Vgl. Tak (1993), blz. $185 \mathrm{en} \mathrm{Tak} \mathrm{(1997),} \mathrm{blz.} \mathrm{117.} \mathrm{Zie} \mathrm{hierover} \mathrm{5.3.2.}$

8. Zie 5.3.2.

9. Zie hierover met betrekking tot de invordering onder meer 5.3.4 en 10.6. De voorgestelde titel betreffende bestuursrechtelijke geldschulden bevat ook een aantal bepalingen met betrekking tot de betaling van deze geldschulden. 
en dus ook geen uitdrukkelijke grondslag voor de intrekking van de toekenningsbeslissing en/of de terugvordering bevat; in dat geval bestaat de (publiekrechtelijke) intrekkings- en/of terugvorderingsbevoegdheid niet. Tot voor kort werd dan door onder meer de Afdeling (bestuurs)rechtspraak aangenomen dat het besluit om terug te vorderen moest worden gezien als een rechtshandeling naar burgerlijk recht. ${ }^{10}$ Tegen deze jurisprudentie is fel geageerd, onder meer door Teunissen. ${ }^{.1}$

Ook ik ben van mening dat uit het legaliteitsbeginsel voortvloeit dat wanneer een publiekrechtelijke bevoegdheidsgrondslag voor de intrekking en de terugvordering ontbreekt, deze bevoegdheid in abstracto niet aanwezig is. Ik zou willen spreken van absolute onbevoegdheid. Het aannemen van een privaatrechtelijke bevoegdheid zou, evenals in de situatie waarin de bevoegdheid in concreto niet bestaat, waarin sprake is van wat relatieve onbevoegdheid kan worden genoemd, dit beginsel op onaanvaardbare wijze uithollen. Wat heeft het immers voor zin om een uitdrukkelijke wettelijke publiekrechtelijke grondslag te eisen voor een bevoegdheid, wanneer de conelusie luidt dat bij het ontbreken van een dergelijke grondslag (en dus bij het ontbreken van een publiekrechtelijke bevoegdheid) 'gewoon' sprake is van de uitoefening van een privalatrechtelijke bevoegdheid? De conclusie is dan ook dat de overheid bij terugvordering in deze situatie niet beschikt over een privaatrechtelijke bevoegdheid. $\mathrm{Nu}$ een publiekrechtelijke bevoegdheidsgrondslag ontbreekt, kan het privaatrecht uiteraard ook niet invullend worden gebruikt.

In het voorgaande ben ik als gezegd uitgegaan van de situatie dat ten onrechte of te veel is betaald, ofwel omdat het toekenningsbesluit onjuist is, ofwel omdat meer is betaald dan waarop de betrokkene aanspraak had op grond van het juiste toekenningsbesluit. In dat geval is er een bestaande relatie tussen het betalende bestuursorgaan en de ontvanger van de betaling. Er kan zich ook een situatie voordoen waarin er geen sprake is van een dergelijke relatie. Er is bijvoorbeeld door een vergissing ten onrechte betaald aan een willekeurige derde of er heeft in het verleden een (publiekrechtelijke) relatie bestaan tussen het bestuursorgaan en de ontvanger van de betaling, maar deze relatie is beëindigd.

In het eerste geval kan niet worden teruggevallen op een specifieke regeling met betrekking tot terugvordering. Als bijvoorbeeld de gemeentelijke uitkeringsinstantie door een vergissing de bijstandsuitkering aan de verkeerde persoon uitbetaalt door storting van het bedrag op diens bankrekening, terwijl die persoon geen bijstandsuitkering heeft en ook nooit een dergelijke uitkering heeft gehad, dan is er geen sprake van een betaling ten titel van bijstand; er is geen sprake van een

10. Zie 8.2.5.

11. Zie Teunissen (1996), blz. 233 en Teunissen (1997), blz. 97-98. Hij spreekt in dit verband vant de paradox van de legaliteit en van etikettenzwendel, zie hierover 9.3.3. 
bijstandsuitkering. ${ }^{12}$ De publiekrechtelijke terugvorderingsregeling, in dit geval zoals neergelegd in de Algemene bijstandswet, is niet van toepassing. Algemener kan worden gesteld dat indien door een vergissing aan een willekeurige derde wordt betaald, er geen (publiekrechtelijke) titel is voor de betaling, ${ }^{13}$ zodat ook niet kan worden teruggevallen op de in een specifieke (publiekrechtelijke) regeling neergelegde bepalingen met betrekking tot terugvordering. Dat het betaalde in de regel moet kunnen worden teruggevorderd, is duidelijk. Het is alleen de vraag hoe dit moet geschieden. De algemene opvatting is in dit geval ongetwijfeld dat de overheid moet kunnen terugvorderen door een beroep te doen op de regeling van onverschuldigde betaling zoals neergelegd in het BW. Enerzijds valt hier wel wat voor te zeggen, nu men kan betwisten dat het legaliteitsbeginsel in deze situatie van toepassing is. Dit beginsel is immers een publiekrechtelijk beginsel en het is de vraag of de terugvordering in dit geval moet worden beheerst door het publiekrecht. Anderzijds is het de vraag of het niet beter zou zijn om hiervoor een publiekrechtelijke regeling in het leven te roepen. Ik zal dit uitwerken in 11.3.

In het tweede geval heeft in het verleden een publiekrechtelijke relatie bestaan tussen het betalende bestuursorgaan en de ontvanger van de betaling, maar is deze relatie inmiddels beëindigd. In die situatie is het de vraag of de regeling op grond waarvan in het verleden de publiekrechtelijke relatie heeft bestaan tussen het betalende bestuursorgaan en de ontvanger van de betaling, van toepassing is. Dit zal afhankelijk zijn van de omstandigheden van het concrete geval. ${ }^{14}$ Zo zou ik een betaling die heeft plaatsgevonden direct nadat de relatie is beëindigd, de zogenaamde doorgeschoten betaling, willen zien als een betaling ten titel van de betrokken regeling. Als bijvoorbeeld iemand die een bijstandsuitkering ontving, werk heeft aanvaard waardoor het recht op de uitkering is vervallen, hetgeen hij heeft medegedeeld aan de uitkerende instantie, waama vervolgens door een vergissing of doordat sprake is van geautomatiseerde betalingen toch nog geld wordt overgemaakt op zijn bankrekening door de uitkerende instantie, dan is sprake van een betaling ten titel van bijstand, zodat de terugvorderingsbepalingen uit de Abw van toepassing zijn. ${ }^{15}$ Hetzelfde geldt als er weliswaar enige tijd is verstreken tussen het beëindigen van de aanspraak en de uitbetaling, maar de betrokkene ervan is uitgegaan dat mogelijk nog recht bestond op een uitbetaling, bijvoorbeeld indien hij (mogelijk zelfs pas na de uitbetaling) in de veronderstelling verkeerde dat het een verrekening of een achterstallige uitbetaling betrof, bijvoorbeeld van de vakantietoeslag.

In deze situaties is naar mijn mening sprake van een betaling ten titel van de

12. Het is overigens de vraag of dit soort situaties zich in de praktijk vask zullen voordoen, nu banken controleren of naam en rekeningnummer overeenstemmen. De situatie dat dus aan $A$ had moeten worden betaald, terwijl per ongeluk aan $B$ is betaald, zal zich in de praktijk hoogstwaarschijnlijk alleen maar voordoen indien A en $B$ dezelfde naam en woonplaats hebben.

13. Vgl. 6.5.5.1.

14. Zie 6.5.4 en 6.5.5, waar een aantal voorbeelden wordt gegeven uit de praktijk.

15. Anders (in een overweging ten overvloede) $\mathrm{Ktr}$. Utrecht 6 november 1984, JABW 1986, 3, zie 6.5.5.1. 
betrokken regeling, waarbij het legaliteitsbeginsel in acht moet worden genomen. Dit betekent dat de bevoegdheid tot terugvordering niet kan worden gebaseerd op de regeling van onverschuldigde betaling uit het $\mathrm{BW}$. Waar de grens ligt tussen een betaling ten titel van de betrokken regeling en een betaling waaraan geen publiekrechtelijke titel ten grondslag ligt, is niet precies aan te geven, dit is als gezegd sterk afharkelijk van de omstandigheden van het geval. Hierbij kan onder meer van belang zijn de vraag of de ontvanger van het geld voorafgaande aan de ontvangst een bericht heeft gekregen van de gemeente, of hij nog recht heeft op een nabetaling, of de betrokken regeling mogelijk voorziet in betalingen nadat het recht op uitkering is beëindigd, et cetera. ${ }^{16}$

De omstandigheden van het geval zullen ook doorslaggevend zijn bij de beantwoording van de vraag op grond van welke bepalingen kan worden teruggevorderd in de situatie waarin er weliswaar een (publiekrechtelijke) relatie bestaat tussen het bestuursorgaan en de betrokkene, maar deze relatie niet de grondslag kan zijn voor de uitbetaling. Zo heeft binnen een gemeente het college van burgemeester en wethouders vele verschillende bevoegdheden. Het is onder meer het bevoegde orgaan met betrekking tot de toekenning van bijstandsuitkeringen. ${ }^{17}$ Uitoefening van een van die bevoegdheden kan een publiekrechtelijke relatie in het leven roepen tussen een burger en het bestuursorgaan, in casu het college. Indien dit college bijvoorbeeld op grond van een gemeentelijke verordening bevoegd is een woningverbeteringssubsidie toe te kennen, bestaat tussen de gemeente en de burger die een dergelijke subsidie aanvraagt en toegekend krijgt een publiekrechtelijke relatie. Als diezelfde burger ten onrechte en door een vergissing een uitbetaling op zijn bankrekening gestort krijgt van de gemeentelijke instantie die bijstandsuitkeringen verstrekt, dan is er weliswaar een publiekrechtelijke relatie tussen de betrokkene en het bestuursorgaan, alleen kan dan worden betoogd dat de betaling niet uit die relatie voortvloeit. ${ }^{18}$ Betoogd kan worden dat er dan geen (publiekrechtelijke) titel is voor de betaling, zodat de situatie dezelfde is als wanneer er geen relatie bestaat tussen het uitbetalende bestuursorgaan en de betrokkene aan wie is uitbetaald.

Uit het voorgaande blijkt dat bij terugvordering in de meeste gevallen het legaliteitsbeginsel strikt moet worden gehanteerd: er dient een uitdrukkelijke publiekrechtelijke bevoegdheidsgrondslag te bestaan voor zowel de intrekking als de terugvordering. Ruimte voor het privaatrecht als bevoegdheidsgrondslag is er dan niet. In andere gevallen kunnen daar mogelijk vraagtekens bij worden gezet; het legaliteitsbeginsel is mogelijk niet van toepassing. De vraag rijst dan waarom in het ene geval dit beginsel wel strikt moet worden gehanteerd en in het andere

16. Zie bijvoorbeeld CRvB 15 mei 1980, RSV 1980, 261 en CRvB 13 september 1989, AB 1990, 147, m.nt. de L., RSV 1990, 237, m.nt. J.J.A. Kooijman. Zie 6.5.5.2. In beide gevallen ging het om doorbetaling van een uitkering na het overlijden van de betrokkene.

17. Zie artikel 67 Abw.

18. Vgl. Verheij (1999), blz. 43-44, noot 100. 
geval mogelijk niet. Naar mijn mening hangt dit samen met de aard van de rechtsbetrekking. Het legaliteitsbeginsel is een publiekrechtelijk beginsel, dat dan ook alleen van toepassing is wanneer sprake is van een publiekrechtelijke rechtsbetrekking. Binnen een dergelijke rechtsbetrekking moet er dus bij terugvordering een uitdrukkelijke publiekrechtelijke bevoegdheidsgrondslag zijn; als geen sprake is van een publiekrechtelijke rechtsbetrekking is dit mogelijk anders en kan mogelijk de regeling betreffende de onverschuldigde betaling uit het BW als bevoegdheidsgrondslag worden gehanteerd. Uiteraard is dan van belang om nader te bekijken wanneer bij terugvordering sprake is van een publiekrechtelijke rechtsbetrekking.

\subsection{De publiekrechtelijke rechtsbetrekking In het kader van de terugvorde- ring}

Het legaliteitsbeginsel speelt dus bij een terugvordering die plaatsvindt binnen een publiekrechtelijke rechtsbetrekking of een publiekrechtelijke rechtsverhouding (ik gebruik deze termen als synoniemen) een doorslaggevende rol; binnen cen dergelijke rechtsbetrekking moet er een uitdrukkelijke publiekrechtelijke bevoegdheidsgrondslag zijn voor zowel het intrekkingsbesluit als voor het terugvorderingsbesluit. Is deze er niet, dan mag niet worden ingetrokken en teruggevorderd. De overheid beschikt niet over een privaatrechtelijke bevoegdheid om terug te vorderen. In deze paragraaf zal ik uitwerken wanneer sprake is van een publiekrechtelijke rechtsverhouding. De criteria die ik hierbij aanleg, zullen meer algemene criteria zijn, die dus ook buiten het terrein van de terugvordering gelden. Hierbij moet wel worden bedacht dat het mogelijk is om de vraag wanneer sprake is van een publiekrechtelijke rechtsbetrekking verder uit te diepen dan met betrekking tot terugvordering noodzakelijk is en dus dan zal gebeuren in deze paragraaf. In de volgende paragraaf zal ik een aantal lijnen die ik in deze paragraaf uitzet in meer algemene zin iets verder doortrekken.

Het duidelijkste criterium zou zijn dat sprake is van een publiekrechtelijke rechtsbetrekking als bij die rechtsbetrekking de overheid of een overheidsorgaan is betrokken. Afbakeningsproblemen zouden dan niet bestaan. ${ }^{19} \mathrm{Nu}$ het huidige systeem, zowel waar het het materiële als het formele recht betreft, met de consequenties van deze stap niet uit de voeten zou kunnen, zouden daarmee tegelijkertijd zoveel nieuwe, andere problemen worden binnengehaald dat dit criterium (in ieder geval in de nabije toekomst) niet goed hanteerbaar is. Wel dient het feit dat een van de partijen overheid is, een sterke aanwijzing te zijn dat sprake is van een publiekrechtelijke rechtsverhouding.

Op het eerste gezicht zou een ander geschikt criterium zijn de vraag of sprake is van de behartiging van het algemeen belang. Ook dit lijkt mij niet hét criterium; de overheid kan immers niet anders dan het algemeen belang behartigen, zij

19. Althans als helder is wanneer sprake is van de overheid of van een overheidsorgaan. 
heeft geen andere belangen. ${ }^{20}$ Dit betekent dat feitelijk alles wat de overheid doet in het algemeen belang is (of moet worden geacht te zijn), zodat het criterium wederom zou zijn de vraag of de overheid bij de rechtsbetrekking is betrokken. $\mathrm{Zo}_{\mathrm{o}}$ is het bijvoorbeeld in het algemeen belang dat de overheid ten onrechte betaalde gelden zoveel mogelijk terugvordert, ook als an een willekeurige derde is betaald. Zoals gezegd kan men zich afvragen of de terugvordering in dat geval plaatsvindt binnen een publiekrechtelijke rechtsbetrekking.

Een eerste definitie zou als volgt kunnen luiden: er is sprake van een publiekrechtelijke rechtsverhouding, wanneer het een rechtsverhouding betreft die door het bestuursrecht wordt beheerst. Hiermee wordt het probleem echter slechts verlegd, want wanneer wordt een rechtsverhouding door het bestuursrecht beheerst? In de meeste gevallen zal wel duidelijk zijn of we te maken hebben met een publiekrechtelijke rechtsverhouding. Anderzijds is het zo dat, zolang niet wordt gekozen voor het criterium van de betrokkenheid van de overheid (hetgeen als gezegd momenteel een stap te ver is), welk criterium ook wordt gehanteerd om te bepalen of een rechtsverhouding publiekrechtelijk is, er altijd grens- en dus twijfelgevallen zullen (blijven) bestaan.

In zijn preadvies voor de VAR poogt ook Verheij een criterium te geven voor een publiekrechtelijke rechtsbetrekking. Daarbij kiest hij in eerste instantie voot een praktisch criterium: als 'een specifieke bestuursbevoegdheid of een uitdrukkelijk opgedragen, specifieke publieke taak wordt uitgevoerd', dan is sprake van een publiekrechtelijke rechtsbetrekking. ${ }^{21} \mathrm{Hij}$ geeft echter direct toe dat dit criterium het probleem niet oplost. Als de overheid immers zou besluiten geen gebruik te maken van zijn publiekrechtelijke bevoegdheden, maar in plaats daarvan privaatrechtelijke bevoegdheden uitoefent, zou geen sprake zijn van een publiekrechtelijke rechtsbetrekking. Verheij verruimt het criterium dan ook:

'er is een publiekrechtelijke rechtsbetrekking, niet alleen wanneer een specifieke bestuursbevoegdheid wordt uitgeoefend, maar zodra het bestuur een specifiek opgedragen taak uitvoert of optreedt ter behartiging van een belang, voor de behartiging waarvan specifieke bestuursbevoegdheden zijn toegekend. (...) Er is dus niet pas een publiekreehtelijke rechtsbetrekking als bestuursbevoegdheden worden uitgeoefend, maar reeds als zij kunnen worden uitgeoefend. Sterker nog, er is ook een publiekrechtelijke rechtsbetrekking als die bestuursbevoegdheden wel zijn toegekend, maar in concreto niet kunnen worden uitgeoefend, omdat niet aan de wettelijke voorwaarden is voldaan. In al deze gevallen wordt een publiekrechtelijke rechtsbetrekking gevestigd zodra tussen bestuur en burger een concrete, geĩndividualiseerde relatie ontstaat'. ${ }^{22}$

Ook ik zou in ieder geval een publiekrechtelijke rechtsbetrekking willen aannemen indien aan dit criterium wordt voldaan. Voor de terugvordering betekent dit dat er sprake is van een dergelijke rechtsbetrekking zodra het bestuur optreedt ter behartiging van een belang, voor de behartiging waarvan specifieke bestuursbe-

20. Vgl. Tak (1993), blz. 180-181, Tak (1998), blz. 8 en 5.3 .2$.

21. Verheij (1999), ble. 62.

22. Verheij (1999), blz. 63. 
voegdheden zijn toegekend. Dit is het geval als er een uitdrukkelijke wettelijke bevoegdheidsgrondslag bestaat tot het nemen van een toekenningsbesluit en een dergelijk toekenningsbesluit ook daadwerkelijk is genomen of de aanvraag daartoe is afgewezen. Door het toekenningsbesluit of het afwijzen van de aanvraag daarvan ontstaat een publiekrechtelijke rechtsbetrekking. Mocht vervolgens ten onrechte of te veel worden betaald, ofwel omdat het toekenningsbesluit achteraf onjuist blijkt te zijn, ofwel omdat meer is betaald dan waarop op grond van het correcte toekenningsbesluit aanspraak bestond, dan vindt deze betaling in ieder geval plaats binnen het kader van die publiekrechtelijke rechtsbetrekking. Dit betekent dat een eventuele intrekking van het toekenningsbesluit en terugvordering ook plaatsvindt binnen het kader van dezelfde publiekrechtelijke rechtsbetrekking. Dit is ook het geval als weliswaar een publiekrechtelijke bevoegdheidsgrondslag bestaat voor het toekenningsbesluit, maar voor het intrekkingsbesluit en het terugvorderingsbesluit een dergelijke grondslag ontbreekt.

Naar mijn mening duurt de publiekrechtelijke rechtsbetrekking voort wanneer sprake is van een doorgeschoten betaling. Onder omstandigheden is dit ook zo bij betalingen die zijn verricht nadat de op grond van het bovenstaande criterium bestaande publiekrechtelijke rechtsverhouding strikt gezien is verbroken, maar hierbij zullen de omstandigheden van het geval doorslaggevend zijn. Naar mijn mening is in dat geval doorslaggevend of de betrokkene erop vertrouwde en erop mocht vertrouwen dat de betaling werd gedaan in het kader van de voorheen bestaande publiekrechtelijke rechtsbetrekking. Hetzelfde geldt bij betalingen die niet zijn gedaan in het kader van de concrete publiekrechtelijke rechtsverhouding, terwijl wel tussen de ontvanger van de betaling en het betalende bestuursorgaan een andere publiekrechtelijke rechtsverhouding bestaat. ${ }^{23}$ Hierbij is dus doorslaggevend of de betrokkene erop vertrouwde en erop mocht vertrouwen dat de betaling werd gedaan in het kader van de andere, bestaande publiekrechtelijke rechtsbetrekking. Mij lijkt overigens dat dit niet snel het geval zal zijn.

In het voorgaande ben ik ervan uitgegaan dat er een publiekrechtelijke bevoegdheidsgrondslag bestaat voor het toekenningsbesluit, waardoor een publiek-

23. Dit is de situatie waarin Verheij betoogt dat er weliswaar een publiekrechtelijke rechtsbetrekking bestaat, maar dat de betaling niet voortvloeit uit 'die rechtsbetrekking', Verheij (1999), blz. 4344 , noot 100, zie 11.2. Overigens zou ik in het voorbeeld dat Verheij geef, niet zonder meer willen concluderen dat de betaling niet heeft plaatsgevonden in het kader van de publiekrechtelijke rechtsbetrekking tussen hem en het ministerie van Justitic. Integendeel, ik zou als uitgangspunt nemen dat dat wel het geval is. Zijn voorbeeld is het volgende. De minister van Justitie betaalt per vergissing een aan zijn naaste collega $M$. Verheij toegekende gratificatie uit aan $\mathrm{N}$. Verheij, ook werkzaam bij dat ministerie. Maar hoe zit het dan als - een aangenaam verraste - N. Verheij, gelet op zijn grote verdienste op het terrein van đe A.wb-wetgeving, erop vertrouwde (en mogelijk ook erop mocht vertrouwen) dat de gratificatie wel voor hem was bedoeld? Het criterium van die rechisbetrekking zou ex bijvoorbeeld ook toe kunnen leiden, dat wanneer meer wordt betaald dan waarop op grond van een toekenningsbesluit recht bestaat, word: geconcludeerd dat de betaling van het meerdere niet uit de rechtsbetrekking voortvloeit die is ontstaan door het toekenningsbesluit, wodat de terugvordering langs privaatrechtelijke weg dient te geschieden. Ik heb reeds aangegeven dat dit naar mijn mening, niet zo is, zie supra. 
rechtelijke rechtsbetrekking bestaat of op enig moment heeft bestaan tussen he betalende bestuursorgaan en de ontvanger van de betaling. Het kan echter ook a zijn dat een toekenning plaatsvindt, ondanks het feit dat een dergelijke bevoegc heidsgrondslag voor het toekenningsbesluit ontbreekt. Deze situatie wordt nie 'gedekt' door de door Verheij gegeven omschrijving. Naar mijn mening kan oo: dan een publiekrechtelijke rechtsverhouding bestaan. Er is dan sprake van absolut (publiekrechtelijke) onbevoegdheid, dit in tegenstelling tot het door Verheij reed aangehaalde geval waarin de 'bestuursbevoegdheden wel zijn toegekend, maar in concreto niet kunnen worden uitgeoefend, omdat niet aan de wettelijke voorwaar den is voldaan', de relatieve onbevoegdheid. ${ }^{24} \mathrm{Als}$ de overheid bij absolute onbe voegdheid toch overgaat tot uitoefening van de gepretendeerde, want niet bestaas de bevoegdheid, dan is er sprake van een publiekrechtelijke rechtsbetrekking naast het uitoefenen van een (in abstracto) bestaande bestuursbevoegdheid ben it van mening dat ook het uitoefenen van een gepretendeerde bestuursbevoegdheil een publiekrechtelijke rechtsverhouding creëert. Dit lijkt ook de opvatting van d wetgever wanneer subsidie wordt verleend, terwijl daarvoor de wettelijke grond slag ontbreekt. Volgens de memorie van toelichting op artikel 4:23 Awb heeft he ontbreken van een dergelijke wettelijke grondslag en dus het ontbreken van d. bevoegdheid om subsidie te verlenen, in het algemeen slechts interne gevolger. De bepalingen uit de subsidietitel in de Awb, en dus ook de bepalingen met betrekking tot intrekking en terugvordering, zijn ook in dat geval van toepassing. ${ }^{25}$ Overigens heb ik niet de indruk dat deze situatie zich vaak voordoet bij terugvorclering.

In een situatie waarin geen publiekrechtelijke bevoegdheidsgrondslag bestaat voor een toekenning en de overheid ook niet pretendeert gebruik te maken van een dergelijke (niet bestaande) publiekrechtelijke bevoegdheid, zal naar mijn mening objectief moet worden gekeken naar de bedoeling van de overheid. Tracht zij op deze wijze toch een bepaalde (publiekrechtelijke) taak te vervullen of een bepaald beleid te verwezenlijken, dan is er sprake van een publiekrechtelijke rechtsverhouding. Veelal zal dan kunnen worden gesteld dat objectief gezien sprake is van (bewuste of onbewuste) omzeiling van het legaliteitsvereiste. Dit zal bijvoorbeeld het geval zijn als een wettelijke grondslag om subsidie te verlenen ontbreekt en de overheid ook niet pretendeert een subsidie te verlenen, maar stelt dat sprake is van een (privaatrechtelijke) schenking. Indien er (objectief gezien) niets publiekrechtelijks te ontdekken valt aan de bedoeling van de overheid, dan lijkt mij dat de conclusie voor de hand ligt dat geen sprake is van een publiekrechtelijke rechtsbetrekking. Wel kan in bepaalde gevallen het feit dat de betrokkene erop vertrouwde en erop mocht vertrouwen dat een bestuursbevoegdheid werd uitgeoe-

24. Zie 11.2 .

25. PG Awb III, blz. 200, zie hierover verder 8.2.2.2. Het ontbreken van een publiekrechtelijke bevoegdheidsgrendslag betekent zelfs niet dat het toekenningsbesluit om die reden kan worden ingetrokken. Intrekking zal onder omstandigheden slechts mogelijk zijin als de betrokkene wist of had behoren te weten dat de bevoegdheidsgrondslag ontbrak, zie 8.2.2.2. 
fend (zelfs als de overheid niet pretendeert een bestuursbevoegdheid uit te oefenen) ertoe leiden dat sprake is van een publiekrechtelijke rechtsverhouding.

Samengevat is bij terugvordering naar mijn mening sprake van een publiekrechtelijke rechtsverhouding, indien ten minste één van de bij die rechtsverhouding betrokken partijen een overheidsorgaan is en er sprake is van de uitoefening van een bestaande dan wel gepretendeerde, uitdrukkelijke dan wel geîmpliceerde bestuursbevoegdheid, waarbij onder omstandigheden daarmee kan worden gelijk gesteld, dat de betrokkene erop vertrouwde en erop mocht vertrouwen dat een dergelijke bestuursbevoegdheid werd uitgeoefend. Voorts kan onder omstandigheden sprake zijn van een publiekrechtelijke rechtsverhouding als een bestuursbevoegdheid ontbreekt en het bestuursorgaan ook niet pretendeert een publiekrechtelijke bevoegdheid uit te oefenen. In dat geval moet worden getracht de (objectieve) bedoeling van het bestuursorgaan vast te stellen: probeert het een publiekrechtelijke taak of een beleid uit te voeren, dan is sprake van een publiekrechtelijke rechtsverhouding. Uitgangspunt dient dan te zijn dat, nu de overheid partij is in de rechtsbetrekking, sprake is van een publiekrechtelijke rechtsverhouding.

Indien op grond van de bovenstaande criteria moet worden geconcludeerd dat geen sprake is van een publiekrechtelijke rechtsbetrekking, dan kan de overheid bij het ontbreken van andere wegen om terug te kunnen vorderen, gebruik maken van de regeling van onverschuldigde betaling, uit het $\mathrm{BW}$. Uiteraard moet wel rekening worden gehouden met het feit dat een van de betrokken partijen overheid is. Hierdoor kan het privaatrecht - de regeling betreffende de onverschuldigde betaling - dus wel worden ingekleurd, zie de artikelen $3: 14 \mathrm{BW}$ en $3: 1$ lid 2 Awb. ${ }^{26}$ Mijns inziens zijn in dit kader dan ook de artikelen 2:1 en 2:5 BW van belang. Datzelfde geldt wanneer het gaat om een betaling aan een willekeurige derde, waarbij nog geen publiekrechtelijke rechtsverhouding bestond tussen het betalende bestuursorgaan en deze derde. In dat geval wordt door deze betaling geen publiekrechtelijke rechtsbetrekking geschapen.

Overigens kan de wetgever ook voor deze gevallen een publiekrechtelijke regeling in het leven roepen. Dit is mogelijk door in bijvoorbeeld de Awb een algemene regeling met betrekking tot terugvordering door de overheid op te nemen. Op die wijze creëert de wetgever de publiekrechtelijke bevoegdheid om het onverschuldigd betaalde terug te vorderen, zodat de (mogelijkheid tot) uitoefening van die bevoegdheid leidt tot het ontstaan van een publiekrechtelijke rechtsbetrekking. In dat geval wordt de weg naar het privaatrecht wederom afgesneden. Dit heeft ook mijn voorkeur, nu op deze wijze discussies over het antwoord op de vraag of de terugvordering plaatsvindt in het kader van een publiekrechtelijke rechtsbetrekking worden voorkomen. ${ }^{27}$ Wel zal in die regeling duidelijk moeten worden ge-

26. Zie: over deze artikelen 5.2 .4

27. Ik. heb in 10.4.4 reeds aangegeven hoe deze algemene regeling er in grote lijnen dient uit te zien, waarbij in beginsel de bevoegdheid om terug te vorderen ruimer mag zijn dan wanneer de terugvordering plaatsvindt in het kader van een reeds bestaande publiekrechtelijke rechtsbetrekking. 
maakt dat deze slechts van toepassing is indien de terugvordering, niet plaatsvindt in het kader van een reeds bestaande publiekrechtelijke rechtsbetrekking tussen het bestuursorgaan en de ontvanger van de betaling. In die gevallen dient er immers een specifieke bevoegdheidsgrondslag voor de intrekking en de terugvordering te zijn neergelegd in de specifieke publiekrechtelijke wettelijke regeling.

\subsection{De publiekrechtelijke rechtsbetrekking en het gebruik van privaatrecht door de overheid}

In de vorige paragraaf heb ik aangegeven wanneer naar mijn mening sprake is van een publiekrechtelijke rechtsbetrekking bij terugvordering. De daar gegeven criteria hebben ook meer algemeen gelding, dus buiten het terrein van de terugvordering. Hierbij moet wel worden bedacht dat de criteria voor het bestaan van een publiekrechtelijke rechtsbetrekking in dat geval verder kunnen worden uitgewerkt. Zo acht ik het bijvoorbeeld mogelijk dat ook feitelijk handelen door de overheid kan leiden tot het ontstaan van een dergelijke rechtsbetrekking. In het kader van dit onderzoek is het echter niet nodig en ook niet mogelijk om een sluitende definitie te geven van de publiekrechtelijke rechtsbetrekking; dit zou een onderzoek vergen op het gehele terrein van het bestuursrecht.

Het gevolg van het bestaan van een publiekrechtelijke rechtsbetrekking is bij terugvordering dat de overheid niet beschikt over een privaatrechtelijke bevoegdheid om het onverschuldigd betaalde terug te vorderen. Als immers sprake is van een publiekrechtelijke rechtsverhouding, dan wordt deze rechtsverhouding volledig beheerst door het legaliteitsbeginsel. Op grond van dit beginsel is bij terugvordering een uitdrukkelijke publiekrechtelijke wettelijke grondslag vereist, hetgeen niet mag worden omzeild door het aannemen van een privaatrechtelijke bevoegdheid. Ik ben van mening dat deze conclusie kan worden veralgemeniseerd. Een publiekrechtelijke rechtsbetrekking wordt beheerst door publiekrechtelijke normen en beginselen, waaronder het legaliteitsbeginsel. Dit betekent dat bestuursbevoegdheden waardoor bevoegdheden, rechten en plichten van burgers kunnen worden vastgesteld of gewijzigd, in beginsel een uitdrukkelijke wettelijke grondslag behoeven. In sommige gevallen is het voldoende dat de wet een positieve indicatie bevat voor een dergelijke bevoegdheid. ${ }^{28}$

De consequentie hiervan is dat de overheid in een publiekrechtelijke rechtsbetrekking niet beschikt over een privaatrechtelijke bevoegdheden. Hoe verhoudt dit zich tot de doorkruisingsleer, die mag worden gezien als de heersende leer waar het het gebruik van privaatrecht door de overheid betreft? ${ }^{29}$ Het uitgangspunt van de Hoge Raad in het Windmill-arrest, dat kan worden gezien als toonzettend voor deze leer, is dat de overheid 'ter behartiging van zekere belangen' gebruik mag maken 'van haar in beginsel krachtens het privaatrecht toekomende bevoegdhe- 
den', ook wanneer 'haar bij een publiekrechtelijke regeling ter behartiging van (die) belangen bepaalde bevoegdheden zijn toegekend'. ${ }^{30}$

Ik ben van mening dat dit uitgangspunt niet het juiste is. Als aan de overheid ter behartiging van bepaalde belangen bij een publiekrechtelijke regeling bepaalde bevoegdheden zijn toegekend, dan zijn dit dus publiekrechtelijke bevoegdheden. Op het moment dat deze bevoegdheden kunnen worden uitgeoefend is er sprake van een publiekrechtelijke rechtsbetrekking. De overheid treedt dan immers op ter behartiging van een belang, voor de behartiging waarvan een specifieke bestuursbevoegdheid is toegekend. Wilt de overheid dat belang behartigen, dan dient zij dit te doen via de uitoefening van die bestuursbevoegdheid, met alle eventuele beperkingen die zijn aangebracht in de betreffende publiekrechtelijke regeling en door algemene publiekrechtelijke normen. De publiekrechtelijke bevoegdheid wordt met ander woorden volledig genormeerd door het publiekrecht. Het daarnaast aannemen van privaatrechtelijke bevoegdheden voor de overheid kan slechts leiden tot een uitholling van dat bestuursrechtelijk normenstelsel en dus van het legaliteitsbeginsel, waardoor de betekenis van dit beginsel illusoir wordt: wat heeft het voor zin om publiekrechtelijke bevoegdheden toe te kennen en te reguleren als de overheid deze bevoegdheden en de eventuele regulering daarvan in beginsel kan omzeilen door privaatrechtelijk op te treden wanneer haar dat beter uitkonnt? Dit betekent dan ook dat de overheid niet beschikt over een haar in beginsel krachtens het privaatrecht toekomende bevoegdheid.

Hetzelfde geldt als er geen specifieke publiekrechtelijke bevoegdheidsgrondslag bestaat. Wanneer de overheid optreedt binnen een publiekrechtelijke rechtsbetrekking, bijvoorbeeld omdat zij een specifiek opgedragen taak uitvoert, dan dient er een publiekrechtelijke bevoegdheidsgrondslag te zijn voor de uitoefening van specifieke bevoegdheden. ${ }^{31}$ Is deze er niet, dan bestaat de bevoegdheid niet; de overheid beschikt niet over een privaatrechtelijke bevoegdheid. Dit kan worden toegelicht aan de hand van het Brandweerkostenarrest. ${ }^{32}$ De gemeente Vlissingen trachtte de kosten van nabluswerkzaamheden op het schip Rize $\mathrm{K}$ via privaatrechtelijke weg te verhalen op de reder. Volgens het hof was dit niet mogelijk. Het cassatiemiddel stelde vervolgens 'de vraag aan de orde of een overheidslichaam dat bij de uitoefening van een hem bij een publiekrechtelijke regeling opgedragen publieke taak kosten heeft gemaakt, deze kosten langs privaatrechtelijke weg kan verhalen'. De Brandweerwet 1985 bevatte op het punt van kostenverhaal geen regeling; wel bleek uit de wetsgeschiedenis dat 'de wetgever van oordeel was dat het niet aangaat kosten van de hier aan de orde zijnde publieke takkuitoefening langs een publiekrechtelijke weg aan burgers in rekening te brengen ${ }^{3} \cdot{ }^{33}$ Kosten-

30. HR 26 januari 1990, NJ 1991, 393, m.nt. MS onder 394, AB 1990, 408, m.nt. G.P. Kleijn, zie 5.2.5.

31. Als gezegd kan in bepaalde gevallen sprake, zijn van een impliciete bevoegdheid, zie 9.3.2.

32. HR 11 december 1992, NJ 1994, 639, m.nt. MS, AB 1993, 301, m.nt. G.A. van der Veen.

33. Verder zou kostenverhaal een drempel kunnen opwerpen om de hulp van de brandweer in te roepen en betrof het een kerntaak van de overheid, welke van oudsher werd uitgeoefend zonder dat daarvoor kosten in rekening werden gebracht, aldus de Hoge Raad. 
verhaal langs privaatrechtelijke weg zou volgens de Hoge Raad neerkomen op een onaanvaardbare doorknising van de publiekrechtelijke regeling en was dus niet toegestaan.

Naar mijn mening had de burgerlijke rechter in dit geval moeten oordelen dat, nu er sprake was van een publiekrechtelijke rechtsbetrekking, het gaat immers om de uitoefening van een de overheid bij een publiekrechtelijke regeling opgedragen publieke taak, er een publiekrechtelijke bevoegdheidsgrondslag dient te zijn voor het verhaal van de kosten. Nu deze er niet is, kan geen kostenverhaal plaatsvinden; een privaatrechtelijke bevoegdheid is niet aan de orde. De vraag of door het uitoefenen van een privaatrechtelijke bevoegdheid de publiekrechtelijke regeling wordt doorkruist, is dan ook niet relevant; de overheid beschikt immers niet over een privaatrechtelijke bevoegdheid.

Het uitgangspunt van de Hoge Raad dat de overheid gebruik mag maken van haar in beginsel krachtens het privaatrecht toekomende bevoegdheden, ook wanneer haar bij een publiekrechtelijke regeling ter behartiging van die belangen bepaalde bevoegdheden zijn toegekend, is dus onjuist. Nu de tweewegenleer van hetzelfde uitgangspunt uitgaat, kan ook deze leer niet standhouden. Volgens die leer mag de overheid immers ook kiezen tussen de publiekrechtelijke en de privaatrechtelijke weg. ${ }^{34}$

Ook de gemene rechtsleer kent een onjuist uitgangspunt. Volgens deze leer is immers het privaatrecht het (al)gemene recht, dat ook van toepassing is op de overheid, tenzij er een publiekrechtelijke uitzondering bestaat. ${ }^{35}$ Dit betekent dat de overheid in beginsel beschikt over privaatrechtelijke bevoegdheden, ook in een publiekrechtelijke rechtsbetrekking. Slechts als er een publiekrechtelijke bevoegdheidsgrondslag is, is de privaatrechtelijke weg afgesloten. Bij het ontbreken van een dergelijke publiekrechtelijke bevoegdheidsgrondslag beschikt de overheid volgens deze leer in beginsel over een privaatrechtelijke bevoegdheid. Als gezegd is dit niet juist. Als er geen publiekrechtelijke bevoegdheidsgrondslag is, bestaat de bevoegdheid niet.

Samengevat komt het voorgaande op het volgende neer: daar waar de legaliteitseis voor het bestuursoptreden een (uitdrukkelijke of in bepaalde gevallen impliciete) wettelijke, publiekrechtelijke grondslag vereist, waarin de bevoegdheid tot dat bestuursoptreden is neergelegd (of bij een impliciete bevoegdheid: waanuit die bevoegdheid voortvloeit), zou het een onaanvaardbare uitholling van dat vereiste zijn om bij gebreke van een dergelijke grondslag een privaatrechtelijke bevoegdheid aan te nemen, waardoor alsnog kan worden bereikt wat langs publiekrechtelijke weg niet mag worden bereikt. Waar een publiekrechtelijke bevoegdheid wel aanwezig is, dient de uitoefening van die bevoegdheid door het bestuursrecht te worden genormeerd. Deze publiekrechtelijke normering mag niet worden uitgehold door tevens privaatrechtelijke bevoegdheden aan te nemen, welke kunnen worden uitgeoefend naast of in plaats van de publiekrechtelijke bevoegdheid. 
Gaat het dus om een publiekrechtelijke rechtsverhouding, om een door het bestuursrecht beheerste rechtsverhouding, dan is een publiekrechtelijke bevoegdheid vereist. Als die bevoegdheid aanwezig is (en wordt uitgeoefend), betekent dit dat op die rechtsverhouding de regels van publiekrecht van toepassing zijn. De regels uit het privaatrecht, en in het bijzonder uit het BW, zijn dan niet rechtstreeks van toepassing; zij zijn immers opgesteld voor privaatrechtelijke verhoudingen, en niet voor publiekrechtelijke verhoudingen. ${ }^{36}$ Dit wil niet zeggen dat deze regels niet kunnen worden gebruikt als invulling van het publiekrecht. Dit vooronderstelt dat publiekrechtelijke regels ontbreken en dat de regeling uit het privaatrecht een uitwerking vormt van een algemene, dus niet alleen voor het privaatrecht maar ook voor het publiekrecht geldende, rechtsregel. Wel zal dan bij de toepassing van die regel moeten worden geabstraheerd van de specifiek-privaatrechtelijke uitwerking, zoals die algemene rechtsregel die heeft gekregen in het privaatrecht. ${ }^{37}$

\subsection{Verdere kritiek op de doorkruisingsleer}

De vooronderstelling van de Hoge Raad dat de overheid in beginsel beschikt over privaatrechtelijke bevoegdheden, is onjuist, zo heb ik aangegeven in 11.4, althans voor zover het een publiekrechtelijke rechtsverhouding betreft. Het legaliteitsvereiste eist immers een (uitdrukkelijke dan wel in bepaalde gevallen impliciete) wettelijke, publiekrechtelijke grondslag waarop de bevoegdheid berust, indien door uitoefening van die bestuursbevoegdheid bevoegdheden, rechten en plichten van burgers kunnen worden vastgesteld.

Gelet op het feit dat de doorkruisingsleer nog steeds de nodige aanhangers heeft, wil ik hier toch kort ingaan op de vraag, of deze leer stand kan houden als men het algemene uitgangspunt van die leer aanvaardt, dat de overheid inderdaad in beginsel beschikt over privaatrechtelijke bevoegdheden. Naar mijn mening is dat niet het geval. Volgens deze leer mag de overheid gebruik maken van haar privaatrechtelijke bevoegdheden, tenzij zij daardoor de publiekrechtelijke regeling op onaanvaardbare wijze doorkruist. Dit klopt ook niet. Indien er een publiekrechtelijke regeling is, zou het uitgangspunt toch moeten zijn dat deze regeling exclusief is. ${ }^{38}$ Het bestaan van de publiekrechtelijke regeling dient dan ook de privaatrechtelijke weg af te sluiten, tenzij uit die publiekrechtelijke regeling blijkt dat dit in beginsel niet zo is. In beginsel, want als de publiekrechtelijke regeling de privaatrechtelijke weg openlaat, zal toch nog moeten worden bekeken of het gebruik van de privaatrechtelijke weg in het concrete geval toelaatbaar is, of dat

36. Zie ook de toelichting op de regeling van publiekrechtelijke geldvorderingen in het voorontwerp vierde tranche Awb, Voorontwerp Commissie-Scheltema Awb IV (1999), blz. 49 en 50. Zie hierover 5.3.4.

37. Vgl. Tak (1997), blz. 117. Zie hierover 5.3.2. Zie ook Simon (1993), blz. 198.

38. In dit opzicht is de 'traditionele' gemene rechtsleer dus consequenter dan de daarop voortbouwende tweewegenleet en doorkruisingsleer: als er publiekrecht is, moet dit worden toegepast, pas wanneer publiekrecht ontbreekt, kan worden teruggevallen op het gemene recht; zie 5.2.1. 
het de publiekrechtelijke weg op onaanvaardbare wijze doorkruist. Dit kan het geval zijn omdat de publiekrechtelijke regeling meer rechtsbescherming biedt dan de privaatrechtelijke weg, hetgeen met de uitbouw van de bestuursrechtelijke rechtsbescherming een steeds belangrijker aspect wordt, of omdat langs de publiekrechtelijke weg inmiddels hetzelfde resultaat kan worden behaald; de mogelijkheden hiertoe worden steeds uitgebreider, denk bijvoorbeeld aan de regeling van de bestuursrechtelijke dwangsom in de Awb. ${ }^{39}$

Naar mijn mening zou de conclusie bij aanvaarding van het uitgangspunt dat de overheid kan beschikken over privaatrechtelijke bevoegdheden, dan ook moeten luiden dat als de publiekrechtelijke regeling de mogelijkheid openlaat om de privaatrechtelijke weg te volgen, er steeds zal moeten worden bekeken of in het concrete geval hierdoor niet de bestuursrechtelijke regeling of - beter: - het bestuursrecht wordt doorknuist. Is dat het geval, dan is de privaatrechtelijke weg alsnog afgesloten. Deze benadering zou veel meer recht doen aan de ontwikkeling van het bestuursrecht, zoals die heeft plaatsgevonden sinds de Tweede Wereldoorlog.

\subsection{Conclusie}

In dit hoofdstuk heb ik bekeken of de overheid gebruik mag maken van het privaatrecht bij terugvordering. Naar mijn mening kan het privaatrecht niet ais bevoegdheidsgrondslag dienen voor de terugvordering door de overheid. In het algemeen dienen immers de intrekkings- en terugvorderingsbevoegdheid op een uitdrukkelijke, wettelijke, publiekrechtelijke bevoegdheidsgrondslag te berusten. Dit vloeit voort uit (mijn opvatting betreffende) het legaliteitsbeginsel. Het aannemen van een privaatrechtelijke bevoegdheid naast of in plaats van de publiekrechtelijke bevoegdheid kan enkel leiden tot een onaanvaardbare uitholling van dit beginsel. Het legaliteitsbeginsel is echter een publiekrechtelijk beginsel; hierin zit naar mijn mening een beperking. Het geldt namelijk alleen wanneer sprake is van een publiekrechtelijke rechtsbetrekking. Voor de terugvordering betekent dit, dat het alleen geldt wanneer de terugvordering plaatsvindt binnen een dergelijke rechtsbetrekking. Nu zal dit vrijwel altijd het geval zijn wanneer de overheid onverschuldigd gedane betalingen terugvordert. Slechts in uitzonderingssituaties, bijvoorbeeld wanneer de betaling plaatsvindt aan een willekeurige derde, kan dit anders zijn.

Dit leidt ertoe dat wanneer sprake is van een publiekrechtelijke rechtsbetrekking, het uitgangspunt van de Hoge Raad dat de overheid in beginsel beschikt over haar krachtens het privaatrecht toekomende bevoegdheden onjuist is; in een dergelijke rechtsbetrekking beschikt de overheid in beginsel niet over privaatrech-

39. Zo ook Verheij (1999), blz. 65: '(Ik) vind (...), met 'Maastricht', dat de HR in Windmill eigenlijk het verkeerde uitgangspunt kiest. Het is niet zo dat de overheid het privaatrecht mag gebruiken tenzij het publiekrecht wordt doorkruist. Er moet juist een bijzondere reden zijn om in afwijking van de hoofdregel toe te staan dat de overheid privaatrechtelijke vormen gebruikt. Soms is die er; daarom hebben we de artikelen 2:1 jo. 2:5 BW nodig. Maar die artikelen kunnen redelijkerwijs niet betekenen dat de overheid alles mag wat U en ik mogen'. 
telijke bevoegdheden. Dit geldt ook buiten de terugvordering. Uiteraard is het van belang vast te stellen wanneer sprake is van een publiekrechtelijke rechtsbetrekking. Waar het de terugvordering betreft heb ik dit uitgewerkt in 11.3; buiten de terugvordering kan het door mij gegeven criterium verder worden uitgewerkt. Dit vergt echter een meer omvattend onderzoek.

De conclusie is dus dat de overheid in een publiekrechtelijke rechtsbetrekking in beginsel niet beschikt over privaatrechtelijke bevoegdheden. Wel kan onder bepaalde voorwaarden het privaatrecht invullend worden gebruikt, namelijk in de situatie waarin er een (voldoende specifieke) publiekrechtelijke bevoegdheidsgrondslag is, maar de publiekrechtelijke regeling leemtes bevat waar het de regulering van de uitoefening van die bevoegdheid betreft. De regeling in het privaatrecht kan in dat geval dienst doen als rechtsvindingshulpmiddel. Dit is de kern van de zogenaamde invullende rechtsleer. 



\section{RECHTSBESCHERMING: BESTUURSRECHTER OF BURGERLIJKE RECHTER?}

\subsection{Inleiding}

In de vorige hoofdstukken is de vraag an de orde geweest wanneer de overheid. onverschuldigd betaalde gelden mag terugvorderen. Ik ben tot de conclusie gekomen dat dit slechts mag wanneer daarvoor een uitdrukkelijke, publiekrechtelijke, wettelijke bevoegdheidsgrondslag aanwezig is, althans wanneer de terugvordering plaatsvindt binnen een publiekrechtelijke rechtsverhouding. Over privaatrechtelijke bevoegdheden beschikt de overheid niet binnen een dergelijke rechtsbetrekking. Dit laatste (binnen een publiekrechtelijke rechtsbetrekking beschikt de overheid in beginsel niet over privaatrechtelijke bevoegdheden) geldt naar mijn mening ook buiten het terrein van de terugvordering. Een vraag die weliswaar een aantal keren is angestipt, maar nog niet (expliciet) is beantwoord, is welke rechter rechtsbescherming (zou) moet(en) bieden tegen de overheid, of meer algemeen gesteld, geschillen (zou) moet(en) beoordelen waarbij de overheid partij is en die zich afspelen binnen een publiekrechtelijke rechtsbetrekking. Mijns inziens maakt het voor de beantwoording van deze vraag niet veel verschil of het terugvordering betreft of andere terreinen. Om deze reden zal de opzet van dit hoofdstuk dan ook meer algemeen zijn en zich dus minder specifiek richten op de terugvordering dan de vorige hoofdstukken.

De vraag die in dit hoofdstuk dus centraal staat is of binnen een publiekrechtelijke rechtsbetrekking ruimte bestaat voor een concurrerende competentie van de bestuursrechter en de burgerlijke rechter, of dat een van deze rechters exclusieve competentie dient te knijgen. In 12.2 en $12.3 \mathrm{zal}$ ik de huidige regels met betrekking tot de rechtsmacht van de bestuursrechter bespreken, waarbij ik tevens een aantal problemen (en mogelijke oplossingen) die door deze regels optreden, zal behandelen. In $12.4 \mathrm{zal}$ ik voorstellen een nieuw bevoegdheidscriterium te hanteren, namelijk de aard van de rechtsbetrekking. Hantering van dit criterium zal naar mijn mening niet alleen gevolgen hebben voor de bevoegdheid van de burgerlijke rechter, maar (mogelijk) ook voor het gebruik van privaatrecht door de overheid. Dit komt in 12.5 aan de orde. Wel ben ik van mening dat deze wijziging van de rechtsmachtverdeling tussen de burgerlijke en de bestuursrechter gepaard dient te gaan met het over de gehele linie onderbrengen van de bestuursrechtspraak bij de rechterlijke macht. Ik zal dit uitwerken in 12.6, waama ik ten slotte in 12.7 de vraag zal behandelen hoe de door mij voorgestelde wijzigingen zich verhouden tot het huidige grondwettelijke stelsel met betrekking tot de rechtsmachtverdeling. 


\subsection{Rechtsbescherming door de bestuursrechter}

De rechtsmacht van de bestuursrechter is veelal gekoppeld aan het voorliggen van een besluit. Dit betekent dat deze rechter veelal niet bevoegd is als er voor het bestuursoptreden geen publiekrechtelijke bevoegdheidsgrondslag is. Het vereiste van een bevoegdheidsgrondslag is namelijk terug te vinden in het besluitbegrip uit de Awb, althans in de wijze waarop dit besluitbegrip wordt uitgelegd. Dit is weer terug te voeren op de wijze waarop in de Wet bab en de Wet arob het beschikkingsbegrip werd uitgelegd. ${ }^{1}$ Zo omschreef bijvoorbeeld artikel 2 Wet bab een beschikking als 'de eenzijdige naar buiten gerichte schriftelijke wilsverklaring van een administratief orgaan van de centrale overheid, gegeven krachtens een in enig staats- of administratiefrechtelijk voorschrift vervatte bevoegdheid of verplichting...', waarmee volgens de toelichting 'het publiekrechtelijk karakter van de beschikking tot uitdrukking is gebracht'. ${ }^{2}$ Hieruit werd geconcludeerd dat de beschikking een publiekrechtelijk karakter moet bezitten. Niets meer. ${ }^{3}$

Het publiekrechtelijk karakter moest kennelijk blijken uit de publiekrechtelijke bevoegdheidsgrondslag. Dit is later zo ingevuld dat wanneer een uitdrukkelijke publiekrechtelijke bevoegdheidsgrondslag ontbrak, er (veelal) sprake was van een rechtshandeling naar burgerlijk recht, althans daar waar een 'parallelle' bevoegdheid kon worden gevonden in het privaatrecht. Deze uitleg/invulling is mijns inziens terug te voeren op de gemene rechtsleer, die in die periode (de jaren zestig) mocht worden gezien als de heersende leer: kent het publiekrecht geen uitzondering, dan is het gemene (privaat)recht van toepassing. ${ }^{4}$ Geleidelijk is het vereiste van een uitdrukkelijke wettelijke grondslag iets afgezwakt. Zo volstond onder de Wet arob in een aantal gevallen het 'publieketaakcriterium', terwijl ook subsidiebesluiten veelal als beschikkingen werden aangemerkt, ook als daarvoor geen expliciete wettelijke grondslag was aan te wijzen. ${ }^{5}$ Vereist bleef echter, dat sprake moest zijn van een publiekrechtelijke bevoegdheid of verplichting.

Ontbreekt voor de bestuursbeslissing een publiekrechtelijke bevoegdheidsgrondslag, er is sprake van absolute onbevoegdheid, ${ }^{6}$ dan kan geen sprake zijn van een besluit en dit heeft dus veelal weer tot gevolg dat de bestuursrechter geen rechtsmacht heeft met betrekking tot deze beslissing. ${ }^{7}$ De hoofdregel is immers

1. Zie hierover 4.2 .

2. Memorie van toelichting, Tweede Kamer 1958-1959, 5363, nr. 3, blz. 12.

3. Aldus De Goede (1972), blz. 1185, verwijzend naar Kan/Van Maarseveen (1964). Zie ook 4.2.1.

4. Zie 5.2 .1 tot en met 5.2.3.

5. Zie 4.2 .2 en 8.2.4.

6. Zie 11.2 .

7. Er kan wel sprake zijn van een besluit als er een publiekrechtelijke bevoegdheidsgrondslag is, maar deze bevoegdheid in het concrete geval niet kan worden uitgeoefend, bijvoorbeeld omdat niet aan de voorwaarden voor uitoefening van de bevoegdheid is voldaan; er is dan sprake van relatieve onbevoegdheid, zie 11.2 . 
dat de bestuursrechter in beginsel slechts bevoegd is te oordelen over een besluit. Indien de bestuursrechter niet bevoegd is, dan zal veelal de burgerlijke rechter als restrechter rechtsbescherming (moeten) bieden. De bevoegdheid van deze rechter is immers niet afhankelijk van de vraag of de aard van het geschil privaatrechtelijk is, maar van de wijze waarop eiser zijn vordering inkleedt." Dit heeft als consequentie dat in bepaalde gevallen bij deze rechter typisch bestuursrechtelijke vragen worden beantwoord aan de hand van het privaatrecht, waarbij ook de bevoegdheidsgrondslag voor het bestuursoptreden in het privaatrecht kan worden gevonden. Hoewel rekening wordt gehouden met het feit dat een der partijen overheid is, en dus het privaatrecht een publiekrechtelijke inkleuring zal krijgen, blijft het privaatrecht dat rechtstreeks wordt toegepast. Dit is evenwel niet toegestaan in een publiekrechtelijke rechtsverhouding. ${ }^{10}$ Het feit dat de burgerlijke rechter bevoegd is te oordelen over een geschil binnen een publiekrechtelijke rechtsverhouding, heeft dus ook (ongewenste) consequenties voor het gebruik van privaatrecht door de overheid. Dit komt aan de orde in 12.5.

Inmiddels is een aantal bestuursrechters de constructie gaan toepassen dat bij het ontbreken van een uitdrukkelijke wettelijke grondslag voor de bevoegdheid, deze bevoegdheid kan worden ontleend aan een algemeen rechtsbeginsel, bijvoorbeeld bij terugvordering het beginsel dat hetgeen onverschuldigd is betaald, kan worden teruggevorderd. ${ }^{\text {" }}$ Op deze manier is een publiekrechtelijke bevoegdheidsgrondslag gecreëerd, waar deze voorheen niet werd aangenomen door de rechter. Ik heb deze constructie uitdrukkelijk verworpen; algemene rechtsbeginselen kunnen geen publiekrechtelijke bevoegdheden creëren, dit is naar mijn mening in strijd met het legaliteitsbeginsel. Dit geldt ook voor de jurisprudentie van de andere bestuursrechters, die niet (expliciet) overwegen dat het rechtsbeginsel bevoegdheidscheppend is. ${ }^{12}$

8. Op deze hoofdregel bestaat een aantal belangrijke vitzonderingen. Zo zijn bijvoorbeeld de ambtenarenrechter en het $\mathrm{CBB}$, oordelend op grond van zijn algemene bevoegdheid, ook bevoegd andere handelingen van het bestuursorgaan te beoordelen, zie onder meer 3.5. Daamaast breidt onder meer de Awb de rechtsmacht van de besturssechter ook uit, zie bijvoorbeeld artikel 6:2. Anderzijds worden ook bepaalde besluiten uitgezonderd van beroep bij de bestuursrechter, zie onder meer de artikelen 8:2 tot en met 8:5 Awb.

9. Zie 2.6, alwaar is beschreven dat sinds het arrest Guldemond-Noordwijkerhout uit 1915 de Hoge Raad definitief het objectum litis bepalend acht voor de bevoegdheid van de burgerlijke rechter. Sinds dat arrest is sprake van vaste jurisprudentie, hoewel hierop uitzonderingen bestonden, zie HR 26 maart 1971, NJ 1971, 434, AB 1971, 135, m.nt. D.J. Veegens (Verkiezingsafspraak Elsloo) en de jurisprudentie genoemd in 4.3.2. Sinds het Changoe-arrest en HR 19 november 1999, NJ 2000, 160, m.nt TK, AB 2000, 387, m.nt. ThGD, JB 2000, 1, m.ne R.J.N. S. (Tegelen-Provincie Limburg) mag worden aangenomen, dat de Hoge Raad deze uitzonderingen niet meer hanteert, zie $2.6,72.4 .3$ en 8.4.5. In zijn noot in $A \bar{B}$ onder het arrest TegelenProvincie Limburg stelt Drupsteen overigens terecht en treffend, dat de 'Guldemond-Noordwijkerhout-jurisprudentie" een hoog 'Sesam-open-U-gehalte' heeft.

10. Zie 11.4

11. Zie bijwoorbeeld ABRvS 21 oktober 1996, AB 1997, 496, m.nt. NV, JB 1996, 232, m.nt. HJS (Nanne), zie: ook: 5.3 .3 en 8.2 .6 .

12. Zie 9.3 .2 . 
Wel is deze jurisprudentie in een bepaald opzicht een verbetering ten opzichte van de voordien gehanteerde constructie, dat bij het ontbreken van een publiekrechtelijke bevoegdheidsgrondslag sprake is van een rechtshandeling naar burgerlijk recht. Het lijkt er dan ook op dat de bestuursrechters een (publiekrechtelijke) bevoegdheid hebben gecreëerd om zodoende de beslissing van het bestuursorgaan als besluit aan te kunnen merken, zodat zij bevoegd zijn over dit besluit te oordelen. De gehanteerde constructies zouden dan doelconstructies zijn, bedoeld om de bestuursrechter rechtsmacht te geven. Dit lijkt plausibel, hoewel het dan niet voor de hand ligt on vervolgens een processueel connexiteitsvereiste te stellen, waardoor het effect van deze bevoegdheidsverruiming weer deels teniet wordt gedaan. ${ }^{13}$

Het voordeel voor de betrokkenen zou hierin kunnen zitten, dat de bestuursrechter mogelijk terughoudender zal zijn met het toestaan van terugvordering. ${ }^{14}$ Ik denk hierbij vooral aan een beperking in de tijd van de mogelijkheid tot terugvordering. ${ }^{15}$ Als de terugvorderingsbeslissing wordt gezien als rechtshandeling naar burgerlijk recht, dan is hierop de verjaringstermijn uit het BW van toepassing. Deze kan oplopen tot twintig jaar. ${ }^{16}$ De tendens bij bestuursrechters lijkt te zijn om kortere termijnen te hanteren, veelal tot maximaal vijf jaar.

13. In eerste instantie leek de ABRvS (bij zuivere schadebesluiten) dan ook een beperkt(er) processueel connexiteitsvereiste te stellen. In ABRvS 29 november 1996, AB 1997, 66, m.nt. PvB, JB 1996, 253, m.nt. red. (Alpha Kledingreinigingsbedrijf) leek zij het vereiste te gebruiken om te bepalen welke bestuursrechter bevoegd is over het schadebesluit te oordelen. Mogelijk is zij vervolgens geschrokken van de soms heftige reacties op deze jurisprudentieomslag en heeft ajj wat gas willen terugnemen, en wel door het processuele connexiteitsvereiste in volgende uitspraken te verruimen in die zin, dat wanneer geen bestuursrechter bevoegd is kennis te nemen van het beroep tegen schadeoorzaak, bijvoorbeeld omdat de schade werd veroorzaakt door cen feitelijke handeling, er ook geen bestuursrechter bevoegd is kennis te nemen van het beroep tegen het schadebesluit.

14. Het nadeel lijkt te zijn dat bij zuivere schadebesluiten de bestuursrechier terughoudender is dan de burgerlijke rechter bij het toekennen van schadevergoeding, zie Bollen (2000), blz. 309-311 met verdere verwijzingen.

15. $\mathrm{Vgl}$. de jurispruđentie van de ambtenarenrechter met betrekking tot de toepassing van de verjaringstermijnen uit het BW, zie 6.5 .2 en 7.2.4.2. Het is overigens de vraag of de andere bestuursrechters deze jurisprudentie in een voorkomend geval zullen overnemen. Deze vraag is vooral van belang in het socialezekerheidsrecht, waar de wetgever van mening is dan door het schrappen van de specifieke terugvorderingstermijnen de verjaringstermijnen uit het $\mathrm{BW}$ van toepassing worden, zie 6.45.3. Naar mijn mening zou de CRvB als socialezekerheidsrechter de jurisprudentie van de CRvB als ambtenarenrechter moeten volgen, zie 6.5.2, maar tot heden lijkt de socialezekerheidsrechter niet geneigd hiertoe over te gaan. Op andere terreinen heeft hij immers uitdrukkelijk de koers zoals uitgezet door de wetgever gevolgd, mijns inziens ten onrechte, zie bijvoorbeeld 10.5 met betrekking tot de zogenaamde zesmaandenjurisprudentic.

16. Zie 1.5 .2 en 6.5 .2 . 


\subsection{Het besluit als publiekrechtelijke rechtshandeling en het besluit als rechtsingang bij de bestuursrechter}

Het probleem blijft echter, als gezegd, dat algemene rechtsbeginselen geen bevoegdheden kunnen scheppen. Als een publiekrechtelijke bevoegdheidsgrondslag ontbreekt, dan bestaat de bevoegdheid niet; er is sprake van absolute onbevoegdheid. ${ }^{17}$ Er zal echter een rechter moeten zijn die deze onbevoegdheid kan vaststellen. Hetzelfde geldt als de bevoegdheid in abstracto wel aanwezig is, maar gelet op de normering van die bevoegdheid in het concrete geval niet kan worden uitgeoefend, wanneer er dus sprake is van relatieve onbevoegdheid. De meest geêigende rechter hiertoe is mijns inziens de bestuursrechter.

De bestuursrechter reageert momenteel echter op verschillende manieren op het ontbreken van een publiekrechtelijke bevoegdheidsgrondslag. Hierbij moet worden bedacht dat in een procedure voor deze rechter veelal niet de primaire beslissing van het bestuursorgaan het onderwerp van beroep vormt, maar de beslissing op bezwaar, het secundaire besluit. ${ }^{18}$ De primaire beslissing speelt slechts indirect een rol. Als het bestuursorgaan het bezwaar tegen deze primaire beslissing verwerpt, gaat de betrokkene in beroep tegen de beslissing op bezwaar. Om te beoordelen of die beslissing correct is, zal de bestuursrechter de primaire beslissing moeten beoordelen. Als hij van mening is dat het bezwaar doel had moeten treffen, zal de uitspraak strekken tot gegrondverklaring van het beroep. De rechter zal dan het besluit op bezwaarschrift vernietigen. Het bestuursorgaan moet dan een nieuwe beslissing op het bezwaarschrift nemen. Eventueel kan de rechter zelf in de zaak voorzien, waarbij zijn uitspraak in de plaats treedt van de beslissing op bezwaar, zie artikel 8:72 lid 4 Awb. De primaire beslissing blijft dus formeel in stand zolang het bestuursorgaan deze niet heeft ingetrokken of gewijzigd of de bestuursrechter niet zelf in de zaak heeft voorzien. Deze constructie maakt het bestuursprocesrecht er niet overzichtelijker op.

De reactie van de bestuursrechter op het ontbreken van een publiekrechtelijke grondslag is dus niet eenduidig, althans (voornamelijk) in de situatie waar de bevoegdheid in abstracto niet bestaat, wanneer dus sprake is van absolute onbevoegdheid. In een aantal gevallen heeft hij de beslissing op bezwaar vernietigd, omdat eiser ten onrechte niet niet-ontvankelijk werd verklaard. Veelal voorziet de rechter dan zelf in de zaak en verklaart eiser alsnog niet-ontvankelijk. Dit zal zich voordoen indien de rechter van oordeel is dat geen sprake is van een besluit, maar van een rechtshandeling naar burgerlijk recht. Als het bestuursorgaan in dat geval een bezwaarschrift tegen de primaire beslissing toch in behandeling neemt, zal de

17. Zie 11.2 .

18. Dit blijkt ook uit artike! 7:1 lid 2 Awb: 'Tegen de beslissing op het bezwaar kan beroep worden ingesteld ...' Zie hierover onder meer Tak (1995), blz. 19 en 314 en Van Wijk/Konijnenbelt \& Van Male (1999), blz. 591 en 628. 
bestuursrechter de besiissing op bezwaar vernietigen. ${ }^{19}$ Tegenwoordig is de be: stuursrechter in deze situatie geneigd waar mogelijk de constructie van bevoegd heidscheppende algemene rechtsbeginselen te hanteren, waardoor een publiekrechr telijke bevoegdheid aanwezig wordt geacht en de bestuursrechter bevoegd is ovei dit besluit te oordelen, indien is voldaan aan het vereiste van processuele connexiteit. Dit betekent dat in dat geval het bestuursorgaan eiser ontvankelijk moel verklaren in zijn bezwaar.

Een andere situatie is die, waarin een publiekrechtelijke bevoegdheid ont: breekt zodat geen sprake is van een besluit in de zin van artikel 1:3 Awb, en ir het privaatrecht ook geen 'parallelle' bevoegdheid kan worden gevonden, zodal ook geen sprake kan zijn van een rechtshandeling naar burgerlijk recht. Heeft hel bestuursorgaan in dat geval een beslissing op het bezwaarschrift genomen, dan zal de rechter het beroep gegrond verklaren en de beslissing op bezwaar vernietiz gen. ${ }^{20}$ Eventueel kan hij vervolgens zelf in de zaak voorzien door alsnog hel bestuursorgaan onbevoegd te verklaren.

Een 'tussensituatie' is die, waarin het primaire besluit deels wel, deels niel berust op een wettelijke grondslag. Dit heeft zich bijvoorbeeld voorgedaan in situaties, waarin naast terugvordering van onverschuldigd gedane betalinger (veclal vareradiuldigd beiaalde subsidies) tevens werlelijke rente of een boete werd gevorderd, terwijl voor dit laatste geen wettelijke grondslag bestond. De bestuursrechter heeft in dat geval de beslissing op bezwaar vernietigd, althans voor zover een wettelijke grondslag voor het primaire besluit ontbrak. ${ }^{21}$

Ten slotte is er nog het geval waarin geen bezwaar kan worden ingediend tegen de primaire beslissing en de betrokkene dus direct naar de bestuursrechter moet gaan, bijvoorbeeld wanneer aan de beslissing een uitgebreide openbare voorbereidingsprocedure is voorafgegaan (artikel 7:1 lid 1 aanhef en sub d Awb). Als het bestuursorgaan niet bevoegd was het besluit te nemen, zal de bestuursrechter zich onbevoegd moeten verklaren. Er is namelijk geen sprake van een besiuit in de zin van artikel 1:3 Awb, zodat hiertegen geen beroep openstaat. Op grond van artikel 8:1 lid 1 Awb kan de belanghebbende immers slechts in beroep tegen een besluit. Ook in dit geval zal de rechter slechts indirect, door zich onbevoegd te verklaren, zijn oordeel geven over de primaire beslissing van het bestuursorgaan.

19. In die gevallen is de bestuursrechter bevoegd, nu de beslissing op bezwaar wel als besluit in de zin van artikel 1:3 Awb wordt gezien, zie bujvoorbeeld uitdrukkelijk ABRvS 18 februari 1997, AB 1997, 143, m.nt. PvB, JB 1997, 47, m.nt. HJS (Beurskens). Bij relatieve onbevoegdheid, er is een publiekrechtelijke bevoegdheidsgrondslag, maar de bevoegdheid kan in het concrete geval niet worden uitgeoefend, zie 11.2, lijken er minder problemen te bestaan; de bestuursrechter zal niet snel tot niet-ontvankelijkheid beslissen omdat sprake is van een rechtshandeling naar burgerlijk recht.

20. Ook in deze gevallen is de bestuursrechter bevoegd omdat de beslissing op bezwaar een besluit is in de zin van artikel 1:3 Awb.

21. Bijvoorbeeld ARRvS 30 juni 1992, AB 1993, 447, m.nt. AFMB, ARRvS 4 november 1993, AB 1994, 182, m.nt. NV en Rb. Leeuwarden 21 april 2000, JB 2000, 173, m.nt. Carlos Bollen. 
Uit het voorgaande volgt, dat de bestuursrechter zich in de meeste gevallen slechts indirect kan uitspreken over de primaire beslissing indien de (publiekrechtelijke) bevoegdheid voor het nemen van die beslissing ontbreekt, althans het zal vaak onduidelijk zijn of hij zich uitspreekt over die primaire beslissing. Naar mijn mening is dit geen wenselijke situatie. Zoals gezegd heeft dit te maken met het feit, dat veelal de beslissing op het bezwaarschrift het onderwerp is van beroep. ${ }^{22}$ Het ontbreken van een publiekrechtelijke bevoegdheidsgrondslag mag in ieder geval niet leiden tot de conclusie dat sprake is van een rechtshandeling naar burgerlijk recht, althans voor zover de rechtshandeling heeft plaatsgevonden binnen een publiekrechtelijke rechtsverhouding. ${ }^{23}$

Daarnaast zou het ontbreken van een publiekrechtelijke bevoegdheidsgrondslag niet tot onbevoegdheid van de bestuursrechter of niet-ontvankelijkheid van het beroep moeten leiden. Er zou dan ook een andere invulling moeten worden gegeven aan het besluitbegrip voor zover dit dienst doet als rechtsingang bij de bestuursrechter. Ook naar mijn mening moet een besluit als bestuurshandeling een publiekrechtelijke bevoegdheidsgrondslag hebben. Daar waar die grondslag ontbreekt, mag het bestuur niet handelen, zodat 'eigenlijk' geen sprake is van een besluit. ${ }^{24}$ Als het bestuur ondanks het ontbreken van een dergelijke grondslag zijn handelen 'verkleedt' als een besluit, als dus het bestuurshandelen de uiterlijke schijn van een besluit heeft, zal door een rechter moeten worden vastgesteld dat de bevoegdheid ontbreekt en dus dat geen sprake is van een besluit dan wel dat sprake is van een nietig besluit. De meest geëigende rechter hiertoe is de bestuursrechter. Mij lijkt dat in dat geval het besluitbegrip als rechtsingang bij de bestuursrechter anders moet worden uitgelegd dan nu geschiedt. De bevoegdheidsvraag dient namelijk niet aan de orde te komen bij de vraag of er sprake is van een appellabel besluit in de door mij hiervoor bedoelde zin, welke vraag dus bepaalt of de bestuursrechter bevoegd en bet beroep ontvankelijk is, maar pas nadat de vraag naar de bevoegdheid van deze rechter en de ontvankelijkheid van het beroep aan de orde is geweest.

Dit leidt ertoe dat eerst moet worden gekeken of sprake is van een schriftelijke beslissing van een bestuursorgaan, die is gericht op rechtsgevolg en die is genomen in het kader van een door het bestuursrecht beheerste verhouding. Als hieraan is voldaan, staat de bevoegdheid van de bestuursrechter vast en zal het

22. Ik vraag mij dan ook af of niet de primaire bestissing het onderwerp van het beroep zou moeten zijn. De bestuursrechter zou zich dan namelijk rechtstreeks, in het dictum, moeten uitlaten over die primaire beslissing en niet, zoals nu vaak het geval is, slechts indirect. Uiteraard kan de beslissing op het bezwarschrift er wel toe leiden dat de primaire beslissing wordt gewijzigd, zodat in dat geval deze gewijzigde primaire beslissing het onderwerp van beroep zou moeten worden. Eventueel zou kunnen worden teruggekeerd tot de constructie van de 'voor beroep vatbare beslissing', zie Tak (1987-II), blz. 177. Wat de precieze consequenties van deze stap zijn en of dit haalbaar is, gaat het onderwerp van dit onderzoek te buiten.

23. Zie hierover uitgebreid hoofdstuk 11 , met name 11.4 .

24. Tak (1998), blz. 11, stelt zelfs dat in dat geval geen sprake kan zijn van een publieksechtelijke rechtshandeling - een publiekrechtelijke rechtshandeling is namelijk een publiekrechtelijke bevoegdheidsuitoefening -, maar dat sprake is van publiekrechtelijk feitelijk handelen. 
beroep ontvankelijk zijn, tenzij er andere gronden zijn om tot onbevoegdheid dan wel niet-ontvankelijkheid te oordelen. De bestuursrechter zal zich vervolgens moeten uitspreken over de bevoegdheid van het bestuursorgaan tot het nemen van de bestreden beslissing. Wanneer een (uitdrukkelijke dan wel impliciete) bevoegdheidsgrondslag ontbreekt, dient de nietigheid van het (pretense) besluit vast te worden gesteld door die rechter, bijvoorbeeld wegens strijd met het recht. ${ }^{25,26}$

Dit betekent dat een onderscheid moet worden gemaakt tussen het besluitbegrip in de zin van artikel 8:1 Awb, dus als ingang bij de bestuursrechter, en het besluitbegrip in de zin van artikel 1:3 lid $1 \mathrm{Awb}$, als bestuurshandeling. Op die wijze kan het legaliteitsvereiste strakker worden gehanteerd en hoeft de bestuursrechter niet terug te vallen op rechtsstatelijk gezien onjuiste constructies als het bestaan van bevoegdheidscheppende rechtsbeginselen.

In de zaak Nanne, waarin de Afdeling bestuursrechtspraak aannam dat het algemene rechtsbeginsel dat hetgeen onverschuldigd is betaald, kan worden terug. gevorderd, een bevoegdheid voor het bestuursorgaan schept, had de Afdeling mijns inziens dan ook als volgt moeten oordelen. De schriftelijke beslissing van het bestuursorgaan tot terugvordering was een besluit in de zin van artikel $8: 1$ Awb. De handeling had immers een beoogd rechtsgevolg; zij was gericht op terugvordering van het onverschuldigd betaalde. Voorts was het besluit genomen in het kader van een door het bestuursrecht beheerste verhouding. Daarnaast was de beslissing schriftelijk en afkomstig van een bestuursorgaan. Er was dus sprake van een pretens besluit, alleen ontbrak de (uitdrukkelijke) publiekrechtelijke bevoegdheid om dit besluit te nemen. Een impliciete bevoegdheid kon niet worden aangenomen, nu het immers een nieuwe verplichting betrof. ${ }^{27}$ Het nemen

25. Uiteraard kan in bepaalde gevallen het ontbreken van een publiekrechtelijke bevoegdheid ook leiden tot spontane vernietiging door de Kroon, zie bijvoorbeeld artikel 268 lid 1 Gemeentewet en artikel 261 lid 1 Provinciewet, althans dat is de heersende opvatting. Ook hier kan het ontbreken van de publiekrechtelijke bevoegdheid echter theoretisch tot problemen leiden: volgens genoemde artikelen kunnen slechts beshiten (of niet-schriftelijke beslissingen gericht op enig rechtsgevolg) worden vernietigd en aan een besluit dient een publiekrechtelijke bevoegdheid ten gronde te liggen, zo hebben we net gezien. Ook in dit geval kan dit probleem worden opgelost door het maken van een onderscheid tussen het besluit als bestuurshandeling en het besluit dat het onderwerp vormt van de toetsing door de Kroon in het kader van het repressief toezicht.

26. Ook Prins stipt in zijn rede De kapitein van Köpenick in de rechisstaat de vraag aan welke rechter een oordeel moet geven over een onbevoegd gegeven besluit. Hij beschrijft eerst de situatic, zoals die was in Frankrijk voor 1908. De Conseil d'État besliste tot dat jaar dat klachten tegen een nietige beschikking niet-ontvankelijk waren. Prins hekelde deze jurisprudentie, die volgens hem slechts een 'juridisch steekspel' was. 'Logisch vervolgd zou het standpunt van de conseil d'état trouwens ieder beroep op strijd met de wet tot niet-ontvankelijkheid moeten doemen, want ook een in beginsel bevoegde instantie is niet bevoegd om in strijd met de wet te handelen (...). De vraag zai (...) nu juist meestal zijn, of de overheid al dan niet verder is gegaan dan de wet haar toestond en, zo ja, in hoeverre deze overschrijding van bevoegdheid de daarmede besmette rechtshandeling van het beoogde effect berooft', Prins (1969), blz. 11. Zie ook Vegting (1954), blz. 260, waarnaar Prins verwijst. De Conseil d'État is in 1908 op de genoemde rechtsprakk teruggekomen.

27. Zic 9.3 . 
van het besluit was dus in strijd met het recht en dus diende de nietigheid van het besluit te worden vastgesteld door de bestuursrechter.

Ik vat het voorgaande samen: een bestuursorgaan mag niet handelen zonder dat het daartoe bevoegd is: het besluit als bestuurshandeling dient een bevoegdheidsgrondslag te hebben. Er zal echter een rechter moeten zijn, die kan vaststellen of de bevoegdheid tot het handelen, in casu het nemen van het besluit, aanwezig was. De meest geëigende rechter hiertoe is de bestuursrechter. Zolang het besluit de ingang bij de bestuursrechter vormt, leidt dit ertoe dat het beshit als ingang bij die rechter zo moet worden uitgelegd, dat deze rechter hierover kan oordelen, ook als de bevoegdheidsgrondslag voor het nemen van dat besluit als bestuurshandeling ontbreekt. Dit kan, door an het besluit als ingang bij de bestuarsrechter geen andere eisen te stellen, dan dat sprake moet zijn van een schriftelijke beslissing van een bestuursorgaan, inhoudende een rechtshandeling genomen in het kader van een door het bestuursrecht beheerste verhouding. De bestuursrechter zal vervolgens moeten oordelen dat, wanneer de bevoegdheid tot het nemen van dat besluit ontbreekt, er sprake is van strijd met de wet dan wel strijd met het recht. De conclusie mag in ieder geval niet zijn dat dan sprake is van een rechtshandeling naar burgerlijk recht.

\subsection{De publiekrechtelijke rechtsbetrekking als bevoegdheidscriterium}

Het zou echter beter zijn indien de bevoegdheidsafbakening tussen de burgerlijke rechter en de bestuursrechter niet wordt bepaald aan de hand van de vraag of een besluit voorligt, maar aan de hand van de vraag of sprake is van een publiekrechtelijke rechtsverhouding. Is hiervan geen sprake, dan dient de burgerlijke rechter competent te zijn en kunnen regels van privaatrecht worden toegepast; is wel sprake van een publiekrechtelijke rechtsbetrekking dan is de bestuursrechter bevoegd en moet het bestuursrecht worden toegepast. Leemtes in het bestuursrecht kunnen eventueel worden ingevuld door (analoge toepassing van) regels afkomstig uit het privaatrecht. Dit leidt ertoe dat zowel de burgerlijke als de bestuursrechter zijn bevoegdheid moet bepalen aan de hand van het fundamentum petendi. Ten opzichte van de huidige situatie lijkt dit een ware revolutie, en in bepaalde gevallen is het dit ook. Aan de andere kant is het momenteel al zo, dat de bestuursrechter op bepaalde terreinen zijn competentie (materieel gezien) reeds in die richting is aan het oprekken. ${ }^{28}$ Bovendien zijn er al bestuursrechters die, eveneens materieel gezien, dit criterium reeds moeten hanteren, bijvoorbeeld de

28. Zie bijvoorbeeld de publieketaakjurisprudentie en de jurisprudentie over het, zuiver schadebesluit en terugvordering. Zie hierover onder meer 9.4.3 en 9.4.4. 
ambtenarenrechter. ${ }^{29}$ Dit is van belang, nu de bestuurskamer van de rechtbank de ambtenarenrechter in eerste aanleg is en dus de rechters in deze kamer reeds bekend zijn met dit criterium.

Ook in de literatuur gaan stemmen op het besluit als ingang bij de bestuursrechter te vervangen door de publiekrechtelijke rechtsverhouding. ${ }^{30}$ Ook de algemene vergadering van de VAR sprak zich uit voor een dergelijke stap. De aan de vergadering voorgelegde stelling dat de bestuursrechter bij uitsluiting bevoegd dient te zijn dan wel te worden in geschillen omtrent onverschuldigde betaling in het kader van een publiekrechtelijke rechtsbetrekking, werd door de overgrote meerderheid onderschreven; een meerderheid was het eens met de stelling dat de bestuursrechter op langere termijn bij uitsluiting bevoegd dient te zijn dan wel te worden in alle geschillen uit publiekrechtelijke rechtsbetrekking ontstaan, waarbij werd aangetekend dat 'nogal wat' aanwezigen zich van stemming onthielden. ${ }^{31}$

Het belangrijkste probleem bij het afbakenen van de bevoegdheid van beide rechters aan de hand van de rechtsverhouding, is uiteraard te bepalen wanneer sprake is van een publiekrechtelijke rechtsverhouding. Ik heb in 11.4 een eerste definitie gegeven van deze rechtsverhouding; deze zal verder moeten worden uitgewerkt.

\subsection{Overheid, burgerlijke rechter en burgerlijk recht}

Het hanteren van het fundamentum petendi als criterium voor het afbakenen van de bevoegdheid van de burgerlijke en de bestuursrechter dient ook ertoe te leiden dat het gebruik van privaatrecht door de overheid binnen een publiekrechtelijke rechtsverhouding een halt wordt toegeroepen.

Momenteel is het zo dat de burgerlijke rechter veelal bevoegd is kennis te nemen van vorderingen door en tegen de overheid, mits deze bij hem worden ingekleed als 'privaatrechtelijke' vorderingen. Zeker wanneer het de overheid is die een vordering instelt tegen een burger, zal de rechter haar regelmatig ontvangen in haar vordering. Het feit dat de burgerlijke rechter bevoegd en eiser regelmatig ontvankelijk is, heeft een historische achtergrond. Ik heb deze uiteengezet in hoofdstuk 2. Doordat er in het begin van de negentiende eeuw geen specifieke

29. Het criterium voor de ambtenarenrechter is weliswaar niet of er sprake is van een publiekrechtelijke rechtsverhouding tussen de overheid en de ambtenaar, maar of er sprake is van een besluit of andere handeling waarbij een ambtenaar als zodanig belanghebbende is, artikel 8:1 lid 2 Awb. Zoals gezegd, materieel gezien komt dit mijns inziens neer op de vraag of tussen het bestuursorgaan en de ambtenaar een publiekrechtelijke rechtsverhouding bestaat.

30. Zie bijvoorbeeld Verheij (1999), blz. 67, waarbij moet worden angetekend dat hij 'er mordicus tegen (zou) zijn om morgen een wetsvoorstel in te dienen dat de bestuursrechter bevoegd makt kennis te nemen van alle geschillen, uit publiekrechtelijke rechtsbetrekkingen ontstaan'. Daarvan zijn naar zijn mening de gevolgen thans niet te overzien. Hij pleit dan ook voor wetenschappelijke theorievorming op grond waarvan de wetgever vervolgens overzienbare, beheersbare stappen kan zetten naar een ruimere bevoegdheid van de bestuursrechter, zie blz. 68 .

31. Verslag VAR (2000), blz. 93-94. 
rechter was die de burger rechtsbescherming kon bieden tegen de overheid, is de burgerlijke rechter deze taak op zich gaan nemen. Hiertoe had hij ook de mogelijkheid; artikel $165 \mathrm{Gw} 1815$ bevatte de bepaling dat 'alle twistgedingen over eigendom of daaruit voortspruitende regten, over schuldvordering of burgerlijke regten' bij uitsluiting tot de kennisneming van de rechterlijke macht behoorden. Bedoeling van dit artikel (en van het vrijwel gelijkluidende artikel 2 R.O.) was een onafhankelijke rechter bescherming te laten bieden tegen aantasting van het particulier vermogen, ook en vooral door de overheid. ${ }^{32}$ De Hoge Raad heeft deze bepalingen vervolgens ruim uitgelegd; alle genoemde twistgedingen behoren bij uitsluiting tot de kennisneming van de rechterlijke macht, 'zonder uitzondering tusschen welke personen, of door of jegens welke ligchamen die twistgedingen worden gevoerd', 33 Hiermee bood het artikel niet langer alleen rechtsbescherming tegen de overheid, maar ook voor de overheid. Ook de overheid kon nu een vordering instellen tegen een burger bij de burgerlijke rechter. ${ }^{34}$ Hierbij is verder van belang dat bestuursrecht grotendeels ontbrak en dat voor de burgerlijke rechter het privaatrecht het bekende recht was; hij was gewend dit recht toe te passen. Dit deed hij dan ook steeds meer wanneer een vordering tegen de overheid werd ingesteld. Dit leidde ertoe dat de overheid zich ook steeds meer ging beroepen op privaatrechtelijke verweren en zich ten slotte ook ging beroepen op privaatrechtelijke bevoegdheden. De burgerlijke rechter liet haar daartoe vervolgens de ruimte, ook in gevallen waarin de overheid op die wijze een publiekrechtelijk doel trachtte te bereiken. ${ }^{35}$ Mijns inziens is dit de 'bakermat' van het gebruik van privaatrecht door de overheid. Aan het einde van de negentiende eeuw is deze praktijk vervolgens van een theoretische grondslag voorzien: de gemene rechtsleer. ${ }^{36}$ Deze leer heeft vervolgens weer de praktijk beïnvloed. De moeizame en versnipperde uitbouw van de rechtsbescherming door bestuursrechtelijke rechtsgangen is er zowel een oorzaak als een gevolg van. Mede door deze historische ontwikkeling geldt momenteel nog steeds het (door mij bestreden $^{37}$ ) uitgangspunt, dat de overheid publiekiechtelijke belangen 'ook mag behartigen door gebruik te maken van haar in beginsel krachtens het privaatrecht toekomende bevoegdheden, ${ }^{38}$ Samengevat kan dus worden gezegd, dat het feit dat de overheid partij kan zijn in een geschil dat wordt beoordeeld door de burgerlijke rechter, ertoe heeft geleid dat de overheid gebruik kan maken van het privaatrecht, ook in een bestuursrechtelijke rechtsverhouding, althans dit feit heeft daartoe in belangrijke mate bijgedragen.

32. Zie hierover 2.2 .

33. HR 12 januari 1844 , W. 469 , Van den Honert, Gemengde zaken deel 2, no. 89 (Weduwe Zuithoff).

34. Zie 2.3.

35. Zie 2.6 .

36. Zie 5.2.1.

37. Zie hoofdstuk 11 , met name 11.4 .

38. HIR 26 januari 1990, NJ 1991, 393, m.nt. MS onder 394, AB 1990, 408, m.nt. G.P. Kleijn (Windmill). 
Het hiervoor gestelde, het feit dat voor de burgerlijke rechter het privaatrecht het bekende recht is en dat hij gewend is dit recht toe te passen, is nog steeds het geval. Dit leidt mijns inziens ook tot het hanteren van foute uitgangspunten door de burgerlijke rechter, zoals het uitgangspunt dat de overheid beschikt over privaatrechtelijke bevoegdheden. De conclusie dient dan ook te zijn dat de burgerlijke rechter niet langer bevoegd dient te zijn in een publiekrechtelijke rechtsbetrekking.

\subsection{Bestuursrechtspraak en de rechterlijke macht}

Het is echter de vraang of bij deze door mij voorgestane ontwikkeling de huidige organisatie van de verschillende rechters, en dan vooral van de bestuursrechtspraak, moet worden gehandhaafd. Momenteel is sprake van een historisch gegroeid, ${ }^{39}$ halfslachtig systeem, waarbij er een aantal 'hoogste' administratieve rechters is, ieder werkzaam op zijn eigen terrein met zijn eigen jurisprudentie, waarbij zij in de praktijk wel rekening houden met elkaars beslissingen, maar waarbij toch ook opmerkelijke verschillen zijn aan te wijzen ${ }^{40}$ Daamaast is er de 'eerste-aanleg'-rechter, namelijk de bestuurskamer bij de arrondissementsrechtbanken, die in beginsel als eerste instantie fungeert. Hierop bestaan overigens tal van uitzonderingen, waarbij deze eerste instantie wordt gepasseerd, ${ }^{41}$ maar de hoofdregel is momenteel dat een bestuursrechtelijk geschil kan worden beoordeeld in twee instanties. Deze bestuurskamers hebben overigens een belangrijke rol gespeeld bij de interpretatie van de Awb; zij waren immers de eerste aan wie op grote schaal geschillen werden voorgelegd, zodoende hebben zij door hun jurisprudentie de Awb 'mee gevormd'. Zij werden ingesteld in 1992, toen de Raden van Beroep en de Ambtenarengerechten bij de rechtbanken werden geïntegreerd. ${ }^{42}$ Op 1 januari 1994 traden de eerste twee tranches van de Awb in werking en begonnen de bestuurskamers hun werkzaamheden als algemene bestuursrechtelijke beroepsrechter. Hiermee was de eerste fase van de herziening van de rechterlijke organisatie voltooid.

Door het onderbrengen van de bestuurskamers bij de arrondissementsrechtbanken is er een splitsing ontstaan tussen de bestuursrechters die tot de rechterlijke macht behoren, namelijk de bestuurskamers bij de rechtbanken, ${ }^{43}$ en de bestuursrechters die geen deel uitmaken van de rechterlijke macht, waaronder de

39. Zie de hoofdstukken 2 en 3.

40. Zo zijn er bijvoorbeeld verschillen te zien in de wijze waarop de bestuursrechters tot een besluit komen in hun jurisprudentie betreffende het zuivere schadebesluit, zie 9.3.2.

41. Zo oordeelt het CBE veelal in eerste en enige aanleg, evenals de ABRvS in procedures inzake de Algemene wet milieubeheer.

42. De Wet voorintegratic, zie 3.4.4.

43. Overigens maakte een aantal 'bestuurs'rechters al deel uit van de rechterlijke macht, bijvoorbeeld de belastingrechter (de belastingkamers bij de gerechtshoven en de derde kamer van de Hoge Raad) en de bijstandrechter onder de oude ABW. 
Afdeling bestuursrechtspraak van de Raad van State, de Centrale Raad van Beroep en het College van Beroep voor het bedrijfsleven. Oorspronkelijk was het de bedoeling dat deze scheiding niet zou blijven bestaan; de derde fase van de herziening van de rechterlijke organisatie zou de voltooiing van het stelsel van bestuursrechtelijke rechtsbescherming omvatten, waarbij het hoger beroep en (eventueel) cassatie in de administratieve rechtspraak definitief zouden worden geregeld. Het meest voor de hand liggend was dat hiertoe bestuurskamers zouden worden ingesteld bij de gerechtshoven en bij de Hoge Raad, zodat de hele bestuursrechtspraak zou zijn ondergebracht bij de rechterlijke macht. Deze ontwikkeling is echter bevroren in 1997. De (officiële) reden hiervoor was, dat een aantal andere projecten dat van invloed was op de structuur binnen de magistratuur, in gang was gezet en de uitkomst hiervan naar de mening van de minister diende te worden afgewacht. ${ }^{44}$

Deze bevriezing is door verschillende auteurs toegejuicht. Het voornaamste punt van kritiek op het onderbrengen van het hoger beroep en cassatie bij respectievelijk de hoven en de Hoge Raad was dat hierdoor de momenteel bij de bestuursrechters bestaande specialisatie verloren zou gaan. ${ }^{45}$ Ik deel deze kritick niet. In de eerste plaats zie ik niet in waarom eventueel bestaande expertise niet behouden zou kunnen blijven. Dit zou bijvoorbeeld kunnen worden bereikt door voor bepaalde terreinen gespecialiseerde kamers in te stellen bij de gerechtshoven, zoals nu ook reeds het geval is op bepaalde terreinen van de civiele rechtspraak, zie bijvoorbeeld de pachtkamer van het Arnhemse Hof en de ondernemingskamer van het Hof Amsterdam. In de tweede plaats zal wel moeten worden aangetoond dat behoud van de bestaande specialisatie door scheiding van rechtsgebieden noodzakelijk is. ${ }^{46}$ Hiervan is vooralsnog niet iedereen overtuigd. De Haan voert terecht aan dat de integratie van verschillende terreinen in eerste aanleg, bij de bestuurskamers van de rechtbanken dus, ook goed is verlopen. 'Waarom zou dit in hoger beroep dan anders liggen?', zo vraagt hij zich af. ${ }^{47}$

Uiteraard moeten er goede redenen zijn om de herziening op dit terrein voort te zetten. Deze zijn er ook. In de eerste plaats kan de eenheid binnen het bestuursrecht beter worden bereikt. Hier zal uiteraard een cassatiestelsel een belangrijke

44. Brief van de minister van Justitie met betrekking tof de herziening rechterlijke macht, Tweede Kamer 1996-1997, 25 425, nr. 1, blz. 11-12.

45. Zie bijvoorbeeld het preadvies van Loeb voor de NJV, Loeb (1997). Ook de vergadering van de NJV sprak zich uit tegen de derde fase van de herziening van de rechterlijke organisatie, zie Polak (1997).

46. Zie bijvoorbeeld de mede-preadviseurs van, Loeb, Van den Haak en De V́ries Robbé, Mogelijk dat een dergelijke aparte kamer bij een bepaald hof zin heeft in gevallen waarin sprake is van bijzonder ingewikkelde materie, die gespecialiseerde kennis vereist, zie Van den Haak (1997), blz. 137. Een veel gegeven voorbeeld is het terrein van het economisch ordeningsrecht, dat momenteel wordt 'bestreken' door het CBB. Op dit terrein speelt naast de zeer gespecialiseerde Nederlandse regelgeving ingewikkelde Europese regelgeving een belangrijke rol. Dit zou een aparte kamer kunnen rechtvaardigen. Zie De Vries Robbé (1997), blz. 179 en. Van den Haak. (1997), blz. 141.

47. De Haan (1998-III), blz. 68. 
rol spelen. ${ }^{48}$ Vanzelfsprekend dient het mogelijk te blijven om rekening te houden met het feit dat men te maken heeft met bijzondere terreinen binnen het bestuursrecht. Bijzondere terreinen. rechtvaardigen uiteraard bijzondere regels; onnodige verschillen moeten echter worden voorkomen. Verder kan door integratie bestaande expertise makkelijker worden uitgewisseld dan nu het geval is; speciale overlegstructuren zoals die nu bestaan tussen de hoogste bestuursrechters, waarin onderling de jurisprudentie wordt afgestemd, zijn dan niet meer nodig.

In de tweede plaats zijn sommige leerstukken grensoverschrijdend. Een aantal problemen doet zich zowel in het burgerlijk recht als in het bestuursrecht voor. In bepaalde situaties bestaat er geen goede reden om die problemen op deze terreinen verschillend op te lossen. Een voorbeeld hiervan is het terrein van de schadevergoeding. Als onrechtmatig schade is veroorzaakt, moet deze worden vergoed. Hierbij zal het zo moeten zijn dat het in beginsel geen verschil maakt of deze schade is veroorzaakt in een publiekrechtelijke of in een privaatrechtelijke rechtsverhouding. Ook voor aansprakelijkheid zal dit in beginsel het geval zijn. Op deze terreinen heeft de burgerlijke rechter in de loop van de tijd een grote expertise opgebouwd; er kunnen dan ook goede redenen bestaan om aansluiting te zoeken bij de jurisprudentie van die rechter. De bestuursrechter heeft voorts in een aantal gevallen er blijk van gegeven (te) weinig kennis te hebben van het aansprakelijkheids- en schadevergoedingsrecht. Dit heeft er een aantal maal toe geleid dat een betrokkene bij de bestuursrechter (onaanvaardbaar) veel slechter af was dan hij in een vergelijkbaar geval (als geen sprake was geweest van een bestuursrechtelijke rechtsverhouding) zou zijn geweest bij de burgerlijke rechter, terwijl voor dit verschil geen rechtvaardiging is te vinden in het feit dat er sprake was van een publiekrechtelijke rechtsverhouding. ${ }^{49}$ Op deze terreinen zou uitwisseling van expertise vruchtbaar kunnen zijn. Momenteel wordt reeds binnen de rechtbanken gebruik gemaakt van 'in-house'-kennis; bepaalde (bestuursrechtelijke) geschillen, waarbij zich in het civielrecht tot ontwikkeling gekomen vraagstukken voordoen, worden behandeld door een zogenaamde combi-kamer, waarin naast bestuursrechters ook een rechter met een civielrechtelijke achtergrond zitting heeft. Hier werpt de integratie dus al haar vruchten af. Deze wisselwerking kan overigens ook omgekeerd werken: als sprake is van een privaatrechtelijke rechtsverhouding, is de burgerlijke rechter bevoegd en moet privaatrecht worden toegepast. Als nu een privaatrechtelijk geschil bestaat waarbij de overheid is betrokken, moet de rechter rekening houden met het feit dat de overheid een van de partijen is. Hierdoor wordt het privaatrecht 'gekleurd'. In die gevallen zou een bestuursiechter zitting kunnen hebben in de civiele kamer, waardoor gebruik kan worden gemaakt van de binnen de rechterlijke macht bestaande bestuursrechtelijke expertise.

48. Gelet op de te verwachten belasting van de Hoge Raad als deze ook over bestuursrechtelijke geschillen moet gaan oordelen, is van verschillende zijden gepleit voor het invoeren van een verlofstelsel, zie bijvoorbeeld De Vries Robbé (1997), blz. 190-197 en De Haan (1998-III), blz. 69.

49. Zie bijvoorbeeld CRvB 11 november 1999, JB 1999, 306, m.nt. G.E. van Maanen. Van Maanen trekt in zijn noot dan ook fel van leer tegen deze beslissing. Zie verder hierover ook Hartlief (2000-I), blz. 189, die verdere voorbeelden uit de rechtspraak vermeldt. 
Ten slotte - en dit is misschien wel het belangrijkste punt - moet rechtsbescherming, ook (en misschien wel vooral) tegen de overheid, worden geboden door een rechter. Een vereiste hiervoor is naar mijn mening, dat deze rechter deel uitmaakt van de rechterlijke macht, waarbij de onafhankelijkheid en onpartijdigheid van de rechter een belangrijk aspect is. Momenteel maken de meeste hoogste bestuursrechters geen deel uit van de rechterlijke macht. De vraag is dan of dit een probleem is, nu voor benoeming als raadsheer in een van deze colleges veelal dezelfde eisen worden gesteld als voor benoeming als rechter.

Onafhankelijkheid en onpartijdigheid is dus een belangrijk vereiste. Bij deze onafhankelijkheid en onpartijdigheid kunnen vragen worden gesteld waar het de Afdeling bestuursrechtspraak van de Raad van State betreft. ${ }^{50}$ Dit heeft (uiteraard) te maken met de historische functie van de Raad van State als hoog college van staat. De Raad van State heeft immers niet alleen een rechtsprekende, maar ook een adviserende taak. Dit leidt ertoe dat de leden van de Raad van State, de staatsraden, mede worden benoemd op grond van hun politieke kleur, terwijl zij ook vaak een bestuurlijke achtergrond hebben en juist vanwege deze achtergrond en hun kennis van het bestuurlijke métier worden binnengehaald. Voorts worden ook niet-juristen benoemd als staatsraden. ${ }^{51}$ Brenninkmeijer stelt dan ook de vraag of '(v)alt te rechtvaardigen dat een belangrijk deel van de bestuursrechtspraak (...) opgedragen is aan een hoog college van staat waarvan de leden mede langs partijpolitieke lijnen geselecteerd worden' ${ }^{52}$ Verder speelt ook de 'Procolaproblematiek' een rol; nu de Raad van State zowel een rechtsprekende als een adviserende taak heeft, is het mogelijk dat hij geroepen wordt als rechter in een

50. Vgl. Corstens (2001), blz. 124.

51. Bij de invoering vañ de Wet arob en de dasmee gepaard gaande wijziging van de Wet RvS is de vraag of de leden van de Afdeling rechtspraak en de staatsraden in buitengewone dienst juridisch gekwalificeerd moesten zijn, uitdrukkelijk aan de orde gekomen. De regering vond toen op principiêle gronden van wel; er was immers sprake van rechtspraak en dit diende te geschieden door juristen. Vanuit de Tweede Kamer werd echter een aantal amendementen ingediend om de in het wetsvoorstel neergelegde eis van juridische kwalificatie te laten vervalien. Voor de regering was dit een zodanig principiele kwestie, dat de minister van Justitie hiertegen een zwaar middel inzette; hij dreigde met het aanhouden van verdere behandeling voor nader beraad en liet doorschemeren dat als de Kamer vasthield aan het laten vallen van de eis van juridische kwalificatie, het mogelijk was - een 'eventualiteit' - dat het wetsontwerp zou worden ingetrokken, zie PG arob, blz. 483. Hierop haalde de Kamer bakzeil en uiteindelijk werd deze eis neergelegd in artikel 65 Wet RvS. Zie over de parlementaire beraadslagingen omtrent dit artikel PG arob, blz. 464-493. Toen vervolgens de eerste twee tranches van de Awb in werking traden werd ook de Wet RvS gewijzigd, waarbij onder andere de Afdeling bestuursrechtspraak de Afdeling rechtspraak verving. Artikel 29 lid 2 Wet RvS bepaalt dat bij de Afdeling bestuursrechtspraak slechts 'de voorzitter van de Afdeling, degene die hem vervangt, degene die zitting heeft in een enkelvoudige kamer en de meerderheid van de leden van een meervoudige kamer' jurist moeten zijn. De memorie van toelichting geeft slechts als argument dat de eis van het zijn van jurist voor de leden van de andere afdelingen niet geldt en dat de staatsraden, ook die in buitengewone dienst, algemeen inzetbaar moeten zijn, dus ook binnen de Afdeling bestuursrechtspraak, zie PG Awb II, blz. 530-531. Door dit weinig principiele argument is nu dus de eis van het zijn van jurist vervallen.

52. Brenninkmeijer (1997), blz. 1025. 
geschil een wet te moeten beoordelen, waarover hij in een eerdere fase heeft geadviseerd. Het Europees Hof voor de rechten van de mens heeft in de Procolazaak de staf gebroken over een vergelijkbare situatie in Luxemburg; er was geen sprake van een onafhankelijke en onpartijdige rechter, zoals werd vereist door artikel 6 EVRML. ${ }^{53}$ De twijfel of de situatie in Nederland tot een zelfde conclusie kan leiden, is tot op heden niet weggenomen. Inmiddels is voor het Europees Hof voor de rechten van de mens een zaak aanhangig waarin de vraag naar de onafhankelijkheid en onpartijdigheid van de Raad van State als rechter aan de orde is. ${ }^{54}$

Naar mijn mening moet de Raad van State meer worden gezien als een (weliswaar vrij onafhankelijk) verlengstuk van het bestuur dan als onafhankelijke rechter. Bij een college, voor een belangrijk deel bestaande uit mensen afkomstig uit de bestuurlijke praktijk en (mede) op partijpolitieke achtergrond geselecteerd, zal snel de neiging kunnen bestaan de zaken vooral vanuit de optiek van het bestuur te bekijken. Vanuit rechtsbeschermingsoogpunt is dit ongewenst. Zonder hier verder uitgebreid op in te gaan - dit gaat immers het onderwerp van het onderzoek te buiten - ben ik van mening dat de taken van de verschillende afdelingen van deze Raad meer dienen te worden afgestemd op zijn historische taak als adviseur en als controleur van het bestuur, en niet liggen op het terrein van het bieden van rechtsbescherming. ${ }^{55,56}$ Als de gehele bestuursrechtspraak wordt ondergebracht bij de rechterlijke macht, dan staat in ieder geval buiten kijf dat wordt voldaan aan de vereisten van artikel 6 EVRM.

Het onderbrengen van de bestuursrechtspraak bij de rechterlijke macht zou verder als voordeel kunnen hebben dat het hanteren van het criterium 'publiekrechtelijke rechtsverhouding' aanzienlijk zou kunnen worden vereenvoudigd, althans dat probleemgevallen eenvoudig tot een oplossing kunnen worden gebracht. In gevallen waarin het niet aanstonds duidelijk is of sprake is van een publiekrechtelijke rechtsverhouding, zou de beslissing daarover bijvoorbeeld kunnen worden overgelaten aan een conflictenkamer, een kamer bestaande uit zowel civiele als bestuursrechters, die tezamen moeten beslissen of het voorliggende geval moet worden

53. EHRM 28 september 1995, Pub ECHR, Series A vol. 326, NJ 1995, 667, m.nt. EAA, AB 1995, 588, m.nt. ICvdV, JB 1995, 251, m.nt. red.

54. EHRM 3 mei 2001, NJB 2001, afl. 25, nr. 26, blz. 1167-1168. Het Hof heeft de vraag of de Raad van State een onafhankelijk en onpartijdig gerecht is voor commentaar voorgelegd aan de Nederlandse regering en zijn oordeel op dit punt aangehouden.

55. Vgl. Tak (1998), blz. 23.

56. De scheiding tussen doelmatigheids- en rechtmatigheidscontrole zou hier een rol kunnen spelen. De rechter zou dan de rechtmatigheid van het overheidsoptreden hebben te beoordelen, de Raad van State de doelmatigheid. In het kader van de doelmatigheidstoets zou kunnen worden gedacht aan het overnemen van een aantal taken van de Kroon, zoals de spontane vernietiging, en een toezichtstaak. Daarnaast zouden betrokkenen besluiten van bestuursorganen aan de Raad moeten kunnen voorleggen, waarbij deze de gemaakte beleidskeuzes kan controleren. De bestuursrechter dient dan het overheidsoptreden op rechtmatigheid te toetsen. Hiermee wordt voorkomen dat de rechter op de stoel van het bestuur gaat zitten. 
behandeld door de civiele of door de bestuurskamer. Uiteraard zou dit ook mogelijk zijn wanneer de bestuursrechters niet over de volle linie deel gaan uitmaken van de rechterlijke macht, de coördinatie lijkt mij in dat geval aanzienlijk moeilijker.

De conclusie luidt dat de bestuursrechtspraak over de gehele linie moet worden ondergebracht bij de rechterlijke macht. Hierbij zullen de bestuursrechters veel meer moeten terugkeren naar de oorspronkelijke uitgangspunten van het bestuursprocesrecht. In de praktijk blijken (een aantal van) die uitgangspunten te zijn verwaterd..$^{57}$

\subsection{Bevoegdheid van de burgerlijke rechter en artikel $112 \mathrm{Gw}$}

De bestuursrechtspraak moet dus worden ondergebracht bij de rechteriijke macht, waartoe bij de gerechtshoven en bij de Hoge Raad bestuurskamers moeten worden ingesteld. Deze kamers moeten een algemene bevoegdheid krijgen te oordelen over geschillen, ontstaan in een publiekrechtelijke rechtsverhouding. De bevoegdheid van de burgerlijke rechter moet dan worden beperkt tot geschillen ontstaan uit een privaatrechtelijke rechtsverhouding. De aard van de rechtsverhouding wordt dan dus bepalend voor de bevoegdheid van beide rechters. Dit betekent dat voor beiden het fundamentum petendi beslissend wordt. De vraag is of dit mogelijk is binnen het huidige grondwettelijke stelsel.

Ik heb dit stelsel besproken in 9.4.2. Ik zal hier nogmaals kort de regeling weergeven, zoals die is neergelegd in artikel $112 \mathrm{Gw}$. Dit artikel bepaalt:

"1. Aan de rechterlijke macht is opgedragen de berechting van geschillen over burgerlijke rechten en over schuldvorderingen.

2. De wet kan de berechting van geschillen die niet uit burgerlijke rechtsbetrekkingen zijn ontstaan, opdragen hetzij aan de rechterlijke macht, hetzij aan gerechten die niet tot de rechterlijke macht behoren. De wet regelt de wijze van behandeling en de gevolgen van de beslissingen'.

Op grond van lid 1 is de rechterlijke macht - lees in het huidige stelsel: de burgerlijke rechter - bevoegd met betrekking tot geschillen over burgerlijke rechten en over schuldvorderingen, waarbij het niet uitmaakt in welke rechtsverhouding deze geschillen zijn ontstaan. Geschillen met betrekking tot burgerlijke rechten en schuldvorderingen, ontstaan in een publiekrechtelijke rechtsverhouding kunnen ook worden opgedragen aan gerechten die niet tot de rechterlijke macht behoren. Is dit gebeurd, dan is er dus sprake van concurrerende rechtsmacht. Geschillen die uit een publiekrechtelijke rechtsverhouding zijn ontstaan en die geen burgerlijke rechten of een schuldvordering betreffen, kunnen ofwel aan de rechterlijke macht ofwel aan een gerecht dat niet tot de rechterlijke macht behoort worden opgedragen.

57. Zie Bollen (2000), blz. 311 en 1.6 . 
Als de bestuursrechters deel gaan uitmaken van de rechterlijke macht, dan kunnen zij zonder verdere wettelijke opdracht als wordt bedoeld in het tweede lid van artikel 112 geschillen over burgerlijke rechten en over schuldvorderingen gaan berechten. Volgens De Haan ligt het grootste voordeel van integratie dan ook "besloten in de mogelijkheid die zich dan pas gaat voordoen om alle rechtsmacht inzake bestuursrechtelijke geschillen toe te dienen aan de administratieve kamers van rechtbanken, gerechtshoven en Hoge Raad'. ${ }^{58}$ Wel zal dan nog de verdeling van de rechtsmacht tussen de burgerlijke en de bestuurskamers moeten worden geregeld. Hierbij dient de burgerlijke rechter bevoegd te zijn met betrekking tot geschillen over burgerlijke rechten en schuldvorderingen, ontstaan uit burgerlijke rechtsbetrekkingen, in een privaatrechtelijke rechtsverhouding dus, en de bestuursrechter met betrekking tot geschillen over burgerlijke rechten en schuldvorderingen, ontstaan in een publiekrechtelijke rechtsverhouding. Hiermee zou de aanvullende rol die de burgerlijke rechter de burgers in het verleden heeft geboden (en door het ontbreken van administratiefrechtelijke rechtsgangen ook heeft moeten bieden), zijn uitgespeeld; de rechtsbescherming tegen de overheid komt dan geheel in handen van de bestuursrechter. De meest logische plaats voor een dergelijke regeling voor de verdeling van rechtsmacht lijkt mij de Wet op de rechterlijke organisatie. Op zich kan deze wijziging worden doorgevoerd zonder dat een aanpassing van artikel $112 \mathrm{Gw}$ noodzakelijk is. Beter zou het echter zijn om het tweede lid van dit artikel aan te passen aan de dan ontstane situatie, waarbij dit tweede lid nog slechts een regeling dient te bevatten omtrent de berechting van publiekrechtelijke geschillen die niet over burgerlijke rechten of schuldvorderingen gaan. ${ }^{59}$ De berechting van die geschillen kan dan worden opgedragen hetzij aan de rechterlijke macht, waarbij uiteraard opdracht aan de bestuurskamers voor de hand ligt, hetzij aan gerechten die niet tot de rechterlijke macht behoren. In dat laatste geval kan worden gedacht aan de Raad van State.

Het feit dat de bestuursrechters publiekrechtelijke geschillen berechten, en wel exclusief, leidt er dus toe dat de burgerlijke rechter op dat terrein onbevoegd is, althans zich onbevoegd dient te verklaren. Dit is niet in strijd met artikel 112 $\mathrm{Gw}$; het is immers nog steeds de rechterlijke macht die het geschil berecht.

De bestuursrechters dienen dus over de gehele linie deel te gaan uitmaken van de rechterlijke macht. Op dit moment is dit nog niet het geval. Het is de vraag of in de huidige situatie, waarbij dus het grootste deel van de bestuursiechters geen deel uitmaakt van de rechterlijke macht, het toekennen van exclusieve rechtsmacht aan

58. De Haan (1998-III), blz. 67

59. Enkele voorbeelden van deze geschillen zijn geschillen met betrekking tot verkiezingsafspraken, zie HR 26 maart 1971, NJ 1971, 434, AB 1971, 135, m.nt. DJ. Veegens (Verkiezingsafspraak Elsloo) en geschillen met betrekking tot gemeentelijke herindelingen, zie HR 19 november 1999 . NJ 2000, 160, m.nt. TK, AB 2000, 387, m.nt. ThGD, JB 2000, 1, m.nt. R.J.N. S. (TegelenProvincie Limburg). In dit laatste arrest nam de Hoge Raad overigens aan dat de burgerlijke rechter bevoegd was kennis te nemen van het geschil en lijkt hij hiermee terug te komen op de in het arrest Verkiezingsafspraak Elsloo neergelegde jurisprudentie, zie 2.6. 
de (niet tot de rechterlijke macht behorende) bestuursrechter wanneer sprake is van een publiekrechtelijke rechtsverhouding, in strijd is met artikel $112 \mathrm{Gw}$.

De wetgever zal in dat geval de berechting van die geschillen opdragen aan de bestuursrechter, of beter: aan een bestuursrechter. De burgerlijke rechter blijft dan echter ook bevoegd, dus naast de bestuursrechter, wanneer sprake is van een geschil over burgerlijke rechten of schuldvorderingen. $\mathrm{Er}$ is dan dus sprake van een concurrerende bevoegdheid. Hiermee is niet gezegd dat de burgerlijke rechter gebruik moet maken van zijn bevoegdheid; de burgerlijke rechter kan er voor kiezen zich terug te trekken middels een onbevoegdverklaring indien een (naar zijn mening met voldoende rechtswaarborgen omklede) bestuursrechtelijke rechtsgang openstaat of heeft opengestaan. ${ }^{60}$ De burgerlijke rechter kan daar bij de huidige tekst van artikel $112 \mathrm{Gw}$ echter niet toe worden verplicht. ${ }^{61}$ Toekenning van exclusieve rechtsmacht, in de zin dat de burgerlijke rechter niet meer bevoegd is, zou dus in strijd zijn met artikel $112 \mathrm{Gw}$.

De conclusie is dat een onbevoegdverklaring door de burgerlijke rechter zelf niet in strijd is met artikel $112 \mathrm{Gw}$; exclusieve rechtsmachttoedeling door de wetgever aan de bestuursrechter wanneer sprake is van een geschil over burgerlijke rechten of over een schuldvordering is dat in het huidige stelsel wel.

\subsection{Conclusie}

In de vorige hoofdstukken heb ik geconcludeerd dat voor een terugvordering die plaatsvindt binnen een publiekrechtelijke rechtsbetrekking altijd een uitdrukkelijke wettelijke grondslag aanwezig moet zijn; over privaatrechtelijke bevoegdheden beschikt de overheid niet. Deze conclusie heb ik. vervolgens veralgemeniseerd: binnen een publiekrechtelijke rechtsbetrekking beschikt de overheid niet over privaatrechtelijke bevoegdheden. Het uitgangspunt van de burgerlijke rechter is echter een ander. In het Windmill-arrest overwoog de Hoge Raad immers dat de overheid in beginsel beschikt over haar krachtens het privaatrecht toekomende bevoegdheden, zelfs wanneer 'haar bij een publiekrechtelijke regeling ter behartiging van (die) belangen bepaalde bevoegdheden zijn toegekend'. Deze opvatting is historisch te begrijpen en is (mede) een consequentie van het feit dat de rechtsbescherming tegen de overheid lange tijd slechts door de burgerlijke rechter kon worden geboden, terwijl die rechter door de versnipperde ontwikkeling van de bestuursrechtspraak ook binnen het huidige stelsel aanvullende rechtsbescherming moet kunnen blijven bieden. Deze situatie is echter niet gewenst. Geschillen met

60. Dit heeft de burgerlijke rechter in het verleden dan ook een aantal maal gedaan; ik wijs slechts op HR 13 november 1941, NJ 1942, 172, AB 1942, 485 (Ambtenarenwetarrest). Zie verder uitgebreider 4.3.2.

61. Op dit moment is het: zo, dat de burgerlijke rechter zich wel bevoegd acht, maar eiser niet ontvankelijk verklaart wanneer een met voldoende rechtswaarborgen omklede bestuursrechtelijke. rechtsgang openstaat of heeft opengestaan. zie hierover uitgebreider 4.3.3 en 4.3.4. Op deze regel bestaan uitzonderingen, bijvoorbeeld de jurisprudentie inzake het zuiver schadebesluit, zie 9.6.1. 
de overheid zouden dan ook exclusief tot de competentie van de bestuursrechter moeten behoren. Dit kan worden gerealiseerd door als rechtsingang bij zowel de burgerlijke als de bestuursrechter het fundamentum petendi te hanteren, de aard van de rechtsbetrekking. Dit zou betekenen dat de bestuursrechter exclusief bevoegd is wanneer sprake is van een publiekrechtelijke rechtsbetrekking. Hierbij dient de besturursrechter wel deel te gaan uitmaken van de rechterlijke macht; de derde fase van de herziening van de rechterlijke organisatie dient te worden doorgevoerd door het instellen van bestuurskamers bij de gerechtshoven en de Hoge Raad. Wanneer dat is gebeurd, bestaat voor het hanteren van het fundamentum petendi als rechtsingang geen grondwettelijke belemmering.

Zolang deze situatie niet is gerealiseerd, ben ik van mening dat in de gevallen waarin de bevoegdheid van de bestuursrechter afhankelijk is van het voorliggen van een besluit, aan het besluitbegrip voor zover dit dient als rechtsingang bij de bestuursrechter andere eisen dienen te worden gesteld dan aan het besluitbegrip als bestuurshandeling. Het feit dat een bevoegdheidsgrondslag ontbreekt voor het bestuursoptreden, dient er niet toe te leiden dat de bestuursrechter niet mag oordelen over het geschil; deze rechter zou juist moeten kunnen vaststellen dat de bevoegdheid ontbreekt en dus dat het bestuursoptreden in strijd is met de wet of met het recht. 


\section{SAMENVATTING}

Dit boek bevat het verslag van het onderzoek naar onverschuldigde betaling door de overheid. Centraal stond de vraag wanneer de overheid onverschuldigd gedane betalingen mag terugvorderen. Een doel van het onderzoek was te bekijken of, en zo ja in hoeverre, de overheid bij terugvordering gebruik mag maken van het privaatrecht, zowel in de situatie dat er een publiekrechtelijke terugvorderingsmogelijkheid bestaat als in de situatie dat deze ontbreekt. Tevens ben ik nagegaan of het mogelijk is om met behulp van het antwoord op deze vraag een meer algemene conclusie te trekken met betrekking tot het gebruik van privaatrecht door de overheid: kunnen bepaalde door mij met betrekking tot het gebruik van privaatrecht bij terugvordering getrokken lijnen worden doorgetrokken naar de vraag of de overheid in het algemeen gebruik mag maken van het privaatrecht? Hierbij dient te worden bedacht dat de conclusies met betrekking tot de meer algemene vraag naar het gebruik van privaatrecht door de overheid niet hun grond vinden in een alomvattend onderzoek op alle terreinen waarop de overheid optreedt. Ik heb dit zo veel mogelijk ondervangen door het onderzoek naar de terugvordering in een breder kader te plaatsen door ook de algemene geschiedenis en theorie van het gebruik van het privaatrecht door de overheid bij het onderzoek. te betrekken. Aangezien het gebruik van het privaatrecht door de overheid mede een gevolg was van de rol die de burgerlijke rechter speelde en van de ontwikkeling van de bestuursrechtspraak, heb ik in het onderzoek ook de vraag betrokken welke rechter het overheidsoptreden dient te beoordelen, primair bij terugvordering, maar ook daarbuiten.

De algemene historische en theoretische ontwikkelingen heb ik beschreven in deel I van het onderzoek. De historische beschrijving begint rond 1815. In die tijd ontbrak administratieve rechtspraak vrijwel geheel, terwijl ook het bestuursrecht onderontwikkeld was, zeker vergeleken met het privaatrecht. Vooral het ontbreken van administratieve rechtspraak heeft ertoe geleid dat de burgerlijke rechter de burgers rechtsbescherming is gaan bieden tegen de overheid, voor zover artikel $165 \mathrm{Gw} 1815$ en later artikel 2 R.O. en de door deze rechter aan deze artikelen gegeven uitleg hem daartoe de ruimte gaven. Nadat aanvankelijk niet geheel duidelijk was hoe deze artikelen moesten worden uitgelegd, heeft de Hoge Raad in 1915 niet de aard van de rechtsbetrekking, het fundamentum petendi, maar het. voorwerp van het geschil, het objectum litis, doorslaggevend geacht voor de bevoegdheid van de burgerlijke rechter. Sinds ongeveer 1840 is ook de overheid gebruik gaan maken van de rechtsgang naar de burgerlijke rechter. Dit heeft ertoe geleid dat ook in verboudingen die tegenwoordig als publiekrechtelijk zouden worden betiteld, het gebruik van privaatrecht door de overheid is geaccepteerd. De burgerlijke rechter was namelijk van nature geneigd het hem bekende privaatrecht 
toe te passen, ook als de overheid bij de rechtsverhouding was betrokken. Hierbij speelde mee dat publiekrecht grotendeels ontbrak. Dit heeft er bijvoorbeeld toe geleid dat ook bij terugvordering het privaatrecht een rol kon spelen. Deze praktijk heeft later een theoretisch onderbouwing gekregen met de gemene rechtsleer. Volgens deze leer was het privaatrecht het altijd en voor iedereen geldende recht, dus ook voor de overheid, tenzij er een publiekrechtelijke uitzondering op bestond.

Met de opkomst van de administratieve rechtspraak werden de mogelijkheden voor de burger om bij de burgerlijke rechter een vordering in te stellen tegen de overheid beperkter. Zo was het feit dat een bestuursrechtelijke rechtsgang bestond voor de burgerlijke rechter veelal reden om het geschil niet inhoudelijk te beoordelen, onder meer door zichzelf onbevoegd of eiser in diens vordering nietontvankelijk te verklaren. De ontwikkeling van de administratieve rechtspraak verliep echter stroef. Pogingen om een algemene regeling van bestuursrechtspraak te maken, strandden. Sinds het begin van de twintigste eeuw zien we dan ook de uitbouw van deze rechtspraak via regelingen op specifieke terreinen, waarbij specifieke rechters competent zijn. Dit begon met de Centrale Raad van Beroep als socialezekerheidsrechter. Deze versnipperde uitbouw van de rechtsbescherming tegen de overheid heeft ertoe geleid dat de burgerlijke rechter altijd aanvuliende rechtsbescherming is blijven bieden, ook nadat pogingen om een meer algemene regeling van bestuursrechtelijke rechtsbescherming te maken, succes hadden.

Kan de burger in een geschil met de overheid dus steeds minder gebruik maken van het privaatrecht en van de rechtsgang naar de burgerlijke rechter, voor de overheid werden daarentegen de mogelijkheden om gebruik te maken van het privaatrecht steeds ruimer. Was het onder de gemene rechtsleer nog zo dat het gebruik van het privaatrecht werd begrensd indien er publiekrecht voorhanden was, onder de tweewegenleer had de overheid zelfs in dat geval de mogelijkheid om te kiezen voor het gebruik van privaatrecht. Wel werden allengs meer en meer publiekrechtelijke normen ingebouwd in de privaatrechtelijke weg wanneer de overheid koos voor het volgen van deze weg. Hierdoor ontstond volgens een antal auteurs een gemengd recht: de gemengde rechtsleer. Deze leer lijkt het uitgangspunt te zijn geweest in de twee grote codificaties van de twintigste eeuw, het BW en de Awb. Doordat steeds meer publiekrechtelijke elementen werden betrokken bij de vraag of de overheid gebruik mocht maken van het privaatrecht, werd uiteindelijk de tweewegenleer als zodanig verlaten ten faveure van de doorkruisingsleer. Volgens deze leer is het antwoord op de vraag of de overheid gebruik mag maken van het privaatrecht in een concreet geval afhankelijk van het antwoord op de vraag of door het gebruik van dat privaatrecht een publiekrechtelijke regeling wordt doorkruist. Is dat het geval, dan is de privaatrechtelijke weg niet toegestaan. Ook deze leer is bekritiseerd, onder meer omdat het uitgangspunt van deze leer is dat de overheid. beschikt over haar in beginsel krachtens het privaatrecht toekomende bevoegdheden. Volgens de door sommigen als alternatief. voorgestelde invullende rechtsleer is dit onjuist, nu de overheid. slechts kan beschikken over haar krachtens, het publiekrecht toekomende bevoegdheden, hetgeen een uitvloeisel is van het legaliteitsbeginsel. Het BW kan in die leer niet 
als bevoegdheidverschaffende grondslag voor de overheid dienen. Inmiddels lijkt deze leer langzamerhand in de jurisprudentie en in de wetgeving terug te worden gevonden. De heersende leer is echter nog steeds de doorkruisingsleer.

In deel II van het onderzoek heb ik bekeken in hoeverre op een aantal bestuursrechtelijke terreinen terugvorderingsbepalingen zijn terug te vinden in de relevante wetgeving, hoe de op het desbetreffende terrein bevoegde bestuursrechter omgaat met terugvordering en in hoeverre op die terreinen ruimte bestaat voor toepassing van het privaatrecht en voor ingrijpen door de burgerlijke rechter.

De socialezekerheidswetten bevatten momenteel een vrijwel uitputtende regeling met betrekking tot terugvordering. Deze regelingen laten dan ook bijna geen ruimte voor toepassing van het privaatrecht. Slechts met betrekking tot de terugvorderingstermijnen is dit anders, aangezien de wetgever ervoor heeft gekozen deze termijnen niet te regelen, zodat de verjaringstermijnen uit het BW van toepassing zijn, aldus de wetgever. Ik bestrijd dit laatste echter. Nu de bestuursrechter, in casu de Centrale Raad van Beroep, een uitgebreide competentie heeft op dit terrein, is er geen ruimte meer voor aanvullende rechtsbescherming door de burgerlijke rechter.

In het ambtenarenrecht bestaat geen wettelijke regeling met betrekking tot terugvordering van onverschuldigd gedane betalingen; de Ambtenarenwet heeft dienaangaande nooit bepalingen bevat. Niettemin heeft de Centrale Raad van Beroep als ambtenarenrechter al vrij vroeg geoordeeld dat onder omstandigheden kan worden teruggevorderd: het algemeen rechtsbeginsel dat degene die onverschuldigd heeft betaald, dit kan terugvorderen, geldt ook in het bestuursrecht. Wel was deze terugvorderingsbevoegdheid niet onbeperkt, andere beginselen zoals het vertrouwensbeginsel en het rechtszekerheidsbeginsel konden zich in een concreet: geval verzetten tegen (onbeperkte) terugvordering. Daar de bevoegdheid van de Centrale Raad ruim was, is de rol die het privaatrecht en die de burgerlijke rechter hebben gespeeld vrij gering geweest.

Waar het terugvordering van subsidies betreft, was de situatie tot voor kort de volgende. Wanneer de betrokken wettelijke regeling geen terugvorderingsbepalingen bevatte, dan nam de Afdeling (bestuurs)rechtspraak van de Raad van State, de algemene bestuursrechter, veelal aan dat sprake was van een rechtshandeling naar burgerlijk recht, waarover de burgerlijke rechter bevoegd was te oordelen. In 1996 vond echter een omslag plaats. In de uitspraak Nanne overwoog de Afdeling bestuursrechtspraak dat een terugvorderingsbeslissing veelal een besluit in de zin van artikel 1:3 Awb was, ook als daarvoor geen uitdrukkelijke grondslag was te vinden in de wet. De (publiekrechtelijke) bevoegdheid kon namelijk worden gevonden in het algemene rechtsbeginsel dat hij die onverschuldigd heeft betaald, dit kan terugvorderen. Dit heeft tot gevolg dat bij terugvordering de ruimte voor het privaatrecht en de burgerlijke rechter zeer sterk is teruggedrongen. Bovendien staat een wijziging van de subsidietitel in de Awb op het programma, waardoor er bij subsidies een algemene terugvorderingsgrondslag wordt geschapen in de wet.

Binnen het sociaal-economische recht is het College van Beroep voor het bedrijfsleven de veelal bevoegde rechter. Bij terugvordering moet een onderscheid 
worden gemaakt tussen de situatie waarbij dit college algemene rechtsmacht heeft op grond van eerst de Wet arbo, nu de Wbbo, en die waarbij sprake is van een specifieke bevoegdheid. In het laatste geval volgde het college de jurisprudentie van de Afdeling (bestuurs)rechtspraak, waarbij de terugvorderingsbeslissing tot voor kort bij het ontbreken van een uitdrukkelijke wettelijke grondslag werd aangemerkt als rechtshandeling naar burgerlijk recht, waarover de burgerlijke rechter diende te oordelen. Aangenomen mag worden dat ook het college dergelijke terugvorderingsbeslissingen tegenwoordig zal zien als (veelal appellabele) besluiten. In het eerste geval achtte het college zich snel bevoegd over de terugvordering te beslissen, mits het bestuursorgaan maar handelde binnen de uitoefening van zijn publiekrechtelijke taak.

In deel III van het onderzoek ten slotte heb ik bekeken wanneer de overheid onverschuldigd gedane betalingen mag terugvorderen. Op basis van mijn opvatting met betrekking tot het legaliteitsbeginsel ben ik tot de conclusie gekomen dat voor een dergelijke terugvordering een uitdrukkelijke publiekrechtelijke wettelijke grondslag moet bestaan wanneer de terugvordering plaatsvindt in het kader van een reeds bestaande publiekrechteliike rechtsbetrekking. Is deze wetteliike grondslag er niet, dan mag niet worden teruggevorderd. Het privaatrecht kan in ieder geval niet een dergelijke bevoegdheidsgrondslag bieden. Dit betekent dat in de verschillende wettelijke regelingen op grond waarvan personen tegenover de overheid aanspraak kunnen krijgen op financiële middelen, een uitdrukkelijke bevoegdheid tot terugvordering moet worden opgenomen. Niet kan worden volstaan met een algemene regeling, nu de terugvorderingsbevoegdheid zal moeten worden gereguleerd: de gevallen waarin en de termijnen gedurende welke kan worden teruggevorderd zullen van wettelijke regeling tot wettelijke regeling moeten worden bekeken. Dit vraagt om maatwerk. Wel kan een aantal algernene uitgangspunten worden gegeven, nu de terugvorderingsbevoegdheid in de verschillende regelingen door algemene publiekrechtelijke beginselen dient te worden begrensd. Zo zal terugvordering in strijd zijn met het vertrouwensbeginsel indien door een adrninistratieve vergissing te veel is betaald en de betrokkene dit niet wist en dit ook niet hoefde te weten. In alle andere gevallen moet in beginsel wel kunnen worden teruggevorderd. Deze terugvorderingsmogelijkheid moet wel in de tijd worden begrensd. Hoe deze begrenzing er precies dient uit te zien, moet worden bepaald aan de hand van het doel van de regeling, waarbij onder meer gelet moet worden op de vraag in hoeverre betrokkenen financieel afhankelijk zijn van de bijdrage en in hoeverre die bijdrage beoogt te voorzien in de primaire levensbehoeften. Het feit dat niet kan worden volstaan met een algemene regeling wilt overigens niet zeggen dat er geen algemene regeling dient te komen. Een dergelijke regeling kan een 'vangnetfunctie' vervullen, terwijl het voorts is aan te bevelen om een (publiekrechtelijke) bevoegdheid te creëren voor de situatie waarin de terugvordering niet plaatsvindt in het kader van een reeds bestaande publiekrechtelijke rechtsbetrekking.

Het privaatrecht kan dus in mijn visie in beginsel geen rol meer spelen bij terugvordering door de overheid, wanneer deze plaatsvindt binnen een publiek- 
rechtelijke rechtsbetrekking. Gelet op de betekenis die ik heb gegeven aan het legaliteitsbeginsel geldt deze regel ook meer in het algemeen: in een publiekrechtelijke rechtsverhouding kan het privaatrecht geen rol spelen. Binnen een dergelijke rechtsbetrekking moet er een publiekrechtelijke bevoegdheidsgrondslag zijn voor het optreden van de overheid wanneer door dat optreden bevoegdheden, rechten en plichten van burgers kunnen worden vastgesteld of gewijzigd. Het privaatrecht kan een dergelijke grondslag niet bieden. Dit betekent ook dat de rol van de burgerlijke rechter in geschillen waarbij de overheid partij is verandering behoeft. Nu deze rechter tot heden altijd geneigd is geweest om het gebruik van privaatrecht door de overheid toe te staan, is het de vraag of hij deze geschillen nog wel moet beoordelen. Het wordt dan ook tijd om de bestuursrechter algemeen bevoegd te maken indien een geschil plaatsvindt binnen een publiekrechtelijke rechtsverhouding. De mogelijkheid hiertoe bestaat ook, wanneer de burgerlijke rechter zijn bevoegdheid niet langer laat afhangen van het voorwerp van het geschil, het objectum litis, maar van de aard van de rechtsverhouding, het fundamentum petendi. Een voorwaarde hiertoe lijkt mij wel dat de bestuursrechtspraak, anders dan in de huidige situatie, wordt ondergebracht bij de rechterlijke macht. Gebeurt dit, dan kan de door mij voorgestane bevoegdheidsafbakening plaatsvinden binnen het huidige grondwettelijke stelsel. 



\section{SUMMARY}

This book describes the study of undue payment by public authorities. The conditions under which public authorities may recover what has been unduly paid forms the central question of this research. One objective of the study was to investigate whether and, if so, to what extent, public authorities, when claiming undue payments, may make use of private-law rules, also in the event that the payment unduly made may be recovered under public law. Departing from the answer to this question, the author has also examined whether it is possible to draw a more general conclusion with regard to the use of private law by the administration. Is it possible to answer the question as to whether the administration in general is allowed to make use of private law on the basis of what has been found in relation to the use of private law by the administration to recover undue payment? It should be borne in mind here that the conclusions drawn by the author with regard to the more general question of the use of private law by the administration are not based on an investigation of all the areas in which the administration operates. The author has attempted to make allowances for this by placing the investigation into recovery of undue payment in a broader context so as to also include the general history and theory of the use of private law by public authorities. Inasmuch as the use of private law by the administration is in part the result of the role of the civil courts and the development of administrative case law, the study also deals with the question as to which court should review administrative action.

The general historical and theoretical developments are discussed in Part I. The history is described from around 1815 onwards. In those days, administrative justice as such was virtually non-existent. Moreover, in particular in comparison with private law, administrative law was underdeveloped. The absence of administrative justice entailed that the civil courts began to protect citizens against administrative action in cases permitted by Article 165 of the 1815 Dutch Constitution and, since 1827, Article 2 of the Judicial Organisation Act, as interpreted by the civil courts. Although, initially, it was not very clear how these articles should be construed, in 1915, the Dutch Supreme Court held that the objectum litis, the issue, rather than the nature of the legal relation, the fundamentum petendi, was decisive for the question of the competence of the civil courts. From approximately 1840 onwards, the administration began to submit issues to the civil courts as well. This resulted in acceptance of the use of private law in legal relations that now would be conceived of as public in nature. The civil courts had a natural tendency to apply familiar private law in cases in which the administration was one of the parties. One of the reasons was, of course, that there was virtually no public law. In consequence, private law also played a role in recovery proceedings. The doctrine of "general applicability of private law" (gemene rechtsleer) eventually provided this practice 
with a theoretical foundation. Under this doctrine, private law applied to each and all in all circumstances, and therefore to the administration, unless there existed an exception under public law.

With the emergence of administrative justice, the possibilities for citizens to institute civil proceedings against the adrninistration decreased. The fact that it was possible to bring administrative issues before administrative adjudicators was often sufficient reason for the civil courts not to judge the issue, by declaring, for instance, not to have jurisciiction in the matter or ruling that the plaintiff's claim was inadrnissible. Administrative justice did not develop smoothly, however. Attempts to establish a "general" administrative adjudicator failed. Since the beginning of the twentieth century, administrative justice has developed through rules governing specific areas of law, in which "special" adjudicators have jurisdiction. The first such adjudicator was the Central Appellate Administrative Tribunal (Centrale Raad van Beroep), which adjudicated social security cases. As a result of this fragmented development of citizens' legal protection against administrative action, the civil courts have continued to this day to provide additional legal protection, even after efforts to achieve a more general regulation of legal protection against administrative action became more successful.

Whereas, in disputes with the administration, the possibilities for citizens to use private law and civil action steadily decreased, the administration was increasingly afforded more possibilities to make use of private law. Whilst under the doctrine of general applicability of private law the use of private law was limited to cases for which there was no public-law option, under the "dual-track" doctrine (tweewegenleer), the administration was allowed, even where there was a public-law option, to institute civil proceedings. In the course of time, however, more and more public-law norms were introduced in such civil proceedings, even where the administration opted for the application of private law. Thus, according to some authors, a mixed system of justice developed: the "mixed-law" doctrine (gemengde rechisleer). This doctrine seems to have been the starting point for the two major codifications of the twentieth century, the 1992. Dutch Civil Code and the General Administrative Law Code. Since more and more public-law elements were involved in answering the question as to whether the administration was allowed to make use of private law, the dual-track doctrine was eventually abandoned in favour of the doctrine of "unacceptable interference" (doorkruisingsleer). Under the latter, the answer to the question as to whether the administration is allowed to nake use of private law in a particular case is contingent on the answer to the question as to whether the use of private law unacceptably interferes with rules of public law. If this is the case, then private law is no longer an option. This doctrine has also been criticised, among other things because it assumes that the administration has powers conferred under private law. Under the doctrine of "private law as ancillary law" (invullende rechtsleer), which was introduced by some as an alternative, this is an incorrect assumption, since the administration, in adherence to the principle of legality, only has powers conferred pursuant to public law. Under this doctrine, the Civil Code cannot serve to empower the administration. It seems to slowly find its way to case law and legislation. The prevailing doctrine continues, however, to be, 
the doctrine of unacceptable interference.

In Part II of the study, the author examines for a number of areas of administrative law whether the relevant legislation contains provisions governing recovery of undue payment; how the competent administrative adjudicators deal with recovery of undue payment; and the extent to which private law may be applied and the civil courts may intervene in these areas.

The laws governing social security contain a virtually exhaustive regulation with regard to recovery of undue payment. Consequently, these rules allow very little room for the application of private law. This is different only in respect of the time limits applicable to recovery of undue payment. The legislator has opted not to provide for such time limits, so that, according to the legislator, the time limits prescribed in the Civil Code apply. The author does not concur. Inasmuch as the special adjudicator in administrative matters, in effect the Central Appellate Administrative Tribunal has extensive powers in this area, there is no longer room for additional legal protection through the civil courts.

The law governing public servants does not contain provisions relating to recovery of undue payment; the Public Servants Act has never contained such provisions. Nonetheless, in its capacity of adjudicator of public service cases, the Central Appellate Administrative Tribunal quite early on decided that, in certain circumstances, payments can be recovered. It ruled that the general principle of law that the person who made an undue payment, was entitled to recover it, also applied in administrative law. However, this power of recovery was not unlimited; other principles, such as the principle of legitimate expectations (vertrouwensbeginsel) and the principle of legal certainty are capable of blocking (unlimited) recovery in concrete cases. Inasmuch as the Central Appellate Administrative Tribunal held wide powers, private law and the civil courts played a rather insignificant role.

Until recently, the situation with regard to recovery of subsidies was as follows: if the relevant legal rules did not contain provisions on recovery, the (Administrative) Review Section of the Council of State (Afdeling! [bestuurs]rechtspraakvan de Raad van State), the "general" adjudicator of administrative cases, would often assume that the case involved a juridical act (rechtshandeling) governed by private law and falling within the jurisdiction of the civil courts. In 1996, however, a turnabout occurred. In the Nanne case, the Administrative Review Section ruled that an order for recovery in many instances constituted a decision (besluit) within the meaning of Article 1:3 General Administrative Law Act (Awb), even if the relevant statute did not expressly provide a legal basis for this, because the (public-law) power was founded in the general legal principle that a person who made an undue payment, was entitled to recovery. In consequence, the possibilities to use private law and civil proceedings to recover subsidies have been reduced dramatically. Furthermore, the subsidy title of the Awb is scheduled for amendment, so that there will be a general legal basis for recovering subsidies.

Within the field of socio-econonnic law, the Corporations Tribunal (College van Beroep voor het bedrijfsleven) often has jurisdiction. In relation to recovery, a distinction must be made between situations, in which the adjudicator has "general" 
jurisdiction pursuant to, originally, the Wet administratieve rechtspraak bedrijfsorganisaties, now the Wet bestuursrechtspraak bedrijfsorganisaties (Administrative Review [Corporations] Act), and situations in which this adjudicator has "special" jurisdiction. In the latter case, the adjudicator followed the case law of the (Administrative) Review Section of the Council of State, in which until recently, in the absence of an express legal basis, recovery orders were classified as juridical acts governed by private law, falling within the jurisdiction of the civil courts. Nowadays, it can be assumed that this adjudicating body will also regard such recovery orders as decisions (beshuiten), which in many cases are open to appeal. In the former case, the adjudicators readily declared themselves competent to decide on the recovery claim, providing that the claimant administrative organ acted in the exercise of its public-law duties.

In Part III of the study, the author examines the conditions under which public authorities may claim recovery for undue payment. In view of his perception of the principle of legality, the author concludes that there must be an express legal basis in administrative law, if recovery is based on an existing legal relation of a public nature. Where such a legal basis is absent, there is no right of recovery. In any case, such a legal basis cannot be provided by private law. This means that in the various legal regulations entitling persons to apply to the administration for financial support, an express right of recovery must be included. General rules will not suffice, since the right of recovery will have to be regulated with regard to the cases and the time limits within which recovery is possible. This will have to be examined on a one by one basis, regulation by regulation, requiring a made-to-measure approach. Admittedly, a number of general premises may be provided, since the right of recovery as provided for by the various special regulations must find its limitation in the general principles of administrative law. For instance, recovery will be in contravention of the principle of legitimate expectations, if too much was paid out by administrative error and the recipient was not aware and was not expected to be aware of this. In all other cases, it must be possible to recover undue payment. How these limitations must be formulated, will have to be determined according to the aim of the regulation in question, with due regard, among other things, to the extent to which the person in question is dependent on the contribution and the extent to which such payment is intended to contribute to the basic neans of subsistence. The fact that a general regulation will not suffice does not mean that such a regulation should not be created. It may very well serve as a safety net. It is also advisable to create a public-law power for situations in which recovery is not claimed in the context of an existing legal relation of a public nature.

In this view, private law can no longer play a role where it is the administration claiming recovery and does so within an existing legal relation of a public nature. In view of the meaning given by the author to the principle of legality, this rule also has a more generall application: in legal relations of a public nature, private law has no place. Within such a legal relation, there must be a public-law basis for the administration's power to act, if by such administrative action citizens' powers, rights and duties are established or annended. Private law cannot offer such at legal basis. 
This also entails that in disputes to which the administration is a party, the role of the civil courts needs to be reconsidered. Until now, the civil courts tended to allow the use of private law by the administration. The question is therefore whether they should continue to adjudicate these disputes. It is time to confer general jurisdiction in administrative matters on administrative adjudicators, where there is a dispute within a legal relation of a public nature. This will become possible, if the civil courts make their jurisdiction dependent on the nature of the legal relation, the fundamentum petendi, rather than the objectum litis, the issue. A precondition, however, is that, in principle, all jurisdiction in administrative matters be vested in the judiciary. This is not the case now. If this is brought about, the delineation of powers, as proposed by the author, may take place within the boundaries of the current constitutional system.

Translation by Louise Rayar 



\title{
LIJST VAN AANGEHAALDE LITERATUUR
}

\section{Literatuur}

\author{
Alen (1984)
}

André Alen, Rechter en bestuur in het Belgische publiekrecht. De grondslagen van de rechterlijke wettigheidskontrole (diss. K.U. Leuven), twee delen, Kluwer rechtswetenschappen, Antwerpen 1984

Van Angeren (1968)

J.A.M. van Angeren, De gewone rechter en de administratieve rechtsgangen (diss. Leiden), A.E. Kluwer, Deventer 1968

Asser-Hartkamp I (2000)

Mr. C. Asser's Handleiding tot de beoefening van het Nederlands burgerlijk recht, Verbintenissenrecht, De verbintenis in het algemeen, bewerkt door A.S. Hartkamp, 11 e druk, W.E.J. Tjeenk. Willink, Deventer 2000

Asser-Hartkamp II (2001)

Mr. C. Asser's Handleiding tot de beoefening van het Nederlands burgerlijk recht, Verbintenissenrecht, Algemene leet der overeenkomsten, bewerkt door A.S. Hartkamp, Hle druk, W.E.J. Tjeenk Willink, Deventer 2001

Asser-Hartkamp III (1998)

Mr. C. Asser's Handleiding tot de beoefening van het Nederlands burgerlijk recht, Verbintenissenrecht, Deel III, De verbintenis, uit de wet, bewerkt door A.S. Hartkamp, 10e druk, W.E.J. Tjeenk Willink, Deventer 1998

Asser-Scholten (1912)

Mr. C. Asser's Handleiding, tot de beoefening van het Nederlandsch burgerlijk recht, Eerste deel, Inleiding - personenrecht, bewerkt door P. Scholten, 4e druk, W.E.J. Tjeenk Willink, Zwolle 1912

Asser-Scholten (1927)

Mr. C. Asser's Handleiding tọt de beoefening van het Nederlandsch burgerlijk recht, Tweede deel, Zakenrecht, bewerkt door P. Scholten, 6e druk, W.E.J. Tjeenk Willink, Zwolle 1927

Asser-Scholten (1931)

Mr. C. Asser's Handleiding tot de beoefening van het Nederlandsch burgerlijk recht, Algemeen deel, door P. Scholten, W.E.J. Tjeenk Willink, Zwolle 1931

Asser-Scholten (1934)

P. Scholten, Mr. C. Asser's handleiding tot de beoefening van het Nederlandsch burgerlijk recht, Algemeen deel, $2 e$ druk, W.E.J. Tjeenk Willink, Zwolle 1934

Van den Berg (2000)

E.A.H. van den Berg, Opheffing College van beroep studiefinanciering, PS Documenta 2000, nr.

12, blz. 1473-1476

Ten Berge/Reinders (1984)

J.B.J.M. ten Berge en A.J.G. Reinders, De subsidie bestuursrechtelijk verankerd. Over rechtszekerheid voor het specifiek welzijn, in: M.C.B. Burkens en R. Crince Le Roy (red.), Burger en overheid (Steenbeek-bundel), Vuga, 's-Gravenhage 1984, blz. 40-64.

Ten Berge/Tak (1983)

J.B.J.M. ten Berge en A.Q.C. Tak, Nederlands administratief procesrecht (deel I), W.E.J. Tjeenk Willink , Zwolle 1983

Beurskens (1997)

W.J.J. Beurskens, De Hoge Raad en de twee-wegenleer, Ars Aequi Libri, Nijmegen 1997 
Bloembergen (1976)

A.R. Bloembergen, Overeenkomsten met de overheid, in het bijzonder in de bouw, in: A.R. Bloembergen en W.J. Slagter, Contracten met de overheid, in het bijzonder in de bouw/Projectontwikkelingscontracten (Bouwrecht monografieên 3), Kluwer/Samsom, Deventer/Alphen aan den Rijn 1976, ook opgenomen in: Bloembergens Werk, Kluwer, Deventer 1992, blz. 219-283

Bloembergen (1977)

A.R. Bloembergen, De eenheid van privaatrecht en administratief recht, WPNR 1977, nr. 5372, blz. 1-5, nr. 5373, blz. 17-23, nr. 5374, blz. 33-36, nr. 5375, blz. 49-54, ook opgenomen in: Bloembergens Werk, Kluwer, Deventer 1992, blz. 305-351

Bloembergen (1992)

A.R. Bloembergen, Overheidsprivaatrecht: schets van een algemeen deel, WPNR 1992, nr. 6074, blz. $950-957$

De Boer (1981)

J. de Boer, Terugvordering door de overheid van onverschuldigde betalingen, RM Themis 1981, blz. 248-282

Bohtlingk (1958)

F.R. Bohtlingk, De rechtsstaat Nederland, Samsom, Alphen aan den Rijn 1958

Bollen (1996)

C. Bollen, De rechtsgevolgen van het verstrijken van de terugvorderingstermijnen in het sociale zekerheidsrecht, SR 1996, nr. 10, blz. 264-267

Bollen (1997)

C. Bolleni, De Centrale Râad vân Beroep en (privaautrechtelijkè) verjaringstermijnen, JB 1997, afi. 7, blz. 495-500 (nr. 111)

Bollen (1999)

C. Bollen, Verknoeit het Europese recht ook ons bestuursrecht? Terugvordering van in strijd met het Europese recht door de overheid verleende steun, in: M.A. Heldeweg, E.C.H.J. van der Linden en R.J.N. Schlössels (red.), Uit de school geklapt? Opstellen uit Maastricht, Sdu, Den Haag 1999, blz. 39-63

Bollen (2000)

C. Bollen, Het arrest Groningen/Raatgever, of hoe een foute beslissing wél tot een rechtvaardige uitkomst leidt..., NTBR 2000, afl. 7, blz. 302-313

Bolt (1988)

H. Bolt, De aanvullende taak van de Afdeling rechtspraak Raad van State op het terrein van het sociaal-economisch recht, SEW 1988, no. 9, blz. 519-537

Van Boneval Faure (1893)

R. van Boneval Faure, Het Nederlandsche burgerlijk procesrecht, le deel, 3e herziene druk, EJ. Brill, Leiden 1893

Borman (1981)

J.A. Borman, Administratieve rechter en rechtshandeling naar burgerlijk recht (Handelingen der Nederlandse Juristen-Vereniging, jrg. 111, dl. 1, tweede stuk), W.E.J. Tjeenk Willink, Zwolle 1981, blz. 3-84

Bouwens, (1996)

W.H.A.C.M. Bouwens, Onderhoudsplicht en bijstand (diss. Nijmegen), Ars Aequi Libri, Nijmegen 1996

Brenninkmeijer (1997).

A.F.M. Brenninkmeijer, Integratie als argument voor de inrichting van de derde fase van de herziening van de rechterlijke organisatie. Bespreking van het preadvies van H.F. van den Haak, NJB 1997, atl. 23, blz. 1021-1026

Van Bruggen/Van Lakerveld (1930),

J. van Bruggen en A.F. van Lakerveld, De Ziektewet. Handieiding voor de practijk, Æ. E. Kluwer, Deventer 1930

De Bruijn/Klein Egelink (1996)

W.P.F. de Bruijn en E. Klein Egelink, Terugvordering: de deur van het kantongerecht staat nog slechts op een kier, reactic, Trema 1996, nr. 2, blz. 35-36 


\section{Buijs (1887)}

J.T. Buijs, De Grondwet, toelichting en kritiek, tweede deel, P. Gouda Quint, Amhem 1887 Buijs (1891)

J.T. Buijs, De regeling der administratieve rechtspraak (Handelingen der Nederlandsche Juristen-Vereeniging, jig. 22, dl. 1), Belinfante, 's-Gravenhage 1891, blz. 65-135

Burkens (1978)

M.C. Burkens, De plaats van de administratieve rechtspraak in het constitutionele bestel en de verhouding tot de rechtspraak van de gewone rechter, in: Ten Berge/Stroink, Wet administratieve rechtspraak overheidsbeschikkingen (losbladig), Alphen aan den Rijn, Algemeen commentaar, hoofdstuk 3, supplement januari 1978

Van Buuren (1997)

P.J.J. van Buuren, Grenscorrectic tussen bestuursrecht en privaatrecht via het zelfstandig schadebesluit, NJB 1997, afl. 17, blz. 759-763

Corstens (2001)

G.J.M. Corstens, Reorganisatie van de rechterlijke macht, NJB 2001, afl. 3, blz. 124-125

Daalder (1990)

EJ. Daalder, Toegang tot de burgerlijke rechter, TAR 1990, blz. 722-724

Damen (1987)

L.J.A. Damen, Ongeregeld en ondoorzichtig bestuur: staats- en bestuursrechtelijke beschouwingen naar aanleiding van de steunverlening aan individuele ondememingen (diss. Groningen), Kluwer, Deventer 1987

Damen (1999-I)

L.J.A. Damen, Rechtsvorming door de bestuursrechter onder de Awb, in: F.A.M. Stroink, A.W.

Heringa en A.R. Neerhof (red.), Vijf jaar JB en Awb, Sdu, Den Haag 1999, blz. 9-37

Damen (1999-II)

L.J.A. Damen, Het legaliteitsbeginsel als partieel gecodificeerde constitutionele norm, in: Het bestuursrecht als agenda voor het staatsrecht, W.E.J. Tjeenk Willink, Deventer 1999, blz. 35-67

Degenkamp (1989)

J.Th. Degenkamp, Inleiding economisch recht, 2e druk, Samsom H.D. Tjeenk Willink "Alphen aan den Rijn 1989

Dijkers (1995)

W.J.A.M. Dijkers, Terugvordering, de deur van het kantongerecht stat nog slechts op een kier,

Trema 1995, nr. 9, blz. 286-290

Donner (1953)

A.M. Donner, Nederlands bestuursrecht, Algemeen deel, uitgave 1953, N. Samsom, Alphen aan den Rijn 1953

Donner (1974),

A.M. Donner, Nederlands bestuursrecht, Algemeen deel, 4e herziene druk, Samsom, Alphen aan den Rijn 1974

Donner (1987)

A.M. Donner, Nederlands bestuursrecht, Algemeen deel, 5 e herziene druk, Samsom H.D. Tjeenk

Willink , Alphen aan den Rijn 1987

Dorhout (1991)

L. Dorhout, De Beroepswet, nu en straks, NJB 1991, afl. 36, blz. 1461-1466

Drion (1950)

J. Drion, Administratie contra rechter tot de intrekking van het conflictenbesluit (diss. Leiden),

Martinus Nijhoff, 's-Gravenhage 1950 (Een identieke handelseditie verscheen in 1958)

Drupsteen (1990)

Th.G. Drupsteen, De Pina-Helmond; het einde van de twee-wegenleer, AAe 1990, afl. 11, blz.

$840-845$

Drupsteen (1997)

Th.G. Drupsteen, Het zelfstandig schadebesluit en de ondragelijke lichtheid van de Nederiandse

Grondwet, NJB 1997, afl. 34, blz. 1596-1598 
Van Eijck/Maes (1991)

L.H.H. van Eijck en J.M.M.B. Maes, De 'aanvullende" bevoegdheidl van de civiele rechter II, TAR 1991, blz. 49-50

Van Ettekoven/Schueler (1998)

B.J. van Ettekoven en B. Schueler, 'Een ramp, een absolute ramp'. Reacties op het zelfstandig schadebesluit, NJB 1998, afl. 8, blz. 346-350

Faber (1992)

W. Faber, 90 jaren in beroep, W.E.J. Tjeenk Willink, Zwolle 1992

Ferf (1864),

H. Ferf, De regten der ambtenaren (diss. Leiden), Gebroeders Van den Hoek, Leiden 1864 Fokker (1897)

E. Fokker, Welke is de aard der rechtsverhouding van den Staat tot zijn ambtenaren; moet zij wettelijk worden geregeld; en zoo ja, hoe in hoofdzaak?, (Handelingen der Nederlandsche Juristen-Vereeniging, jrg. 28), Belinfante, 's-Gravenhage 1897, blz. 136-255

Fruytier (1991)

M.P.A.M. Fruytier, Toegang tot de burgerlijke rechter (TAR. 1990, blz. 722), TAR 1991, blz. 162-164

Van Galen/Van Maarseveen (1978)

A.G. van Galen en H.Th.J.F. van Marseveen, Beginselen van administratief procesrecht, preadvies voor de Vereniging voor Administratief Recht (VAR-geschrift LXXXII), H.D. Tjeenk Willink, Alphen aan den Rijn 1978

De Goede (1972)

B. de Goede, Staats - of administratiefrechtelijk voorschrif? NJB 1972, afl. 43, blz. 1183-1186

De Groot/Van der Meulen/Van Rossum (1994)

G.R.J. de Groot, B.M.J. van der Meulen en A.A. van Rossum, Subsidies, beleidsregels, bestuursorganen. Het wetsvoorstel derde tranche van de Algemene wet bestuursrecht, NJB 1994, afl. 35 , blz. 1193-1200

Van den Haak (1997)

H.F. van den Haak, Appel op integratie, in: Beroep in herziening, Handelingen NJV 1997-I,

W.E.J. Tjeenk Wilink, Deventer 1997, blz. 61-152

De Haan (1998-1)

P. de Haan, Wetmatigheid van bestuur: eis of beginsel? Opnieuw een vijftal proefschriften over

de verhouding publiek-/privaatrecht, Bouwrecht 1998, afl. 8, blz. 631-644

De Haan (1998-II)

P. de Haan, De: overheid in het burgerlijk recht van A.Q.C. Tak (boekbeschouwing), NTB i998, afl. 4 , blz. $94-99$

De Haan (1998-III)

P. de Haan, Het modeme bestuursrecht en de verhouding publiek-/privaatsecht, preadvies voor de Christen Juristenvereniging, z.p., 1998

De Haan/Drupsteen/Fernhout I (2001)

P. de Haan, Th.G. Drupsteen en R. Fernhout, Bestuursrecht in de sociale rechtsstaat. Deel 1 Ontwikkeling, Organisatie, Instrumentarium, vijfde geheel herziene druk, Kluwer, Deventer 2001 Van der Ham (1997)

A.B.J. van der Ham, Kruisbestuiving tussen Centrale Raad van Beroep en Afdeling bestuursrechtspraak werpt vruchten af, NJB 1997, aff. 23, blz. 1032-1039

Hamaker (1894)

H.J. Hamaker, De tegenstelling van publiek- en privaatrecht, Verslagen en Mededeelingen der Koninklijke Akademie van Wetenschappen, Afdeling Letterkunde, 3e reeks, deel 11, blz. 46-74, ook opgenomen in: Verspreide geschriften, verzameld door W.L.P.A. Molengraaff en C.W. Star Busmann, deel VII. Algemeene rechtsgeleerdheid, Erven F. Bohn "Haarlem. 1913, blz. 134-163 Hartlief (2000-I)

T. Hartlief, Overheidsaansprakelijkheid wegens vemietigde besluiten: de positie van de burgerlijke rechter in het geding, AAe 2000, aft. 3, blz. 181-192 


\section{Hartlief (2000-II)}

T. Hartlief, Het wetsvoorstel kosten bestuurlijke voorprocedures: over een overheid die slecht

tegen haar verlies kan en zelf (wel) op de kleintjes let, NJB 2000, af. 18, blz. 921 -927

Hazewindus (1992)

P. Hazewindus, Intrekking, wijziging en beetindiging van subsidies, in: W. Konijnenbelt (red.),

De derde tranche. Commentaar op het voorontwerp voor de derde tranche van de Algemene wet

bestuursrecht, Samsom H.D. Tjeenk Willink, Alphen aan den Rijn 1992, blz. 70-81

Heerma van Voss (1996)

G.J.J. Heerma van Voss, De nieuwe Algemene Bijstandswet: een tussenstap, geen keerpunt, NJB

1996, nr. 1, blz. 10-15

Hirsch Ballin (1986)

E.M.H. Hisch Ballin, Annotatiekroniek, TAR 1986, blz. 216-218

Hirsch Ballin (1993)

E.M.H. Hirsch Ballin, Normhandhaving en rechtsbescherming. Speech van de minister van justitie op het Raiocongres 1993, Trema 1993, nr. 7, blz. 272-275

Van der Hoeven (1967),

J. van der Hoeven, Pseudo-wetgeving, W.E.J. Tjeenk Willink, Zwolle 1967, ook opgenomen in:

Staatsrecht en Bestuursrecht, Opstellen van Mr. J. van der Hoeven, W.E.J. Tjeenk Willink, Zwolle 1984, blz. 134-149

Van der Hoeven (1970)

J. van der Hoeven, De magische lijn. Verkenningen op de grens van publiek- en privaatrecht, in:

Honderd jaar rechtsleven, Tjeenk Willink, Zwolle 1970, blz. 201-219, ook opgenomerı in: Staatsrecht en Bestuursrecht. Opstellen van Mr. J. van der Hoeven, W.E.J. Tjeenk Willink, Zwolle 1984, blz. 177-195

Van der Hoeven (1989)

J. van der Hoeven, De drie dimensies van het bestuursrecht (VAR-reeks 100), Samsom H.D.

Tjeenk Willink, Alphen aan den Rijn 1989

Van Houten (1891)

S. van Houten, Op welke grondslagen moet de regeling, der administratieve rechtspraak berusten?

(Handelingen der Nederlandsche Juristen-Vereeniging, jrg. 22, dl. 1), Belinfante, 's-Gravenhage 1891, blz. 47-64

Huart (1927)

F.J.A. Huart, Misbruik van burgerlijk recht door de administratie, in: Staatsrechtelijke opstellen, uitgegeven ter gelegenheid van het aftreden van Prof. H. Krabbe als hoogleeraar aan de Rijks Universiteit te Leiden, tweede deel: bijdragen van oud-leerlingen, Martinus Nijhoff, 's-Gravenhage 1927, blz. 176-197, ook opgenomen in: Verspreide geschriften, N. Samsom, Alphen aan den Rijn 1949, blz. 13-29

Hugenholtz/Heemskerk (1998)

W. Hugenholtz, Hoofdlijnen van Nederlands burgerlijk procesrecht, voortgezet door W.H. Heemskerk, 19e druk, VUGA, 's-Gravenhage 1998

Jacobs (1999)

M.J. Jacobs, Subsidieovereenkomsten. Een onderzoek naar de rechtsvormen van subsidies, in het. bijzonder overeenkomsten (diss. Vrije Universiteit Amsterdam), Elsevier, 's-Gravenhage 1999

De Jonge (1865)

W.A.C. de Jonge, Administratic en justitie, Gebroeders Belinfante, 's-Gravenhage 1865

$\mathrm{Kan} / \mathrm{Van}$ Maarseveen (1964)

J.M. Kan en H.Th.J.F. van Maarseveen, Wet beroep administratieve beschikkingen. Teksten, commentaar en jurisprudentie betreffende de Wet beroep administratieve beschikkingen en. daarmee samenhangende regelingen, N. Samsom, Alphen aan den Rijn 1964 (losbladig)

Konijnenbelt (1975)

W. Konijnenbelt, Rechtsverwerking door het bestuur: het vertrouwensbeginsel in het administratieve recht, in: De rechtsverwerking in het administratieve recht, preadvies voor de Vereniging voor Administratief Recht (VAR-geschrift LXXIV), H.D. Tjeenk Willink, Groningen 1975 
Konijnenbelt (1982)

W. Konijnenbelt, Donner en het materièle wetsbegrip, NJB 1982, afl. 22, blz. 653-655

Kooijman (1997)

J.J.A. Kooijman, Nieuwe terugvorderingsregels in de sociale verzekeringen, Rechtshulp 1997, nr. 8/9, blz. 3-19

Kooijman (1998)

J.J.A. Kooijman, Nieuwe terugvorderingsregels in de Algemene bijstandswet (I) en (II),

Rechtshulp 1998, nr. 4, blz. 2-12, nr. 5, blz. 14-22

Koopmann (1993)

M.W.E. Koopmann, Bevrijdende verjaring (diss. Vrije Universiteit Amsterdam), Kluwer, Deventer 1993

Korteweg-Wierts (1991)

M.J.S. Korteweg-Wiers, De 'aanvullende' bevoegdheid van de civiele rechter I, TAR 1991 blz. $47-49$

Kortmann (1987)

C.A.J.M. Kortmann, De Grondwetsherzieningen 1983 en 1987, Kluwer, Deventer 1987

Kortmann (1997-I)

C.A.J.M. Kortmann, De Grondwet en de jurisprudentie inzake het zelfstandige schadebesluit, NJB 1997, afl. 29, blz. 1327-1328

Kortmann (1997-II)

C.A.J.M. Kortmann, De vliegende Grondwet. Naschrift bij Th.G. Drupsteen, K. Frielink en

B.A.W. Ten Holter, NJB 1997, aff. 34, biz. 1599

Kortmann (2001)

C.A.J.M. Kortmann, Constitutioneel recht, geheel herziene 4e druk, Kluwer, Deventer 2001

Krabbe (1883)

H. Krabbe, De burgerlijke staatsdienst in Nederland (diss. Leiden), S.C. van Doesburgh, Leiden. 1883

Krabbe (1897)

H. Krabbe, Welke is de aard der rechtsverhouding van den Staat tot zijn ambtenaren; moet zij wettelijk worden geregeld; en zoo ja, hoe in hoofdzaak?, (Handelingen der Nederlandsche Juristen-Vereeniging, jrg. 28), Belinfante, 's-Gravenhage 1897, blz. 63-102

Krabbe (1906)

H. Krabbe, Die Lehre de rechtssouverănitat. Beitrag zur Staatslehre, J.B. Wolters, Groningen 1906

Kranenburg (1927)

R. Kranenburg, Publiek- en privaatrecht, in: Staatsrechtelijke opstellen, uitgegeven ter gelegenheid van het aftreden van Prof. H. Krabbe als hoogleeraar aan de Rijks Universiteit te Leiden, tweede deel: bijdragen van oud-leerlingen, Martinus Nijhoff, 's-Gravenhage 1927, blz. 60-84

Van Kreveld (1988)

J.H. van Kreveld, Juridische ontwikkeling van subsidieverhoudingen, in: Rechtstatelijke subsidieverhoudingen, preadvies voor de Vereniging voor Administratief Recht (VAR-geschrift XCIX), Samsom H.D. Tjeenk Willink, Alphen aan den Rijn 1988

De Leede (2001)

LJ.M. de Leede, Eeuwfeest. Sociale Verzekeringsbank. Honderd jaar verplichte verzekering,

SMA 2001, nr. 6, blz. 321-329

Levelt-Overmars (1997)

W.M. Levelt-Overmars, Terugvordering, in: A.F.M. Brenninkmeijer en R.P.Th. Elshoff (red.),

RSV Special Basisjurisprudentie februari 1997, blz. 108-121 (nr. 16)

Levenbach (1953)

M.G. Levenbach, Sociale verzekering, in: Kranenburg e.a., Nederlands bestuursrecht, uitgave

1953, II bijzonder deel, N. Samsom, Alphen aan den Rijn 1953, blz. 777-832

Van der Linden (1998)

E.C.H.J. van der Linden, Formele en materiēle rechtskracht. De kleren van de Keizer (diss.

Maastricht), Sdu Uitgevers, Den Haag 1998 
Loeb (1997)

L.W.R. Loeb, Appèl op maat, in: Beroep in herziening, Handelingen NJV 1997-I, W.E.J. Tjeenk

Willink, Deventer 1997, blz. 1-59

Loeff (1887)

J.A. Loeff, Publiekrecht tegenover privaatrecht (diss. Leiden), S.C. van Doesburgh, Leiden 1887 Lubach (1982)

D.A. Lubach, Beleidsovereenkomsten (diss. Groningen), Kluwer, Deventer 1982

Lubach (1986)

D.A. Lubach, De verhouding privaat-publiekrecht in het licht van het NBW, in: Bestuursrecht en

(nieuw) burgerlijk recht, preadvies voor de Vereniging voor Administratief Recht (VAR-geschrif Luja (2000)

XCIV), Samsom H.D. Tjeenk Willink, Alphen aan den Rijn 1986

R.H.C. Luja, De implementatie van beschikkingen tot terugvordering van staatssteun in het

Nederlandse bestuursrecht, NTER 2000, nr. 10, blz. 243-255

Van Maanen (1996)

G.E. van Maanen, De wonderbaarlijke geschiedenis van de onrechtmatige overheidsdaad in de

19 e en 20e ecuw, Ars Aequi Libri, Nijmegen 1996

Van Maanen/De Lange (2000)

G.E. van Maanen en R. de Lange, Onrechtmatige overheidsdaad (studiepockets privaatrecht 28),

W.E.J Tjeenk Willink, Deventer 2000

Maas (1986)

H.H. Mas, Rechtsbescherming volgens het voorstel van wet op de studiefinanciering, NJB 1986 , afl. 5 , blz. 145-15!

Van Male/De Waard (1993)

R.M. van Male en B.W.N. de Waard (red.), Adviezen aan de Awb-wetgever. Doorzend- en

verwijsregels. Proceskosten in voorprocedures, W.E.J. Tjeenk Willink, Zwolle 1993

Mannoury/Asscher-Vonk (1987),

J. Mannoury en I.P. Asscher-Vonk, Hoofdtrekken van de sociale verzekering, $2 \mathrm{e}$ geheel herziene. druk, Samsom H.D. Tjeenk Willink, Alphen aan den Rijn 1987

Meijers (1916)

E.M. Meijers, Noot onder Arrest van den Hoogen Raad van 3 December 1915, WPNR 1916, 2439, blz. $464-470$

Meijers (1925)

E.M. Meijers, De onrechtmatige overheidsdaad (I) en (II), WPNR 1925, nr. 2883, blz. 224-226, nr. 2884, blz. 241-244, ook opgenomen in: Verzamelde privaatrechtelijke opstellen, derde deel, Verbintenissenrecht, Universitaire Pers, Leiden 1955, blz. 143-157

Van der Meulen (1998)

B.M.J. van der Meulen, De novemberrevolutie gesmoord, in: L.J.A. Damen e.a. (red.), Rechtspraak Bestuursrecht 1996-1997: de annotaties, VUGA, 's-Gravenhage 1998, blz. 153-179

Michiels (1987)

F.C.M.A. Michiels, De Arob-beschikking (diss. Nijmegen), z.p. 1987

Mok/Tjittes (1995)

M.R. Mok en R.P.J.L. Tjittes, Formele rechtskracht en overheidsaansprakelijkheid, RM Themis

1995, afl. 9, blz. 383-404

Mulder (1980)

A. Mulder, Vijfentwintig jaar College van Beroep voor het bedrijfsleven, SEW 1980, nr. 7/8, blz. 393-399

Mulder/Duk (1985)

A. Mulder en R.A.A. Duk, Schets van het sociaal-economisch recht in Nederland, 3e herziene druk, W.EJ. Tjeenk Willink, Zwolle 1985

Nicolaĩ (1990)

P. Nicolaī, Beginselen van behoorlijk bestuur (diss. Universiteit van Amsterdam), Kluwer, Deventer 1990 
Nieuwenhuis (1997)

J.H. Nieuwenhuis, Vechten met de beer? De strijd om het legaliteitsbeginsel (redactionele kanttekening), RM Themis 1997, afl. 9, blz. 351-352

Nuver (1952)

E.H. Nuver, Is terugvordering van te veel betaald salaris geoorloofd?, Tijdschrift voor overheidsadministratie 1952, nr. 364, blz. 193-198

Van Ommeren (1996).

F.J. van Ommeren, De verplichting verankerd. De reikwijdte van het legaliteitsbeginsel en het materiele wetsbegrip (diss. Vrije Universiteit Amsterdam), W.E.J. Tjeenk Willink, Deventer 1996

Van Ommeren (1998)

F.J. van Ommeren, Op weg naar publiekrechtelijk vermogensrecht. Het legaliteitsbeginsel en het zelfstandig schade- en terugvorderingsbesluit, NTBR 1998, afl. 4, blz. 115-123

Van Ommeren (1999)

F.J. van Ommeren, De betekenis van het legaliteitsbeginsel voor het staatsrecht. Referaat bij het preadvies van L.J.A. Damen, in: Het bestuursrecht als agenda voor het staatsreche, W.E.J. Tjeenk. Willink, Deventer 1999, blz. 69-85

Onrechtmatige daad V.A. (Damen)

Losbladige Onrechtmatige daad, onder redactie van C.J.J.M. Stolker, hoofdstuk V.A Rechtsmachtsverdeling. Bevoegdheid, ontvankelijkheid en voorrang voor de bestuursrechtelijke procedures/de bestuursrechter, bewerkt door L.J.A. Damen, Kluwer, Deventer, z.j.

Ossenbahl (1998)

Fritz Ossenbohl, Staatshaftungsrecht, 5., neu bearbeitete und erweiterte Auflage, C.H. Beck, München 1998

Van Poelje (1931)

G.A. van Poelje, Osmose, een aanteekening, over het elkander doordringen van de beginselen van openbaar bestuur en particulier beheer, N. Samsom, Alphen aan den Rijn 1931

Van Poelje (1984)

S.O. van Poelje, Het Conflictenbesluit en de politieke ondergang van C.F. van Maanen: cen staatsrechtelijk trauma?, Bestuurswetenschappen 1984, nr. 2, blz. 110-136

Polak (1970)

J.M. Polak, De overheid in het privaatrecht. Inleidende opmerkingen, WPNR 1970, nr. 5067, blz. $11-15$

Polak (1997)

J.M. Polak, Beroep in herziening, NJB 1997, afl. 27, blz. 1205-1206

Polak (1999)

J.E.M. Polak, Burgerlijke rechter of bestuursrechter? De gewenste verJeling van de rechtsmacht bij: regelgeving, schadeveroorzakend overheidshandelen, tweewegenleer-vragen (diss. Universiteit van Amsterdam), Kluwer, Deventer 1999

Poortinga (1987)

E. Poortinga, De scheiđing tussen publiek- en privaatrecht bij Johan Ruđolph Thorbecke (17981872). Theorie en toepassing (diss. Utrecht), Ars Aequi Libri, Nijmegen 1987

Van Praag (1923)

L. van Praag, Op de grenzen van publiek- en privaatrecht, Boekh. vh. gebr. Belinfante, 's-Gravenhage 1923

Van Praag (1925)

L. van Praag, Publick- en privaatrecht. Rechtsregel of rechtsverhouding uitgangspunt, Themis 1925, blz. 130-136

Praktijkboek Bestuursrecht (Van der' Vlies)

1. van der Vlies, IX. Subsidiëring, in: N.S.J. Koeman (red.), Praktijkboek Bestuursrecht, losbladige uitgave, supplement 59 (oktober 1997), Kluwer, Deventer

Prins (1969)

W.F. Prins, De kapitein van Köpenick in de rechtsstaat (Mededelingen der Koninklijke Nederlandse Akademie van Wetenschappen, afdeling Letterkunde, Nieuwe reeks - deel 32 - No. 3), Noord-Hollandsche Uitgevers Maatschappij, Amsterdam-Londen 1969 


\section{Rank (1996)}

W.A.K. Rank, Geld, geldschuld en betaling (diss. Leiden), Kluwer, Deventer 1996

Van Ravels (2001)

B.P.M. van Ravels, Kroniek Schadevergoeding (w.o. onrechtmatige overheidsdaad), NTB 2001 , afl. 7, blz. 196-209

Reinders (1981)

A. Reinders, Subsidiêring van instellingen, Van Loghum Slaterus/W.E.J. Tjeenk Willink, Deventer/Zwolle 1981

Van Rossum (1997)

A.A. van Rossum, Rol burgerlijk(e) recht(er) uitgespeeld? (I) en (II), WPNR 1997, nr. 6290, blz. 759-763, nr. 6292, blz. 791-797

Van Rossum (1999)

A.A. van Rossum, Recente ontwikkelingen in het overheidsaansprakelijkheidsrecht, NJB 1999, afl. 5, blz. 201-209

Ruiter (1998)

D.W.P. Ruiter, Zelfstandige schadebesluiten: rechtschepping of rechtvaststelling?, NTB 1998, aff. 9, blz. 281-289

Van Schaik (1905)

J.R.H. van Schaik, De overheid tegenover de artikelen 1401 en v. B.W. (diss. Utrecht), P. den Boer, Utrecht 1905

Schell (1995)

J.L.M. Schell, De algemene bijstandswet (diss. Tilburg), Tilburg University Press, Tilburg 1995 Scheltema (1996)

M. Scheltema, Van rechtsbescherming naar een volwaardig bestuurșrecht, NJB 1996, af . 33, blz. $1355-1361$

Scheltema (1997)

M.W. Scheltema, Onverschuldigde betaling (diss. Leiden), Kluwer, Deventer 1997

Scheltema (1998)

M.W. Scheltema, Onverschuldigde betaling in het publiekrecht, NJB 1998, afl. 21, blz. 943-950

Scheltema (1999)

M. Scheltema, (Hoe) verder met de Awb?, in: F.A.M. Stroink, A.W. Heringa en A.R. Neerhof (red.), Vijf jaar JB en Awb, Sdu, Den Haag 1999, blz. 123-129

Schippers (1959)

L.J. Schippers, De structuur van de verordeningen der bedrijfs- en produktschappen, SEW 1959 , no. 10/11, blz. 331-357

Schlōssels (1998)

R.J.N. Schlossels, Het specialiteitsbeginsel. Over de structuur van bevoegdheden, wetmatigheid van bestuur en beleidsvrijheid (diss. Maastricht), Sdu Uitgevers, Den Haag 1998

Schlōssels (1999)

R.J.N. Schlossels, Tussen finaliteit en fuik? Over de omvang van het bestuursrechtelijk geding in eerste aanleg en appèl, in: M.A. Heldeweg, E.C.H.J. van der Linden en R.J.N. Schlossels (red.), Uit de school geklapt? Opstellen uit Maastricht, Sdu, Den Haag 1999, blz. 177-203

Schlossels (2000)

RJ.N. Schlossels, Het besluitbegrip: doos van Pandora of hoofd van Medusa?, NTB 2000, afl. 1, blz. 1-13

Schoonenberg/Vleesch Dubois, (1957)

J. Schoonenberg en H.D. Vleesch Dubois, Het administratieve procesrecht volgens de Beroepswet, Kring van directeuren en administrateurs van bedrijfsverenigingen, Amsterdam 1957

Schueler (1997)

B.J. Schueler, Schadevergoeding onder de Algemene wet bestuursrecht, Monografietn Awb B7, Kluwer, Deventer 1997

Simon (1989)

H.J. Simon, De Arob-rechter en de rechtshandeling naar burgerlijk recht, RM Themis 1989, nr. 10, blz. 469-489 


\section{Simon (1993)}

Henk Simon, Publiekrecht of privaatrecht? Een geschiktheidsonderzoek aan de hand van het nutsmaximalisatiebeginsei toegespitst op het gebruik van het privaatrecht door het bestuur (diss.

Vrije Universiteit Amsterdam), W.E.J. Tjeenk Willink, Zwolle 1993

Simon (1997)

HJ. Simon, Handboek bestuurs(proces)recht volgens de Awb, Sdu, 's-Gravenhage 1997

Simon (1998)

H.J. Simon, Handleiding Awb-praktijk, 2e druk, Sdu, 's-Gravenhage 1998

Simon/Bok (1997)

HJ. Simon en A.J. Bok, Subsidies, in: A.J. Bok e.a. (red.), Nieuw bestuursrecht: Derde tranche

Algemene wet bestuursrecht, Ars Aequi Libri, Nijmegen 1997, blz. 49-94

Simon/Tak (1994)

H.J. Simon en A.Q.C. Tak, Het BW als 'zwart gat'. De onttakeling van het publiekrecht door

een 'gemene' rechter, NTBR 1994, afl. 8, blz. 173-180

Sluijs (1995)

M.J. Sluijs, Naar een nieuwe regeling voor herzien en terugvorderen van uitkeringen: een requiem voor de rechtszekerheid, SR 1995, nr. 11, blz. 338-341

Snijders (1988)

W. Snijders, Artikel 3.1.1.15 nieuw B.W. en de schakelbepalingen nader bezien, in: J.A.F. Peters

en M.H. Kobussen (red.), Bestuursrecht en Nieuw B.W., W.E.J. Tjeenk Willink, Zwolle 1988, biz. $49-69$

Van Soeren (1966)

L.C. van Soeren, 65 Jaren sociale verzekering in Nederland 1901-1966, Arnsterdann 1966

Spetter $N$ aandrager (1992)

M. Spetter en M. Vaandrager, Studiefinaneiering in de jaren 90: valt er nog wat te halen?, AAe 1992, afl. 2, blz, 92-95

Ter Spill/Tak (1981)

F.W. ter Spill en A.Q.C. Tak, Onwetmatig bestuur, preadvies voor Je Vereniging voor Administratief Recht (VAR-geschrif LXXXVI), H.D. Tjeenk. Willink, Alphen aan den Rijn 1981

Stijnen (1995)

R. Stijnen, Tussen oud en nieuw: terugvorderingsperikelen ingevolge de Algemene Bijstandswet,

Gst. 1995, nr. 7021, blz. 621-626

Stijnen (1996)

R. Stijnen, Tussen privaat- en bestuursrecht: dubbele procedure bij terugvordering bijstand, Gst.

1996, nr. 7028, blz. 162-165

Stroink: (1979)

F.A.M. Stroink, Rechtshandeling naar burgerlijk recht en/of AROB-beschikking? (I) en (II), TvO

1979, nrs. 18 en 19, blz. $391-395$ en $423-427$

Struycken (1910)

A.A.H. Struyeken, Administratie of rechter, S. Gouda Quint, Amhem 1910

Tak (1987-I)

A.Q.C. Tak, Drie magische lijnen?, AAe 1987, afl. 5, blz. 281-290

Tak (1987-II)

A.Q.C. Tak, Naar een Algemene wet bestuursrecht? Impressies van een nieuwe codificatieTak (1990)

arbeid, Bestuur. Maandblad voor overheidskunde 1987, nr. 6, blz. 174-179

A.Q.C. Tak, Publiek domein, overheidscontract en rechteriijke wetshandhaving، NTB 1990, afl.

Tak (1993)

9, blz. 265-270

A.Q.C. Tak, Overheid en Burgerlijk Wetboek. Naar een invullende rechtsleer, Recht en kritiek

1993, afl. 2, blz. 174-190

Tak (1995)

A.Q.C. Tak, Hoofdlijnen van het Nederlands bestuursprocesrecht, derde, geheel herziene druk,

W.E.J. Tjeenk Willink, Zwolle 1995 
Tak (1996)

A.Q.C. Tak, Een volwaardig bestuursrecht. In discussie met Scheltema, NTB 1996, aff. 9, blz. 299-303

Tak (1997)

A.Q.C. Tak, De overheid in het burgerlijk recht, VUGA, 's-Gravenhage 1997 Tak (1998)

A.Q.C. Tak, Dimensies van overheidshandelen. In het bijzonder betrokken op de rechtsbescherming, in: E.C.H.J. van der Linden, R.J.N. Schlossels, R.J.G.H. Seerden (red.), Spectraal recht? De bevoegdheidsuitoefening door de overheid als rechtsfeit, Sdu Uitgevers, Den Haag 1998, blz. $1-28$

Tak (1999-I)

A.Q.C. Tak, Verhoogde rechtsbescherming?, NJB 1999, afl. 35, blz. 1679-1682 Tak (1999-II)

A.Q.C. Tak, De overheid in het maatschappelijk rechtsverkeer, Sdu, Den Haag 1999 Teunissen (1996)

J.M.H.F. Teunissen, Het burgerlijk kleed van de staat. Beschouwingen over de tweewegenleer

(diss. Maastricht), W.E.J. Tjeenk Willink, Zwolle 1996

Teunissen (1997)

J.M.H.F. Teunissen, Afrekening met de gemene rechtsleer en de tweewegenleer (I) en (II), Gst.

1997, nr. 7048, blz. 85-98, nr. 7049, blz. 125-134

Teunissen (1999)

J.M.H.F. Teunissen, De emancipatie van het bestuursrecht. Een beschouwing over de opkomst van een publiekrechtelijk vermogensrecht en over de betekenis van het legaliteitsbeginsel, in: M.A. Heldeweg, E.C.H.J. van der Linden en R.J.N. Schlossels (red.), Uit de school geklapt? Opstellen uit Maastricht, Sdu Uitgevers, Den Haag 1999, blz. 245-274

Teunissen (2001)

J.M.H.F. Teunissen, De autonomie van het bestuursrecht Lo.v, het privaatrecht, in: H. Koning en E.M.J. Crombag (red.), De autonomie van het bestuursrecht, Boom Juridische uitgevers, Den Haag 2001, blz. 73-99.

Teunissen/Tak (1994)

J.M.H.F. Teunissen en A.Q.C. Tak, Recht ist was der Umwelt nutzt? Over zorgplichten, civiele acties en tweewegenleer. Een overdenking, n.a.v. de opneming van een zorgplichtbepaling in de Wet milieubeheer, NJB 1994, afl. 18, blz. 605-616

Thorbecke (1843)

J.R. Thorbecke, Aanteekening, op de Grondwet, tweede deel, 2e uitgave, Johannes Muller, Amsterdam 1843

Thorbecke (1848)

J.R. Thorbecke, Bijdrage tot de herziening der Grondwet, P. H. van den Heuvell, Leiden 1848 (gebruikte uitgave: Nieuwe, uitgave, Martinus Nijhoff, 's-Gravenhage 1907)

Troostwijk (1956)

M. Troostwijk, Het gebruik maken van burgerrechtelijke vormen bij de behartiging van openbare belangen, preadvies voor de Vereniging voor Administratief Recht (VAR-geschrift XXXIV), H.D. Tjeenk Willink \&. Zoon, Haarlem 1956

Van der Veen (1997)

G.A. van der Veen, Openbare zaken. Betekenis van het aloude publiek domein na vestiging van het primaat van het publiekrecht (diss. Utrecht), W.E.J. Tjeenk Willink, Zwolle 1997

Vegting (1954)

W.G. Vegting, Het algemeen. Nederlands administratiefrecht, eerste deel, N. Samsom, Alphen aan den Rijn 1954

Vegting (1957)

W.G. Vegting, Het algemeen Nederlands administratiefrecht, tweede deel, N. Samsom, Alphen aan den Rijn 1957 
Verheij (1994)

N. Verheij, Bevoegdheidsverdeling tussen burgerlijke rechter en bestuursrechter, preadvies voor de Nederlandse Vereniging voor Rechtsvergelijking, no. 50, Kluwer, Deventer 1994

Verheij (1997)

N. Verheij, Vertrouwen op de overheid. Het vertrouwensbeginsel in het Nederlandse staats- en bestuursrecht, preadvies voor de Vereniging voor de vergelijkende studie van het recht van Belgiê en Nederland, W.E.J. Tjeenk. Willink, Deventer 1997, blz. 39-90

Verheij (1999)

N. Verheij, Een eigen recht(er). Recente verschuivingen in de bevoegdheidsverdeling tussen burgerlijke rechter en bestuursrechter, in: Verschuiving van de magische lijn, preadvies voor de Vereniging voor Administratief Recht (VAR-reeks 122), Samsom, Alphen aan den Rijn 1999

Verheij/Lubberdink (1996)

N. Verheij en H.G. Lubberdink, Algemene wet bestuursrecht derde tranche (studiepockets staatsen bestuursrecht 29), W.E.J. Tjeenk Willink, Zwolle 1996

Verslag NJV (1891)

Handelingen der Nederlandsche Juristen-Vereeniging, jrg. 22, dl. II, Belinfante, 's-Gravenhage 1891

Verslag NJV (1897)

Handelingen der Nederlandsche Juristen-Vereeniging, jrg. 28, dl. II, Belinfante, 's-Gravenhage. 1897

Verslag VAR (2000)

Verschuiving van de magische lijn. Verslag van de algemene vergadering gehouden op 23 april 1999 ter behandeling van de preadviezen van Mr. A.J.C. de Moor-van Vugt, Mr. J.L de Wijkerslooth, Mr. N. Verheij, (VAR-reeks 123), Boom Juridische vitgevers, Den Haag 2000

De Vierde tranche Awb (2000).

VAR-werkgroep Vierde tranche Awb, De Vierde tranche Awb. Commentaar en vraagpunten, Boom Juridische uitgevers, Den Haag 2000

Viering (1994)

M.L.W.M. Viering, Het toepassingsgebied van artikel 6. EVRM (diss. Nijmegen), W.E.J. Tjeenk: Willink, Zwolle 1994

Van der Vlies (1984)

1.C. van der Vlies, Het wetsbegrip en beginselen van behoorlijke regelgeving (diss. Universiteit

van Amsterdam), Vuga Uitgeverij, 's-Gravenhage 1984

Van der Vlies. (1997)

I.C. van der Vlies, Zelfstandige schadebesluiten, AAe 1997, aff. 9, blz. 602-611.

Vos (1902)

H. Vos, Administratieve rechtspraak, tweede gedeelte, L.J. Veerman, Heusden 1902

De Vries (1917)

C.W. de Vries, Het arrest van den Hoogen Raad van 31 December 1915, W.v.h.R. ñ. 9947 , aangaande de bevoegdheid van de rechterlijke macht krachtens art. 2 der Wet op de Rechterlijke: Organisatie, Themis 1917, blz. 337-361

De Vries Robbé (1997)

J.G. đe Vries Robbé, Bestuursrechtspraak op koers, in: Beroep in herziening, Handelingen NJV

1997-1. W.E.J. Tjeenk Willink, Deventer 1997, blz. 153-200

Widdershaven (1989)

R.J.G.M. Widdershoven, Gespecialiseerde rechtsgangen in het administratieve recht (diss:

Utrecht), W.E.J. Tjeenk Willink in samenwerking met NISER, Zwolle 1989

Wiersma (1958)

K. Wiersma, De sociaal-economische wetgeving en de burgerlijke rechter, SEW 1958, no. 3/4/5,

blz. 100-124.

Wiersma (2002)

H.W. Wiersma, Inhaalmanoeuvres van het burgerlijk procesrecht. De hercodificatie van wetsvoorstel 26855 c.a. per 1 januari 2002, NJB 2002, afl. 1, blz. 6-19 
Van Wijk/Konijnenbelt (1988)

H.D. van Wijk, Hoofdstukken van administratief recht, bewerkt door Willem Konijnenbelt, $6 e$ druk, Uitgeverij Lemma, Culemborg 1988

Van Wijk/Konijnenbelt \& Van Male (1999)

H.D. van Wijk, Hoofdstukken van bestuursrecht, 11e, herziene druk bewerkt door Willem Konijnenbelt en Ron M. van Male, Elsevier, Den Haag 1999

Zonderland (1954)

P. Zonderland, Het kort geding tegen de overheid (diss. Leiden), W.E.J. Tjeenk Willink, Zwolle 1954

\section{Rapporten en verslagen van (Staats)commissies en wetsontwerpen}

Verslag Staatscommissie Kappeyne van de Coppello (1894)

Verslag der Stantscommissie benoemd bij Koninklijk besluit van 16 September 1891, no, 14, tot voorbereiding der uitvoering van de voorschriften der Grondwet, aangaande regeling van de Administratieve Rechtspraak, Van Weelden en Mingelen, 's-Gravenhage 1894

Ontwerp-Loeff (1905)

Wettelijke maatregelen tot regeling der administratieve rechtspraak, Wetsontwerpen en toelichtende memorièn, Belinfante, 's-Gravenhage 1905

Ontwerp-Loeff (1915)

Wettelijke maatregelen tot regeling der administratieve rechtspraak, deel III, 1e stuk: Ontwerpen I en II - Verslag (le Gedeelte), Belinfante, 's-Gravenhage 1915

Verslag Staatscommissie-Dresselhuys (1919)

Verslag van de Staatscommissie ter voorbereiding van algemeene wettelijke regelen betreffende den rechtstoestand van ambtenaren (ingesteld bij Kon. Besluit van 21 Mei $1917 \mathrm{n}^{\circ}$. 27.), Algemeene Landsdrukkerij, "s-Gravenhage 1919

Verslag Commissie-Koolen (1932)

Verslag van de Commissie van advies, ingesteid bij beschikking van den Minister van Justitic. van 13 Februari 1931 (verhoogde rechtsbescherming tegenover de overheid), Algemeene landsdrukkerij, 's-Gravenhage 1932

Verslag Commissie-De Monchy (1950)

Verslag van de Commissie van advies inzake verhoogde rechtsbescherming, ingesteld bij beschikking van de. Ministers van Binnenlandse Zaken en van Justitie van 10 december 1946, Staatsdrukkerij- en uitgeverijbedrijf, 's-Gravenhage 1950

Verslag Commissie-Van der Grinten (1951)

Verslag van de Commissie van advies inzake administratieve en tuchtrechtspraak bedrijfsorganisatie, ingesteld bij beschikking van de Minister van Justitie en de Staatssecretaris van Economische Zaken van 9 Mei 1949, Staatsdrukkerij, 's-Gravenhage 1951

Rapport Subcommissie-Jansen (1953)

De geschiedenis van de burgerlijke pensioenwetgeving in Nederland, Rapport van de Subcommissie voor de beschrijving van de burgerlijke pensioenwetgeving, Eerste deel (eigen pensioen. vóór 1 juli 1922), Staatsdrukkerij- en uitgeverijbedrijf, 's-Gravenhage 1953

Rapport Staatscommissie-Kranenburg (1958),

Rapport van de Staatscommissie van advies inzake de status van de ambtenaren, Staatsdrukkerijen uitgeverijbedrijf, 's-Gravenhage 1958

Rapport ABAR (1959)

Algemene bepalingen van administratief recht, Rapport van de commissie inzake algemene bepalingen van administratief recht (Rapport ABAR), 2e bijgewerkte druk, H.D. Tjeenk Willink \& zoon, Haarlem 1959

Rapport Commissic-Wiarda (1968)

Rapport van de commissie verhoogde rechtsbescherming met betrekking tot. beschikkingen van organen van lagere overheidslichamen, Staatsuitgeverij, 's-Gravenhage 1968 
Rapport werkgroep-Wiersma (1972)

Gedachten over de toekomst van de rechtspleging, Rapport van de werkgroep herziening rechterlijke organisatie ingesteld bij beschikking van de Minister van Justitie van 23 december 1971, Staatsuitgeverij, 's-Gravenhage 1972

Rapport ABAR (1973)

Algemene bepalingen van administratief recht, Rapport van de commissie inzake algemene bepalingen van administratief recht (Rapport ABAR), 4e bijgewerkte druk, H.D. Tjeenk Willink, Groningen 1973

Rapport ABAR (1976)

Algemene bepalingen van administratief recht, Rapport van de commissie inzake algemene bepalingen van administratief recht (Rapport ABAR), 4e bijgewerkte druk, supplement, H.D. Tjeenk Willink, Groningen 1976

Rapport ABAR (1984)

Algemene bepalingen van administratief recht, Rapport van de commissie inzake algemene bepalingen van administratief recht (Rapport ABAR), 5e geheel herziene druk, Samsom H.D. Tjeenk Willink, Alphen aan den Rijn 1984

Rapport Staatscommissie-Van Zeben (1984)

Eindrapport van de Staatscommissie Herziening Rechterlijke Organisatie (deel I), Staatsuitgeverij, 's-Gravenhage 1984

Voorontwerp Commissie-Scheltema Awb IV (1999)

Commissie wetgeving algemene regels van bestuursrecht, Voorontwerp Algemene wet bestuursrecht vierde tranche, Den Haag 1999

\section{Parlementaire geschiedenis-uitgaven}

$P G$ arob

Pariementaire geschiedenis van de Wet arob alsmede van de daarmee samenhangende wijziging van de Wet op de Raad van State, bewerkt door J.H. van Kreveld en M. Scheltema, H.D. Tjeenk Willink, Groningen 1976

PG Grondwet 1983

Algehele grondwetsherziening, eerste lezing, deel VI Rechtspraak (Naar een nieuwe grondwet, documentatiereeks, deel 23), Staatsuitgeverij, 's-Gravenhage 1983

PG Awb I

De parlementaire geschiedenis van de Algemene wet bestuursrecht. Eerste tranche, samengesteld door E.J. Daalder, G.R.J. de Groot met medewerking van J.M.E. van Breugel, Samsom H.D. Tjeenk Willink, Alphen aan den Rijn 1993

PG Awb II

De parlementaire geschiedenis van de Algemene wet bestuursrecht. Tweede tranche, samengesteld door E.J. Daalder, G.R.J. de Groot en J.M.E. van Breugel, Samsom H.D. Tjeenk Willink, Alphen aan den Rijn 1994

PG Awb III

De parlementaire geschiedenis van de Algemene wet bestuursrecht. Derde tranche, samengesteld door E.J. Daalder, G.R.J. de Groot en J.M.E. van Breugel, Samsom H.D. Tjeenk Willink, Alphen aan den Rijn 1998

PG Boek 3 BW

Parlementaire geschiedenis van het nieuwe Burgerlijke Wetboek, door CJ. van Zeben en J.W. Du Pon met medewerking van M.M. Olthof, Boek 3: Vermogensrecht in het algemeen, Kluwer, Deventer 1981

PO Inv. Bock 3 BW

Parlementaire geschiedenis van het nieuwe Burgerlijke Wetboek, Invoering boeken 3, 5 en 6 , door W.H.M. Reehuis en E.E. Slob, Boek 3: Vermogensrecht in het algemeen, Kluwer, Deventer 1990 


\section{LIJST VAN AANGEHAALDE RECHTSPRAAK}

EHRM 19 april 1994, NJ 1995, 462, m.nt. EAA (Van de Hurk-Nederland)

EHRM 28 september 1995, Pub ECHR, Series A vol. 326, NJ 1995, 667, m.nt.

EAA, AB 1995, 588, mnt. ICvdV, JB 1995, 251, mnt. red. (Procola)

HvJ EG 4 april 1960 (Mannesmann A.G. e.a.-Hoge Autoriteit EGKS,

gevoegde zaken 4 tot 13-59), Jurispr. 1960, blz. 245

Hoog Geregtshof der Vereenigde Nederlanden 28 oktober 1818, Algemeen

Rijksarchief 's-Gravenhage, Archief Hooggerechtshof 1811-1838,

Eerste civiele kamer, inv, nr. 497, ongefolieerd, audiëntieblad 1143

(rosolymolen)

HR 12 januari 1844, W. 469, Van den Honert, Gemengde zaken deel 2, no. 89

(Weduwe Zuithoff)

HR 13 november 1846 , W. 772 , Ned. regtspraak deel 25,859

HR 10 oktober 1851, Van den Honert, Gernengde zaken deel 11, no. 532

HR 18 december 1857, W. 1917

HR 24 februari 1865, W. 2671

$2.4 .1,2.4 .3$

7.2 .2 .1

2.4 .1

HR 24 maart 1865, W. 2681

HR 23 november 1866 , W. 2854

$2.4 .2,2.5,6.2 .1$

HR 17 oktober 1873 , Ned. regtspraak, deel 105, $\$ 9$

$2.4 .1,2.4 .3$

2.4.1

7.2.2.1

HR 4 juli 1875 , W. 3863

HR 28 januari 1886, W. 5266

HR 29 mei 1896, W. 6817 (Vrouwe Elske)

HR 21 april 1898, W. 7116 (Rhedense koe)

HR 20 december 1907, W. 8641

HR 12 juni 1908, W. 8722

HR 19 juni 1908, W. 8722 (Meester-Staat)

HR 30 juni 1911, W. 9197, m.nL. J.W.M.

$2.6,4.3 .2$

HR 31 december 1915, NJ 1916, 407 (Noordwijkerhout-Guldemond)

4.3.2

HR 16 december 1920, NJ 1921, 220

HR 12 januari 1923, NJ 1923, 307

HR 20 april 1923, NJ 1923, 689

HR 16 april 1925, NJ 1925, 649

HR 6 mei 1925, NJ 1925, 756

HR 29 januari 1926, NJ 1926, 231, m.nt. E.M.M.

HR 1 april 1926, NJ 1926, 577

HR 25 maart 1927, NJ 1927, 385, m.nt. E.M.M.

HR 7 december 1928, NJ 1929, 788, m.nt. E.M.M.

HR 14 november 1930, NJ 1931, 222, m.nt. E.M.M.

HR 13 november 1941, NJ 1942, 172, AB 1942, 485

(Ambtenarenwetarrest) 
HR 18 augustus 1944, NJ 1944-1945, 598 (Alkmaar-Noord-Holland)

HR 14 januari 1949, NJ 1949, 557, m.nt. D.J.V. onder 559 (Zandvoortse woonruimtevordering)

HR 25 februari 1949, NJ 1949, 558, m.nt. D.J.V. onder 559 (Doetichemse woonruimtevordering)

HR 24 maart 1950, NJ 1950, 662

HR 15 december 1950, NJ 1951, 221, m.nt. Ph.A.N.H.

$4.3 .2,7.2 .3 .2$

6.3 .3

5.2 .2

5.2 .3

4.3 .3

5.2 .4

5.2 .3

HR 19 mei 1967, NJ 1967, 261, m.nt. G.J.S. (Saladin-HBU)

HR 19 januari 1968 , NJ 1968, 166, m.nt. G.J.S., AE 1968, 585, m.nt. S.

(Eindhoven-Staals)

HR 26 maart 1971, NJ 1971, 434, AB 1971, 135, m.nt. D.J. Veegens

(Verkiezingsafspraak Elsloo)

$2.6,12.2,12.7$

HR 22 juni 1973, NJ 1973, 386, m.nt. A.R.B., AB 1973, 187, m.nt. V.d.H.

(Fluorideringsarrest)

HR 31 maart 1978, NJ 1978, 363, m.nt. G.J.S. (SVB-Stichting St. Jansgeleen)

(St. Oedenrode-Driessen)

J. Riphagen

FHvdB (Avanti)

HR 16 mei 1986, NJ 1986, 723, m.nt. MS, AB 1986, 573, m.nt. FHvdB

(Heesch-Van de Akker)

HR 27 maart 1987, NJ 1987, 727, m.nt. MS; AB 1987, 273, m.nt. FHvdB (Amsterdam-Ikon)

HR 4 december 1987, NJ 1988, 295, m.ne WHH, AB 1988, 189, m.nt. FHvdB (Du Pied)

HR 26 januari 1990, NJ 1991, 393, m.nt. MS onder 394, AB 1990, 408, m.nt. G.P. Kleijn (Windmili)

HR 9 juli 1990, NJ 1991, 394, m.nt. MS, AB 1990, 547, m.nt. G.P. Kleijn (De Pina-Helmond)

HR 31 mei 1991, NJ 1993, 112, m.nt. CJHB, AB 1992, 290, m.nt. FHvdB onder 291 (Van Gog-Nederweert)

HR 25 juni 1991, NJ 1992, 216, m.nt. C.

(Kunst- en Antickstudio Leiystad)

HR 25 oktober 1991, NJ 1992, 299, m.nt. JBMV, AB 1992, 88, m.nt. FHvdB

$$
\text { (Comelissen-Groningen) }
$$

$5.3 .3,6.2 .3,6.5 .5 .1$

HR 28 februari 1992, NJ 1992, 687, m.nt. MS, AB 1992, 301, m.nt. FHvdB

\section{(Changoe)}

$4.3 .2,4.3 .4,7.2 .3 .2,7.2 .4 .3,9.6 .1$

HR 24 aprii 1992, NJ 1993, 232, m.nt. MS, AB 1992, 542 (Zeeland-Hoondert)

HR 10 augustus 1992, NJ 1993, 636, m.nt. MS, AB 1993, 12

$$
\text { (M.-Roosendaal en Nispen) }
$$

$5.3 .3,6.5 .5 .1,6.5 .6$

HR 11 december 1992, NJ 1994, 639, m.nt. MS, AB 1993, 301, m.nt. G.A. van der Veen (Brandweerikosten)

HR 28 mei 1993, NJ 1994, 435, m.nt. HJS (Nieuwkoop-Staat) 
HR 18 februari 1994, NJ 1995, 718, m.nt. MS (Kabayel)

HR 14 oktober 1994, NJ 1995, 720, m.nt. MS, AB 1995, 48, m.nt. G.A. van der Veen (Wrakkenwet)

HR 3 maart 1995, NJ 1995, 327

HR 18 april 1997, NJ 1997, 499

HR 15 januari 1999, NJ 1999, 306, m.nt. ARB, AB 2000, 196, m.nt. ThGD, JB 1999, 45, m.nt. ARN (De Eemshom)

HR 19 november 1999, NJ 2000, 160, m.nt. TK, AB 2000, 387, m.nt. ThGD, JB 2000, 1, m.nt. R.J.N. S. (Tegelen-Provincie Limburg)

HR 17 december 1999, NJ 2000, 87, m.nt. ARB onder 88, AB 2000, 89, m.nt. PvB, JB 2000, 4, m.nt. F.A.M. S. (Groningen-Raatgever)

$7.2 .4 .4 n 9.6 .1$

HR 27 april 2001, AB 2001, 361, m.nt. ThGD, RvdW 2001, 93, JB 2001, 126, m.nt. F.A.M. S. (Leers-Staat)

Provinciaal Geregtshof Noord-Brabant 20 juni 1854, Ned. regtspraak, deel 50, § 81

Geregtshof 's-Hertogenbosch 13 februari 1877, WBA 1877, 1453

Hof 's-Gravenhage 16 december 1907, W. 8636

Hof 's-Hertogenbosch 8 december 1986, JABW 1987, 60

6.5 .5 .1

6.5.6

6.5 .7

Hof Leeuwarden 1 juni 1994, JSV 1994, 134

6.2 .1

$\mathrm{Rb}$. Rotterdam 3 januari 1866, W. 2761

$\mathrm{Rb}$. 's-Gravenhage 9 januari 1906, W. 8327

4.3.2.

Rb. Maastricht 25 april 1935, NJ 1935, 1285

$4.3 .5,6.3 .3$

Rb. Dordrecht 11 mei 1938, NJ 1939, 571

6.3 .3

$\mathrm{Rb}$. Dordrecht 20 december 1939, rolnr. 132-1937, niet gepubliceerd

4.3.5

Rb. 's-Hertogenbosch 13 oktober 1950, NJ 1951, 501

6.5 .6

6.5 .6

Rb. 's-Gravenhage 16 februari 1971, NJ 1971, 225

7.2 .4 .3

Rb. Amsterdam 15 juni 1971, AB 1972, 55

4.3.2

$\mathrm{Rb}$. 's-Gravenhage 11 januari 1973, NJ 1973, 233

6.2 .3

Rb. Rotterdam 30 november 1981, JABW 1982, 35

6.5 .3

Rb. 's-Hertogenbosch 1 juni 1984, Jurisprudentie WWV/WSW 1986, 36

6.5.5.1

Rb. Amsterdam 8 mei 1985, AB 1987, 212, m.nt. JHS onder 213

Rb. Roermond 9 juni 1988, NJ 1989, 524

6.5 .5 .1

$\mathrm{Rb}$. Groningen 29 november 1988, JABW 1990, 16

6.5 .5 .1

$\mathrm{Rb}$. Groningen 2 november 1990, JABW 1991, 5

Rb. 's-Gravenhage 3 september 1997, JB 1997, 247

7.2 .4 .2

$\mathrm{Rb}$. 's-Gravenhage 5 november 1997, TAR 1998, 35

6.4 .5 .3

$\mathrm{Rb}$. 's-Gravenhage 26 februari 1998, USZ 1998, 126, m.nt. MD.

Rb. Maastricht 14 maart 2000, USZ 2000, 138, m.nt. E.E.V. Lenos

$\mathrm{Rb}$. Leeuwarden 21 april 2000, JB 2000, 173, m.nt. Carlos Bollen

$\mathrm{Rb}$. Utrecht 19 juli 2000, NJ 2001, 89

Rb. Groningen 4 augustus 2000, JABW 2000, 143, Gst. 7133, 13, m.nt. WdB 
Ktr. Leeuwarden 25 juni 1946, NJ 1948, 27

Ktr. Utrecht 6 november 1984, JABW 1986, 3

Ktr. Utrecht 20 november 1984, JABW 1986, 4

Ktr. Utrecht 13 december 1985, JABW 1986, 147

Ktr. Groningen 12 april 1988, JABW 1988, 296

Ktr. Groningen 8 november 1989, JABW 1990, 37

KB 16 juni 1913, Stb. 277, Stcrt. 158

KB 29 november 1979, AB 1980, 177, m.nt. V.d. N.

ARRvS 29 juni 1977, tB/S V, blz. 73, m. aant. tB/S

ARRvS I september 1977, AB 1977, 366, m.nt. v.d.V. (Uitwegvergunning Maastricht I)

ARRvS 10 mei 1979, tB/S III, nr. 124, m. aant. tB/S

ARRvS 20 december 1981, tB/S V, blz. 1045 (aantekening, 2 bij nr. 258)

ARRvS 31 juli 1984, tB/S V, nr. 352, m. aant. B

ARRvS 29 februari 1988, AB 1989, 356, m.nt. onder 357 H.J. Simon

ARRvS 1 maart 1990, JSV 1990, 101

ARRvS 31 juli 1991, AB 1992, 76

ARKvS 30 juni 1992, AB 1993, 447, m.nt. AFMB

Vz. ARRvS 18 februari 1982, tB/S V, nr. 258, m. aant. tB/S

Wnd. Vz. ARRvS 31 december 1982, tB/S V, nr. 290, m. aant. tB/S

Vz. ARRvS 24 maart 1988, JSV 1988, 111

8.2 .3

8.2 .3

8.2 .3

Vz. AKRvS 21 november 1989, JSV 1990, 8

Vz. ARRvS 24 juli 1990, JSV 1990, 237

ABRvS 30 oktober 1995, AB 1996, 310, m.nt. AFMB

ABRvS 2 november 1995, JB 1995, 333, m.nt. F.A.M. S.

ABRvS 21 oktober 1996, AB 1996, 496, m.nt. NV, JB 1996, 232, m.nt. HS

(Nanne)

$4.2 .3,5.3 .3,6.5 .2,7.2 .3 .3,8.2 .6,8.4 .3,9.2,9.5,12.2$

ABRvS 29 november 1996, AB 1997, 66, m.nt. PvB, JBi 1996, 253, m.nt. red.

(Alpha Kledingreinigingsbedriji)

$4.2 .3,5.3 .3,7.2 .3 .3,8.4 .3,9.5,12.2$

ABRvS 10 februari 1997, AB 1997, 427, m.nt. NV

ABRvS 18 februari 1997, AB 1997, 143, m.nt. PvB, JB 1997, 47, m.nt. HJS (Beurskens)

ABRvS 13 maart 1997, ABkort 1997, 262

ABRvS 6 mei 1997, AB 1997, 229, m.nt. PvB, JB 1997, 118, m.nt. HJS (Van Vlodrop)

ABRvS 26 augustus 1997, AB 1997, 461, m.nt. NV, JB 1997, 265, m.nt. HOS

(Samenwerkingsverband Noord-Kennemerland)

ABRvS 8 februari 2000, AB 2001, 118, m.nt. LD, JB 2000, 91, m.nt. C.L.G.F.H. A

ABRvS 4 april 2000, AB 2000, 250, m.nt. NV

ABRvS 14 december 2000, JB 2001, 29 
CRvB 19 december 1950, AB 1951, 196

7.2.3.3

CRvB 2 oktober 1951, AB 1952, 190 (Hoitsma-Wonseradeel)

7.2 .3 .3

CRvB 25 maart 1952, AB 1952, 698

$7.2 .3 .3,7.3 .3$.

7.2 .3 .3

7.2 .3 .3

CRvB 16 december 1952, AB 1953, 473

CRvB 30 december 1952, AB 1953, 477 (Schouten-Zonnemaire).

CRvB 19 oktober 1954, AB 1955, 125

CRvB 12 juli 1955, AB 1956, 242

$5.3 .3,6.3 .3,7.2 .3 .3,8.4 .3$,
9.3 .2
6.4 .2

$6.4 .2,6.4 .4 .2$

6.4 .2

CRvB 13 december 1955, AB 1957, 12

CRvB 26 juni 1959, AB 1960, 469

$7.2 .3 .3,7.2 .4 .2$

6.4 .2

6.4 .2

6.4 .2

6.4 .2

CRvB 9 november 1962, AB 1963, 732

CRvB 22 december 1964, RSV 1965, 22

CRvB 11 mei 1966, AB 1967, 578

CRvB 29 oktober 1970, AB 1971, 117

$7.2 .3 .3,7.3 .4 .3$
6.4 .2

$7.2 .3 .3,7.3 .4 .3$
6.4 .2

CRvB 31 december 1970, RSV 1971, 142.

CRvB 3 mei 1972, AB 1973, 232, m.nt. v.d. H.

$4.2 .3,8.4 .3$

7.3 .4 .3

6.4 .2

CRvB 15 oktober 1973, RSV 1974, 112

6.4 .2

7.2 .4 .2

CRvB 27 januari 1978, AB 1978, 186

6.5 .5 .2

7.3 .4 .3

7.3 .4 .3

7.3 .4 .3

CRvB 25 september 1980, AB 1981, 117

CRvB 4 november 1982, AB 1983, 192

CRvB 24 februari 1983, AB 1984, 507, m.nt. vE

CRvB 12 juli 1985, RSV' 1987, 96

$6.4 .4 .4,10.5$

6.4 .4 .4

6.4 .4 .4

CRvB 20 februari 1986, RSV 1986, 198

$6.5 .3,6.5 .5 .1$

CRvB 7 april 1986, RSV 1986, 207

6.4 .4 .5

CRvB 12 maart 1987, RSV 1988, 6

CRvB 18 maart 1987, RSV 1988, 7

$6.4 .4 .4,6.4 .4 .5$

CRvB 14 mei 1987, RSV 1988, 35

$6.4 .4 .4,10.5$

CRvB 17 september 1987, TAR 1987, 245

7.2 .4 .2

7.2 .4 .2

6.4 .4 .2

6.4 .4 .2

6.4 .4 .5

6.4 .4 .5

6.4 .4 .4

6.4 .4 .2

6.4 .4 .2

6.4 .4 .5

CRvB 4 april 1989, RSV 1989, 269

CRvB 22 juni 1989, RSV 1990, 51.

CRvB 20 juli 1989, AB 1989, 421, RSV 1989, 305

$6.4 .4 .4,6.4 .4 .5$

7.2 .4 .2

CRvB 13 september 1989, AB 1990, 147, m.nt. de L., RSV 1990, 237, m.nt. J.J.A. Kooijman

$6.5 .5 .2,11.2$

$6.4 .4 .4,6.4 .4 .5$

$6.4 .4 .4,6.4 .4 .5$

6.4 .4 .2

CRvB 4 oktober 1989, RSV 1990, 109

CRvB 20 december 1989, RSV 1990, 315

$6.4 .4 .4,10.5$

CRvB 20 februari 1990, RSV 1990. 248

CRvB 26 april 1990, AB 1991, 157, mnt. HH, TAR 1990, 138

CRvB 17 mei 1990, RSV 1990, 333

CRvB 19 september 1990, RSV 1992, 63 
CRvB 12 oktober 1990, RSV 1991, 235

CRvB 8 november 1990, JSV 1991, 203

CRvB 20 december 1990, JSV 1991, 114

7.3 .4 .3

CRvB 30 januari 1991, RSV 1992, 17

6.4 .4 .2

CRvB 11 april 1991, AB 1991, 469, m.nt. HH

7.2 .4 .3

CRvB 23 mei 1991, RSV 1992, 112

6.4 .4 .4

CRvB 23 mei 1991, RSV 1992, 290

6.4 .4 .2

CRvB 12 september 1991, RSV 1992, 226

7.3 .4 .3

CRvB 18 december 1991, RSV 1992, 291

6.4 .4 .5

6.4 .4 .2

CRvB 10 januari 1992, RSV 1992, 292

7.3 .4 .3

CRvB 16 juli 1992, RSV 1993, 30

CRvB i6 februari 1993, RSV 1994, 22, m.nt. A. Rutten

$6.4 .4 .2,6.4 .4 .4$

6.4 .4 .5

6.4 .4 .4

CRvB 14 mei 1993, RSV 1994, 21

6.4 .4 .5

CRvB 22 september 1993, RSV 1994, 80

CRvB 23 december 1993, RSV 1994, 196

$6.4 .4 .4,10.5$

CRvB 26 juli 1994, AB 1995, 229, JB 1994, 220, RSV 1995, 54 en 93, JABW 1995, 24

CRvB 28 juli 1994, AB !995, 133, m.nt. RMvM, JB 1994, 221, m.nt.

\section{ELB/ABJH}

CRvB 21 oktober 1994, RSV 1995, 122

CRvB 25 oktober 1994, RSV 1995, 123

CRvB 13 december 1994, RSV 1995, 227

CRvB 29 december 1994, RSV 1995, 197

CRvB 6 januari 1995, AB 1995, 388

CRvB 9 februari 1995, RSV 1995, 228

CRvB 2. augustus 1995, NJB katem 1996, blz. 108, nr. 5

CRvB 19 oktober 1995, JB 1996, 11

CRvB 14 december 1995, TAR 1996, 32

CRvB 23 januari 1997. TAR 1997, 42

CRvB 24 september 1997, AB 1997, 431, m.nt. FP

CRvB 23 april 1998, AB 1998, 251, m.nt. HBr

CRvB 24 juni 1999, AB 1999, 406, m.nt. HH

CRvB 21 september 1999, AB 1999, 464, m.nt. HBr

CRvB 11 november 1999, J日 1999, 306, m.nt. G.E. van Maanen

CRvB 17 maar 2000, USZ 2000, 115

CRvB 19 juli 2000, nr. 98/4833 WW (niet gepubliceerd)

CRvB 3 augustus 2000, AB 2000, 413, m.nt. HH

CRvB 15 augustus 2000, J日 2000, 277, m.nt. C.L.G.F.H. A., USZ 2000, 257

$4.2 .3,5.3 .3,8.4 .3,9.5$

6.4 .4 .4

6.4 .4 .4

6.4 .4 .6

$6.4 .4 .3,6.4 .4 .6$

6.41.4.6

6.4 .4 .2

6.4 .4 .5

$6.5 .2,7.2 .4 .2$

$6.5 .2,7.2 .4 .2$

$6.5 .2,7.2 .4 .2$

$4.2 .3,9.5$

$4.2 .3,9.5$

7.2.4.2, 10.5

6.4.5.4

12.6

6.4.5.4

6.4.5.4

$7.2 .42,10.5$

6.4.5.4

6.4 .5 .4

6.2 .4

CRvB 9 januari 2001, USZ 2001, 94, m.nt. A.E.L.T. Balkema

CRvB 25 september 2001, USZ 2001, 299, m.nt. Red.

6.5.2. 7.2.4.2. 10.5

RvB Amsterdam 30 oktober 1908, WRSV 1909, afl. 10, nr. 13

$4.3 .3,7.2 .3 .3$

4.3.3

6.4 .2

6.4 .2

RvB 's.Hertogenbosch 20 december 1960, AB 1961, 570

6.5 .5 .1

RvB Rotterdam 13 september 1984, Jurisprudentie WWV/WSW 1984, 165

6.5 .3

RvB̈ Roermond 13 september 1989, JSV 1990, 1

Ag. Haarlem 17 februari 1959 en (in hoger beroep) CRvB 26 juni 1959, AB 1960,469 
CBB 10 april 1964, SEW 1964, 211 (blz. 559-561), m.nt. J.P.

8.4 .4

CBB 22 april 1975, AB 1975, 149, m.nt. J.P., SEW 1975, blz. 449-452,

m.nt. J.P.

$4.2 .3,8.4 .3$

CBB 27 december 1977, AB 1978, 334, SEW 1978, blz. 693-696, m.nt. JHvK

$8.4 .3,8.4 .4$

CBB 2 september 1987, AB 1988, 426, m.nt. JHvK, UCB 1988, 48, m.noten $\mathrm{KM}$ en BO

8.4 .4

8.4 .4

CBB 19 mei 1994, AB 1994, 642, m.nt. JHvdV

8.4 .3

CBB 26 maart 1996, JB 1996, 135, m.nt. A.B

CBB 19 februari 1997, AB 1997, 144, m.nt. JHvdV, JB 1997, 92, m.nt. HUS

CBB 9 november 1999, AB 2000, 233, m.nt. JHvdV

$5.3 .3,7.2 .3 .3,8.4 .3,8.4 .4,9.5$

Cbsf 23 mei 1996, JB 1996, 177, m.nt. red.

8.2.2.5

Cbsf 9 april 1997, JB 1997, 105, m.nt. HJS

$5.3 .3,7.2 .3 .3,8.4 .3,9.5$

$5.3 .3,7.2 .3 .3,8.3 .2,9.3 .2$ 



\section{CURRICULUM VITAE}

Carlos Bollen werd geboren op 15 oktober 1962 te Maastricht. In 1981 behaalde hij het diploma atheneum A aan de Scholengemeenschap Jeanne d'Arc te Maastricht. Vanaf 1987 studeerde hij rechten aan de Rijksuniversiteit Limburg en Lancaster University (Groot-Brittannië), na tussen 1981 en 1983 Pedagogische en andragogische wetenschappen te hebben gestudeerd aan de Rijksuniversiteit Groningen en tussen 1982 en 1988 als concertorganisator te hebben gewerkt in een jongerencentrum te Maastricht. Hij studeerde af in augustus 1992. Vanaf oktober 1994 is hij werkzaam bij eerst de Rijksuniversiteit Limburg, nu Universiteit Maastricht, tot 1 januari 2000 als assistent in opleiding, vanaf die datum als universitair docent. Tussen 1994 en 1996 was hij tevens waarnemend griffier bij de arrondissementsrechtbank te Maastricht, waarbij hij als zodanig optrad bij kort gedingen. 
Centraal in dit onderzoek staat de vraag wanneer de overheid onverschuldigd gedane betalingen mag terugvorderen. Verschillende publiekrechtelijke regelingen bevatten bepalingen met betrekking tot de terugvordering; in andere gevallen is dit echter niet zo. Een van de vragen die in het onderzoek wordt beantwoord, is of deze bepalingen voldoen en of in de gevallen waarin de publiekrechtelijke regeling geen terugvorderingsbepalingen bevat, deze er alsnog dienen te komen. Daarnaast is het de vraag of de overheid de publiekrechtelijke weg mót bewandelen, of dat het haar is toegestaan gebruik te maken van het privaatrecht. Met het beantwoorden van deze laatste vraag - mag de overheid bij terugvordering gebruik maken van de privaatrechtelijke weg, naast of in plaats van de publiekrechtelijke weg? - wordt tevens beoogd een bijdrage te leveren aan de discussie over het gebruik van privaatrecht door de overheid in het algemeen. 